WETENSCHAPPELIJKE RAAD VOOR HET REGERINGSBELEID

\title{
Waarden, normen en \\ de last van het gedrag
}


De Wetenschappelijke Raad voor het Regeringsbeleid werd in voorlopige vorm ingesteld in 1972. Bij wet van 30 juni 1976 (Stb. 413) is de positie van de raad definitief geregeld. De huidige zittingsperiode loopt tot 31 december 2007.

Ingevolge de wet heeft de raad tot taak ten behoeve van het regeringsbeleid wetenschappelijke informatie te verschaffen over ontwikkelingen die op langere termijn de samenleving kunnen beïnvloeden. De raad wordt geacht daarbij tijdig te wijzen op tegenstrijdigheden en te verwachten knelpunten en zich te richten op het formuleren van probleemstellingen ten aanzien van de grote beleidsvraagstukken, alsmede op het aangeven van beleidsalternatieven.

Volgens de wet stelt de WRR zijn eigen werkprogramma vast, na overleg met de minister-president die hiertoe de Raad van Ministers hoort.

De samenstelling van de raad is (tot 31 december 2007):

prof.mr. M. Scheltema (voorzitter)

prof.dr. W.B.H.J. van de Donk

prof.dr. P.L. Meurs

prof.dr. J.L.M. Pelkmans

prof.dr.mr. C.J.M. Schuyt

prof.dr. J.J.M. Theeuwes

prof.dr. P. Winsemius

Secretaris: dr. A.C. Hemerijck

De WRR is gevestigd:

Plein 1813, nr. 2-4

Postbus 20004

2500 EA 's-Gravenhage

Telefoon 070-356 46 oo

Telefax 070-356 4685

E-mailinfo@wrr.nl

Website http://www.wrr.nl 
WETENSCHAPPELIJKE RAAD VOOR HET REGERINGSBELEID

\section{Waarden, normen en de last van het gedrag}


ISBN 90-5356-659-7 


\section{WRR}

WETENSCHAPPELIJKE RAAD VOOR HET REGERINGSBELEID

Aan de Minister-President

Minister van Algemene Zaken

De heer mr.dr. J.P. Balkenende

Postbus 20001

2500 EA Den Haag

ons kenmerk

2003196/ms/mn

Onderwerp

Rapport nr. 68 doorkiesnummer

$070-3564662$

email

scheltema@wrr.nl telefax

$070-3564685$

datum

21 oktober 2003

Hierbij zenden wij u het rapport 'Waarden, normen en de last van het gedrag', dat de raad uitbrengt als gevolg van de adviesaanvraag van het kabinet van 8 november 2002.

Het kabinet stelde daarin de vraag welke fundamentele waarden onze samenleving bindt en over welke waarden conflicten kunnen rijzen, mede gezien in het licht van culturele verschillen. De wRR heeft de probleemstelling van de adviesaanvraag enigszins verruimd. De achtergrond ervan was immers niet alleen een gevoel van onzekerheid over de gemeenschappelijkheid van waarden en normen in onze huidige samenleving. Het ging evenzeer over het gegeven dat het feitelijk gedrag van velen niet in overeenstemming is met die gemeenschappelijke waarden. Ergernissen daarover liggen aan veel discussies over het onderwerp ten grondslag.

In het rapport wordt het belang van de problematiek onderschreven, maar wordt wel aangegeven dat een nadere strücturering nodig is om tot een zinvol beleid te komen. De bijdrage die dit rapport wil leveren bestaat in de eerste plaats uit:

(a) een systematische analyse en structurering van de zeer diverse problematiek die schuilgaat onder de noemer 'waarden en normen';

(b) het afzonderlijk onder de aandacht brengen van de gedragscomponent van de waarden- en normenproblematiek; en

(c) het aanbrengen van een toekomstperspectief op de centrale en gemeenschappelijke waarden die van belang zullen zijn voor de samenleving als geheel in de komende tien tot twintig jaar.

De raad meent dat de taak van de overheid bestaat uit het garanderen van de waarden van een open en democratische rechtsstaat, en het ondersteunen van de publieke moraal. Voor het overige is het in de eerste plaats de samenleving zelf die waarden vormt en onderhoudt. Veel instituties als scholen, media en maatschappelijke organisaties zijn werkplaatsen voor waarden, normen en gedrag. De overheid heeft daarbij wel de taak hen in die functie serieus te nemen en te stimuleren, en hen niet alleen 'af te rekenen' op direct zichtbare prestaties als het bereiken van een bepaald kennisniveau.

Volgens de procedure van de Instellingswet WRR ziet de raad graag de bevindingen van de ministerraad tegemoet.
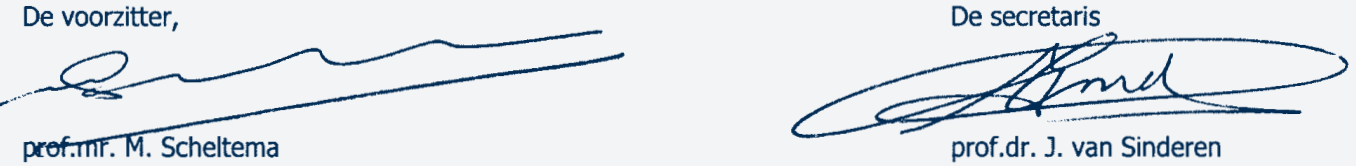

Plein 1813 nrs. 2 en 4, Postbus 20004, 2500 EA Den Haag 


\section{INHOUDSOPGAVE}

Samenvatting

I Inleiding en probleemstelling 19

1.1 Aanleiding tot een rapport over waarden en normen 19

1.2 Waarden en normen in recente openbare discussies 20

1.3 Probleemstelling van het rapport 24

1.4 Maatschappelijke achtergrond van de discussie over waarden en normen $\quad 26$

1.5 Niet voor het eerst en niet alleen in Nederland 28

$\begin{array}{ll}\text { 1.5.1 Voorgangers uit het recente verleden } & 28\end{array}$

1.5.2 De discussie in het buitenland 32

$\begin{array}{lll}\text { 1.6 De opbouw van het rapport } & 37\end{array}$

2 Een verkenning van de begrippen 'waarden' en 'normen' en de problemen die hiermee samenhangen 41

2.1 Zijn waarden definieerbaar? $\quad 41$

2.2 De praktische benadering van Rescher 43

2.3 Twee problemen: de veelheid en de abstractiegraad van waarden $\quad 45$

$\begin{array}{lll}2.3 .1 & \text { De waarde van waarden } & 45\end{array}$

2.3.2 Enkele onderscheidingen van waarden $\quad 46$

2.3.3 De abstractiegraad van waarden $\quad 48$

$2.4 \quad$ Waarden en het goede leven $\quad 52$

2.4.1 Verschillende visies op het goede leven 52

2.4.2 Monisme, pluralisme, relativisme 54

2.5 Analyse van het begrip 'norm': om welke normen gaat het? $\quad 58$

2.5.1 Eigenschappen van normen en regels $\quad 58$

2.5.2 Morele, juridische en sociale normen 60

2.5.3 Van onprettig naar onwettig: een principiële en praktische

$\begin{array}{ll}\text { kwestie } & 62\end{array}$

$\begin{array}{lll}2.6 & \text { Conclusies } & 65\end{array}$

3 Waarden, normen en gedrag: de mening van de bevolking 69

$\begin{array}{lll}3.1 & \text { Inleiding } & 69\end{array}$

3.2 Het meten van meningen over waarden, normen en gedrag 70

$\begin{array}{lll}3.3 & \text { Waarden } & 72\end{array}$

$\begin{array}{lll}3.4 & \text { Normen } & 75\end{array}$

$\begin{array}{ll}3.5 & \text { Gedrag }\end{array}$

$\begin{array}{lll}3.6 & \text { Generatie-effecten? } & 83\end{array}$

$\begin{array}{lll}3.7 & \text { Conclusies } & 87\end{array}$ 
$4 \quad$ Normoverschrijdend gedrag $\quad 89$

4.1 Inleiding 89

4.2 Wat verklaart normoverschrijdend gedrag? 90

4.3 De dynamiek van normoverschrijding 93

4.4 Buurtproblemen, onveiligheid en criminaliteit 96

$\begin{array}{lll}4.4 .1 & \text { Buurtproblemen } & 96\end{array}$

$\begin{array}{lll}4.4 .2 & \text { Onveiligheid } & 97\end{array}$

$\begin{array}{ll}4.4 .3 & \text { Criminaliteit en geweld }\end{array}$

$\begin{array}{ll}4.5 & \\ 4.6 & \text { Wangedrag op school }\end{array}$

$\begin{array}{ll}4.6 & \text { Jeugdcriminaliteit } \\ 4.7 & \text { Zinloos }\end{array}$

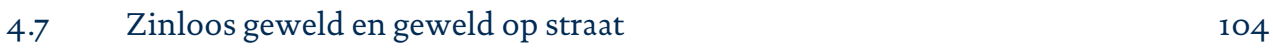

$\begin{array}{lll}4.8 & \text { Voetbalvandalisme } & 105\end{array}$

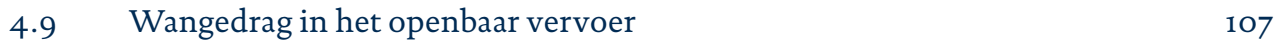

4.10 Wangedrag in het verkeer 110

4.11 Wangedrag op het werk 112

$\begin{array}{lll}4.12 & \text { Fraude } & 114\end{array}$

4.13 Conclusies 119

Bijlage: Een rationele-keuze-analyse van normen en gedrag $\quad 127$

5 Pluriformiteit en gemeenschappelijke waarden in de $\begin{array}{ll}\text { democratische rechtsstaat } & 141\end{array}$

$\begin{array}{lll}\text { 5.1 Pluraliteit als kenmerk van onze cultuur } & 141\end{array}$

$\begin{array}{ll}\text { 5.2 Gemeenschappelijke waarden } & 143\end{array}$

5.3 Liberaal denken en gemeenschapsdenken $\quad 148$

5.4 De waarde en de dynamiek van de democratische rechtsstaat $\quad 154$

5.5 Botsende waarden, botsende grondrechten 157

5.6 Afsluitende opmerking: maatschappelijke waarden als voorwaarden voor $\begin{array}{ll}\text { een goed functionerende rechtsstaat } & 166\end{array}$

$6 \quad$ Samenleven met verschillende culturele normen $\quad 169$

$\begin{array}{lll}6.1 & \text { Inleiding } & 169\end{array}$

$\begin{array}{ll}\text { 6.2 Culturele diversiteit en dynamiek } & 172\end{array}$

$\begin{array}{lll}6.3 & \text { De betekenis van groepsnormen } & 174\end{array}$

6.3.1 Normhandhaving binnen de eigen groep en afvalligheid 178

6.3.2 Positie van de vrouw 180

6.3.3 Positie van het kind ten opzichte van de ouders $\quad 185$

6.3.4 Het opleggen van de groepsnormen aan de samenleving als geheel 188

$\begin{array}{lll}6.4 & \text { Strategieën } & 190\end{array}$

$\begin{array}{lll}6.5 & \text { Conclusies } & 193\end{array}$ 
7.1 Inleiding: deel van het probleem, deel van de oplossing

7.2 Waarden, normen, regels en gedrag in een institutionele context

7.4.2 Gevolgen voor de overdracht en handhaving van waarden en normen

7.4.3 Interacties tussen instituties

Waarden en normen in het onderwijs

7.5.3 Primaire, secundaire en tertiaire taken van het onderwijs

7.7.2 De inhoudelijke invloed van de media op waarden en normen

$\begin{array}{lll}\text { 7.7.4 Verantwoordelijkheid en verantwoording } & 233\end{array}$

$\begin{array}{ll}8.2 & \text { Het belang van een publieke moraal } \\ 8.39\end{array}$

8.3 De beantwoording van de onderzoeksvragen

8.4 De praktische taken van de overheid ten aanzien van waarden, normen en gedrag

8.6 De opbrengst van investeringen in waarden, normen en gedrag

$\begin{array}{ll}8.7 .2 & \text { Concrete aanbevelingen } \\ 8.7 .3 & 265\end{array}$

$\begin{array}{lll}8.7 .3 & \text { Tot besluit } & 272\end{array}$ 


\section{SAMENVATTING}

Dit rapport behandelt de vraag welke gemeenschappelijke waarden onze samenleving binden en over welke waarden conflicten kunnen rijzen, mede gezien in het licht van culturele verschillen. Het toenmalige kabinet legde deze vraag voor aan de Wetenschappelijke Raad voor het Regeringsbeleid, in zijn adviesaanvraag van 8 november 2002, in het kader van het derde spoor van het debat over waarden en normen.

De WRR heeft de probleemstelling enigszins verruimd. De achtergrond ervan was immers niet alleen een gevoel van onzekerheid over de gemeenschappelijkheid van waarden en normen in onze huidige samenleving. Het ging ook om het gegeven dat feitelijk gedrag vaak niet in overeenstemming is met die gemeenschappelijke waarden of met bepaalde, al dan niet wettelijke, normen. Ergernissen daarover liggen aan veel discussies over waarden en normen ten grondslag. In dit rapport stelt de WRR derhalve twee hoofdthema's aan de orde:

1 het vraagstuk van normoverschrijdend gedrag, van fatsoenlijke omgangsvormen en het niet nakomen van vele, vaak niet precies omschreven gedragsnormen; en

2 het vraagstuk van de gemeenschappelijkheid en de pluriformiteit van waarden en het omgaan met uiteenlopende stelsels van waarden en normen, die met cultuurverschillen samenhangen.

De raad onderschrijft het belang van beide thema's, maar geeft in het rapport wel aan dat een nadere structurering van de zeer algemene problematiek nodig is, om te komen tot zinvol beleid. Ook behandelt het rapport de bijdrage die de samenleving zelf kan leveren aan het onderhouden en overdragen van belangrijke waarden en normen en de specifieke rol die de overheid hierbij zou kunnen, en op sommige punten zou moeten, spelen. De raad meent dat de taak van de overheid allereerst bestaat uit het tegengaan van wettelijke normoverschrijdingen en uit het voorzien in een effectieve rechtshandhaving; daarnaast uit het garanderen van de waarden van een open samenleving en de democratische rechtsstaat, en uit het ondersteunen van de publieke moraal. Voor het overige is het in de eerste plaats de samenleving zelf, die waarden vormt en onderhoudt. Instituties zoals scholen, media en andere maatschappelijke organisaties leveren bij het vervullen van hun eigen taken ook een bijdrage aan het algemene onderhoud van waarden en normen. De taak van de overheid is hier vooral stimulerend en ondersteunend.

\section{Waarden verschillen van normen}

Waarden hebben structureel andere kenmerken dan normen, zodat een automatische koppeling van waarden aan normen eerder verwarrend werkt dan verhelderend. Waarden scheppen ruimte, normen brengen beperkingen aan; waarden geven aan wat in abstracte zin goed, gewenst en waardevol wordt gevonden, normen geven meestal veel concreter aan wat onjuist en ongewenst wordt geacht. Waarden bepalen geen specifieke gedragingen, normen geven wel concrete richtlijnen voor gedrag. Ook al onderschrijven mensen dezelfde waarden, toch kan 
hun feitelijke gedrag, dat op die waarden is georiënteerd, zeer ver uiteenlopen. $\mathrm{Bij}$ normen is het nuttig onderscheid te maken tussen enerzijds rechtsnormen, die voor iedereen verplichtend zijn en anderzijds bepaalde sociale en morele normen, die geen wettelijke bekrachtiging kennen en die beperkt blijven tot bepaalde sociale groepen. Het begrip normoverschrijdend gedrag kan in negatieve zin zowel betrekking hebben op sociale en morele, als op wettelijke normen. Op sociale en morele normoverschrijdingen, die niet samenvallen met wettelijke normoverschrijdingen, dient principieel anders te worden gereageerd dan op onduldbare en onwettige gedragingen, al is een precieze grens tussen deze soorten gedragingen in een samenleving nooit voor honderd procent scherp te trekken. Omdat conflicten over waarden en normen in een samenleving onvermijdelijk zijn, zijn stabiele manieren om deze conflicten op zo'n manier op te lossen dat de samenleving niet intern wordt verscheurd, van uitermate groot belang. De democratische rechtsstaat en de daarin tot uitdrukking gekomen waarden en normen bieden dit stabiele en gemeenschappelijke kader.

\section{De steun van de bevolking voor gemeenschappelijke waarden}

Het is verre van eenvoudig een goed en betrouwbaar beeld te krijgen van de ontwikkelingen in de tijd ten aanzien van waarden, normen en verschillende vormen van normoverschrijdend gedrag. Indien men gebruik maakt van bevolkingsenquêtes, onder andere van het Sociaal en Cultureel Planbureau, dan kan met enige voorzichtigheid worden gezegd dat het pessimisme over de ontwikkeling van zeden en gedrag in Nederland sterk is toegenomen, terwijl tegelijkertijd de onzekerheid afnam over de vraag wat goed en slecht is. Dit suggereert dat Nederlanders steeds zelfbewuster en kritischer zijn geworden over het gedrag van hun landgenoten. De steun onder de Nederlandse bevolking voor de waarden van de rechtsstaat en de democratie is groot en lijkt eerder toe dan af te nemen. Nederland verschilt hierin niet sterk van andere EU-landen. Bij de steun voor algemene waarden is er geen sprake van eenduidige tendenties die zonder meer kunnen worden geïnterpreteerd als 'verval van waarden en normen'. Wel kunnen wetsovertredingen rekenen op weinig begrip van de Nederlandse bevolking. Over twee specifieke vormen van wetsovertredingen - sociale zekerheidsfraude en belastingontduiking - zijn Nederlanders in de jaren negentig strenger gaan oordelen. Slechts ten aanzien van softdruggebruik oordelen Nederlanders milder dan inwoners van andere landen. Jongere generaties blijken iets minder streng te oordelen over 'zeden en gedrag' van anderen dan de oudere generaties.

\section{Normoverschrijdend gedrag}

Er bestaat een grote variatie aan normoverschrijdend gedrag, dat heel vaak overlast met zich mee brengt voor medeburgers. Naast lichtere vormen van overschrijdingen van bepaalde sociale, niet-wettelijk voorgeschreven normen die als 'onprettig' kunnen worden beschouwd, komen er onbehoorlijke, onduldbare en vooral onwettige gedragingen voor, die zwaardere vormen van normoverschrijding inhouden. Enkele zware vormen van onwettig gedrag, waaronder geweldpleging, zijn de afgelopen tien à vijftien jaar in aantal sterk toegenomen. Het problematische normoverschrijdende gedrag concentreert zich voor een belang- 
rijk deel bij een relatief kleine groep mannelijke adolescenten en jongvolwassenen. Geweld en agressie op school, in het openbaar vervoer, in het verkeer en rond het voetbalstadion worden voor een groot deel gepleegd door mannen in de leeftijd tussen vijftien en dertig jaar. Vaak opereren ze in een groep waarbinnen andere normen gelden dan de algemeen aanvaarde. Dit hoeft echter niet te betekenen dat door de leden van een dergelijke groep in onze maatschappij gangbare waarden en normen in het geheel niet worden onderschreven. Het normoverschrijdende gedrag van deze groepen blijkt samen te hangen met hun onvermogen in de gewone maatschappij een plaats te veroveren of erkenning te krijgen. Dit geldt met name voor veel jongeren uit immigrantenmilieus. Ook gewone burgers vertonen echter normoverschrijdend gedrag, met name bij emotionele reacties op onaangename gebeurtenissen, zoals bij agressie in het verkeer of in het openbaar vervoer. Berekenende vormen van normoverschrijdend gedrag, zoals zwartwerken en belastingontduiking, worden vaak gerechtvaardigd met een verwijzing naar het normoverschrijdend gedrag van 'anderen'.

Er zijn verschillende gradaties van normoverschrijdend gedrag te constateren: van onprettig tot onwettig gedrag. Reactiewijzen zoals dulden en het bespreekbaar maken van onbehoorlijk gedrag horen bij lichtere overschrijdingen van sociale normen. Formele overheidsreacties zoals verbieden en handhaven van normen horen bij zwaardere en onduldbare normoverschrijdingen, maar ook hier past het bespreken van het gedrag en het confronteren van de daders met de gevolgen ervan. Een nadere analyse van normoverschrijdend gedrag laat zien dat voorbij een bepaald omslagpunt een kleine afname van formele sociale controle kan leiden tot een sterke toename van normoverschrijdend gedrag. Als bepaalde normen zijn afgekalfd, vraagt herstel een onevenredig grote inspanning. Herstel van de oorspronkelijke mate van normconform gedrag is dan niet meer uitsluitend te bereiken via formele overheidscontrole; het vertrouwen in de norm is dan al ondermijnd. Informele sociale controle, in tal van sociale instituties en organisaties, is voor een dergelijk herstel onmisbaar. Overheid en instituties dragen daarvoor gezamenlijk verantwoordelijkheid, waarbij de overheid de primaire taak houdt van een strikte rechtshandhaving. In het rapport beschrijft de WRR verschillende strategieën om binnen instituties en organisaties en vanuit de overheid de vele vormen van normoverschrijdend gedrag te blijven bestrijden.

\section{Pluriformiteit en gemeenschappelijkheid van waarden}

Pluriformiteit in waarden en normen is een kenmerk van een moderne samenleving. Door de maatschappelijke veranderingen van de afgelopen dertig jaar is een geïndividualiseerd waardepatroon beter mogelijk geworden, waarbij overigens de waarden van persoonlijke vrijheid en gelijkheid als centrale waarden van een burgerlijke samenleving onveranderd hoog worden gehouden. Een moderne samenleving staat voor de opgave de grote mate van pluriformiteit te laten samengaan met voldoende eenheid en gemeenschappelijkheid. Men hoeft niet precies dezelfde redenen te hebben om bepaalde centrale waarden te onderschrijven, als men deze waarden maar in praktisch gedrag blijft ondersteunen. De waarden van de democratische rechtsstaat en die van een open samenleving 
vormen een gemeenschappelijke kern, die de pluriformiteit van waarden mogelijk maakt en zelf bepaalde waarden inhoudelijk ondersteunt. Die kern maakt het tegelijk mogelijk voldoende overeenstemming te behouden over de wijze waarop waardeconflicten moeten worden bijgelegd. Inhoudelijke waarden, die de open, westerse samenleving hebben gevormd en die ook voor de toekomst blijven gelden als belangrijke richtinggevende waarden, zijn onder andere: geloof in de toekomst, de bescherming van persoonlijke vrijheid en autonomie, rede en redelijkheid, universaliteit, rechtvaardigheid en gelijkheid. Deze waarden zijn echter zo abstract, dat ze een dynamische ontwikkeling om aan deze waarden concrete inhoud en richting te geven, stimuleren. Dit geldt evenzeer voor de centrale waarden van de rechtsstaat, waaronder grondrechten die telkens een nieuwe, soms verruimende, soms beperkende interpretatie kunnen krijgen. Botsingen van grondrechten zijn onvermijdelijk, maar kunnen door de kracht van de rechtsstatelijke instituties in goede banen worden geleid.

\section{Botsing van waardestelsels en omgaan met culturele verschillen}

De culturele diversiteit in de Nederlandse samenleving is toegenomen, maar daardoor is het belang van het beginsel van de waardepluriformiteit niet veranderd. Het benadrukken van culturele verschillen in termen van afwijkende normen en waarden kan leiden tot culturele isolatie en reacties gericht op culturele eenvormigheid. De problemen die samenhangen met culturele diversiteit moeten echter wel realistisch bespreekbaar worden gemaakt. Sommige praktijken van leden van bepaalde etnische groepen zijn in strijd met de Nederlandse wet, andere praktijken verhouden zich moeizaam met wat in Nederland belangrijk wordt gevonden, met name het beginsel van persoonlijke auto-nomie, de positie van vrouwen en meisjes en de reacties op afwijkend gedrag in eigen kring. Groepsnormen worden nu nog vaak ingezet om persoonlijke keuzen van de leden van bepaalde groepen tegen te gaan of te onderdrukken. Vaak ontbreekt een exit-optie en dit ontbreken staat op gespannen voet met het algemeen aanvaarde beginsel van de individuele waardekeuze. Er is echter sprake van een glijdende schaal in de mate waarin groepsnormen strijdig zijn met in Nederland aanvaarde normen. Bij het inzetten van strategieën voor de omgang met deze verschillen en strijdpunten is het van belang na te gaan wat wezenlijk in strijd is met de waarden en normen van de democratische rechtsstaat en wat als niet-essentieel bespreekbaar kan worden gemaakt of, al of niet tijdelijk, kan worden geduld. Het spreekt vanzelf dat de overheid de primaire verantwoordelijkheid heeft bij het normeren en verbieden van praktijken die in strijd zijn met de wet. De overheid zou, meer dan nu gebeurt, zichtbaar moeten optreden en duidelijk moeten maken wat in Nederland niet wordt aanvaard. Aan de andere kant kan de overheid bevorderen dat verschillen worden geaccepteerd en dat het dulden van verschillen een noodzakelijke voorwaarde is om een pluriforme samenleving in stand te houden. In situaties die niet zonder meer onwettig zijn, maar wel zodanig conflictueus dat oplossingen nodig zijn, heeft de overheid een procedurele rol te vervullen: de verschillen bespreekbaar maken en zorgen voor goede conflictbeslechtende mechanismen, van formele en van informele aard. 


\section{De bijdrage van de samenleving, in het bijzonder van het onderwijs}

De samenleving is deel van het probleem van waarden en normen, en is daarmee tevens een deel van de oplossing. Burgers, maatschappelijke organisaties en instituties hebben zelf de verantwoordelijkheid om gewenste waarden en normen te onderhouden, te verbreiden en over te dragen. Deze taak berust niet primair bij de overheid. Versterking van de eigen inbreng van instituties ten aanzien van waarden en normen, is nodig. Die inbreng kan worden bevorderd door meer ruimte en aandacht te schenken aan de normatieve en morele aspecten van de werkzaamheden binnen instituties; te beginnen met een goede handhaving van gedragsregels binnen instituties. Instituties zijn evenzeer verantwoordelijk voor de effecten die zij hebben op de werking van andere instituties en op de samenleving als geheel, met name wat betreft de handhaving van algemene gedragsnormen.

Aan de school en aan het onderwijs wordt vaak een bijzondere taak toegekend bij de overdracht van algemene waarden en normen. Dit is in zoverre juist dat in de verschillende onderdelen van het onderwijs, met name in de lessen, waarden worden aangeleerd. Maar ook in het algehele klimaat op school, in de gedragsregels die er bestaan en in de discipline die wordt aangeleerd, heeft het onderwijs een belangrijke morele en pedagogische taak. Deze taak hoeft niet te worden ondergebracht in een apart vak 'waarden en normen', maar dient wel in het bestuur en beheer van de school en in de beoordeling van de kwaliteit van het onderwijs expliciet aan de orde te komen. De specifieke overdracht van belangrijke waarden van de rechtsstaat, de democratie en burgerschap dient deel uit te maken van bestaande vakken zoals geschiedenis en maatschappijleer. In lerarenopleidingen voor met name het voortgezet onderwijs dient meer tijd en aandacht te worden besteed aan gedragsregels en de handhaving ervan, alsook aan het omgaan met morele vraagstukken in de klas. Ten aanzien van inburgering bepleit de raad dat deze bijdraagt aan een aanzienlijke verhoging van de arbeidsparticipatie van nieuwkomers. De raad vindt dat de bureaucratisering rond inburgeringcursussen moet worden teruggedrongen. Hierbij dient het vak maatschappijoriëntatie meer gericht te zijn op burgerschapsvorming en de beginselen van de rechtsstaat.

\section{Conclusies en aanbevelingen}

Ten aanzien van de rol van de overheid komt de WRR in dit rapport tot twee hoofdconclusies.

1 De overheid heeft ten aanzien van de waarden- en normenproblematiek een primaire taak in het bewaken van de gemeenschappelijke waarden, met name die van de democratische rechtsstaat. Hiervoor dient een publieke moraal te worden gestimuleerd, ten behoeve van een vreedzaam en fatsoenlijk verloop van de soms gespannen onderlinge verhoudingen tussen burgers. Openbare gezagsdragers moeten zelf het voorbeeld geven van een integer openbaar bestuur.

2 De overheid heeft een primaire taak in het tegengaan van gedrag dat wettelijke normen schendt, maar het tegengaan van de vele vormen van normoverschrijdend gedrag in het algemeen kan niet uitsluitend worden gerekend tot de verantwoordelijkheid van de overheid. De pijlers van de samenleving, dat wil 
zeggen burgers, organisaties en instituties, zijn daarvoor ieder op zijn eigen wijze verantwoordelijk. De overheid zal deze eigen maatschappelijke verantwoordelijkheid wel beter moeten ondersteunen.

Het rapport eindigt met zeven aanbevelingen.

1 Het bestrijden van wettelijke normoverschrijdingen, met name wanneer die de persoonlijke integriteit aantasten en het onderlinge vertrouwen tussen burgers ondermijnen, dient een aanhoudende zorg van de regering te blijven, zoals reeds in het WRR-rapport over de toekomst van de rechtsstaat en in de daarop aansluitende regeringsreactie is gesteld.

2 Naast effectieve rechtshandhaving dienen overheid en maatschappelijke instellingen een intensief preventiebeleid te voeren, dat mede gericht dient te zijn op het voorkomen van marginalisering en uitsluiting van groepen, die onvoldoende kunnen voldoen aan de eisen die onze samenleving stelt aan volwaardige participatie.

3 Er dient ruimere beschikbaarheid te komen van vrijwillige opvoedingsondersteuning voor ouders naast een effectievere samenwerking tussen al die instanties die opvoedingstekorten proberen op te vangen en op te heffen. Ondersteuning van buurtprojecten die de onderlinge betrokkenheid van bewoners en sociale controle in de buurt vergroten, dient versterkt te worden. Initiatieven van onderop voor het opstellen van buurtregels en stadsetiquettes in probleemwijken dienen door de lokale overheid ondersteund te worden.

4 De overheid heeft met maatschappelijke instellingen een taak om verschillende waardeopvattingen, vooral wanneer die samenhangen met cultuurverschillen, op ruime schaal bespreekbaar te maken. De discussies dienen om schadelijke en negatieve stereotyperingen tegen te gaan en om burgers met ogenschijnlijk onverenigbare waarden praktisch met elkaar te laten samenleven.

5 Met het oog op te voorziene en onvermijdelijke waardeconflicten heeft de overheid samen met maatschappelijke instellingen de taak om praktische programma's te ontwikkelen voor conflictpreventie en conflictbeslechting. Hierbij staat de gedrags- en handelingscomponent centraal. Deze programma's kunnen op scholen, in buurten, in organisaties en instellingen worden geïntroduceerd.

6 De overheid dient instituties, organisaties en instellingen, die publieke taken vervullen, op ruimere schaal gelegenheid te geven om de morele dimensie van hun werkzaamheden niet te verwaarlozen. De overheid kan dit doen door zelf deze instellingen ruimer te beoordelen dan alleen op meetbare prestaties. Ondersteuning van instituties door de overheid dient vooral stimulerend te zijn en rekening te houden met de institutionele context.

7 Er is een behoefte om de publieke discussie over waarden, normen en normoverschrijdend gedrag te structureren. Dit kan door gebruik te maken van bestaande instellingen, die hier vaak al mee bezig zijn. In deze werkplaatsen voor waarden en normen gaat het om voorlichting en elektronische informatievoorziening, om het entameren van levensbeschouwelijke discussies, om het ontwikkelen van rolmodellen, om conflicten over waarden en normen vreedzaam te laten verlopen en om een verdere wetenschappelijke verdieping van de waardeproblematiek in een pluriforme samenleving. 




\section{TEN GELEIDE}

Dit rapport is voorbereid door een interne projectgroep van de WRR. Voorzitter was prof. dr. mr. C.J.M. Schuyt, lid van de raad. Verder maakten de volgende raads- en stafleden deel uit van de projectgroep: prof. dr. P.T. de Beer (projectsecretaris), drs. D.W.J. Broeders, drs. H. van de Bund, dr. P. den Hoed, prof. dr. P.L. Meurs, mr. J.C.I. de Pree en prof. mr. M. Scheltema.

De analyses in dit rapport zijn mede gebaseerd op bijdragen die door verschillende auteurs in opdracht van de raad zijn geschreven. Kort na dit rapport worden gepubliceerd:

P. de Beer en C.J.M. Schuyt (red.) (2004) Bijdragen aan waarden en normen, WRR Verkenning 2, Amsterdam: Amsterdam University Press, en G.J.M. van den Brink (2004) Schets van een beschavingsoffensief: over normen, normaliteit en normalisatie in Nederland, WRR Verkenning 3, Amsterdam:

Amsterdam University Press.

Bij de voorbereiding van dit advies is voorts, zoals ook in de adviesaanvraag is gevraagd, overleg geweest met (vertegenwoordigers van) de Onderwijsraad, de Raad voor Maatschappelijke Ontwikkeling (RMO) en het Sociaal en Cultureel Planbureau (SCP). 


\subsection{AANLEIDING TOT EEN RAPPORT OVER WAARDEN EN NORMEN}

Waarden en normen passen niet op een spandoek. De hernieuwde aandacht voor de problematiek van waarden en normen in de Nederlandse samenleving is voortgekomen uit een zeker onbehagen. De discussie duidt op een niet precies omschreven gevoel dat de sociale binding in de huidige samenleving aan het verminderen is, het vertrouwen tussen burgers onderling en tussen burgers en overheid verslechterd is en dat in toenemende frequentie gedragingen worden geconstateerd die in strijd komen met elementaire waarden en normen. Hierbij valt onder andere te denken aan voorvallen van geweld op straat, agressie op scholen, in ziekenhuizen en in het openbaar vervoer, bedreigingen van politici en medeburgers.

Een discussie over waarden en normen is op de maatschappelijke agenda gekomen als uitdrukking van een politiek onderscheid. In de aanloop van de verkiezingen van mei 2002 werd het onderwerp 'waarden en normen' onderdeel van het politieke programma van het CDA en de LPF. Het CDA had al enkele jaren daarvoor het gemeenschapsdenken, waarin gemeenschappelijk gedeelde waarden en normen in een samenleving centraal staan, gesteld tegenover de meer op 'materialistische' belangen georiënteerde politiek van het tweede Paarse kabinet. De LPF vroeg, in het verlengde van deze kritiek op Paars, eveneens meer aandacht voor de lange wachttijden in de zorg, de neergang van bepaalde buurten in grote steden, een sterkere handhaving van recht en orde en de problematische positie van niet-geïntegreerde allochtonen in de samenleving. In het politiek roerige jaar 2002 is de problematiek van 'waarden en normen' als thema, dat zeer uiteenlopende onderwerpen en maatschappelijke ergernissen met elkaar verbond, niet meer van de politieke en maatschappelijke agenda verdwenen. De publieke meningsvorming werd erdoor gevoed, zoals omgekeerd het publieke debat over waarden en normen in kranten, tijdschriften en andere media de politici aanspoorde om de problematiek die eronder schuilgaat, serieus te nemen.

Het politiek geweld, de moord op Fortuyn voor de verkiezingen en de bedreigingen aan het adres van andere politici in de periode na de verkiezingen vermeerderden het reeds bestaande gevoel van onbehagen over de sociale en politieke situatie in Nederland. Het onbehagen kreeg een nog sterkere morele toon: wat was er mis met de waarden en normen, dat zoiets ongehoords onverwacht in Nederland kon gebeuren? Zou een moreel herstel niet het antwoord moeten zijn op deze onduldbare gebeurtenissen?

De politieke aardverschuiving van de verkiezingen in mei 2002 resulteerde in de vorming van het kabinet-Balkenende I. In de plannen van dit kabinet (Strategisch Akkoord 2002: 72-73) en bij de Algemene Politieke Beschouwingen over de regeringsverklaring, op 18 en 19 september 2002, werd een aanpak van 'waarden en 
normen in de samenleving' in het vooruitzicht gesteld. Per brief van 4 oktober 2002 aan de Tweede Kamer (Tweede Kamer 2002-2003, 28600, nr. 42) zette minister-president Balkenende drie sporen uit waarlangs de aanpak zou verlopen: 1) een inventarisatie van de voornaamste ergernissen van burgers; 2) een departementale inventarisatie van reeds lopende overheidsprojecten, die bij zouden kunnen dragen aan de problematiek van waarden en normen; en 3) een adviesaanvraag aan de Wetenschappelijke Raad voor het Regeringsbeleid over de vraag welke fundamentele waarden onze samenleving bindt en over welke waarden conflicten kunnen rijzen, mede gezien in het licht van culturele verschillen. Op 8 november 2002 ontving de WRR de officiële adviesaanvraag, die dienovereenkomstig de grondslag vormt voor dit rapport. De adviesaanvraag is als bijlage aan dit rapport toegevoegd.

\section{WAARDEN EN NORMEN IN RECENTE OPENBARE DISCUSSIES}

Dat de belangstelling voor het onderwerp waarden en normen in brede lagen van de bevolking werd gedeeld, bleek uit opinieonderzoek van het onderzoeksinstituut NIPO, dat in september 2002 bekendmaakte dat "Nederlanders in alle lagen van de bevolking het verval van normen en waarden, overigens samen met criminaliteit en de problemen in de gezondheidszorg, de voornaamste maatschappelijke kwestie vinden". Ongeveer gelijktijdig deed de toenmalige minister Heinsbroek het voorstel om een mediacampagne rond het thema te starten ('Ook normen kun je met marketing verbreiden’).

Het debat in de Tweede Kamer over het specifieke onderwerp van waarden en normen (18 december 2002) gaf op enkele momenten blijk van verwarring. Wat was nu eigenlijk het probleem? Waar moest het debat over gaan? Over welke verschijnselen ging het: over het bijbrengen van fatsoensregels of over de fundamentele waarden die ten grondslag liggen aan elke samenleving? Over wetten of bijbelse waarden? Het debat zelf was, mede door de strakke vormregels van de parlementaire discussie, een mooi voorbeeld van welke onderwerpen zoal aan de orde kunnen komen in een openbaar debat over waarden en normen. Het ging zowel over het belang van bijbelse waarden in de samenleving als over de plaats van de grondrechten. Er ontspon zich een interessante en pittige discussie over de vraag naar een hiërarchie tussen deze grondrechten. De waarden van gezin en opvoeding kwamen aan de orde, evenals de waarden van solidariteit en het belang van sociale cohesie. Telkens werden deze belangrijke waarden aan beleidsvoornemens van de regering gekoppeld, waardoor enige onduidelijkheid ontstond over het verschil tussen algemene politieke beschouwingen en een parlementair debat over waarden en normen. Het was daarbij soms moeilijk het algemene en abstracte onderwerp van waarden en normen los te blijven zien van allerhande afzonderlijke en bijzonder concrete onderwerpen. Er werden door enkele woordvoerders pogingen gedaan om een grens af te bakenen tussen rechtsnormen en leefregels, die voor iedereen gelden, en andere normen zoals bijvoorbeeld fatsoensregels. Worden de waarden van de samenleving in wetten neergelegd of bestaan er ook daarbuiten nog regels waarvoor de overheid zich 
verantwoordelijk mag of zelfs moet stellen? Over de precieze taak van de overheid in deze algemene kwestie werden verschillende standpunten geformuleerd. Het debat kreeg echter geen vastomlijnde conclusie en dat was, gezien de veelheid en abstractiegraad van de besproken onderwerpen, ook zeer lastig (Handelingen Tweede Kamer, 2002-2003, nr. 35 2609-2646).

Hiermee heeft de politiek een belangrijk thema op de maatschappelijke agenda geplaatst, dat vruchtbaar kan worden uitgewerkt, mits de problematiek niet eindeloos wordt opgerekt of ongedefinieerd gelaten. Dat is de taak die de WRR in dit rapport op zich genomen heeft. Want zowel uit het debat in de Tweede Kamer als uit de daarna veelvuldig gehouden gesprekken en debatten in de media blijkt dat weinig personen moeite hebben om een concreet maatschappelijk verschijnsel waaraan problematische kanten zitten, te koppelen aan de veel ruimere en algemene problematiek van waarden en normen. Men heeft het er dan over dat mensen in de tram niet meer opstaan voor ouderen of men stoort zich aan het gedrag van anderen in de openbare ruimte. Men ergert zich aan rommel en rotzooi, afval en hondenpoep op straat. Er wordt schande gesproken over onfatsoenlijk gedrag in het verkeer en over onbehoorlijk, assertief en zelfs agressief gedrag jegens medeburgers. Het zijn stuk voor stuk voorbeelden van irriterende en bedreigende ervaringen die misschien geen wetsovertredingen zijn, maar wel een sociale norm overschrijden. Het lijkt alsof burgers niet meer fatsoenlijk met elkaar om kunnen gaan. Weer anderen weten daaraan toe te voegen dat scholen en onderwijzers geen opvoedkundige taken meer kennen, of niet meer aan deze taken toekomen door het lerarentekort of andere negatieve invloeden van buitenaf. Al met al ontstaat zo een beeld van Nederland waarin de teloorgang van de publieke en semi-publieke ruimte aan de orde is: bushaltes, treinperrons en stations zijn plekken waar men zich beter niet kan vertonen; prullenbakken zijn overvol, reclamezuilen zijn kapot, de verlichting werkt niet. Men wijst op de verwaarlozing van stadsbuurten als gevolg van verval en leegstand van huizen, verslaafden en dealers op straat, hetgeen een onveilig en ontheemd gevoel teweegbrengt. Naast deze gevoelens van onveiligheid zijn er concreet ervaren gevolgen van geweldsmisdrijven, van veelvuldige winkelinbraken met geweld, van lichamelijke en psychische bedreigingen, bij elkaar tastbare gedragingen die duidelijke wettelijke normen overschrijden.

Dergelijke observaties worden door velen herkend en men staat niet meer stil bij de vraag in hoeverre dit beeld, gebaseerd op enkelvoudige en niet-systematische waarnemingen en selectieve gevoeligheid, een overdrijving vormt van de werkelijke situatie in Nederland. Wat wel goed gaat en waar het wel goed gaat wordt zo aan de aandacht onttrokken. Niettemin hebben dergelijke feiten en gevoelens met elkaar gemeen dat ze vooral een overschrijding van een bepaalde norm aangeven. Het betreft ofwel een norm die in de wet is vastgelegd en waarvan de overtreding in principe strafbaar is (kleine criminaliteit, niet betalen in tram of bus, verkeersovertredingen, geweldsmisdrijven), ofwel een norm die verwijst naar een idee van algemeen fatsoen en correct gedrag (opstaan in de tram, niet met de benen op de zitting van bus en tram). Er is een oplopende schaal van 
normoverschrijdingen die gaat van onprettige naar onwettige gedragingen, met als tussenliggende gradaties onbehoorlijke, overlast bezorgende en ronduit onduldbare gedragingen.

Er zijn echter ook voorbeelden te noemen van onderwerpen die in discussies over waarden en normen veelvuldig aan bod komen, maar die algemener en abstracter van aard zijn. Hierbij moet gedacht worden aan thema's als tolerantie ('Is er te weinig tolerantie of is er juist sprake van doorgeschoten tolerantie?'), gezamenlijkheid, een gevoel van verlies aan gemeenschapszin door de aanwezigheid van andere culturen en culturele uitingen van andere religies (hoofddoekjes). Een veelgehoord thema hierbij is dat mensen zeggen niet over dergelijke onderwerpen te durven spreken uit angst om voor racist te worden uitgemaakt. In algemene zin lijkt dit ongenoegen te bestaan in de vrees dat belangrijke waarden in de samenleving, zoals het streven naar gelijkheid tussen mannen en vrouwen, het niet gebruiken van geweld in de opvoeding of tussen partners en de openlijke aanvaarding van homoseksualiteit niet meer door iedereen worden onderschreven.

Anderzijds klagen mensen eveneens over het feit dat dergelijke belangrijke westerse liberale waarden te ver zijn doorgeschoten. De democratiseringsgolf en de emancipatiebewegingen uit de jaren zestig zouden burgers te veel vrijheden hebben opgeleverd, zonder dat daar voldoende controle of grenzen door de overheid tegenover gesteld werden. Dit patroon van te veel of te weinig vrijheid, te veel of te weinig integratie, te veel of te weinig inleving in de culturele waarden van anderen, schept een diffuus gevoel van onbehagen, dat zich uit in en vastklampt aan steeds wisselende onderwerpen en concrete probleemgevallen of incidenten. De diffuusheid van dit patroon van bestaande waarden en normen maakt het voor nieuwkomers extra moeilijk om te weten hoe ze zich aan moeten aanpassen en waar ze zich aan moeten houden.

Wat kan men leren van deze openbare discussies over waarden en normen? Welke conclusies zou men eruit kunnen trekken? Allereerst een negatieve: een discussie over waarden en normen kan in principe over alles gaan met het niet irreële gevaar dat het dan tot niets leidt. Een waarden- en normendiscussie zonder een duidelijke probleemafbakening ('Wat is precies het probleem?') of duidelijke begripsomschrijving ('Waar hebben we het over?') levert geen resultaat op en zal op den duur juist gaan irriteren. De waarden- en normendiscussie loopt een constant gevaar een politieke slogan te worden, zoals werd geïllustreerd in de reclametekst van Postbus 51, het voorlichtingsorgaan van de rijksoverheid: 'Wij zijn vóór waarden en normen'. Welke waarden? Wiens normen? Welk soort gedrag? Waarden en normen lenen zich niet voor een billboard. Men kan niet vóór waarden en normen zijn, zoals men ook niet vóór het weer kan zijn. Er kunnen in abstracto geen problemen zijn met 'waarden en normen', zoals er ook geen problemen kunnen zijn met het weer in zijn algemeenheid: bedoelt men dat er te lange droogte is (waardoor boeren en burgers gaan klagen), of dat er te veel regen valt (waardoor boeren en burgers gaan 
klagen)? Zonder nadere definiëring van problemen en begrippen wordt een discussie in zijn algemeenheid over waarden en normen in de samenleving uitzichtloos.

Daarom is een andere conclusie te trekken uit de vele discussies. Er zijn duidelijk twee centrale thema's te benoemen die in de discussies over waarden en normen telkens aan de orde worden gesteld:

1 fatsoenlijke omgangsvormen en het niet nakomen van vele, vaak niet precies omschreven gedragsnormen; dit is het vraagstuk van normoverschrijdend gedrag; en

2 het omgaan met uiteenlopende waarden en cultuurverschillen; dit is het vraagstuk van gemeenschappelijkheid en pluriformiteit.

Ad 1. Bij de handhaving van normen gaat het om een veelheid en veelsoortigheid van normen. Het gaat zowel om praktische fatsoensnormen op school, op het werk, in het openbaar vervoer en vooral in de publieke ruimte, alsook om regelmatige overtredingen van rechtsnormen in de vorm van kleine en grotere criminaliteit. Het gaat, kortom, om de zorg over onprettig, onbehoorlijk en onwettig gedrag. Met dit thema van normhandhaving en normoverschrijdend gedrag hangen enkele subthema's samen, zoals (a) het algemenere probleem van criminaliteit en veiligheid, (b) de gevolgen hiervan voor de directe leefomgeving in verwaarloosde grote stadsbuurten, (c) het ervaren gebrek aan fatsoen op straat en in de openbare ruimte.

Ad 2. Er is onzekerheid over de rol die andere dan de vertrouwde westerse culturele waarden in de samenleving spelen. Daarmee hangt het gedrag van immigrantengroepen direct samen: wat mag van hen verwacht en verlangd worden in de integratie in de Nederlandse samenleving? Als subthema's zijn hier te noemen: (a) de vraag naar de verenigbaarheid van het karakter van de verschillende waarden, zowel religieuze waarden als seculiere waarden, en van het samengaan van zeer uiteenlopende levensstijlen, van zowel jonge als oudere mensen, (b) de al of niet geslaagde integratie van nieuwkomers en daarmee samenhangende processen van segregatie, (c) de gevolgen van de aanslagen op het WTC en het Pentagon op 11 september 2001 voor de onderlinge verhoudingen tussen diverse bevolkingsgroepen en (d) de positie van de islam als tweede grote godsdienst in onze samenleving.

In feite vragen beide hoofdthema's naar de minimaal noodzakelijke gemeenschappelijkheid in de huidige, uiterst pluriform geworden samenleving. De vraag naar minimale gemeenschappelijkheid strekt zich verder uit dan alleen tot de hierboven aangeduide relatie tussen de islam en westerse waarden. Het betreft evenzeer de vraag wat EO-jongeren, leden van studentencorpora en de gay-scene in Amsterdam nog met elkaar verbindt. In vergelijking met vroegere discussies over ethische kwesties in de samenleving, bijvoorbeeld het 'ethisch reveil' in de jaren zeventig, valt het op dat het eerste thema nu veel meer betrekking heeft op allerhande soorten normen en gedragingen en niet uitsluitend op 
ethische normen met betrekking tot abortus, euthanasie en gemeenschapszin, terwijl het tweede hoofdthema nu als nieuw op de morele maatschappelijke agenda naar voren is gekomen. Deze vaststelling heeft gevolgen voor de probleemstelling en de verdere inhoudsbepaling van dit rapport.

\subsection{PROBLEEMSTELLING VAN HET RAPPORT}

Uit het voorgaande overzicht van de discussie in Nederland komt naar voren dat er verschillende concrete onderwerpen centraal staan in de problematiek van waarden en normen in een samenleving. Het gaat om het belang van gemeenschappelijke waarden in een heterogeen geworden moderne samenleving, om mogelijke waardeconflicten die samenhangen met cultuurverschillen, om geconstateerde ernstige tekorten in normhandhaving en de frequenties van normoverschrijdend gedrag (van onprettig, via onbeschaafd, naar onwettig gedrag), om de ingewikkelde relatie tussen waarden, normen en gedrag. Ook komt de vraag aan de orde of het onderwijssysteem kan worden belast met extra taken, namelijk met het overdragen van waarden die in de multiculturele samenleving als gemeenschappelijke waarden centraal staan. Heeft de overheid een rol te spelen bij al deze kwesties, die deels in de particuliere sfeer liggen, deels tot de alledaagse en normale onderwerpen van overheidsbeleid gerekend worden? In de adviesaanvraag van het kabinet staan deze onderwerpen duidelijk omschreven. Deze adviesaanvraag is allereerst een leidraad geworden voor de probleemstelling van dit rapport. De in de adviesaanvraag aan de WRR gestelde vragen dienen in dit rapport in elk geval beantwoord te worden. Daarnaast en daarna mogen ook andere vragen gesteld worden en is de WRR vrij om de gestelde vragen enigszins te kantelen en te herformuleren, of in een ander vruchtbaar perspectief te zetten.

Dit resulteert in de volgende algemene probleemstelling.

Is er in Nederland sprake van een afnemende steun voor essentiële waarden en normen in onze samenleving? Is er sprake van een afnemende naleving van deze waarden en normen? Op welke wijze kan de overheid de steun voor en naleving van deze waarden en normen bevorderen?

Gelet op de adviesaanvraag valt het eerste deel van deze probleemstelling uiteen in vier deelvragen met betrekking tot de waarden en normen.

1 Welke gemeenschappelijke waarden en normen zijn essentieel voor het goed functioneren van onze samenleving?

2 In welke mate worden deze waarden en normen door de bewoners van ons land onderschreven en in welke mate is er sprake van conflicterende waarden en normen, al dan niet samenhangend met cultuurverschillen?

3 Wat is de gewenste en mogelijke rol van de overheid bij het bevorderen van de gemeenschappelijke waarden en normen?

4 Welke waarden zijn vooral van belang voor de toekomstige Nederlandse samenleving? 
Omdat de aanleiding van de adviesaanvraag in elk geval ook de zorgen om uiteenlopende afkeurenswaardige gedragspatronen in de samenleving behelsde, vindt de raad het gewenst om ook expliciet aandacht te besteden aan deze gedragingen. De gedragscomponent heeft de raad, op eigen gezag, aan de probleemstelling toegevoegd. Hij is verwoord in het tweede deel van de algemene probleemstelling. Vanwege de belangrijke rol die instituties spelen in de overdracht en de handhaving van waarden en normen, ligt het daarnaast voor de hand aparte aandacht te wijden aan de rol van instituties. De onvermijdelijkheid ervan - waarden staan immers nooit los van een institutionele context - dwingt het rapport als het ware aandacht te schenken aan de sociale mechanismen die de werking van instituties verzwakken of versterken. Bij dergelijke mechanismen moet men denken aan de vele vormen van formele en informele sociale controle, aan het belang van professionele normen en waarden, aan de effecten van schaal op normbeleving en op het gedrag van personen en aan de verschillende wijzen waarop sociale binding in die instituties totstandkomt. De rol van instituties in het algemeen en die van enkele instituties in het bijzonder, zal derhalve, conform de adviesaanvraag, uitvoerig aan de orde komen.

Dit resulteert in de volgende deelvragen met betrekking tot het (normoverschrijdende) gedrag.

5 In welke mate is er sprake van een toename van gedrag dat strijdig is met belangrijke gemeenschappelijke waarden en normen?

6 Welke relatie bestaat er tussen dit gedrag en de waarden en normen die de normovertreders al dan niet onderschrijven?

7 Welke rol spelen maatschappelijke instituties, zoals onderwijs, media en inburgering, bij de overdracht en de handhaving van waarden en normen en bij het omgaan met conflicten?

8 Wat is de gewenste en mogelijke rol van de overheid bij het tegengaan van normoverschrijdend gedrag, het bevorderen van normconform gedrag en het ondersteunen van instituties bij de overdracht en handhaving van waarden en normen?

De WRR heeft met deze probleemstelling en onderzoeksvragen de opdracht van de adviesaanvraag verruimd. De specifieke bijdrage die de raad met dit rapport wil leveren bestaat uit: (a) een systematische analyse en structurering van de zeer diverse problematiek die schuilgaat onder de noemer 'waarden en normen', (b) de aparte aandacht die gegeven wordt aan de gedragscomponent van de waarden- en normenproblematiek, (c) het aanbrengen van een toekomstperspectief op de centrale en gemeenschappelijke waarden die van belang zullen zijn voor de samenleving als geheel in de komende tien tot twintig jaar, (d) het stimuleren van een publieke discussie over het belang van waarden en normen in de samenleving.

Naast dit rapport brengt de raad nog enkele wetenschappelijke verkenningen uit, waarin zelfstandige - en vaak kritische - bijdragen zijn opgenomen van een 
groot aantal wetenschapsbeoefenaren uit verschillende disciplines. Uiteenlopende aspecten van deze waarden- en normenproblematiek, die specifiek spelen in verschillende maatschappelijke sectoren, worden op deze wijze nog eens uitvoerig belicht.

\subsection{MAATSCHAPPELIJKE ACHTERGROND VAN DE DISCUSSIE OVER WAARDEN EN NORMEN}

De belangstelling voor waarden- en normenproblematiek komt niet zomaar uit de lucht vallen en is niet plotseling naar voren gekomen als een politieke twistappel in een spannende verkiezingsstrijd. Er heerst al veel langer onvrede in de westerse landen over de stand van de moraal. Misschien is onvrede over de moraal wel van alle tijden en kan ze gewaardeerd worden als een blijvende impuls tot verbetering van het samenleven. Zowel in het publieke debat als in de moraalfilosofie van de twintigste eeuw wordt herhaaldelijk de vraag opgeworpen of er sprake is van een neergang van de moraal. Morele overtuigingen zijn aan sterke veranderingen onderhevig en deze veranderingen worden vaak ervaren en geïnterpreteerd als ondermijning van een oude en gevestigde moraal. Vooral op het gebied van opvoeding en zedelijkheid zijn de dagelijkse praktijken, als neerslag van normen en waarden, in snel tempo veranderd. Nogal eens wordt in dit verband het bekende gedicht van de Ierse dichter Yeats aangehaald als symbolische samenvatting van een wijdverbreid gevoel van morele verwarring en desintegratie:

"Things fall apart; the center cannot hold;

Mere anarchy is loosed upon the world,

(...)

The best lack all convictions, while the worst

Are full of passionate intensity." (Yeats, Collected Poems)

Maar Yeats schreef dit in de jaren twintig van de vorige eeuw, zodat het gevoel van desintegratie al veel ouder is dan de laatste twee decennia. De desintegratiethese, dat wil zeggen de bewering dat de moraal in westerse landen uiteengevallen is in ontelbare individuele en vaak niet met elkaar in overeenstemming te brengen morele overtuigingen, wordt door velen omarmd, maar is tegelijk omstreden (Kekes 1993). Waar het in deze discussie steeds om gaat is de interpretatie en waardering van de vaak door iedereen als feitelijkheid aanvaarde maatschappelijke veranderingen, zoals de groeiende internationale aard van de onderlinge betrekkingen en communicatievormen, de toenemende individualisering en de vele individuele keuzen die mensen moeten maken in hun leven en de overweldigende invloed van de modernisering door wetenschap en techniek.

Moderne samenlevingen hebben inderdaad grote veranderingen ondergaan. Ze zijn cultureel veelvormig geworden en naar samenstelling van de bevolking zeer heterogeen, onder andere door immigratiestromen, culturele vermengingen en door het uiteenlopen, als een effect van secularisatie en ontzuiling, van reli- 
gieuze en niet-religieuze levensbeschouwingen. Deze diversiteit doorbreekt een vroeger bestaande dominante orde, die een zekere eenheid oplegde aan de interpretaties van de werkelijkheid. Thans zijn er zeer veel verschillende identiteiten en levenswijzen (Emberley 1995: 3-5).

De traditionele bronnen van overdracht van morele overtuigingen en gedragswijzen zijn al lange tijd onder vuur komen te liggen. Met name betreft het hier het gezin, de kerken en traditionele gemeenschappen. Het gezinsleven is opengebroken door beroepsarbeid en moderne communicatiemiddelen. De waarden van een kerkelijke levenswijze staan vaak ver af van de normen die gelden in het moderne wetenschappelijke onderzoek. Traditionele gemeenschappen, kloosterof geloofsgemeenschappen, kleine dorpskernen en ambachtelijke verenigingen hebben het veld geruimd voor grootstedelijke, op rationele grondslag gevestigde, veelal anonieme levenswijzen met een hoge mate van externe mobiliteit. Rituelen en gewoonten die oude morele overtuigingen symboliseerden zijn verbleekt of verdwenen. Er is door een golf van grootschalige organisatievormen en andere permanente reorganisaties een grotere afstand opgetreden tussen burgers en bestuurders. De binding aan en legitimiteit van deze bestuursvormen en organisaties is daardoor verminderd en wordt eerder betwist.

Wat ervoor in de plaats is gekomen is een zeer gefragmenteerd scala aan maatschappelijke instituties en organisaties, die allemaal op eigen wijze morele codes uitzenden. In de huidige samenleving kan men dagelijks geconfronteerd worden met zeer uiteenlopende en soms ook zeer tegenstrijdige morele boodschappen: televisiemaatschappijen en filmindustrie hebben ieder hun eigen morele wereld geschapen waarin goed en kwaad, onschuld en geweld bijna niet meer van elkaar zijn te onderscheiden; religieuze sekten doen van zich horen op landdagen waaraan veel publiciteit wordt gegeven; rechtbanken doen in het volle licht van de schijnwerpers uitspraken over wat wel en niet mag in de maatschappij; commissies voor gelijke rechten en organisaties ter bescherming van mensenrechten doen veelvuldig een appèl op ieders morele sensitiviteit, reclames voor de autoindustrie gaan hand in hand met de luide boodschappen van milieuorganisaties, rapzangers brengen hun eigen moraal of anti-moraal onder de aandacht van hun jonge leeftijdgenoten, mondiale televisiezenders fungeren als gemeenschappelijke nieuwsvoorziening met hun eigen daaraan verbonden morele codes. Kortom, de bronnen van moraal, van wat als goed en juist wordt ervaren, zijn polycentrisch geworden. Het kenmerkende van de huidige situatie is dat geen van deze centra van morele overtuigingen nog een dwingend gezag heeft over elkaar, noch over de leden van de samenleving als geheel. Al deze leden 'kiezen' uit het overstelpende aanbod wat hun goeddunkt. De moraal is geïndividualiseerd. Kritiek over en weer op de feitelijke keuze is afwezig of wordt als 'ongepast' afgewezen (Emberley, ibidem).

Met de fragmentering van de moraal is het gezag van moraal als zodanig veranderd. Begrippen als gezag, respect, ethiek en geweten worden minder vaak gebezigd en worden nu aangevuld met begrippen als autonomie, eigen keuze en eigen 
verantwoordelijkheid. Sterker gezegd: dat nu de discussie wordt gevoerd in termen van waarden en normen, in plaats van te verwijzen naar een aristotelische deugdenethiek of een christelijke moraal, is zelf al een teken aan de wand van een fundamenteel veranderd moreel besef. Immers, het begrip 'waarden' komt pas als veelgebruikte term op in de loop van de negentiende eeuw, onder andere in de filosofie van Nietzsche. Aan het einde van die eeuw krijgt het begrip 'waarde' opeens veel meer maatschappelijk gewicht in de sociologie van Weber en in de economische nutstheorie van de Oostenrijkse school (vgl. De Vries 2004; Emberley 1995: 55; Voegelin 1952: 13-22). Deze geleerden voerden de begrippen 'waarde' en 'waardevrijheid' in om zich af te zetten tegen de normatieve christelijke moraal, die in hun ogen een waardevrije wetenschap onmogelijk maakte. Over de inhoud van waarden kon en mocht de wetenschapsbeoefenaar niet oordelen. Dat was een persoonlijke, vaak irrationele keuze die zich verder niet rationeel liet rechtvaardigen. Met deze positivistisch georiënteerde waardevrijheid bracht Weber een enorme relativering teweeg van de bestaande christelijke moraal en die van alle andere wereldgodsdiensten, die hij uitvoerig beschreef, alsook van alle andere morele oordelen. De beslissingen over waarden komen helemaal voor rekening van het individu, zoals Weber dat in 1918 kernachtig onder woorden bracht: "Men heeft te kiezen tussen religieuze waardigheid, die door deze ethiek wordt gebracht, en de mannelijke waardigheid, die iets heel anders predikt, namelijk: 'Weersta het kwaad, anders ben je medeverantwoordelijk voor zijn overmacht.' Naar gelang van de definitieve keuze is voor de enkeling het ene een duivels en het andere een goddelijk gebod. De enkeling moet kiezen wat voor hem goddelijk en wat duivels is. Zo gaat het op alle terreinen des levens" (Weber 1970: 24).

Geen enkel moreel oordeel lijkt zo nog gezag te hebben voor alle leden van een samenleving. Dit besef had Nietzsche er al eerder toe aangezet om te spreken van een Umwertung aller Werte, een radicale subjectivering en relativering van elke publieke moraal, in het bijzonder de christelijke. Het gevoel van morele verwarring dat Yeats zo mooi onder woorden bracht is voortgekomen uit de invloed van Nietzsche, uit de opkomst van een waardevrije weberiaanse sociologie en een economisch denken dat afziet van een inhoudelijk waardeoordeel. Alledrie hebben ze sindsdien een nog sterkere invloed gehad op het openbare leven en het publieke denken in de westerse wereld. De subjectivering van een morele keuze lijkt al bijna een grondrecht te zijn geworden en een vanzelfsprekend uitgangspunt bij elke inrichting van de hedendaagse westerse samenleving.

\subsection{NIET VOOR HET EERST EN NIET ALLEEN IN NEDERLAND}

\subsubsection{VOORGANGERS UIT HET RECENTE VERLEDEN}

Een debat over waarden en normen is in zijn expliciete benaming een bijzonderheid, maar onderwerpen met die strekking spelen in feite permanent tijdens parlementaire debatten over wetsontwerpen met een morele connotatie - niet alleen bij zedelijkheidswetgeving in strikte zin, maar ook bij uiteenlopende zaken als 
rechtspleging, de wetgeving met betrekking tot de kansspelen, de filmkeuring, het bibliotheekwezen, de zondagsheiliging, de geestelijke verzorging, de inrichting van de sociale zekerheid en de verhouding tussen werk en zorg, de begrafenis- en crematiewetgeving en wetgeving over de regeling van het begin en einde van het leven. Bijna elk wetsontwerp heeft in deze zin een morele component.

Het is dan ook niet verwonderlijk dat in de naoorlogse parlementaire geschiedenis enkele voorlopers van het huidige waarden- en normendebat zijn aan te wijzen. Hierbij gaat het vooral om kwesties waarbij het initiatief voor een moreel appèl lag bij politici, die uiteraard in nauwe relatie staan tot initiatieven in de samenleving als geheel. Als het initiatief bij de politiek of bij afzonderlijke politici ligt, is dat een bijzonderheid, mede vanwege de gevoelige relatie tussen politiek en moraal en de angst voor een van bovenaf opgelegde staatsmoraal. Initiatieven voor een moreel appèl vanuit de samenleving, zoals bijvoorbeeld de Morele Herbewapening in de jaren vijftig of het kerkelijke streven naar een Nieuwe Levensstijl in de jaren tachtig (o.a. Goudzwaard en De Lange 1986) hebben een andere oorsprong en krijgen daardoor ook een andere beoordeling. In een levendige civil society ontstaan talloze initiatieven van onderop en van velerlei aard, waarop de politiek zelfstandig kan en mag reageren. Als de politiek echter het initiatief neemt, krijgt het morele debat een aparte lading. In verschillende perioden van de naoorlogse parlementaire geschiedenis is zo'n initiatief aanwezig geweest, waarbij opvalt hoezeer elk debat door de maatschappelijke situatie en historische context werd bepaald. Niet de gelijkenis, maar juist het contrast met de huidige onderwerpen van het waarden- en normendebat valt op.

De periode $1945^{-1956}$ is een van de tijdvakken waarin een debat over de moraal in brede kring werd gevoerd. In de eerste jaren na de bevrijding werd een breed gedragen beschavingsoffensief ingezet in reactie op de veronderstelde en wellicht ook reële 'zedenverwildering' en het afgenomen normbesef tijdens de bezetting, in het bijzonder onder de jeugd. De morele verontrusting strekte zich niet alleen uit over seksuele normloosheid, maar ook over aberraties als zwarte handel, gebrek aan arbeidsethos en de positie van maatschappelijk zwakke gezinnen. In de tweede helft van de jaren vijftig baarde vooral de rock-'n-rolljeugd grote zorgen voor de opvoeders en de samenleving als geheel. Tijdens de toenmalige algemene beschouwingen zijn elementen van al deze onderwerpen ter sprake gekomen. Het gehele debat speelde zich echter af binnen de gesloten en vertrouwde gemeenschappen van een verzuilde samenleving, die zelf bijeen werd gehouden door een gevoel van nationale verbondenheid (Schuyt en Taverne 2000: hoofdstuk 9 en 15).

Een tweede periode waarin het normen- en waardendebat vanuit de politiek een belangrijke impuls heeft gekregen is de tweede helft van de jaren zeventig. Het $\mathrm{CDA}$, met name de toenmalige premier Van Agt, blies toen het ethisch reveil in reactie op het losser worden van het normen- en waardenpatroon in de jaren zestig en zeventig, een ontwikkeling waar hij als minister van Justitie veelvuldig en hardhandig mee was geconfronteerd, bijvoorbeeld in de kwestie rond de 
abortuswetgeving. Het normen- en waardendebat in die periode werd als zodanig in het parlement gevoerd rond ethische kwesties als euthanasie en abortus, maar er vonden ook principiële debatten plaats in de Tweede Kamer over de rechtvaardiging en de grenzen van burgerlijke ongehoorzaamheid. Men krijgt een evenwichtiger oordeel over de betekenis van het ethisch reveil, als men bedenkt dat andere politieke partijen, vooral de Partij van de Arbeid, in de jaren zestig en zeventig bijzondere nadruk waren gaan leggen op emancipatie, met name van minderheidsgroepen, op persoonlijke seksuele bevrijding en op een meer gelijke verdeling van schaarse goederen in de samenleving. Hoewel deze kwesties niet in de eerste plaats als morele, maar vooral als politieke kwesties werden gezien, behelsden ze natuurlijk wel nadrukkelijk bepaalde nagestreefde morele waarden. Het morele gelijk dat deze partijen nastreefden deed niet onder voor dat van de tegengestelde waarden van het ethisch reveil. Het was een periode waarin de zo vaak geroemde Nederlandse tolerantie wederzijds niet hoog in het vaandel stond. In hoeverre het ethisch reveil is overstemd door de grote zorgen om de nadien snel teruglopende economische ontwikkeling in de jaren tachtig, moet aan het historische oordeel worden overgelaten. Een parallel met de huidige discussie is niet denkbeeldig.

Het ethisch reveil dat aan het eind van de jaren zeventig op de kaart werd gezet, is waarschijnlijk de bekendste voorloper van de huidige discussie over waarden en normen. Toch betrof het debat geheel andere onderwerpen dan die nu aan de orde zijn. Van Agt verzette zich tegen een verruiming van de wetten op het gebied van abortus en euthanasie en bepleitte een morele heroriëntatie in dit land. Het ging Van Agt in de eerste plaats om de waarden en de normen die betrekking hebben op het recht om (medische) hulp te verlenen bij het beëindigen van het leven van anderen als sprake is van ondraaglijk lijden, of om de mogelijkheden om de ontwikkeling van leven voor de geboorte voortijdig af te breken. Zo beschouwd wekt het misschien minder verwondering dat diezelfde Van Agt zich liet ontvallen geen enkel heil te zien in het huidige debat. Zijn oproep destijds was van levensbeschouwelijke en religieuze aard en hij voelde zich als een roepende in de woestijn. Nu echter is volgens Van Agt aan zo ongeveer iedereen wel bekend wat er mis is met de normen en de waarden en moet de overheid gewoon tot handelen overgaan om een einde te maken aan de misstanden en verloedering. Zoals echter uit het summiere overzicht van de discussieonderwerpen eerder bleek, zijn wel meer mensen van mening dat het zonneklaar is waar de schoen wringt in dit land, ook al lopen die visies flink uiteen.

Een ander debat dat is opgenomen in het collectieve geheugen van de politieke discussies in Nederland, is de tweestrijd die ontstond nadat minister Ruding de zogenaamde 'jansaliementaliteit' van werklozen had gehekeld (1984). Niet veel later verklaarde de toenmalige premier Lubbers, in een rede aan de Universiteit van Nijmegen in 1990, Nederland 'ziek' vanwege het zeer hoge aantal arbeidsongeschikten. De overstap in politiek taalgebruik, van de morele sfeer naar een medische metafoor, was opvallend, hoewel de suggestie van 'ziek door eigen schuld' de morele connotatie niet ontbeerde. 
Deze politieke debatten vertoonden evenmin als het vorige veel overeenkomsten met de huidige discussie. Dit korte overzicht laat echter wel zien waar het momenteel niet om gaat en kan als zodanig behulpzaam zijn bij het bepalen van de thematische afbakening van de huidige discussie. Er zijn zeer vele onderwerpen te noemen die met 'waarden en normen' van doen hebben, maar die nu niet in het centrum van de belangstelling staan. Uitkeringsfraude, arbeidsethos, abortus en euthanasie lijken voorlopig als morele en politieke twistpunten uitgedoofd.

Een ander initiatief vanuit de politiek vormde in juni 1992 het voorstel van de toenmalige minister van Onderwijs, Cultuur en Wetenschappen Ritzen om meer aandacht te schenken aan morele waarden in het onderwijs. In de nota De pedagogische Opdracht van het Onderwijs, een uitnodiging tot gezamenlijke actie werd geconstateerd dat in het onderwijs het een en ander schortte aan de invulling en vormgeving van de opvoedende functie. De moraal moest in het klaslokaal terugkeren. Er werd gevraagd hoe een evenwicht bewaard kon worden tussen vrijheid en individualiteit: "We zullen vanuit een gemeenschappelijk onderkend belang bij een samenleving die gedragen wordt door gedeelde waarden en normen, met elkaar in gesprek moeten raken over die waarden en normen, over de balans tussen individualiteit en gemeenschappelijkheid" (Ritzen 1992: 3). De waarden die vervolgens genoemd werden zijn: respect, rechtvaardigheid, eerlijkheid, verantwoordelijkheidsbesef, gemeenschapszin, solidariteit, tolerantie. Daarnaast werd het belang van omgangsvormen en sociale vaardigheden in het onderwijs onderkend. Maar ook dit initiatief kreeg geen gevolg; de aandacht voor de pedagogische functie verslapte, mogelijkerwijs mede omdat niet goed kon worden aangegeven hoe in de dagelijkse praktijk van het onderwijs aan de morele dimensie vorm kon worden gegeven.

Veel dichter in de buurt van de zaken die nu nog hoog worden opgespeeld komen debatten over individualisering, gemeenschapszin en moraal (1995) en het debat over sociale cohesie (1997). IJkpunten voor het eerste zijn de herdenkingsrede van koningin Beatrix naar aanleiding van de vijftigste verjaardag van de bevrijding, de publicatie van een artikel van Etzioni in de Volkskrant ('Wij zijn de stem van de moraal kwijtgeraakt') en het rapport van de Teldersstichting Tussen vrijblijvendheid en paternalisme. Bespiegelingen over communitarisme, liberalisme en individualisering (1995). Het onderwerp sociale cohesie brengt het gevoel onder woorden dat de moderne samenleving onder invloed van een combinatie van grootschalige commerciële belangen van massaproductie en -consumptie en gelijktijdige sociale individualisering haar vertrouwde samenhang aan het verliezen is. Het sluit aan bij de al langdurig aanwezige angst voor het uiteenvallen van de samenleving in een zeer grote hoeveelheid kleine eilandjes, individuen, die van elkaar niet weten en ook niet hoeven te weten wat ze doen. Vertrouwde kaders als werk, kerk, vakbond en vereniging vallen hierbij in het niet, hetgeen vertaald kan worden als een moreel verlies of zelfs verval. Indien hierbij tegelijkertijd de invloed van de media in het vertonen van extreme gedragingen en extravagante opvattingen, bekentenissen en zelfonthullingen ('de Jerry Springer 
Show en andere programma's van de vermaakindustrie') wordt opgeteld, dan is een morele verontrusting over de aard en de beleving van 'waarden en normen' in onze samenleving niet erg verwonderlijk meer. De uitroepen 'Wat is er toch aan de hand?' en 'Waar gaat het naar toe?' vullen de huiskamers, waar vaak in sociale afzondering naar dergelijke programma’s wordt gekeken.

In de debatten over sociale cohesie wordt een spanning geconstateerd tussen de gevolgen van individualisering en het ontstaan van een 'ik-tijdperk' (Wolfe, 1976) enerzijds en de blijvende behoefte aan maatschappelijke verbanden, sociale bindingen en gemeenschappelijkheid anderzijds. De uitingen van verminderde sociale binding aan publieke belangen vinden natuurlijk niet uitsluitend plaats aan de onderkant van de samenleving. Aan de top van het internationale bedrijfsleven is eveneens een cultuur te constateren van 'eigen belang eerst'. Het gedrag van bestuurders van sommige grote ondernemingen (o.a. World Online, Enron) heeft grote schade toegebracht, niet alleen aan de belangen van kleine beleggers, maar minstens net zozeer aan het besef van morele binding aan de rest van de samenleving. Door deze vormen van 'normoverschrijdend gedrag' aan de bovenkant van de samenleving is een discussie op gang gekomen over de maatschappelijke voorbeeldwerking van dergelijke topfiguren en over de beperkingen die in hun gedrag zouden kunnen worden aangebracht. Er blijft een spanning tussen de ongeremde uitoefening van vrijheid en autonomie en de binding aan een grotere gemeenschap, tussen 'ik' en 'wij'. Deze spanning is typisch voor een moderne westerse samenleving en vormt hiermee een van de diepere drijfveren voor politiek en samenleving om aandacht te schenken aan waarden en normen die een samenleving bij elkaar kunnen houden.

\subsubsection{DE DISCUSSIE IN HET BUITENLAND}

De vraag of het Nederlandse waarden- en normendebat uniek is te noemen, is eenvoudig met 'nee' te beantwoorden. Ook in andere landen staat de morele staat van de natie regelmatig in de publieke en politieke belangstelling en ontstaan debatten over waarden en normen. Die debatten kunnen vele vormen aannemen zoals dat in Nederland over de jaren heen ook is gebeurd. Sommige debatten zijn daarbij hardnekkiger dan andere en in een enkel geval leidt een debat over waarden en normen tot overheidsbemoeienis, of wordt het thema door een regering tot speerpunt verheven. De hoofdthema's van het huidige Nederlandse debat in termen van 'normhandhaving, normoverschrijdend gedrag en praktische fatsoensnormen in de openbare ruimte' en in termen van 'integratie en islam' zijn echter ook elders in Europa terug te vinden.

Het probleem van normhandhaving is de breedte van het onderwerp. Nagenoeg al het normoverschrijdend gedrag is onder deze noemer te vangen. Een mogelijk gevaar daarvan is dat het debat over alles gaat en uiteindelijk op niets uitloopt. Dat dit geen denkbeeldig gevaar is, bewijzen de ervaringen van de Noorse commissie voor Menselijke Waarden, het model dat premier Balkenende oorspronkelijk wilde gebruiken voor een Nederlandse commissie voor waarden 
en normen. Deze commissie, die in 1998 door de toenmalige christen-democratische premier Bondevik werd geïnstalleerd, kreeg een zeer breed mandaat en werd uitzonderlijk breed en 'representatief' samengesteld. Het mandaat van de commissie was nagenoeg alomvattend: "The main goal of the Commission on Human Values is to contribute to a broad mobilization for human values and socio-ethics, in order to enhance positive joint values, and strengthen the responsibility for the environment and community. It is important to work against indifference, and promote personal responsibility, participation and democracy"(http://www.verdikommisjonen.no/goals_strategy_projects.htm).

De commissie zelf werd bovendien bont samengesteld en gepresenteerd als een 'dwarsdoorsnede' van de bevolking. Naast de onvermijdelijke professoren betekende dit het lidmaatschap van een boer, een fabrieksarbeider, een 'artiest' en een leerling van 'Vietnamese afkomst'. Ook was er een voetbalsupporter vertegenwoordigd die uiteindelijk concludeerde dat de commissie zichzelf te serieus was gaan nemen en niet meer het debat stimuleerde, maar mensen voor wilde schrijven hoe ze moeten leven (NRC 2002). De commissie heeft de wind eigenlijk vanaf de eerste dag tegen gehad en ontmoette hoofdzakelijk kritiek en hoon. Het eindrapport dat na drie jaar studie werd aangeboden aan een nieuwe, sociaal-democratische regering omvatte aanbevelingen op bijna elk denkbaar terrein, variërend van de maximumsnelheid, het milieu en immigratie tot de hoogte van het bedrag dat aan ontwikkelingssamenwerking besteed dient te worden (Reformatorisch Dagblad 2001).

In 1993 gaf Major, toen premier van Groot-Brittannië, tijdens een partijbijeenkomst van de Conservatieven in Blackpool de aftrap voor wat bekend werd als de back to basics-campagne (The Guardian 1993). De centrale gedachte van deze campagne verwoordde hij als volgt: "It is time to get back to basics: to selfdiscipline and respect for the law, to consideration for others, to accepting responsibility for yourself and your family, and not shuffling it off on the state." Traditionele waarden waren volgens de premier weggevallen of als gedateerd gebrandmerkt en opzijgeschoven, een proces dat slechts verval had opgeleverd en moest worden gestopt. Het was tijd om terug te keren naar 'the old values of neighbourliness, decency and courtesy'. De back to basics-campagne werd echter niets minder dan een boemerang voor de Conservatieve Partij. De pers greep de hoge toon van moraliteit in de speech aan om diep te graven in het privé-leven van leden van het kabinet en de Conservatieve Partij en diepte vele seks- en omkopingsschandalen op, die de betrokkenen in de regel politiek gezien de kop kostten (Daily Telegraph 2002). Door deze negatieve gevolgen voor de regering werd de campagne het toonbeeld van mislukking en kregen morele campagnes een bijsmaak in de Britse politiek. De poging van Labourpremier Tony Blair om in 1999 een campagne te starten 'to create a new moral purpose in Britain' werd door een groot deel van zijn achterban met afgrijzen ontvangen. De titel van een artikel in The Guardian over de reactie in de Labourpartij spreekt wat dat betreft boekdelen: "Blair revives back to basics angst" (The Guardian 1999). Dit schoolvoorbeeld van een mislukte campagne voor het herstel van waarden en normen 
stortte definitief in elkaar toen in 2002 werd onthuld dat Major zelf een affaire had gehad. Een oproep vanuit de regering aan de bevolking tot een herstel van waarden en normen loopt een permanent risico van hypocrisie, saying the one while doing the other. Geconstateerde hypocrisie is een van de sterkste ondermijningen van het vertrouwen in en het gezag van politici.

In Frankrijk en Duitsland zijn er op regeringsniveau geen initiatieven genomen voor een nieuw moreel beschavingsoffensief, maar komt het overheidsbeleid op specifieke punten toch zeer overeen met dat in Nederland. Veiligheid en criminaliteit, vooral in de grote steden in Frankrijk, vormen een overheersend thema, dat vergelijkbare discussie heeft opgeroepen over tolérance zéro. Verloedering van grotestadsbuurten wordt door Franse criminologen in relatie gebracht met de toename van kleine en grote criminaliteit. Roché gebruikt hiervoor de overkoepelende term incivilités, hetgeen neerkomt op het ergerlijke en onbeschaafde gedrag in de Nederlandse discussie over waarden en normen (CDV, december 2002). De Franse onderzoekster Bui Trong ziet slordigheid in het omgaan met de publieke ruimte, het op straat laten liggen van rotzooi en het stichten van kleine brandjes als voorliggende stadia van ernstigere vormen van publiek geweld (Bui Trong 2000).

De Duitse discussie spitst zich toe op weer een ander bekend onderwerp in de waarden- en normendiscussie, namelijk de orde en tucht op scholen en hoffelijkheid en discipline in het onderwijs. Hoewel een vergelijking van onderwijsregimes tussen Europese schoolsystemen aan het licht brengt dat qua orde en ordelijkheid het Nederlandse systeem verreweg de meeste vrijheid laat aan leerlingen en leerkrachten (Jippes 2003) en het Duitse systeem nog als zeer degelijk wordt beschreven, wijzen de klachten in Duitsland over de ordelijkheid op scholen in dezelfde richting als in ons land: een heimwee naar oude waarden. Volgens een overgrote meerderheid van de Duitse bevolking, waaronder ook alle jongeren, moeten waarden als hoffelijkheid, orde en netheid in het dagelijkse leven weer terugkeren. Kledingvoorschriften op school, liefst in schooluniform, met een verbod op blote buiken, worden door ongeveer de helft op prijs gesteld, evenals het opnieuw invoeren van cijfers voor 'gedrag en vlijt', zoals vroeger. De rapportage hierover met enquêtegegevens in Der Spiegel, wordt echter onderbroken door de gebruikelijke commerciële boodschappen, zeer sexy ingericht en mét blote buik (Der Spiegel 2003, 28: 124-137). De fragmentatie van en tegenstrijdigheid in de morele boodschappen zetten zich dus ook voort in de mediabelangstelling voor waarden en normen.

Het tweede hoofdthema van het huidige waarden- en normendebat is de integratieproblematiek, de positie van immigranten en de rol van de islam. Dit raakt nauw aan de algemene, reeds gevoerde integratiediscussie, die op zijn beurt sinds de aanslagen van 11 september 2001 steeds meer in het licht van de islam is komen te staan. De integratiediscussie zoals die in Nederland wordt gevoerd, kenmerkt zich door een grote nadruk op (vermeende) cultuurverschillen en de vraag of en in hoeverre immigranten zich in culturele zin moeten aanpassen aan 
Nederlandse waarden en normen. Dit roept automatisch de vraag op wat die Nederlandse waarden en normen waaraan immigranten zich aan moeten passen, eigenlijk zijn. Zo is het debat over integratie en multiculturaliteit ook in zekere mate een debat over de onderscheidende kenmerken van de Nederlandse nationale identiteit geworden. Dit debat is zeker geen exclusief Nederlands verschijnsel. In heel Europa spelen - vaak al langere tijd - varianten van dit debat met als belangrijkste element de plaats van de islam, de nationale identiteit, het vraagstuk van culturele aanpassing en minimaal gedeelde waarden tussen immigrant en land van vestiging.

De verhouding tussen moslims en de landen van vestiging is in verschillende landen al aanleiding geweest voor verhitte debatten. Zo lokte de fatwa tegen Salman Rushdie in heel Europa heftige reacties uit, enerzijds bij gelovige moslims, anderzijds bij verlichte kunstenaars en politici, in het bijzonder in het Verenigd Koninkrijk. De onrusten en de publieke boekverbrandingen in steden als Bradford brachten een schok teweeg in de Britse samenleving en waren aanleiding tot een debat over de grenzen van het Britse multiculturalisme en de vraag wat de "Britse gewoonten en tradities die elke minderheidsgroep dient te respecteren” eigenlijk zijn (Broeders 2001). Ook de kwesties rondom het dragen van hoofddoekjes zijn bepaald geen nieuw verschijnsel in Europa. In Frankrijk werd in 1989 al een publieke strijd gevoerd tussen de neutrale Franse staat en het openlijk belijden van het moslimgeloof door middel van het dragen van een hoofddoekje op school in wat bekend is geworden als l'affaire foulard. Deze affaire werd uiteindelijk met een compromis afgehandeld - toenmalig minister van Onderwijs Jospin stond het dragen van hoofddoekjes toe zolang de draagsters 'geen bekeerlingen trachten te maken of anderszins de les verstoorden' maar liet bij het Franse publiek een gevoel van onbehagen achter over de verhouding tussen de islam en 'de ondeelbare republiek' (Feldblum 1999; Schnapper et al. 2000). In Noorwegen kwam het debat over integratie gaandeweg ook steeds meer in het licht van (afwijkende) cultuur en de onverenigbaarheid ervan met de Noorse cultuur te staan. De voornaamste steen des aanstoots was hier de positie van vrouwen binnen bepaalde migrantengroeperingen. Zaken als gearrangeerde huwelijken vallen slecht in een land dat zich voor laat staan op gender-gelijkheid als een centrale waarde en zorgen voor heftige politieke debatten (Hagelund 2002).

In de afgelopen jaren zijn de debatten over integratie in veel landen steeds meer en openlijker debatten geworden over nationale identiteit en de mate waarin immigranten zich daaraan moeten aanpassen. Geconfronteerd met afwijkende en soms zeer uitgesproken minderheidsculturen en de angst voor het ontstaan van een etnische onderklasse is culturele aanpassing weer in beeld gekomen en heeft het multiculturele model afgedaan (Joppke 2003). Bovendien zijn in veel landen naar aanleiding van het integratievraagstuk stevige debatten ontstaan over de nationaliteitswetgeving. Strijdpunten waren onder andere de vraag hoe inclusief of exclusief het nationaliteitsrecht moet zijn en hoe 'aangepast' immigranten moeten zijn om ervoor in aanmerking te komen (Hansen en Weil 2001). 
Het meest uitgesproken voorbeeld van een campagne rondom identiteit was die van de Duitse CDU onder de vlag van de Leitkultur. Migranten moesten zich bij de integratie in de Duitse samenleving richten op deze Leitkultur en zich aanpassen aan de centrale waarden en normen die daaronder vielen. Pogingen om de Leitkultur te omschrijven zijn echter zeldzaam en komen vaak niet verder dan centrale waarden die veelal breder zijn dan alleen de Duitse samenleving, zoals constitutionele normen, vrouwengelijkheid en de taal. In veel Europese landen heeft zich eenzelfde ontwikkeling voorgedaan, waarbij enerzijds meer culturele aanpassing van immigranten wordt verwacht en anderzijds de politiek moeite heeft om aan te geven wat de culturele standaarden waaraan men zich aan dient te passen precies omvatten. Ook de Britse overheid acht het noodzakelijk dat immigranten een 'sense of belonging and identity' hebben met de Britse samenleving en legt in haar laatste white paper sterke nadruk op burgerschap en nationaliteit. Maar in de beschrijving van wat de fundamentele beginselen van het Britse burgerschap behelzen, somt de white paper een belangrijk, maar weinig specifiek Brits rijtje op: "that we respect human rights and freedoms, uphold democratic values, observe laws faithfully and fulfill our duties and obligations" (geciteerd in Joppke 2003). Met andere woorden: in de meeste Europese landen wordt de vraag wat de specifieke kernwaarden van de samenleving zijn van een antwoord voorzien, namelijk dat dit de basisspelregels zijn van de democratische rechtsstaat.

Een onderdeel van de discussie over een multiculturele samenleving is steevast een pleidooi voor een vaste plaats voor civic education in alle lagen van het onderwijs. Deze discussie is vooral opgebloeid in landen als de Verenigde Staten en Canada, waar de diversiteit van de bevolking enorm groot is en waar inheemse groepen, taalgroepen, immigrantengroepen en etnische minderheidsgroepen allemaal een erkende plaats willen krijgen in het onderwijs en in de samenleving als geheel. Canada is nu een interessant laboratorium geworden van een moderne multiculturele samenleving.

Door de grote verscheidenheid echter in particuliere en openbare scholen in beide landen, spitste de discussie zich vooral toe op de vraag of en hoe de overheid hier een verplichting kan opleggen aan de particuliere, niet-gesubsidieerde scholen (Macedo 2000). Vaak worden de tekorten in moreel gedrag die in de maatschappij worden ondervonden, bestreden door een groot beroep te doen op het onderwijs om tenminste voor de toekomst en tenminste voor de jongere leden van de samenleving deze tekorten te verminderen. De scholen zelf voelen vaak minder voor deze extra taken, mede gevoed vanuit de onzekerheid dat men niet goed weet hóe men deze waarden dan al zo vroeg in het onderwijs moet bijbrengen. Ook de scepsis dat hiermee de verantwoordelijkheid voor morele opvoeding wel erg sterk alleen bij de scholen komt te liggen en niet waar die in eerste instantie thuishoort, bij de ouders en evenzeer bij de rest van de samenleving, verklaart de terughoudendheid van scholen voor deze opdracht. De civic education in Noord-Amerika kan ondanks deze aarzelingen niettemin bogen op een lange traditie. Er bestaat reeds vanaf begin van de jaren zeventig een sterke 
aandacht en aparte organisaties voor Values Education (Emberley 1995). Oorspronkelijk bedoeld als een moreel tegenwicht tegen een overheersende technische cultuur hebben ze zich ontwikkeld tot een expertisecentrum voor de wijze van overdracht van waarden en normen in het onderwijs. Verschillende modellen zijn hiervoor ontwikkeld (Emberley 1995). Opvoeding tot waardebeleving wordt dus al heel lang als specifiek onderwerp bestudeerd. Er bestaat sinds 1969 een apart Center for Value Inquiry, met een eigen tijdschrift, het Journal of Value Inquiry, en met werkelijk talloze publicaties over verschillende aspecten van het onderzoek naar waarden (Hull 1994). Het ontbreekt niet aan kennis en wetenschappelijke discussie over het onderwerp, maar tussen weten en doen ligt een kloof die wellicht het moeilijkst te vatten onderdeel vormt van de huidige problematiek van waarden en normen.

\subsection{DE OPBOUW VAN HET RAPPORT}

Dit rapport is als volgt opgebouwd. Het begint met een begripsmatige verkenning van de uiterst algemene en dus lastige begrippen 'waarden' en 'normen'. Zonder enige nadere omschrijving van termen en begrippen en van de context waarin deze begrippen een belangrijke rol spelen, is een bijdrage aan de discussie over waarden en normen nagenoeg onmogelijk. Hier wordt ook het onderscheid uitgewerkt tussen onprettig en onwettig gedrag, met andere woorden tussen de overschrijdingen van sociale normen en van wettelijke normen. In hoofdstuk 2 wordt een verkenning van dien aard geboden, die vanwege de uitgebreidheid van de twee sleutelbegrippen toch niet uitputtend kan zijn.

De hoofdstukken 3 en 4 vormen samen het materiaal dat aangedragen wordt om het eerste hoofdthema van dit rapport, de problematiek van fatsoensnormen en andere vormen van normoverschrijdend gedrag, te analyseren en te beoordelen. In hoofdstuk 3 wordt een overzicht geboden van de thans op basis van bevolkingsonderzoeken bekende gegevens, waaronder materiaal dat is verzameld door het SCP over de (verbale) steun die de bevolking geeft aan centrale waarden en normen. De relatie tussen de uit de enquêtes blijkende steun en het gedrag wordt daarin ook aan de orde gesteld. Daarna volgt in hoofdstuk 4 een overzicht van de beschikbare kennis van de vele vormen van normoverschrijdend gedrag. Dit hoofdstuk biedt een analyse van vormen van normoverschrijdend gedrag, hier slechts in negatieve zin opgevat. Al het normoverschrijdend gedrag waarmee mensen meer doen dan van hen gevraagd wordt en waar een positieve werking van uitgaat voor de gehele samenleving - een meestal verwaarloosd onderdeel van de discussie over waarden en normen - wordt hier weggelaten. Er zijn nauwelijks systematische gegevens over deze vormen van gedrag verzameld, zodat men wel heel erg zou moeten steunen op spectaculaire voorbeelden en adhocsituaties. Het hoofdstuk bevat hoofdzakelijk een overzicht van wat nu vanuit wetenschappelijk onderzoek bekend is over de vele vormen van negatief normoverschrijdend gedrag. Het gaat derhalve vooral over die zaken waar veel burgers zich zorgen over maken: kleine en grote criminaliteit, buurtoverlast, onveiligheidsgevoelens, straatgeweld en dergelijke. Ook gedrag in het verkeer en in het 
openbaar vervoer wordt behandeld. In het algemeen gaat het vooral om gedrag in de publieke sfeer. De conclusie van dit hoofdstuk is dat er wel degelijk zorgelijke ontwikkelingen zijn waar te nemen als het gaat om daadwerkelijk gedrag. De relatie met waarden is hier complex en kan meestal niet meer rechtstreeks worden gelegd. De oplossing van dergelijke gedragsproblemen moet dan ook niet gezocht worden in de sfeer van het aansporen om 'waarden' in abstracte zin meer te eerbiedigen, maar juist in een betere controle op eenvoudige regels en op feitelijk gedrag en in een consistentere handhaving van normen door tal van maatschappelijke instituties, waaronder politie en justitie. Ten slotte biedt het hoofdstuk tevens een analyse van de sociale mechanismen, zoals de verminderde bereidheid om zich aan regels en wetten te houden, die het gevolg kunnen zijn van verminderde sociale controle.

Het tweede hoofdthema, de gemeenschappelijkheid en pluriformiteit in waarden, komt in de volgende twee hoofdstukken aan de orde. Hoofdstuk 5 gaat over de waarden en normen die als gemeenschappelijk en als bindend kunnen worden beschouwd. Een van de meest kenmerkende eigenschappen van moderne democratieën is echter dat zij stelselmatig ruimte bieden voor een grote pluriformiteit van opvattingen en waarderingen. Deze ruimte voor pluriformiteit veronderstelt echter wel de bereidheid om voorspelbare conflicten over waarden en normen op een vreedzame, al of niet juridische, wijze te beslechten. De grondwet en de beginselen van de rechtsstaat garanderen die ruimte voor diversiteit en pluriformiteit én bieden tevens de mogelijkheden tot dergelijke conflictbeslechting. Dit leidt tot het enigszins paradoxale inzicht dat het garanderen van deze pluriformiteit tegelijk een van de meest gemeenschappelijke waarden is die onze samenleving bijeenhoudt. De rol die het recht en de bescherming van grondrechten daarbij spelen, komt eveneens aan de orde in hoofdstuk 5.

In hoofdstuk 6 staan cultuurverschillen en het samenleven met verschillende culturele normen centraal. Er wordt een overzicht geboden van de discussies die gevoerd zijn over integratie van nieuwkomers en over de mogelijkheden en grenzen om tot integratie en aanpassing te komen. Niet alle gedragingen die door een groot deel van de bevolking als vreemd of afkeurenswaardig worden beschouwd, kunnen of moeten te vuur en te zwaard bestreden worden, conform de ruimte voor pluriformiteit. Aan de hand van vele gedragsvoorbeelden en conflictsituaties wordt voorgesteld de ingewikkelde thematiek op een gedifferentieerde wijze tegemoet te treden. Drie strategieën worden ontwikkeld: 1) het instandhouden van een zone van gelatenheid en tolerantie, waar het om niet-principiële cultuurverschillen gaat; 2) confronteren waar het wel principiële verschillen betreft, maar waar deze verschillen in gedrag en waardebeleving niet 'met het zwaard' of van hogerhand kunnen ongedaan worden gemaakt; 3) verbieden van die gedragingen die de integriteit van personen in gevaar brengen en die in strijd zijn met de uitgangspunten van de rechtsstaat en de democratische samenleving. Hierbij wordt ook gewezen op de mogelijkheden en grenzen van een fundamentalistische geloofsopvatting. 
Hoofdstuk 7 en 8 geven aan wat de overheid en de samenleving als geheel nu al doen en eventueel meer zouden kunnen doen aan de overdracht en het onderhoud van waarden en normen. In hoofdstuk 7 ligt het accent op een beschrijving van enkele institutionele mechanismen die in de verschillende sectoren van de samenleving aanwezig zijn en die het onderhouden van een bepaalde waardevolle levenswijze versterken of juist verhinderen. Het onderhoud van waarden en normen is niet uitsluitend een taak van de overheid. Integendeel, uit de analyse van dit rapport wordt duidelijk dat waarden en normen in de samenleving ontstaan en daar ook worden overgedragen en onderhouden. Instituties en organisaties hebben allemaal een eigen waardevolle en waardengeoriënteerde taak, en de samenleving als geheel floreert en functioneert beter wanneer die primaire taken door organisaties nauwgezet worden uitgevoerd. Het opleggen van waarden en normen van bovenaf, met name door een centrale overheid, komt niet alleen in strijd met enkele basiswaarden van de democratische samenleving, maar is ook niet erg effectief. We raden derhalve een algemeen beleid van de overheid op het gebied van waarden en normen af. Wat daarentegen wel nodig en urgent is, zijn de specifieke taken op het gebied van directe normhandhaving en het tegengaan van die normoverschrijdingen die het grootste deel van de overlast en ellende voor de samenleving opleveren. Als de overheid haar primaire taak in dit opzicht vervult, kan al heel veel ergernis worden weggenomen. 


\subsection{ZIJN WAARDEN DEFINIEERBAAR?}

Het geven van een definitie van waarden is een bijna onbegonnen zaak. Er zijn wel honderden definities in omloop. Een van de redenen van de moeilijkheid om tot een heldere begripsmatige afbakening van het begrip 'waarde' te komen is de relatie tussen het zelfstandige naamwoord waarde en het actieve werkwoord waarderen. Alles wat gewaardeerd wordt door mensen krijgt waarde. Dit kunnen voorwerpen zijn, situaties, landschappen, bijzondere ervaringen, relaties met andere mensen of abstracte systemen zoals de democratie. Omdat het object van waardering niet bij voorbaat inhoudelijk bepaald hoeft te zijn, is het aantal daarvan afgeleide inhoudelijke waarden in principe onuitputtelijk. Pepper is zich hiervan ten volle bewust en geeft daarom in zijn studie The Sources of Value (1959) een omschrijving van waarden in de breedste zin: "anything good or bad..." Hij somt vervolgens op: wensen en noden; alles wat plezier geeft en pijn vermijdt; voorkeuren, nut en middelen die doelen helpen bereiken; integratie, vitaliteit, zelfverwerkelijking; gezondheid, overleven, evolutionaire fitness, aanpassing; individuele vrijheid, sociale solidariteit, wets- en plichtsbetrachting; gewetensvolheid, deugden, idealen en normen; vooruitgang, oprechtheid, schoonheid, waarheid, werkelijkheidszin (Pepper 1959: 7).

Waarden kunnen dus vele vormen aannemen: voorkeuren en individuele smaken, maar ook het voorzien in basisnoden van mensen, de condities waaronder mensen floreren, de belangen waar men voor opkomt of de verlangens die men nastreeft. Door de veelheid van mogelijke verschijnselen die van waarde worden geacht, eindigt een abstracte discussie over waarden vaak in een ondoorzichtige mist. De kans dat men langs elkaar heen praat, omdat iedere gesprekspartner een ander waardevol verschijnsel op het oog heeft, blijft levensgroot. Waar het om gaat is, in de woorden van Pepper, "how to bring order and clarity into this apparently heterogeneous mass of subject matter" om daarmee enige greep te krijgen op de processen van waardetoekenning en waarderingen.

De moraalfilosofie en de ethiek zijn van oudsher de wetenschappen waarin op systematische wijze het verschijnsel van waarden en waarderingsprocessen worden bestudeerd. Daarin is vooral na de Tweede Wereldoorlog een aparte tak ontstaan, Value Theory, die zich speciaal bezighoudt met 'waarden' in hun algemeenheid (axiologie), maar ook met praktische zaken als het analyseren van morele dilemma's, stadia van morele ontwikkeling en met value education (Emberley 1995). Maar binnen deze waardeleer zijn er tegelijkertijd talloze waardetheorieën ontwikkeld, die onderling net zo verschillen als de waarden op zichzelf. Zo legt een utilistische waardetheorie een sterke, bijna uitsluitende 
nadruk op het nastreven van plezier en het vermijden van pijn. Een waarde is dan al hetgeen ten dienste staat van iemands pleasure of wat displeasure tegengaat: goed voedsel, geld, een mooi uitzicht, het verhinderen van pijn en lijden (Creel 2001:153).

Voor anderen daarentegen is deze verankering van waarden in individuele voorkeuren en nuttigheden te oppervlakkig. Het gaat om het verschil tussen spontane, momentane voorkeuren en langdurige en stabiele voorkeuren, die pas na enige reflectie op de gronden en gevolgen van de spontane voorkeuren totstandkomen. Hieraan correspondeert het verschil tussen 'smaak' en 'waarde'. Smaken verschillen en over smaak valt, spreekwoordelijk, niet te twisten. De relativiteit van voorkeuren ('Is koek lekkerder dan kaas?') wordt algemeen aanvaard. Bij waarden is dit minder het geval, ze lijken een objectievere, althans een meer intersubjectieve basis te bezitten. Het verschil tussen smaak en waarde wordt in discussies over waarden en normen vaak vergeten, mede door een lange utilitaristische traditie waarin het onderscheid tussen smaak en waarde of tussen objectieve noden en subjectieve wensen niet wordt gemaakt. Alle voorkeuren hebben in deze theorie een subjectieve oorsprong en er is geen mogelijkheid om tussen deze voorkeuren een objectief oordeel te vellen. Het onderscheid tussen smaak en waarde kan leiden tot twee totaal verschillende benaderingen van waarden en derhalve ook van ethiek en moraal. Het 'smaakmodel' heeft als uitgangspunt: iets is waardevol omdat ernaar wordt verlangd. Het tegenovergestelde 'waardemodel' stelt: iets wordt verlangd ómdat het waardevol is (Griffin 1997: 19-29).

Deze twee verschillende benaderingen laten een lang spoor na in de geschiedenis van ethiek en moraal (Hume versus Kant), maar zijn ook praktisch te herkennen in de huidige waarden- en normendiscussie. Immers, als te weinig rekening wordt gehouden met het onderscheid tussen smaak en waarde, tussen willekeurige en gereflecteerde voorkeuren, als alles of elke smaakvoorkeur een 'waarde' wordt genoemd, met daarbij de relativerende houding die bij een smaakdiscussie hoort, dan lijkt het erop alsof alle waarden relatief zijn geworden: ik doe wat ík denk dat goed is; daar heb ik niemand anders meer bij nodig - een typische houding in een postmoderne samenleving. Een van de vragen die in dit hoofdstuk moeten worden opgelost is de verhouding tussen de veelheid van bestaande waarden en het waarderelativisme (zie paragraaf 2.4)

Er is een sceptische traditie in de wetenschap, langdurig gevoed door de sterke invloed van het positivisme, die zegt dat het onmogelijk is om evaluatieve maatstaven te vinden voor goed en slecht in de wereld (Mackie 1977). De wetenschap kan zich slechts bij de feiten houden. Het meest uitgesproken hierover was Ayer in zijn invloedrijke boek uit 1936 Language, Truth and Logic: "Since the expression of a value judgment is not a proposition, the question of truth and falsehood does not arise here" (Ayer 1971: 29). Hieruit volgt voor Ayer en voor veel van zijn volgelingen: "Ethical concepts are pseudoconcepts and consequently indefinable” (ibidem: 149-150). Deze angst voor ethisch geladen begrippen heeft ertoe geleid dat het onderwerp 'waarden en normen' binnen de sociale wetenschappen 
lange tijd zeer is verwaarloosd. Dit heeft weer indirect bijgedragen aan een verdere subjectivering van de moraal en een relativerende houding jegens het 'waardevraagstuk'.

Recentelijk echter is dit positivistische dogma aan het wankelen gebracht en wordt er meer werk gemaakt van wetenschappelijk onderzoek naar waarden en evaluatieprocessen (Putnam 2002). Zo schrijft de econoom-filosoof Anderson laconiek dat het mysterie van 'goed en slecht' gemakkelijk kan worden ontraadseld, als we maar (willen) kijken naar wat de gewone alledaagse ervaringen met waarden zijn: "We ervaren dingen niet enkel als goed en slecht, maar altijd als goed en slecht in bepaalde opzichten, hetgeen een bepaalde reactie bij ons oproept. Er is niets mysterieus aan het feit dat een toetje lekker, een grap schitterend, een voetbalwedstrijd opwindend en een revolutie bevrijdend worden genoemd. Zo vinden we iemands complimenten flemerig, een taak zwaar, een toespraak saai. Iets als goed ervaren is dus er gunstig door worden gestemd erdoor te worden geïnspireerd, aangetrokken, geïnteresseerd, aangenaam verrast, verwonderd" (1995: 1-2, vertaling WRR).

Ze geeft vervolgens een omschrijving van het waarderingsproces waaruit waarden resulteren: "Iets waarderen is er een samenstel van positieve houdingen tegenover hebben, beheerst door afzonderlijk herkenbare maatstaven voor perceptie, emotie, overweging, verlangens en gedrag" (ibidem). Ouders zien graag dat het goed gaat met hun kinderen en betreuren het wanneer ze schade lijden of gewond raken. Dit betekent dat ze rekening houden met hun noden en behoeften, hun welzijn serieus nastreven en in hun eigen gedrag mee laten tellen, in actie komen, wanneer ze dat nodig vinden om hun zorg concreet te maken. Anderson concludeert hieruit dat dit allemaal de 'waarde' van ouderlijke liefde uitdrukt. Waarden laten zich in de dagelijkse praktijk van menselijk gedrag wel degelijk waarnemen en beschrijven. Niet het bestaan van waarden, maar hun onoverzichtelijke hoeveelheid en onderlinge verhoudingen vormen het moeilijkste bestanddeel van een houdbare en bruikbare waardeleer.

\subsection{DE PRAKTISCHE BENADERING VAN RESCHER}

De Amerikaanse filosoof Rescher doet in zijn klassieke studie Introduction to Value Theory (1969) geen poging om het begrip waarden te omschrijven. Hij vraagt zich slechts af: hoe worden waarden zichtbaar in het dagelijkse leven? Deze vraag is wel te beantwoorden: "Waarden weerspiegelen zich in rechtvaardigingen van en in aanbevelingen voor gedragingen" (1969:3). Hij wijst op het januskopkarakter van waarden, waarmee hij bedoelt dat het steeds gaat over twee aspecten van waarden, namelijk verbal behavior en overt action.

a Zeg-gedrag (rechtvaardiging van handelingen, aansporingen tot dat handelen en inner discourse, inwendige beraadslaging over welke koers van handelen gevolgd zal/moet worden).

b Doe-gedrag (acting in accordance with the value, promoting adoption by others). 
De relatie tussen zeg-gedrag en doe-gedrag is altijd problematisch vanwege:

- het gevaar van hypocrisie (saying the one, while doing the other); lippendienst bewijzen aan de waarde, maar er niet naar handelen; dit leidt tot de ondermijning van vertrouwen, vooral het vertrouwen in gezagsdragers (Matza 1969);

- conformiteit in gedrag zonder dat men in de waarde zelf gelooft; dit is het probleem van de openlijke conformist, die de waarde eventueel geheel verwerpt als hij/zij de kans krijgt, maar zich wel naar de opgelegde regels gedraagt;

- er zijn altijd meer invloeden op het gedrag dan waarden; men onderschrijft de waarde, maar leeft er niet naar; dit is het omgekeerde gedrag van dat van de conformist;

- de abstractiegraad van waarden; er zijn vele afleidingen te maken van waarden in concrete omstandigheden; waarden zijn niet gedragsspecifiek;

- de contextafhankelijkheid van waarden en gedrag.

Rescher benadrukt het gegeven dat uit de waarden geen specifiek gedrag kan worden afgeleid, maar dat uit het vertoonde gedrag wel waarden kunnen worden afgeleid. $\mathrm{N}$ is (of rijdt) voorzichtig betekent dat $\mathrm{N}$ voorzichtigheid als waarde aanneemt. Waarden worden zichtbaar ín het getoonde gedrag (Rescher 1969: 9).

Met de twee aspecten van waarden corresponderen twee methoden van onderzoek naar waarden.

1 Gedragsonderzoek, bijvoorbeeld budgetonderzoek: hoe besteedt men resources, materiële bronnen, hoe besteedt men tijd? De bestedingen worden gezien als uitdrukkingen van gekozen waarden.

2 Inhoudsanalyse van teksten en toespraken, van gedane uitspraken en van antwoorden in questionnaires, waarbij hetzelfde lastige probleem speelt van de relatie tussen zeg-gedrag en doe-gedrag. Vragenlijstonderzoek beperkt zich vaak tot verbale reacties op verbale vragen (zie verder ook hoofdstuk 3 ).

Rescher verbindt de relevantie van waarden voor het gedrag vervolgens aan het hebben van een bepaalde levensvisie: "Man imputes a value to characterize his vision on the good life or the good society or his vision of how life ought to be lived." De relevantie van waarden bestaat erin dat waarden functioneren als beperkingen (constraints) en als stimuli, als verboden en als geboden. Rescher: "The fabric of value is woven of the thoughts people entertain about their actions within the framework of their view of the good life" (1969: 6). Omdat waarden ingepast zijn in een bepaalde levensvisie, is er ook sprake van een persoonlijke keuze van de waarden die mensen nastreven. Persoonlijke, existentiële ontwikkeling bestaat eruit dat men bepaalde waarden nastreeft en probeert na te leven en andere waarden juist niet verkiest. Omdat deze persoonlijke keuzen in een moderne samenleving zeer uiteenlopen, ontstaat er een grote pluriformiteit en zijn conflicten tussen waarden, zowel in het persoonlijke bestaan als in de maatschappij als geheel, een onvermijdelijk iets (zie voorts paragraaf 2.4 van dit hoofdstuk). 
Een eerste conclusie uit deze praktische benadering van Rescher is de volgende: bestudering van waarden kan nimmer los gezien worden van de bestudering van gedragingen. Waarden moeten worden geplaatst binnen een bepaalde levensvisie (het veelvuldig kijken naar televisie is daardoor geen waarde geworden, omdat het niet geplaatst is binnen een bepaalde levensvisie; het wordt pas een waarde als het nadrukkelijk geplaatst wordt binnen zo'n levensvisie: televisiekijken als belangrijk onderdeel van het leven, bijvoorbeeld van een televisierecensent).

Een tweede conclusie: de thans in de samenleving als probleem gevoelde verwaarlozing van 'waarden en normen' bestaat misschien wel vooral uit het feit dat een groot en groeiend aantal personen in hun gedragingen niet meer leven naar de waarden die ze zeggen aan te houden en na te streven. Dit is de gedragscomponent van de waarden- en normenproblematiek (in hoofdstuk 4 verder uitgewerkt). Dat het daarnaast ook als problematisch wordt ervaren dat andere personen en groepen wel leven volgens hún waarden en normen, binnen een consistente levensvisie, maar dat deze niet met de westerse waarden overeenkomen, wijst op een andere component in de huidige problematiek. Dit is de component van de culturele waardeverschillen (in hoofdstuk 6 verder uitgewerkt).

Een derde conclusie: waarden zijn niet gedragsspecifiek, dat wil zeggen dat uit waarden zeer uiteenlopende en verschillende normen en gedragingen kunnen voortvloeien. Men kan in een samenleving wel streven naar een consensus over waarden, maar doordat die gemeenschappelijk gedeelde waarden toch tot zeer uiteenlopende gedragingen kunnen leiden, zijn de problemen van het samenleven nog lang niet opgelost. Dit vereist een nadere uitwerking.

\subsection{TWEE PROBLEMEN: DE VEELHEID EN DE ABSTRACTIEGRAAD VAN WAARDEN}

\subsubsection{DE WAARDE VAN WAARDEN}

De waarde van waarden is dat ze de reflectiegraad van het handelen van personen verhogen. Handelen vanuit waarden is niet 'zomaar wat doen' (bijvoorbeeld zinloos geweld). Als de dader erover zou hebben nagedacht, zou hij niet tot zulk gedrag zijn gekomen. Waarden verhogen daarmee de doorzichtigheid en de begrijpelijkheid van het handelen, hetgeen niet gelijkstaat met het aanvaarden ervan. Alles begrijpen is niet alles vergeven. Rescher: "The fundamental role of a person's value is to underwrite the evaluation of his actions" (1969: 11). Deze evaluatie van gedrag leidt tot praktisch redeneren en tot doelgericht denken over welke handelingen er gevolgd moeten worden om een gewenst doel te bereiken, inclusief de daarbijbehorende doel-middelrelaties tussen handelingen en doelstellingen. Het praktische nut van een beredeneerde afweging van middelen in relatie tot doeleinden in het menselijk gedrag, is reeds door Aristoteles, een van de eerste moraalfilosofen, erkend: 
We gaan bij onszelf niet te rade over onze doelen, maar over de middelen om deze te realiseren. Een arts immers denkt er niet over na of hij zijn patiënt gezond zal maken, een redenaar niet of hij zijn gehoor zal overtuigen; een politicus overweegt niet of hij een goede rechtsorde zal realiseren, en net zo min gaat iemand anders bij zichzelf te rade over zijn doel. Men stelt echter zijn doel en overdenkt dan hoe en door welke middelen het gerealiseerd kan worden. Wanneer het duidelijk is dat het doel door meer middelen tot stand wordt gebracht, bekijkt men door welk middel dit het gemakkelijkst en best gebeurt. Als één middel voldoende is om het doel te verwezenlijken, gaat men na op welke wijze dit middel het doel kan realiseren, en welk middel dit middel op zijn beurt realiseert, totdat men bij de eerste oorzaak komt, die bij dit procédé de laatste stap is (Ethica Nichomachea 1112b, 12-2O; Ned. vertaling 1997: 127).

Waarden verhogen de reflexiviteit in een samenleving en vereenvoudigen daarmee de inzichtelijkheid van het samenleven. Maar hier doen zich enkele complicaties voor, want over welke waarden hebben we het nu steeds? Waarden zijn naar hun vorm zeer abstract. Zij verwijzen naar zeer abstract geformuleerde doeleinden. Naar de inhoud echter kunnen waarden overal over gaan, kan men er alle kanten mee uit. Het is derhalve noodzakelijk voor elke zinvolle discussie over waarden zowel het probleem van de veelheid als het probleem van de abstractiegraad onder ogen te zien. Een zekere ordening van de waarden of een classificatie van de belangrijkste waarden is nodig om een toegespitste analyse mogelijk te maken. Gaat de discussie uitsluitend over morele waarden of ook over andere waarden, zoals bijvoorbeeld hoffelijkheid? Zijn alle waarden even belangrijk? Is er bij botsing van waarden een hiërarchie van waarden aan te brengen en op welke grond berust dan zo'n hiërarchie? Kunnen waarden met elkaar in strijd komen, bijvoorbeeld de economische waarde van voorspoed en vooruitgang en de ecologische waarde van behoud van de natuurlijke omgeving?

\subsubsection{ENKELE ONDERSCHEIDINGEN VAN WAARDEN}

Voor een beter begrip van waarden is het derhalve nuttig enkele onderscheidingen op een rij te zetten (Rescher 1969). Deze onderscheidingen betreffen telkens wisselende dimensies van waarden, die bovendien vaak gelijktijdig aanwezig kunnen zijn bij de actieve waardering van objecten. Van belang hierbij blijft het besef dat in principe alles object van waardering kan worden en dus een waarde kan vertegenwoordigen en 'van waarde' kan zijn: dingen en voorwerpen, geestelijk en cultureel erfgoed, omgevingen, individuen en relaties tussen individuen, persoonlijke karaktertrekken, groepseigenschappen zoals respect en vertrouwen, kenmerken van maatschappelijke systemen zoals rechtvaardigheid, rechtsgelijkheid en vrijheid. Daarnaast is het van belang onderscheid te maken naar de personen (of groepen) voor wie de waarde geldt, naar de inhoud van de waarden die men hooghoudt, naar de begunstigde personen die van de waarden profijt trekken en naar het klassieke onderscheid tussen intrinsieke en extrinsieke waarden. 


\section{$1 \quad$ Wiens waarden?}

Een persoon kan persoonlijke waarden kiezen; beroepsgroepen, bijvoorbeeld artsen en advocaten, kennen specifieke beroepswaarden; een arbeidsorganisatie of onderneming benadrukt speciale waarden die aan arbeid gerelateerd zijn, zoals de veiligheid van werknemers; steden hebben hun geschiedenis en hun eigen waarde; een natie ten slotte heeft nationale waarden ontwikkeld (zoals een besef tot een nationale gemeenschap te behoren, een historisch bewustzijn, of trots) die door zeer veel burgers gedeeld worden. De voornaamste dragers van waarden kunnen steeds wisselen en bestaan uit individuele personen, groepen, organisaties, steden, natiestaten en dergelijke.

\section{Wat wordt gewaardeerd?}

Welk object of welke toestand wordt gewaardeerd? Welke inhoud heeft een waarde? Welke noden, wensen, verlangens of belangen worden door de waarden behartigd? Dit kunnen materiële, economische, morele, sociale, politieke, esthetische, religieuze, wetenschappelijke, intellectuele, professionele of sentimentele waarden zijn, et cetera. Doordat de inhoud van waarden zo uiteen kan lopen, mede omdat alles object 'van waarde' kan worden, komt de vraag naar een rangorde van waarden vanzelf aan de orde. Zijn er 'hogere' en 'lagere' waarden? Zijn morele waarden hoger of belangrijker dan materiële waarden? Er is tussen waarden wel een zekere hiërarchie mogelijk: zo gaat gezondheid boven comfort en rechtvaardigheid boven hoffelijkheid, maar het is veel moeilijker om tussen de core values van een samenleving tot een sluitende en alom aanvaarde hiërarchie te komen. Behoren de waarden van de rechtsstaat tot de basiswaarden van een samenleving? Of behoren daartoe óók de materiële welvaart en de voorspoed? De nationale veiligheid?

In de discussie over waarden en normen gaat het meestal over morele waarden, maar juist de onderlinge verhouding tussen verschillende sóórten waarden (morele versus economische, ethische versus esthetische, hogere versus lagere) speelt altijd impliciet mee in de discussie. Explicitering van de onderlinge verhoudingen is daarom ook noodzakelijk.

\section{Wie zijn de begunstigden van waarden?}

Er kunnen verschillende ontvangers zijn van waardevol geachte activiteiten. Daarom maakt men onderscheid tussen egoïstische, self-oriented waarden (succes, privacy) enerzijds en altruïstische, other-oriented waarden anderzijds. Deze laatste kunnen weer onderscheiden worden naar de groep die men tot voordeel wil strekken, met name :

- ingroup-waarden (eigen gezin, beroep en reputatie van dat beroep, natie (vaderlandsliefde), maatschappij (rechtvaardigheid));

- outgroup-waarden (humanistische waarden, esthetische waarden ten behoeve van mankind of humanity). 


\section{$4 \quad$ Intrinsieke en extrinsieke waarden}

Extrinsieke waarden verwijzen naar andere waarden of zijn een wenselijk middel in het bereiken van een andere waarde. Bij extrinsieke waarden gaat het steeds om doel-middelrelaties tussen verschillende nagestreefde waarden. Vandaar dat ze ook wel instrumentele waarden worden genoemd. Zo verwijzen spaarzaamheid en zuinigheid naar welstand of welvaart. Generositeit verwijst naar geluk van en voor anderen. Intrinsieke of niet-instrumentele waarden verwijzen naar zichzelf, zijn doel op zich en staan dus niet in een doel-middelrelatie tot andere waarden: rechtvaardigheid, moraliteit, naastenliefde, blijheid. Deze waarden worden nagestreefd en nageleefd om zich zelfs wille. Vaak botsen extrinsieke waarden (welvaart) met intrinsieke waarden (rechtvaardigheid, moraliteit), zoals ook een instrumentalistische opvatting van waarden kan botsen op een niet-instrumentalistische. Waarden zijn niet bij voorbaat intrinsiek of extrinsiek: gelijkheid kan worden nagestreefd ofwel om meer vrijheid te bereiken (extrinsiek), ofwel omdat zij als een zelfstandige waarde wordt gezien, los van een ander na te streven doel (intrinsiek).

\section{$5 \quad$ Op welke termijn heeft de waarde betrekking?}

Kortetermijnwaarden (jaarlijkse winst, koopkrachtbehoud) en langetermijnwaarden (continuïteit van de onderneming, begrotingsevenwicht) staan vaak op gespannen voet met elkaar. Dit geldt niet alleen voor één persoon die moet kiezen tussen verschillende waarden in haar of zijn leven, maar ook voor organisaties en voor grotere sociale systemen. Economische groei kan voor de korte termijn worden nagestreefd, maar kan botsen met andere waarden die vooral op de lange termijn gelden, zoals het behoud van het natuurlijke milieu. Solidariteit tussen generaties is een langetermijnwaarde die opofferingen vraagt op de korte termijn. Dit temporele aspect van waarden is een vaak verborgen factor bij veel waardeconflicten en kan expliciet gemaakt worden bij de analyse van moeilijke en soms pijnlijke afwegingen tussen diverse waarden onderling.

De hierboven gemaakte onderscheidingen zijn niet uitputtend, maar ze bieden meer dan een Chinese classificatie. Ze kunnen duidelijk maken waarom er zoveel misverstanden ontstaan als men ongedifferentieerd gaat debatteren over waarden en normen. Steeds moet men zich afvragen: wiens waarden? Welk object of welke toestand wordt gewaardeerd? In wiens voordeel en in wiens nadeel worden waarden nagestreefd? Voor wie zijn de waarden bedoeld? Op welke termijn spelen ze?

\subsubsection{DE ABSTRACTIEGRAAD VAN WAARDEN}

In deze opsomming van waarden valt het op hoe algemeen de formuleringen zijn waarmee de waarden worden aangeduid: waarheid, rechtvaardigheid, solidariteit, respect en hoffelijkheid. De manieren waarop deze waarden kunnen worden bereikt zijn zelf schier onuitputtelijk. Een van de basisbehoeften (en dus basiswaarden) van het menselijk bestaan is het tot zich nemen van voedsel, maar de manier waarop deze behoefte wordt vervuld of deze waarde wordt gereali- 
seerd, ligt op geen enkele manier vast, naar tijd noch plaats. Men kan op talloze manieren aan de hongerimpuls tegemoetkomen: een snack, een losse boterham, een gevulde koek in de kantine, een copieus diner enzovoort. Men kan zelfs zonder dat men honger heeft, uitvoerig tafelen. Er is, met andere woorden, geen directe of causale relatie tussen de waarde op zich en de manier waarop die waarde in een concrete situatie wordt gepraktiseerd. Waarden zijn voor hun realisatie contextafhankelijk. Als de context verschilt, verschilt de invulling van de abstracte waarde.

De contextafhankelijkheid is een belangrijk gegeven. Enerzijds verklaart dit de soms verrassende overeenstemming in waarden tussen culturen onderling, tussen verschillende tijdperken in de geschiedenis en tussen de grote wereldgodsdiensten, die allemaal varianten van de tien geboden hebben geformuleerd (Choraqui 2002). Al deze waarden zijn zodanig abstract geformuleerd ('eerbied voor het leven, rechtvaardigheid, naastenliefde, respect voor de medemens') dat de verschillen in inhoudsbepaling van die waarden niet scherp kunnen worden onderscheiden, tenzij men een zeer gedetailleerde studie zou maken van de totstandkoming en de betekenis van die begrippen in hun historische context, zoals bijvoorbeeld Lewis gedaan heeft voor het begrip 'rechtvaardigheid' vanaf de Griekse Oudheid, via de Middeleeuwen en de Renaissance tot aan de hedendaagse samenleving (Murphy 2001). Anderzijds kan dit ook de grote onenigheid verklaren die herhaaldelijk, in verschillende historische tijden en op verschillende plaatsen, valt waar te nemen als het gaat om de concrete invulling van de als zodanig door iedereen aanvaarde waarden. De godsdienstoorlogen die Europa in de zestiende eeuw hebben geteisterd, ontstonden over de juiste uitleg van bijbelse teksten, waarvan de waarde door niemand werd betwist of over de juistheid waarvan men - in abstracto - niet van mening verschilde. Dat men gedoopt moest worden stond vast, maar wanneer en met welke graad van bewustheid dat diende te geschieden, leidde tot felle twisten. Evenzo was het gesteld met de vraag of mensen gedwongen konden worden te geloven, waarbij de waarde van het christelijke geloof niet werd betwijfeld. Men veroordeelde algemeen het gedrag van ketters, maar er ontstonden levensgrote verschillen van mening over de vraag of en om welke reden men die ketters dan mocht doden.

Met andere woorden, er is niet alleen een vraag naar de hiërarchie tussen waarden, in de waarden zelf is ook steeds een hiërarchische structuur te onderkennen. Rechtvaardigheid en gelijkheid zijn als waarden onbetwist, maar wat in welke situaties als rechtvaardig geldt en wat als gelijk en ongelijk telt, daarover verschillen de meningen permanent. In deze hiërarchie komt ook de structurele relatie tussen waarden en normen naar voren. Uit waarden kunnen velerlei normen worden afgeleid die allemaal, maar allemaal op een verschillende manier, de waarde kunnen realiseren. Over normen zijn meer twisten mogelijk dan over waarden, wanneer die maar algemeen en abstract genoeg worden geformuleerd. Om de discussie over morele waarden te verhelderen heeft Rescher in zijn monumentale studie The Validity of Values (1993: 189-198) een implementatieladder ontwikkeld, die via enkele treden afdaalt van het niveau van de hoogste 
waarden naar concrete (morele) beslissingen in concrete situaties. De vijf treden van deze ladder worden allereerst geïllustreerd voor een van de centrale waarden, waarna overeenkomstig ook andere waarden en normen met deze ladder kunnen worden geïdentificeerd:

Niveau 1: nagestreefde doelwaarde: RESPECT voor de MEDEMENS;

Niveau 2: verwijzende, instrumentele waarden en beginselen: EERLIJKHEID;

Niveau 3: normen: niet liegen, de waarheid spreken;

Niveau 4: gedragsregels: geef geen misleidende informatie bij het afleggen van verklaringen;

Niveau 5: beslissing over een concrete gedraging: antwoord naar waarheid op deze vraag van mevrouw Jansen (vrij ontleend aan Rescher 1993: 192; 1997: 137).

Dit ladderschema van hoogste doelwaarde, via normen naar eenvoudige gedragsregels en concrete gedragingen, kan men voor alle doelwaarden aflopen. Enkele voorbeelden ter illustratie.

Voorbeeld A

1 Doelwaarde: ZORG VOOR ANDEREN;

2 Verwijzende waarden: VEILIGHEID, GENEROSITEIT, EERBIED;

3 Normen: doe mensen niet onnodig pijn, bedrieg je medemensen niet, wees gastvrij;

4 Gedragsregels: verdoof mensen bij een operatie, speel niet vals, betaal je belasting;

5 Beslissing: geef het geld terug dat je van X hebt geleend, gooi je afval niet in de rivier, laat die kinderen niet met lucifers spelen (Rescher ibidem).

Voorbeeld B (vrije toepassing van Reschers schema)

1 Doelwaarde: wetenschappelijke WAARHEID;

2 Verwijzende waarden: ACCURAATHEID, NAUWKEURIGHEID;

3 Normen: doe zorgvuldige waarnemingen, verdoezel of vervals geen gegevens, verwijs waar nodig naar het onderzoek van anderen, pleeg geen plagiaat;

4 Gedragsregels: verifieer altijd alle gegevens, check alle berekeningen minstens tweemaal, laat het werk door anderen controleren en kritiseren, gebruik géén ad-hominemargumenten;

5 Beslissing: organiseer de (financiële) mogelijkheden voor een double blindexperiment.

Voorbeeld C (vrije toepassing van Reschers schema)

1 Doelwaarde: MACHT;

2 Verwijzende waarden: POLITIEKE INVLOED, PRESTIGE;

3 Normen: zorg voor een goede reputatie, oefen je in welsprekendheid, geef geen aanstoot aan de kiezers;

4 Gedragsregels: zoek zo veel mogelijk de aandacht van de media, controleer het eigen 'image' en onderdruk waar mogelijk negatieve berichtgeving; werk 
ondertussen aan een netwerk van relaties en bouw een imponerend cv op; gebruik, waar nodig, ad-hominemargumenten;

Beslissing: sta dit interview voor deze krant toe, ga met $\mathrm{X}$ dineren.

De laatste twee voorbeelden geven tegelijkertijd aan hoezeer verschillende waarden die in verschillende sectoren van de samenleving worden nagestreefd, op gespannen voet met elkaar kunnen staan. Van de twee uiteenlopende en opzichzelf staande waarden (WAARHEID en INVLOED) kunnen twee lijnrecht tegenover elkaar staande normen afgeleid worden, namelijk: gebruik geen respectievelijk wel ad-hominemargumenten. Omdat alle waarden door zeer veel en zeer uiteenlopende normen worden geïmplementeerd en daarmee gerealiseerd, zijn de mogelijkheden tot dergelijke botsingen zeer talrijk. Waardeconflicten en botsende normen zijn onvermijdelijk in een vrije samenleving.

Maar ook wanneer er binnen de maatschappij volledige overeenstemming (consensus) bestaat over een doelwaarde (EERBIED VOOR HET LEVEN), of binnen een bepaalde deelsector van de samenleving volledige overeenstemming bestaat over de binnen die sector gewenste doelwaarde (WAARHEID voor de wetenschapsbeoefening), dan nog ontstaan er verschillen van mening (dissensus) over de manier waarop deze waarde via normen moet worden geïmplementeerd of in concrete omstandigheden moet worden toegepast. Geldt de eerbied voor het leven onder alle omstandigheden, of moet deze basiswaarde wijken voor bijvoorbeeld de bestrijding of het voorkómen van een terroristische aanval waarbij zeer veel onschuldige slachtoffers kunnen vallen? Alle wetenschapsbeoefenaren streven naar waarheid, maar de concrete opvattingen daarover lopen zeer ver uiteen. Met andere woorden, het bereiken van overeenstemming over bepaalde grondwaarden zegt nog weinig over de wijze van implementatie, die voor het samenleven als zodanig van minstens net zo veel gewicht is als de geformuleerde waarden zelf.

De abstractiegraad van waarden kan mede verklaren waarom er steeds een grote afstand blijft bestaan tussen de beleden en nagestreefde waarden en het actuele handelen, dat vaak niet in overeenstemming is met die waarden. We gebruiken heel vaak het begrip waarden, maar geven ons er bijna geen rekenschap hoe we dat begrip gebruiken. Vaak slagen we er niet in ernaar te leven. Hoe komt dat? Omdat we ons de redenen en de motivatie voor het goede handelen niet voldoende eigen hebben gemaakt, of uit laksheid, inertie, besluiteloosheid, de onderworpenheid aan andere neigingen, wilszwakte, of gewoon uit gemakzucht? In al deze gevallen is er een botsing tussen de waarden en het gedrag dat niet conform de van de waarden af te leiden norm is. Het volgende is hiervan een goed en herkenbaar voorbeeld.

Voorbeeld D

1 Doelwaarde: GEZONDHEID;

2 Verwijzende waarden: FYSIEKE EN MENTALE FITHEID, ENERGIE;

3 Normen: gij zult niet roken, gij zult vaak bewegingsoefeningen doen; 
4 Gedragsregels: in dit gebouw wordt niet gerookt, elke maandag joggen;

5 Beslissing: ik koop nu geen pakje sigaretten, ik ga naar het fitnesscentrum.

Hoewel iedereen weet hoe belangrijk gezondheid is in het leven en hoezeer gezondheid uit onderzoekingen altijd als een van de hoogst gewaardeerde waarden naar voren komt, overtreden zeer velen de vrijwillig aanvaarde normen en andere gedragsregels die de gezondheid bevorderen. Weten dat je niet moet roken geeft kennelijk onvoldoende reden en motivatie om dat ook niet te doen. Het voorbeeld van het roken is uit te breiden tot talloze andere voorbeelden in de waardesfeer, inclusief de waarden die met het wettelijk afgedwongen gedrag te maken hebben. Tussen de waarde en de norm en tussen de norm en het gedrag liggen brede en diepe kloven die nog onvoldoende zijn verkend.

Deze korte analyse van de abstractiegraad van waarden brengt enkele regelmatigheden over waarden en normen aan het licht:

- hoe abstracter waarden worden geformuleerd, des te meer overeenstemming erover in een samenleving kan worden verwacht en vaak ook zal worden geconstateerd; dit geldt met name voor de meest fundamentele basiswaarden;

- naarmate men de ladder van abstractie afdaalt, ontstaat er meer onenigheid over de toepassing en implementatie van waarden, met name tot aan het niveau van normen; er is geen overeenstemming over welke normen uit de waarde moeten worden afgeleid;

- op het niveau van de gedragsregels en van concrete beslissingen en gedragingen wordt weer gestreefd naar een praktische, zij het vaak tijdelijke consensus;

- het handelen is vaak niet in overeenstemming met de waarden die worden nagestreefd, mede omdat de abstractie van de waarde veel ruimte overlaat.

Er is ten slotte een belangrijke conclusie te trekken uit de analyse van de veelheid en de abstractiegraad van waarden: een publieke discussie over de waarden- en normenproblematiek waarin niet voldoende wordt gelet op de vele niveaus waarop men met elkaar over die waarden spreekt en de gezichtspunten van waaruit men spreekt (wiens waarden, welke objecten, welke inhoudelijk nagestreefde doelen etc.), heeft weinig zin. Zo'n discussie kan zelfs tot weerzin leiden, hetgeen jammer is, omdat de problematiek van waarden en normen wel een hernieuwde aandacht in de samenleving verdient.

\subsection{WAARDEN EN HET GOEDE LEVEN}

\subsubsection{VERSCHILLENDE VISIES OP HET GOEDE LEVEN}

Tot nu toe is in de analyse van het waardebegrip geen onderscheid gemaakt in de soort waarden waarover de discussie primair gaat. De eigenschappen van waarden (veelomvattendheid, abstractie, niet-gedragsbepalend) gelden immers 
evenzeer voor esthetische, economische, ecologische of emotionele waarden. Maar de waarden- en normendiscussie vindt vooral plaats in een politiek-maatschappelijke context, waar de vraag hoe het gesteld is met het morele gehalte van gedragingen en waarderingen de hoofdaandacht opeist. Het gaat met name om het samenleven in het gemeenschappelijke politiek bestel van de natiestaat en internationale verbanden. Daar hebben zich zo veel veranderingen voorgedaan (onder andere internationalisering, individualisering, interculturalisering en informatietechnologie) dat een hernieuwde oriëntatie gewenst is omtrent de waarden die vastgehouden moeten worden of die kunnen veranderen. Die morele oriëntaties worden vaak samengevat in visies op 'het goede leven' en de daarbij behorende consequenties over de inrichting van de samenleving.

In de westerse samenlevingen zijn in de loop van de geschiedenis verschillende morele visies op het goede leven ontwikkeld. Taylor (1985) beschrijft kernachtig de verschillen tussen deze visies, waarin gemakkelijk de verschillende politieke stromingen te herkennen zijn. In de eerste visie is het leven gericht op persoonlijke integriteit, waarin men zichzelf verplicht te handelen in overeenstemming met de eigen overtuiging en alle druk en dwang van sociale aard probeert te weerstaan: persoonlijke autonomie is het voornaamste doel. In de tweede visie is het leven gewijd aan gemeenschappelijke liefde (agapè), waarin men er zo veel mogelijk naar streeft om een voertuig te worden van Gods liefde voor de mensen: christelijke naastenliefde is het voornaamste doel. De derde visie is gericht op bevrijding, zowel zelfbevrijding als bevrijding die voortkomt uit een gemeenschappelijk streven naar maatschappelijke verandering in het lot van bepaalde maatschappelijke groepen of klassen: solidariteit is het voornaamste doel. Ten slotte is er een vierde, niet onbelangrijke visie, die met een beroep op de rede vraagt om een objectieve blik en die alle interpretaties van de werkelijkheid en het leven onderwerpt aan het "koude, illusieloze licht van de moderne wetenschap" (Taylor 1985: 234; Schuyt 1995a: 14-15).

De invloed van elk van deze verschillende visies en de daarin geconcentreerde morele waarden op de ontwikkeling van de westerse samenleving is groot geweest. De Europese verzorgingsstaat wordt vaak beschreven als een per land verschillende samensmelting van liberale waarden, christelijke naastenliefde en socialistische solidariteit (Esping-Andersen 1990). Sociaal-economische ontwikkelingen hebben ertoe bijgedragen dat de accenten op de verschillende waarden konden verschuiven. Terwijl de verzorgingsstaat gegrondvest is op sociaaldemocratische solidariteit en christelijke naastenliefde, Taylors tweede en derde visie, heeft de staat mede geleid (misschien door zijn eigen succes) tot een sterk individualistische en liberale moraal van de autonome burger (Schuyt 1995a:15). Politieke keuzes en sociaal-economische ontwikkelingen bevatten aldus steeds belangrijke morele componenten en de steeds terugkerende vraag hierbij is of de veranderingen in de publieke moraal en in morele voorkeuren van de burger als een verslechtering of als een verschuiving moeten worden geïnterpreteerd. Betekent meer vrijheid voor autonome burgers automatisch minder solidariteit of gemeenschapszin? Dienen nieuwe visies zich aan in een nieuw maatschappelijk 
krachtenveld? Met andere woorden: hoe verhouden de verschillende morele visies zich tot elkaar en hoe gaan ze met elkaar om in een en dezelfde politieke ruimte?

\subsubsection{MONISME, PLURALISME, RELATIVISME}

Een politieke gemeenschap verschilt in bepaalde opzichten van andere gemeenschappen, zoals een godsdienstige gemeenschap, een kloostergemeenschap, een familie, een vereniging of genootschap of zelfs een scholengemeenschap. De meeste gemeenschappen bestaan uit gelijkgezinden die op vrijwillige basis bij elkaar horen en ook bij elkaar willen blijven. In een politiek bestel, bijvoorbeeld een natiestaat, moet men met 'andersdenkenden' en met alle 'gezindten', personen en groepen met andere opvattingen en levenswijzen rekening houden. Dit stelt hoge eisen aan de inrichting van staat en samenleving. Er zal een minimum aan gemeenschappelijke waarden noodzakelijk zijn en tegelijk voldoende ruimte open moeten blijven voor verschillen. Maar welke waarden kunnen als noodzakelijk minimum gelden en welke als variabele keuzen? Gaat het bij de inrichting van de samenleving vooral om morele waarden of toch ook om andere, nietmorele waarden, zoals de waarde van een eigen beroepskeuze, van een goede gezondheid, of de mogelijkheden van een goede, ongestoorde nachtrust? In de huidige waarden- en normendiscussie wordt soms gesuggereerd dat die uitsluitend zou gaan over morele waarden en dat deze morele waarden een hogere status zouden bezitten dan andere, meer seculiere waarden (Kinneging 2003).

De liberale filosoof Kekes $(1989,1993)$ heeft een verhelderende bijdrage geleverd, zowel over de verhouding tussen minimale basiswaarden en andere, 'vrijere' waarden als over het al of niet samengaan van morele en niet-morele waarden bij het streven naar het goede leven en de daaruit volgende inrichting van staat en samenleving. Allereerst geeft Kekes een korte maar uiterst krachtige definitie van waarden: "Possibilities whose realization may make lives good" (1993: 27). Een prachtige definitie, want ze wijst op het abstracte karakter van waarden, in de zin van mogelijkheden, en tegelijk op de opdracht om die waarden in concreto te realiseren. Pas als waarden gerealiseerd worden, wordt hun werking zichtbaar. Kekes geeft als voorbeeld de mensenrechten, die als onbetwistbare waarden worden erkend. Maar ze zijn lang nog niet overal ter wereld realiteit. De daadwerkelijke realisering ervan zou het leven van vele mensen in vele landen inderdaad tot een goed leven maken. De mensenrechten behoren tevens tot die minimale waarden waarover een grote eensgezindheid bestaat. Het respecteren van mensenrechten kan tot de basiswaarden van een samenleving gerekend worden, gerelateerd als ze zijn aan de minimaal nood-zakelijke levensbehoeften van de mens: fysiologische behoeften als voedsel, kleding en een dak, psychologische als liefde en vrijwaring van vernedering, sociale als respect en vrijwaring van exploitatie en slavernij. Niet gemarteld worden, niet vernederd worden, niet geëxploiteerd worden als mens of van alle individuele rechten verstoken blijven, zijn minimale voorwaarden voor een beschaafd, menselijk bestaan. Ze kunnen tot basiswaarden van een samenleving gerekend worden. In deze benadering van 
waarden is ook plaats voor idealen. Als men waarden opvat als 'mogelijkheden waarvan de realisering het leven tot een goed leven maakt', dan verwijzen deze abstracte mogelijkheden naar bepaalde idealen die nagestreefd kunnen (en moeten) worden. Waarden krijgen zo een aantrekkingskracht die het persoonlijke en maatschappelijk handelen een bijzondere motivatie meegeven. Als zodanig zijn waarden, hoe abstract en potentieel ook, onmisbaar voor een decente samenleving (Van der Burg 2001).

Het abstracte karakter van die basiswaarden laat evenwel in het midden op welke wijze hieraan wordt voldaan. Naar tijd, plaats en sociale gewoonten kunnen er andere eisen worden gesteld aan het voorzien in eten, drinken en huisvesting. Dus zelfs basiswaarden hebben een variabel aspect, gelijktijdig met hun invariabele kern. In de waardetheorie van Kekes is er geen absolute tegenstelling tussen basiswaarden en conventionele waarden, die afhankelijk van sociale gebruiken en gewoonten enorm kunnen verschillen. Het geheel van waarden in een samenleving of in een cultuur is steeds een bepaalde mengeling van onbetwiste, nader in te vullen en te concretiseren basiswaarden en een grote reeks van afzonderlijke, soms vertrouwde, soms zeer vreemde conventionele waarden (Kekes 1993: 18 e.v.). De verscheidenheid aan culturen en historische perioden heeft dan ook een even grote verscheidenheid aan dergelijke conventionele waarden te zien gegeven.

De vraag of het goede leven voornamelijk bestaat uit morele waarden wordt door Kekes negatief beantwoord: "Het goede van een leven kan afhankelijk worden gedacht van ofwel de persoonlijke bevrediging die het verschaft aan de handelende persoon, ofwel van de morele verdiensten die het heeft. Discussies over wat een leven goed maakt zijn daarom ambivalent en helderheid vereist dat die ambivalentie wordt weggenomen. Een leven wordt goed genoemd, alleen als het zowel persoonlijk bevredigend wordt gevonden en moreel verdienstelijk is. Elk van deze componenten alleen zou niet voldoende zijn om een leven goed te maken. Want persoonlijke bevrediging zou kunnen worden bereikt ten koste van heel veel leed en kwaad en de prijs van morele verdienste kan een veelvuldige frustratie van redelijke verlangens opleveren; noch kwaad noch gefrustreerde levens kunnen worden verondersteld goed te zijn” (Kekes 1993: 9, eigen vert.).

Een goede inrichting van de samenleving geeft dus aan individuen én aan de samenleving als geheel hun goed recht op een goed leven. Persoonlijke belangen en voorkeuren, ook al zijn die niet van morele aard, zoals een beroeps- of partnerkeuze, het ontwikkelen van een vreemdsoortige hobby, het volgen van een beroepsloopbaan, financiële onafhankelijkheid verwerven et cetera, leggen wel degelijk gewicht in de schaal van waarden in een samenleving; al was het alleen maar om het feit dat het blijvend frustreren van op zichzelf redelijke persoonlijke behoeften of keuzen tot sociale wrijvingen en onvrede leidt. Aan persoonlijke keuzes wordt aldus een intersubjectieve waarde toegekend. De samenleving als geheel heeft er belang bij dat personen eigen waarden kiezen en ontwikkelen, 
mits zij daarbij de persoonlijke keuzen van medeburgers geen schade toebrengen. Het telkens weer aangeven van de verhouding tussen morele en niet-morele waarden en van hun grenzen is een permanente aangelegenheid van praktische politieke besluitvorming. Dit uitgangspunt brengt echter wel enkele consequenties en noodzakelijke verplichtingen met zich mee.

Een van de consequenties is de onvermijdelijkheid van conflicten over waarden, zowel in het leven van een individu als tussen individuen en in de samenleving als geheel. Juist omdat waarden bestaan uit mogelijkheden tot een goed leven en omdat er zeer veel mogelijkheden zijn om een goed leven te realiseren, kunnen waarden met elkaar in conflict komen. Men kan alle mogelijkheden aanwenden, maar nimmer alle mogelijkheden tegelijk realiseren. Men kan een goed nachtelijk gesprek over waarden en normen hoog op prijs stellen - op zich een weg naar de realisering van een respectabele waarde - en men kan veel waarde hechten aan een goede nachtrust, maar beide, op zichzelf redelijke handelingen, kunnen niet tegelijk gerealiseerd worden. Zo zijn er nog veel meer en veel belangrijker keuzen, zoals tussen een carrière en het opvoeden van kinderen, tussen veel en zwaar tafelen en slank blijven, tussen veel geld verdienen en jezelf opofferen voor de zorg van zieke familieleden. Liefde betekent meer afhankelijkheid van anderen en is daarom moeilijker met een volstrekte onafhankelijkheid te verenigen. Analoog aan persoonlijke keuzes ontmoet men in het maatschappelijke handelen talloze waardeconflicten: tussen meer eigen verantwoordelijkheid en sociale controle, tussen sociale gelijkheid en welvaartsvermeerdering, tussen onpartijdige rechtvaardigheid en vriendschap. Men moet steeds kiezen en dit geldt voor alle waarden en in alle verhoudingen tussen waarden. Berlin heeft deze gelijktijdige onverenigbaarheid van de meest centrale waarden van de westerse wereld - vrijheid en gelijkheid - tot de hoeksteen van zijn politieke filosofie gemaakt (Berlin 1969). Ook tussen morele en niet-morele waarden dient gekozen te worden, omdat ze vaak niet beide tegelijk kunnen worden gerealiseerd: een persoonlijke ambitie volgen en zich op morele gronden wegcijferen voor anderen gaan niet samen, hoezeer beide levenskeuzen op zich te eerbiedigen zijn. Er zijn verschillende invullingen van het goede leven, die allemaal even moreel juist of waardevol zijn, hoewel ze niet met elkaar zijn te vergelijken of te verenigen: de non, de handelsreiziger of de artieste kunnen alledrie, afhankelijk van hun omstandigheden en wensen, een waardevolle vervulling aan hun leven geven, ook al lopen de drie levens mijlenver uiteen.

Waardeconflicten zijn onvermijdelijk en hieruit volgt een verplichting om op de vele niveaus van de samenleving waarin deze conflicten zich voordoen redelijke vormen van conflictbeslechting uit te vinden en te ontwikkelen. De ontwikkeling van een democratische rechtsstaat kan in dit licht worden gezien als een min of meer stabiele manier om de onvermijdelijke waardeconflicten in een samenleving zó op te lossen dat de samenleving niet uiteenvalt en dat de minimale basiswaarden, de mensenrechten, daarbij niet worden geschonden (zie hiervoor ook hoofdstuk 5). 
Het bestaan en de frequentie van waardeconflicten leiden theoretisch en praktisch tot de vraag of dergelijke conflicten kunnen worden opgelost door het opstellen van een hiërarchie van waarden of een combinatie van bepaalde waarden. Dit is een bekend probleem in de geschiedenis van de moraal en het probleem is op verschillende manieren opgelost. Een monistische oplossing stelt dat een dergelijke hiërarchie te maken valt (of in de natuur gegeven ligt) en dat bepaalde waarden te allen tijde en in alle omstandigheden boven andere waarden gesteld kunnen worden. Met andere woorden: er zijn waarden die andere waarden altijd kunnen aftroeven. Een pluralistische oplossing stelt dat een dergelijke hiërarchie tussen waarden niet te geven valt, omdat de concrete omstandigheden, naar tijd en plaats verschillend, nimmer zo'n absolute afweging mogelijk maken. Waarden zijn, als mogelijkheden die gerealiseerd worden in concrete gevallen, altijd voorwaardelijk, dus aan bepaalde voorwaarden gebonden. Steeds zijn er uitzonderingen, zelfs als het gaat om basiswaarden als de eerbied voor het leven: iemand wil zijn/haar leven offeren om de tirannie te bestrijden, zoals bij de aanslag op Hitler in 1944, of ter voorkoming van een massale nucleaire terreuraanval zal men de daders onschadelijk mogen maken. Het monisme en het pluralisme van waarden verschillen dus principieel in hun antwoord op de manier waarop waardeconflicten moeten worden beoordeeld. Het monisme stelt dat er één hoogste goed is, dat op verschillende manieren kan worden bereikt; het pluralisme stelt dat er verschillende vormen zijn van een hoog goed (in casu een goed leven) en dat die verschillende vormen ook nog eens op verschillende manieren te bereiken zijn (vergelijk de drie uiteenlopende levensvervullingen). Een van de oorzaken van de morele verwarring en gevoelens van morele desintegratie die thans zo veelvuldig te bespeuren zijn, zegt Kekes, ligt in de verschuiving van een lange traditie van een waardemonisme naar een pluralisme: "Waar deze veranderingen vooral op wijzen is dat we van een monistische naar een pluralistische moraal onderweg zijn en sommige van de veranderingen waar we rondom ons heen en in onszelf getuige van zijn, zijn diep omdat de overgang van monisme naar pluralisme zo fundamenteel is als iets in de geschiedenis van onze moraal ook maar kan zijn (Kekes 1993: 15, eigen vert.).

Leidt dit pluralisme tot relativisme? Relativisten stellen zich op het standpunt dat er geen enkel rationeel criterium te vinden is om tussen de veelheid van met elkaar strijdende waarden te kiezen. Relativisten zijn het met pluralisten eens dat er geen allesoverheersende waarde of combinatie van waarden te vinden is, maar ze verschillen van pluralisten in de mening dat er geen enkel waardeoordeel onafhankelijk van een context kan worden gegeven. Alles is conventie. Pluralisten, zoals Kekes, wijzen dan op de basiswaarden die met de natuurlijke aard van de mens te maken hebben. Hoewel de concrete realisatie van deze basiswaarden conventionele elementen bevat (zie boven), bevat de kern van het menselijk bestaan een op zichzelf staande morele waarde, weliswaar niet absoluut (ze kunnen botsen met andere basiswaarden) maar ook niet volstrekt willekeurig. Alleen voor wie geen onderscheid wil maken tussen basiswaarden en conventionele waarden, zijn alle waarden relatief (Kekes 1993: 31). Dat pluralisme niet tot relativisme leidt, blijkt vooral uit het vasthouden aan de basiswaarde van 
menselijke waardigheid, zoals die concreet in de mensenrechten is beschreven, vastgelegd en beschermd. De mensenrechten hoeven als basiswaarden niet beschouwd te worden als louter toevallige, in de geschiedenis van de westerse wereld opgekomen waarden die - vanwege die historische context - geen universele gelding zouden bezitten. Ook al zijn de omstandigheden waaronder deze mensenrechten worden gerealiseerd historisch, sociaal en cultureel variabel, daaruit volgt niet dat individuele personen in andere tijden en streken minder waarde zouden hechten aan hun recht op leven en op een menswaardig bestaan.

\subsection{ANALYSE VAN HET BEGRIP 'NORM': OM WELKE NORMEN GAAT HET?}

\subsubsection{EIGENSCHAPPEN VAN NORMEN EN REGELS}

Waarden en normen worden vaak in een adem genoemd en zijn zo langzamerhand een gevleugeld begrippenpaar geworden. Toch verschillen ze in belangrijke opzichten van elkaar. Hoewel normen natuurlijk ook abstract en algemeen van aard zijn, hebben waarden in logische zin een hogere abstractiegraad. Waarden zijn meestal zeer ruim en algemeen geformuleerd. Rechtvaardigheid, gastvrijheid, gelijkheid, schoonheid zijn allemaal erkende waarden, die juist vanwege hun algemeenheid nog voor zeer wisselende en uiteenlopende uitleg vatbaar zijn. In die abstractie ligt juist de kracht van waarden. Want daardoor kunnen ze fungeren als ruime oriëntatiepunten voor gedrag, als rechtvaardiging voor gedrag, en spelen ze een belangrijke rol bij de beoordeling van handelingen. Maar als gedragsbepalende factor schieten waarden te kort. Waarden kunnen mensen met elkaar verenigen en binden, maar tegelijk kunnen ze ruzie over de uitleg ervan opleveren (vandaar dat een al te grote of al te frequente explicitering van waarden de verschillen doet toenemen en zo kan leiden tot grote en soms onverzoenlijke maatschappelijke conflicten, zoals godsdienstoorlogen). Waarden zijn meestal positief geformuleerd, geven waardevolle wenselijkheden weer; normen daarentegen zijn zeer vaak negatief geformuleerd en zeggen wat niet mag. Waarden hebben zo een open horizon, normen juist een gesloten ruimte waarbinnen men moet blijven. Waarden zijn onbegrensd, normen trekken per definitie een grens.

Normen zijn minder algemeen dan waarden, maar moeten ook 'in actie' gebracht worden, dat wil zeggen vertaald worden in concreet gedrag, in concrete omstandigheden. Dit gedragselement komt in alle omschrijvingen van normen terug. Zo omschrijft de Australische rechtsfilosoof Pettit normen als een regelmatigheid in gedrag waaraan men zich moet conformeren: "First, if a regularity is a norm in a society, then it must be a regularity with which people generally conform; lipservice is not enough on its own. And second that people in the society generally approve of conformity and disapprove of deviance: they may believe that conformity is an obligation of some sort" (Pettit 2002: 311). Anders dan bij waarden gaat er van normen een striktere dwang uit tot confor- 
miteit aan die normen. Normen (norms) en regels (rules) worden in dit verband meestal als synoniem gebruikt. Het begrip norm of regel is immers afgeleid van het Latijnse begrip norma, dat oorspronkelijk meetlat of winkelhaak betekende, maar gaandeweg wet, regel, maatstaf of richtsnoer (Latijn: regula) is gaan betekenen (Woldring 2004; De Vries 2004). Normen en regels zijn verplichtend ten opzichte van het gedrag, terwijl waarden door hun ruime uitleg en hun gedragsongespecificeerdheid slechts in morele zin verplichtend zijn. Andere auteurs benadrukken eveneens de gedragsconformiteit en het verplichtende karakter van normen. Zo omschrijft Elster in The Cement of Society (1989: 99): "For norms to be social they must be (a) shared by other people and (b) partly sustained by their approval and disapproval." Normen worden ondersteund door gevoelens van ongemak, verwarring, schuld en schaamte bij overtreding: "Social norms have a grip on the mind that is due to the strong emotions their violations can trigger" (ibidem: 100).

De structuur van verplichtende normen en regels is eenvoudig: 'gij zult' of 'gij zult niet', 'do' of 'don't'. Naast verplichtende normen zijn er binnen het geheel van een normsysteem ook andere regels en normen, zoals procedureregels, regels over de toepassing of verandering van regels en de zogenaamde rules of recognition (Hart 1969). Voor de dagelijkse praktijk van het samenleven zijn de verplichtende normen erg belangrijk, omdat de dagelijkse verwachtingen over het gedrag van andere mensen erdoor wordt bepaald. Het sociaal vertrouwen tussen mensen bestaat er vooral in dat de primaire gedragsregels worden geëerbiedigd. Dit vertrouwen wordt het meest geschokt door schending van de primaire dagelijkse verwachting, bijvoorbeeld als men op straat door een medeburger wordt beroofd.

Sociale normen - in de omschrijving van Pettit en Elster - moeten onderscheiden worden van morele normen, van rechtsnormen en van beroepsnormen. Deze normen hebben het verplichtende karakter gemeen, maar ze verschillen in de mate waarin de normen zijn opgetekend (de geschreven normen van het recht versus de sociale mores) of de mate waarin overtredingen tot sancties leiden: morele normen, bijvoorbeeld van vlijt en ijver in het werk, leiden bij niet-nakoming tot schaamte bij degene die deze hoge norm aan zichzelf stelt, maar hoeven niet gesanctioneerd te worden. Rechtsnormen hebben soms geen morele inhoud, maar leiden wel - als het goed is tenminste - tot sancties bij overtreding. Fatsoensnormen, bijvoorbeeld de hoed afnemen, groeten, opstaan in de tram, niet spuwen op straat et cetera, zijn typische voorbeelden van sociale normen, en zij verschillen van rechtsnormen in de mate waarin ze door de overheid bij overtreding van sancties mogen worden voorzien. Rechtsnormen verhinderen soms zelfs dat verregaande sociale sancties worden uitgeoefend bij overtreding van sociale normen: zo mag ik iemand die mij's morgens op het werk niet begroet, geen klap verkopen als sanctie op de ochtendlijke onbeleefdheid.

Het feit dat in de wetenschappelijke literatuur over normen zo veel nadruk wordt gelegd op gedragsconformiteit met en nakoming van de normen, leidt 
bijna automatisch tot de gedachte dat een van de maatschappelijke redenen voor het 'waarden- en normendebat' zou kunnen liggen in de in ons land veelvuldig gepercipieerde afname van normconformiteit en sanctietoepassing: de normen voldoen niet meer aan de basisverwachting die men van normen heeft, namelijk dat ze worden nageleefd. Kortom, niet de inhoud van waarden en normen vormt als zodanig het probleem, maar hun niet-nakoming (zie hoofdstuk 4).

\subsubsection{MORELE, JURIDISCHE EN SOCIALE NORMEN}

Normen zijn overal. Het sociale leven wordt op alle plaatsen en in alle situaties gekenmerkt door de aanwezigheid van normen. De rechtssocioloog Geiger vatte dit kernachtig samen met zijn bewering "Es gibt keine ungenormierte Situation" (Geiger 1947). Zelfs als mensen vrij zijn zich te gedragen zoals ze zelf willen, bijvoorbeeld door een raar hoedje op hun hoofd te zetten (het voorbeeld is van Geiger uit 1947), bestaat er een norm die andere mensen verbiedt dat hoedje van het hoofd te slaan. Vrijheid voor de een brengt een verplichting voor de ander. Inmiddels is het hoedje veranderd in een hoofddoek en moet de rechter uitmaken of een bepaald hoofddeksel wel of niet mag worden gedragen bij bepaalde gelegenheden. Ook als men, zoals onlangs in Rotterdam is voorgesteld, in een bepaalde buurt een groetplicht wil instellen voor de buurtbewoners, dan brengt dit toch vragen met zich mee voor degenen die zich daar niet aan (willen) houden. Het voldoen of niet voldoen aan de groetplicht anno 1937 in Duitsland, kreeg in deze geheel andere historische context een speciale betekenis met sociale en politieke gevolgen, ondanks het feit dat er geen juridische verplichting tot groeten op een bepaalde wijze bestond. Sociale normen waren toen krachtiger dan juridische (Schuyt 1997).

Door de alomtegenwoordigheid van normen is het ondoenlijk een overzichtelijke ordening aan te brengen in de hoeveelheid bestaande normen en normenstelsels. Naast zuiver technische normenstelsels, zoals het laadvermogen van vrachtauto's of het fysieke draagvlak van een brug, bestaan er normen voor de deelname aan en toelating tot de Olympische Spelen, de Cito-toetsen voor advisering voor vormen van voortgezet onderwijs, de Zalmnorm voor het begrotingsbeleid en de Nederlandse Norm voor Gezond Bewegen (dertig minuten per dag, gedurende minstens vijf dagen per week) et cetera. Daarnaast heeft bijna elke sociale groep en elk gezin eigen normen, die slechts aan de groepsleden bekend zijn. Een uitputtende classificatie kan hier dan ook niet gegeven worden, ondanks de soms moedige pogingen die daartoe gedaan zijn (Geiger 1947).

Het is voor een beter begrip van de discussie over waarden en normen van belang een onderscheid aan te brengen tussen morele, juridische en sociale normen. Alledrie leiden ze tot verplichtingen, maar de gevolgen van die verplichtingen verschillen. Alledrie worden ze gedragen door brede lagen in de bevolking, maar toch is de bindende kracht ervan verschillend.

- Morele normen geven een beoordeling van gedrag in termen van goed en kwaad. 
- Juridische normen geven beoordelingen van gedrag in termen van legaal of niet legaal, juridisch geoorloofd of niet geoorloofd.

- Sociale normen beoordelen gedrag in termen van gepast en ongepast.

Tekening 2.1 Overlappende normen

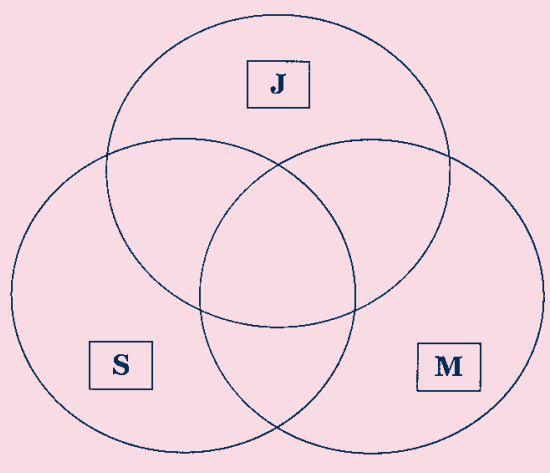

Vaak overlappen morele, sociale en juridische normen elkaar, zoals bij diep verankerde normen als het verbod te doden of te stelen. De meeste strafbepalingen in het commune strafrecht hebben ook een morele en sociale grondslag. Dit zijn de zogenaamde mala in se: de gedragingen zijn verboden omdat ze moreel slecht zijn en door iedereen slecht gevonden worden. Vaker echter hebben moderne, 'gemaakte' juridische normen geen zware morele lading, zoals het percentage af te dragen BTW of de verplichting een vergunning aan te vragen voor het kappen van een boom of het vissen in een vijver. Dit zijn de mala prohibita: gedragingen zijn slecht omdat ze verboden zijn. Heel veel moderne rechtsnormen hebben dit kenmerk.

De relaties tussen deze drie normenstelsels vormen een groot deel van het huidige debat over normen en normhandhaving. Is de gewoonte om hier niet met een volledig gesluierd gezicht over straat te lopen nu een sociale, een morele of een juridische norm? Een sociale burenplicht tot hulpverlening kan onder concrete omstandigheden, bijvoorbeeld bij gevaar voor leven, een juridische plicht blijken te zijn, waarvan nalatigheid strafbaar is. Sociale normenstelsels hebben zich in aantal sterk vermeerderd en zich van elkaar gedifferentieerd, onder meer door het opbloeien van zeer uiteenlopende levensstijlen, van een gay-cultuur tot EO-jongerendagen, alsmede door de aanwezigheid van andere culturen in ons land. Hierbij blijft het steeds onzeker wanneer en onder welke omstandigheden dergelijke sterke sociale normen van een minderhedencultuur wel of niet in strijd komen met de Nederlandse rechtsorde. Botsing van normenstelsels in dit opzicht is problematischer dan theoretisch botsende waardestelsels, omdat normen minder vrije interpretatieruimte laten (hoewel die ruimte nooit tot nul daalt). Botsingen tussen amorele juridische normen en sociale normen kunnen in principe gemakkelijker opgelost worden dan die tussen diep- 
verankerde morele normen van de ene groep en diep verankerde rechtsnormen van de andere groep (bijvoorbeeld bij de vrije partnerkeuze of bij eerwraak).

\subsubsection{VAN ONPRETTIG NAAR ONWETTIG: EEN PRINCIPIËLE EN PRAKTISCHE KWESTIE}

Het hier gemaakte onderscheid tussen morele, juridische en sociale normen is van praktisch én van principieel belang in de waarden- en normendiscussie. Immers, als een minister of een andere regeringsfunctionaris oproept om bepaalde fatsoensregels meer in acht te nemen, dan is zo'n oproep als politieke of morele aansporing nog wel te plaatsen. Maar als de overheid bepaalde fatsoensregels met sancties zou gaan ondersteunen of burgers zou oproepen zelf sancties uit te oefenen op overtredingen van dergelijke sociale fatsoensregels, dan staat er een staatsrechtelijk principe op het spel. Dit standpunt vereist enige uitwerking. De bestaande onvrede over te geringe handhaving van normen maakt nauwelijks onderscheid in de aard van de frequent overschreden normen. De ergernissen over niet-nakoming en niet-handhaving kunnen betrekking hebben op ernstige tekorten in de opsporing, vervolging en berechting van serieuze misdrijven, bijvoorbeeld winkelkraken en bepaalde geweldsmisdrijven. Maar ze kunnen ook slaan op gedragingen die liggen in de eigen morele privé-sfeer, zoals de overtredingen tegen het derde, vierde, zesde of negende gebod van de tien geboden (Exodus 20: 1-17) of in de sfeer van je fatsoen houden in de openbare ruimte. Met andere woorden, gaat het om onprettige, onbehoorlijke, overlast bezorgende of onduldbare en onwettige handelingen die allemaal in staat zijn ergernis op te wekken?

\section{Onprettige gedragingen}

Voorbeelden van onprettige handelingen zijn legio, maar ze zijn tegelijk erg afhankelijk van de sociale groep of sociale klasse waartoe men behoort (bijvoorbeeld jongeren versus ouderen). Iedereen ergert zich ergens anders aan. De normen van fatsoenlijk gedrag zijn zowel zeer wisselend als zeer onduidelijk en omstreden en bovendien niet aan juridische sancties onderworpen. Neem als voorbeeld het telefoneren in de treincoupé. Zeer veel reizigers storen zich hieraan, maar de overheid kan er geen paal en perk aan stellen, laat staan een officieel verbod effectief handhaven. Men moet over het algemeen deze onaangename zaken in lijdzaamheid dulden. Wel zou de betreffende maatschappelijke organisaties, in dit geval de Ns, er iets aan kunnen doen, door bijvoorbeeld inventieve voorzieningen te treffen, zoals aparte treincoupés waarin wel en waarin niet gebeld mag worden. Dan verstoren de bellers slechts elkaar. Heel veel onprettige gedragingen in de openbare ruimte moeten worden verdragen in een zone van gelatenheid (niet opstaan in tram of bus, voordringen, niet groeten, niet met twee woorden spreken, snauwen tegen kinderen, telefoneren en niet uitkijken op straat, astrologische rubrieken in kranten en media, spel- en taalfouten in openbare stukken, lelijke of zinnenprikkelende reclame, luidruchtige televisiespotjes, uitdagende videoclips, enzovoort. 
Naast de praktische conclusie dat een overheid al deze ergernissen niet kan verhinderen, is er een principiële kwestie óf de overheid bij dergelijke fatsoensnormen een rol te spelen heeft. De stelling in de VVD-publicatie Respect en burgerzin, waarden en normen in liberaal perspectief (VVD 2003: 55) dat "toezicht op fatsoenlijk gedrag door burgers onderling een zeer belangrijke manier is om een norm te doen gelden”, is daarom op zijn minst dubbelzinnig te noemen. Welk soort norm - moreel, juridisch, sociaal - wordt hiermee bedoeld? Als het erom gaat om burgers aan te sporen elkaar op onprettig en onfatsoenlijk gedrag aan te spreken, is het slechts aanvaardbaar zolang het bij 'aanspreken' blijft (hoewel dat ook vaak onverstandig, want escalerend kan blijken te zijn). Zodra het aanspreken 'met harde hand' vergezeld gaat, wordt een juridische norm overschreven bij de poging een sociale fatsoensnorm te handhaven. De hieraan gekoppelde stelling dat "bij wangedrag sociale correctie door medeburgers duidelijk dient te worden gesteund" (2003: 55) is evenzeer kwestieus, als die steun van de overheid dient te komen en als de uitleg van de termen 'wangedrag' en 'sociale correctie' volledig aan de burgers zelf over wordt gelaten.

De ergernissen over onbehoorlijk gedrag dienen bestreden te worden door in de organisaties en instellingen waarin het ergerniswekkende gedrag veelvuldig voorkomt meer aandacht en ruimte te geven voor het bewaren en bewaken van sociale codes voor fatsoenlijk gedrag (zie hiervoor hoofdstuk 7). In opvoeding en onderwijs zou meer aandacht kunnen worden besteed aan het bestaan en de inhoud van dergelijke fatsoencodes; de overheid zou eigen initiatieven van burgers daartoe bij het beheer van de openbare ruimte kunnen ondersteunen, maar een van bovenaf opgelegde fatsoenscode en een aansporing aan burgers om die op willekeurige wijze zelf te handhaven, is tegenstrijdig aan het waarden- en normenpatroon van een samenleving, waarin een bepaalde vrijheid in de persoonlijke sfeer wordt geëerbiedigd.

\section{Van onbehoorlijke tot onduldbare gedragingen}

De ergernissen om wangedrag, wanordelijk gedrag en onbeschofte en onuitstaanbare gedragingen kunnen niet met eenzelfde gelatenheid geduld worden. Er is een oplopende reeks van ergerniswekkend gedrag, waarbij de overlast van deze gedragingen voor burgers toeneemt en groter en minder duldbaar wordt. Het is moeilijk om de precieze grenzen tussen onprettig, onbehoorlijk en onuitstaanbaar te trekken. Maar veel gedragingen van meer bezwarende aard hebben meestal een juridische component of overschrijden reeds een rechtsnorm. Een paradigmatisch voorbeeld is hier, net als zojuist, ontleend aan het openbaar vervoer: reizigers die hun benen op een andere zitbank leggen, iets wat niet uitsluitend door jongeren in Enkhuizen wordt gedaan, maar ook door vermoeide yuppies aan het einde van een werkdag. Onprettig? Onbehoorlijk? Onuitstaanbaar? Onduldbaar? Onwettig? Er kan tegen worden opgetreden, maar dit is vooral een kwestie van de eigen verantwoordelijkheid van de betreffende organisatie en de kosten en moeite die deze hiervoor over heeft. Zo zijn er meer voorbeelden te geven waar het betreurde gedrag en de irritatie zwaarder van aard worden, maar de handhaving en sanctionering evenredig lastig of zeer kostbaar 
blijven: zwartrijden in het openbaar vervoer, asbakken legen, vuil of ander afval (bekertjes, aluminium blikjes) wegwerpen op straat, verbale bedreigingen aan medeburgers ('Ik weet je wel te vinden vanavond'). Van al deze zaken zou men bij de politie aangifte kunnen doen (schade toebrengen aan eigendommen of personen), maar de aard van de klacht is meestal zo dat de politie er weinig mee kan doen. Echter, door de aard en de frequentie van dergelijke onduldbare gedragingen zou gelatenheid hier niet op zijn plaats zijn. De maatschappelijke organisaties die het betreft zouden de confrontatie met dergelijke systematische en frequente normoverschrijdingen zelf kunnen aangaan en vooral op het systeemniveau van de organisatie (onder andere meer tijd en geld voor toezicht, meer geld naar preventie) oplossingen kunnen vinden die de ergernis bij burger én overheid weg zouden kunnen nemen.

De zone tussen onduldbare gedragingen en onwettige gedragingen is vaak grijs. Een goed voorbeeld hiervan levert het pesten op school, dat wettelijk nergens is verboden en dus strikt genomen niet valt onder onwettige gedragingen. Toch is veelvoorkomend pesterig gedrag op scholen niet te dulden en doen scholen er, onder aansporing en ondersteuning van het ministerie van Onderwijs, Cultuur en Wetenschappen, veel aan om dit gedrag tegen te gaan. Wat precies wel en niet onder pesten valt en in welke frequentie dit gedrag vóórkomt valt onder de oordeelsbevoegdheid van de school zelf, maar de overheid stelt die scholen wel in staat het betreffende kwalijke gedrag te bestrijden. De sociale code van de schoolgemeenschap zelf bestrijdt hier een andere sociale code, die leeft onder bepaalde leerlingen, terwijl de overheid een actief interventiebeleid voert zonder daartoe wettelijk verplicht te zijn. Er is dus sprake van een dynamische interactie tussen de drie soorten normen.

Ook in andere gevallen kan de sociale norm vooruitlopen op de juridische norm of die zelfs overbodig maken. Zo sprak de toenmalige minister-president Kok zich in het openbaar negatief uit over de exorbitant hoge extra beloningen die leden van raden van bestuur van grote ondernemingen ontvingen. Later formuleerde een speciale commissie onder leiding van Tabaksblat normen voor het gedrag van leden van raden van bestuur en voor commissarissen. Net als bij het pesten op school is hier sprake van een sociale code (zelfverrijking onder bestuurders) die openlijk botste met andere sociale codes (tegen zelfverrijking). Het gedrag wordt gereguleerd door een nieuw afgesproken code, met steeds de mogelijkheid om van deze nieuwe sociale code een wettelijk geregelde gedragscode te maken. De overheid, in casu een minister-president, fungeerde hier als morele aanjager van zelfregulerend gedrag, al of niet vooruitlopend op een parlementaire meerderheid die de waarden van een sociale code in wetten neerlegt.

\section{Onwettige gedragingen}

In theorie biedt deze categorie van normoverschrijdingen de minste problemen, in de praktijk echter komt hier het gehele politie- en justititiebeleid aan de orde. Als het voorbeeld van de gedragingen in het openbaar vervoer wordt vastgehouden, gaat het hierbij om zwartrijden in tram, metro of trein, om het bedreigen of 
molesteren van treinpersoneel, en om het bedreigen of beroven van medereizigers. Al deze gedragingen zijn in strijd met wettelijke bepalingen, maar de vraag is hier niet of er mag worden opgetreden of geïntervenieerd, maar wanneer. De kwestie draait vooral om de opportuniteit en prioriteit van het politie- en justitieoptreden. Welke normen en normoverschrijdingen komen het eerst en het meest in aanmerking voor een straffe aanpak? Moeten alle, veel én weinig voorkomende normoverschrijdingen van alle burgers opgespoord en vervolgd worden (de zogenaamde zero tolerance) of is een bepaalde mate van selectief opsporings- en vervolgingsbeleid te aanvaarden? Een effectieve aanpak van de meest bedreigende vormen van onwettige gedragingen kan door burgers van een overheid geëist worden (WRR 2002). Hierbij zal het vooral gaan om die normoverschrijdingen die (a) de persoonlijke, fysieke en psychische integriteit van burgers aantasten en (b) die de coöperatie en het onderlinge vertrouwen van burgers in de samenleving als geheel doen afnemen. Juist deze laatste normoverschrijdingen krijgen, als daar niet of niet effectief tegen wordt opgetreden, een negatieve spiraalwerking voor ander normoverschrijdend gedrag en voor het gedag van andere burgers (zie bijlage hoofdstuk 4).

Uit deze noodzakelijk korte analyse van de drie soorten normen, namelijk morele, juridische en sociale, en van de oplopende reeks van normoverschrijdende gedragingen kan de volgende gevolgtrekking worden gemaakt:

- bij 'onprettige' of 'onbehoorlijke' gedragingen hoort onvermijdelijk een zone van gelatenheid; ditzelfde geldt voor 'overlast' bezorgende gedragingen, afhankelijk van de mate van overlast en de ernst en de dreiging van de gedragingen; bespreekbaar maken van het bekritiseerde gedrag in en door organisaties ligt meer voor de hand dan het op eigen gezag van burgers 'aanspreken' van medeburgers op hun niet nader gedefinieerde 'slechte' gewoonten of gedragingen;

- bij 'onduldbare' gedragingen of bij de ernstige 'overlast' hoort een stevige confrontatie, met name afkomstig van die organisaties die er het meeste aan kunnen doen, soms op aandringen van de overheid (pesten) of op aangeven van belangrijke overheidsvertegenwoordigers (ministers of de ministerpresident);

- bij onwettige gedragingen hoort een consistente en effectieve aanpak, door de overheid zelf, van de meest bedreigende normoverschrijdingen, met name diegene die het onderlinge vertrouwen tussen burgers sterk ondermijnen.

Een verdere analyse van de vele vormen van normoverschrijdend gedrag en wat eraan te doen valt, evenals een discussie over de rol van de overheid, wordt gegeven in hoofdstukken 4, 7 en 8.

\subsection{CONCLUSIES}

1 Er is een bruikbare definitie van waarden te geven, voorzover die betrekking heeft op de inrichting van staat en samenleving: "waarden zijn mogelijkheden waarvan de realisering het leven tot een goed leven maakt” (Kekes 1993).

2 Waarden worden structureel door andere kenmerken gekarakteriseerd dan 
normen, zodat een automatische koppeling van waarden aan normen (of omgekeerd) meer verwarrend dan verhelderend werkt. Waarden scheppen ruimte, normen brengen beperkingen aan; waarden wekken op, normen grenzen af; waarden geven aan wat goed, gewenst en waardevol wordt gevonden, normen meestal wat onjuist en ongewenst wordt geacht; waarden zijn abstract, normen geven concrete richtlijnen voor gedrag; waarden bepalen geen specifieke gedragingen zijn dus niet gedragsspecifiek, normen bepalen specifiek welke gedragingen wel of niet mogen.

3 Rechtsnormen zijn voor ieder verplichtend, sociale en morele normen zijn dat niet, tenzij zij samenvallen met - gecodificeerde - rechtsnormen; rechtsnormen vertegenwoordigen de morele categorie van het 'moeten' (ought), sociale normen die van het 'behoren' (shall). Normoverschrijdend gedrag kan - in negatieve zin - betrekking hebben op sociale, op morele en op rechtsnormen. Voor de reacties op normoverschrijdend gedrag maken de onprettige, onbehoorlijke en overlast bezorgende gedragingen een principieel verschil uit met onduldbare en onwettige gedragingen, al is de precieze afbakening tussen deze categorieën niet voor honderd procent scherp te trekken.

4 Algemene discussies over waarden en normen hebben weinig zin, tenzij wordt aangegeven over welke inhoudelijke waarden en normen en op welk abstractieniveau de discussie gevoerd wordt.

5 Indien veel waarden wel worden onderschreven, maar het gedrag van (grote) groepen in de bevolking tegenstrijdig is aan de onderschreven waarden, heeft dit meer te maken met motivatie en morele wilszwakte dan met de inhoud van deze waarden. Andere waarden wegen dan feitelijk zwaarder. Soms wil men wel de waarde respecteren, maar weet men niet hoe. In dit geval moet dat dan aangeleerd worden.

6 Een algemeen overheidsbeleid ten aanzien van 'waarden en normen' heeft vanwege de ongedefinieerdheid, veelheid en abstractiegraad van waarden weinig zin, tenzij dit beleid zich richt op specifieke problemen of probleemgebieden waarop bepaalde, nader gespecificeerde waarden betrekking hebben.

7 Maatschappelijke waarden kunnen in wetten en rechtsnormen worden vastgelegd. Algemene wetten zijn gestolde waarden en bepalen de hier geldende rechtsnormen. Soms worden deze rechtsnormen voorafgegaan door sociale normen, neergelegd in speciale sociale codes.

8 Uit de veelheid van gekozen waarden door leden van de bevolking en door groepen uit de bevolking ontstaat een zodanige heterogene stroom (conventionele en persoonlijke) waarden dat sturing door een centrale overheid praktisch onwenselijk wordt. De meeste van deze waarden komen voort uit de maatschappij zelf (civil society). Een uitzondering hierop betreffen de basiswaarden van een samenleving, zoals neergelegd in de rechten van de mens en de grondregels van de democratische rechtsstaat (zie hoofdstuk 5).

9 Waardeconflicten zijn onvermijdelijk in een samenleving. Hieruit volgt een verplichting om op de vele niveaus van de samenleving waar zich deze conflicten voordoen, redelijke vormen van conflictbeslechting te vinden, te ontwikkelen en te onderhouden. De ontwikkeling van de democratische 
rechtsstaat kan in dit licht worden gezien als een min of meer stabiele manier om onvermijdelijke waardeconflicten zó op te lossen dat de samenleving niet uiteenvalt en dat minimale basiswaarden, neergelegd in de mensenrechten, daarbij niet worden geschonden (zie ook hoofdstuk 5). 


\section{WAARDEN, NORMEN EN GEDRAG: DE MENING VAN DE BEVOLKING}

\subsection{INLEIDING}

Voor wie zijn oor in de samenleving te luisteren legt, kan er geen misverstand over bestaan: volgens de burgers is er sprake van een schrikbarend verval van normen en waarden. Meer dan twee op de drie Nederlanders (69\% in 1998; Dekker 2001: 38) zijn van mening dat de opvattingen over gedrag en zeden in ons land steeds meer achteruitgaan. Steeds meer mensen dringen voor bij het instappen in bus, tram of trein en staan niet meer op voor een oudere, mensen gooien hun afval op straat, fietsers en automobilisten stoppen niet meer voor rood licht, voor het minste of geringste krijg je een klap of zelfs een mes tussen je ribben en steeds minder mensen zijn nog bereid zonder betaling iets voor een ander te doen. Hoe breed deze opvattingen ook mogen worden gedeeld, het is niet eenvoudig om een goed beeld te krijgen van de stand van zaken en de ontwikkelingen ten aanzien van waarden, normen en gedrag in Nederland. Klachten over verval van waarden en normen zijn van alle tijden en 'vroeger' was het altijd al beter. Hoe kun je onderscheid maken tussen modieuze grillen en ongenoegens en reële ontwikkelingen?

Dit hoofdstuk wil niet meer dan een overzicht bieden van de publieke opinie over waarden, normen en gedrag. Het gaat om gegevens die zijn ontleend aan grootschalige persoonsenquêtes waarin een representatieve steekproef uit de bevolking wordt gevraagd naar zijn perceptie en opvattingen over een grote verscheidenheid aan waarden, normen en gedragingen. De gegevens in dit hoofdstuk zijn voor het grootste deel afkomstig uit een rapport dat het Sociaal en Cultureel Planbureau in samenwerking met de WRR ten behoeve van het project waarden, normen en gedrag heeft opgesteld (Dekker et al. 2003). Dit achterliggende rapport biedt niet alleen een uitvoeriger overzicht van het beschikbare cijfermateriaal, maar gaat ook in op de representativiteit van de gegevens en op een aantal methodologische aspecten. De uitspraken die respondenten in een enquête doen over hun eigen opvattingen en gedragingen en over die van hun medeburgers, hoeven natuurlijk niet overeen te komen met de werkelijkheid. In paragraaf 3.2 wordt hierop wat nader ingegaan. Niettemin bieden deze enquêteresultaten wel enig inzicht in de achtergronden van de huidige onvrede over waarden, normen en gedrag en helpen daarmee het waarden- en normendebat in het juiste perspectief te plaatsen. In hoofdstuk 4 worden vervolgens de beschikbare gegevens in kaart gebracht over de feitelijke gedragingen van de Nederlandse bevolking die strijdig zijn met gangbare en/of wettelijke normen. 


\subsection{HET METEN VAN MENINGEN OVER WAARDEN, NORMEN EN GEDRAG}

Waarden en normen kun je niet zien, voelen of ruiken: ze zitten verborgen in de hoofden en harten van mensen. Om toch iets te weten te komen over de waarden en normen die mensen aanhangen kun je twee wegen bewandelen: je kunt mensen er rechtstreeks naar vragen en je kunt hun gedrag observeren en daaruit hun waarden en normen proberen af te leiden. In het algemeen leiden beide wegen niet naar dezelfde bestemming. Het zeg-gedrag van mensen hoeft niet overeen te komen met hun doe-gedrag. Zo geven mensen vaak sociaal wenselijke antwoorden die niet overeenkomen met wat zij werkelijk vinden, laat staan met wat zij doen. Over het algemeen levert het waarnemen van gedrag betrouwbaarder uitkomsten op dan het stellen van een opinievraag (economen spreken in dit verband van revealed preference). Toch is het bij het meten van waarden onvermijdelijk om een beroep te doen op het zeg-gedrag van mensen. Waarden zijn over het algemeen namelijk zo abstract dat er geen eenduidige gedragsregels uit kunnen worden afgeleid (vgl. hoofdstuk 2). Dit betekent dat verschillende gedragingen overeen kunnen komen met dezelfde waarde en dat identieke gedragingen kunnen voortvloeien uit verschillende waarden.

Het is bovendien de vraag of het wel zo erg is als mensen op een vraag naar hun waarden een sociaal wenselijk antwoord geven. Het feit dat iemand een bepaald antwoord sociaal wenselijk acht, betekent immers dat hij of zij van mening is dat de betreffende waarde in de samenleving belangrijk wordt gevonden en dat men zich daarbij dient aan te sluiten (vgl. Dekker 2001: 17). Als iemand bijvoorbeeld zwarten minderwaardig vindt, maar niettemin zegt dat hij alle mensen, ongeacht hun ras, als gelijkwaardig beschouwt, dan erkent hij daarmee dat gelijkwaardigheid een belangrijke maatschappelijke waarde is. Uiteindelijk is het minder interessant wat mensen werkelijk, diep in hun hart vinden dan hoe zij zich publiekelijk uiten en gedragen.

Bij normen is de spanning tussen zeg-gedrag en doe-gedrag problematischer. Als iemand zegt een bepaalde norm te onderschrijven, terwijl zijn gedrag daarmee flagrant in strijd is, dan heeft die norm blijkbaar geen betekenis voor hem.

Wie zegt belastingontduiking af te wijzen, maar niettemin ieder jaar een valse belastingaangifte doet, geeft daarmee te kennen de betreffende norm niet te onderschrijven. Overigens is het ook in dit geval niet zonder betekenis dat men de betreffende norm toch sociaal wenselijk acht en daarom niet durft te zeggen dat men haar niet onderschrijft. Het komt echter ook veelvuldig voor dat men een norm overschrijdt die men wel degelijk onderschrijft, omdat men aan andere overwegingen een zwaarder gewicht toekent. Zo kan iemand door rood licht rijden omdat hij grote haast heeft, maar toch de betreffende verkeersregel in het algemeen best onderschrijven.

Gedragingen kan men, anders dan waarden en normen, wel direct waarnemen. In beginsel zijn ontwikkelingen in het gedrag dan ook gemakkelijker te 'meten' 
dan trends in waarden en normen. Hoofdstuk 4 geeft een overzicht van de beschikbare gegevens over een aantal uiteenlopende vormen van normoverschrijdend gedrag. Dit hoofdstuk beperkt zich tot de perceptie van normoverschrijdend gedrag door de burgers. Zoals bekend hoeft dit niet overeen te komen met het feitelijke vóórkomen van normoverschrijdend gedrag. De uitspraken die mensen doen over de toename of afname van gedrag waaraan zij zich storen, geven echter wel een indruk van de ernst van de problematiek van normen en gedrag in de visie van de 'gemiddelde' burger. Behalve aan normoverschrijdend gedrag wordt ook enige aandacht besteed aan positief gedrag: mensen die méér doen dan de algemeen aanvaarde normen voorschrijven, zoals vrijwilligerswerk en giften aan 'goede doelen'.

De hierboven geschetste problemen bij het meten van waarden, normen en gedrag zijn het grootst indien men een uitspraak wil doen over de stand van zaken op een bepaald moment. Hoeveel procent van de bevolking onderschrijft vrijheid van meningsuiting? Hoeveel procent vindt dat je je moet houden aan de maximumsnelheid? En hoeveel procent heeft wel eens zwartgewerkt? De absolute percentages die je hierover uit onderzoek kunt afleiden, zeggen niet veel: de eerste twee zijn waarschijnlijk veel te hoog en de laatste te laag. Het kan echter wel zinvol zijn om vergelijkingen tussen percentages te maken. Als de vertekening die optreedt als gevolg van sociaal wenselijke antwoorden en andere verstorende factoren (zoals verschillen in interpretatie van een bepaalde vraag) in de loop van de tijd constant is en niet varieert tussen verschillende groepen, dan is het mogelijk om redelijk betrouwbare uitspraken te doen over ontwikkelingen in de tijd en over verschillen tussen bevolkingsgroepen of tussen landen. De empirische gegevens in dit hoofdstuk beperken zich dan ook voornamelijk tot dergelijke vergelijkingen. Daarnaast zal ook een poging worden gedaan om de ontwikkelingen in de tijd te relateren aan de aflossing van generaties. Zijn veranderingen in waarden, normen en gedrag (mede) het gevolg van het feit dat oudere generaties worden opgevolgd door jongere generaties die zich kenmerken door andere waarden, normen en gedrag? Of doen zich in alle generaties vergelijkbare ontwikkelingen voor?

Het was - op een uitzondering na - niet mogelijk voor dit rapport nieuwe data te (laten) verzamelen. De empirische gegevens in dit hoofdstuk zijn dan ook afkomstig uit eerder door andere instanties verricht onderzoek. Het is daardoor onvermijdelijk dat de gepresenteerde gegevens vaak niet aansluiten bij de definities en interpretaties die in dit rapport van waarden, normen en gedrag worden gegeven. Dit betekent dat bij voorbaat de nodige terughoudendheid gewenst is bij het verbinden van conclusies aan het empirische materiaal. In de meeste gevallen is het alternatief echter dat men afgaat op de eigen persoonlijke ervaringen of op de indrukken die worden opgeroepen door de media. Aangezien deze waarschijnlijk een nog sterker vertekend beeld van de werkelijkheid geven, verdient het toch de voorkeur zich bij een analyse van waarden, normen en gedrag (mede) te baseren op het beschikbare empirische materiaal, hoe gebrekkig dit ook moge zijn. 
De meeste gegevens die hier worden gepresenteerd, zijn afkomstig uit grootschalige enquêtes (surveys) onder een representatieve steekproef van de bevolking. Voor Nederland gaat het hierbij in het bijzonder om het onderzoek Culturele veranderingen in Nederland (CV) van het Sociaal en Cultureel Planbureau (SCP) en het onderzoek Sociaal-culturele ontwikkelingen in Nederland (SOCON) van de universiteiten van Nijmegen en Tilburg. CV wordt sinds 1975 om de een of twee jaar gehouden. Voor sommige vragen kan op basis van eerdere onderzoeken een tijdreeks vanaf 1970 worden geconstrueerd. SOCON wordt sinds 1985 iedere vijf jaar gehouden. Om vergelijkingen tussen landen te maken is gebruikgemaakt van enkele internationale onderzoeken. Het gaat om respectievelijk de European Values Study (EVS), het International Social Survey Programme (ISSP) en de Eurobarometer van de Europese Commissie.

\section{$3 \cdot 3$ WAARDEN}

Meer dan twee derde van de bevolking is van mening dat de opvattingen over gedrag en zeden in ons land steeds meer achteruitgaan. Bovendien groeit dit aandeel sinds 1970 gestaag (zie tabel 3.1). Tegelijkertijd neemt de onzekerheid van de burger over wat goed en verkeerd is af; in 1970 verkeerde ongeveer de helft van de bevolking hierover in onzekerheid, in 1996 was dit nog maar ongeveer een derde. Een mogelijke interpretatie van deze uitkomst zou kunnen zijn dat mensen steeds negatiever worden over 'gedrag en zeden in ons land' doordat zij

Tabel 3.1 Mening over achteruitgang van gedrag en zeden en onzekerheid over waarden en normen (in \%), 1970-1998

\begin{tabular}{|c|c|c|c|c|c|c|c|}
\hline & 1970 & 1975 & 1980 & 1985 & 1991 & 1996 & 1998 \\
\hline $\begin{array}{l}\text { De opvattingen over gedrag en zeden in } \\
\text { ons land gaan steeds meer achteruit }\end{array}$ & 39 & 53 & 60 & 56 & . & 61 & 69 \\
\hline $\begin{array}{l}\text { Er zijn zo veel verschillende opvattingen } \\
\text { over wat goed en verkeerd is dat je soms } \\
\text { niet meer weet waar je aan toe bent }\end{array}$ & 56 & 52 & 52 & 47 & 43 & 38 & . \\
\hline $\begin{array}{l}\text { Alles verandert heden ten dage zo snel } \\
\text { dat men vaak nauwelijks meer weet wat } \\
\text { goed en wat slecht is }\end{array}$ & 45 & 44 & 40 & 35 & 34 & 33 & . \\
\hline
\end{tabular}

Bron: SCP (CV'70-'98)

zelf steeds meer uitgesproken opvattingen hebben 'over wat goed en verkeerd is'. Een andere interpretatie is echter dat mensen hypocrieter worden: wellicht vinden zij het gemakkelijker te oordelen over goed en kwaad omdat zij deze vooral op anderen en niet op zichzelf van toepassing achten.

Waarden zijn er in zeer uiteenlopende soorten en maten, zo is in hoofdstuk 2 uiteengezet. Het is dan ook onmogelijk om in het bestek van dit hoofdstuk een 
uitputtend overzicht te geven van de steun onder de bevolking voor allerlei waarden. De aandacht beperkt zich hier daarom tot een aantal waarden die ten grondslag liggen aan de rechtsstaat en de elementaire burgerrechten. Meer dan bij veel andere waarden is het immers van groot belang dat deze waarden een breed draagvlak onder de bevolking hebben (zie ook hoofdstuk 5).

Het Sociaal en Cultureel Rapport 1998-25jaar socialeverandering (hoofdstuk 5 en 6) biedt een overzicht van de ontwikkeling van een aantal waarden sinds het begin van de jaren zeventig. De steun voor democratische vrijheden als demonstreren, staken, publiceren wat men wil en in het openbaar zeggen wat men wil, nam in de jaren zeventig licht af (sic!), maar is sinds 1980 gestaag toegenomen (SCP 1998: 131; de meest recente gegevens zijn echter van 1995). De mate waarin men godsdienstige groepen vrij wil laten in hun doen en laten loopt sinds 1985 echter terug (SCP 1998: 138; SCP 2003a: 111). Dit geldt het sterkst voor de vrijheid die men islamieten gunt (van $80 \%$ in 1985 naar $57 \%$ in 2000 ), maar in mindere mate ook voor katholieke en protestantse groepen. De tolerantie jegens godsdienstige groepen in het algemeen lijkt dus kleiner te worden. Wellicht hangt dit samen met het feit dat steeds meer mensen van mening zijn dat politiek en godsdienst los van elkaar moeten staan: in 1975 vond 57 procent van de bevolking dit, in 199673 procent (SCP 1998: 172). Helaas zijn aan de ondervraagden geen concrete activiteiten van godsdienstige groepen voorgelegd, zodat onduidelijk is ten aanzien van welke aspecten van bijvoorbeeld de islam men minder tolerant is geworden.

Een internationale vergelijking van de steun voor de waarden van de rechtsstaat kan worden gebaseerd op de Eurobarometer 47 uit 1997. Hierin werd de steun van de bevolking van de landen van de EU onderzocht voor een aantal rechten en vrijheden, waaronder vrijheid van meningsuiting, vrijheid van vereniging, godsdienst- en gewetensvrijheid en gelijkheid voor de wet. Tabel 3.2 geeft een overzicht van de belangrijkste uitkomsten voor een zevental landen. Over het algemeen worden de elementaire rechten en vrijheden door een ruime meerderheid van de bevolking van de EU-landen gesteund. Alleen de vrijheid van vereniging en het actieve en passieve kiesrecht worden door een grote minderheid niet vanzelfsprekend gevonden. Nederland blijkt ten aanzien van een aantal grondrechten - vrijheid van meningsuiting, vrijheid van vereniging, recht op eigen taal en cultuur en kiesrecht - relatief laag te scoren. Ten aanzien van godsdiensten gewetensvrijheid en het recht op bescherming tegen discriminatie scoort Nederland daarentegen wel hoog.

Het is lastig om deze cijfers te interpreteren. Zo is aan de respondenten alleen gevraagd of de betreffende rechten en vrijheid 'onder alle omstandigheden moeten worden gerespecteerd, of dat dit afhangt van de omstandigheden'. Men kon dus niet antwoorden dat men een recht of vrijheid in zijn algemeenheid afwijst, terwijl de 'omstandigheden' niet nader werden gespecificeerd. De 'omstandigheden' die de respondenten in gedachten hebben, zouden dan ook kunnen samenhangen met uiteenlopende ervaringen in de verschillende landen. 


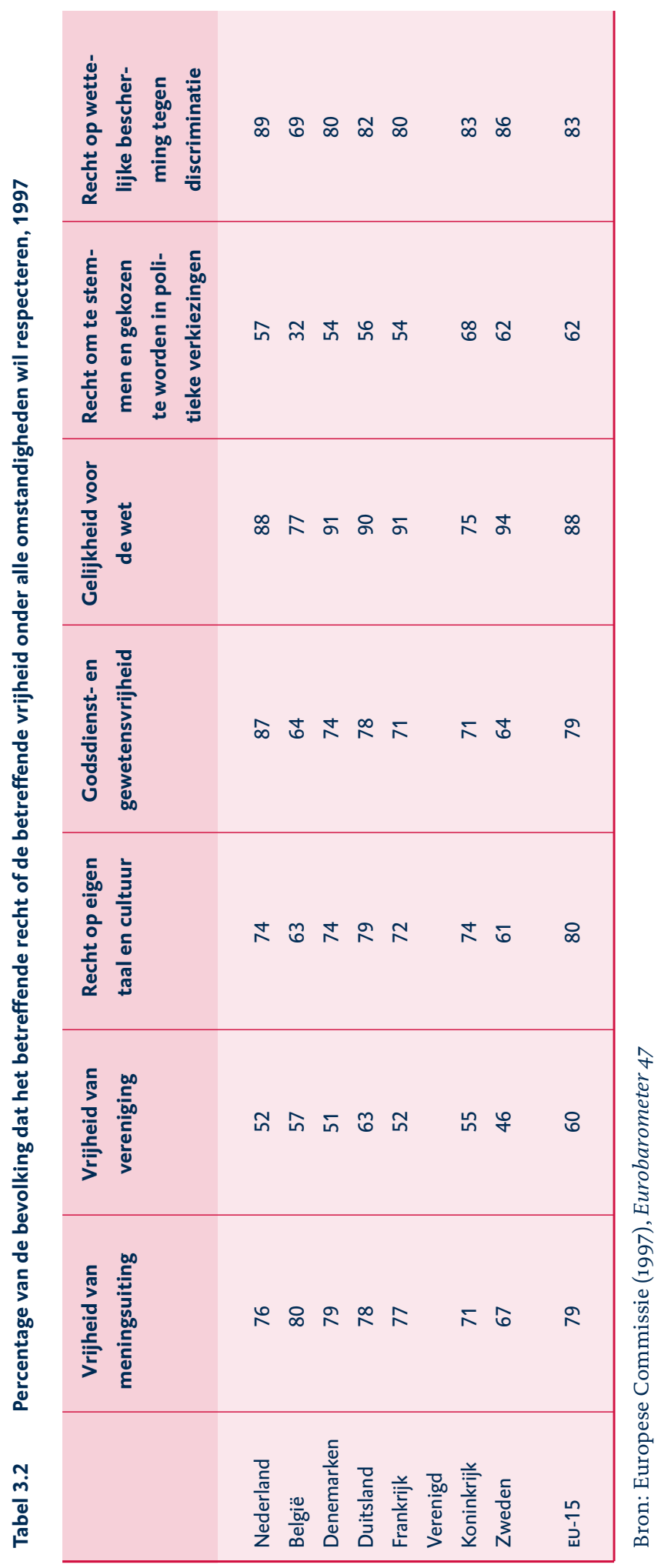


Enkele internationaal vergelijkende cijfers over de steun voor de democratie kunnen worden ontleend aan de European Values Study (EVs). Tabel 3.3 geeft de uitkomsten voor enkele West-Europese landen in 1999/200o.

Tabel 3.3 Opvattingen over democratie, 1999/2000 (in \%)

\begin{tabular}{|l|c|c|} 
& $\begin{array}{c}\text { Een democratisch politiek } \\
\text { systeem hebben is: }\end{array}$ & $\begin{array}{c}\text { Democratie mag dan } \\
\text { problemen hebben, het } \\
\text { is beter dan enige andere } \\
\text { regeringsvorm: }\end{array}$ \\
& zeer/tamelijk goed & (sterk) mee eens \\
Nederland & 96 & 96 \\
België & 89 & 82 \\
Denemarken & 98 & 99 \\
Duitsland & 95 & 97 \\
Frankrijk & 89 & 93 \\
Groot-Brittannië & 88 & 78 \\
Zweden & 97 & 94 \\
Gemiddelde West-Europa & & 94 \\
\hline
\end{tabular}

Bron: Dekker et al. (2003)

De steun voor de democratie als staatsvorm is over het algemeen zeer groot. Alleen de Britten en Belgen hebben er wat meer bedenkingen bij. Nederland behoort tot de landen die het hoogst scoren. De scepsis van de Britten over de democratie als 'beste' regeringsvorm is opmerkelijk, aangezien hun steun voor actief en passief kiesrecht blijkens tabel 3.2 relatief groot is.

\subsection{NORMEN}

Normen kan men onderscheiden in onder meer formele juridische normen en informele sociale normen (vgl. hoofdstuk 2). De aandacht beperkt zich in deze paragraaf tot formele normen. Niet alleen is daarover meer informatie beschikbaar, maar de mate waarin deze normen worden onderschreven is ook gemakkelijker te waarderen. Als een informele norm (bijvoorbeeld elkaar groeten op straat) in de loop van de tijd minder steun krijgt, is het niet zonder meer duidelijk of men dit als een ongunstige ontwikkeling moet aanmerken. Als een formele, wettelijke norm echter op steeds minder steun kan rekenen, duidt dit in het algemeen op een probleem: ofwel de wet dient te worden gewijzigd omdat zij achterhaald is, ofwel er is meer aandacht nodig voor de internalisering of de handhaving van de norm. 


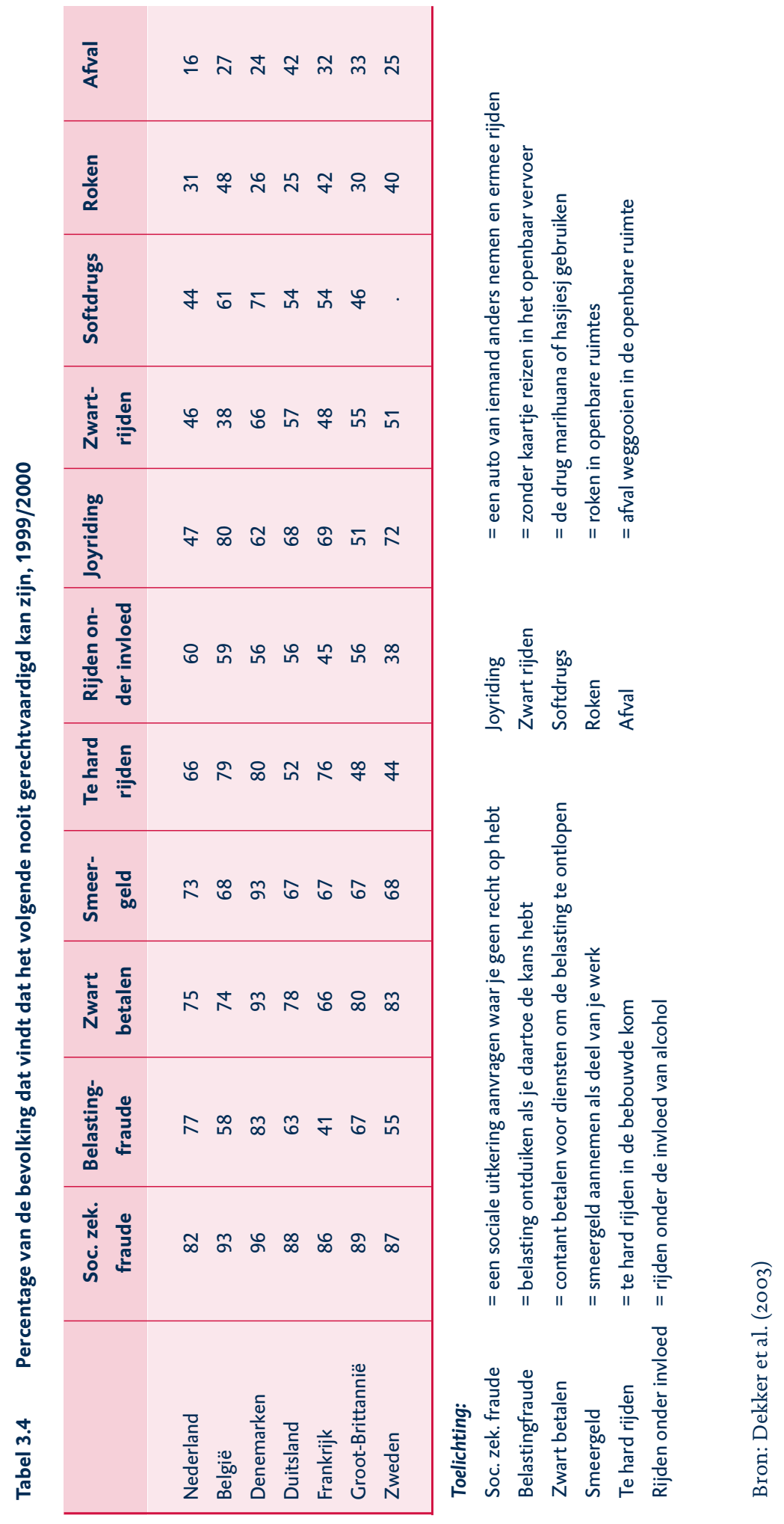


In de European Values Study (EVS) van 1999/200o is gevraagd of bepaalde vormen van normoverschrijdend gedrag nooit, soms of altijd te rechtvaardigen zijn. Tabel 3.4 geeft een aantal uitkomsten die voornamelijk betrekking hebben op lichte tot middelzware vormen van wetsovertreding.

Over het algemeen staan West-Europeanen weinig tolerant tegenover de genoemde vormen van wetsovertreding. Voor de meeste overtredingen geldt dat de meerderheid deze nooit te rechtvaardigen vindt. Nederlanders oordelen streng over socialezekerheids- en belastingfraude en mild over afval weggooien en roken in openbare ruimtes. Vergeleken met andere West-Europeanen wijzen Nederlanders vooral belastingfraude, smeergeld en rijden onder invloed sterk af (hoewel de Denen bij de eerste twee nog strenger zijn), terwijl Nederlanders relatief tolerant zijn ten aanzien van socialezekerheidsfraude, softdrugsgebruik, joyriding en afval weggooien. Over het geheel genomen wijken Nederlanders in hun beoordeling van wetsovertredingen echter niet sterk af van andere WestEuropeanen.

Op basis van gegevens uit het internationale onderzoek ISSP is het mogelijk iets te zeggen over veranderingen in de acceptatie van twee vormen van normoverschrijdend gedrag, namelijk socialezekerheidsfraude en belastingfraude (tabel 3.5). Tweemaal, in 1991 en 1998, is gevraagd of men het 'acceptabel' vond of 'verkeerd, maar begrijpelijk' dat 'iemand niet al zijn inkomsten opgeeft om zo minder belasting te hoeven betalen' of dat 'iemand de overheid onjuiste informatie geeft over zichzelf om een uitkering te krijgen waar hij geen recht op heeft' (de andere antwoordmogelijkheden waren 'verkeerd' en 'absoluut verkeerd'). Net als uit de eerdergenoemde onderzoeken blijkt ook hieruit dat belastingfraude eerder wordt geaccepteerd dan socialezekerheidsfraude. Dat iemand niet al zijn inkomsten opgeeft voor de belasting vond in 19982 procent van de Nederlanders 'acceptabel' en 37 procent 'verkeerd, maar begrijpelijk', terwijl deze percentages voor ten onrechte een uitkering aanvragen slechts o respectievelijk 3 waren. Tussen 1991 en 1998 nam zowel de acceptatie van belastingfraude als van socialezekerheidsfraude af, zij het sterker bij belastingfraude. In overeenstemming met de uitkomsten van de Evs oordelen Nederlanders, vergeleken met Italianen, Noren, Britten en Amerikanen, relatief mild over belastingontduiking en streng over socialezekerheidsfraude. Ook in de andere landen is de tolerantie tegenover socialezekerheidsfraude tussen 1991 en 1998 afgenomen (het sterkst in GrootBrittannië), maar het oordeel over belastingfraude is in Italië, Noorwegen en Groot-Brittannië juist iets milder geworden.

\section{$3 \cdot 5 \quad$ GEDRAG}

Doordat gedrag - anders dan de waarden en normen die mensen onderschrijven - direct kan worden waargenomen, is het in beginsel eenvoudiger om hierover gegevens te verzamelen. Bij veel - maar zeker niet alle - gedrag is het bovendien relatief eenvoudig vast te stellen of het in overeenstemming of strijdig is met bepaalde normen (denk bijvoorbeeld aan te hard rijden, afval weggooien op 


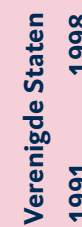

n $\subsetneq$ ப

$\sim m$ นू

ثे

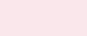

$+\stackrel{m}{m}$

$\sim+$ L
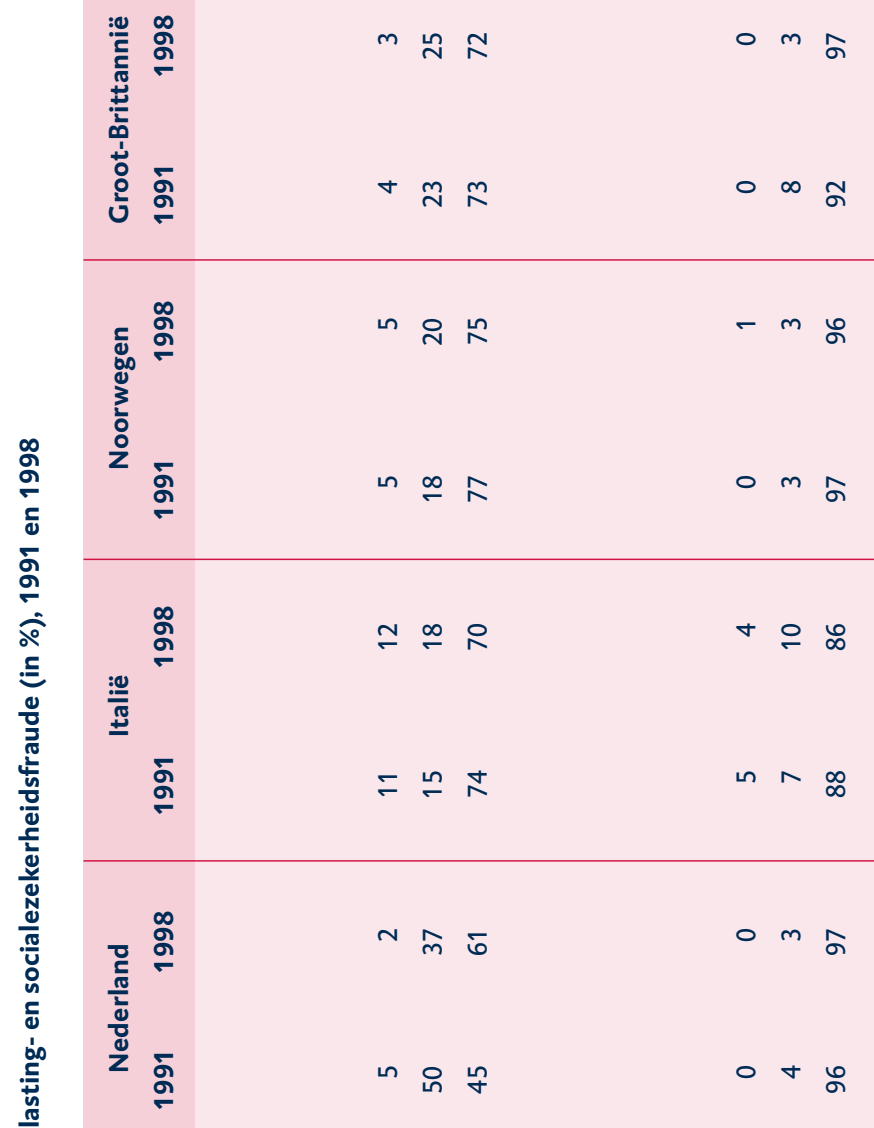
straat en beroving). De variëteit aan gedragingen die kan worden geanalyseerd om het vóórkomen van normconform of normoverschrijdend gedrag in kaart te brengen is dan ook onuitputtelijk.

De aandacht beperkt zich hier tot de perceptie van wetsovertreding en criminaliteit door de burgers en enkele vormen van normoverschrijdend gedrag waarover in grootschalige enquêtes informatie wordt verzameld. Hiernaast is het interessant om gegevens te verzamelen over 'lofwaardig' gedrag, dat wil zeggen gedrag dat niet slechts in overeenstemming is met algemeen aanvaarde normen, maar doorgaans wordt toegejuicht omdat het getuigt van gemeenschapszin. Te denken valt aan vrijwilligerswerk en lidmaatschap of donateurschap van ideële organisaties. Vaak wordt verondersteld dat een toename van normoverschrijdend gedrag samengaat met een afname van lofwaardig gedrag. Ook over dit soort gedrag zijn niet erg veel gegevens beschikbaar. Bovendien zijn deze grotendeels gebaseerd op zelfrapportage, hetgeen gemakkelijk tot een te positieve beoordeling kan leiden.

\section{Perceptie van wetsovertreding}

Een zeer grote meerderheid van de bevolking - acht à negen op de tien mensen is van mening dat 'de misdadigheid in Nederland de laatste tijd toeneemt'. Dit is overigens al sinds 1980 het geval (zie tabel 3.6). Een ongeveer even hoog percentage ( 83 procent in 1980 en 84 procent in 1996) vindt 'dat de misdaad in Nederland een echt probleem aan het worden is’ (SCP 1998: 638; SCP 2002: 656).

Tabel 3.6 Bent u van mening dat de misdadigheid in Nederland de laatste tijd toeneemt, gelijk blijft of afneemt? (in procenten)

\begin{tabular}{|l|c|c|c|} 
Jaar & Neemt toe & Blijft gelijk & Neemt af \\
1980 & 89 & 10 & 1 \\
1996 & 83 & 15 & 2 \\
2000 & 85 & 14 & 1 \\
\hline
\end{tabular}

Bron: SCP (CV’8o, CV’96 en CV20oo)

Een internationale vergelijking van de perceptie van criminaliteit en wetsovertreding kan worden ontleend aan de Evs van 1999/2000. Hierin is aan de respondenten gevraagd hoeveel mensen zich naar hun oordeel schuldig maken aan verschillende vormen van wetsovertreding. Het gaat hierbij om een deel van de overtredingen en misdrijven die in tabel 3.4 zijn vermeld. Tabel 3.7 geeft de resultaten voor zeven landen.

Hoewel de groeiende onvrede over normvervaging en criminaliteit anders doet vermoeden, blijken in Nederland veel minder mensen dan in de meeste andere West-Europese landen van mening dat veel van hun landgenoten zich schuldig maken aan de in tabel 3.7 genoemde vormen van wetsovertreding. Minder dan 
Tabel 3.7 Hoeveel van uw landgenoten doen volgens u het volgende? (antwoordcategorieën 'bijna iedereen' en 'veel' in \%), 1999/2000

\begin{tabular}{|c|c|c|c|c|c|c|c|}
\hline & $\begin{array}{c}\text { Soc. zek. } \\
\text { fraude }\end{array}$ & $\begin{array}{c}\text { Belasting- } \\
\text { fraude }\end{array}$ & $\begin{array}{c}\text { Zwart } \\
\text { betalen }\end{array}$ & $\begin{array}{c}\text { Te hard } \\
\text { rijden }\end{array}$ & $\begin{array}{l}\text { Rijden on- } \\
\text { der invloed }\end{array}$ & Softdrugs & Afval \\
\hline Nederland & 7 & 48 & 46 & 36 & 10 & 9 & 31 \\
\hline België & 33 & 68 & 62 & 60 & 35 & 23 & 38 \\
\hline Denemarken & 31 & 50 & 76 & 70 & 21 & 26 & 44 \\
\hline Duitsland & 49 & 64 & 58 & 74 & 36 & 22 & 57 \\
\hline Frankrijk & 38 & 40 & 39 & 64 & 50 & 31 & 46 \\
\hline Groot-Brittannië & 61 & 64 & 66 & 77 & 42 & 63 & 76 \\
\hline Zweden & 33 & 52 & 56 & 62 & 13 & 12 & 58 \\
\hline
\end{tabular}

Toelichting:

Soc. zek. fraude = een sociale uitkering aanvragen waar zij geen recht op hebben

Belastingfraude = belasting ontduiken als zij daartoe de kans hebben

Zwart betalen = contant betalen voor diensten om de belasting te ontlopen

Te hard rijden = te hard rijden in de bebouwde kom

Rijden onder invloed $=$ rijden onder de invloed van alcohol

Softdrugs = de drug marihuana of hasjiesj gebruiken

Afval = afval weggooien in de openbare ruimte

Bron: Dekker et al. (2003)

een op de tien Nederlanders meent dat veel landgenoten ten onrechte een uitkering aanvragen of softdrugs gebruiken. Belastingfraude en zwart betalen worden nog als de meest 'algemene' vormen van wetsovertreding beschouwd, maar ook hier scoort Nederland laag in vergelijking met de meeste andere landen. Het is niet duidelijk hoe deze uitkomst moet worden geïnterpreteerd. Men dient te bedenken dat niet is gevraagd naar het vóórkomen van wetsovertreding, maar naar een schatting van het aantal mensen dat zich daaraan schuldig maakt. Het is dus denkbaar dat Nederlanders niet minder wetsovertreding signaleren dan de inwoners van andere Europese landen, maar deze alleen aan een kleiner deel van de bevolking toeschrijven. Indien deze interpretatie juist is, maken Nederlanders veel scherper onderscheid dan andere Europeanen tussen de grote meerderheid van 'brave' burgers en een kleine groep wetsovertreders.

Zoals opgemerkt is een grote meerderheid van de Nederlandse bevolking al jarenlang van mening dat de criminaliteit toeneemt. Het is echter de vraag of men bij verschillende vormen van wetsovertreding een gelijksoortige ontwikkeling meent waar te nemen. Enig inzicht hierin kan worden verkregen door de uitkomsten van een onderzoekje dat in 1991 in opdracht van de Volkskrant werd uitgevoerd te vergelijken met een herhaling van dit onderzoek in opdracht van de WRR in het najaar van 2003. In dit onderzoek is gevraagd of men zich schuldig zou maken aan enkele vormen van relatief veelvoorkomende fraude en of men 

(in procenten van de bevolking van 18 jaar en ouder)

\begin{tabular}{|c|c|c|c|c|}
\hline & \multicolumn{2}{|c|}{1991} & \multicolumn{2}{|c|}{2003} \\
\hline & Zelf doen & Anderen & Zelf doen & Anderen \\
\hline $\begin{array}{l}\text { Stel dat u iemand als werkster wilt aannemen; u } \\
\text { vindt een goede kandidaat, maar zij wenst uitsluitend } \\
\text { zwart te werken, omdat zij een uitkering heeft } \\
\text { Stel dat u uw keuken wilt laten verbouwen; u vindt } \\
\text { een aannemer, die de verbouwing voordelig wil doen, } \\
\text { maar dan zonder BTw } \\
\text { Stel dat u een belastingvoordeel kunt behalen door } \\
\text { bepaalde inkomsten voor de belasting te verzwijgen, } \\
\text { inkomsten die door de belasting waarschijnlijk niet } \\
\text { te achterhalen zijn } \\
\text { Stel dat u een reisverzekering heeft afgesloten en } \\
\text { uw koffer is gestolen; de verzekering dekt alleen } \\
\text { schade boven } 500 \text { gulden / } 300 \text { euro; u kunt uw vol- } \\
\text { ledige schade wel vergoed krijgen door ten onrechte } \\
\text { op te geven dat ook uw fototoestel is gestolen }\end{array}$ & 64 & 87 & 49 & 71 \\
\hline
\end{tabular}

* De introductie van de vraag luidde: 'Ik ga u nu enkele situaties beschrijven waar je als burger mee te maken kunt krijgen. Het gaat om situaties waarbij het lonend kan zijn om je niet aan de wet te houden.

Wilt u mij steeds zeggen of $\mathrm{u}$ in die situatie zeker voor de verleiding zou bezwijken, waarschijnlijk wel, waarschijnlijk niet of zeker niet? (....) En wat denkt u dat de meeste mensen in dat geval zullen doen?' (De antwoordcategorieën 'zeker doen' en 'waarschijnlijk doen' zijn opgeteld.)

Bron: InterView (1991), Interview-NSS (2003)

van mening is dat veel anderen zich daaraan schuldig maken. Tabel 3.8 geeft de uitkomsten van dit onderzoek. Zoals geen verbazing zal wekken zijn de ondervraagden van mening dat anderen zich vaker schuldig maken aan fraude dan zijzelf. Niettemin geeft ongeveer de helft toe dat zijzelf gebruik zouden maken van een 'zwarte' werkster of 'zwart' hun keuken zouden laten verbouwen. Een kwart zegt inkomsten te verzwijgen voor de belasting als dit mogelijk is zonder betrapt te worden, en eveneens een kwart schrikt er niet voor terug om een reisverzekeringsmaatschappij op te lichten. In alle gevallen is een ruime meerderheid van mening dat anderen (ook) voor de verleiding van een frauduleus verkregen voordeel zouden bezwijken.

Vergelijkt men de uitkomsten in beide jaren, dan valt op dat de burgers in 2003 beduidend minder vaak erkennen zich aan fraude schuldig te maken dan in 1991. Of dit veel zegt over het feitelijke gedrag is de vraag. De afname vormt wel een aanwijzing dat meer mensen zich bewust zijn van de sociale ongepastheid van belastingontduiking en daarom in ieder geval het sociaal wenselijke antwoord 
geven. Dit is in overeenstemming met de cijfers in tabel 3.5, waaruit blijkt dat belastingontduiking in 1998 minder werd geaccepteerd dan in 1991. Opmerkelijk is wel dat ook minder ondervraagden van mening zijn dat anderen zich aan belastingfraude schuldig maken, al gaat het nog altijd om een grote meerderheid. Het pessimisme over het gedrag van anderen is dus weliswaar groot, maar lijkt het afgelopen decennium niet verder te zijn toegenomen.

\section{Lofwaardig gedrag}

Een veelgebruikte indicator voor gedrag dat getuigt van gemeenschapszin is deelname aan vrijwilligerswerk. Betrouwbare cijfers hierover zijn echter niet eenvoudig te verkrijgen, aangezien veel vrijwilligerswerk uit zijn aard niet wordt geregistreerd. Verschillende onderzoeksmethoden leveren ook niet altijd eenduidige uitkomsten op. Tabel 3.9 geeft enige cijfers over het percentage van de bevolking dat in een willekeurige week vrijwilligerswerk doet en de tijd die men daaraan per hoofd van de bevolking besteedt op basis van verschillende onder-

Tabel 3.9 Vrijwilligerswerk volgens uiteenlopende onderzoeken (percentage van de bevolking van 18 jaar en ouder dat vrijwilligerswerk doet en gemiddeld aantal uren vrijwilligerswerk)

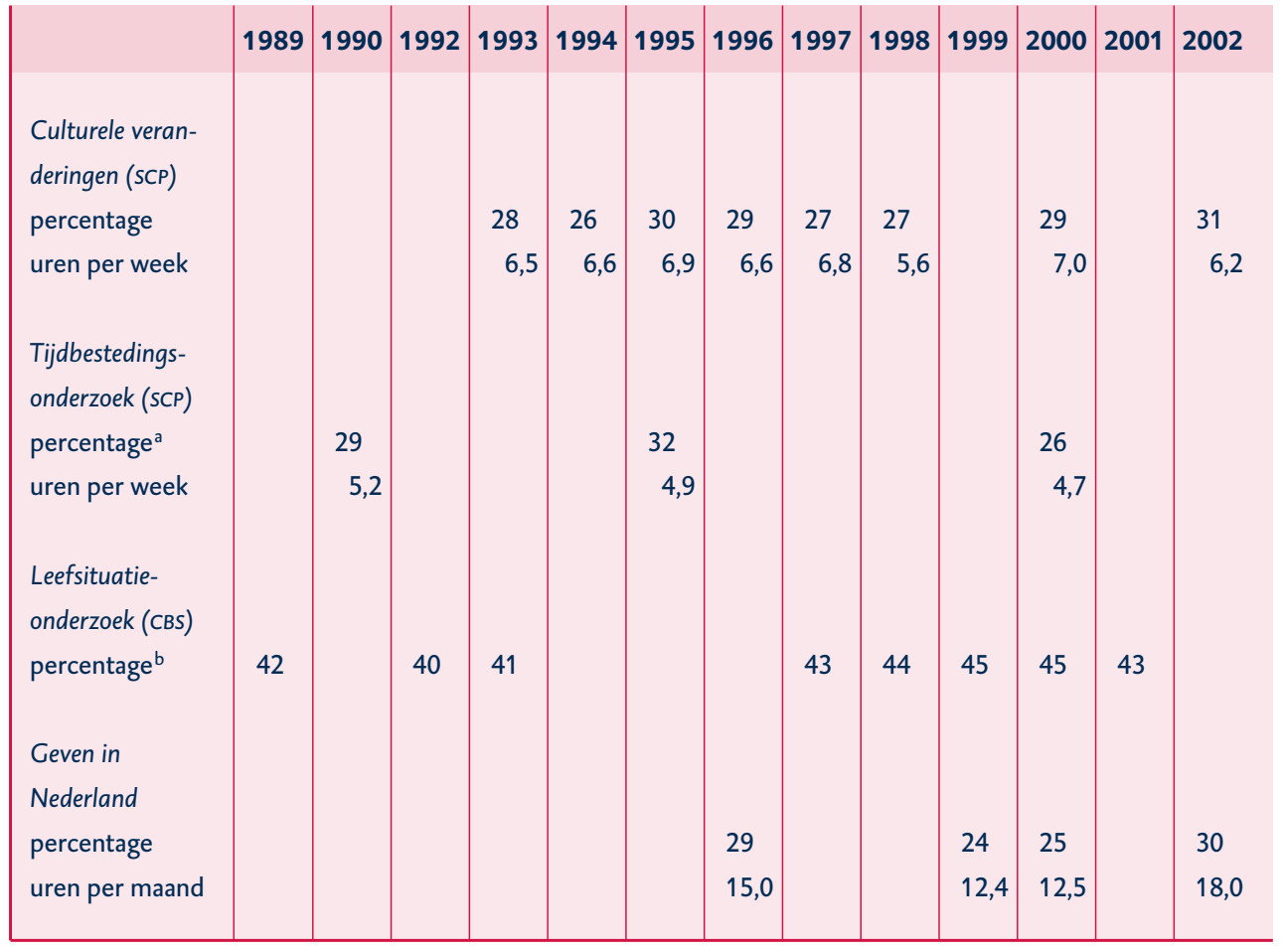

a In de afgelopen week.

b In de afgelopen maand. 
zoeken. Anders dan vaak wordt verondersteld bieden deze cijfers geen aanwijzing voor een afnemende bereidheid om vrijwilligerswerk te doen. Afhankelijk van de geraadpleegde bron verrichtte in de afgelopen decennia steeds een kwart tot bijna de helft van de volwassen bevolking vrijwilligerswerk. Ook het aantal uren vrijwilligerswerk dat gemiddeld per hoofd van de bevolking wordt verricht is weinig veranderd.

Uitsplitsing van de cijfers leert echter wel dat er aanzienlijke verschillen zijn tussen verschillende bevolkingsgroepen. Jongeren zijn steeds minder vrijwilligerswerk gaan doen, terwijl de deelname van ouderen, in ieder geval tot begin jaren negentig, een licht stijgende trend vertoont (zie ook Dekker 2001). Dat de gemiddelde deelname aan vrijwilligerswerk betrekkelijk stabiel is, is dus mede te danken aan de vergrijzing van de bevolking. Internationaal gezien is de deelname aan vrijwilligerswerk in Nederland groot. In de European Values Study zegt exact de helft van de Nederlanders onbetaald vrijwilligerswerk te doen, tegenover 43 procent van de Britten, 37 procent van de Denen, 36 procent van de Belgen en slechts 21 procent van de Duitsers. Alleen van de Zweden zegt een nog groter percentage (56\%) vrijwilligerswerk te doen (Dekker et al. 2003).

Een andere indicator voor de bereidheid om zich vrijwillig in te zetten voor anderen of voor de gemeenschap is het lidmaatschap van ideële organisaties. Tabel 3.10 laat zien dat het aantal leden en donateurs van grote maatschappelijke organisaties (met minimaal 50.000 leden) tussen 1980 en 2000 met 33 procent is gestegen van ruim 26 miljoen naar bijna 35 miljoen. Hierbij dient men wel te bedenken dat de nauwkeurigheid van de opgaven door de organisaties te wensen kan overlaten en dat veel mensen lid zijn van meerdere organisaties, zodat het aantal leden veel groter is dan het aantal personen dat lid is. Bovendien is in de beschouwde periode de bevolking van 15 jaar en ouder met 18 procent gegroeid. Ook als hiervoor wordt gecorrigeerd is er echter nog altijd sprake van een aanzienlijke ledenaanwas met 16 procent voor alle organisaties tezamen. Ook de opbrengst van fondsenwerving door ideële organisaties laat een forse stijging zien: van 535 miljoen euro in 1991 naar 1.729 miljoen in 2001 (Dekker et al. 2003). Dit wordt vaak geïnterpreteerd als een verschuiving van actieve naar passieve participatie ('giroboeksolidariteit'), hoewel hierboven bleek dat de deelname aan vrijwilligerswerk in ieder geval niet is afgenomen.

\subsection{GENERATIE-EFFECTEN?}

Veranderingen in waarden, normen en gedrag kunnen onder meer het gevolg zijn van veranderingen in de samenstelling van de bevolking. Als bevolkingsgroepen die een bepaalde norm het sterkst onderschrijven in omvang teruglopen, terwijl groepen die deze norm minder sterk hebben geïnternaliseerd groeien, zal de gemiddelde steun voor de betreffende norm onder de bevolking afnemen. Het is echter ook mogelijk dat de steun voor een bepaalde norm in alle groepen in dezelfde richting verandert. Met betrekking tot waarden, normen en gedrag wordt nogal eens verondersteld dat jongere generaties verschillen van 
Tabel 3.10

Leden/donateursaantallen $(\times 100.000)$ van grote maatschappelijke organisaties in Nederland, 1980-2000a

\begin{tabular}{|c|c|c|}
\hline & 1980 & 2000 \\
\hline Politieke partijen & 3 & 2 \\
\hline Vrouwen & 3 & 2 \\
\hline Kerk en godsdienst ${ }^{b}$ & 95 & 80 \\
\hline Omroeporganisaties ${ }^{c}$ & 36 & 34 \\
\hline Werknemers & 15 & 18 \\
\hline Sport en recreatie & 41 & 47 \\
\hline Werkgevers en zelfstandigen & 2 & 3 \\
\hline Ouderen & 4 & 5 \\
\hline Consumenten & 32 & 48 \\
\hline Gezondheidszorg & 16 & 36 \\
\hline Internationale solidariteit & 19 & 44 \\
\hline Natuur en milieu & 4 & 30 \\
\hline Abortus/euthanasie & 0 & 2 \\
\hline Totaal & 270 & 352 \\
\hline
\end{tabular}

a Organisaties met in een peiljaar 50.000 of meer leden/donateurs.

$\mathrm{b}$ Incl. Nederlands gereformeerde kerken en gereformeerde gemeenten in Nederland.

c Excl. voo.

Bron: Dekker et al. (2003)

oudere generaties. De geleidelijke vervanging van de oudere door de jongere generaties zou dan een belangrijke verklaring zijn voor verschuivingen in de waarden, normen en het gedrag. In empirisch onderzoek is het overigens lastig om dergelijke generatie-effecten te onderscheiden van leeftijdseffecten. Het is bekend dat jongeren er vaak andere opvattingen op na houden dan ouderen, maar met het ouder worden zouden de jongeren hun opvattingen weer kunnen aanpassen. Indien men slechts op één moment de opvattingen van verschillende bevolkingscategorieën vergelijkt, kan men dan ook niet vaststellen of het om leeftijdsverschillen of om generatieverschillen gaat. Alleen als men dezelfde opvattingen over een langere periode volgt, kan men hieruit meer inzicht verkrijgen. Met behulp van gegevens uit de onderzoeken Culturele Veranderingen en de European Values Study is het mogelijk voor een aantal waarden en normen te onderzoeken of er daadwerkelijk sprake is van generatie-effecten.

Tabel 3.11 geeft een beeld van verschillen tussen generaties in hun opvatting over gedrag en zeden. Verschillende generaties zijn hier onderscheiden op basis van het decennium waarin zij geboren zijn (eigenlijk gaat het dus om geboortecohorten). In ieder jaar blijken de oudere generaties vaker dan de jongere generaties van mening dat gedrag en zeden achteruitgaan, al valt op dat deze verschillen in 
de jaren negentig aanzienlijk kleiner waren dan in de jaren zeventig: de opvattingen van de generaties lijken naar elkaar toe te groeien. Verder blijkt iedere generatie pessimistischer te worden over gedrag en zeden naarmate zij ouder wordt. Diagonaal (van linksboven naar rechtsonder) kan men in tabel 3.11 de verandering in de opvatting van verschillende leeftijdscategorieën in de loop van de tijd volgen. Zo was het geboortecohort 1900-'og in 1975 even oud (nl. 66-75 jaar) als het geboortecohort 1910-'19 in 1985 en bij benadering even oud als het geboortecohort 1920-'29 in 1996. Vergelijkt men de verschillende leeftijdscategorieën

Tabel 3.11 Percentage van de bevolking dat van mening is dat de opvattingen over gedrag en zeden in ons land steeds meer achteruitgaan

\begin{tabular}{|cc|c|c|c|c|c|c|c|c|}
\multicolumn{10}{|c|}{ Geboortejaar } \\
Jaar & $1900-09$ & $1910-19$ & $1920-29$ & $1930-39$ & $1940-49$ & $1950-59$ & $1960-69$ & $1970-79$ & Totaal \\
1970 & 60 & 56 & 46 & 38 & 24 & 24 &. &. & 39 \\
1975 & 70 & 73 & 58 & 55 & 46 & 37 &. &. & 54 \\
1980 & 77 & 76 & 69 & 64 & 56 & 51 & 46 &. & 60 \\
1985 & $\cdot$ & 80 & 69 & 69 & 56 & 49 & 38 &. & 57 \\
1996 & $\cdot$ & $\cdot$ & 65 & 72 & 62 & 62 & 59 & 50 & 61 \\
\hline
\end{tabular}

Bron: SCP (CV'70-'96); wRR-bewerking

door de tijd heen, dan lijkt er bij de meeste categorieën een tendens te zijn om geleidelijk iets pessimistischer te worden over gedrag en zeden. Nadere analyse (zie Dekker et al. 2003) leert dat het toegenomen pessimisme over gedrag en zeden voornamelijk moet worden verklaard uit een verandering in de 'tijdgeest', waardoor over de gehele linie mensen negatiever zijn gaan oordelen. Dit effect is enigszins afgezwakt door de vervanging van oudere door jongere generaties, aangezien de jongere geboortecohorten minder negatief zijn dan met name de generatie die vóór 1920 is geboren.

Tabel 3.12 geeft een vergelijkbaar overzicht voor de onzekerheid over wat goed en wat verkeerd is. In de jaren zeventig en tachtig blijken de verschillen tussen de generaties klein te zijn, maar in de jaren negentig tonen de jongere generaties zich beduidend minder onzeker dan de oudere generaties. Er is een lichte tendens om met het ouder worden minder onzeker te worden, maar alleen bij de naoorlogse generaties is dit effect substantieel. Vergelijkt men de verschillende leeftijdscategorieën in de loop van de tijd (diagonaal gearceerd in tabel 3.12), dan is steeds sprake van afnemende onzekerheid met het vorderen van de tijd. Dit suggereert dat hier vooral sprake is van een periode-effect, dat wil zeggen dat alle groepen in de loop van de tijd minder onzeker worden. Een meer verfijnde analyse bevestigt dat er inderdaad geen significant generatie- of leeftijdseffect is, maar uitsluitend een periode-effect. 
Tabel 3.12 'Er zijn zoveel verschillende opvattingen over wat goed en wat verkeerd is dat je soms niet meer weet waar je aan toe bent' (percentage van de bevolking dat het hier 'volkomen mee eens' of 'in grote lijnen mee eens' is)

\begin{tabular}{|l|c|c|c|c|c|c|c|c|c|}
\multicolumn{10}{|c|}{ Geboortejaar } \\
Jaar & $1900-09$ & $1910-19$ & $1920-29$ & $1930-39$ & $1940-49$ & $1950-59$ & $1960-69$ & $1970-79$ & totaal \\
1970 & 64 & 65 & 55 & 54 & 49 & 60 &. &. & 56 \\
1975 & 56 & 60 & 57 & 47 & 46 & 51 &. &. & 52 \\
1980 & 56 & 54 & 52 & 55 & 45 & 52 & 54 &. & 53 \\
1985 & $\cdot$ & 51 & 54 & 50 & 45 & 43 & 45 &. & 47 \\
1992 & $\cdot$ & 58 & 55 & 55 & 41 & 36 & 34 & 44 & 43 \\
1996 & $\cdot$ & $\cdot$ & 50 & 49 & 39 & 35 & 32 & 35 & 39 \\
\hline
\end{tabular}

Bron: SCP (CV'70-'96); wRR-bewerking

Tabel 3.13 geeft een indruk van de verschillen tussen generaties ten aanzien van de mate waarin men socialezekerheidsfraude en belastingfraude afwijst. De jongere cohorten zijn over het algemeen minder streng dan de oudere cohorten, maar alle cohorten stonden in 1990 sterker afwijzend tegenover fraude dan in 1981. Vergelijkt men verschillende leeftijdsgroepen (op de gearceerde diagonalen), dan blijken jongeren over het algemeen minder 'streng' te zijn dan ouderen. Uit een nadere analyse blijkt dat bij socialezekerheidsfraude zowel het cohort-

Tabel 3.13 Percentage van de bevolking dat van mening is dat socialezekerheidsfraude en belastingfraude nooit te rechtvaardigen is, naar kalenderjaar en geboortejaar

\begin{tabular}{|l|c|c|c|c|c|c|c|c}
\multicolumn{1}{|c|}{ Geboortejaar } \\
Jaar & $\begin{array}{c}1920 \text { en } \\
\text { eerder }\end{array}$ & $1921-30$ & $1931-40$ & $1941-50$ & $1951-60$ & $1961-70$ & $1971-81$ & Totaal \\
Socialezeker- \\
heidsfraude
\end{tabular}

Bron: EVS (1981, 1990, 1999); SCP-bewerking 
effect als het periode-effect significant is. Bij belastingfraude is echter alleen het periode-effect significant.

\subsection{CONCLUSIE}

De inventarisatie in dit hoofdstuk van het beschikbare statistische materiaal over waarden, normen en gedrag maakt twee dingen duidelijk.

In de eerste plaats is het verre van eenvoudig om een goed en betrouwbaar beeld te krijgen van de ontwikkelingen in de tijd en van de verschillen tussen landen ten aanzien van waarden, normen en gedrag. Niet alleen sluit de vraagstelling in de beschikbare surveys vaak niet aan bij die van dit rapport, daarnaast zijn er vele redenen om te twijfelen aan de betrouwbaarheid en vergelijkbaarheid van de gepresenteerde cijfers. Bij het meten van de maatschappelijke steun voor verschillende waarden en normen is men onvermijdelijk aangewezen op de meningen zoals mensen die in enquêtes uitspreken. Niet alleen kan men vraagtekens zetten bij de oprechtheid van die antwoorden, bovendien is het vaak lastig om deze antwoorden te interpreteren. Omdat vrijwel altijd gebruik wordt gemaakt van vaste antwoordcategorieën ('gesloten vragen'), is lang niet altijd duidelijk wat de respondenten met hun antwoord bedoelen.

In de tweede plaats maken de beschikbare cijfers duidelijk dat men zeer terughoudend dient te zijn met algemene uitspraken over veranderingen in waarden, normen en gedrag. De trends die in dit hoofdstuk zijn geschetst en de internationale vergelijkingen leveren een nogal diffuus beeld op. Er is geen sprake van eenduidige tendensen die zonder meer kunnen worden geïnterpreteerd als 'verval' van waarden en normen of als een afname van lofwaardig gedrag.

Met de nodige voorzichtigheid kunnen uit de gepresenteerde cijfers de volgende conclusies worden getrokken.

- Een sterke toename van het pessimisme over de ontwikkeling van 'zeden en gedrag' in Nederland is samengegaan met een afname van de onzekerheid over wat goed en slecht is. Dit suggereert dat Nederlanders steeds zelfbewuster worden en minder in verwarring verkeren over goed en kwaad, maar wel zeer kritisch staan tegenover het gedrag van hun landgenoten.

- De steun onder de Nederlandse bevolking voor de waarden van de rechtsstaat en de democratie is groot en lijkt eerder toe dan af te nemen. Nederland verschilt in dit opzicht niet sterk van de meeste andere EU-landen.

- Wetsovertreding kan over het algemeen op weinig begrip rekenen van de Europese bevolking; dit geldt ook voor de Nederlandse bevolking, die alleen ten aanzien van softdrugsgebruik duidelijk toleranter is dan de inwoners van andere landen (met uitzondering van Groot-Brittannië). Over in ieder geval twee specifieke vormen van wetsovertreding - socialezekerheidsfraude en belastingontduiking - zijn Nederlanders in de jaren negentig strenger gaan oordelen.

- Al meer dan twintig jaar lang is een overgrote meerderheid van de Nederlan- 
ders van mening dat de criminaliteit de laatste tijd toeneemt. Toch zijn Nederlanders minder vaak dan de inwoners van andere West-Europese landen van mening dat veel landgenoten zich schuldig maken aan zaken als belasting- en socialezekerheidsfraude, verkeersovertredingen en zelfs softdrugsgebruik.

- Er zijn geen aanwijzingen dat lofwaardig gedrag als vrijwilligerswerk en lidmaatschap van maatschappelijke organisaties terugloopt. Wel concentreert dit gedrag zich in sterkere mate in de oudere leeftijdscategorieën.

- Veranderingen in opvattingen over waarden en normen zijn vooral een uiting van de 'tijdgeest', dat wil zeggen dat zij zich bij alle leeftijdscategorieën en geboortecohorten manifesteren. Daarnaast blijken de jongere generaties minder streng te oordelen over wetsovertreding en minder negatief te oordelen over 'zeden en gedrag' van anderen dan de oudere generaties, hetgeen in beperkte mate heeft bijgedragen aan een minder sterk 'normbesef'.

In dit hoofdstuk ging het om de opinie van de 'doorsnee'-Nederlander over de waarden, normen en het gedrag, de ontwikkeling daarin in de loop van de tijd en overeenkomsten en verschillen met andere Europese landen. Het meten van de publieke opinie is belangrijk om inzicht te krijgen in de aard en achtergronden van het waarden- en normendebat. In hoofdstuk 1 is echter geconstateerd dat de belangrijkste problemen die aanleiding hebben gegeven tot het huidige debat, zijn gelegen in het vóórkomen van allerlei vormen van normoverschrijdend gedrag. Om deze problemen te kunnen aanpakken zal men derhalve meer inzicht moeten verkrijgen in de feitelijke ontwikkelingen ten aanzien van normoverschrijding en wetsovertreding. Dit hoofdstuk met opinies wordt daarom gevolgd door een hoofdstuk waarin de beschikbare feiten over normoverschrijdend gedrag worden geïnventariseerd. 


\section{NORMOVERSCHRIJDEND GEDRAG}

\subsection{INLEIDING}

Hoewel de gevleugelde woorden 'waarden en normen' anders doen vermoeden, lijkt de maatschappelijke onvrede die mede aanleiding was tot de adviesaanvraag aan de WRR vooral verband te houden met een (vermeende) toename van ongewenst gedrag (zie hoofdstuk 1). In hoofdstuk 3 bleek dat er onder de Nederlandse bevolking een hoge mate van overeenstemming bestaat over de gedragsnormen waaraan men zich heeft te houden. Tegelijkertijd is een grote meerderheid van de bevolking van mening dat het hier juist aan schort: te veel mensen zouden zich niet aan de algemeen aanvaarde normen houden. In dit hoofdstuk wordt onderzocht of deze perceptie juist is. Hoe is het gesteld met de feitelijke omvang en de ontwikkeling van diverse vormen van normoverschrijdend gedrag in Nederland?

De ernst en zorgelijkheid van normoverschrijdend gedrag wordt vanzelfsprekend in hoge mate bepaald door de aard van de norm die wordt overschreden. Er is een groot verschil tussen het overtreden van een fatsoensnorm als het openhouden van een deur en het schenden van het strafrechtelijke verbod op het doden van een ander mens. Zoals in hoofdstuk 2 is aangegeven zou men globaal een indeling kunnen maken van onprettig gedrag, via onbehoorlijk en onduldbaar gedrag tot onwettig gedrag. Gedrag van anderen dat men als onprettig ervaart maar waarvan men geen schade ondervindt, dient men in het algemeen gelaten te verdragen. Onbehoorlijk gedrag hoeft men niet zonder meer te accepteren. In het algemeen dienen de organisaties en instellingen waarbinnen dit ergerlijke gedrag zich voordoet, erop toe te zien dat bepaalde codes voor fatsoenlijk gedrag worden nageleefd. Bij onduldbaar gedrag gaat het om gedrag dat weliswaar overlast voor anderen veroorzaakt maar (net) niet strijdig is met een wettelijke regel. Doorgaans is dit gedrag wel in strijd met de interne gedragsregels van organisaties en instellingen, zoals bijvoorbeeld de Nederlandse Spoorwegen of onderwijsinstellingen. Deze organisaties zijn er dan ook verantwoordelijk voor om dergelijk gedrag, zeker wanneer het zich frequent voordoet, aan te pakken. Bij onwettig gedrag is het in het algemeen de taak van de overheid - meer concreet: politie en justitie - om dergelijk gedrag aan te pakken en tegen te gaan.

Dit hoofdstuk tracht enig inzicht te bieden in de factoren die ten grondslag (kunnen) liggen aan diverse vormen van normoverschrijdend gedrag. De paragrafen 4.2 en 4.3 geven enige theoretische beschouwingen over de wisselwerking tussen formele en informele controle en sancties, en over internalisering van normen en normoverschrijdend gedrag. De paragrafen 4.4-4.12 geven vervolgens een overzicht van beschikbaar empirisch onderzoek naar uiteenlopende vormen van normoverschrijdend gedrag. Paragraaf 4.4 schetst een aantal algemene trends in de ontwikkeling van normoverschrijding, variërend van onpret- 
tig tot onwettig gedrag. Hierbij past bij voorbaat de kanttekening dat over ernstiger vormen van normoverschrijding, in het bijzonder zware criminaliteit, meer bekend is dan over de lichtere vormen. De verklaring hiervoor is eenvoudig: vanwege de ernst ervan wordt (zware) criminaliteit veel beter geregistreerd en intensiever onderzocht dan de onprettige gedragingen die geen wetsovertredingen inhouden maar niettemin de nodige ergernis kunnen oproepen. Hierover zijn alleen enkele gegevens voorhanden die afkomstig zijn uit grote publieksenquêtes. Deze hebben echter onvermijdelijk in hoge mate een subjectief karakter, doordat hierin alleen de percepties van burgers worden gemeten. De paragrafen 4.5-4.12 zoomen vervolgens in op een aantal concrete vormen van relatief veelvoorkomend normoverschrijdend gedrag. Deze paragrafen beogen op basis van het beschikbare sociaal-wetenschappelijk onderzoek wat meer inzicht te bieden in de factoren die ten grondslag liggen aan uiteenlopende vormen van normoverschrijding. Dit hoofdstuk pretendeert echter geenszins een uitputtend overzicht te geven van het beschikbare onderzoek naar en datamateriaal over normoverschrijdend gedrag. Het hoofdstuk bevat slechts een kleine selectie hiervan, die echter wel een goed beeld geeft van de grote variatie in normoverschrijding en in de factoren die daaraan ten grondslag (kunnen) liggen. Achtereenvolgens komen aan de orde:

- wangedrag op school (par. 4.5);

- jeugdcriminaliteit (par. 4.6);

- zinloos geweld en geweld op straat (par. 4.7);

- voetbalvandalisme (par. 4.8);

- wangedrag in het openbaar vervoer (par. 4.9)

- wangedrag in het verkeer (par. 4.10);

- wangedrag op het werk (par. 4.11);

- fraude (par. 4.12).

De slotparagraaf (4.13) trekt enkele algemene conclusies over de factoren die ten grondslag liggen aan normoverschrijdend gedrag en de strategieën die men zou kunnen volgen om normoverschrijding tegen te gaan of terug te dringen. Dit hoofdstuk neemt de bestaande, breed onderschreven of wettelijke normen als een gegeven aan en gaat niet in op veranderingen in de normen zelf. Een toename van normoverschrijdend gedrag kan echter ook een aanwijzing zijn dat de norm zelf aan verandering toe is. Aan de dynamiek van waarden en normen zelf wordt in de hoofdstukken 5 en 6 aandacht geschonken.

\subsection{WAT VERKLAART NORMOVERSCHRIJDEND GEDRAG?}

Wie alleen afgaat op de berichtgeving in de media kan gemakkelijk de indruk krijgen dat normoverschrijdend gedrag in Nederland inmiddels de regel is geworden en normconform gedrag de uitzondering. Dit is natuurlijk niet juist. Het overgrote deel van de bevolking gedraagt zich nog altijd in het overgrote deel van de gevallen in overeenstemming met de wettelijke regels en ook in overeenstemming met vele, breed gedragen informele normen. De meeste mensen groeten hun buren, gooien hun afval in een vuilnisbak, betalen hun belasting, stop- 
pen voor het rode stoplicht, kopen een treinkaartje en plegen geen winkeldiefstal, hoewel zij er in de meeste gevallen voordeel bij zouden hebben om anders te handelen.

Waarom gedragen de meeste mensen zich overwegend in overeenstemming met de geldende normen? Er is een problematische, enigszins raadselachtige relatie tussen normen en gedrag. Het gedrag in action kan door heel veel verschillende factoren ontstaan. De aard en de ouderdom van de norm en de mate van navolging in de groep of samenleving als geheel spelen bij normconform gedrag wel een rol, maar het blijft uiterst lastig om hierover een algemene theorie van normconformiteit op te stellen. Daarvoor zijn de normsferen eenvoudig te uiteenlopend: het gedrag in het verkeer (snelheidsnormen, gevaarzettingen) is totaal verschillend van het invullen van het belastingbiljet en die twee sferen verschillen weer enorm van bijvoorbeeld de normen voor integriteit bij de vervulling van ambten. Elke normsfeer heeft een eigen dynamiek en regelmaat.

Niettemin kan in het algemeen wel worden gesteld dat mensen normen niet alleen gehoorzamen uit angst om gepakt en gestraft te worden indien zij de normen overtreden. In veel gevallen weegt dit risico niet op tegen het verwachte voordeel van normoverschrijdend gedrag. De meeste mensen worden - behalve door de externe prikkels van beloning en straf - ook door intrinsieke motivatie gedreven om zich normconform te gedragen. Soms is dit simpelweg omdat zij geen voordeel kunnen ontlenen aan overtreding van de norm. Een bekend voorbeeld hiervan is rechts rijden op de openbare weg: wie deze norm overtreedt, treft daarmee in de eerste plaats zichzelf, vanwege het grote risico op een aanrijding. Een dergelijke norm vervult primair een coördinatiefunctie en wordt dan ook vrijwel zonder uitzondering nageleefd, zonder dat daarvoor controle en sancties nodig zijn. Voor vormen van normoverschrijdend gedrag die wel een direct voordeel opleveren - variërend van belastingfraude tot door rood licht rijden en winkeldiefstal - is dit minder vanzelfsprekend. Dat toch relatief weinig mensen zich hieraan schuldig maken, duidt erop dat de meeste deze normen hebben 'verinnerlijkt': zij ervaren het als een (morele) plicht om de norm na te leven. In de criminologie is de internalisering van normen als factor in normconform gedrag vooral bestudeerd bij jongeren. Zowel bij de overdracht van waarden als bij de internalisering van normen zijn voorbeelden van significante personen het belangrijkst voor het aanleren en in praktijk brengen van normen (Levering 2004). Ontbreken dergelijke personen met wie kinderen en jongeren een affectieve relatie onderhouden, dan ontstaat vaak normoverschrijdend gedrag (zoals ernstige jeugdige delinquenten zeer vaak een disharmonische opvoeding in een gebroken gezin achter de rug hebben). Maar vanaf een bepaalde leeftijd worden sociale normen van de eigen leeftijdsgroep minstens even belangrijk. Wanneer die sociale groepsnormen (peergroup norms) afwijken van de algemene maatschappelijke normen of van de ouderlijke normen, dan ontstaan er veel botsingen. 
Heel algemeen gesteld gedragen mensen zich dus normconform omdat normoverschrijdend gedrag hun geen voordelen oplevert, omdat zij de norm hebben geïnternaliseerd of omdat zij het risico om gepakt en gestraft te worden te groot achten. In veel gevallen gaat het natuurlijk om een combinatie van deze factoren. De 'externe' controle en sancties die mensen van normoverschrijdend gedrag kunnen afhouden, omvatten niet alleen de formele controle en sancties door daartoe aangestelde toezichthouders (bijvoorbeeld politie) en rechtsprekers (bijvoorbeeld rechters). Zij omvatten ook de informele sociale controle en sancties die door medeburgers worden uitgeoefend. Het feit dat men door anderen wordt aangesproken indien men een (formele of informele) norm overschrijdt en als gevolg hiervan een sanctie ondervindt, bijvoorbeeld in de vorm van reputatieverlies, schaamte of uitstoting uit de groep waarvan men deel uitmaakt, kan een belangrijke prikkel zijn om de norm na te leven.

De invloed van sancties op de internalisering van normen is met grote wetenschappelijke onzekerheid omgeven (Malsch 2004). Soms helpen affectieve en cognitieve identificaties met andere personen meer dan welke sanctie dan ook, maar in de meeste situaties zijn jongeren bij een bepaald normbesef wel degelijk gevoelig voor het toepassen van beloningen voor goed gedrag en sancties voor slecht gedrag. Belonen helpt meestal beter dan straffen. Er is bovendien een verschuiving te zien van de meer morele vormen van sociale controle (groepsdwang en een appèl op het geweten) naar instrumentele sociale controle (belonen en straffen) en van een informele sociale controle naar een formele sociale controle, uitgeoefend door (formele) instanties. In het algemeen kunnen deze formele sancties niet uitsluitend de norminternalisering bewerkstelligen, zoals stelsels die uitsluitend met repressieve maatregelen werken hebben ondervonden. Het gaat steeds om een subtiele wisselwerking tussen informele en formele sociale controle. Beide vormen vullen elkaar aan.

Formele controle valt onder de hoede van de overheid en andere instanties en wordt via rechtsnormen uitgeoefend. Informele controle is minder goed stuurbaar en richtbaar en valt in feite onder de noemer van sociale normen. Deze twee normenstelsels staan in een zeer subtiele verhouding tot elkaar. Soms leidt formele controle, bijvoorbeeld cameratoezicht in de horecabuurten van grote steden, tot een reductie van normoverschrijdend gedrag binnen de gecontroleerde sfeer, maar leidt ze - onverwacht - tegelijk tot een verzwakking van de informele sociale controle ('alles wat buiten het oog van de camera valt, is toegestaan'). Soms leidt een sterke informele sociale controle van een groep, bijvoorbeeld van een peergroup of oudere familieleden, tot onweerstaanbare gedragsbeinvloeding, die zelfs tot verhoging van normoverschrijdend gedrag kan leiden. Zo kan een jongen zich door zijn vrienden onder druk gezet voelen om mee te doen aan het vernielen van een bushokje.

Van normoverschrijding zal dus in het algemeen sprake zijn indien de combinatie van deze factoren tekortschiet, dat wil zeggen indien de intrinsieke motivatie om zich normconform te gedragen te gering is en/of de externe formele of infor- 
mele controle tekortschiet en/of men aan een andere, conflicterende norm meer gewicht toekent.

\subsection{DE DYNAMIEK VAN NORMOVERSCHRIJDING}

Internalisering van normen, formele controle en informele controle staan niet los van elkaar, maar kunnen elkaar wederzijds beïnvloeden. Dit betekent dat wanneer een van deze factoren tekortschiet, ook de andere factoren hierdoor kunnen worden verzwakt. Een aanvankelijk kleine toename van normoverschrijdend gedrag kan een sterke dynamiek op gang brengen, waardoor zich in de loop van de tijd grote verschuivingen kunnen voordoen in zowel de steun voor een norm als het gedrag. Als eenmaal een bepaald omslagpunt is gepasseerd, kan zich een sneeuwbaleffect voordoen, waardoor een bepaalde vorm van normoverschrijdend gedrag steeds algemener wordt en de betreffende norm geleidelijk afkalft, tot zij op den duur mogelijk zelfs geheel verdwijnt.

Dit mechanisme kan worden geillustreerd aan de hand van een eenvoudig theoretisch model, waarmee de wisselwerking tussen internalisering van normen, formele en informele controle en gedrag op het niveau van een groep (bijvoorbeeld een buurt of club, of de Nederlandse samenleving als geheel) kan worden geanalyseerd. Dit model is gebaseerd op de rationelekeuzetheorie, waarin wordt verondersteld dat individuele personen afwegingen maken tussen de kosten en baten van verschillende gedragsalternatieven. Anders dan gebruikelijk in rationelekeuzemodellen wordt er hier expliciet rekening mee gehouden dat het gedrag van mensen niet alleen wordt bepaald door prikkels 'van buiten', maar ook door intrinsieke motivatie, die het resultaat is van de internalisering van bepaalde normen (zie bijvoorbeeld Akerlof 1980 en Coleman 1990). Hier wordt volstaan met een verbale beschrijving van het model. De bijlage bij dit hoofdstuk bevat een formele, wiskundige uitwerking van het model.

Stel dat een individu voordeel kan behalen door een bepaalde norm die geldt in de groep waarvan hij of zij deel uitmaakt, te overtreden. Door internalisering van de norm, formele controle en informele controle kan hij of zij er niettemin van worden weerhouden om in strijd met de norm te handelen. Wie de norm heeft geïnternaliseerd, krijgt spijt, berouw of een schuldgevoel als hij de norm zou overtreden. Wie vindt dat men geen diefstal mag plegen, maar in een winkel toch in de verleiding komt om iets te stelen, kan zichzelf daarvan weerhouden als hij zich realiseert dat die daad een schuldgevoel zou oproepen - ook als niemand anders er weet van zou hebben. Men kan ook van normoverschrijdend gedrag afzien uit angst voor de gevolgen indien men wordt betrapt door een officiële toezichthouder. De kans dat men door een bewaker of het winkelpersoneel wordt betrapt op winkeldiefstal en de straf die daarop zou volgen, kunnen zo groot zijn dat ook iemand die winkeldiefstal niet afkeurt, ervan wordt weerhouden. Ten slotte kan men zich normconform gedragen vanwege informele sociale controle. Als men niet door een officiële bewaker wordt betrapt, maar wel door anderen die men persoonlijk kent, kan dit schaamtegevoelens oproepen of repu- 
tatieverlies veroorzaken. De kans om door je buren of kennissen erop aangekeken te worden als je regelmatig iets steelt, kan voldoende reden zijn om je aan deze norm te houden.

Stel nu dat aanvankelijk het overgrote deel van de leden van een groep een bepaalde norm onderschrijft en zich conform de norm gedraagt. Dit doen zij niet alleen omdat zij de norm hebben geïnternaliseerd, maar ook omdat zij zich bewust zijn van de formele en informele sancties die normovertreding met zich mee kan brengen. In de praktijk hoeven deze sancties echter slechts zelden te worden toegepast, doordat bijna niemand de norm overtreedt. In deze situatie lijkt er weinig bezwaar tegen te zijn om de formele controle op normoverschrijdend gedrag te verminderen. De reden hiervoor kan zijn gelegen in kostenbesparing of in een afkeer van controle. Zo werden in Nederland in de loop van de jaren zestig en zeventig tal van controlemechanismen verminderd: de conducteurs verdwenen van de trams, het perronkaartje werd afgeschaft en vele winkels gingen over op zelfbediening. Ook de informele controle nam af, onder meer doordat de geografische mobiliteit toenam en de sociale band tussen buurtbewoners verzwakte.

Aanvankelijk heeft de afname van formele en informele controle geen merkbare invloed op het gedrag van mensen, doordat de normen voldoende sterk zijn geïnternaliseerd om zich ook bij iets minder controle normconform te blijven gedragen. Dit versterkt de argumenten om de controle nog verder te verminderen. Op een gegeven moment zijn de sancties op normoverschrijdend gedrag echter zo sterk verminderd dat sommigen de verleiding niet langer kunnen weerstaan om de norm te overtreden. Het betreft in eerste instantie mensen die ofwel de norm niet geïnternaliseerd hebben, ofwel weinig angst hebben voor een formele bestraffing, ofwel weinig gevoelig zijn voor de effecten van sociale controle en bijvoorbeeld geen schaamte voelen als anderen hen aanspreken op hun gedrag. Zij rechtvaardigen winkeldiefstal bijvoorbeeld als proletarisch winkelen, zwartrijden als een middel om gratis openbaar vervoer te bepleiten en belastingontduiking omdat je anders een dief van je eigen portemonnee bent.

Ook al gaat het in eerste instantie om een kleine groep, als anderen zien dat je ongestraft de normen kunt overtreden, tast dit op den duur ook hun geloof in de norm aan. Het is immers aannemelijk dat de mate waarin de leden van een groep een norm onderschrijven mede wordt bepaald door het percentage groepsleden dat zich normconform gedraagt. Naarmate een kleiner deel de norm gehoorzaamt, zal ook het percentage dat de norm onderschrijft, afnemen. Bovendien is het aannemelijk dat naarmate minder leden van de groep de norm onderschrijven, informele sociale controle minder effectief wordt. Immers, iemand die de norm zelf niet onderschrijft, zal een ander er in het algemeen niet op aanspreken als hij ziet dat deze de norm overtreedt. Ook als slechts een relatief kleine groep de norm overtreedt, kan hierdoor op iets langere termijn zowel het geloof in de norm als de sociale controle afkalven. Als gevolg daarvan zullen weer nieuwe mensen in de verleiding komen om de norm te overtreden. Op deze wijze kan er 
een neerwaartse spiraalbeweging in gang worden gezet, waardoor steeds meer mensen de norm overtreden, steeds minder mensen de norm onderschrijven en de sociale controle op het gedrag steeds zwakker wordt. Terwijl een vermindering van controle dus lange tijd geen noemenswaardig effect heeft op de naleving van een norm, wordt op een gegeven moment een omslagpunt bereikt, waarna een kleine verdere afname van controle een sterke toename van normoverschrijdend gedrag tot gevolg heeft (vgl. Gladwell 200o). Er doet zich dan plotseling een sneeuwbaleffect voor. Normoverschrijding door de een tast het geloof in de norm van de ander aan, waardoor de informele sociale controle afneemt en formele controle minder effectief wordt. Dit verleidt nog meer mensen tot normoverschrijdend gedrag, enzovoorts.

Waar dit proces eindigt, valt niet in zijn algemeenheid te zeggen. Het is denkbaar dat de norm op den duur volledig verdwijnt, doordat niemand de norm meer gehoorzaamt of onderschrijft. Het is echter ook denkbaar dat een bepaald deel van een groep zo sterk van de norm overtuigd is dat dit deel zich ook normconform blijft gedragen als de formele en informele controle volledig zijn verdwenen. Zo zou zich een kleine groep 'orthodoxe gelovigen' kunnen handhaven te midden van een grote meerderheid die afscheid heeft genomen van de betreffende norm. Ook als vrijwel niemand meer een kaartje voor de tram koopt, blijven er misschien mensen die trouw hun strippenkaart afstempelen.

Vanzelfsprekend is dit theoretische model een sterke vereenvoudiging van de werkelijkheid. Het is zeker niet bedoeld om te suggereren dat iedere vorm van normoverschrijdend gedrag op deze wijze kan worden verklaard. Bovendien zijn zeker niet alle normconforme of normoverschrijdende gedragingen het resultaat van een rationele afweging tussen intrinsieke motivatie en extrinsieke, formele en informele controle. Gedrag wordt ook vaak gestuurd door emoties, zonder dat daaraan een afweging van de kosten en baten voor het individu ten grondslag ligt. Woede, angst en haat kunnen belangrijke drijfveren zijn voor normoverschrijdend gedrag, zoals liefde en medelijden dat kunnen zijn voor lofwaardig gedrag - al geldt soms ook het omgekeerde. Hoewel in dit hoofdstuk de meeste aandacht uitgaat naar min of meer rationeel gedrag, is daarmee zeker niet gezegd dat het meeste normconforme of normoverschrijdende gedrag rationeel is. Rationeel gedrag biedt over het algemeen wel meer aanknopingspunten voor beïnvloeding dan zuiver emotioneel gedrag.

De mate waarin internalisering van normen en formele en informele controle afdoende zijn om normoverschrijdend gedrag tegen te gaan, hangt sterk af van de context waarin dit gedrag zich afspeelt. Thuis wordt het gedrag door geheel andere factoren beïnvloed dan op het werk, op school of in de publieke ruimte - op straat, in het openbaar vervoer, in het verkeer, in het voetbalstadion of in een winkel. Maar ook twee gezinnen of twee scholen zijn nooit hetzelfde. Als men zich prettig en veilig voelt in een omgeving en/of als men zich bewust is van de aanwezigheid van formele of informele controleurs, zal men zich eerder aan de normen houden dan in een omgeving waarin deze factoren geheel of 
gedeeltelijk ontbreken. De institutionele context van normconform en normoverschrijdend gedrag komt in dit hoofdstuk echter slechts terloops ter sprake. Hoofdstuk 7 gaat uitgebreider in op de rol van instituties bij het tegengaan van normoverschrijdend gedrag.

\subsection{BUURTPROBLEMEN, ONVEILIGHEID EN CRIMINALITEIT}

\subsubsection{BUURTPROBLEMEN}

Sinds 1993 wordt iedere twee jaar, als onderdeel van de Politiemonitor Bevolking, een representatieve steekproef van de Nederlandse bevolking ondervraagd over de ergernissen die men in de eigen buurt ervaart. Tabel 4.1 laat zien dat hondenpoep en te hard rijden de meest voorkomende ergernissen zijn: ongeveer de helft van de bevolking zegt dat dit in zijn of haar buurt vaak voorkomt. Ruim een kwart klaagt over rommel op straat en een op de vijf burgers zegt in de buurt vaak te worden geconfronteerd met vernield straatmeubilair en agressief verkeersgedrag.

Tabel 4.1 Buurtproblemen, 1993-2001 (percentage van de bevolking dat zegt dat dit vaak voor komt)

\begin{tabular}{|c|c|c|c|c|c|c|}
\hline & 1993 & 1995 & 1997 & 1999 & 2001 & $\begin{array}{c}\text { Mutatie } \\
\text { 1993-2001 }\end{array}$ \\
\hline Verloedering: & & & & & & \\
\hline Hondenpoep op straat & 47 & 50 & 53 & 50 & 48 & 1 \\
\hline Rommel op straat & 22 & 25 & 27 & 26 & 29 & 7 \\
\hline $\begin{array}{l}\text { Bekladding van muren, } \\
\text { gebouwen }\end{array}$ & 16 & 15 & 16 & 16 & 13 & -3 \\
\hline $\begin{array}{l}\text { Vernieling van straatmeubilair } \\
\text { Geluidsoverlast }\end{array}$ & 16 & 17 & 18 & 19 & 20 & 4 \\
\hline $\begin{array}{l}\text { (niet door verkeer) } \\
\text { Verkeersoverlast: }\end{array}$ & 12 & 11 & 11 & 8 & 9 & -3 \\
\hline Te hard rijden & 48 & 46 & 46 & 48 & 47 & -1 \\
\hline Geluidsoverlast door verkeer & 16 & 15 & 15 & 13 & 14 & -2 \\
\hline $\begin{array}{l}\text { Agressief verkeersgedrag } \\
\text { Dreiging: }\end{array}$ & 20 & 21 & 25 & 20 & 19 & -1 \\
\hline $\begin{array}{l}\text { Dronken mensen op straat } \\
\text { Mensen worden op straat }\end{array}$ & 8 & 7 & 7 & 8 & 8 & 0 \\
\hline lastiggevallen & 4 & 4 & 3 & 4 & 3 & -1 \\
\hline Drugsoverlast & . & . & 8 & 6 & 6 & . \\
\hline
\end{tabular}


In de periode 1993-2001 deed zich geen eenduidige trend voor in deze buurtproblemen. De rommel op straat en vernieling van straatmeubilair namen volgens de ondervraagden toe, maar graffiti en geluidsoverlast namen af. Hoe deze ergernissen zich op langere termijn hebben ontwikkeld is onbekend.

\subsubsection{ONVEILIGHEID}

Uit dezelfde Politiemonitor Bevolking blijkt dat bijna een derde van de bevolking zich soms en zes procent zich vaak onveilig voelt (tabel 4.2). Dit percentage is tussen 1993 en 2001 niet noemenswaardig veranderd. Ook het percentage van de bevolking dat vanwege de ervaren onveiligheid vermijdingsgedrag vertoont, laat in de jaren negentig geen eenduidige trend zien.

Tabel 4.2 Onveiligheidsgevoelens, 1993-2001 (in procenten van de bevolking)

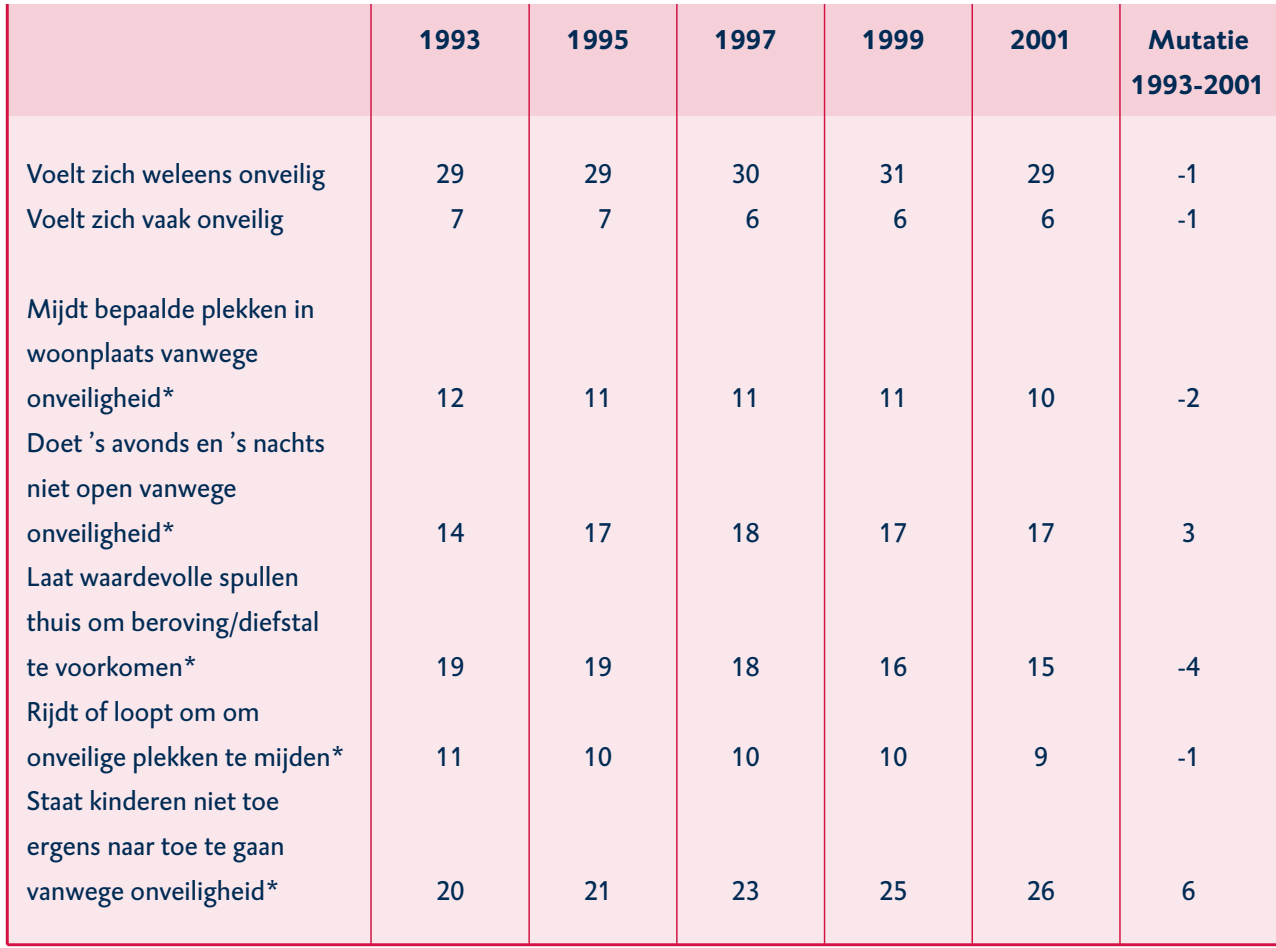

* Het betreft het percentage van de bevolking dat zegt dat dit vaak voorkomt.

Bron: Politiemonitor Bevolking (2001)

Uit onderzoek blijkt overigens steevast dat het subjectieve gevoel van onveiligheid niet evenredig is met de objectieve kans om slachtoffer te worden van delicten of van geweld. Bij ouderen in bepaalde wijken van de grote steden zijn de onveiligheidsgevoelens het grootst, terwijl de feitelijke criminaliteit in die wijken minder groot is. Vrouwen voelen zich over het algemeen onveiliger dan mannen, hoewel zij minder vaak slachtoffer van een misdrijf zijn. Omgekeerd 
voelen mannen onder de 45 jaar zich het minst onveilig, terwijl de kans dat zij betrokken raken bij ernstige criminaliteit, hetzij als slachtoffer hetzij als dader, het grootst is. Dit geldt het sterkst voor de jongeren in de uitgaansgebieden van de vier grote en de middelgrote steden.

\subsubsection{CRIMINALITEIT EN GEWELD}

De geregistreerde criminaliteit in Nederland is sinds 1960 sterk gestegen (figuur 4.1). De belangrijkste toename vond plaats in de vermogenssfeer. Na 1970 en nogmaals na 1990 vindt een stijging plaats, maar sinds 1994 is de omvang van de criminaliteit per saldo nauwelijks meer veranderd. Binnen dit algemene patroon van stabilisatie doet zich echter, vooral sinds 1990, wel een sterke stijging voor van geweldsmisdrijven. Het aantal geregistreerde gevallen van geweldscriminaliteit steeg van 532 per 100.000 inwoners in 1994 naar 774 in 2001. Andere opvallende kenmerken van de criminaliteitsontwikkeling in de laatste tien jaar zijn de sterke stijging van het aandeel van (met name allochtone) jongeren, een relatieve stijging van het aandeel van vrouwen en meisjes en een stijging van het aandeel van delinquenten met een psychiatrische aandoening (Ministerie van Justitie 2002).

Figuur 4.1 Misdrijven per 100.000 inwoners, 1950-2001

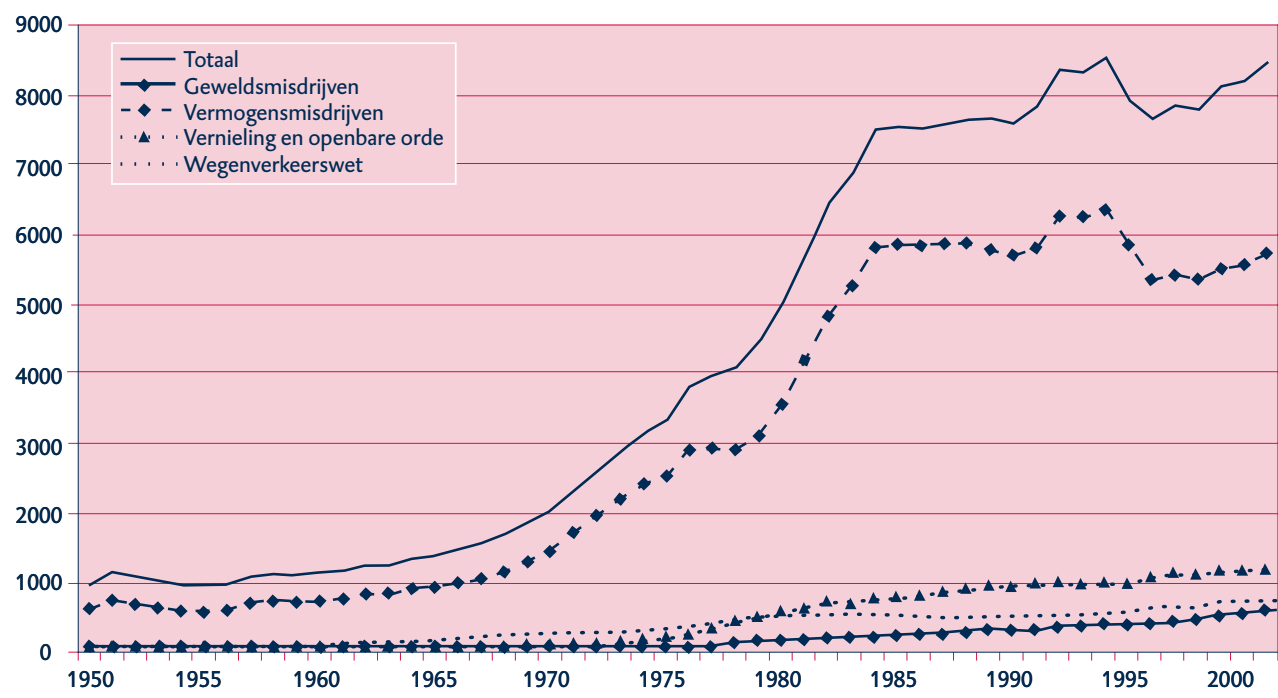

Bron: CBS (Statline)

Er is een discussie ontstaan of binnen de stabiliserende criminaliteit de gewelddadige criminaliteit, met name onder jongeren, daadwerkelijk is toegenomen. Deze stijging wordt namelijk niet bevestigd door slachtofferenquêtes; die laten sinds het midden van de jaren tachtig zelfs een licht dalende trend zien. Bron van deze uiteenlopende oordelen zijn definitiekwesties (wat wordt onder geweld gerekend?), registratieverschillen (enquêtegegevens sporen niet met de politieregistraties), registratie-effecten (sommige zaken worden nu wel geregistreerd en 
werden vroeger afgedaan zonder vermelding) en trendextrapolaties (welke jaren en tijdreeksen als uitgangspunt worden genomen). Wittebrood en Junger (1999) vinden de meest aannemelijke verklaring voor de uiteenlopende cijfers dat de registratie door de politie aanzienlijk is verbeterd. Terwijl in het begin van de jaren tachtig slechts een op de 25 delicten die in slachtofferenquêtes werden gemeld, in de politiestatistieken terechtkwam, was deze verhouding in de tweede helft van de jaren negentig toegenomen tot een op de tien. Volgens Wittebrood en Junger (1999) geven de slachtofferenquêtes een betrouwbaarder beeld. Over het geheel genomen zou de geweldscriminaliteit in de jaren negentig dan niet zijn toegenomen. In de meest recente jaren is echter wel sprake van een lichte stijging (van $5 \%$ in 2000 naar $6 \%$ in 2002). Bovendien komt uit de slachtofferenquêtes al sinds 1996 een toename van het aantal bedreigingen naar voren (van 2,5\% naar 3,7\% in 2002), hetgeen wellicht heeft bijgedragen aan gevoelens van onveiligheid, al is het ook denkbaar dat men bepaalde gedragingen eerder als 'bedreiging' is gaan aanmerken. Daarnaast is ook het aantal gevallen van moord en doodslag, waarvan wel betrouwbare registraties beschikbaar zijn, sinds de jaren zeventig gestaag gegroeid: van 0,5 per 100.000 inwoners rond 1970 naar circa 1,2 halverwege de jaren negentig (Wittebrood en Junger 1999). Verder zijn er sterke aanwijzingen dat de geweldscriminaliteit door jongeren wel degelijk is toegenomen en niet kan worden afgedaan als een mediahype (zie par. 4.6).

Hoewel het dus de vraag is of geweldscriminaliteit in het algemeen is toegenomen, geldt dit in ieder geval wel voor de zwaarste vormen (moord en doodslag) en voor geweld door jongeren.

\subsection{WANGEDRAG OP SCHOOL}

Klachten over 'de jeugd van tegenwoordig' zijn van alle tijden. Zo maakte men zich kort na de Tweede Wereldoorlog, een periode die nu vooral associaties oproept met knusheid, saaiheid en hard werken, grote zorgen om het gebrek aan werklust en het nihilisme van de jongeren. Dit betekent echter niet dat we zorgen over de jeugd met een eenvoudig schouderophalen kunnen afdoen. Er zijn wel degelijk aanwijzingen dat uiteenlopende vormen van wets- en normovertreding onder jongeren toenemen. Deze paragraaf richt zich op het wangedrag van jongeren op en rond school. Volgens Junger-Tas (2002: 5) is hier sprake van serieuze problemen: "Spijbelen, schooluitval, geweld en wangedrag zijn actuele problemen waar scholen speciale aandacht aan dienen te besteden." Cijfers van het Sociaal en Cultureel Planbureau, ontleend aan het Nationale Scholierenonderzoek (NSO), bevestigen dit.

Tabel 4.3 geeft enkele gegevens over spijbelen, drank- en drugsgebruik en kleine criminaliteit voor het begin van de jaren negentig en het jaar 2002. Dit overzicht beperkt zich overigens niet tot misdragingen op school, waarover weinig afzonderlijke gegevens beschikbaar zijn. Het spijbelen is in de jaren negentig sterk toegenomen, vooral het frequent spijbelen. Meer dan een kwart van de scholieren zegt de afgelopen maand ten minste één keer te hebben gespijbeld en 7 procent zelfs tien of meer keer. Mogelijk is dit nog een onderschatting van het 


\begin{tabular}{|l|c|c|} 
& $1990 / 92$ & 2002 \\
Afgelopen maand gespijbeld & 11 & $28^{\mathrm{a}}$ \\
Afgelopen maand dronken geweest & 7 & $14^{\mathrm{b}}$ \\
Afgelopen maand cannabis gebruikt & 6 & $9^{\mathrm{b}}$ \\
Afgelopen maand paddo's, xTc of amfetamine gebruikt & 1 & $2^{\mathrm{b}}$ \\
Deelgenomen aan serieuze vechtpartij op school & $7 \mathrm{c}$ \\
lemand zo geslagen dat hij/zij verbonden moest worden of & & 9 \\
naar een dokter moest & 8 & 6 \\
Fiets gepikt & 6 & 6 \\
lets op school gestolen & $\cdot$ & 9 \\
lets uit een winkel gestolen & 9 & 7 \\
Opzettelijk schooleigendommen vernield & 5 & 10 \\
Opzettelijk iets op straat vernield & 10 & \\
\end{tabular}

a 2001 / b 1999 / c 1994

Bron: Wittebrood en Keuzekamp (2000); Wittebrood (2003) WRR-bewerking

werkelijke cijfer, omdat degenen die het meest spijbelen de grootste kans hadden niet aanwezig te zijn bij het afnemen van de enquête! Ook overmatig drankgebruik en drugsgebruik laten een forse stijging zien. Tussen 1996 en 1999 nam het drugsgebruik overigens weer iets af. De andere vormen van normoverschrijdend gedrag, zoals mishandeling, diefstal en vandalisme, waren in de jaren negentig echter stabiel, met uitzondering van vechtpartijen en vernieling van schooleigendommen, die wel licht zijn toegenomen.

In de BVE-sector (Beroepsonderwijs en volwasseneneducatie, waaronder het $\mathrm{MBO}$ ) is in 2001 en 2002 onderzoek gedaan naar verschillende vormen van normoverschrijdend en ander ongewenst gedrag (Neuvel 2002). Hieruit komt naar voren dat 48 procent van de cursisten weleens spijbelt, 7 procent drugs gebruikt, 7 procent een wapen draagt, 7 procent andere cursisten pest, 2 procent zich schuldig maakt aan vandalisme, 2,5 procent aan diefstal, 1 procent aan bedreiging en 3 procent weleens lichamelijk geweld gebruikt. Niettemin voelt 91 procent van de cursisten zich veilig in de klas, 85 procent in het schoolgebouw en 80 procent op het schoolterrein of de stalling.

Hoe is wangedrag op school te verklaren? Een rapport van het onderzoeksbureau Motivaction (1999) concludeert: "De huidige generatie jongeren is een individualistische generatie, als groep tolerant, internationaal georiënteerd en in staat om op een strategische wijze om te gaan met maatschappelijke complexiteit en verandering. Levensvreugde wordt geput uit beleven, ervaren en genieten. De jongeren van nu zijn sterk gemotiveerd om hun individuele doelen te bereiken en maken zich weinig zorgen over maatschappelijke ontwikkelingen als individualisering 
en het milieu." Blijkbaar voelen nogal wat jongeren zich niet gehinderd om voor het bereiken van die individuele doelen een aantal algemeen aanvaarde normen te overtreden. Hierbij moet wel worden aangetekend dat de ernstiger vormen van wangedrag zich concentreren bij een relatief kleine groep die wordt gekenmerkt door een cumulatie van problemen: overmatig drugs- en drankgebruik, spijbelen, slechte schoolprestaties, emotionele problemen en een slechte relatie met ouders en leeftijdgenoten (Zeijl 2003). Het is echter niet duidelijk welke causale relatie er bestaat tussen deze gedragsproblemen: is spijbelen het voorportaal van criminaliteit of zijn delinquente scholieren eerder geneigd te spijbelen? Of worden wellicht beide problemen veroorzaakt door eerdere problemen thuis?

\subsection{JEUGDCRIMINALITEIT}

Jeugdcriminaliteit is geen apart soort criminaliteit maar een die wordt gepleegd door minderjarigen. Toch is aparte aandacht voor deze vorm van criminaliteit in dit overzicht gerechtvaardigd, omdat jeugdcriminaliteit zich in een aantal opzichten onderscheidt van de criminaliteit door volwassenen en omdat (een deel van) deze criminaliteit als zeer zorgelijk moet worden aangemerkt (vgl. Ministerie van Justitie 2002). Men zou verwachten dat, als gevolg van de 'ontgroening' van de bevolking, het aandeel van de jongeren in de totale criminaliteit terugloopt. Figuur 4.2 laat zien dat het aandeel van de minderjarigen in het totale aantal verdachten van misdrijven tussen 1961 en 1990 inderdaad sterk verminderde: van 27 procent naar 15 procent. In de jaren negentig is het aandeel van jongeren in de criminaliteit echter weer licht toegenomen. Dit is vooral een gevolg van het grotere aandeel van jongeren in geweldscriminaliteit en vernielingen en ordeverstoringen (misdrijven tegen de openbare orde). In beide vormen

Figuur 4.2 Aandeel verdachten jonger dan 18 jaar (in \% van totaal), 1951-2001

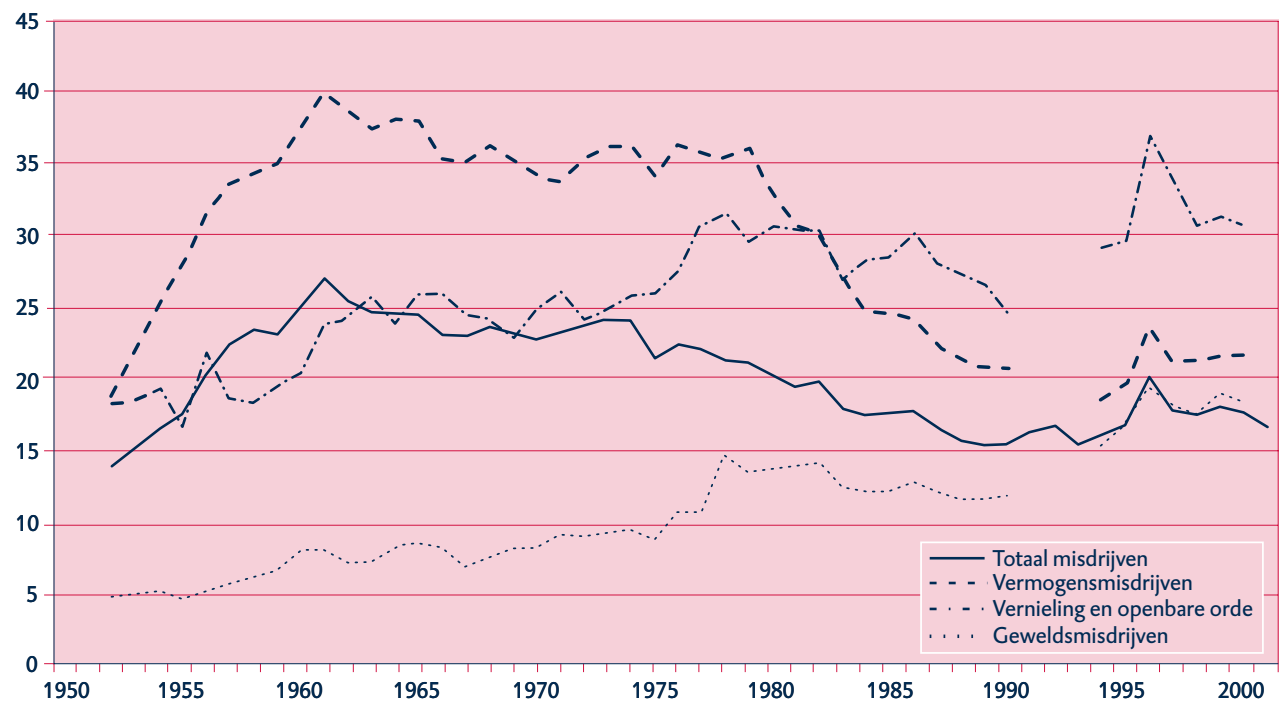

Bron: CBS (Statline) 
van criminaliteit groeide het aandeel van de jongeren al in de jaren zeventig, om in de jaren negentig opnieuw een aanzienlijke toename te vertonen.

Wordt de mate waarin jongeren zich schuldig maken aan criminaliteit op zich bezien - los van de omvang van de totale criminaliteit -, dan is al vanaf het begin van de jaren zestig een trendmatige stijging te signaleren, zo laat figuur 4.3 zien. Werd in 19631,5 procent van de jongeren onder 18 jaar gehoord als verdachte van een misdrijf, in 1996 werd een piek bereikt van bijna 4,7 procent. In de laatste jaren is dit percentage overigens weer iets teruggelopen, naar 4, o. Bij geweldsmisdrijven was echter ook in de tweede helft van de jaren negentig nog sprake van een stijging. Jaarlijks wordt op iedere honderd jongeren van 12-18 jaar er een aangehouden vanwege een geweldsmisdrijf. Voorzover sommige jongeren meerdere malen per jaar worden opgepakt, is het feitelijke percentage jongeren dat wordt aangehouden overigens kleiner.

\section{Figuur 4.3 Minderjarige verdachten per 1.000 jongeren van 12-17 jaar, 1952-2001}

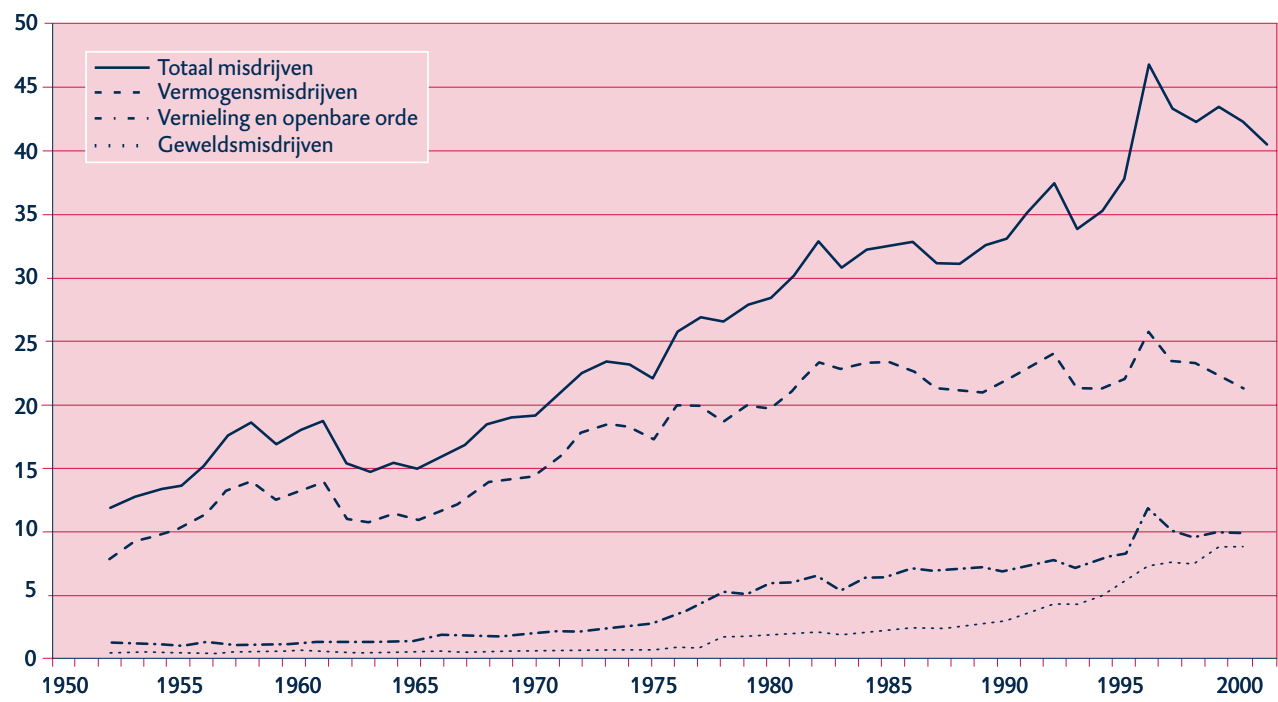

Bron: CBS (Statline)

De trend in de jeugdcriminaliteit die kan worden vastgesteld aan de hand van het aantal gehoorde verdachten, hoeft niet overeen te komen met de werkelijke trend indien het opsporingspercentage van misdrijven verandert. Het hiervoor geschetste beeld beperkt zich bovendien tot de meer ernstige vormen van criminaliteit waarvan aangifte wordt gedaan en een verdachte wordt aangehouden. Een andere bron van informatie, die niet onder deze tekortkomingen lijdt maar wel andere problemen oproept, is de zelfrapportage door jongeren in het onderzoek dat het Wetenschappelijk Onderzoek en Documentatiecentrum van het ministerie van Justitie (WODC) sinds 1988 iedere twee jaar uitvoert. Dit onderzoek laat globaal hetzelfde patroon zien: tussen 1988 en 1996 groeide het percentage jongeren dat toegaf bepaalde delicten te hebben gepleegd, in het bijzonder 
winkeldiefstal (van 5,4 naar 10,o procent), diefstal op school (van 6,5 procent in 1990 naar 10,1 procent), heling (van 3,5 naar 8,6 procent), vernieling (van 8,9 naar 14,6 procent) en iemand in elkaar slaan (van 1,9 naar 3,3 procent). Maar tussen 1996 en 1998 lieten al deze delicten weer een aanzienlijke daling zien (Kruissink en Essers 2001: 22).

Extra zorgelijk is dat vooral de geweldscriminaliteit door jongeren sterk is toegenomen. Zo nam het aantal misdrijven tegen het leven (of pogingen daartoe) gepleegd door jongeren tussen 12 en 17 jaar toe van 1 op de 100.000 in 1952 tot 10 per 100.000 in 1990 en ruim 30 per 100.000 in 1996. Deze stijging zet zich nog steeds voort (Wittebrood 2000: 23). Het aantal minderjarigen, verdacht van mishandeling, nam evenzeer toe: van 1952 tot 1970 was dit aantal stabiel, namelijk 50 per 100.000. Sinds het begin van de jaren zeventig stijgt dit tot 200 en er vindt wederom een sterke stijging plaats na 1990 tot 425 per 100.000 jongeren in de leeftijd 12-17 jaar. Voor de delicten bedreiging met geweld, diefstal met geweld en afpersing valt eveneens een stijging te constateren, zij het niet zo scherp: van 10 in 1978 tot 80 per 10o.ooo jongeren in 1996 (Wittebrood 2000: 25). De conclusie is gewettigd: zowel in absolute aantallen als in relatieve zin neemt de geweldscriminaliteit onder jongeren sterk toe.

Hoewel vaak wordt gesuggereerd dat jeugddelinquentie zich op steeds jongere leeftijd manifesteert, biedt het zelfrapportageonderzoek van het wODC hiervoor geen aanwijzingen. De leeftijd waarop men zegt voor het eerst een strafbaar feit te hebben gepleegd is voor alle onderscheiden delicten tussen 1988 en 1998 nagenoeg gelijk gebleven. Hierop is slechts één uitzondering, maar wel een belangrijke: de leeftijd waarop jongeren naar eigen zeggen voor het eerst iemand in elkaar hebben geslagen daalde van 13,5 jaar in 1988 naar 12,3 jaar in 1994, om daarna overigens weer te stijgen naar 13,1 jaar in 1998 (Kruissink en Essers 2001: 27). Gegevens van het Openbaar Ministerie wijzen echter wel uit dat het aandeel zeer jeugdigen (12-14 jarigen) onder de minderjarigen waartegen een strafzaak aanhangig wordt gemaakt, tussen 1995 en 2000 licht is toegenomen, van 25 procent naar 26,3 procent van alle minderjarige verdachten (Ministerie van Justitie 2002: 27).

Jeugdcriminaliteit wordt vaak in verband gebracht met bepaalde groepen allochtonen, in het bijzonder Marokkanen en Antillianen. Inderdaad zijn er veel aanwijzingen voor een toenemende oververtegenwoordiging van allochtonen onder de jeugdige criminelen, hoewel hierover weinig harde cijfers voorhanden zijn. Een op de vier verdachten in de leeftijdsgroep 12-24 jaar blijkt in het buitenland geboren te zijn, vooral in Marokko en in de Nederlandse Antillen. Ook relatief gezien, in verhouding tot de omvang van de bevolkingsgroep, is het aantal verdachten van Antilliaanse en Marokkaanse afkomst het grootst (resp. 11\% en $8 \%$ van de groep 12-24-jarigen) (Ministerie van BZK 2002: 41-43). De tweedegeneratieallochtonen, die in Nederland zijn geboren, ontbreken echter in deze cijfers, zodat mag worden aangenomen dat het totale aandeel allochtonen onder de jeugdige verdachten nog beduidend groter is. 


\subsection{ZINLOOS GEWELD EN GEWELD OP STRAAT}

De maatschappelijke verontrusting over criminaliteit in de afgelopen jaren is mede gevoed door enkele bijzonder ernstige incidenten van zinloos geweld die veel aandacht kregen in de media. Naar aanleiding van de Tjoelker-zaak in Leeuwarden heeft de Tweede Kamer aangedrongen op een specifiek onderzoek naar geweld op straat. In dit onderzoek is 'geweld op straat' geïnterpreteerd als geregistreerde misdrijven in de openbare en semi-openbare ruimte (dus niet in winkelcentra of andere particuliere eigendomsruimten). Op basis van een steekproef van 1300 gevallen van openbaar geweld, in één jaar in twee politiedistricten gepleegd, constateerden de onderzoekers drie contexten van geweld op straat. In volgorde van frequentie waren dit: 1) buurtgeweld en buurtonveiligheid, 2) verkeersgeweld, conflicten tussen weggebruikers en 3) horecageweld en in en om uitgaansgelegenheden, waarbij drankgebruik een belangrijke rol speelde (Terlouw et al. 1999: 27).

Uit dit onderzoek kwamen enkele belangrijke kenmerken van straatgeweld naar voren.

- Het is vaak toeval wie dader is en wie slachtoffer; aan het fysieke geweld gaat verbaal geweld van beide kanten vooraf. Bestudering van het verloop van deze conflicten is onthullend voor het agressieve karakter van alle betrokkenen en voor de futiliteit van de conflictaanleiding (vaak symbolische gebaren of verbale beledigingen).

- Er is een stijgend aandeel in dit geweld op straat van jongeren in de leeftijd van 13-16 jaar; maar bij deze groep gaat het nog vooral om vandalisme. 42 procent van alle gevallen betrof daders in de leeftijd van 12-17 jaar, en 28 procent in de leeftijd van 18-24 jaar, dus in twee derde van alle gevallen betrof het jongeren.

- Het geweld gepleegd door de iets oudere leeftijdsgroep van 17-20 jaar, is ernstiger van aard en veroorzaakt meer serieus letsel. Dit duidt op een 'leereffect' en op een vergroving van het geweld naarmate men ouder wordt (Terlouw et al. 1999: ibidem).

Interviews met (een beperkt aantal) daders en slachtoffers van de betrokken incidenten bevestigen dat de aanleiding voor het incident vaak uiterst gering is en dat de daders zich vaak zelf zien als slachtoffers. Een algehele gevoeligheid voor inbreuk op het eigen psychische territoir, een snelle gekwetstheid van het ego en een geringe rem op gewelddadige reacties valt bij daders (maar ook bij toevallige slachtoffers) waar te nemen (Beke et al. 2001).

Een bijzondere vorm van geweld is de beroving van nietsvermoedende personen op straat door middel van straatroof of gekwalificeerde diefstal (diefstal met geweld). Voor de slachtoffers hiervan zijn dit buitengewoon ingrijpende en ernstige ervaringen, met vaak langdurende slapeloosheid, woede, onmacht en schaamte (om de onmacht) als gevolg. In het delict van straatroof komt een gegeneraliseerde bedreiging van de persoonlijke levenssfeer naar voren. Vermoedelijk 
heeft het daarom een enorme impact op algemene gevoelens van onveiligheid. De daders hebben vaak een instrumentele houding ten opzichte van de keuze van de slachtoffers en van de gebruikte wapens: messen en scheermesjes en ander ernstig letsel toebrengende wapens worden welbewust ingezet. Een aanzienlijk deel van de daders is jonger dan 18 jaar en van buitenlandse herkomst (vooral onevenredig veel Marokkanen). Vaak is het delict gerelateerd aan drugsgebruik: 40 procent van de Amsterdamse straatrovers is verslaafd (Ferwerda et al. 2002).

\subsection{VOETBALVANDALISME}

Sport verbroedert, luidt het gezegde. Maar wie bij sport vooral aan wedstrijden in het betaald voetbal denkt, zal daarbij wellicht eerder associaties met agressie en massaal geweld hebben. Naast de wedstrijd op het veld vindt er de laatste decennia immers vaak een tweede wedstrijd plaats, namelijk die tussen de supporters van beide ploegen. Voetbalvandalisme, zoals het meestal wordt genoemd, of supportersgeweld, wat misschien een toepasselijker aanduiding is, is langzamerhand een 'gewoon' verschijnsel geworden, dat echter bij het publiek toch telkens weer afgrijzen en onbegrip oproept.

Sinds het seizoen 1986-'87 verzamelt het Centraal Informatiepunt Voetbalvandalisme gegevens over voetbalvandalisme. Hieraan zijn de cijfers in tabel 4.4 ontleend over de supporters die in de afgelopen tien jaar door de politie zijn aangehouden.

Tabel 4.4 Aanhoudingen vanwege voetbalvandalisme, 1997-2002

\begin{tabular}{|c|c|c|c|c|c|c|}
\hline \multirow[t]{2}{*}{ Seizoen } & \multirow{2}{*}{$\begin{array}{l}\text { Totaal } \\
\text { aantal }\end{array}$} & \multirow{2}{*}{$\begin{array}{c}\text { First } \\
\text { offenders } \\
(\%)\end{array}$} & \multicolumn{4}{|c|}{ Aandeel in procenten } \\
\hline & & & 12-18 jaar & 19-24 jaar & 25-30 jaar & $\begin{array}{c}\text { Ouder dan } \\
30 \text { jaar }\end{array}$ \\
\hline 1991-'92 & 977 & . & . & . & . & . \\
\hline 1992-'93 & 1012 & . & . & . & . & . \\
\hline 1993-'94 & . & . & . & . & . & . \\
\hline 1994-'95 & 1933 & . & . & . & . & . \\
\hline 1995-'96 & 1550 & . & 21 & 44 & 25 & 10 \\
\hline 1996-'97 & 1614 & . & 20 & 48 & 24 & 8 \\
\hline 1997-'98 & 1294 & 70,8 & 18 & 37 & 27 & 10 \\
\hline 1998-'99 & 1554 & 78,4 & 26 & 41 & 23 & 11 \\
\hline $1999-2000$ & 1568 & 75,6 & 22 & 41 & 24 & 13 \\
\hline 2000-'01 & 1200 & 75,5 & 18 & 45 & 21 & 16 \\
\hline 2001-'02 & 1887 & 74,9 & 18 & 41 & 24 & 18 \\
\hline
\end{tabular}

Bron: CIV (1999; 2002); Bol en Netburg (1997) 
Hoewel het aantal aanhoudingen in het voorlaatste voetbalseizoen (2001-'02) tweemaal zo groot was als aan het begin van de jaren negentig, mag hieruit niet worden geconcludeerd dat het supportersgeweld trendmatig toeneemt. Daarvoor zijn de schommelingen van jaar tot jaar te groot. Bovendien hangt het aantal aanhoudingen ook samen met de alertheid waarmee de politie optreedt. Uit tabel 4.4 blijkt dat steeds ongeveer driekwart van de aangehouden supporters voor de eerste maal bij een voetbalwedstrijd wordt aangehouden ('first offenders') en dat de gemiddelde leeftijd van 'hooligans' laag is: zo'n zestig procent is jonger dan 25 jaar. Wel groeit het aandeel van de iets oudere groep: in het laatste seizoen was bijna een op de vijf aangehouden supporters ouder dan 30 jaar. Verder kan nog worden opgemerkt dat de aangehouden supporters vrijwel allen mannen zijn.

Waarom gedragen sommige voetbalsupporters zich gewelddadig? Gedegen onderzoek hiernaar is schaars, omdat een onderzoeker zich hiervoor gedurende langere tijd onder de hooligans dient te begeven om te bestuderen wat hen drijft. Adang (1998), die eind jaren tachtig een groot aantal risicowedstrijden bezocht, constateerde dat over het algemeen slechts een zeer klein deel van de supporters zich te buiten gaat aan geweld. Zelfs in de vakken waarin zich rellen voordoen, neemt in de meeste gevallen hooguit tien procent van de aanwezigen daaraan actief deel. De grote meerderheid van de supporters die niet aan het geweld deelneemt, geeft vrijwel nooit enige blijk van afkeuring, laat staan dat zij een poging doen het geweld te beëindigen. Volgens Adang maken "hun passieve of actieve ondersteuning en afwezigheid van iedere vorm van afkeuring (...) het ontstaan en de escalatie van geweld mogelijk" (Adang 1998: 40). Wel zijn er aanwijzingen dat de aanwezigheid van vrouwen te midden van de supporters uitbarsting van geweld kan tegengaan (Roberts en Benjamin 200o). Duidelijk zichtbare aanwezigheid van politie in de directe nabijheid van de betreffende groep supporters verkleint de kans op geweld, vooral als zij vroegtijdig optreedt, nog voordat er sprake is van daadwerkelijk geweld (Adang 1998: 52, 55). Als er eenmaal geweld wordt gepleegd, draagt politieoptreden er echter niet meer toe bij om dit sneller te beëindigen. De aanwezigheid van videocamera's lijkt niet van invloed te zijn op het uitbreken van geweld (Adang 1998: 28).

Wat drijft hooligans? Gaat het om ontspoorde jonge mannen die zich ook op andere momenten veelvuldig agressief en normoverschrijdend gedragen of betreft het voor het overige eerzame burgers die een aandrang voelen om zich af en toe te buiten te gaan aan gewelddadige uitspattingen? Het beschikbare onderzoek is niet geheel eenduidig ten aanzien van deze vraag. Volgens Van Netburg en Ter Horst-Van Breukelen (200o) zijn de informele leiders en aanstichters van de rellen vaak wat oudere supporters die al jaren meelopen en meestal niet zelf deelnemen aan de ongeregeldheden. Zij zijn "de meer intellectuele figuren (...) uit de midden- en hogere klasse" die meestal een baan hebben. De supporters die het meeste geweld plegen (de 'harde kern') zijn vaak afkomstig uit de lagere sociale milieus en hebben geen of nauwelijks schoolopleiding en een laaggekwalificeerde functie (Van Netburg en Ter Horst-Van Breukelen 200o; Dunning 200o). 
Adang (1998) stelt echter: "Hooligans zijn afkomstig uit alle denkbare milieus en niet bij uitstek werkeloos e.d." Wel hebben zij vaker dan andere jonge mannen problemen gehad op school (bijvoorbeeld conflicten met leraren) of thuis (afwezigheid van effectieve sociale controle) (Bol en Van Netburg 1997; Adang 1998: 39,40 ). Hooligans gaan ook in andere situaties relatief vaak tot geweld over of maken zich schuldig aan crimineel gedrag (bijvoorbeeld in de vorm van uitgaansgeweld). Een aanzienlijk deel, vooral van de iets oudere voetbalvandalen (boven de 20 jaar), is al eerder met justitie in aanraking geweest (Bol en Van Netburg 1997). Opmerkelijk is dat zich onder de hooligans maar weinig jongeren uit de etnische minderheden bevinden.

Belangrijke motieven om geweld te plegen zijn niet alleen de 'kick' die men van geweld krijgt, maar vooral dat het een manier is om prestige en status te verwerven (Bol en Van Netburg 1997; Adang 1998: 44). Aandacht van de media vergroot de status van voetbalvandalen (Bol en Van Netburg 1997). Verder wordt gewelddadig gedrag vaak gestimuleerd door het gebruik van (hard)drugs, zoals XTC. Overmatig drankgebruik lijkt minder voor te komen (Bol en Van Netburg 1997), al wordt dit niet door alle onderzoeken bevestigd (vgl. Van Gageldonk 1999 en Spaaij en Van der Torre 2003).

Concluderend lijkt supportersgeweld vooral een uitlaatklep te zijn voor jonge mannen die in het dagelijkse leven niet in staat zijn een gerespecteerde maatschappelijke positie en de bijbehorende status te verwerven en daarom langs andere wegen proberen een zeker prestige op te bouwen. Behalve bij voetbalwedstrijden vertonen zij vaak ook in andere omstandigheden delinquent of deviant gedrag. Het schaarse beschikbare onderzoek duidt er niet op dat hooligans geheel andere waarden aanhangen dan de doorsnee burger. Er zijn bijvoorbeeld geen aanwijzingen dat zij racistische of extreem-rechtse opvattingen huldigen. In het voetbalstadion en bij andere confrontaties met 'vijandige' supporters hanteren zij echter geheel andere normen dan in het normale maatschappelijke verkeer. Het grotendeels afwezig zijn van informele controlemechanismen in en rond het voetbalstadion lijkt een belangrijke factor om het ontstaan en escaleren van geweld te verklaren. Daarom is een zeer intensieve en alerte formele controle door de politie vereist om het gebrek aan informele controle en het effect van de geïnternaliseerde 'supportersnormen' te compenseren. Maar ook het stimuleren van semi-informele controle door supporters zelf (bijvoorbeeld in de vorm van stewards) in te schakelen bij het toezicht in het stadion zou een matigend effect op het supportersgeweld kunnen hebben.

\subsection{WANGEDRAG IN HET OPENBAAR VERVOER}

De populariteit van het openbaar vervoer - bus, tram, trein, metro - blijft ver achter bij die van de auto: op een schaal van 1 (zeer negatief) tot 7 (zeer positief) krijgt het openbaar vervoer gemiddeld een 3,1 en de auto een 5,5 (SCP 2003: bijlage 8.1). Dit verschil valt onder meer te verklaren uit de voordelen die de auto biedt ten aanzien van directe beschikbaarheid, vrije keuze van bestemming, een 
(meestal) hogere snelheid en meer comfort en privacy. Maar wellicht heeft het er ook mee te maken dat sommigen het openbaar vervoer als onveilig ervaren.

Terwijl automobilisten afgeschermd zijn van hun medeweggebruikers, die doorgaans op gepaste afstand blijven (zie echter ook de volgende paragraaf), worden de reizigers in het openbaar vervoer (letterlijk) lijfelijk geconfronteerd met hun medereizigers. Om te voorkomen dat deze confrontatie op conflicten en botsingen uitloopt, wordt van de reizigers een grote mate van discipline en zelfbeheersing gevraagd. Als een relatief klein deel van de reizigers zich niet aan de geschreven en ongeschreven gedragsregels in het openbaar vervoer houdt, kan dit het reisgenot van de grote meerderheid aanzienlijk schaden. Bovendien kan het normoverschrijdende gedrag van de een voor de ander aanleiding zijn om zich ook niet meer aan de regels te houden. Als anderen niet wachten met instappen tot alle passagiers zijn uitgestapt, waarom zou je je daar zelf dan wel aan houden, met het risico dat je geen zitplaats kunt bemachtigen? Zo zou zich een negatieve spiraalbeweging in werking kunnen zetten, die ertoe leidt dat steeds minder mensen zich nog aan de regels houden en steeds meer mensen het openbaar vervoer mijden.

Uit periodiek onderzoek van het bureau ES\&E blijkt dat sinds 1993 het percentage van het rijdend personeel (bestuurders en controleurs) in tram, bus en metro dat zegt het afgelopen jaar slachtoffer te zijn geweest van een 'incident', tussen 50 en 75 schommelt, maar geen eenduidige trend vertoont (tabel 4.5). Bij incidenten gaat het om treiteren, lastigvallen, diefstal, bedreiging en mishandeling. Met de laatste drie soorten strafbare incidenten wordt jaarlijks 37 tot 54 procent geconfronteerd. Treinpersoneel (met name conducteurs) is het vaakst slachtoffer, buspersoneel het minst vaak. Niettemin voelt nog altijd bijna de helft van het personeel in het openbaar vervoer (exclusief treinpersoneel) zich veilig of zeer veilig en niet meer dan 12 procent voelt zich onveilig (Jansen et al. 2002).

Tabel 4.5 Slachtofferschap personeel openbaar vervoer, 1993-2002 (in procenten)

\begin{tabular}{|l|r|r|r|r|r|r|c|} 
& 1993 & 1994 & 1995 & 1996 & $\mathbf{1 9 9 7}$ & $\mathbf{2 0 0 0}$ & $\mathbf{2 0 0 2}$ \\
Totaal incidenten & 75 & 68 & 65 & 69 & 50 & 64 & 61 \\
Strafbare incidenten & 51 & 48 & 47 & 54 & 37 & 42 & 44 \\
w.v. mishandeling: & & & & & & & \\
$\quad$ Trein & 13 & 22 & 25 & 26 & 25 & 29 &. \\
Metro & 26 & 7 & 12 & 12 & 9 & 8 & 13 \\
Tram & 15 & 11 & 9 & 16 & 14 & 11 & 14 \\
$\quad$ Bus & 6 & 7 & 5 & 6 & 6 & 5 & 9 \\
\hline
\end{tabular}

Bron: Jansen et al. (2002)

Van de reizigers in bus, tram en metro is ongeveer een kwart in het voorgaande jaar slachtoffer of getuige geweest van een of meer incidenten: een op de vijf busreizigers en een op de drie tram- en metroreizigers. 3 Procent van de busreizi- 
gers en 6 procent van de tram- en metroreizigers is zelf lastiggevallen. Van de treinreizigers is in het voorgaande jaar 15 procent slachtoffer geweest en nog eens 15 procent ooggetuige van een incident. 0,5 Procent is mishandeld, 3 procent is bestolen, 4 procent is bedreigd en 16 procent is lastiggevallen. ${ }^{1}$ Toch waarderen meer dan negen op de tien bus-, tram-, metro- en treinreizigers de sociale veiligheid in het voertuig als voldoende of goed. Doordat de onderzoeksmethode in het jaar 2002 verschilde van die in eerdere jaren (1993-1997), is het niet mogelijk om vast te stellen of de onveiligheid voor reizigers in het openbaar vervoer toeof afneemt (De Bie en Korpel 2002).

Agressie kan worden onderscheiden in instrumentele agressie en affectieve agressie. Instrumentele agressie - ook wel intentionele of proactieve agressie genoemd - is een middel om een bepaald doel te bereiken, affectieve agressie - ook wel reactieve, situationele, emotionele, boze of vijandige agressie genoemd - is een emotionele reactie op een frustratie. De ene vorm van agressie sluit de andere overigens niet uit. Bij instrumentele agressie creëert men vaak doelbewust een aanleiding om geweld te kunnen gebruiken. Het motief voor agressie in het openbaar vervoer is vaak een combinatie van verveling en behoefte aan spanning. Het kan echter ook gaan om al dan niet georganiseerde criminaliteit die is gericht op persoonlijk gewin (zakkenrollerij, beroving). Meestal wordt deze agressie gepleegd door jonge mannen die vaak in groepsverband opereren en alcohol of drugs hebben gebruikt en ook elders (uitgaansleven, voetbal) geweld plegen (Bunkers 1995). Het kan echter ook gaan om verslaafden en zwervers die op stations rondhangen en reizigers lastigvallen.

Affectieve agressie in het openbaar vervoer krijgt doorgaans minder aandacht, maar is waarschijnlijk niet minder belangrijk. Het gaat hierbij over het algemeen om 'gewone' reizigers die agressief reageren op een vervelende gebeurtenis. Waar instrumentele agressie meestal op medereizigers is gericht, keert affectieve agressie zich vaker tegen het personeel van het openbaar vervoer. Een veelvoorkomende aanleiding is controle van een reiziger zonder geldig plaatsbewijs. Of een reiziger hierop agressief reageert, hangt niet alleen af van zijn persoonlijkheid (sommige 'hoog-agressieve' mensen reageren sneller agressief dan anderen), maar ook van de houding en het gedrag van de controleur. Zo roept een controleur eerder agressie op naarmate hij of zij de reiziger onbeleefder en agressiever aanspreekt en minder (fysieke) afstand bewaart (Winkel 1995). Ook onduidelijkheid en willekeur in het optreden van het personeel kan mede debet zijn aan agressief gedrag van reizigers. Als iets de ene keer wel en de andere keer niet wordt geaccepteerd, is de kans op een agressieve reactie in het laatste geval groter (Hauber 1995). Ook de situatie kan agressief gedrag bevorderen. Als reizigers te maken hebben met vertragingen en slechte informatie en dan ook nog eens worden geconfronteerd met het weinig voorkomende gedrag van een conducteur, kan gemakkelijk een agressieve reactie worden opgeroepen. 


\subsection{WANGEDRAG IN HET VERKEER}

In het verkeer ontmoeten dagelijks honderdduizenden 'anonieme' mensen elkaar, de meeste met het doel zo snel mogelijk de eigen bestemming te bereiken. Om dit proces soepel en zonder botsingen (zowel letterlijk als figuurlijk) te laten verlopen is een nauwgezette en intensieve coördinatie nodig. Het wegenverkeersreglement is daar een van de middelen voor. Omdat iedere weggebruiker er belang bij heeft dat het verkeer soepel verloopt, is het voor veel regels niet of nauwelijks nodig om normconform gedrag af te dwingen. Zo houdt vrijwel iedereen zich aan de regel dat men op de openbare weg rechts rijdt, aangezien ieder die niet levensmoe is, er geen enkel belang bij heeft deze regel te overtreden.

Er zijn in het verkeer echter ook tal van formele en informele regels die niet direct in het belang zijn van de individuele weggebruiker, maar hooguit indirect. Vaak doen zich prisoner's dilemma's voor, waarbij navolging van een regel bijdraagt aan het realiseren van het maatschappelijke optimum, maar ieder individu afzonderlijk niettemin voordeel kan behalen door de regel te overtreden. Dit geldt bijvoorbeeld voor voorrangsregels en voor het zogenaamde ritsen op de snelweg. Zolang ieder zich aan deze regels houdt, is de verleiding om deze te overtreden doorgaans gering. Maar naarmate het vaker voorkomt dat iemand de regel overtreedt, wordt het ook voor anderen verleidelijker om zich niet meer conform de regel te gedragen. Dit kan leiden tot een toename van onbeschoft of 'hufterig' gedrag in het verkeer.

Veel mensen lijken van mening dat het inderdaad bergafwaarts gaat met de waarden en normen in het verkeer en vervoer. Het is echter niet zo eenvoudig om vast te stellen of dit ook werkelijk het geval is, doordat veel normovertredingen (vooral als het om informele normen gaat) niet worden geregistreerd. Weliswaar is het aantal bekeuringen wegens verkeersovertredingen sinds het midden van de jaren negentig verdrievoudigd, vooral ten gevolge van de explosieve groei van het aantal boetes voor het overtreden van de maximumsnelheid. Deze toename vormt echter minder een indicatie dat automobilisten steeds vaker te hard rijden dan van een intensivering van de controle door de politie (SwOV 2003).

Richt men de aandacht op de zwaarste vormen van normoverschrijdend gedrag in het verkeer, namelijk de misdrijven op grond van de Wegenverkeerswet, dan tekent zich ook een sterke toename af (figuur 4.4). Tussen 1990 en 2001 is het aantal geregistreerde verkeersmisdrijven met de helft toegenomen, van 82.0oo naar 120.00o. Het gaat hierbij voornamelijk om doorrijden na een ongeval en rijden onder invloed. De stijging in de jaren negentig wordt volledig verklaard door de toename van het doorrijden na een ongeval. Het aantal processenverbaal wegens rijden onder invloed is in de jaren negentig per saldo zelfs iets teruggelopen. Opmerkelijk is dat het aantal verkeersmisdrijven in de jaren tachtig betrekkelijk stabiel was, na in de jaren zeventig sterk te zijn gegroeid. Hierbij dient men wel te bedenken dat ook deze cijfers worden beïnvloed door de opsporingsintensiteit van de politie. Het is dus niet zeker dat het werkelijke 
aantal verkeersmisdrijven dezelfde ontwikkeling vertoont. Zo komt uit zogenaamde slachtofferenquêtes (CBS, POLS) geen duidelijke stijging van het doorrijden na een ongeval in de periode 1992-2002 naar voren. Deze cijfers hebben, vanwege de betrekkelijk kleine steekproef, bovendien een grote onzekerheidsmarge.

Bij de beoordeling van het aantal verkeersmisdrijven dient men ook rekening te houden met de verkeersintensiteit: als het verkeer toeneemt, duidt een stijging van het aantal verkeersmisdrijven niet per se op een verslechtering van het verkeersgedrag. Daarom is in figuur 6.1 het aantal verkeersmisdrijven ook gerelateerd aan het aantal door automobilisten afgelegde kilometers (de bovenste stippellijn). Het relatieve aantal geregistreerde verkeersmisdrijven blijkt dan tussen 1985 en 1992 met 17 procent te zijn gedaald, om daarna weer met 25 procent toe te nemen, maar het niveau was in 2001 niet veel hoger dan halverwege de jaren tachtig.

\section{Figuur 4.4 Misdrijven op grond van de Wegenverkeerswet, 1957-2001}

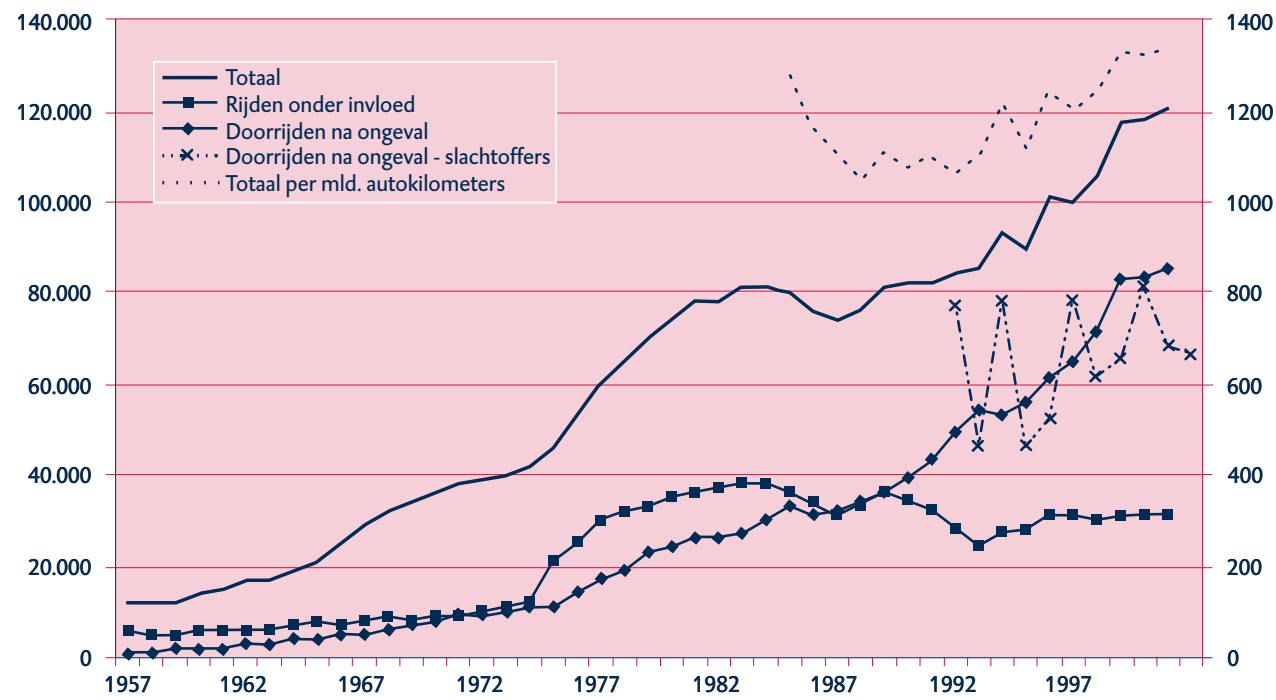

Bron: CBS (Statline)

Al met al duiden de meeste 'objectieve' indicatoren op een forse toename van verkeersovertredingen en verkeersmisdrijven in de jaren negentig, maar is niettemin onzeker of deze cijfers ook de werkelijke ontwikkeling van het normoverschrijdende gedrag in het verkeer weerspiegelen. Over lichtere vormen van normoverschrijdend of onfatsoenlijk gedrag in het verkeer zijn zo goed als geen gegevens beschikbaar.

Naar agressie in het verkeer - vooral agressie van automobilisten - is het nodige onderzoek gedaan (zie bijvoorbeeld Tasca 2000; Levelt 2001; Parker et al. 2002). Bij agressief rijgedrag gaat het bijvoorbeeld om 'plakken', 'snijden', veel te hard rijden, onnodig toeteren, obscene gebaren maken en schelden. In extreme geval- 
len (aangeduid als road rage) kan er ook sprake zijn van fysiek geweld, waarbij men de auto als wapen gebruikt (een andere weggebruiker opzettelijk aanrijden) of de auto verlaat om een andere weggebruiker te lijf te gaan. Levelt (2001) schat op grond van berichten in de pers dat er in Nederland in een periode van 2,5 jaar (halverwege de jaren negentig) 29 van dergelijke excessieve voorvallen zijn geweest. Iets minder dan één op de duizend verkeersdoden zou hieraan zijn toe te schrijven (dat wil zeggen ongeveer één verkeersdode per jaar). ${ }^{2}$ In een enquête onder Nederlandse automobilisten zei 83 procent het afgelopen jaar last te hebben gehad van agressiviteit in het verkeer (Levelt 2001).

Agressie in het verkeer kan, net als agressie in het openbaar vervoer, worden onderscheiden in instrumentele en affectieve agressie. Bij instrumentele agressie gaat het bijvoorbeeld om toeteren in de hoop dat een andere automobilist uit de weg gaat. Affectieve agressie is bijvoorbeeld een boze reactie op een verkeersovertreding of onbeschoft gedrag van een medeweggebruiker. Hoewel agressie meestal door een concrete ergernis wordt opgeroepen - bijvoorbeeld oponthoud door andere weggebruikers - liggen er vaak ook eerdere gebeurtenissen aan ten grondslag. De stemming waarin men verkeert als men de weg op gaat, heeft een grote invloed op het ontstaan van agressie als men onderweg met een hinderlijke situatie wordt geconfronteerd. Zowel persoonlijkheidskenmerken als omgevingsfactoren zijn verder van invloed op het ontstaan van agressie. Agressief rijgedrag komt het meest voor onder jonge, laagopgeleide mannen, die zich vaak ook buiten het verkeer onderscheiden door geweld, crimineel gedrag en drugsof alcoholproblemen (zoals voetbalhooligans; zie Spaaij en Van der Torre 2003: 18). Toch blijken ook eerzame burgers zich soms aan zeer agressief verkeersgedrag te buiten te gaan.

Omstandigheden die agressiviteit in het verkeer bevorderen zijn de onverwachtheid van de gebeurtenis (een onverwachte file roept meer agressie op dan een aangekondigde file), de anonimiteit van de verkeersdeelnemers (als men de bestuurder van een andere auto kan zien, reageert men minder agressief), de mogelijkheid om snel weg te komen, een hoge temperatuur (airconditioning kan de kans op agressiviteit verminderen) en lawaai (Mizell 1997; Connell en Joint 1997; Tasca 2000; Levelt 2001).

\subsection{WANGEDRAG OP HET WERK}

Hoewel de doorsneeburger slechts een klein deel van zijn of haar leven op het werk doorbrengt (De Beer 2001), zien de meesten hun werk als een belangrijk onderdeel van hun leven. Werk structureert de tijd, brengt sociale contacten met zich mee, levert maatschappelijke waardering en zelfrespect op en biedt mogelijkheden tot persoonlijke ontplooiing (vgl. WRR 1990). Zaken als waardering, zelfrespect en ontplooiing vereisen echter wel een veilige en respectvolle omgeving en daar lijkt het ook op de werkvloer nogal eens aan te schorten. Steeds vaker zijn geluiden te horen over werknemers die het slachtoffer zijn van wangedrag van klanten of van hun collega's. Hoe wijdverbreid is dit verschijnsel? 
Volgens het evaluatierapport over de Arbowet (Soethout en Sloep 200o: II) heeft 40 procent van de werknemers ervaring met agressie op het werk, 14 procent is weleens slachtoffer geweest van seksuele intimidatie en 23 procent van de werknemers is weleens gepest. In iets meer dan de helft van de gevallen van agressie en seksuele intimidatie was de dader een collega (inclusief leidinggevenden); pesterijen komen zelfs voor 64 procent voor rekening van collega's. Uit het meer recente TNO Arbeidssituatie Survey (TNO Arbeid 2003) blijkt dat in 200213 procent van de Nederlandse werkenden werd geïntimideerd door chefs en collega's. Er zijn aanwijzingen dat de gevolgen voor het welzijn en de gezondheid van het slachtoffer ernstiger zijn wanneer de dader een collega dan wanneer deze een klant is. Niettemin baart ook de bejegening van werknemers door klanten en bezoekers (waaronder patiënten en leerlingen) soms zorgen. Het TNO-onderzoek wijst uit dat 7 procent van de Nederlandse werkenden slachtoffer is geworden van fysiek geweld door klanten en 3-7 procent van seksuele intimidatie, terwijl in totaal 22 procent werd geconfronteerd met intimidatie door klanten.

Vooral de beroepsgroepen die veel met klanten en bezoekers te maken hebben worden geconfronteerd met wangedrag: agressie en geweld komen bovengemiddeld vaak voor in de gezondheidszorg, de maatschappelijke dienstverlening en het vervoer. Pesten gebeurt vooral binnen de handel, horeca, overheid en overige dienstverlening. Seksuele intimidatie komt het meest voor in de zorgsector en de horeca (Soethout en Sloep 2000; TNO Arbeid 2003).Van den Brink (2001) ondervroeg professionals uit verschillende maatschappelijke domeinen naar het door henzelf ervaren wangedrag dat in de uitoefening van hun beroep tegen hen was gericht. Een derde van de ondervraagden voelde zich meermalen bedreigd en was daadwerkelijk slachtoffer geweest. Driekwart had in de diensttijd agressief gedrag waargenomen. De hoogste bedreigingsscores werden gevonden bij professionals in de jeugdzorg, in het club- en buurthuiswerk, de politie, gevolgd door het voortgezet onderwijs en het basisonderwijs. De laagste scores werden gevonden bij het hoger onderwijs (Van den Brink 2001: 423-429). Of dergelijke vormen van wangedrag op de werkvloer in frequentie toenemen is onduidelijk; verschillende indicatoren geven tegenstrijdige ontwikkelingen aan (Soethout en Sloep 2000: 7).

In een onderzoeksrapport voor het ministerie van Binnenlandse Zaken hebben Middelhoven en Driessen (2001) een poging gedaan de daders van agressie tegen werknemers te beschrijven. Het blijken meestal 'gewone mensen' te zijn, vooral mannen, van uiteenlopende leeftijden, van 24 jaar tot 40 jaar. Gewone ANWBleden blijken hun agressie bij teleurstellende situaties niet te kunnen beheersen (zie par. 4.10). Hetzelfde geldt voor gewone treinreizigers of cliënten van de Gemeentelijke Sociale Dienst. De gevolgen voor de organisaties zijn echter aanzienlijk: bij het Gemeentelijk Vervoersbedrijf in Amsterdam (GVB) kreeg een kwart van de 4.800 medewerkers te maken met lichamelijke agressie in de uitvoering van hun functie. Mede hierdoor zit tien procent van het personeel ziek thuis (HP/De Tijd 2003). Deze schaarse empirische onderzoekingen duiden erop dat traditionele, relatief geweldsvrije beroepssferen in toenemende mate te 
maken hebben gekregen met ruwere omgangsvormen. Er is een sfeer aan het ontstaan van intimidatie en agressie om bepaalde doeleinden te bereiken in de sociale interacties. Dit doet zich zowel voor tussen burgers onderling als tussen burgers in hun rol als klant en in hun rol als dienstverlener.

Bij het wangedrag van collega's onderling lijkt de relatie tussen formele en informele controle op het werk van belang. In de praktijk worden pesterijen en seksuele intimidatie door leidinggevenden vaak gebagatelliseerd of ontkend. Dit versterkt een sfeer waarin dergelijk wangedrag wordt getolereerd. Vooral een sterk hiërarchische of 'macho'-sfeer op het werk blijkt aanleiding te geven tot seksuele intimidatie, discriminatie en pesterijen (De Vries et al. 2002: 81). Formeel beleid om wangedrag te voorkomen is van belang, maar is pas effectief wanneer de norm van gelijkwaardigheid en wederzijds respect voldoende is geïnternaliseerd en ook tot uitdrukking komt in informele controlemechanismen. Zo constateren Soethout en Sloep (2000: VI): "Groepsprocessen kunnen algemene waarden als respect, tolerantie en fatsoen naar de achtergrond drukken ten gunste van groepsnormen." Dit wordt nog versterkt door het tekortschieten van de formele controle: "Het merendeel van de slachtoffers meldt zijn ervaringen aan een persoon of instantie die actie kan ondernemen na een dergelijke melding. Desondanks verandert er vaak niets op het werk of voor het slachtoffer persoonlijk" (Soethout en Sloep 20oo: II). Het falen van de formele controle verzwakt op zijn beurt de informele en interne controle; wanneer de bevoegde personen niets doen met meldingen van wangedrag, bevestigen ze daarmee impliciet dat de meldingen niet serieus genomen hoeven te worden. Volgens De Vries et al. (2002: 83) is beleid tegen wangedrag effectiever wanneer zowel strategieën van boven uit als van onder uit de organisatie gehanteerd worden. Dit kan worden vertaald in een wederzijdse ondersteuning van formele en informele controle. Ook het aanleren en onderhouden van de vaardigheid om met conflicten om te gaan kan helpen om wangedrag tegen te gaan.

\subsection{FRAUDE}

De meest zichtbare en tastbare vormen van normoverschrijdend gedrag, zoals verloedering van de openbare ruimte, bedreiging en geweld op straat en in het openbaar vervoer, alsmede inbraak en diefstal roepen doorgaans de meeste zorg en ergernis op. Sommige vormen van normoverschrijdend gedrag blijven echter grotendeels onzichtbaar en trekken minder de aandacht, doordat er geen directe slachtoffers zijn of doordat de slachtoffers niet merken dat zij benadeeld worden. Het gaat hierbij om verschillende vormen van 'witteboordencriminaliteit', zoals fraude en corruptie. Vaak is de overheid of een andere publieke instantie (bijvoorbeeld een uitkeringsorgaan) hiervan het slachtoffer, zodat de burger niet direct wordt geconfronteerd met de nadelige gevolgen. Opmerkelijk is dat deze vorm van wetsovertreding in het huidige waarden- en normendebat weinig aandacht krijgt. Alleen recente affaires als de bouwfraude en andere ongeoorloofde praktijken in grote ondernemingen (bijvoorbeeld Ahold) en instellingen (bijvoorbeeld fraude in het $\mathrm{HBO}$ ) worden een enkele keer in verband gebracht met (ver- 
val van) waarden en normen, maar deze vormen van normoverschrijding staan geenszins centraal in het huidige debat. Toch kunnen zich ook op dit gebied zorgwekkende ontwikkelingen voordoen. Als zaken als misbruik van sociale voorzieningen en belastingontduiking ongestraft blijven of zelfs oogluikend worden toegestaan, kan hiervan een eroderend effect uitgaan op het normbesef en het gedrag van de 'gemiddelde' burger. Zoals in paragraaf 4.3 is geschetst zou hierdoor op den duur een negatieve spiraal van afnemend normbesef en toenemende normoverschrijding in beweging kunnen worden gezet. Deze paragraaf geeft enkele gegevens over de (geregistreerde) omvang van fraude en andere vormen van witteboordencriminaliteit. Vervolgens wordt iets dieper ingegaan op een specifieke vorm, te weten uitkeringsfraude. De reden hiervoor is niet dat deze vorm ernstiger of wijder verbreid zou zijn dan andere vormen, maar dat hiernaar relatief veel onderzoek is gedaan, zodat over de motieven van de daders iets meer te zeggen valt dan bij andere vormen van fraude.

Voor alle vormen van fraude geldt dat de werkelijke omvang ervan veel groter is dan het aantal geconstateerde en vervolgde fraudegevallen. De werkelijke omvang kan alleen met indirecte methoden worden geschat (voor een overzicht zie Lensvelt-Mulders et al. 1999), die elk hun beperkingen hebben. Schattingen van de omvang van het 'zwarte circuit' lopen hierdoor sterk uiteen, van één procent tot wel 30 procent van het bruto binnenlands product (vgl. De Beer 1994: 30, Heertje en Cohen 1980: 125 e.v.). Gezien de zeer grote onzekerheidsmarges waarmee dit onderzoek onvermijdelijk behept is, kan er ook geen zinnige uitspraak worden gedaan over de ontwikkeling in de tijd. Men dient er dan ook voor te waken om de toegenomen aandacht in de media voor zaken als witwaspraktijken, belastingvlucht, effectenhandel met voorkennis, tewerkstelling van illegalen en corruptie te interpreteren als een aanwijzing dat deze onoorbare praktijken in omvang toenemen. Het is even goed mogelijk dat er simpelweg meer zaken boven water komen, bijvoorbeeld doordat de opsporing is geïntensiveerd. Schommelingen in de publieke aandacht voor fraude en het zwarte circuit zeggen dan ook niets over de feitelijke ontwikkeling van de omvang ervan.

Ook in internationaal perspectief is het moeilijk iets te zeggen over de omvang van de zwarte economie in Nederland. Tabel 4.6 geeft een overzicht van schattingen voor de meeste OESO-landen ontleend aan twee verschillende bronnen. In beide overzichten neemt Nederland een middenpositie in. De grote verschillen tussen de schattingen onderstrepen echter nog eens de grote onzekerheidsmarges waarmee deze berekeningen omgeven zijn. Ook de relatieve positie van Nederland ten opzichte van de andere landen is allerminst een vaststaand feit.

Over een aantal specifieke vormen van fraude valt echter iets meer te zeggen. Figuur 4.5 geeft een beeld van de ontwikkeling van het aantal geregistreerde gevallen van verduistering en bedrog sinds 1950. Tot het midden van de jaren vijftig halveerde het aantal processen-verbaal wegens verduistering of bedrog (in verhouding tot de bevolkingsomvang) ruimschoots, maar vanaf het midden van de jaren tachtig neemt het aantal weer fors toe. Niettemin was het relatieve 
Tabel 4.6

Twee schattingen van de omvang van de zwarte economie (in procenten van het bruto binnenlands product)

\begin{tabular}{|l|c|c} 
& A & B \\
Australië & 8,4 & 13,0 \\
België & 10,9 & 20,8 \\
Canada & 10,7 & 13,5 \\
Denemarken & 10,1 & 15,0 \\
Duitsland & 8,7 & 12,5 \\
Frankrijk & 11,4 & 13,8 \\
Griekenland & 29,4 & $\cdot$ \\
Groot-Brittannië & 6,8 & 11,2 \\
lerland & 3,9 & 14,2 \\
Italië & 17,4 & 24,0 \\
Nederland & 9,6 & 12,7 \\
Nieuw-Zeeland & $\cdot$ & 9,0 \\
Noorwegen & 5,5 & 16,7 \\
Oostenrijk & 4,2 & 6,1 \\
Portugal & 15,6 & $\cdot$ \\
Spanje & 11,1 & 17,3 \\
Verenigde Staten & 11,3 & 8,2 \\
Zweden & 10,1 & 17,0 \\
Zwitserland & $\cdot$ & 6,9 \\
\hline
\end{tabular}

Bron: Williams en Windebank (1998: 100) (A); Schneider en Enste (2000: 11) (B)

aantal geconstateerde verduisteringen in 1999 nog altijd beduidend lager dan in 1950. Het relatieve aantal gevallen van bedrog steeg in de jaren negentig echter zo snel dat het inmiddels ruim boven het niveau van 1950 ligt.

Het aantal processen-verbaal dat jaarlijks wordt opgemaakt wegens belastingfraude schommelt sinds 1983 tussen de 300 en 6oo, zonder een duidelijke trend te laten zien. Wel is het totale bedrag dat hiermee is gemoeid, sterk gegroeid, van 64 miljoen euro in 1983 tot 258 miljoen in 1999, al wordt dit ten dele verklaard door de economische groei in deze periode (WODC 2001: bijlage 4; Belastingdienst 2002). Het geringe aantal geconstateerde gevallen van belastingfraude in verhouding tot het enorme aantal belastingaangiften dat jaarlijks wordt gedaan, doet vermoeden dat het hier slechts om het topje van de ijsberg gaat. Er zijn echter nauwelijks mogelijkheden om de werkelijke omvang met enige betrouwbaarheid te schatten.

Er is weinig reden om aan te nemen dat fraude aan de 'onderkant' van de samenleving vaker voorkomt dan aan de 'bovenkant'. Integendeel, een onderzoek van het NIPO levert aanwijzingen op dat een bevolkingscategorie die als 'carrièremakers' wordt aangeduid en voornamelijk bestaat uit hoogopgeleide werkende 
Figuur 4.5 Processen-verbaal wegens verduistering en bedrog (per 100.000 inwoners), 1950-1999

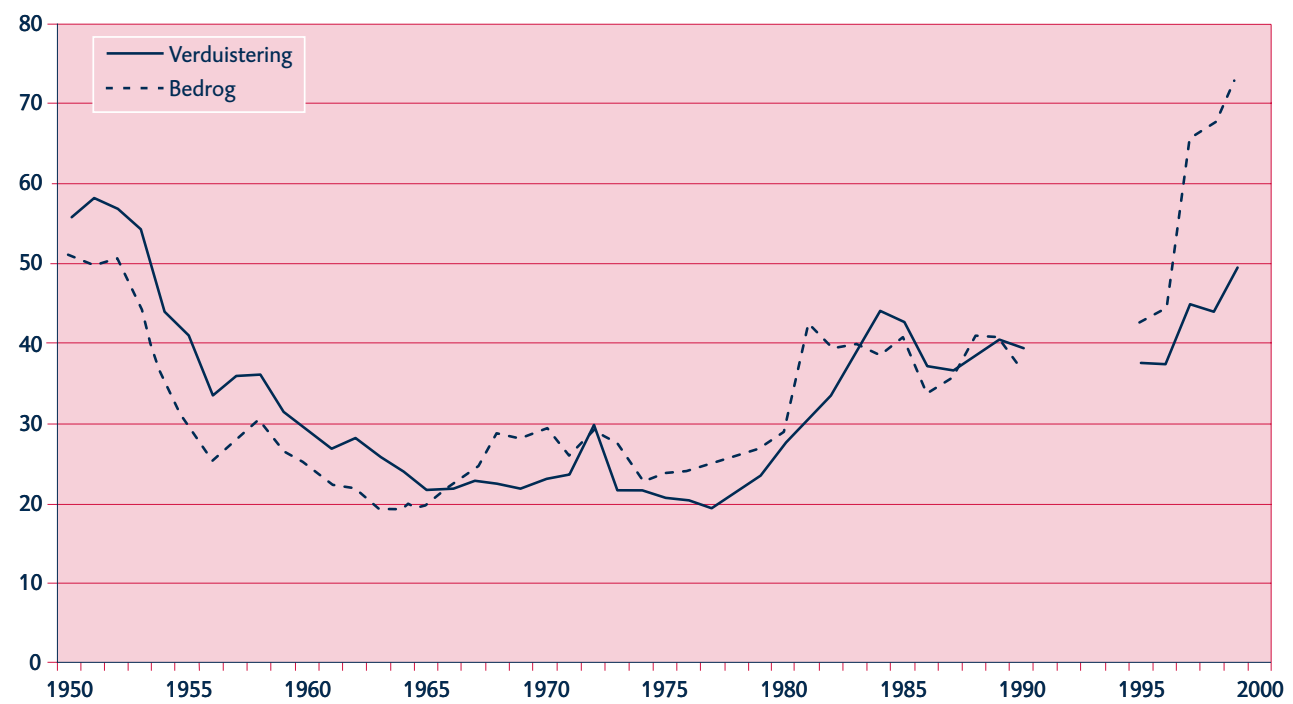

Bron: CBS (Statline); wRR-bewerking

mannen met een hoog inkomen, het meest geneigd is om de wet te overtreden en antisociaal gedrag te vertonen (Hessing-Couvret en Reuling 2002: hoofdstuk 5). Hoewel de aard van de wetsovertreding hierbij niet nader is gespecificeerd, is het aannemelijk dat (belasting)fraude hier zeker toe behoort. Ook in het onderzoekje naar fraude dat Interview-NSS (2003) in opdracht van de WRR heeft verricht (zie par. 3.5), geven de hogere inkomensgroepen vaker toe dat zij de belasting zouden ontduiken dan de lagere inkomensgroepen.

Toch worden in de praktijk veel meer gevallen van socialezekerheidsfraude geconstateerd dan van belastingfraude. Tabel 4.7 laat zien dat het per jaar om zeker 50.000 gevallen gaat (de cijfers met betrekking tot de bijstand betreffen een periode van een halfjaar). Jaarlijks wordt bij circa een op de 50 ontvangers van een uitkering krachtens een werknemersverzekering (AAW/WAO, WW, ZW, TW, WAZ en Wajong) fraude geconstateerd, bij circa een op de tien bijstandontvangers en bij niet meer dan een op de 10.000 ontvangers van een volksverzekering (vooral AOw en kinderbijslag). Dat deze cijfers vele malen hoger zijn dan bij belastingfraude (behalve bij de volksverzekeringen) kan onder meer te maken hebben met verschillen in prioriteitsstelling en in de moeilijkheid van opsporing. Een belangrijk verschil is bijvoorbeeld dat ontvangers van een sociale uitkering moeten aantonen dat zij recht hebben op een uitkering, terwijl bij belastingbetalers de bewijslast veeleer bij de Belastingdienst rust.

Een andere methode om inzicht te krijgen in uitkeringsfraude is de uitkeringsgerechtigden er zelf naar te vragen. Uiteraard kan men bij de betrouwbaarheid hiervan vraagtekens zetten, aangezien het de vraag is of veel uitkeringsgerechtigden 


\begin{tabular}{|c|c|c|c|}
\hline & $\begin{array}{l}\text { Werknemers- } \\
\text { verzekeringen }^{a}\end{array}$ & $\begin{array}{c}\text { Volks- } \\
\text { verzekeringen }^{\text {b }}\end{array}$ & Bijstand $^{c}$ \\
\hline geconstateerde fraudegevallen & 26734 & 390 & 17610 \\
\hline w.v. witte fraude ${ }^{d}$ & 13162 & . & . \\
\hline zwarte fraude ${ }^{d}$ & 806 & . & $\cdot$ \\
\hline $\begin{array}{l}\text { fraudegevallen in \% van } \\
\text { het aantal uitkeringen }\end{array}$ & 2,0 & 0,01 & 5,2 \\
\hline $\begin{array}{l}\text { gemiddelde fraudebedrag } \\
\text { (euro) }\end{array}$ & 710 & . & 2565 \\
\hline
\end{tabular}

a WW, AAW/WAO, ZW, TW, WAZ en WAjong; de cijfers betreffen het jaar 2000.

b AOW, ANW, AKW, PGB en enkele kleinere regelingen; de cijfers betreffen het jaar 2001.

C Eerste helft van 2002.

d Bij witte fraude gaat het om het verzwijgen van administratief traceerbare inkomsten, bij zwarte fraude om administratief niet traceerbare inkomsten.

Bron: Lisv (2001), SVB (2002), CBS (a)

- zelfs als hun de garantie wordt geboden van volstrekte anonimiteit - bereid zijn hierover juiste informatie te verschaffen. De schattingen van het aandeel uitkeringsgerechtigden dat informele of zwarte neveninkomsten heeft, lopen dan ook sterk uiteen. Van Eck en Kazemier (1989) vonden dat 11 procent van de uitkeringsgerechtigden zwarte bijverdiensten had, tegenover 9 procent van de werkenden. Koopmans (1989) schatte daarentegen dat iets meer dan de helft (52\%) van de werkloze uitkeringsgerechtigden zwartwerkte, tegenover 13 procent van de arbeidsongeschikten en 37 procent van de werkenden. Recenter vonden Engbersen en Staring (2002) dat ongeveer een kwart van de langdurig uitkeringsgerechtigden informele arbeid verricht en nog eens een kwart deze in het verleden had verricht. Bij drie op de vijf personen ging het daarbij overigens om een relatief klein bedrag aan bijverdiensten van minder dan 100 euro per maand.

Op zichzelf zou het niet verwonderlijk zijn als uitkeringsgerechtigden vaker fraude plegen dan werkenden. Uitkeringsgerechtigden dienen doorgaans aan veel meer regels te voldoen dan werkenden, bijvoorbeeld ten aanzien van het zoeken van werk, het deelnemen aan scholing, het hebben van neveninkomsten, de samenlevingsvorm en het inkomen van de eventuele partner. ${ }^{3}$ Daar komt nog bij dat zwartwerken uitkeringsgerechtigden in beginsel een groter financieel voordeel oplevert dan personen die geen uitkering ontvangen. Zij sparen hiermee niet alleen belastingen en premies uit, maar voorkomen tevens dat hun neveninkomsten worden gekort op hun uitkering. Op grond hiervan valt te 
verwachten dat uitkeringsgerechtigden relatief vaak zwartwerken. Het feit dat het percentage uitkeringsgerechtigden dat zelf toegeeft zwart te werken (of te hebben gewerkt) vele malen groter is dan het percentage geconstateerde fraudegevallen, duidt erop dat de pakkans voor uitkeringsgerechtigden met zwartwerk klein is, waarschijnlijk minder dan 10 procent. Dit suggereert dat het niet in de eerste plaats een rationele afweging van de kosten en baten is die het merendeel van de uitkeringsgerechtigden ervan weerhoudt zwart bij te verdienen.

Onderzoek onder uitkeringsgerechtigden heeft meermalen uitgewezen dat 1o à 20 procent van de uitkeringsgerechtigden de officiële regels met betrekking tot hun uitkering systematisch negeert (zie bijvoorbeeld Kroft et al. 1989; Engbersen 1990; Hoff en Jehoel-Gijsbers 1998). Deze 'alternatieven', 'calculerenden' of 'autonomen', zoals zij in verschillende onderzoeken worden genoemd, hechten weinig waarde aan betaald werk, solliciteren niet (meer) en richten zich op andere activiteiten, hetzij onbetaald (zoals vrijwilligerswerk), hetzij zwart. Hun uitkering zien zij veelal als een soort basisinkomen. Deze groep heeft afstand genomen van het maatschappelijke doel van regulier betaald werk en bedient zich bovendien van ongeoorloofde middelen. Over het algemeen achten zij de kans op formele sancties klein, terwijl zij vaak in een milieu verkeren waarin mensen er niet op worden aangekeken als ze geen betaald werk hebben. Overigens bevinden zich ook onder de overige uitkeringsgerechtigden wel groepen die het niet zo nauw nemen met de regels, maar bij hen komt dit niet doordat zij zich van regulier betaald werk hebben afgekeerd (Kroft et al. 1989 duiden hen aan als 'ondernemenden').

\subsection{CONCLUSIES}

De verschillende vormen van normoverschrijdend gedrag die in de voorgaande paragrafen zijn besproken laten zien dat er een gecompliceerde en allerminst eenduidige relatie bestaat tussen internalisering van normen, formele en informele instituties en normoverschrijdend gedrag. Het is op grond van dit beperkte aantal voorbeelden niet mogelijk algemene conclusies te trekken over de relatie tussen normen en gedrag. Niettemin valt in deze voorbeelden een aantal zaken op die meer algemene geldigheid lijken te hebben.

Allereerst concentreert het problematische normoverschrijdende gedrag zich voor een belangrijk deel bij een relatief kleine groep mannelijke adolescenten en jongvolwassenen. Geweld en agressie op school, op straat, in het openbaar vervoer, in het verkeer en in en rond het voetbalstadion wordt voor een groot deel gepleegd door mannen tussen vijftien en dertig jaar. Bovendien zijn het voor een deel dezelfde personen die in verschillende situaties over de schreef gaan. Voor deze groep is normoverschrijdend gedrag een min of meer bewuste keuze op basis van een afweging van de baten (de 'kick', de status en het geldelijk gewin) en de kosten (de kans om gepakt en bestraft te worden). Vaak opereren zij in een groep waarin andere normen gelden dan de algemeen aanvaarde (bijvoorbeeld 
toepassing van geweld als middel om een doel te bereiken). Dit hoeft overigens niet te betekenen dat zij de in onze maatschappij gangbare (gedrags)normen in het geheel niet onderschrijven. Een deel van deze groep heeft bijvoorbeeld een betaalde baan en soms ook een gezin, hetgeen impliceert dat zij zich op andere momenten wel aan de gangbare normen (dienen te) houden. Het normoverschrijdende gedrag van deze groep lijkt eerder voort te komen uit hun onvermogen om in de 'gewone' maatschappij prestige te verwerven en een aantrekkelijke maatschappelijke positie te bereiken. De frustratie die voortkomt uit het feit dat zij niet op 'normale', geaccepteerde wijze maatschappelijk aanzien en materiële status kunnen verwerven, brengt hen ertoe gelegenheden te zoeken om op een andere, minder acceptabele wijze aan deze behoeften te voldoen. Deze gelegenheden - een voetbalstadion, het openbaar vervoer, de openbare weg - worden meestal gekenmerkt door een tekortschietende formele controle en een vrijwel geheel afwezige informele controle.

Overigens zou men kunnen stellen dat er in bijna alle tijden en culturen een groep adolescenten en jonge mannen is die mogelijkheden zoekt om hun behoefte aan agressie en geweld op enigerlei wijze te botvieren. Waar zij vroeger jaarmarkten, kermissen en protestdemonstraties aangrepen voor een stevige vechtpartij, zijn nu voetbalwedstrijden, houseparty's, het openbaar vervoer en - nog steeds - demonstraties geschikte gelegenheden. De (over)gevoeligheid van de samenleving voor dergelijke vormen van geweld lijkt echter toegenomen, waardoor zij steeds minder worden geaccepteerd als een weliswaar onprettig, maar niettemin 'normaal' maatschappelijk (bij)verschijnsel.

Zeker niet alle ongewenste, normoverschrijdende gedrag kan echter worden geweten aan een groep jonge mannen met onvoldoende maatschappelijke kansen. Frustraties over niet-gerealiseerde doeleinden en tekortschietende formele en informele controle kunnen ook 'eerzame' burgers verleiden normen - die zij op zichzelf wel onderschrijven - te overtreden. Het kan hierbij gaan om een spontane, emotionele reactie op een onaangename gebeurtenis, zoals de agressieve reactie van een automobilist op een medeweggebruiker die hem hindert of van een reiziger in het openbaar vervoer op een conducteur die hem onheus bejegent. Het kan echter ook gaan om meer berekenende vormen van normoverschrijdend gedrag, die men voor zichzelf rechtvaardigt met het argument dat men niet eerlijk wordt behandeld, zoals de uitkeringsgerechtigde die zwart bijverdient of de hardwerkende ondernemer die de belasting ontduikt. Of men rechtvaardigt het normoverschrijdende gedrag met het argument dat 'iedereen het doet', zoals een werkster of aannemer zwart betalen of een collega pesten.

Hoe dient men normoverschrijdend gedrag aan te pakken? Zowel de grote variatie in de aard als in de ernst van normoverschrijdend gedrag impliceert dat er niet één standaardreactie is die in alle gevallen gepast en effectief is. Zoals in hoofdstuk 2 een onderscheid is gemaakt tussen onprettig, onbehoorlijk, onduldbaar en onwettig gedrag, zo is er ook een gradatie aan gepaste reacties. In figuur 4.6 
geven de gearceerde vlakken gepaste reacties aan, terwijl de reacties in de witte vlakken in het algemeen niet passen bij het betreffende gedrag.

Figuur 4.6 Mogelijke reacties op normoverschrijdend gedrag

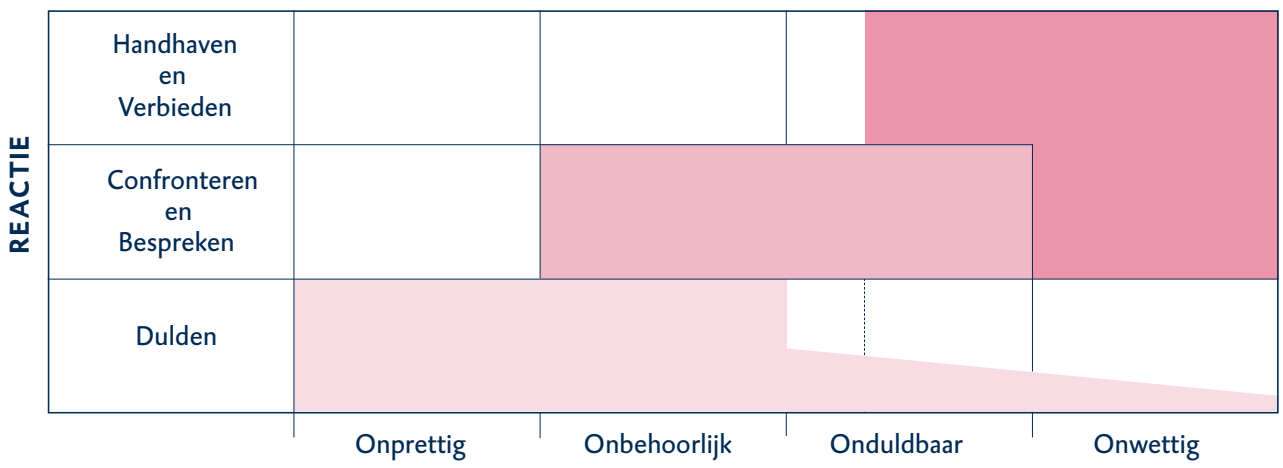

GEDRAG

Bij onprettig gedrag waarvan men geen schade ondervindt, dient men in het algemeen een zone van gelatenheid in acht te nemen. Wil men in onze pluriforme samenleving daadwerkelijk met elkaar blijven samenleven, dan zal men veelvuldig gedragingen van anderen die men als onprettig ervaart, moeten dulden. Dit neemt niet weg dat men soms degene die zich onprettig gedraagt, hierop kan aanspreken om diens gedrag bespreekbaar te maken en te trachten een voor beide partijen bevredigende uitkomst te bereiken.

Wie zich onbehoorlijk of onfatsoenlijk gedraagt, maar geen wettelijke regels overtreedt, dient hier in het algemeen op te worden aangesproken. Soms kan echter niet worden volstaan met het gedrag bespreekbaar te maken, maar dient men een directe confrontatie aan te gaan om degene die zich misdraagt duidelijk te maken dat diens gedrag niet acceptabel is. In het algemeen kan men bij onbehoorlijk gedrag echter geen sanctie opleggen, omdat geen formele normen worden overschreden. Men zal de ander moeten proberen te overtuigen van de onbetamelijkheid van zijn of haar gedrag. Wie de confrontatie met de normovertreder moet aangaan, kan van geval tot geval verschillen. In veel gevallen is dit de taak van de formele vertegenwoordigers van de institutie waar het normoverschrijdende gedrag plaatsvindt, zoals conducteurs, leerkrachten, stadionsuppoosten en leidinggevenden in bedrijven. Maar wanneer deze formele toezichthouders afwezig zijn, kan het ook wenselijk zijn dat burgers elkaar aanspreken: zo kunnen reizigers in het openbaar vervoer een medepassagier terechtwijzen die voordringt bij het instappen of kunnen voetgangers een fietser tot de orde roepen die over het trottoir fietst. Het dient echter te blijven bij aanspreken en verbaal confronteren: burgers kunnen nooit het recht in eigen hand nemen, zeker niet als het gaat om het overtreden van informele normen. 
Onduldbaar gedrag vereist doorgaans meer dan een terechtwijzing van de dader: de organisatie of instelling onder wier verantwoordelijkheid dit gedrag valt, zal het daadwerkelijk moeten verbieden en herhaling trachten te voorkomen. Het gaat hierbij immers vaak om een overtreding van de (huis)regels van de institutie. Bij het pesten van scholieren of collega's kan niet worden volstaan met een vermanend woord. Er moet daadwerkelijk actie worden ondernomen om te voorkomen dat het wangedrag wordt voortgezet. Hetzelfde geldt voor misdragingen in het openbaar vervoer, zoals roken waar dit verboden is of het bekladden of vernielen van het interieur.

Onwettig gedrag is per definitie verboden en dient in beginsel dan ook niet te worden getolereerd. De overheid en haar vertegenwoordigers, zoals politie en justitie, zijn de aangewezen instanties om onwettig gedrag tegen te gaan. Hierbij kunnen zij vaak echter niet zonder de medewerking van de instanties die het meest direct met het normoverschrijdende gedrag te maken hebben. Zo is winkeldiefstal niet alleen een zaak voor de politie, maar ook een belangrijke verantwoordelijkheid van het winkelbedrijf. Openbaarvervoerbedrijven zijn medeverantwoordelijk voor het bestrijden van vandalisme en agressie in treinen en bussen, scholen moeten bijdragen aan het tegengaan van spijbelen en criminaliteit op school en voetbalclubs hebben een verantwoordelijkheid ten aanzien van het wangedrag van hun supporters. Het daadwerkelijk aanpakken, berechten en bestraffen van de daders is echter een verantwoordelijkheid van politie en justitie. Eigenrichting is te allen tijde uit den boze. Er is overigens een niet onbelangrijk verschil tussen een formeel, wettelijk verbod op bepaalde gedragingen en het handhaven van dit verbod. Het is vrijwel nooit mogelijk om een verbod in alle gevallen te handhaven. Dit zou permanente controle en een zeer strikt optreden van de toezichthouders vergen. Als een verbod echter vrijwel straffeloos kan worden overtreden en slechts zelden wordt gehandhaafd, ondermijnt dit het vertrouwen in de betreffende norm. Er is dan een aanzienlijk risico dat de eerder geschetste negatieve spiraal in werking wordt gesteld. Het gaat er dus om een subtiel evenwicht te vinden tussen (te) strenge en (te) soepele handhaving. In ieder geval moet worden voorkomen dat men, door laksheid in de handhaving, een omslagpunt passeert, waarna het zeer moeilijk wordt om de zichzelf versterkende toename van normoverschrijding nog tot staan te brengen.

Aan de voorbeelden van normoverschrijdend gedrag die in dit hoofdstuk zijn besproken, zijn ook enkele meer concrete handelingsstrategieën te ontlenen om dit gedrag tegen te gaan (zie ook Malsch 2004). Het gaat hierbij vooral om strategieën die een preventieve werking kunnen hebben of die herhaling van normoverschrijdend gedrag (recidive) kunnen helpen voorkomen.

- Informatievoorziening: normoverschrijdend gedrag kan soms worden voorkomen door (potentiële) overtreders tijdig en beter te informeren over de situatie waarmee zij worden geconfronteerd. Tijdige en adequate informatie over vertragingen in het openbaar vervoer en over files in het wegverkeer kan emotionele en agressieve reacties van reizigers en automobilisten helpen 
voorkomen. Informatie over de procedures van rechtszaken en de overwegingen die tot een strafoplegging hebben geleid, kan de aanvaarding van de straf door de dader bevorderen en de kans op recidive verminderen (Malsch 2004).

- Correcte bejegening: een correcte bejegening van (potentiële) overtreders door officiële gezagsdragers - politieagenten, conducteurs, leerkrachten vermindert het risico op een agressieve reactie en vergroot de kans dat een terechtwijzing wordt geaccepteerd.

- Zichtbare controle: de duidelijk zichtbare aanwezigheid van formele controleurs, zoals politie, conducteurs, suppoosten, conciërges en dergelijke, verkleint de kans dat mensen tot ongeoorloofd gedrag overgaan. Het 'nut' van deze controleurs moet vooral blijken uit het feit dat zij zo weinig mogelijk daadwerkelijk hoeven op te treden. Een geringe frequentie van normoverschrijdend gedrag is op zichzelf dus geen deugdelijk argument om de formele controle te verminderen. Overigens dient men er wel voor te waken dat een te sterke nadruk op formele controle de informele sociale controle niet ondergraaft.

- Voorbeeldfunctie: het is van groot belang dat verantwoordelijke functionarissen het goede voorbeeld geven. Een leraar die op school rookt, een politieagent die te hard rijdt, een treinconducteur die zich in een eersteklascoupé terugtrekt en een leidinggevende die meedoet aan het pesten van een impopulaire medewerker, dragen alle bij aan het ondermijnen van normen, doordat zij anderen een rechtvaardiging bieden om zich evenmin aan de norm te houden. De overheid heeft, als hoogste gezagsdrager, vanzelfsprekend een bijzondere taak om het goede voorbeeld te geven.

- Participatie: de acceptatie van normen kan ook worden vergroot door burgers zelf te betrekken bij het opstellen en handhaven van die normen. Dit geldt niet alleen voor juridische normen in de vorm van wetten, maar ook voor de interne regels en codes van scholen, bedrijven en andere instellingen. Zo kunnen leerlingen participeren in het opstellen van het schoolreglement en wellicht zelfs in het oordelen over medeleerlingen die de regels hebben overtreden (zie ook hoofdstuk 7). Een actievere participatie van verdachten en slachtoffers in rechtbankzaken kan de acceptatie van de uitspraak van de rechter vergroten (Malsch 2004). Op buurtniveau kunnen burgers gezamenlijk afspraken maken over omgangsvormen om elkaar daarop vervolgens aan te spreken (vgl. de Rotterdamse stadsetiquette, zie Diekstra et al. 2002, Diekstra 2004).

- Een prettige omgeving: het vóórkomen van normoverschrijdend en crimineel gedrag hangt ook samen met de 'uitstraling' van de omgeving. In een vervuilde en verloederde, donkere of onoverzichtelijke omgeving voelen criminelen zich wel en eerzame burgers zich niet thuis. Onveiligheidsgevoelens en criminaliteit kunnen derhalve ook worden bestreden door (semi-)publieke ruimtes schoon te houden, goed te verlichten en overzichtelijk te maken, graffiti te verwijderen, kapotte ramen en beschadigd meubilair te herstellen, enzovoorts. 
Van de hier gesuggereerde strategieën om normoverschrijding tegen te gaan mag men geen wonderen verwachten. In die gevallen waarin normoverschrijding inmiddels een grote vlucht heeft genomen en het geloof in de normen is aangetast, zal het vaak een grote en langdurige inspanning vergen om de mate van normoverschrijding terug te dringen en het geloof in de norm te herstellen. Dit blijkt uit een nadere analyse van het model van normoverschrijdend gedrag dat in paragraaf 4.3 is besproken.

Dit model laat zien dat wanneer eenmaal een bepaald omslagpunt is gepasseerd, een kleine verdere afname van formele controle en sancties een sterke toename van normoverschrijdend gedrag tot gevolg kan hebben. Stel dat men wil proberen om de norm, die door een steeds kleiner deel van de bevolking wordt onderschreven en nageleefd, in ere te herstellen. Het volstaat dan niet om de kleine afname van controle en sancties ongedaan te maken en terug te brengen op het peil toen normconform gedrag nog de regel was. In de beginsituatie was het normconforme gedrag immers mede het gevolg van een breed gedeeld 'geloof' in de norm en van een sterke mate van informele sociale controle. Aangezien deze beide mechanismen om normconform gedrag af te dwingen grotendeels zijn verdwenen, zullen de formele controle en sancties nu veel groter moeten zijn dan destijds het geval was, om mensen weer in het gareel te krijgen. De formele controle zal ook de functie van internalisering van normen en van informele controle moeten overnemen. Herstel van normconform gedrag is dus niet simpelweg een kwestie van het terugdraaien van de eerdere versoepeling van formele controlemechanismen. Meer concreet: om zwartrijden sterk te verminderen volstaat het niet om de conducteur terug te brengen op de tram, omdat inmiddels veel reizigers de norm van 'betalen voor een rit' niet meer onderschrijven en de schaamte vanwege het betrapt worden op zwartrijden bij velen is verdwenen. Evenzo zijn bewakers in winkels niet afdoende om het aantal winkeldiefstallen terug te brengen naar het niveau van enkele decennia geleden.

Er is dus sprake van een asymmetrie in de dynamiek van normen, formele en informele controle en gedrag. Als bepaalde normen eenmaal zijn afgekalfd, vraagt het een onevenredig grote inspanning om deze te herstellen. Dit verklaart bijvoorbeeld waarom extra inspanningen van politie en justitie om criminaliteit te bestrijden vaak zo weinig effectief lijken. Dit hoeft niet per se te duiden op een gebrekkige efficiëntie en een overmatige bureaucratie van het politieapparaat. Herstel van normconform gedrag vereist eenvoudigweg een veel grotere inspanning dan handhaving van eenzelfde mate van normconform gedrag. Het is dan ook de vraag of herstel van de oorspronkelijke mate van normconform gedrag door uitsluitend aanscherping van de formele controle en sancties te realiseren valt. Die aanscherping mag dan een noodzakelijke voorwaarde zijn, het lijkt wenselijk, zo niet noodzakelijk, om tegelijkertijd ook de directe overdracht van normen en herstel van de informele controle te stimuleren. Hierbij spelen tal van maatschappelijke instituties en organisaties een belangrijke rol. In hoofdstuk 7 wordt de aandacht gericht op een aantal van deze 
instituties (in het bijzonder het onderwijs) en de rol die zij (kunnen) spelen bij zowel de overdracht als de handhaving van normen.

Tot slot is het van belang erop te wijzen dat in dit hoofdstuk normen als iets statisch zijn opgevat: de inhoud van de normen blijft gelijk, alleen de mate waarin mensen de normen onderschrijven en overschrijden verandert. In de praktijk kan de inhoud van normen echter geleidelijk veranderen en kunnen oude normen worden vervangen door nieuwe. Het beschreven proces van een norm die door een steeds kleiner deel van de bevolking wordt onderschreven en nagevolgd, kan daarom niet zonder meer als 'normverval' worden aangemerkt. Het is immers denkbaar dat tegelijkertijd een andere norm aan steun wint en geleidelijk de oude norm verdringt. Daaraan kunnen vele oorzaken ten grondslag liggen. Een interessante mogelijkheid is dat de omstandigheden zich zodanig hebben gewijzigd dat de oude norm minder geschikt is om de omgang tussen de leden van een samenleving te reguleren, terwijl de nieuwe norm daarop beter aansluit. De vervanging van oude door nieuwe normen kan dan juist een signaal zijn van een groot aanpassingsvermogen van de samenleving, terwijl een analyse van de naleving van de individuele oude normen de suggestie oproept van erosie en toenemende normloosheid. In zijn studie voor de WRR schetst Van den Brink (2004) hoe periodes van uitwaaierende normen en normvervaging kunnen worden afgewisseld door periodes waarin sprake is van convergentie en een grotere nadruk op normhandhaving. Zo bezien zouden de laatste drie decennia van de vorige eeuw kunnen worden gekenschetst als een periode van diffusie en vervaging van normen, waarna in de loop van de jaren negentig een periode van convergentie en normhandhaving is ingezet. Dit rapport kan dan als een uitdrukking van deze omslag in het maatschappelijke klimaat worden beschouwd. 


\section{NOTEN}

Hoe het mogelijk is dat het percentage reizigers dat is lastiggevallen groter is dan het totale percentage dat slachtoffer van een incident is geweest, wordt in het rapport van De Bie en Korpel (2002) niet verklaard. Een inventarisatie van de American Automobile Association leverde over de jaren 1990-1996 in de Verenigde Staten zelfs 10.000 extreem agressieve incidenten op, waarbij 12.610 gewonden en 218 doden vielen (Mizell 1997).

3 In feite gaat het er natuurlijk niet om dat men per se aan deze regels moet voldoen, maar dat deze een voorwaarde vormen om rechtmatig een uitkering te ontvangen. 


\section{BIJLAGE BIJ HOOFDSTUK 4:}

\section{EEN RATIONELE-KEUZE-ANALYSE VAN NORMEN EN GEDRAG}

De homo economicus uit de standaard (neoklassieke) economische theorie is een egoïstisch, normloos individu dat op rationele wijze zijn eigenbelang najaagt. Deze visie op de mens lijkt wel het minst geschikt om de relatie tussen normen en gedrag te analyseren. Toch zijn in de loop van de tijd diverse pogingen gedaan om de homo economicus te verrijken met andere eigenschappen, waardoor hij meer op een mens van vlees en bloed gaat lijken. Zo hebben verschillende economen de homo economicus minder egoïstisch gemaakt door hem te voorzien van eigenschappen als naastenliefde, altruïsme, solidariteit en normbesef. In navolging van het werk van economen als Becker en Akerlof en een socioloog als Coleman wordt in deze notitie de relatie tussen normen en gedrag geanalyseerd met behulp van een model dat uitgaat van een individu dat rationele keuzen maakt, maar zich aan meer gelegen laat liggen dan alleen zijn directe eigenbelang. De analyse wordt verduidelijkt met een aantal grafische voorstellingen.

\section{Formele controle en normoverschrijdend gedrag}

De analyse start met de gebruikelijke (neoklassieke) economische veronderstelling van een individu dat zijn of haar 'nut' maximaliseert. Dit nut kan alles omvatten wat de persoon in kwestie positief of negatief waardeert. Het begrip 'nut' kan naar believen worden vervangen door termen als welzijn, behoeftebevrediging of geluk.

Stel dat het 'nut' van het individu mede wordt bepaald door de vraag of hij een bepaalde verboden handeling $\gamma$ verricht. $\gamma=$ o duidt aan dat een individu de verboden handeling verricht en $\gamma=1$ dat hij/zij zich volgens de heersende norm gedraagt. De gemiddelde waarde van $\gamma$, aangegeven met $\psi$, is de proportie van de bevolking die zich normconform gedraagt. De handeling die strijdig is met de wet of de norm, levert het individu enerzijds een nutsvoordeel ter waarde van $G$ op, maar roept anderzijds het risico op betrapt en bestraft te worden. Stel dat deze formele controle en bestraffing een verwacht nutsverlies van $S_{0}$ opleveren. De homo economicus zal dan de wet overtreden indien $G$ groter is dan $S_{0}$, oftewel $G-S_{0}>0$. Normoverschrijdend gedrag kan in dit geval alleen worden voorkomen door de kans om betrapt en bestraft te worden te vergroten en de strafmaat te verhogen. Dit is in essentie de benadering van Becker (1968) van crimineel gedrag. Hij laat zien dat voor personen die risicozoekend zijn, een vergroting van de pakkans een groter afschrikwekkend effect heeft dan een even sterke verhoging van de straf, terwijl een verhoging van de straf een groter effect heeft voor personen die risicomijdend zijn. Het feit dat uit onderzoek veelvuldig naar voren komt dat de pakkans een groter effect heeft dan de strafmaat, duidt erop dat de meeste overtreders risico's zoeken. In het vervolg van deze notitie wordt echter geen onderscheid gemaakt tussen pakkans en straf en wordt verondersteld dat de afschrikwekkende werking $S_{o}$ die van beide tezamen uitgaat, voor iedereen gelijk is. 


\section{Internalisering van normen}

Laten we nu echter de mogelijkheid bezien dat het individu enig normbesef kan hebben. In navolging van Akerlof (1980) veronderstellen we dat een deel van de mensen de norm die in hun gemeenschap bestaat, heeft geïnternaliseerd en onderschrijft, terwijl een ander deel de norm niet onderschrijft. Als iemand de norm onderschrijft, wordt dit aangegeven met $\beta=1$, als hij de norm niet onderschrijft met $\beta=$ o. De gemiddelde waarde van $\beta$, aangegeven met $\beta$, is de proportie van de bevolking die de norm onderschrijft. Iemand die de norm onderschrijft, hoeft echter niet per se in overeenstemming met de norm te handelen. Het overtreden van de norm levert de betreffende persoon echter wel spijt, berouw, wroeging, schuldgevoel of gewetensnood op. Als deze spijt zijn nut met een waarde $B_{\mathrm{o}}$ vermindert, dan zal een persoon die de norm onderschrijft, deze toch overtreden indien $G-S_{\mathrm{o}}>B_{\mathrm{o}}$, dat wil zeggen indien het 'extrinsieke' voordeel van normoverschrijding groter is dan de 'intrinsieke' spijt.

Figuur 4.7 geeft dit grafisch weer. In deze figuur wordt verondersteld dat de spijt $B_{\mathrm{o}}$ die men ondervindt als men de norm overtreedt, varieert tussen degenen die de norm onderschrijven. In figuur 4.7 is de populatie geordend naar aflopende spijt (de stippellijn $B_{\mathrm{o}}$ ): helemaal links in de figuur staan degenen die de grootste spijt voelen bij het overtreden van de norm (een waarde van 7 'nutseenheden'); naarmate men meer naar rechts gaat, neemt de spijt af. De laatste 30 procent van de bevolking onderschrijft de norm niet en ondervindt derhalve ook geen spijt bij het overtreden van de norm. Verder wordt verondersteld dat de 'extrinsieke' opbrengst van normoverschrijdend gedrag, $G-S_{\mathrm{o}}$, voor iedereen gelijk is (een waarde van 2). In figuur 4.7 levert normoverschrijdend gedrag aanvankelijk zoveel extrinsiek voordeel op dat alle mensen die de norm niet onderschrijven, deze overtreden $\left(G-S_{0}>0\right)$. Tegelijkertijd is dit voordeel ook zo klein dat allen die de norm wel onderschrijven, deze naleven $\left(G-S_{0}<B_{0}\right)$. Het aandeel van de bevolking dat de norm naleeft, $\psi_{o}$, is dan gelijk aan het aandeel van de bevolking dat de norm onderschrijft, $\underline{\beta}_{0}$. Dit is een stabiel evenwicht $\left(E_{\mathrm{o}}\right)$, dat wil zeggen dat degenen die de norm naleven niet geprikkeld worden om deze in de toekomst te overtreden en degenen die de norm overtreden niet geprikkeld worden deze in de toekomst na te leven. 
Figuur 4.7 Kosten en baten van normoverschrijdend gedrag - internalisering en formele controle $(t=0)$

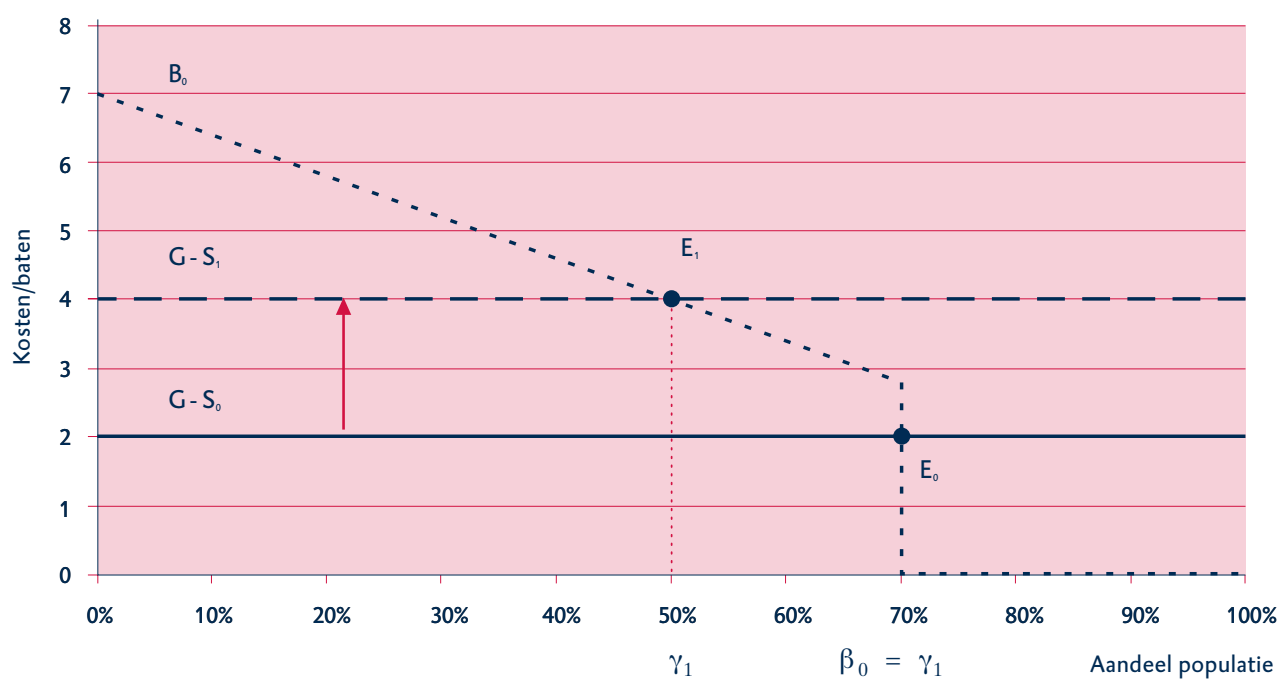

Stel nu echter dat de extrinsieke opbrengst van normoverschrijdend gedrag stijgt, bijvoorbeeld doordat er minder gecontroleerd wordt, waardoor de pakkans afneemt en de verwachte straf $S$ daalt. Dus $S_{1}<S_{0}$, oftewel $G-S_{1}>G-S_{0}$. Aanvankelijk heeft dit geen effect op het percentage $\psi_{0}$ van de bevolking dat de norm naleeft. Maar als de sanctie $S$ op overtreding van de norm maar voldoende daalt, zullen op een gegeven moment ook mensen die de norm onderschrijven in de verleiding komen deze te overtreden. Daardoor daalt de proportie van de bevolking die zich normconform gedraagt van $\psi_{0}$ naar $\psi_{1}$, in figuur 4.7 van 70 naar 50 procent $\left(E_{1}\right)$.

Het feit dat nu minder mensen de norm naleven dan de norm onderschrijven zou op den duur van invloed kunnen zijn op het geloof in de norm. Akerlof maakt de cruciale veronderstelling dat de proportie van de bevolking die de norm onderschrijft, zich geleidelijk aanpast aan de proportie die de norm naleeft. Als minder mensen conform de norm handelen dan de norm onderschrijven, neemt het geloof in de norm af (de curve $B_{1}$ in figuur 4.8). Hierbij wordt verondersteld dat degenen die de minste spijt voelen bij het overtreden van de norm, als eerste hun geloof in de norm verliezen. Na verloop van tijd ontstaat dan een nieuw evenwicht waarin het percentage van de bevolking dat de norm onderschrijft weer gelijk is aan het percentage dat normconform handelt, dat wil zeggen $\beta_{1}=\psi_{1}(50 \%$ in figuur 4.8$)$. (Hoe lang het duurt voor het nieuwe evenwicht wordt bereikt, is in dit model onbepaald. Het zou kunnen gaan om één of twee jaar, maar ook om tien of nog meer jaren.) Als de netto-opbrengst van normoverschrijdend gedrag vervolgens niet meer verandert, dus als $G$ en $S_{1}$ gelijk blijven, is dit opnieuw een stabiel evenwicht $\left(E_{1}\right)$. 
Figuur 4.8 Kosten en baten van normoverschrijdend gedrag - internalisering en formele controle $(t=1)$

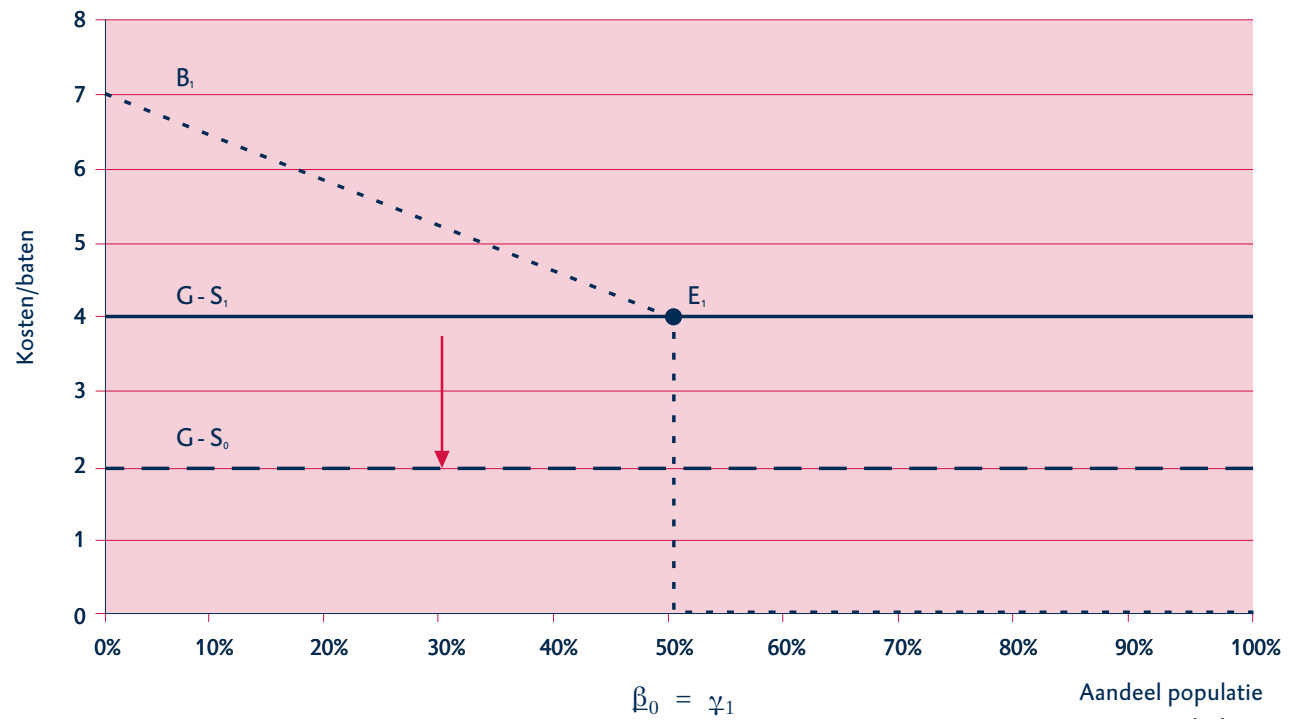

Stel dat men nu wil proberen het aandeel van de bevolking dat zich normconform gedraagt, terug te brengen naar het oude niveau $\beta_{0}$ (70\% in figuur 4.7$)$. Om dit te bereiken wordt de pakkans of strafmaat van normovertreding verhoogd tot het oorspronkelijke niveau. Doordat het geloof in de norm inmiddels is afgenomen, heeft dit echter geen effect op de naleving van de norm: degenen die hun geloof in de norm hebben verloren, worden door de hogere sanctie niet voldoende afgeschrikt om zich weer in overeenstemming met de norm te gaan gedragen. Pas als de (verwachte) sanctie op overtreding hoger wordt dan de opbrengst ervan, dat wil zeggen als $G-\mathrm{S}<0$, kiest ook de zuiver egoïstische homo economicus die de norm niet onderschrijft, eieren voor zijn geld en gaat zich normconform gedragen. In dit geval zal zelfs de totale bevolking zich normconform gedragen, dat wil zeggen $\psi_{2}=1$. Vervolgens zal ook het geloof in de norm weer toenemen tot uiteindelijk de gehele bevolking de norm onderschrijft, dat wil zeggen $\beta_{2}=1$.

Een belangrijke conclusie die uit deze simpele analyse kan worden getrokken, is dat verval en herstel van normconform gedrag geen symmetrische processen zijn. Als door een verlaging van de sanctie op normoverschrijdend gedrag meer mensen zich in strijd met de norm gaan gedragen, kan men de situatie niet eenvoudig terugdraaien door de (kans op een) sanctie weer op het oude peil te brengen. Als inmiddels het geloof in de norm onder de bevolking is afgenomen, zal de sanctie op normovertreding veel hoger moeten worden dan deze aanvankelijk was, om het oorspronkelijke evenwicht te herstellen.

\section{Informele sociale controle}

In het bovenstaande voorbeeld gehoorzamen degenen die de norm niet hebben geïnternaliseerd deze alleen indien de formele sanctie op overtreding zo groot is 
dat een zuiver rationele calculatie iedereen ertoe brengt zich normconform te gedragen. Akerlof stelt echter dat mensen die niet in de norm geloven, deze ook kunnen gehoorzamen als gevolg van informele sociale controle. Hij veronderstelt dat het overtreden van de norm leidt tot reputatieverlies, hetgeen het nut van de overtreder verlaagt. In plaats van reputatieverlies zou men ook kunnen denken aan de schaamte die men voelt als men in het openbaar door anderen op zijn normoverschrijdende gedrag wordt aangesproken. Het verschil tussen spijt en schaamte is derhalve dat de eerste een intrinsiek karakter heeft (men voelt ook spijt als men de norm overschrijdt en niemand anders daarvan op de hoogte is), terwijl de laatste altijd een extrinsieke oorzaak heeft (men schaamt zich alleen in aanwezigheid van anderen).

Een belangrijke veronderstelling die Akerlof vervolgens maakt is, dat het reputatieverlies of de schaamte mede wordt bepaald door het percentage $\beta$ van de bevolking dat de norm onderschrijft. Dit is een plausibele veronderstelling: het is niet aannemelijk dat men door iemand die de norm zelf niet onderschrijft, wordt aangesproken op het overschrijden van de norm. Naarmate meer mensen de norm onderschrijven, wordt de kans op sociale controle en reputatieverlies groter. Verder veronderstelt Akerlof dat de mate waarin men zich schaamt indien men betrapt wordt, uiteenloopt binnen de bevolking. Laten we voor de eenvoud veronderstellen dat degenen die de norm het sterkst geïnternaliseerd hebben, zich ook het meest schamen indien zij de norm overtreden, terwijl degenen die niet in de norm geloven zich het minst schamen. Het reputatieverlies dat persoon $i$ lijdt indien hij de norm overtreedt kan dan worden geschreven als $\beta R^{\mathrm{i}}$, waarin $\beta$ het deel van de bevolking is dat de norm onderschrijft en $R^{\mathrm{i}}$ de persoonlijke beleving van de schaamte indien men wordt betrapt.

Figuur 4.9 Kosten en baten van normoverschrijdend gedrag - internalisering, formele en informele controle $(t=0)$

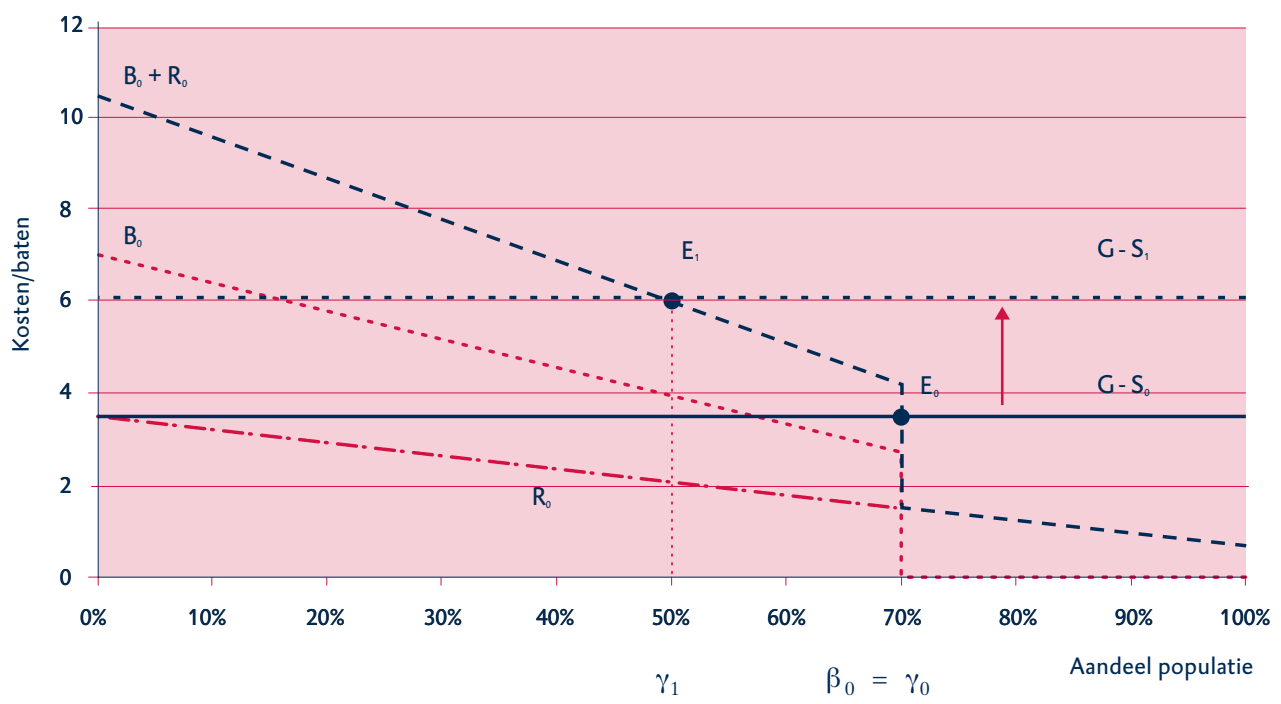


Figuur 4.9 geeft een mogelijke beginsituatie weer die vergelijkbaar is met die in figuur 4.7. Hierin geeft de lijn $R_{\mathrm{o}}$ het reputatieverlies bij het overtreden van de norm aan, terwijl de lijn $B_{\mathrm{o}}$ weer de spijt over de normovertreding weergeeft. Het totale nutsverlies ten gevolge van normoverschrijdend gedrag is dan gelijk aan $B_{\mathrm{o}}+R_{\mathrm{o}}$ (spijt + reputatieverlies). Alle personen die de norm onderschrijven, leven in figuur 4.9 de norm na $\left(\beta_{0}=\psi_{0}=70 \%\right.$ van de bevolking), terwijl degenen die de norm niet onderschrijven deze overtreden. Het verschil met figuur 4.7 is, dat een deel van degenen die de norm onderschrijven (de groep tussen $58 \%$ en $70 \%$ ), deze alleen gehoorzaamt omdat men bang is voor het reputatieverlies of de schaamte bij het overtreden van de norm. Zonder dit reputatieverlies zou de spijt die zij voelen bij normovertreding niet groot genoeg zijn om het voordeel van normovertreding teniet te doen. Dat wil zeggen, voor deze personen geldt: $G-S_{o}>B^{\mathrm{i}}$, maar $G-S_{\mathrm{o}}<B^{\mathrm{i}}+\beta_{\mathrm{o}} R^{\mathrm{i}}$. Voor degenen die de norm niet onderschrijven is het reputatieverlies echter niet groot genoeg om hen ervan te weerhouden de norm te overtreden. Voor hen geldt derhalve $G-S_{\mathrm{o}}>B^{\mathrm{i}}+\beta_{\mathrm{o}} R^{\mathrm{i}}$.

Net als in de vorige paragraaf veronderstellen we dat de formele sanctie op normovertreding in de loop van de tijd daalt. Opnieuw gebeurt er aanvankelijk niets, maar op een gegeven moment wordt normovertreding zo aantrekkelijk dat ook sommigen die de norm onderschrijven deze gaan overtreden. Anders dan in de vorige paragraaf is het nieuwe evenwicht dat ontstaat bij $\chi_{1}(50 \%)$ nu echter geen stabiel evenwicht $\left(E_{1}\right)$. We hebben immers verondersteld dat de grootte van het reputatieverlies mede wordt bepaald door het percentage van de bevolking dat de norm onderschrijft. Als $\beta$ zich aanpast aan het percentage van de bevolking dat de norm overtreedt en dus kleiner wordt $\left(\beta_{1}=\psi_{1}<\beta_{0}\right)$, zal ook het reputatieverlies

Figuur 4.10 Kosten en baten van normoverschrijdend gedrag - internalisering, formele en informele controle $(t=1)$

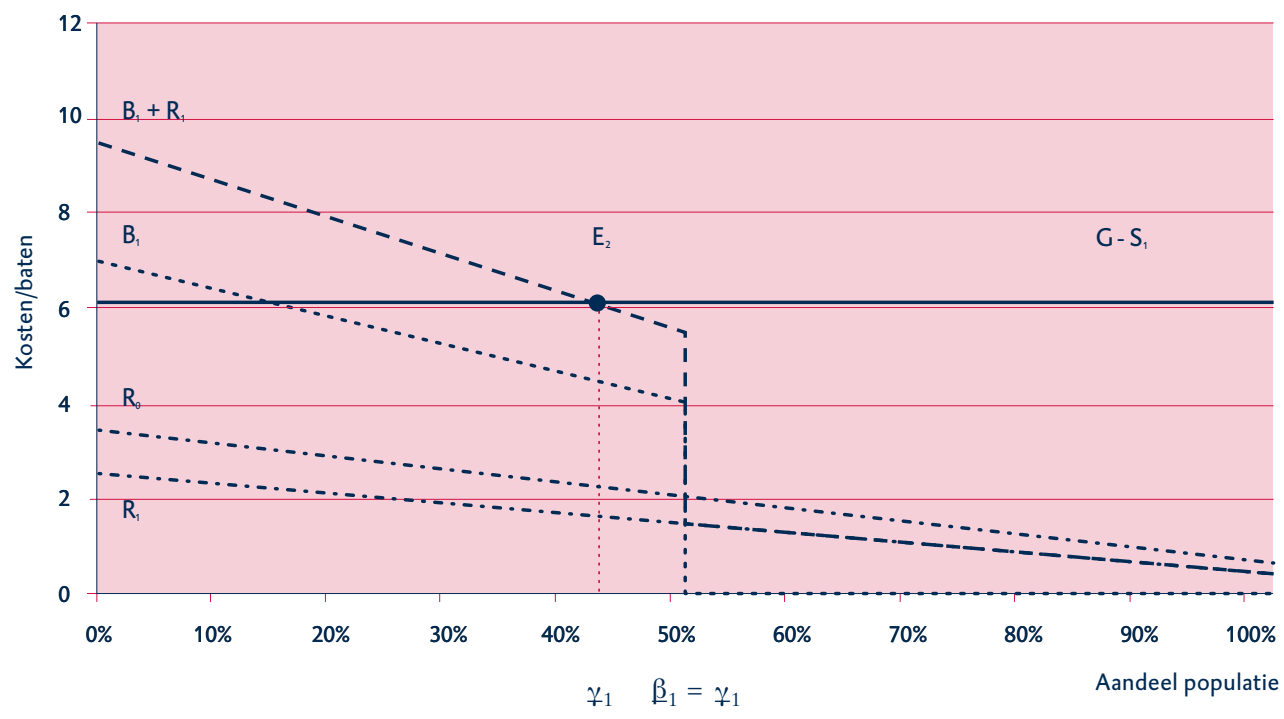


bij normovertreding afnemen. De curve $R_{1}$ in figuur 4.1o ligt dan ook lager dan curve $R_{\mathrm{o}}$ in figuur 4.9 .

Als gevolg hiervan zal opnieuw een deel van degenen die de norm onderschrijven deze niet meer naleven, waardoor het evenwicht nog verder naar links verschuift $\left(E_{2}\right.$ in figuur 4.10). In de volgende periode leidt dit tot een nog verder

Figuur 4.11 Kosten en baten van normoverschrijdend gedrag - internalisering, formele en informele controle $(t=0)$

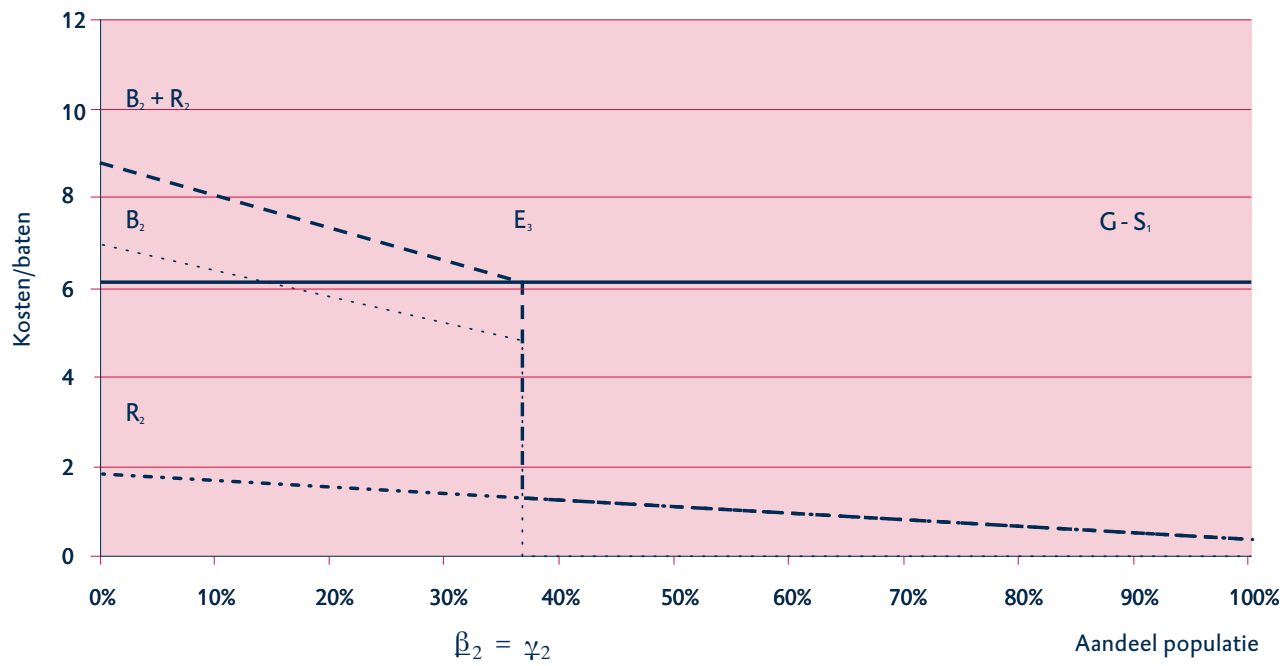

afkalven van het geloof in de norm en dus tot een nog verdere afname van het reputatieverlies, enzovoorts. In het algemeen staat niet vast waar dit 'normverval' eindigt. Als het reputatieverlies bij normoverschrijdend gedrag door het afbrokkelen van het geloof in de norm sneller afneemt dan het geloof van de 'marginale' gelovige toeneemt, dat wil zeggen dat ook degenen die het sterkst in de norm geloven zich uiteindelijk alleen door de angst voor reputatieverlies van normoverschrijdend gedrag laten weerhouden, dan zal het geloof in de norm uiteindelijk geheel verdwijnen, zodat op den duur niemand meer de norm naleeft of onderschrijft. Is de internalisering van de norm bij een deel van de bevolking echter sterk genoeg, dan kan er uiteindelijk een nieuw stabiel evenwicht ontstaan, waarbij een klein deel van de bevolking de norm zowel onderschrijft als gehoorzaamt en het grootste deel de norm niet onderschrijft en niet naleeft. In figuur 4.11 is een dergelijke situatie weergegeven, waarbij in het uiteindelijke, stabiele evenwicht $\left(E_{3}\right)$ nog 36,5 procent van de bevolking de norm zowel onderschrijft $\left(\beta_{2}\right)$ als naleeft $\left(\chi_{2}\right)$.

Om naar de oude situatie terug te keren, volstaat het ook in dit model niet om het oude niveau van de formele sancties op normoverschrijdend gedrag te herstellen. Men zal de sancties zo sterk moeten verhogen dat ook degenen die niet (meer) in de norm geloven voldoende worden afgeschrikt om zich weer 
normconform te gaan gedragen $\left(G-S_{2}\right.$ in figuur 4.12). Slaagt men hierin, zodat na verloop van tijd het bevolkingsaandeel dat de norm naleeft weer is toegenomen tot het oorspronkelijke niveau $\left(\psi_{3}=70 \%\right.$ in figuur 4.12$)$, dan neemt daardoor het geloof in de norm geleidelijk ook weer toe. Vervolgens wint tevens de informele controle weer aan belang. Tot slot schept dit de ruimte om op termijn de teugel van de formele controle weer enigszins te laten vieren, doordat de informele sociale controle deze rol weer (ten dele) overneemt.

Dit tweede model laat nog duidelijker dan het eerste model, waarin alleen sprake was van formele controle en internalisering, zien dat er sprake is van een asymmetrie tussen normverval en normherstel. Als men de formele controle op normoverschrijdend gedrag te zeer heeft laten verslappen, kan zich een sneeuwbaleffect voordoen, waardoor uiteindelijk nog slechts een klein deel van de bevolking zich normconform gedraagt of de norm zelfs geheel verdwijnt. Het vergt dan een zeer grote inspanning om de oude situatie te herstellen.

Figuur 4.12 Kosten en baten van normoverschrijdend gedrag - internalisering, formele en informele controle $(t=3)$

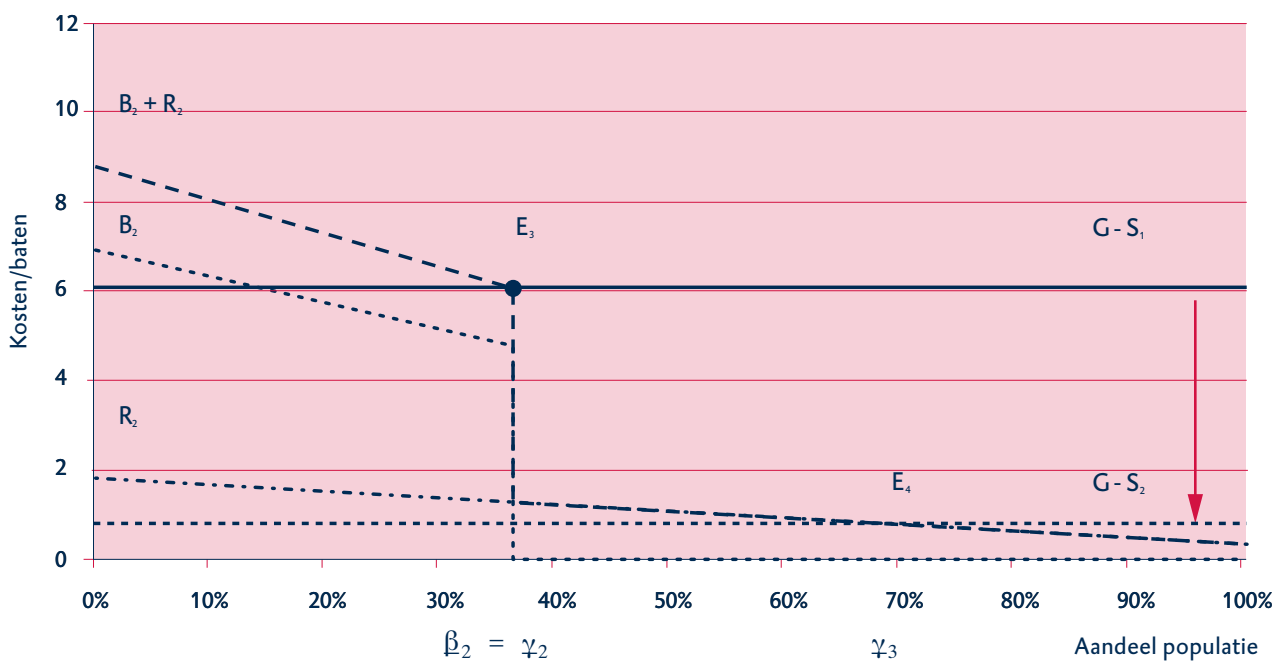

Het model laat ook zien dat er een ingewikkelde relatie bestaat tussen formele en informele controle. Hoewel de twee soorten controle als substituut van elkaar kunnen fungeren, beïnvloeden zij elkaar ook wederzijds. Een afname van formele controle kan een tijdlang worden opgevangen door informele controle. Maar op een gegeven moment brokkelt ook de informele controle af, waardoor men in een neerwaartse spiraal terechtkomt. Alleen een zeer sterke toename van formele controle kan de norm dan weer herstellen. Als men daar uiteindelijk in slaagt, zal de informele controle echter ook weer toenemen, hetgeen vervolgens de ruimte schept om de formele controle weer enigszins te verminderen. Daarbij dient men er echter voor te waken hierin niet te ver te gaan, aangezien het evenwicht dan opnieuw zou worden verstoord. 
Een gevolg hiervan is dat men voorzichtig dient te zijn met uitspraken over de effectiviteit en efficiëntie van het politie- en justitieapparaat. Het is denkbaar dat bij eenzelfde intensiteit van afschrikking door opsporing en bestraffing van misdrijven de doeltreffendheid ervan in termen van preventie van criminaliteit in de loop van de tijd sterk kan verschillen. Zolang rechtsnormen breed worden onderschreven en overtreding daardoor ernstig reputatieverlies oplevert, kan een geringe inspanning van politie en justitie voldoende zijn om de criminaliteit binnen de perken te houden. Zijn het geloof in de rechtsnormen en de sociale controle eenmaal afgebrokkeld, dan kan een veel grotere inspanning toch minder effect op de criminaliteit sorteren. Ogenschijnlijk is de effectiviteit van politie en justitie dan sterk afgenomen, hetgeen gemakkelijk kan leiden tot klachten over de gebrekkige organisatie en de overmatige bureaucratie. De oorzaak van de afgenomen effectiviteit is dan echter veeleer gelegen in de gewijzigde maatschappelijke omstandigheden.

Overigens laten beide modellen ook zien dat het op zichzelf niet zorgelijk hoeft te zijn als een (beperkt) deel van de bevolking de dominante normen niet onderschrijft en naleeft. Er kan een stabiel evenwicht zijn waarbij een constante fractie van de bevolking zich niet aan de regels houdt, zonder dat dit het geloof in en de naleving van deze normen door de meerderheid hoeft aan te tasten. Het is zelfs mogelijk dat er een stabiele minderheidsgroep is die in een overwegend 'normloze' samenleving vasthoudt aan specifieke eigen normen (denk aan een hechte geloofsgemeenschap als de orthodox gereformeerden of vegetariërs). Hierbij past wel de kanttekening dat deze conclusie sterk afhankelijk is van de veronderstelling dat het geloof in een norm zich na verloop van tijd aanpast aan de proportie van de bevolking die zich normconform gedraagt.

\section{Demografische ontwikkelingen}

Met de hiervoor besproken modellen kunnen ook de effecten van demografische ontwikkelingen op het normbesef en normoverschrijdend gedrag worden geanalyseerd. Te denken valt aan immigratie en de opeenvolging van generaties.

Stel allereerst dat de bevolking groeit als gevolg van de toestroom van migranten en stel bovendien dat deze andere normen hebben dan die van de autochtone bevolking. In de situatie die in figuren 4.7 en 4.8 is geschetst, waarin alle personen die de norm hebben geïnternaliseerd deze naleven zonder dat daarvoor externe (sociale) controle nodig is, heeft immigratie geen gevolgen voor het absolute aantal personen dat de norm onderschrijft en naleeft. Wel neemt het percentage van de bevolking dat de 'autochtone' normen onderschrijft af, waardoor het (stabiele) evenwicht naar links verschuift.

In de situatie in figuren 4.9 en 4.10 , waarin in het stabiele langetermijnevenwicht ook sociale controle nodig is om een deel van de bevolking op het rechte pad te houden, is immigratie wel van invloed op de normnaleving. Als door immigratie het percentage van de bevolking dat de norm onderschrijft, daalt, zal immers ook het reputatieverlies bij overtreding van de norm afnemen. Daardoor 
zal een deel van degenen die de norm eerst naleefden, deze nu gaan overtreden. Niet alleen het percentage van de bevolking, maar ook het absolute aantal personen dat zich normconform gedraagt, zal dan dalen. Dit resulteert na enige tijd in een verder afkalven van het geloof in de norm, een verdere vermindering van het reputatieverlies en derhalve nog meer normoverschrijdend gedrag. Immigratie van 'ongelovigen' kan aldus een negatieve spiraal in werking zetten, waarvan niet bij voorbaat vaststaat waar deze eindigt. Gezien het ondermijnende effect van de immigratie van een aanzienlijke groep die de heersende normen niet onderschrijft, kan een forse toename van normoverschrijdend gedrag alleen worden voorkomen ofwel door de formele sanctie hierop fors te verhogen, ofwel via 'inburgering' de heersende normen zo snel mogelijk aan de immigranten over te dragen.

Het effect van de komst van een nieuwe generatie jongeren heeft een vergelijkbaar effect als de komst van immigranten, indien de jongere generatie de traditionele normen in mindere mate onderschrijft dan de oudere generatie. Als de oudste generatie die de normen het sterkst onderschrijft, geleidelijk uitsterft, heeft dit in de figuren tot gevolg dat aan de linkerkant een deel van de bevolking afvalt, terwijl er aan de rechterkant een groep bijkomt. Anders gezegd, de curven die de spijt $(B)$ en schaamte $(S)$ weergeven, verschuiven dan naar links, zodat ook het evenwicht naar links verschuift. Overigens is het natuurlijk heel goed mogelijk dat de nieuwkomers - of dit nu migranten zijn of een nieuwe generatie andere normen hanteren dan de oorspronkelijke bevolking die geleidelijk de dominante normen worden. Er is dan niet zozeer sprake van normverval als wel van een vervanging van oude door nieuwe normen.

\section{Kanttekeningen}

Het hierboven gepresenteerde rationelekeuzemodel van de relatie tussen normen en gedrag is gebaseerd op diverse veronderstellingen waarvan de geldigheid in de praktijk allerminst vanzelf spreekt. In deze paragraaf worden enkele van deze veronderstellingen besproken en wordt bezien op welke wijze het model realistischer kan worden gemaakt en welke consequenties dit zou hebben.

De cruciale vooronderstelling van een rationelekeuzebenadering van normen en gedrag is dat het al dan niet navolgen van een norm een rationele keuze is in de zin dat men verschillende gedragsopties tegen elkaar afweegt. Impliciet wordt hiermee verondersteld dat mensen altijd ertoe kunnen worden gebracht om de normen die zij aanhangen te overtreden als de beloning die daartegenover staat maar groot genoeg is. Een norm geldt dan in zekere zin als een preferentie, die wordt afgewogen tegen andere preferenties. Verschillende auteurs bestrijden echter dat normatief of moreel gedrag als een dergelijk keuzeproces kan worden geanalyseerd (bijvoorbeeld Etzioni 1988, Dan-Cohen 2002). Zo betoogt Dan-Cohen (2002: 125-149) dat bij moreel gedrag in het algemeen geen keuze wordt gemaakt tussen verschillende opties, omdat men alternatieve opties die strijdig zijn met de waarden of normen die men aanhangt, eenvoudigweg niet in overweging neemt. Tegen dit bezwaar zou men kunnen inbrengen dat men ook normen die het aantal 
opties waaruit men kan kiezen, inperken, in het rationelekeuzemodel zou kunnen opnemen, namelijk door de (subjectieve) kosten van het overschrijden van die norm (hiervoor als 'spijt' aangeduid) willekeurig groot te maken. In de figuren in deze bijlage zou dit betekenen dat de lijn $B$ voor degenen die de norm onderschrijven altijd ver boven de lijn $G-S$, die het extrinsieke voordeel van normoverschrijding weergeeft, ligt, zodat zij zich altijd normconform gedragen.

In de bovenstaande modellen is verondersteld dat het geloof in de norm en het reputatieverlies door sociale controle variëren binnen de bevolking, maar niet de waardering van de opbrengst van het normoverschrijdende gedrag en de formele sanctie die daarop staat, dat wil zeggen $G-S$. Nadere inspectie van de figuren 4.7 en 4.9 leert echter dat de eerdere conclusies niet wezenlijk veranderen indien de lijn $G-S$ een monotoon hellend verloop heeft, dat wil zeggen stijgt of daalt naarmate men minder in de norm gelooft. Alleen als $G-S$ sterker zou dalen dan de lijn $B+R$, zouden de eerder afgeleide conclusies niet meer gelden. Dit zou het geval kunnen zijn indien degenen die het sterkst in de norm geloven de extrinsieke opbrengst van normovertreding het hoogst waarderen, hetgeen weinig plausibel is.

Een cruciale veronderstelling voor de dynamiek van de besproken modellen betreft de relatie tussen het geloof in de norm en de mate van normconform gedrag. De veronderstelling dat het percentage van de bevolking dat een norm onderschrijft, op den duur afkalft als het percentage dat de norm overschrijdt toeneemt, is plausibel. Het is echter de vraag of dit ook geldt voor het omgekeerde: neemt het geloof in de norm op termijn weer toe als meer mensen zich, onder druk van formele controle, normconform gaan gedragen? Impliciet wordt hiermee verondersteld dat normen vooral worden overgedragen via de gedragingen van anderen. Dit is zeker geen vanzelfsprekendheid die voor alle vormen van normoverdracht opgaat. Zo lijkt het aannemelijk dat normconform gedrag dat via informele, sociale controle wordt afgedwongen een sterker positief effect heeft op het geloof in de norm dan door formele controle afgedwongen normconform gedrag. Anders gezegd, schaamte lijkt een sterkere drijfveer voor het internaliseren van een norm dan een bureaucratisch opgelegde sanctie. Het is bijvoorbeeld niet zo aannemelijk dat iemand die zich aan de maximumsnelheid houdt om te voorkomen dat hij of zij een bekeuring krijgt, dáárdoor die norm ook eerder gaat onderschrijven. Wie echter door zijn buurtbewoners erop wordt aangekeken dat hij in de straat te hard rijdt, zal de norm mogelijk wel gaan onderschrijven. Kreps (1997) en Frey en Jegen (2001) hebben erop gewezen dat extrinsieke prikkels zelfs de intrinsieke motivatie om zich normconform te gedragen zouden kunnen ondermijnen. Hun analyse beperkt zich overigens tot positieve prikkels: als men vrijwillig lofwaardig gedrag gaat belonen kan dit in sommige omstandigheden de motivatie verminderen.

Als het juist is dat normoverschrijdend gedrag het geloof in een norm aantast, maar een toename van normconform gedrag niet automatisch het geloof in de norm herstelt, wordt de eerdere conclusie over de asymmetrie in de dynamiek 
van normen en gedrag nog versterkt. Als het geloof in en de naleving van een norm eenmaal zijn afgebrokkeld, zal het dan nog meer inspanning vergen om de norm te herstellen. Bovendien zal men dan niet kunnen volstaan met de formele controle op en bestraffing van normoverschrijdend gedrag aan te scherpen, maar zal men ook meer direct moeten trachten het geloof in de norm te versterken via andere vormen van normoverdracht, zoals voorlichting, opvoeding en dergelijke.

\section{De oorsprong van normen}

Een bezwaar tegen het hiervoor gepresenteerde rationelekeuzemodel is, dat de normen hierin geen 'nut' lijken te hebben: normovertreding levert de overtreder direct voordeel op, maar het model zwijgt over de eventuele schade die anderen hiervan ondervinden. Als anderen niet worden geschaad door normovertreding, is het echter lastig te verklaren waarom de betreffende norm überhaupt bestaat.

Er zijn diverse pogingen gedaan om (het ontstaan van) normen te verklaren als optimale strategie om een prisoner's dilemma op te lossen (zie bijv. Coleman 1990, Fershtman en Weiss 1998 en Bowles en Gintis 1998). In een prisoner's dilemma ontmoeten twee personen elkaar, waarbij ieder moet beslissen of hij of zij zich coöperatief of opportunistisch gedraagt. Coöperatief gedrag van beiden levert een groter sociaal voordeel op dan wanneer beiden zich opportunistisch gedragen. Wanneer de een zich opportunistisch gedraagt en de ander coöperatief, behaalt de eerste echter het grootste voordeel, terwijl de ander er nadeel van ondervindt. Zonder coördinatie van de activiteiten zullen daardoor beiden, indien zij rationeel handelen, voor het opportunistische gedrag kiezen, hetgeen maatschappelijk gezien een suboptimale uitkomst oplevert.

Als er in de gemeenschap echter een norm bestaat die coöperatief gedrag voorschrijft en als iedereen zich aan deze norm houdt, wordt het maatschappelijke optimum wel gerealiseerd. In een dergelijke situatie zal ieder individu dat de norm overtreedt, echter een voordeel behalen (het zogeheten free rider-probleem). Het risico bestaat dan dat steeds meer mensen dit slechte voorbeeld navolgen, waardoor de norm afkalft en de maatschappelijke uitkomst verslechtert. Uiteindelijk zal de norm dan verdwijnen en ontstaat er een maatschappelijk suboptimaal evenwicht. Om een stabiel evenwicht van normconform gedrag in stand te houden, dient er een voldoende hoge sanctie te staan op normoverschrijdend gedrag. In beginsel kan deze sanctie elk van de drie vormen aannemen die hierboven zijn geanalyseerd: spijt als gevolg van het overtreden van een geïnternaliseerde norm, schaamte als gevolg van sociale controle en straf als gevolg van formele controle en sancties. Deze sancties fungeren derhalve als sociale mechanismen om het maatschappelijke optimum in stand te houden. Aangezien een gemeenschap waarvan de leden zich normconform gedragen succesvoller is dan een gemeenschap waarin opportunistisch gedrag dominant is, zullen gemeenschappen met sterk gedeelde normen en weinig normoverschrijdend gedrag uiteindelijk overleven en het overheersende patroon vormen. 


\section{Een korte geschiedenis van vijftig jaar normoverschrijdend gedrag}

Hoe simpel en gestileerd het hiervoor beschreven model ook is, het zou een plausibele verklaring kunnen bieden voor de ontwikkeling die zich de afgelopen halve eeuw in Nederland heeft voorgedaan. In de jaren vijftig van de vorige eeuw waren er voor de overgrote meerderheid van de bevolking sterke prikkels om zich normconform te gedragen: de meeste mensen hadden de heersende normen geïnternaliseerd en er was sprake van zowel een sterke formele als een sterke informele (sociale) controle. In de loop van de jaren zestig en zeventig nam de formele controle evenwel af. Enkele voorbeelden hiervan zijn het verdwijnen van de conducteur op de bus en tram, het afschaffen van het perronkaartje en de invoering van zelfbediening in tal van winkels. Aanvankelijk had deze vermindering van de formele controle van normoverschrijdend gedrag geen merkbare gevolgen, doordat de informele controle en de internalisering van de normen sterk genoeg waren. Op een gegeven moment werd echter een grens overschreden, toen ook een - aanvankelijk klein - deel van degenen die de normen nog onderschreven, in de verleiding kwam deze te overtreden. In eerste instantie schaamde men zich daar nog voor. Maar toen men bespeurde dat ook steeds meer anderen zich niet aan de regels hielden, vond men er een rechtvaardiging voor.

Winkeldiefstal werd proletarisch winkelen, zwartrijden was verantwoord omdat het openbaar vervoer eigenlijk gratis moest zijn en wie de belasting niet een beetje ontdook was een dief van zijn eigen portemonnee. Geleidelijk verslapte daardoor ook de sociale controle, waardoor nog meer mensen de regels gingen overtreden en het geloof in de normen verder afkalfde. In de jaren tachtig bereikte het normoverschrijdende gedrag zo'n omvang dat de maatschappelijke tolerantie hiervoor sterk verminderde. Dit werd nog versterkt door de instroom van grote aantallen migranten die er vaak andere gebruiken en zeden op na hielden en zich niet altijd evenveel gelegen lieten liggen aan de in Nederland gangbare normen. Het gedogen van wetsovertreding werd niet langer geaccepteerd. De roep om meer blauw op straat en hardere straffen (lik-op-stukbeleid, zero tolerance) weerklonk steeds luider. Dit leidde ertoe dat er vanaf de jaren tachtig inderdaad steeds strenger werd gestraft en dat er in de loop van de jaren negentig ook weer financiële ruimte kwam om de sterkte van politie, justitie en andere controleurs te vergroten. De conducteur kwam terug op de tram, winkels namen bewakers in dienst en de sociale rechercheur ging op jacht naar zwartwerkers en dubbele tandenborstels. Vooralsnog resulteerde dit echter niet in een substantiële vermindering van normoverschrijdend gedrag. Dit wordt vaak toegeschreven aan de inefficiëntie van politie, justitie, sociale diensten en andere bureaucratische instellingen. Het hierboven geschetste model biedt echter een alternatieve verklaring: doordat zowel de sociale controle als de internalisering van normen sinds de jaren zestig sterk is verminderd, volstaat het niet om de politiesterkte en de strafmaat terug te brengen op het niveau van de jaren vijftig. Er is een aanzienlijk grotere inspanning vereist om weer een nieuw evenwicht tot stand te brengen waarin de meeste mensen de normen onderschrijven én naleven en de sociale controle is versterkt. Behalve via versterking van formele controle en sanctionering van normoverschrijdend gedrag zou dit ook moeten worden 
bevorderd door meer inspanning te verrichten om de normen over te dragen aan jongeren en aan nieuwkomers (via inburgeringscursussen). Pas als door deze combinatie van externe dwang en normoverdracht het evenwicht weer is hersteld, zullen de formele controle en de strafmaat weer enigszins kunnen worden verlicht zonder dat dit onmiddellijk een nieuwe fase van normverval inluidt. 


\section{PLURIFORMITEIT EN GEMEENSCHAPPELIJKE WAARDEN IN DE DEMOCRATISCHE RECHTSSTAAT}

\subsection{PLURALITEIT ALS KENMERK VAN ONZE CULTUUR}

Hoe wordt een steeds heterogener wordende samenleving bijeengehouden? Welke waarden zijn zo bindend dat een bepaalde mate van sociale cohesie door en met deze waarden in stand wordt gehouden? Zijn dergelijke waarden inhoudelijk te bepalen of te benoemen? Deze vragen zijn de lastigste die in het waarden- en normendebat aan de orde komen. Ze veronderstellen immers dat een samenleving vooral bijeen wordt gehouden door waarden en niet door militaire kracht, sociaal-economische voorspoed en belangen of praktisch werkzame samenwerkingsverbanden zoals goed functionerende instituties. Een samenleving kan niet zonder enkele richtinggevende ideeën, zoals een van de eerste commentatoren van de moderne samenleving, De Tocqueville, anderhalve eeuw geleden al constateerde (De Tocqueville 1969: 433). Maar welke? En veranderen dergelijke richtingbepalende ideeën (waarden) naarmate een samenleving zelf sterk aan verandering onderhevig is?

Grote maatschappelijke veranderingen hebben ervoor gezorgd dat een moderne samenleving steeds minder uit één stuk bestaat. Deze veranderingen zijn:

a van een min of meer homogeen samengestelde bevolking naar een heterogeen samengestelde bevolking qua herkomst, huidskleur en gezinssamenstelling;

b van een min of meer uniform en christelijk waardebestel naar een pluriform stelsel van waarden qua religie, levensbeschouwing, politieke gezindheid en persoonlijke levensstijl;

c van een minder gedifferentieerd naar een steeds meer gedifferentieerd maatschappelijk bestel qua arbeidsverdeling, specialisatie van functies, systemen van informatieverwerking en allerhande nieuwe beroepen en roepingen;

d van lokaal naar mondiaal bereik qua informatie, kennis en kennisverwerving en beleving van gebeurtenissen.

De Nederlandse samenleving wordt uiteraard al heel lang gekenmerkt door religieuze verscheidenheid, en mede hierdoor eveneens door talloze immigratiestromen die telkens nieuwe 'inwijkelingen' brachten, maar de godsdienstige verscheidenheid vond plaats binnen het grotere verband van de christelijke cultuur. Religieuze tolerantie was langzaam gegroeid. Het uitgangspunt van tolerantie echter is het achterwege laten van negatieve reacties op overtuigingen of handelwijzen waar men het in principe niet mee eens is (Schuyt 2001: 117). Tolerantie veronderstelt vreedzame onenigheid, dus een pluraliteit van opvattingen. Als men op de traditie van tolerantie wijst als een van de geesteskenmerken van de Nederlandse samenleving, dan wijst dat automatisch op een lange traditie van verdeelde opvattingen. 
Pluraliteit is een kenmerk van onze cultuur, maar ze is van karakter veranderd (De Boer en Griffioen 1995). Men kan de oorsprong van pluraliteit zoeken bij de principiële verschillen die er bestaan tussen individuele personen, die in positie, levensloop en ervaringen steeds unieke personen zullen zijn (Arendt 1958; Rescher 1993). Elke unieke persoon krijgt zo een eigen perspectief op de werkelijkheid als geheel, dat nimmer volledig samenvalt met het perspectief van anderen. De politiek dient dan, in Arendts opvatting, deze pluraliteit te eerbiedigen. Maar de pluraliteit kan ook gevonden worden in de vrijwillige vereniging van personen rondom politieke ideeën, religieuze voorkeuren en andere vrijwillige verbanden. De civil society is altijd een gezonde broedplaats van pluriformiteit geweest. Voorts zijn de wisseling van generaties en de verschillen tussen oudere en jonge leden van een samenleving een voortdurende bron van nieuwe waarden of accentverschuivingen in waardebelevingen. Internationale migratiestromen brengen daarnaast nog de gebruiken en opvattingen van andere culturen binnen de landsgrenzen, zoals niet-christelijke godsdiensten, niet-westerse opvattingen en andere tradities. De groei van deze pluriformiteit van waarden ging gepaard met een sterke welvaartsgroei, die persoonlijke autonomie, met name in de keuze van levensbeschouwing en levensinrichting, vergemakkelijkte. Personen 'kiezen' uit de gegroeide veelheid van waarden en overtuigingen nu meer en meer hun eigen 'pakket'. De waarden zijn niet alleen gepluraliseerd, maar ook geïndividualiseerd. Het geïndividualiseerde waardepatroon moet men echter niet al te letterlijk opvatten. Individuen refereren zich nog steeds aan hun nabije omgeving en aan groepen waarin ze verkeren, bijvoorbeeld aan de populaire jeugdcultuur of aan de 'waarden' van bekende televisiepersoonlijkheden. Er blijkt een patroon te herkennen in de veelheid van individuele keuzes. De waarden gelijkheid en vrijheid blijven als de hoofdkenmerken van een burgerlijke samenleving onveranderd bovenaan staan in de European Value Studies. Binnen dit patroon zijn subtiele nieuwe onderscheidingen waar te nemen. Zo komen het onderzoeksbureau Motivaction en het NIPO tot een achttal verschillende waardenoriëntaties, of levensstijlen, van traditionele burgers tot postmoderne hedonisten. De keuze voor bepaalde waarden ligt niet bij voorbaat vast via geboorte, klasse of godsdienst, maar de individuele keuze komt nog steeds door sociale invloeden tot stand.

Deze onvermijdelijke pluraliteit wekt echter toch ook meermalen zorgen, zoals het volgende citaat laat zien.

Het eigentijdse pluralisme werpt echter ook schaduwen af. Op allerlei terrein is de geconstateerde relationaliteit van waarden omgeslagen in een relativisme van waarden. Normen staan op de tocht. Moraal is gemarginaliseerd tot privé-aangelegenheid. Voor hun diepste levensoriëntatie durven mensen vaak nauwelijks uit te komen. Ouders, opvoeders en onderwijzers zien vooral de overdracht van waarden niet meer zitten. Ook levensbeschouwelijke organisaties, zoals christelijke scholen en christelijke politieke partijen, waarin zoveel normativiteit geïnvesteerd is, hebben de grootste moeite met haar eigen identiteit. En allochtonen wekken met hun gehechtheid aan eigen cultuurvormen dikwijls eerder spot en irritatie dan respect. Kortom, het post- 
moderne pluralisme heeft een klimaat van scepsis en cynisme geschapen. Het heeft ook, van de weeromstuit, geleid tot kunstmatig opgeschroefde vormen van absolutisme en fundamentalisme. Over godsdienstig en moreel verval gesproken! (Klapwijk 1994; Klapwijk 1995: 202)

Dit citaat is typerend voor de (christelijke) gedachtegang vanwaaruit de vraag naar de 'fundamentele' waarden en normen al veel eerder, namelijk in 1994, gesteld is. Men erkent de veelheid van waarden en levensovertuigingen, maar tegelijk vreest men een bijkomend verlies van 'centrale' of 'gedeelde' waarden. De bezorgdheid, vaak nog vergezeld van een negatieve beoordeling van het proces van individualisering, leidt derhalve tot de vraag naar de waarden die, gegeven de toegenomen pluraliteit, voor een zekere eenheid of sociale binding in de samenleving blijven zorgen.

\subsection{GEMEENSCHAPPELIJKE WAARDEN}

In het waarden- en normendebat wordt herhaaldelijk verwezen naar 'gemeenschappelijke waarden', maar zelden durft men deze waarden inhoudelijk aan te wijzen. Om welke waarden gaat het? Wat is gemeenschappelijkheid van waarden eigenlijk ? Zijn dit waarden die vanouds bij de nationale gemeenschap horen en worden overdragen of zijn het waarden waar iedereen, of althans een zeer grote meerderheid, bewust mee ingestemd heeft en daar in gedrag en houding blijk van geeft? De uitdrukking 'gemeenschappelijk' zelf wordt vaak willekeurig ingewisseld voor equivalente uitdrukkingen zoals gedeelde waarden (shared values), kernwaarden, cruciale waarden, fundamentele of essentiële waarden, collectieve waarden- en normenstelsels én noodzakelijke waarden (zie onder meer het verslag van het Kamerdebat op 18 december 2002 over waarden en normen, Tweede Kamer 2002-2003).

Op zichzelf zijn deze wisselende woorden heel begrijpelijk. Men zoekt naar 'iets' wat tegelijk zeer moeilijk valt vast te leggen of te grijpen. Vaak ontglipt het meest vanzelfsprekende aan de aandacht. Een gemeenschappelijke taal is waarschijnlijk fundamenteler dan overeenstemming in bepaalde waarden, want om te begrijpen of men het al of niet met elkaar eens is, moet men in elk geval goed met elkaar kunnen communiceren. De taal schept een morele ruimte waarbinnen mensen met elkaar kunnen samenwerken of elkaar kunnen bekampen. De nadruk die bij inburgering van nieuwkomers wordt gelegd op de beheersing van de Nederlandse taal wordt nu vaak gerechtvaardigd met louter instrumentele argumenten ('goed voor het vinden van een baan'), maar wezenlijker is het feit dat men door een goede taalbeheersing en moeiteloze communicatie toegang heeft tot de morele ruimte en zo de morele sensibiliteiten van een gemeenschap leert kennen. Veel morele misverstanden zouden kunnen samenhangen met onvoldoende deelname aan de morele gemeenschap van de samenleving. De beleving en de betekenis van eigen handelingen en die van anderen wordt pas duidelijk als men een taal perfect beheerst. Meer en betere communicatie tussen gevestigden en buitenstaanders is daarvoor nodig. 
Dit geldt zelfs voor onderdelen van de taal, zoals een specifiek jargon. De uitdrukking shared values, een sleutelwoord in de waarden- en normendiscussie, heeft een geheel eigen en specifieke betekenis gekregen. Gedeelde waarden betekenen hier niet zomaar gedeeld, zoals men een ruimte deelt met een ander, of een gemeenschappelijk risico deelt. Het gaat, in de betekenis die Etzioni eraan geeft, om waarden die verinnerlijkt zijn, niet van boven opgelegd, maar doorgegeven via opvoeding en onderwijs en in een traditie opgenomen. Gedeelde waarden worden niet 'overeengekomen', zoals wanneer men een contract sluit of met elkaar een afspraak maakt (Etzioni 1996: 89-91). Gemeenschappelijke of gedeelde waarden dienen, in deze opvatting, aan heel specifieke kenmerken te voldoen, waardoor men - als men zich hier niet van bewust is - verschillende betekenissen hecht aan de sleuteluitdrukking 'gemeenschappelijk'. Afspraken bijvoorbeeld tussen werkgevers- en werknemersorganisaties of tussen coalitiegenoten leiden in deze opvatting niet tot gedeelde waarden, ook al worden belangrijke zaken voor een bepaalde tijd gemeenschappelijk afgesproken.

Gaat het misschien om noodzakelijke waarden, om minimale afspraken die men met elkaar maakt, bijvoorbeeld de afspraak hoe te handelen bij verschillen van inzicht? De uitdrukking agree to disagree wordt vaak beschouwd als het ethisch minimum op grond waarvan een relatie of een sociaal systeem toch kan blijven bestaan. Maar wat betekent hier 'noodzakelijk'? Een rechtsorde, in een of andere vorm, is noodzakelijk voor het vreedzaam samenleven van mensen, maar bij ontbreken van een aantal andere, voldoende voorwaarden, zegt de aanwezigheid van deze ene noodzakelijke voorwaarde niet zo veel. Er zal altijd een belangrijk aantal waarden tegelijkertijd of een stelsel van waarden noodzakelijk zijn om een samenleving mogelijk te maken of in stand te houden.

Gemeenschappelijk of voor het voortbestaan van een samenleving noodzakelijke waarden worden niet 'gevonden', maar zelf gemaakt door de leden van die samenleving en door die leden ook instandgehouden. Die gemaakte waarden en waardevoorkeuren worden in een moderne samenleving, in een democratische rechtsstaat, gewoonlijk neergeslagen in wetten en in een grondwet, die dan ook bij uitstek de moderne 'vindplaatsen' zijn geworden van wat een samenleving als geheel belangrijk en waardevol vindt. Als heel veel leden in een samenleving bepaalde materialistische waarden zoals bezit, eigenbelang of economische voorspoed belangrijker gaan achten dan immateriële waarden als opofferingsgezindheid of naastenliefde, dan verandert daardoor de samenleving zonder dat deze uiteenvalt of zonder dat er sprake is van een algeheel 'verval' van waarden en normen. Een samenleving kan hierdoor heel veel verandering van waarden ondergaan zonder te desintegreren. Dit is een geruststellend inzicht. Samenlevingen passen zich aan aan veranderingen en vernieuwen zich daardoor. Hoe belangrijk opofferingsgezindheid of naastenliefde ook mogen zijn voor de kwaliteit van de samenleving en voor de onderlinge zorg, als deze waarden en deugden niet in groten getale worden gepraktiseerd door burgers, dan zullen uitspraken daarover dat deze waarden 'centrale' of 'belangrijke' waarden van de samenleving zijn, niet helpen. Slimme wetten en goed ingerichte en functione- 
rende instellingen, bijvoorbeeld in belastingwetgeving en gezondheidszorg, kunnen wél aan de realisering van dergelijke waarden bijdragen, maar men moet daarbij oppassen voor overvraging van burgers. In de discussie over de noodzakelijke gemeenschappelijke waarden worden heel veel good weather values genoemd, waarden die hogelijk worden geprezen en aangeraden. Maar juist de vele oproepen tot deze waarden vormen meestal de bevestiging dat ze op een minder florerende steun kunnen bogen in de samenleving. Verandering van die betreurde toestand zal vervolgens voornamelijk uit de samenleving zelf kunnen komen. Elke samenleving krijgt zo de gemeenschappelijke waarden die ze verdient.

In de zoektocht naar gemeenschappelijke waarden van een samenleving wordt vaak verwezen naar een reeks bekende deugden, die bepaalde waarden vertegenwoordigen. Er is zelfs een neo-aristotelische herleving in de aandacht voor deugden die als onmisbaar worden beschouwd voor goed samenleven (Geach 1977; Comte-Sponville 1995; Van Tongeren 2003). Maar de intensieve beschrijving van deze deugden, bijvoorbeeld door Geach die de zeven kardinale deugden heeft beschreven, of de eenentwintig deugden door Comte-Sponville beschreven, brengen één ding helder aan het licht: ze vragen héél veel van mensen, veel meer dan waar burgers in enige samenleving toe kunnen worden verplicht. Wie de deugd van matigheid bepleit als goed voor een samenleving waarin overvloed en onmatigheid bijna normaal geworden zijn, overvraagt burgers. Hetzelfde geldt voor moed, naastenliefde, geloof, hoop, rechtvaardigheid en bezonnenheid. Dergelijke, voor elke samenleving zéér belangrijke waarden, verhogen zonder twijfel het kwalitatieve peil van het samenleven, maar benadrukken juist hun positie: het zijn persoonlijke keuzes en ze berusten op vrijwilligheid. Zoals elke moraal op vrijwilligheid berust. Lofwaardig gedrag kan niet worden afgedwongen. In een staatsbestel gaat het steeds om verplichting tot naleving van normen die nimmer het morele uiterste of het moreel hoogstaande betreffen.

Mutatis mutandis geldt dit voor andere veelgenoemde en veelgeroemde maatschappelijke waarden die als fundamenteel of gemeenschappelijk worden beschouwd: solidariteit, individuele verantwoordelijkheid, duurzaamheid, vrijheid (Woldring 2004; Adriaansens 2004). Afgezien van het probleem van de inhoudelijke onbepaaldheid van deze waarden, kunnen ze niet verplicht worden opgelegd. Ze kunnen dienen als inspirerende bakens voor het handelen, niet als een reeks verplichte figuren die elke burger eerst moet afleggen voor hij/zij tot een vrije kür mag worden toegelaten. Bij wet worden die verplichtingen vastgesteld. Gemeenschapszin, naastenliefde, zorg voor de naaste en solidariteit kunnen wel sterk worden bevorderd door bepaalde onderlinge verhoudingen in gezinnen, in organisaties en in de maatschappij als geheel goed te onderhouden, maar ze kunnen niet bij wet verplicht worden gesteld, althans niet in een samenleving waar de persoonlijke vrijheid wordt beschermd. Bij deugden gaat het niet om absolute beginselen, maar om een opdracht tot praktisch verstandig handelen. Deugden moeten voortdurend beoefend worden om zo tot praktische 
oplossingen te komen in immer lastige dilemma's. Het eigen handelen komt erdoor in discussie en niet uitsluitend het handelen van anderen of van de overheid.

Een geheel andere benadering van de vraag naar gemeenschappelijke waarden biedt de Franse studie Refondation du monde van Guillebaud (1999). Hierin beschrijft hij uitvoerig zes grondwaarden van de westerse cultuur die voortgekomen zijn uit de Griekse, de joodse en de christelijke cultuur. Dit zijn de volgende zes waarden: een geloof in de toekomst, gelijkheid, rede en redelijkheid, universaliteit, individualiteit en rechtvaardigheid. Het geloof en vertrouwen in de toekomst is afkomstig van het joods-messianistische denken, de waarden van gelijkheid en universaliteit zijn via de Stoa door het christendom in het Westen wijdverbreid, de rede en redelijkheid vonden hun oorsprong in het Griekse wonder van de wetenschap en hebben een blijvende invloed op de latere westerse samenlevingen uitgeoefend. Rechtvaardigheid en individualiteit stammen uit elk van deze grote culturen, die langzaam in een onderlinge bevruchting zijn samengekomen in de hedendaagse westerse cultuur. Via het bijbels humanisme en het geseculariseerde humanisme zijn ze alle zes als uitgesproken waarden van de Verlichting naar voren gekomen. Ze vormen een onderlinge samenhang die niet gemakkelijk kan worden doorbroken.

Volgens Guillebaud verkeren alle zes waarden in een ernstige crisis, omdat ze naar zijn mening allemaal onderhevig zijn aan concurrerende maatschappelijke krachten als excessieve bureaucratisering, een streven naar kortetermijnbevrediging, particuliere economische belangen en een excessieve aandacht voor uiterlijkheid en imagovorming in de moderne massamedia. Hij formuleert enkele gevaren die een discussie over waarden en normen - die hij op zichzelf toejuicht - loopt zoals nostalgie ('vroeger was alles beter'), het centraal willen opleggen van waarden die al verloren zijn gegaan ('niemand kan van buiten of van boven af een specifieke leefwijze opleggen aan geëmancipeerde individuen in een vrije samenleving'). Daarnaast wijst hij erop dat het recht in een westerse samenleving niet alléén kan zorgen voor een revitalisering. Daarvoor is een krachtige civil society van en voor burgers onderling evenzeer nodig. Ten slotte wijst hij op het gevaar van moedeloosheid: er komt zo veel op gewone burgers af (biotechnologie, klonen, terrorisme, watersnoden, oorlogen en onveiligheid) dat ze het allemaal niet meer weten en zich op het eigen erf terugtrekken.

Het geloof in de waarden van de Verlichting en van de westerse cultuur wordt daarmee verzaakt, een verwijt dat Guillebaud vooral richt tot de Europese elite. Hoe men ook over de enigszins sombere beoordeling van Guillebaud denkt, zijn zes centrale waarden komen ineens in een scherp licht te staan als men ze contrasteert men hun 'tegenwaarden', zoals op verrassende wijze door Schnabel werd gedemonstreerd (Schnabel 2004). 


$\begin{array}{ll}\text { Grondwaarden van de westerse cultuur } & \text { Tegenwaarden } \\ \text { Toekomstgeloof } & \\ \text { Gelijkheid } & \text { Eerbied voor verleden } \\ \text { Rede/redelijkheid } & \text { Hiërarchie } \\ \text { Universaliteit } & \text { Traditie } \\ \text { Persoonlijke vrijheid, individualiteit } & \text { Particularisme } \\ \text { Rechtvaardigheid } & \text { Collectiviteit } \\ \text { (Guillebaud 1999) } & \text { Privileges } \\ \end{array}$

Door het gelijktijdige contrast van de zes waarden ziet men de cultuur van een premoderne tijd, die zich echter ook heden ten dage ruimschoots aandient, hetzij in een neo-burkeaanse afwijzing van de verlichtingswaarden, hetzij in bepaalde islamitische geloofsculturen waarin persoonlijke rechten ondergeschikt blijven aan collectieve tradities. Maar ook binnen westerse samenlevingen kan men spanningen in de alledaagse praktijk tussen verlichtingswaarden als universaliteit en rechtvaardigheid enerzijds en de aantrekkingskracht van particularisme en privileges anderzijds ruimschoots waarnemen. Een ongeremd economisch neoliberalisme en marktdenken ondermijnt het geloof in de waarde van gelijkheidwaardigheid en gelijke rechten voor iedereen. Sociale uitsluiting, die door moderne opvattingen over arbeid en arbeidsverhoudingen wordt bevorderd, ondermijnt de universaliteit. Manipulatie van de moderne media ondermijnt rede en redelijkheid.

Een contrastplaatje maakt ineens duidelijk dat de waarden- en normendiscussie voldoende aanleiding kan bieden voor een reflectie op de vraag: welke kant wil men individueel en collectief op? Welke waarden blijven richtinggevend? Dit is op zichzelf een manifestatie van het geloof in een toekomst! Met elkaar vormen de zes centrale verlichtingswaarden de garantie voor een open samenleving (Popper 1946). In een open samenleving is ruimte voor zelfstandig en onafhankelijk wetenschappelijk onderzoek en wordt de vrijheid van meningsvorming en meningsuiting als een vanzelfsprekendheid beschouwd. Kritiek op machthebbers en publieke gezagsdragers wordt niet afgewezen of onmogelijk gemaakt. De kracht van een open samenleving bestaat vooral in het bevorderen van variatie en pluriformiteit, waardoor een constante vernieuwing van het denken en van maatschappelijke verhoudingen mogelijk wordt. De relatief autonome maatschappelijke sectoren (van de vrije markt en het bedrijfsleven, de vrije wetenschap, de media, het openbaar bestuur en wetgeving, van de niet-gouvernementele organisaties (NGO's), van kunst en cultuur) houden elkaar in evenwicht en zorgen ervoor dat macht niet kan stollen in de handen van enkelingen of van kleine elites die niet meer worden gecontroleerd of verantwoording dienen af te leggen. In een open samenleving leert men van elkaar en van de eigen fouten. Een lerende, open samenleving maakt de weg vrij voor participatie van vele burgers en staat in schril contrast tot een gesloten kastenmaatschappij en tot een hiërarchisch ingerichte theocratie. 
Toch zijn ook de hier geformuleerde westerse grondwaarden niet zonder problemen. Zij zijn, zoals alle waarden, uiterst abstract en onbepaald. De 'wisselkoers' van hun waarde is in de loop van de laatste twee eeuwen zéér schommelend geweest en ze zijn op zéér uiteenlopende wijzen in wetten en rechten, in instituties en organisaties neergeslagen. Bovendien staan ze zelf met elkaar op gespannen voet, zoals de eindeloze discussies over de verhouding tussen persoonlijke vrijheid (individualiteit) en gelijkheid bewijzen. Juist vanwege de voortdurende aanwezigheid van dergelijke waardeconflicten is het niet verwonderlijk dat pluralisme en de onvermijdelijkheid van morele waardeconflicten vaak als hét gemeenschappelijke kenmerk van de westerse samenleving wordt genoemd. Waardeconflicten zijn onvermijdelijk vanwege schaarste van te verdelen goederen, vanwege de beperkte welwillendheid van de meeste mensen, vanwege de onverenigbaarheid van gelijktijdig nagestreefde waarden en vanwege het onvolledige begrip tussen mensen (Gutmann en Thompson 1996: 25). Men kan van deze tekorten, deze nood, een deugd maken. Een democratie, waarin op slimme wijze manieren zijn gevonden om met al deze verschillen redelijk vreedzaam om te gaan, is de minst slechte staatsvorm. Niet het zoeken naar inhoudelijk gedeelde of gemeenschappelijke waarden als zodanig, maar het aanvaarden van blijvende, niet op te lossen verschillen in afwegingen tussen verschillende waarden, wordt als het uitgangspunt genomen voor de inrichting van de samenleving. De democratische rechtsstaat biedt ruimte voor pluralisme van waarden en vertegenwoordigt zelf ook belangrijke waarden als vrijheid, gelijkberechtigdheid en de bescherming van persoonlijke en collectieve rechten. De staat reikt bovendien procedures aan om de onvermijdelijke conflicten over waarden en normen in de samenleving op niet-gewelddadige wijze - en op anderszins nietdestructieve manieren - te behandelen en te beslechten. Pluraliteit als waarde die de realisering van andere verschillend gekozen en geïnterpreteerde waarden mogelijk maakt.

De pretenties van deze oplossing, met name het procedurele karakter ervan, zijn de inzet geworden van een stevige discussie tussen liberale filosofen en voorstanders van een communitaristische benadering van de samenleving. Omdat het waarden- en normendebat zeer sterk onder invloed staat van deze theoretische uiteenzettingen over de waarde en de waarden van een procedurele democratie, wordt dit debat als onderdeel van dit rapport hier kort samengevat en van een voorlopige conclusie voorzien.

\subsection{LIBERAAL DENKEN EN GEMEENSCHAPSDENKEN}

Het debat over waarden en normen heeft een politiek-filosofische achtergrond. Al meer dan twintig jaar is er in de voornamelijk Angelsaksische politieke filosofie een discussie gaande tussen aan de ene kant voorstanders van een liberale inrichting van staat en samenleving en aan de andere kant critici van deze liberale aanpak, die onder de brede noemer van het communitarisme een benadering voorstaan waar de waarden van traditionele gemeenschappen worden gewaardeerd en weer centraal worden gesteld bij vragen over de inrichting van een 
goede samenleving. Deze discussies hebben ook in Nederland weerklank gevonden. Zo besteedde het Schoordijk Instituut in Tilburg reeds in 1993 in seminars en congressen zeer ruime aandacht aan de denkbeelden van de diverse protagonisten. In het verslag van deze Tilburgse activiteiten onder de titel Gedeelde normen? wordt reeds ingespeeld op het "verband met het pleidooi in de Nederlandse politiek voor een herwaardering van waarden en normen (CDA) en met de oproep tot burgerzin (PVDA)" (Van Klink, Van Seters en Witteveen 1993: 9). De uitdrukking 'waarden en normen' lijkt rechtstreeks ontleend te zijn aan de shared values die veelvuldig bij communitaristische auteurs voorkomen. Bij de korte uiteenzetting van deze relevante politiek-filosofische discussie past echter een waarschuwing vooraf. De term 'liberaal denken' heeft in de Angelsaksische wereld een andere betekenis dan in de Nederlandse politiek. Het slaat vooral op personen die de waarden van de Verlichting, met name de instelling van persoonlijke rechten en andere op gelijkheid gerichte waarden zoals rechtsgelijkheid, onpartijdigheid en onbevooroordeeldheid, toegepast willen zien in de politieke orde en in de staatsinrichting. Deze voorkeur kan samengaan met zowel een behoudende politieke opstelling ten aanzien van staatsinvloed als met een meer progressieve opvatting over staatsinmenging. Liberal staat zowel voor liberaal in een klassieke betekenis als voor liberaal-progressief. Als zodanig onderscheiden de liberale politieke denkers zich ook van de ultraliberale voorstanders van een ongeremde vrijemarkteconomie die elke vorm van staatsinvloed op het economische en sociale leven afwijzen. Zij zien de staat uitsluitend als hindernis of hooguit als instrument voor het eigenbelang en voor een op hedonistische consumptie gerichte levensstijl. Dit ultraliberalisme staat ver af van politiek filosofen als Rawls, Nozick, Gutman en anderen, die gewoonlijk als liberals te boek staan.

De liberals staan uitdrukkelijk tegenover een conservatieve houding in staatsaangelegenheden die bijvoorbeeld in het neo-burkeaanse denken naar voren komt en die aan de staat een uitdrukkelijke opdracht geeft in morele kwesties (family values, abortus, patriottisme) krachtig orde op zaken te stellen. Ook de communitaristen onderscheiden zich van deze conservatieve benadering van het 'waarden'-vraagstuk (Etzioni 1996). Het communitarisme zoekt als het ware een middenweg tussen het liberalisme en het conservatisme.

De kritiek van de communitaristen, zoals de spraakmakende filosofen MacIntyre, Sandel, Walzer, Taylor, de politicoloog Barber en de bekende sociologen Etzioni en Selznick, is vooral gericht op het verschraalde mensbeeld dat uit de liberale oplossing van de problemen van het menselijk samenleven naar voren komt. Hun kritische pijlen werden met name gericht op het werk van auteurs als Rawls (A Theory of Justice), Dworkin, Gautier, Ackerman en Gutmann, die allemaal in een of andere versie een neutrale houding van de staat bepleiten ten aanzien van de vele morele waarderingen die burgers aan de dag kunnen leggen. Juist door die terughoudendheid en neutraliteit wordt de mogelijkheid van eenieder om zelf inhoud en vorm te geven aan het goede leven het grootst. Persoonlijke rechten, bijvoorbeeld het belijden van een eigen godsdienst, zijn in 
grondwet en andere wetten verankerd en dienen ervoor om een zone van individuele vrijheid af te schermen tegen publieke inmenging. Zo ontstaat er een minimale consensus over hoe de staat zich, vooral via neutrale procedures, ten opzichte van deze precaire zones dient op te stellen.

Die minimale consensus als basis voor gemeenschappelijke waarden wordt door de communitaristen niet voldoende geacht. Sterker zelfs, juist vanwege de neutrale en minimalistische opstelling verschralen de waarden in de samenleving en krijgen ze te weinig aandacht en bescherming. Waarden en zingeving worden niet in het vrije individu gevonden, maar ontstaan in tradities, in levende gemeenschappen zoals in het gezin, in geloofs- en kerkgemeenschappen, op scholen, in buurtgemeenschappen en in andere, grotere eenheden. Een gemeenschap is er eerder dan het individu en een persoonlijke identiteit, zo noodzakelijk in de moderne hedendaagse wereld, bloeit pas op te midden van een groep of gemeenschap. Taylor (1989) noemt ze dan ook treffend sources of the self. De gemeenschappen zijn bronnen van waarden en zo ook van persoonlijke identiteiten. In het communitarisme wordt het individualisme, dat ten grondslag ligt aan de moderne staat, negatief beoordeeld, althans er wordt herhaaldelijk gewezen op de vele negatieve bijverschijnselen die de nadruk op individuele rechten heeft opgeleverd. Zo is er meer aandacht gekomen voor rechten dan voor plichten (bijvoorbeeld aan de gemeenschap), het mensbeeld is verschraald en versmald tot contracterende en calculerende individuen. Neutrale procedures hebben geleid tot een 'waarden-loze' samenleving. Eerherstel voor tradities, voor oude en nieuwe gemeenschappen met hun eigen waarden en voor deugden zouden het antwoord moeten zijn op een steeds verder fragmenterende en atomiserende moderne samenleving waarin de cohesie is gaan ontbreken. Deze opstelling betekent geenszins een heimwee naar vroeger, omdat concrete beleidsvoornemens die van de communitaristische agenda kunnen worden afgeleid ook op moderne problemen betrekking hebben. Etzioni bepleit uitdrukkelijk bijzondere aandacht voor de plaats van het gezin en de familie in de samenleving, voor de positie van sociaal zwakkeren en voor duurzaamheid van het milieu als uitdrukking van een traditionele verbondenheid tussen generaties (Etzioni 1993, 1996). De banden die mensen aan elkaar verbinden mogen niet worden doorgeknipt, omdat anders een samenleving uit elkaar valt. 'Bindende waarden' is derhalve waar het vooral om gaat.

Om te beoordelen in hoeverre deze communitaristische kritiek op het overheersende liberale denken helemaal terecht is, moet men allereerst bedenken dat de twee tegengestelde stromingen niet als twee massieve blokken tegenover elkaar gesteld kunnen worden. Er zijn liberal-liberals en communitarian-liberals, zoals er ook liberal-communitarians zijn. Er bestaan vele nuances binnen elk kamp. Sommige auteurs willen zelfs helemaal niet bij een van de kampen worden ingedeeld, zoals MacIntyre die met zijn deugdenleer juist een aanzet heeft gegeven tot de communitaristische kritiek. In alle eerlijkheid mag men ook de liberale opvattingen niet een traditie of waardering voor de traditie ontzeggen, omdat ze hun ideeën over tolerantie, godsdienstvrijheid, gelijkheid en vrijheid uiteraard 
ontlenen aan een lange geschiedenis en hierin voortbouwen op het gedachtegoed van onder anderen Locke, Kant, Smith en Mill. Het pleidooi voor de scheiding van kerk en staat is in deze traditie dan ook niet voortgekomen uit een minachting voor godsdienst of godsdienstigheid, maar uit het historische gegeven dat godsdienst door sommige van zijn aanhangers zó belangrijk wordt gevonden dat hij kan leiden tot bittere godsdienstoorlogen en andere destructieve daden. Het liberale denken ontkent ook geenszins het belang van groepen en levende gemeenschappen voor het reilen en zeilen van een samenleving. Maar er kan en moet onderscheid gemaakt worden tussen de oorzakelijke totstandkoming van waarden, identiteiten en individualiteit (daarvoor is een gemeenschap inderdaad onontbeerlijk) en de politieke toekenning van waarden en rechten aan een individu. Het individu is weliswaar geen source of value, maar daarom nog wel een locus of value. Dit laatste wordt weer door geen enkele communitarist ontkend, zodat de verschillen tussen de twee politiek-filosofische stromingen eerder van theoretische dan van praktische aard blijken te zijn.

Rawls heeft trouwens zijn theorie van een rechtvaardige - en voor eenieder aanvaardbare - inrichting van staat en samenleving naar aanleiding van de communitaristische kritieken enigszins bijgesteld. In plaats van het zoeken naar een minimale consensus, pleitte hij in zijn nieuwe studie Political Liberalism (1993) voor een overlapping consensus, die daarnaast ook niet meer strikt waardenneutraal hoefde te zijn. Van een overlappende consensus is sprake indien partijen het eens worden over een bepaald resultaat, zonder dat ze het eens hoeven te zijn of te worden over de vele redenen waarom men tot dat resultaat gekomen is. Zoals een wetgevend lichaam, een rechterlijk college of een benoemingscommissie het uiteindelijk eens kan worden over een bepaald wetsontwerp, over een rechterlijk oordeel of over een voorgestelde kandidaat, terwijl de beweegredenen om met dit resultaat in te stemmen zeer uiteen kunnen lopen, zo kan men bij de inrichting van staat en samenleving als geheel vooral letten op datgene waar men het uiteindelijk over eens is, zonder vervolgens te letten op de vele mogelijke metafysische, godsdienstige of andere verschillen van mening en inzicht. Rawls gaat hierbij uit van het realistische inzicht dat het toch nooit zal lukken dat gelovigen van het ene geloof, gelovigen van een ander geloof of overtuigde ongelovigen zullen overtuigen (persuasion). Het omgekeerde valt ook niet te verwachten. Kritiek van ongelovigen op gelovigen heeft meestal weinig gevolg. In die situatie is het beter om niet te streven naar uiteindelijke, gemeenschappelijke waarden, maar om het eens te worden over een aantal beginselen, zonder het eens te hoeven worden over de redenen van de overeenstemming (Rawls 1993: 15): "We should not expect citizens to agree on fundamentals as a condition for their acceptance of particular political arrangements", waarbij hij met deze arrangementen de rechtsstaat en de democratische staatsvorm bedoelt (1993: 9-11 en 133-172). De voor ieder verschillende redenen zijn met waarden beladen, zodat de politieke inrichting niet meer als volledig neutraal kan worden voorgesteld ten opzichte van die waarden. Waarden zijn vrij en verschillend, de staatsinrichting is dat niet meer. 
Ten aanzien van de kritiek van de communitaristen dat een liberale staatsinrichting louter procedurele oplossingen biedt en dat dit de samenleving qua waardebeleving en gemeenschapszin verarmt, is een krachtiger weerwoord gekomen van enkele commentatoren. Zo is het begrip gemeenschap bij de communitaristen wel erg vaag gehouden, zoals ook ruiterlijk wordt toegegeven in een van de recente samenvattingen van dit programma, namelijk in Selznicks The Communitarian Persuasion: "for many thoughtful people community is a very troublesome idea - frustratingly vague, elusive, even dangerous" (Selznick 2002: 16). Bij Etzioni is de samenleving opgebouwd als een stelsel Chinese doosjes: het individu is ingebed in de gemeenschap van gezin en familie, die weer is ingebed in school en buurt, die weer zijn ingebed in godsdienstige gemeenschappen of beroepsgemeenschappen of in een herkenbare gemeenschap van streek en natie, totdat er uiteindelijk een community of communities ontstaat (Etzioni 1996). Maar al deze gemeenschappen worden volgens enkele critici (Sennett 1997; Shapiro 2003) veel te rooskleurig voorgesteld, alsof er nooit sprake is van conflicten binnen en tussen gemeenschappen. Verwijzingen naar het verleden en naar een levende traditie, bijvoorbeeld die van het natuurrecht, doen geen recht aan de historische werkelijkheid. Zo wijst Shapiro erop dat godsdiensten niet uitsluitend gemeenschapszin hebben voortgebracht, maar in de loop der geschiedenis juist vele malen zijn verscheurd vanwege de vele meningsverschillen over de juiste uitleg en interpretatie van heilige boeken of teksten. Ook de geschiedenis van het natuurrecht kent meer perioden van onenigheid dan van overeenstemming (Shapiro 2003: 176). Vaak worden binnen die gemeenschappen conflicten van velerlei soort ofwel verdrongen en verzwegen ofwel hiërarchisch onderdrukt. Zo heeft de katholieke kerk een lange traditie van autoritaire conflictoplossing en werden uiterst immorele gedragingen van priesters in de Amerikaanse kerkprovincie jarenlang van hogerhand verborgen gehouden. Ook in gezinnen ontbreekt het vaak aan een goede manier om conflicten tussen ouders en kinderen op een niet louter op macht gebaseerde wijze aan de orde te stellen en op te lossen. Shapiro concludeert droogjes dat: "In short, appealing to affective communities such as churches or families as a means of wishing away disagreement and conflict of interest seems a less than promising strategy for developing models of legitimate political arrangements" (ibidem). Waar een exit-optie ontbreekt of zeer moeilijk is, zoals in gezinnen en in enkele etnische gemeenschappen, zou participatie in plaats van hiërarchische onderdrukking, bespreekbaar maken (voice) in plaats van stilzwijgen, juist bevorderd moeten worden (zie ook hoofdstuk 6). Procedures voor conflictbescherming kunnen ook in bloeiende en levende gemeenschappen niet gemist worden, zodat de voorkeur van liberale denkers zoals Rawls voor goed geregelde procedures voor conflictbeslechting binnen en tussen groepen en voor de gehele samenleving niet tot een verwijt van bleekheid, maar tot navolging zou moeten leiden. Sennett (1997) vraagt zich in een recensie van Etzioni's hoofdwerk af waar in de communitaristische visie conflicten tussen bijvoorbeeld vakbonden en werkgeversorganisaties, tussen de ene en de andere buurtgemeenschap, tussen belangenorganisaties onderling, tussen leiders en geleiden en dergelijke een plaats krijgen. Als men tot overeenstemming komt en zich aan de uitkomst gebonden acht, waarom zou dat 
dan minder waard zijn dan shared values die rechtstreeks uit een authentieke gemeenschap voortkomen? Aan conflicten kan men de eigen visie, de eigen waardevoorkeuren en de eigen positie scherpen. Verschillen van inzicht worden des te beter waarneembaar als men tot een vergelijk of compromis komt: "The scene of conflict becomes a community in the sense that people learn how to relate to one another, even as they understand better and feel keenly their differences" (Sennett 1997: 3). Afspraken en contracten, belangenverschillen en compromissen, afwijkende meningen en het vinden van een modus vivendiconflicten en hun beslechtingen zijn niet minder een noodzakelijk onderdeel van de moderne samenleving dan gemeenschappelijke waarden die mensen met elkaar verbinden.

Overigens wordt het belang van een kritische houding jegens oude en gesloten gemeenschappen niet ontkend door de twee meest vooraanstaande communitaristische sociologen, Selznick en Etzioni (Selznick 1992, 2002; Etzioni 1996, 2001). In zijn studies over het belang van een morele orde voor de samenleving wijst Etzioni herhaaldelijk op de erkenning van persoonlijke rechten, die ook kunnen worden doorgetrokken naar de sfeer van grote particuliere organisaties en andere sociale verbanden. Selznick had al veel eerder gewezen op de noodzaak van participatie in de besluitvorming van grote organisaties en bureaucratieën. Maar anders dan liberale denkers zijn zij van mening dat dergelijke rechten moeten zijn ingebed in een sociale orde, die zelf doortrokken is van morele waarden. Deze liggen ten grondslag aan elke vorm van samenleven. Selznick gebruikt hiervoor de enigszins vage, maar inspirerende beeldspraak infused with values. Waarden druppelen, als door een infuus, langzaam door naar organisaties en andere vormen van samenleven, en ze beïnvloeden zo de samenleving als geheel, die daar alleen maar sterker en frisser van wordt. De sociale orde wordt aldus een morele orde, een klassiek sociologisch inzicht dat reeds eerder door Durkheim werd geformuleerd. Die morele orde heeft het primaat. Etzioni gaat in zijn recentste studie The Monochrome Society (2001) zelfs zover dat hij aan de staat en de overheid dan ook geen rol wil toekennen in het bevorderen of het terugroepen van deze morele orde. De revitalisering van 'waarden en normen' dient uit de samenleving en uit de zelfstandige sociale en morele verbanden zelf voort te komen (Etzioni 2001; zie ook Reinders 2003).

Uit het voorgaande valt te concluderen dat de nadruk op gemeenschap en het wijzen op het belang van levendige tradities waarin verschillende waarden in stand worden gehouden, zoals dit in het gemeenschapsdenken wordt bevorderd, op geen enkele manier de noodzaak van een democratische rechtsstatelijke inrichting van staat en samenleving uitsluit. Er is geen enkele gemeenschapsdenker die de persoonlijke rechten van het individu, zoals neergelegd in grondwet en grondrechten, ondergeschikt zou willen maken aan het behoren tot een gemeenschap. Grondrechten maken bloeiende gemeenschappen juist mogelijk. Het zelfstandige belang van dergelijke gemeenschappen en van het ontwikkelen, onderhouden en doorgeven van morele waarden, zoals door communitaristen benadrukt, worden daarentegen ook geenszins ontkend door liberale denkers. 
Het belang van de erkenning van de rechten van het individu moet naar hun mening echter stelselmatig onderscheiden worden van het sociologisch proces van individualisering, waarvan de keerzijden kunnen worden onderkend en benoemd. Maar diezelfde persoonlijke rechten zouden ook de donkere zijden van het behoren tot een gemeenschap kunnen verlichten en verminderen. Zodat uiteindelijk, by the end of the day, de hoog opgegeven verschillen tussen het liberale denken en het gemeenschapsdenken niet tot radicaal tegenover elkaar staande standpunten hoeven te leiden. Beide stromingen hechten zeer grote waarde aan de democratische rechtsstaat als onbetwistbare grondslag voor de inrichting van het goede leven, hoezeer de opvattingen over dit goede leven en over de waarden die daarin het meest geëerbiedigd dienen te worden, ook uiteen blijven lopen. De democratische rechtsstaat biedt aldus het gemeenschappelijke uitgangspunt voor een veelheid van uiteenlopende waarden. De rechtsstaat biedt ruimte voor pluralisme, vertegenwoordigt zelf ook belangrijke waarden, zoals neergelegd in grondrechten en andere wetten, en biedt ruime mogelijkheden tot het bijleggen, al is het voorlopig, van talrijke, onvermijdelijke conflicten over waarden en normen en over de concrete interpretaties en realisaties van deze waarden en normen.

\subsection{DE WAARDE EN DE DYNAMIEK VAN DE DEMOCRATISCHE RECHTSSTAAT}

Tot zover is de democratische rechtsstaat geschetst als een kader bij uitstek voor pluriformiteit van waarden. In inhoudelijk opzicht zijn het vooral de klassieke grondrechten die een sfeer van vrijheid tegenover in de eerste plaats de staat beogen te garanderen; ook een democratisch optredende meerderheid moet deze in beginsel ontzien. Van meer procedurele aard zijn het principes als de gelijkheid van alle burgers voor de wet en de aanwezigheid van een onafhankelijke rechter. Het eerbiedigen van deze waarden van de democratische rechtsstaat is een essentiële voorwaarde voor pluriformiteit van waarden in het algemeen. Er is in zoverre sprake van een verplichtende consensus.

De rechtsstaat is een concept dat is ontstaan met het oog op de verhouding staatburgers: machtenscheiding, het legaliteitsbeginsel, onafhankelijke rechtspraak en klassieke vrijheidsrechten beoogden te beschermen tegen staatswillekeur en zo de achterliggende waarden van individuele vrijheid, voorspelbaarheid en gelijkheid te beschermen. Zo bezien gaat het primair om een neutraal kader dat ruimte laat voor pluriformiteit. De feitelijke pluriformiteit van waarden, het bestaan van een verscheidenheid aan fundamentele opvattingen tussen individuen en tussen groepen, is hiermee bijna een vanzelfsprekendheid. Een verdienste van de democratische rechtsstaat is nu dat hij niet alleen ruimte laat voor deze verschillen, maar ook duidelijke aanknopingspunten biedt om de botsing van opvattingen binnen redelijke perken te houden: de democratische rechtsstaat als bindmiddel in een pluriforme samenleving. Kort gezegd: de staat ontziet ieders vrijheden; noodzakelijke beperkingen gelden voor ieder gelijk; beperkend optreden van individuen of groepen tegen fundamentele waarden van medeburgers 
zal vrijwel altijd op staatsingrijpen (met name strafrecht) kunnen rekenen; groepen hebben de mogelijkheid om hun fundamentele waarden in politieke programma's te vertalen en te trachten deze te realiseren, maar ook als hun standpunt een meerderheid verworven heeft, geldt dat de vrijheidsrechten van anderen moeten worden ontzien. De werking van democratische en rechtsstatelijke principes moet immers een grens vinden waar zij tot hun eigen ondergang zouden leiden.

De waarde of de betekenis van de democratische rechtsstaat gaat intussen veel verder. In de eerste plaats gaat het toch om een aantal inhoudelijke waarden, zoals de gelijkwaardigheid van de burgers, de vrijheid om hun eigen levensovertuiging te volgen, de mogelijkheid om zich te ontplooien zonder dat een willekeurig optredende overheid, andere burgers of materieel gebrek daarbij onnodig in de weg staan. Dat inhoudelijke waarden als vrijheid, gelijkheid en solidariteit geen scherp omlijnde begrippen zijn, maar zich voor allerlei interpretaties lenen is bekend, en dat bij hun vaak botsende concretisering allerlei afwegingen onvermijdelijk zijn is dat evenzeer. Waar het hier om gaat is dat zij als voorwaarden voor een samenleving waarin menselijke waardigheid voorop moet staan steeds een centrale plaats innemen.

Het tweede essentiële element is dat ieders invloed op de overheidsbesluitvorming verzekerd is. De bescherming van de inhoudelijke waarden en hun onderlinge afweging door de wetgever en door het bestuur kunnen langs de democratische kanalen beïnvloed worden. Dat een reële mogelijkheid tot participatie niet alleen per definitie een essentiële pijler is van het systeem van de democratische rechtsstaat spreekt welhaast vanzelf. Tegelijk houdt dit democratische aspect de mogelijkheid van verandering en aldus een essentiële openheid in. Het is die veranderbaarheid die ook is waar te nemen in de concretisering van basiswaarden als vrijheid en gelijkheid: terwijl de gehuwde vrouw in de democratische rechtsstaat Nederland tot 1956 nog als (civielrechtelijk) handelingsonbekwaam werd aangemerkt, kan nu discriminatie wegens (onder meer) iemands geslacht een inbreuk op het gelijkheidsbeginsel en zelfs een strafbaar feit opleveren.

Bescherming en garanties zijn de trefwoorden waarmee het derde element van de rechtsstaat kan worden aangeduid. De inhoudelijke waarden kunnen nog zozeer leidraad zijn bij democratisch gelegitimeerd en gecontroleerd optreden, in een aantal opzichten zijn extra voorzieningen gewenst; bepaalde inhoudelijke waarden zijn te belangrijk om met stilzwijgende instemming van een democratische meerderheid te kunnen worden aangetast. Grondrechten, die in veel gevallen slechts door de wetgever kunnen worden beperkt (en soms ook door deze niet), vormen het meest sprekende voorbeeld; de mogelijkheid om geschillen aan de onafhankelijke rechter voor te leggen kan als een tweede garantie worden aangemerkt. Dat de grondrechten te beschouwen zijn als uitwerkingen van de inhoudelijke waarden van vrijheid, gelijkheid en solidariteit is duidelijk, zoals zij ook het aspect van de democratische participatie beschermen. 
Ten slotte biedt de onafhankelijke rechter in de rechtsstaat een geregelde manier om geschillen zo al niet bij te leggen dan toch in elk geval op vreedzame wijze te beslechten. Samen met de parlementaire besluitvorming staat de rechterlijke beslissingsbevoegdheid model voor een niet gewelddadige, niet fanatieke manier om met onvermijdelijke conflicten om te gaan.

De democratische rechtsstaat is zo bezien dus veel meer dan het neutrale kader dat ruimte laat voor pluriformiteit waarvan eerder gesproken werd. Hij drukt wel degelijk zelf ook waarden uit, die weliswaar pas praktische betekenis krijgen als zij worden toegepast en uitgewerkt, maar die tegelijk richtinggevend zijn. De verschillende, meer procedurele en meer inhoudelijke elementen van de democratische rechtsstaat zijn in onze visie niet te scheiden: de keuze voor de ene kant impliceert als vanzelf die voor de andere. En daar is ook weinig mis mee, nu de democratische rechtsstaat in zijn ideale vorm ruimte biedt voor pluriformiteit, openheid, flexibiliteit en dynamiek binnen een geregeld kader dat ieder ruimte biedt om tot zijn/haar recht te komen.

Pluriformiteit en dynamiek en zeker vrijheid en dynamiek zijn aldus onlosmakelijk met elkaar verbonden. Bij de verschillende waardesystemen en pluriformiteiten die wij intussen hebben onderscheiden hoort derhalve ook een dynamiek op vele fronten. Ook de regels en beginselen van de rechtsstaat zelf zijn niet voor eens en altijd gegeven. Door de open interpretaties van deze regels, begrippen en beginselen ontstaat er een ingewikkeld netwerk van zich ontwikkelende normen. Belangrijke elementen die de vorm van de rechtsstaat bepalen, zoals de verhoudingen binnen de trias politica, de inhoud van het legaliteitsbeginsel en de positie van de rechter, zijn wezenlijk anders dan een eeuw geleden, en ondergaan ook nu voortdurend invloed van veranderende omstandigheden. Voor de rol van achterliggende principes als vrijheid en gelijkheid geldt hetzelfde.

Wellicht het sterkst zijn de veranderingen geweest bij de grondrechten. In aantal, type en betekenis zijn zij sterk gegroeid, een ontwikkeling die tot een grotere ruimte voor pluriformiteit zou moeten leiden en die, zolang die verscheidenheid zich binnen de kaders van de rechtsstaat blijft bewegen, zeker niet negatief beoordeeld moet worden. In combinatie met de door immigratie, individualisering en andere oorzaken sterk gegroeide feitelijke verscheidenheid aan waarden bij de Nederlandse bevolking, blijkt de onderlinge verhouding tussen verschillende grondrechten echter steeds vaker vragen op te roepen. De ook in de adviesaanvraag aangekondigde kabinetsnota over grondrechten in een pluriforme samenleving zal, naar de raad heeft begrepen, ook de vereiste feitelijke informatie bevatten, reden waarom de volgende paragraaf zich vooral tot een afweging kan beperken. 


\section{5 -5 BOTSENDE WAARDEN, BOTSENDE GRONDRECHTEN}

\section{Grondrechten en hun beperkingen ${ }^{1}$}

Door de klassieke grondrechten worden bepaalde vrijheden, zo men wil bepaalde aspecten van vrijheid, zoals die van godsdienst of van meningsuiting, beschermd tegen staatsingrijpen. Pluriformiteit van opvattingen en van handelen is strikt genomen niet de doelstelling van de grondrechten, maar zij is wel als vanzelfsprekend vooraf aanwezig en even vanzelfsprekend is zij ook een uitvloeisel van de grondrechtelijke vrijheden.

De bescherming tegen staatsingrijpen is niet onbeperkt: gebruikelijk is dat in één adem vermeld wordt in hoeverre en hoe beperking kan worden aangebracht. De methode die daarbij wordt voorgeschreven, bijvoorbeeld bij de wet (zie de grondwet), of de beperkte redenen waarom tot inperking mag worden overgegaan (zie het Europees Verdrag tot bescherming van de rechten van de mens en de fundamentele vrijheden, verder EVRM) moeten de nodige garanties bieden. Intussen kunnen de beperkingen een zeer gevarieerd karakter hebben. In veruit de meeste gevallen zijn slechts overwegingen aan de orde die met andere grondrechten niets van doen hebben, zoals overwegingen van rust en orde die de oproeping tot gebed of het houden van processies reguleren of bescherming tegen belediging of smaadschrift als grenzen - achteraf - aan het gebruik van de uitingsvrijheid.

Een burger of een groep burgers die meent dat een grondrecht te zeer door een overheidsmaatregel (wetgeving of bestuur) is beperkt kan, of die beperking nu mede is ingegeven door de bescherming van (andere) grondrechten van anderen of door volledig andere overwegingen, die maatregel in een lopende procedure ter toetsing aan de rechter voorleggen (tenzij het gaat om een formele wet die strijdig zou zijn met de grondwet). De rechter zal letten op de kern van het grondrecht en op de methode van beperking (bij toetsing aan de grondwet), of ook accent leggen op de vraag of de beperking in een democratische samenleving nodig is in het belang van de bescherming van een van vele (openbare) belangen (EVRM). Bij die belangen horen ook (andere) grondrechten, maar men lette op (het overigens vooral in relatie tot politieke partijen met extreme opvattingen gehanteerde) artikel 17 van het EVRM: "Geen der bepalingen van dit Verdrag mag worden uitgelegd als zou zij voor een Staat, een groep of een persoon een recht inhouden enige activiteit aan de dag te leggen of enige daad te verrichten met als doel de rechten of vrijheden die in dit Verdrag zijn vermeld teniet te doen of deze verdergaand te beperken dan bij dit Verdrag is voorzien." Geen misbruik van grondrechten dus als argument om andere grondrechten te beperken. In dezelfde lijn ligt de algemeen onderschreven opvatting dat de sociale grondrechten geen basis vormen voor beperking van de klassieke.

\section{Botsing van grondrechten (1)}

Als alleen op grond van of zelfs alleen door algemene regels vrijheidsrechten beperkt kunnen worden en als ook consequent (via het strafrecht) wordt opge- 
treden tegen bedreigingen ervan door (groepen) medeburgers, kunnen de grondrechten hun functie als garanties voor pluriformiteit van waarden in de samenleving blijven vervullen.

Bij dit soort beperkingen van overheidswege is strikt genomen, en in elk geval direct, van botsing van grondrechten geen sprake; het gaat er slechts om of de beperking aan de daarvoor gestelde formele en materiële eisen voldoet. Van botsing van grondrechten wordt in de literatuur alleen gesproken als in een geschil tussen twee burgers of tussen een burger en een niet-overheidsinstantie beide partijen zich beroepen op een grondrecht, soms zelfs op verschillende aspecten van hetzelfde grondrecht. Als bijvoorbeeld een school zich beroept op de vrijheid van onderwijs om kledingvoorschriften te hanteren en de leerling zich op de vrijheid van godsdienst beroept om zich daaraan niet te hoeven onderwerpen, of, tweede situatie, als zowel het slachtoffer van een verkrachting als de dader zich beroept op het recht op lichamelijke integriteit als zij een aidstest (bij de dader) eisen, respectievelijk weigeren. Indien zich dit soort botsingen van een bepaald type veelvuldig voordoet, dan kan de wetgever richtinggevend optreden door, onder meer, zijn beperkte mogelijkheden tot beperking van een of beide grondrechten te gebruiken. Hij kan dit uiteraard ook, als bepaalde conflicten verwacht worden, bij voorbaat doen. Botsing van grondrechten in de oorspronkelijke zin doet zich dan niet voor, maar uiteraard is wel sprake van spanning tussen verschillende grondrechtelijk beschermde waarden.

Hoe dit ook precies zij, als botsing van grondrechten aan de orde is, is het betrekkelijk eenvoudige beeld van overheidsterughoudendheid om vrijheden en daarmee pluriformiteit te waarborgen, ruimschoots verstoord.

In de eerste plaats wijst het verschijnsel erop dat grondrechten inmiddels meer zijn dan de formulering van een vrij klein aantal (aspecten van) vrijheden tegenover de staat (a). In de tweede plaats, en dat is in dit verband van meer belang, roepen meer botsingen meer vragen op tot conflictbeslechting, of dit nu door de rechter of door de wetgever is. Het onvermijdelijke resultaat is beperking, ad hoc of voor een reeks gevallen, van een of meer grondrechten (b). De hier veelgeprezen 'pluriformiteit in het rechtsstatelijk kader' zou dan in de verdrukking kunnen komen. Zowel op de oorzaken (a) als op de gevolgen, de aanpak ervan (b), wordt hier kort ingegaan.

\section{De verruimde betekenis van de grondrechten}

Opvallend is dat juist een aantal ontwikkelingen die elk op zichzelf vooral de bedoeling hebben om de betekenis van de grondrechten te versterken, hoofdoorzaken zijn van de botsingen en aldus een bedreiging kunnen uitlokken van wat zij juist mede beogen te beschermen. Omdat het hier om vrij algemeen bekende verschijnselen gaat, worden zij nu slechts kort aangeduid.

Ten eerste is er de al lang bestaande tendens om het terrein dat bestaande grondrechten beschermen tegenover staatsingrijpen aan te scherpen (of op te rekken, 
als men deze ontwikkeling minder verwelkomt) en nieuwe klassieke grondrechten te formuleren. De aanscherping heeft vooral plaatsgevonden door precisering en inperking van de beperkingsmogelijkheden in wetgeving en door de rechter; uiteraard kan dit ook tot een zekere beperking leiden, maar dat is uitzonderlijk. De eerbiediging van de lichamelijke integriteit en het recht op familieen gezinsleven zijn voorbeelden van nieuwe rechten geformuleerd op nationaal respectievelijk internationaal niveau. Naast deze voorbeelden die kunnen worden toegeschreven aan nieuwe inzichten, zijn er verruimingen die vooral verband houden met technische ontwikkelingen, zoals de uitbreiding van de vrijheid van meningsuiting in artikel 7 van de grondwet en de garanties voor de persoonlijke levenssfeer in artikel 10.

De opkomst van internationale grondrechtenverdragen is niet alleen van belang voorzover zij nieuwe grondrechten geïntroduceerd hebben, maar vooral ook doordat de betrokken bepalingen in een geval rechtstreekse werking blijken te hebben en dan door de rechter met voorrang moeten worden toegepast boven zelfs de nationale formele wet en grondwet. Als dan ook nog een internationale rechter, zoals het Europese Hof voor de rechten van de mens (EHRM), het laatste woord mag spreken over de verenigbaarheid van nationale maatregelen met het verdrag, is duidelijk dat ook hier van een substantiële verruiming gesproken kan worden.

De invoering van de sociale grondrechten heeft vrijwel alleen in naam voor uitbreiding van de grondrechten gezorgd. Voor de meeste geldt dat zij geacht worden de overheid wel tot prestaties te verplichten, maar dat deze toch vooral het karakter van inspanningsverplichtingen hebben. Slechts bij uitzondering zou de grondwet de burger aanspraken op de overheid verlenen, maar de omvang ervan is dan niet omlijnd (zie Prakke, De Reede, Van Wissen 2001: 380 , die als voorbeelden noemen het recht op vrije arbeidskeuze en dat op financiële bijstand van het derde lid van art. 19, resp. art. 20). Dezelfde auteurs wijzen overigens, niet als enigen, een strikt onderscheid tussen sociale en klassieke grondrechten van de hand. Ook als een grondrechtelijke bepaling niet expliciet - zoals bij sociale grondrechten - uitwerking of zelfs optreden voorschrijft, "kan uit een grondrechtsnorm een verplichting tot handelen voortvloeien, terwijl men niettemin van een klassiek grondrecht blijft spreken" (ibid.: 381 ). Het kiesrecht van artikel 4 heeft zonder verdere uitwerking geen betekenis, maar anderzijds staat bij artikel 7 (vrijheid van meningsuiting) overheidsonthouding voorop. Tegelijk is zelfs bij deze laatste bepaling een sociale dimensie onderkend, in jurisprudentie en beleid, onder meer waar de garantie van een pluriforme pers een onderwerp van overheidszorg zou zijn. Niet onbelangrijk is dat het EHRM de laatste jaren steeds meer positieve verplichtingen afleidt uit de 'klassieke' grondrechten van het verdrag, als aanvulling op de onthoudingsplichten. Staten blijken dan verplicht te worden om voorzieningen te treffen die tussen burgers onderling eenzelfde garantie bieden (bijvoorbeeld door te zorgen dat omwonenden geen gezondheidsschade lijden door een particulier bedrijf, of door preventieve maatregelen te nemen die burgers beschermen tegen aanvallen van particulieren, dit ter 
uitwerking van het recht op gezinsleven, woning enz. van artikel 8 van het EVRM, respectievelijk het recht op leven volgens artikel 2).

Deze laatste jurisprudentie wordt overigens meestal gerelateerd aan een vierde verruiming, namelijk de toenemende erkenning van horizontale werking van grondrechten, van de gedachte dat de grondrechtelijke waarden ook (moeten) doorwerken in verhoudingen tussen burgers onderling en tussen niet-statelijke instituties en burgers. De bedoelde internationale rechtspraak zou dan vooral compensatie moeten bieden voor het feit dat het EHRM slechts klachten tegen staten behandelt, zodat daar strikt genomen in het geheel geen horizontale werking bestaanbaar is.

Afgezien van dit specifieke punt verdient het aspect van horizontale werking aandacht, omdat daardoor botsing van grondrechten in zijn 'engere' betekenis het duidelijkst optreedt. De achtergrond van de idee van horizontale werking is dat de waarden die in de grondrechten belichaamd zijn van zo'n fundamentele betekenis zijn dat zij, tot op zekere hoogte, ook buiten de verhouding burgerstaat ingeroepen moeten kunnen worden. Men zou ook kunnen zeggen dat de rechtsstaat zijn theoretische bestaansrecht in niet geringe mate ontleent aan de bescherming van dergelijke waarden in het algemeen. Voor de goede orde: van dit besef wordt ook al lang en op grote schaal blijk gegeven. Uiteraard is al lang bekend dat bijvoorbeeld godsdienstvrijheid pas betekenis heeft als ook wordt opgetreden tegen particulieren die religieuze bijeenkomsten verstoren, en geldt regelgeving ter zake, maar het is het directe beroep op het grondrecht in vergelijkbare gevallen dat 'nieuw' is. Ook de gedachte dat bescherming middels grondrechten ook tegen andere institutionele machten dan de overheid nodig kan zijn leeft al langer: als het gaat om de bescherming van persoonsgegevens of de onaantastbaarheid van het lichaam is het niet relevant of de databeheerder een overheidsinstantie is, respectievelijk of het om een particulier of een gemeentelijk ziekenhuis gaat.

Bij al deze voorbeelden gaat het om optreden van de wetgever. Moeilijker ligt de zaak als de rechter moet beslissen op een direct beroep op een grondrecht door een particulier in een geschil met een andere burger. Zoals Hartkamp (2000: 27) opmerkt zijn de grondrechten niet op dergelijke verhoudingen geschreven, hetgeen in de grondwet met name blijkt uit het feit dat beperkingen (meestal) slechts kunnen worden doorgevoerd bij of krachtens de wet te stellen regels, zodat iemand zich er met succes op zou kunnen beroepen, zelfs tegenover een handelen dat op zichzelf niet onbetamelijk is. Dit zou betekenen dat de handelingsvrijheid van burgers buitensporig wordt beperkt, of dat de rechter het grondrecht beperkt zou moeten uitleggen om een aanvaardbaar resultaat te bereiken, een uitleg die het recht ook in zijn verticale werking zou aantasten, aldus Hartkamp. Als beide partijen zich op een grondrecht beroepen zou, waar een rangorde ontbreekt, een impasse ontstaan. Om deze redenen is de aanpak van de 'indirecte horizontale werking' ontwikkeld: een mildere vorm van doorwerking van grondrechten, namelijk zo "dat zij die rechten - of de erin beli- 
chaamde waarden - in hun overwegingen betrekken wanneer zij algemene privaatrechtelijke begrippen toepassen, zoals redelijkheid en billijkheid, onrechtmatigheid en goede zeden, et cetera. In casusposities waarin aan beide zijden grondrechten in het spel zijn, worden de onderscheiden partijbelangen tegen elkaar afgewogen opdat een acceptabele oplossing voor het geschil gevonden kan worden” (Hartkamp 2000: 28).

De vijfde en laatste verruiming die hier aan de orde komt, heeft in zekere zin geleid tot richtsnoeren voor de rechter bij de behandeling van conflicten als zojuist bedoeld werden. De invoering in artikel 1 van de grondwet van het gelijkheidsbeginsel, en vooral van het discriminatieverbod en de uitwerking daarvan in het strafrecht en in de Algemene wet gelijke behandeling (Awgb), heeft de praktische betekenis van grondrechtelijke waarden sterk vergroot. Enerzijds zou men, vrij negatief, kunnen stellen dat het aantal mogelijke botsingen tussen grondrechten gekwadrateerd wordt. Wat als iemand die strafbare discriminatie wordt verweten 'wegens godsdienst, levensovertuiging, politieke gezindheid, ras, geslacht of welke grond dan ook' zich beroept op zijn eigen vrijheid van godsdienst of meningsuiting die hem daartoe een vrijbrief zou geven? Anderzijds kan men de gevolgen in termen van botsingen van grondrechten - om andere merites gaat het hier uiteraard niet! - ook positief formuleren. Immers, de Algemene wet gelijke behandeling (Awgb) geeft voor een aantal veelvoorkomende verhoudingen, zoals die tussen school en leerkrachten en leerlingen, en tussen ondernemers en werknemers, voor allerlei grondrechtelijke botsingen vrij duidelijke handvatten voor beoordeling die meer toegespitst zijn dan eerder aangeduide privaatrechtelijke begrippen (naast uiteraard handvatten om ongelijke behandeling om andere redenen te beoordelen).

\section{Botsing van grondrechten (2)}

Er zijn uiteraard ook meer voor de hand liggende factoren die tot frequentere botsing tussen grondrechten leiden. De toenemende diversiteit in waardestelsels bij de bevolking, in het bijzonder de snelle groei van het aantal aanhangers van godsdiensten met pertinente opvattingen en dito gedragsregels die in allerlei maatschappelijke situaties gevolgd moeten worden, is één prominente factor, die al is aangestipt. Een andere is de toegenomen neiging zich minder door gezag alleen en meer door argumenten te laten overtuigen, in samenhang met de tendens om zo enigszins mogelijk gelijk te willen krijgen tegenover de overheid en tegenover medeburgers. Beide ontwikkelingen zijn in vrij recente WRRrapporten (Nederland als immigratiesamenleving, De toekomst van de nationale rechtsstaat) uitgebreid aan de orde geweest.

\section{Voorstellen voor de behandeling van botsingen}

Botsing van grondrechten levert uiteraard in de eerste plaats een juridisch probleem op, een vraagstuk dat als het zich voordoet moet worden opgelost. Te veel onbevredigend opgeloste botsingen kunnen hierbij een bedreiging opleveren voor de rol van de grondrechten in verband met pluriformiteit van waarden. In aansluiting op al geleverde suggesties worden hier iets uitvoeriger de verschil- 
lende mogelijkheden voor een aanpak verkend. Uiteraard gaat het dan weer om botsingen in ruime zin, dat wil zeggen niet alleen concrete conflicten die reeds bij de rechter zijn beland.

De eerste figuur waaraan gedacht moet worden is uiteraard de grondwetgever zelf. De eenvoudigste manier is afschaffing van bepaalde grondrechten (zoals Fortuyn - de Volkskrant, februari 2002 - voorstelde ten aanzien van het gelijkheidsbeginsel, dat hij toen overigens net als de vrijheid van meningsuiting en de godsdienstvrijheid volledig in horizontale relaties, tussen burgers dus, leek te bezien).

Een andere methode is het categorisch toekennen van voorrang aan een enkel grondrecht boven andere, zoals Cliteur regelmatig voorstelde voor de vrijheid van meningsuiting tegenover de godsdienstvrijheid. Dergelijke voorkeuren weerspiegelen vrij duidelijk bepaalde opvattingen over politiek en maatschappij. In hoeverre dit ook geldt voor de opvatting van Van der Hoeven die (toen, in 1983) een voorrang zag voor een oud, geworteld grondrecht als de godsdienstvrijheid boven een nieuw zoals het gelijkheidsbeginsel, is minder duidelijk. Persoonlijke opvattingen zouden in elk geval ontbreken bij pogingen om op grond van objectieve criteria te komen tot een alle grondrechten omvattende hiërarchie. Tal van auteurs hebben zich hiermee beziggehouden, waarbij overigens de vraag of die volgorde nu ook expliciet moet worden vastgelegd of dat interpretatie alleen voldoende is, meestal in het midden wordt gelaten. Voor Nederland zijn pogingen ondernomen door Algra en door Van der Hoeven (1983), waarbij de mate waarin beperking mogelijk is wordt vastgesteld op grond van afbakening van het 'kernrecht' en het 'rechtsgoed dat wordt beschermd'. In Duitsland heeft Blaesing de omgekeerde benadering gevolgd door aan de hand van bestaande beperkingsmogelijkheden groepen grondrechten te rangschikken, aangevuld met de idee dat bij botsing van grondrechten uit één groep de mate van betrokkenheid op de menselijke waarde de doorslag moet geven. Burkens (1989: 145 e.v.; zie ook Alkema 1995:53-55) aan wie deze voorbeelden zijn ontleend, beschouwt al deze vormen van conflictoplossing door hiërarchisering als onuitvoerbaar: er zouden twee oriëntatiepunten nodig zijn, de hiërarchie van de grondrechten als zodanig en de hiërarchie van 'verwezenlijkingsintensiteit', die na inbreuk resteert. Concreet: "Een minimale inbreuk op een hoog in de hiërarchie figurerend grondrecht zal in voorkomend geval beter aanvaardbaar zijn dan een maximale inbreuk op een laag geklasseerd grondrecht.” Of nog anders: hiërarchie alleen doet onvoldoende recht aan de bijzonderheden van afzonderlijke gevallen. ${ }^{2}$

Dit geldt op het eerste gezicht evenzeer als de gewone wetgever conflicten beslecht, of probeert te voorkomen. De methode die hem ten dienste staat is het aanbrengen van algemeen geldende beperkingen aan grondrechten, een ingreep die hij overigens uit allerlei overwegingen kan doen en waarop al kort is ingegaan. De Awgb en strafbepalingen inzake vormen van discriminatie, smaad of belediging bijvoorbeeld, kunnen voor groepen gevallen waarbij de artikelen 1 en 
7 betrokken zijn (meer) duidelijkheid verschaffen. Intussen blijven de grondrechten zelf beschermd doordat de beperkingsmogelijkheden gelimiteerd zijn. De Nederlandse grondwet beschermt ze vooral door limitatief aan te geven waar en hoe (wel of niet ook door lagere wetgevers) beperkingen toegestaan zijn (met als gevolg dat sommigen het gelijkheidsbeginsel dat geen beperkingsmogelijkheid noemt voorop zien staan); grondrechtenverdragen leggen het accent op het doel van de beperking, met de EVRM-formule 'noodzakelijk in een democratische samenleving ter bescherming van de veiligheid, gezondheid', enzovoort als de bekendste. Hiernaast zijn er diverse theorieën over grenzen waaraan de wetgever binnen deze kaders gebonden is; de bekendste is vermoedelijk die van het onaantastbare kernrecht, zoals het censuurverbod bij de vrijheid van meningsuiting.

De beperkingen en dus de grondrechten zelf zijn derhalve, tot op zekere hoogte, veranderbaar door de betrokken overheden. Maatschappelijke veranderingen zullen daarbij een belangrijke motor zijn, of die veranderingen nu bestaan uit de opkomst van nieuwe minderheden of uit veranderingen in opvattingen, bijvoorbeeld over de positie van de vrouw. Sommige plannen van de wetgever gaan ver, in het bijzonder bij privaatrechtelijke wetgeving inzake gelijke behandeling die zich ook tot handicap, leeftijd, arbeidsduur en type arbeidscontract zou moeten uitstrekken; het gevaar van 'inflatie van het discriminatiebegrip' heeft hier al tot pleidooien voor enige terughoudendheid geleid (Holtmaat 2003).

Een formule als 'noodzakelijk in een democratische samenleving' geeft ook de rechter invloed op het tempo waarin veranderingen doorwerken. Zo is het Europese Hof onlangs omgegaan waar het de officiële registratie van het nieuwe geslacht van transseksuelen betreft, maar werd een opdracht tot invoering van het homohuwelijk afgewezen, omdat de opvattingen in de meest verdragstaten uit zouden wijzen dat de tijd voor invoering in het hele 'EVRM-gebied' nog niet rijp is. Ook in andere gevallen is de invloed van de rechter onmiskenbaar, met soms als gevolg dat de duidelijkheid die door de wetgever lijkt te zijn beoogd afneemt; typische voorbeelden leveren de zaken Van Dijke en El Moumni op (een directe aanleiding tot de nog in voorbereiding zijnde nota Grondrechten in een pluriforme samenleving), toen bleek dat godsdienstige achtergronden maakten dat strafbare discriminatie van homoseksuelen niet aanwezig werd geacht.

Formeel gezien is in de praktijk altijd het laatste woord bij de rechter in grondrechtelijke zaken. Niet in de zin dat elk verschil van inzicht aan hem wordt voorgelegd, maar wel omdat hij steeds ingeschakeld kán worden, en vooral omdat hij door het brede bereik van rechtstreeks werkende verdragsbepalingen alle nationale wetgeving daaraan kan toetsen, terwijl ook die verdragsbepalingen veel ruimte voor interpretatie laten. Bij de voornaamste verdragsbepalingen, die van het EVRM, is overigens de internationale rechter degene die het laatste woord spreekt. Zoals de activiteiten van nationale (grond)wetgever en bestuur getoetst kunnen worden aan - in dit kader het belangrijkste - de beperkingsmogelijkheden die het verdrag openlaat, zo kunnen ook de uitspraken van de nationale rechter 
getoetst worden. Als zijn uitspraak leidt tot een beperking van een door het EVRM gewaarborgd grondrecht, dan zal die onder meer proportioneel moeten zijn, een beoordeling waarbij hem wel een margin of appreciation wordt gelaten.

Overigens zal in de praktijk een eenvoudige afweging tussen twee grondrechten zelden aan de orde zijn. Gewoonlijk zal de ene partij stellen dat op een grondrecht inbreuk is of dreigt te worden gemaakt, waartegenover de andere partij zich met een beroep op 'zijn' grondrecht probeert de rechtvaardigen. Zeker in de 'pluriformiteitszaken' waar het nu vooral om moet gaan, zal artikel 1 van de grondwet, via het gebod tot gelijke behandeling, de Awgb of strafbepalingen inzake discriminatie, aan één kant een rol spelen. Hiervoor werd de betekenis ervan genoemd als handvat voor de rechter. Het belang van zo'n handvat kan blijken uit het feit dat ten minste vanaf 1983 , toen artikel 1 in de grondwet werd ingevoegd, pogingen zijn ondernomen om voor de verschillende rechters richtsnoeren te formuleren bij grondrechtelijke botsingen waarbij het gelijkheidsbeginsel betrokken is (bijvoorbeeld Bellekom, Elzinga en Goldschmidt 1983; Waaldijk en Tielman 1984, met reactie van Goldschmidt 1984). Ook na de totstandkoming van de Awgb in 1994 is de discussie voortgegaan, nu over de uitwerking van de criteria inzake directe en indirecte discriminatie en de uitzonderingen. De rechter en de in eerste instantie optredende Commissie Gelijke Behandeling (CGB) hebben nog niet definitief een bepaalde methode gekozen; wel kan een aantal lijnen worden vastgesteld, die mede aan de hand van suggesties uit de literatuur zijn ontwikkeld (Mendelts 2002; Gerards 2003, e.v.a.).

Zo is de positie van instellingen die zelf door een grondrecht hun bestaan/vrijheid beschermd weten (onderwijsinstellingen, verenigingen) betrekkelijk groot als het gaat om de eigen identiteit (nog afgezien van hun garanties uit de Awgb); het gelijkheidsbeginsel is in zoverre door hun oprichting en bescherming zelf al grotendeels uitgewerkt. Discriminerende meningsuitingen blijken minder bescherming te krijgen (Centrumdemocraten), dan discriminerende uitingen met een religieuze achtergrond (Van Dijke, El Moumni); het bepleite onderscheid in behandeling tussen public en private speech (Peters 1981) blijkt hier omgekeerd te werken. Of de El Moumni-zaak nu betekent dat de islam in alle opzichten een gelijke behandeling krijgt is niet duidelijk: bij de vaststelling van algemene vrije dagen speelt deze godsdienst nog geen rol. De islam blijkt overigens een zwaar beroep te doen op de kennis van rechters: een bezwaar tegen gemengd zwemmen bijvoorbeeld werd afgewezen met een eigen uitleg van de soera 24, in het bijzonder vers 31 (Gerbranda 2002: 120). De Hoge Raad heeft enerzijds uitgesproken dat het niet de taak van de (overheids)rechter is om zich over dogmatische vraagstukken uit te spreken (HR 15 februari 1957, NJ 201), maar het ging daar wel om een geschil binnen één kerkgenootschap (zodat het beginsel van scheiding van kerk en staat expliciet aan de orde was). Anderzijds heeft de Hoge Raad in het bekende geval van de zuster van Sint Walburga (HR 31 oktober 1986, NJ 1987, 173) duidelijk gemaakt dat het enkel stellen dat iets religieus van aard of achtergrond is niet per se voldoende is. Wellicht is de 'interpretatieve terughoudendheid' (Vermeulen 200o: 82) met het voordeel van de twijfel in 
beginsel bij hetgeen de 'bedreigde' partij stelt, een goede optie. Zo maakte de CGB in een recente uitspraak discussie over het religiebepaalde karakter van het dragen van hoofddoeken praktisch overbodig door dit zonder meer te erkennen, om overigens direct aansluitend het verbod ervan in een katholieke school als gerechtvaardigd aan te merken (CGB Oordeel 2003-12, www.cgb.nl).

Het lijkt nog te vroeg om een algemene conclusie te trekken. Wellicht is het wel zinvol om in het oog te houden dat artikel 1 c.a. mede is vastgesteld om minderheden een zekere extra bescherming te geven. Enig extra begrip voor minderheden lijkt wel op zijn plaats, bijvoorbeeld door het belang dat betrokkenen aan hun 'bijzonderheid' hechten een speciaal gewicht te geven (Saharso en Verhaar, 2003, die een 'contextuele' benadering uitwerken: om mensen rechtvaardig te kunnen behandelen, moet je juist met hun bijzonderheden rekening houden). Een andere optie is te verdisconteren welke minderheidsgroep op het moment in kwestie in de maatschappelijke ontwikkeling het meest bescherming nodig heeft, zodat men tot de conclusie kan komen dat vrouwen en homo's minder behoefte hebben aan artikel 1 van de grondwet dan moslims en streng gereformeerden, althans als het gaat om onderlinge confrontaties (Tigchelaar 2002). Anderzijds kan het toch niet de bedoeling zijn de sociaal zwakste groep van het moment alleen daarom een vrijbrief te geven tot discriminatie van 'gelukkiger' minderheden, om van slachtoffer dader te worden.

\section{Enkele conclusies}

De dynamiek die bij de rechtsstaat hoort doet dat ook bij de grondrechten. Behalve voor pluriformiteit is er ook ruimte voor ontwikkeling. De opvattingen over wat grondrechten wel en niet mogelijk maken zullen blijven veranderen. Dat 'mogelijk maken' is intussen wel waar het, in elk geval bij de klassieke grondrechten, in de eerste plaats om gaat.

Elke algemene beperking, ook als die de strekking heeft de realisering van andere grondrechten te verzekeren, en ook als die voortvloeit uit de noodzaak een botsing tussen grondrechten te reguleren, moet met gepast wantrouwen bekeken worden. A fortiori hoeft de rechtsstaat niet aan zijn eigen ondergang mee te werken door aan een fundamentalistische benadering te veel ruimte te geven.

Deze terughoudende opstelling tegenover algemene beperkingen wijst uiteraard tegelijk op een beginselvoorkeur voor de rechter als het gaat om beslechting van botsing tussen grondrechten 'in engere zin' en ook bij interpretatie in andere gevallen. De verdergaande nuancering, het rekening kunnen houden met de soms zeer specifieke kenmerken van het geval en de snellere actualisering bij veranderende verhoudingen zijn hierbij belangrijke overwegingen. Een duidelijk voordeel boven ingrijpen door de wetgever, die zich wel op een sterkere democratische legitimatie kan beroepen, is (juist) het depolitiserende effect dat een uitspraak van de rechter gewoonlijk heeft doordat deze beperkt is tot het bijzondere geval. Individuele conflicten worden zo ook minder snel geschillen tussen groepen. 
Ten slotte dient te worden bedacht dat het wel de afzonderlijke grondrechten zijn die ruimte laten voor waardepluriformiteit en als zodanig van grote betekenis zijn, maar dat hun strekking niet is om fundamentele waardetegenstellingen tussen (of binnen) bevolkingsgroepen te beslechten.

Ook vormen van religieus getint (rechts)pluralisme als aanzetten tot verzuiling in nieuwe gedaante bieden hier geen uitweg. Integendeel, het EHRM heeft een dergelijk stelsel dat de Turkse Welvaartspartij wilde invoeren afgewezen als strijdig met het non-discriminatiebeginsel van het verdrag (EHRM 13 juli 2001, bevestigd op 13 februari 2003; uitvoeriger hierover Loenen 2003).

De betekenis van de grondrechten bij het hanteerbaar houden van conflicten moet, alles tezamen, primair gezien worden in hun functie als onderdeel van de 'democratisch rechtsstatelijke methode', die een redelijke omgang met verschillen als uitgangspunt, methode en doel tegelijk heeft.

\subsection{AFSLUITENDE OPMERKING: MAATSCHAPPELIJKE WAARDEN ALS VOORWAARDEN VOOR EEN GOED FUNCTIONERENDE RECHTSSTAAT}

Het recht en de rechtsstaat kunnen nooit alleen de bindende factor zijn in een pluriforme samenleving. De rechtsstaat garandeert pluriformiteit, maar creëert die niet uit zichzelf en verplicht er ook niet toe. De staatsvorm die oude en nieuwe waarden of de bloei, het onderhoud en behoud van uiteenlopende, zelfs conflicterende waarden mogelijk maakt, moet zelf ook onderhouden worden. Het recht en de rechtsstaat versterken eerder een tendens tot polarisering van meningen en tot aanscherping van tegenstellingen en conflicten dan tot depolariseren en de-escaleren van conflicten. Om de juiste verhoudingen in een samenleving te vinden en de samenhang tussen tegengestelde delen niet te verliezen zijn bepaalde voorwaarden nodig waaronder de samenbindende werking van de rechtsstaat het best tot uiting komt. Er is immers een verschil tussen je recht hebben en tot elke prijs je recht willen halen, er is onderscheid tussen een juridisch slimme en een maatschappelijk wijze conflictoplossing, er is een maatschappelijk belang bij een verscherping of een verzachting van maatschappelijke tegenstellingen.

Het recht en de werking van het recht moeten derhalve aangevuld worden. Kleine deugden zijn daarvoor nodig, niet de grote, tot absolutisme neigende catch all-uitgangspunten, zoals het hobbesiaanse eigenbelang, het benthamiaanse nutsbeginsel, eeuwige en goddelijke morele wetten of een kantiaans categorisch imperatief. De bloei en ontwikkeling van aristotelische deugden zijn hiervoor belangrijker dan de heroïeke deugden van heldendom, absolute rechtvaardigheid, zendingsdrang en bekeerzucht. Veeleer wordt in de moderne samenleving een afkeer van wreedheid en het toebrengen van leed vereist. Willen de grote waarden van de rechtsstaat, zoals vrijheid, gelijkheid en vertrouwen, voor een langere duur veiliggesteld worden, dan dient de samenleving de 
kleine deugden te bevorderen, zoals waarheidsgetrouwheid, empathie en sympathie voor anderen, respect voor de mening van anderen en de bereidheid tot het corrigeren en laten corrigeren van de eigen oordeelsvorming. Sociale vaardigheden als flexibiliteit, responsiviteit en verantwoordelijkheidszin, een zeker pragmatisme en het kunnen verdragen van onzekerheid en ambivalenties vormen een goede voedingsbodem van een blijvende maatschappelijke pluriformiteit. Naarmate deze kleine deugden aangeleerd en geoefend worden op scholen en andere onderwijsinstellingen en naarmate ze in de dagelijkse praktijk worden beoefend, zullen de grote abstracte waarden van de rechtsstaat en de overige hoge, maar abstracte waarden van de samenleving als geheel beter tot hun recht komen en zal hun een langer leven beschoren zijn.

In deze kleinere deugden komt een eigentijds burgerschap naar voren dat aan belang wint naarmate een samenleving pluriformer geworden is. Alle burgers dienen te beschikken over bepaalde vaardigheden die de grote en abstracte waarden van democratie en rechtsstaat dagelijks in praktijk kunnen brengen, zoals het vermogen tot dialoog en het kunnen relativeren van het eigen gelijk. Nauta noemt dit burgerschapscompetenties die noodzakelijk zijn om de effecten van individualisering in de moderne samenleving in een juist evenwicht te houden (Nauta 2000: 110). Geïndividualiseerde burgers die een sterke eigen wil en identiteit ontwikkelen, dienen tegelijkertijd over het vermogen te beschikken om zich te kunnen verplaatsten in de situatie van iemand anders, of die andere nu een ondergeschikte uitvoerende ambtenaar is of een medeburger die niet als hij/zij over rijke bronnen of competenties beschikt. Daarnaast gaat het om de vaardigheid om zichzelf ten opzichte van anderen te vertegenwoordigen of zich te laten vertegenwoordigen door anderen en het daarbij behorende vermogen om te onderscheiden wat relevante zaken zijn en wat minder relevante bijzaken; om de vaardigheid om aan te spreken en zelf aangesproken te worden op zowel gedragingen als meningen en opvattingen. En ten slotte om de vaardigheid om voor zichzelf op te komen, hetzij door een beroep te doen op de toebedeelde rechten, hetzij om als burger bij te dragen aan rechtsvorming en andere vormen van collectieve besluitvorming (Nauta 2000: 110). De hier geschetste vaardigheden van burgerschap zijn onontbeerlijk om de essentiële waarden van de democratische rechtsstaat levend te houden. De overheid zal het in de huidige situatie van fragmentering van morele bronnen, van individualisering en internationalisering, als haar primaire taak dienen te zien om de ontwikkeling van dergelijke burgerschapsvaardigheden bij zo veel mogelijk burgers aan te moedigen en daadwerkelijk te bevorderen (zie ook hoofdstuk 8). Omwille van het behoud van de gemeenschappelijke waarden van de democratische rechtsstaat is een sterk ontwikkeld, eigentijds burgerschap nodig als een van de noodzakelijke middelen om de uiterst pluriforme samenleving bijeen te houden, nu en in de toekomst. 
De traditionele grondrechten die speciaal op democratische participatie gericht zijn (bijvoorbeeld het kiesrecht) blijven hier buiten beschouwing, evenals het feit dat sommige grondrechten op vrijheid én participatie gericht zijn (uitingsvrijheid). Ook wordt verder weerstand geboden aan de verleiding om de verbanden met de twee aspecten van de democratische rechtsstaat uit te werken. Ditzelfde geldt voor de parallel met de hiervoor behandelde liberale en communitaristische opvattingen, die zich opdringt als men zich realiseert dat de schijnbaar individuele vrijheidsrechten niet alleen voor het individu van betekenis zijn, maar ook en soms bijna uitsluitend collectief betekenis hebben (vrijheid van vereniging, vergadering, van demonstratie, van godsdienstbelijdenis en zelfs van meningsuiting als men zich realiseert hoe overheersend het belang van persvrijheid hierin is).

Een vierde mogelijkheid zou zijn om horizontale werking van grondrechten een duidelijker plaats te geven, hetzij door die werking in een declaratoire bepaling uit te spreken (vergelijk de Zwitserse grondwet), hetzij door de beperkingsclausules mede op die werking toe te snijden. 


\title{
6 SAMENLEVEN MET VERSCHILLENDE CULTURELE NORMEN
}

\begin{abstract}
"Ook vraagt het kabinet de raad in te gaan op eventuele niet algemeen gedeelde respectievelijk conflicterende waarden in onze samenleving, al dan niet samenhangend met cultuurverschillen, in relatie tot de vraag of en in hoeverre het uiteenlopen van bepaalde waarden maatschappelijk problematisch moet worden geacht.” (Adviesaanvraag inzake waarden en normen, 8.11.2002)
\end{abstract}

\subsection{INLEIDING}

De hernieuwde belangstelling voor waarden en normen wordt in belangrijke mate geassocieerd met 'afwijkende' leefstijlen, tradities en gedragspatronen van migranten in het algemeen en met het 'failliet' van de multiculturele samenleving in het bijzonder. Kranten, commentatoren en ook wetenschappers hebben zich uitgeput in voorbeelden van 'mislukte' integratie. De onvrede hierover is dichter aan de oppervlakte komen te liggen en met name na 11 september 2001 wordt steeds vaker gesproken van botsende waarden en normen, die mogelijkerwijs zouden kunnen uitmonden in conflicten en verdere fragmentatie van de Nederlandse samenleving. De vraag van de regering verwijst direct naar deze gevoelens van onbehagen: "in hoeverre moet het uiteenlopen van bepaalde waarden problematisch worden geacht”. Als aanzet voor dit hoofdstuk volgt hieronder een korte schets van het kleine en grote ongenoegen in de Nederlandse multiculturele samenleving waarbij feiten, interpretaties en generalisaties - net als in het huidige debat - door elkaar heen lopen. Het gaat dus expliciet niet om een inventarisatie van 'het probleem', maar om een onvolledige inventarisatie van percepties van het probleem.

Criminaliteit onder allochtone jongeren, en dan met name de kleine straatcriminaliteit waarin een oververtegenwoordiging van bijvoorbeeld Marokkanen en Antillianen is te zien, geeft het beeld van een losgelagen jeugd die de school laat voor wat die is en zich op het criminele pad begeeft. Moslimmeisjes met verschillende achtergronden die met een hoofddoek, gesluierd of recentelijk zelfs geheel bedekt in een zogenaamde nikaab over straat gaan, roepen in Nederland vaak een dubbel onbehagen op. Enerzijds wordt de vraag gesteld in hoeverre het dragen van deze bedekkingen een middel is om vrouwen te beperken en is de emancipatie van de vrouw in het geding. Anderzijds wordt het dragen van hoofddoekjes niet zelden gepropageerd door zelfstandige moslimvrouwen die onder verwijzing naar Nederlandse grondrechten het recht opeisen om een hoofddoekje te dragen. Soms is het dus ook de vrije beleving van een sterk geloof die met de ontzuilde en ver geseculariseerde Nederlandse samenleving botst. En ook daar worden vanuit sommige hoeken van de Nederlandse samenleving vervolgens vraagtekens bij geplaatst. Hoe oprecht is een overtuiging die een persoon zelf in een minderwaardige positie plaatst, hoe sterk is de druk van de omgeving tot conformeren aan de groepsnorm en 
moet de Nederlandse overheid daar wel in meegaan onder het mom van religieuze vrijheden, zijn dan de gehoorde argumenten. De omgang tussen jongens en meisjes is hoe dan ook een steen des aanstoots in het debat over multicultureel Nederland. Meisjes worden thuisgehouden, afhankelijk gemaakt en klaargestoomd voor het huwelijk en het moederschap, is een beeld dat niet zelden aan moslimculturen wordt toegeschreven. Jongens daarentegen krijgen alle vrijheid, worden te weinig gecorrigeerd op onacceptabel gedrag en hebben een beeld van vrouwen dat zich niet verdraagt met de Nederlandse normen. Het gevolg is groepsvorming en intimidatie in het zwembad, seksuele toespelingen en het lastigvallen van vrouwen op straat en in de disco. Vervolgens wordt dergelijk gedrag aan een hele groep gekoppeld en lijden alle groepsleden onder het gedrag van diegenen die zich misdragen. Voor je het weet is elke groep jongeren een bende, houden portiers in de disco's er een etnisch deurbeleid op na en is ieder moslimmeisje een onderdrukte sloof die klaargestoomd wordt voor een repressief huwelijk, een schare kinderen en een leven achter gesloten deuren. Soms wordt Nederland ook opgeschrikt door grote zaken waarbij allochtone groepen zich aan de in Nederland geldende normen onttrekken. Eerwraak, vrouwenbesnijdenis en gearrangeerde huwelijken komen voor in Nederland en roepen vragen op over de verhouding van bepaalde groepen ten opzichte van Nederlandse gebruiken, gewoonten en wetten.

De aanslagen van 11 september 2001 hebben het debat over de multiculturele samenleving nog sterker een debat over loyaliteiten gemaakt. Waar de Nederlandse loyaliteit in de nasleep van de aanslagen bijna automatisch en onverdeeld in de richting van Amerika ging, waren er vanuit sommige groepen andere geluiden te horen. Hoewel er nauwelijks tot geen goedkeuring van de aanslagen te beluisteren viel, werden gedachten over 'de andere kant van de zaak' snel opgevat als een geluid van dissidentie, een breuk in de Nederlandse solidariteit. ${ }^{1}$ Overigens gaat het bij het uitdragen hiervan in de regel om Marokkaanse jongeren. Van andere grote groepen moslims in Nederland wordt op dit punt weinig gehoord. Marokkaanse jongeren lieten ook van zich horen bij de recente oprichting van de Arabisch Europese Liga (AEL) in Nederland. Op de Nederlandse tournee van de voorman van de Belgische AEL, Abou Jahjah, kwamen met name veel jonge Marokkanen af. In de kranten werd vervolgens heel wat afgediscussieerd over de vraag in hoeverre het hier ging om een anti-integratiepartij en bijgevolg anti-integratieallochtonen. Velen hebben de 'populariteit' van deze nieuwe partij in ieder geval opgevat als een verzet tegen Nederland.

Voorbeelden zoals hiervoor aangegeven, worden steeds vaker in het huidige debat over waarden en normen aangetroffen. Het debat kenmerkt zich door generalisatie, polarisatie en simplificatie. Generalisaties treffen we in vele vormen aan. Met gemak wordt gesproken over 'de' allochtonen of over 'de' Nederlandse waarden en normen, daarmee de suggestie wekkend dat er sprake zou zijn van een ondeelbare groep allochtonen met vergelijkbare kenmerken en in dit geval met overeenkomstige waarden en normen. Generalisaties zijn natuurlijk voor een deel onvermijdelijk in de dagelijkse praktijk, maar worden problematisch als ze vervallen in stereotyperingen en vooroordelen. Marokkaans is momenteel nauwelijks meer een gewone aanduiding voor iemands herkomst, maar eerder een stigma waar tal van waardeoordelen aan gehangen worden 
(Harchaoui en Huinder 2003). De generalisaties betreffen overigens niet alleen het gedrag en de opvattingen van anderen, maar ook de beschrijvingen van de Nederlandse samenleving. Alsof Nederland te kenschetsen is door een ondeelbare en door alle Nederlanders gedeelde cultuur. De verscheidenheid en pluriformiteit van de Nederlandse samenleving worden vaak niet serieus genomen; in het aanzien van de vele buitenlanders, zouden Nederlanders opeens één zijn. Generalisaties kunnen leiden tot polarisatie. Het is een kleine stap om het 'wij/zij'-sjabloon te hanteren: zij moeten zich aanpassen aan ons of andersom: zij begrijpen ons niet. Dit stoere taalgebruik kan duiden op een gepolariseerde visie op de samenleving waarin autochtone en allochtone culturen lijnrecht en onbemiddelbaar tegenover elkaar komen te staan. In het debat en uiteindelijk soms ook in gedrag kunnen verschillen tussen groepen worden uitvergroot en in termen van onverenigbaarheid van opvattingen aan de kaak gesteld. Juist de verschillen worden belicht en versterkt weergegeven, het anderszijn wordt beklemtoond. Eén mogelijk gevolg hiervan is dat groepen zich dan ook op de eigen groep terugtrekken en zich volgens de beeldvorming gaan gedragen. Generalisatie kan tot simplificatie leiden. Het feit dat een belangrijk deel van het debat via krant, radio en televisie wordt gevoerd speelt hierbij zeker een rol. In een tijdperk waar het gaat om soundbites en slagzinnen is er minder ruimte voor nuance en voor deliberatie over de complexiteit van vraagstukken zoals deze. Zo wordt in de pleidooien voor verplichte inburgering nauwelijks onderscheid gemaakt tussen formele en materiële inburgering, terwijl dit nu juist essentieel is. Bij formele inburgering gaat het om het respecteren van de Nederlandse rechtsorde en maatschappelijke inrichting, materiële inburgering staat voor het inhoudelijk delen van Nederlandse politieke en levensbeschouwelijke normen en waarden. Het eerste mag van iedereen in een land worden verlangd. Het tweede bij uitstek niet, aangezien eenvormigheid in levensbeschouwelijke waarden niet in overeenstemming is met de Nederlandse geschiedenis, waarin het omgaan met waardepluralisme nu juist centraal staat.

Het huidige debat over de multiculturele samenleving heeft zeker niet alleen negatieve gevolgen. Er is ook winst geboekt. Meer dan ooit staat het thema 'multiculturaliteit' op de agenda en zijn er mogelijkheden voor voor- en tegenstanders om zich uit te spreken, argumenten uit te wisselen en invloed uit te oefenen. In het WRR-rapport Nederland als immigratiesamenleving (2001) is aangegeven dat ontmoeting en confrontatie noodzakelijk en gewenst zijn in een immigratiesamenleving. Door de confrontatie is het mogelijk kennis te nemen van de standpunten van de anderen en kunnen deze ook serieus worden genomen. Anderzijds is het noodzakelijk de vermenging van het 'multiculturele' debat en het debat over waarden en normen met argusogen te bekijken. Een zekere nuancering en precisering is hier op zijn plaats: aan de ene kant laat dit hoofdstuk zien dat er ten onrechte sprake is van het 'bij elkaar brengen' van uiteenlopende kwesties onder de noemer van botsende waarden. Aan de andere kant wordt aandacht besteed aan enkele essentiële verschillen die mogelijkerwijs een bron van conflict kunnen zijn of in de toekomst kunnen worden. Het hoofdstuk wordt afgesloten met een beschou- 
wing over de mogelijkheden om met gesignaleerde verschillen en conflicten om te gaan.

\subsection{CULTURELE DIVERSITEIT EN DYNAMIEK}

Daar waar sprake is van culturele diversiteit is het van belang aandacht te besteden aan de dynamiek en ontwikkeling van migrantengroepen. Diversiteit heeft te maken met de verschillen tussen groepen, verschillen binnen groepen en verschillen tussen generaties. Op individueel en op collectief niveau maken migranten een eigen ontwikkelingsgang door en dat heeft gevolgen voor de mate waarin zij zich identificeren met hun etnische herkomst dan wel door anderen een etnische identiteit krijgen 'opgeplakt'. De assimilatiedruk van de Nederlandse samenleving legt bovendien een behoorlijk gewicht in de schaal. De wijze waarop migranten met die druk omgaan en de effecten al dan niet incorporeren in hun eigen leefstijl draagt eveneens bij aan een groeiende culturele diversiteit binnen en tussen migrantengroepen.

Alvorens we nader op deze aspecten van culturele diversiteit ingaan, dient gewezen te worden op het feit dat in dit hoofdstuk verhoudingsgewijs meer aandacht wordt besteed aan verschillen die te maken hebben met de islam, of beter gezegd met gedragingen van moslims. Daar is een aantal redenen voor te geven. In de eerste plaats staan moslims (terecht of onterecht) in het centrum van het debat over de multiculturele samenleving en worden zij langs deze lijn ook in het debat over waarden en normen 'gezogen'. Daar waar gesproken wordt over verschillen in culturele normen en waarden wordt vaak de facto gerefereerd aan verschillen die worden toegeschreven aan de islam. In de tweede plaats is de groep moslims in Nederland kwantitatief omvangrijk en lijkt de islam voor velen van hen een belangrijke factor in de bepaling van de eigen identiteit. In het Nederlandse debat zijn moslims bovendien vaak een vrij uitgesproken en assertieve groep. Het aantal moslims in Nederland bedraagt naar schatting ongeveer 736.000 personen, hetgeen neerkomt op 4,6 procent van de bevolking (WRR 2001). Hiermee is overigens nog niets gezegd over de beleving van het geloof of verschillen tussen herkomstlanden en generaties. Ook in dit verband is het van belang rekening te houden met de verschillen binnen en tussen groepen moslims.

Verschillen tussen groepen Allochtonen zijn een zeer diverse groep, waarin bovendien alle nationaliteiten meegenomen zijn (inclusief Amerikanen en Europeanen die in de regel als 'niet-problematisch' ervaren worden). In feite kun je dus niet van een groep spreken. Ter illustratie: in 1998 telde ons land al 110 verschillende nationaliteiten (WRR 2001: 45). Verder mag niet onvermeld blijven dat er grote verschillen zijn tussen arbeidsmigranten, asielmigranten en volgmigranten in het kader van gezinshereniging. Ook is sprake van grote verschillen in termen van streek van herkomst, opleidingsniveau en migratiegeschiedenis. Al deze factoren zijn van invloed op de wijze waarop migranten hun weg vinden in de Nederlandse samenleving, de mate waarin zij zich hier thuis voelen en in staat en bereid zijn om te participeren in de Nederlandse samenleving. In dit verband 
is een waarschuwing op z'n plaats. Het overgrote deel van het beschikbare onderzoeksmateriaal heeft betrekking op groepen migranten die al lange tijd in Nederland verblijven: Turken, Marokkanen, Antillianen en Surinamers. Over de nieuwe groepen - met name met een asielgeschiedenis - is veel minder bekend. Er is nog weinig onderzoek naar gedaan en zij zijn nog niet zo lang in Nederland. ${ }^{2}$ Gegeven de grote verschillen in termen van opleidingsachtergrond en land van herkomst is grote voorzichtigheid geboden bij het extrapoleren van de huidige gegevens over de mate van integratie van migranten naar deze nieuwe groepen. Dat gebeurt nog te vaak en het risico bestaat dat het een self-fulfilling prophecy wordt.

Verschillen binnen groepen Verschillen binnen groepen kunnen bijzonder groot zijn in termen van regionale herkomst, opleidingsniveau en culturele achtergronden. In het oog lopende voorbeelden zijn Turken en Turkse Koerden, Marokkanen en Marokkaanse berbers, creolen en Hindoestanen binnen de Surinaamse gemeenschap. Deze verschillen zijn voor buitenstaanders niet altijd zichtbaar en voelbaar met als gevolg dat de kenmerken waar enkelen aan voldoen ten onrechte worden bestempeld als kenmerken van de hele groep. Deze verschillen binnen groepen kunnen leiden tot interne conflicten en spanningen, maar ook tot moeizame relaties met autochtonen, omdat migranten als het ware de 'verkeerde' identiteit krijgen toegeschreven. In dit verband zijn er natuurlijk ook grote verschillen als het gaat om de wijze waarop migranten hun weg vinden in de Nederlandse samenleving en daar passief en actief aan meedoen.

Verschillen tussen generaties Generaties kunnen van elkaar verschillen in termen van opleiding (zeker bij de 'gastarbeiders'), taalbeheersing, maatschappelijke stijging en algehele oriëntatie op Nederland. Tevens is de band met het land van herkomst van een andere orde: kinderen zijn vaak in Nederland opgevoed en niet zoals hun ouders in het land van herkomst. Er zijn ook grote verschillen in de oriëntatie van de eerste en tweede generatie op de islam (zie bijvoorbeeld Waardenburg 2001). Deze generatieverschillen kunnen zowel voor ouders als voor kinderen problematisch zijn. Schuyt (1995b) heeft het over de dubbele emancipatieslag die tweedegeneratiejongeren moet maken, te weten die ten opzichte van de ouders en die ten opzichte van de Nederlandse samenleving. Er zijn verschillende studies verschenen over de moeilijke dilemma's waar kinderen van de tweede generatie mee geconfronteerd worden. Meisjes die aan de ene kant hun familie en de familietradities niet willen verloochenen en zich aan de andere kant verder willen ontwikkelen (opleiding, werk, zelfstandig wonen) naar Nederlandse maatstaven. De keuze voor de ene richting gaat in veel gevallen ten koste van de andere richting.

Assimilatiedruk van Nederland De (vaak sluipende) druk tot aanpassing op allerlei vlakken die van de Nederlandse samenleving en feitelijke omstandigheden uitgaat is zeer groot. Daarbij gaat het bijvoorbeeld om basale zaken als de huwelijksleeftijd en het kindertal, die snel naar de Nederlandse norm convergeren (zie bijvoorbeeld De Valk et al. 2001). Maar ook opleiding, media en werk genereren 
een grote oriëntatie op Nederland. Daarnaast is sprake van de ontwikkeling van jongerenculturen waar Nederlandse jongeren van verschillende herkomst met elkaar omgaan en gewoontes en opvattingen van elkaar overnemen. De assimilatiedruk kent geen lineair maar een grillig verloop. In de praktijk ontstaan allerlei mengvormen waarbij het niet meer zo makkelijk is te onderscheiden wat nu typisch Nederlands is en wat niet. Overigens is het niet denkbeeldig dat de wijze waarop de assimilatiedruk neerslaat op migranten verschilt per stad of gebied. Daar waar veel migranten wonen, verloopt dit proces anders dan in wijken die overwegend 'wit' zijn. Bovendien hangt de mate van sociaal-culturele integratie ook samen met andere factoren, die deels zelf alweer als 'druk' van de Nederlandse samenleving zijn te omschrijven. Zo constateren Dagevos en Schellingerhout (2003) van het SCP een voortschrijdende sociaal-culturele integratie onder de vier grote groepen wanneer gekeken wordt binnen de groep, en dus met name naar generatieverschillen. Dit effect is veel groter dan puur het effect van de tijd, oftewel de duur van het verblijf in Nederland. Ook de mate waarin deze groepen moderne opvattingen - over bijvoorbeeld gezinsverhoudingen, man-vrouwrollen en religieus liberalisme - onderschrijven, varieert tussen de generaties en hangt bovendien sterk samen met het opleidingsniveau.

Uit het voorgaande blijkt dat er nauwelijks gesproken kan worden van coherente groepen in de Nederlandse samenleving die keurig samenvallen met etniciteit, religie of land van herkomst. Toch wordt, zoals eerder betoogd, vaak in termen van groepen over migranten gesproken. Dit heeft aan de ene kant te maken met de neiging tot labelling door autochtonen (dit proces van labelling geld t overigens voor allerlei andere groepen zoals ouderen, gehandicapten, studenten enz.). Deze vorm van labelling wordt bovendien vaak gebruikt ter verklaring van een bepaald gedrag van leden van die groepen. De stap naar generalisatie van een bepaald gedrag als kenmerkend voor de totale groep is dan snel gemaakt. Aan de andere kant is ook sprake van zelflabeling. Veel van het normoverschrijdend gedrag dat frictie geeft in de Nederlandse samenleving ontstaat niet zozeer als gevolg van het gedrag van de specifieke etnische of religieuze groep als geheel, maar ontstaat wanneer leden van een groep zich beroepen op een groepsnorm als rechtvaardiging van hun gedrag. De groepsnorm wordt gebruikt ter rechtvaardiging van een bepaald gedrag dat op zijn beurt strijdig is met in Nederland gangbare normen.

\subsection{DE BETEKENIS VAN GROEPSNORMEN}

In de hierna besproken voorbeelden gaat het vooral om gedragingen die gerechtvaardigd worden door te verwijzen naar de eigen cultuur en die tegelijkertijd in strijd (zouden) zijn met 'het' Nederlandse normen- en waardenpatroon. Het is moeilijk hard te maken dat diegenen die zich beroepen op een groepsnorm ook daadwerkelijk voor de groep kunnen spreken die ze zeggen te vertegenwoordigen: representativiteit is, mede gezien de dynamische ontwikkelingen binnen deze groepen, een probleem in migrantengroepen. Toch wordt het groepsargument vaak in stelling gebracht om gedrag te rechtvaardigen of te verklaren. Als dit gedrag verder geen frictie oplevert met algemene normen en regels in de 
Nederlandse samenleving, zal hier in de regel geen probleem van worden gemaakt. Het gaat dan om een culturele eigenaardigheid die begroet zal worden met reacties die variëren van irritatie, een onverschillig schouderophalen, tot een oprechte interesse in een andere cultuur.

Problematisch wordt het wanneer het groepsargument wordt gebruikt om gedrag te rechtvaardigen dat wel in strijd is met Nederlandse normen, regels en wetten. In het geval van het overtreden van wetten is het probleem misschien nog het minst groot, aangezien het dan duidelijk is welke lijn overtreden is. Maar ook hier spelen culturele achtergronden en het beroep op de groepsnorm nog een belangrijke rol en wordt de rechter vaak gevraagd rekening te houden met specifieke omstandigheden. Het argument van de culturele achtergrond en groepsdwang kan overigens zowel voor als tegen een verdachte worden gebruikt. In het ene geval zal de rechter er een reden voor strafvermindering in zien en in een ander geval juist een reden voor een zwaardere straf om een signaal af te geven aan een bepaalde groep. Het laatste gebeurde bijvoorbeeld in een zaak waar eerwraak in het geding was (Maris van Sandelingenambacht 2002).

Niet alle problemen die te maken hebben met schurende normen tussen groepen zijn keurig onderverdeeld in wat wel en wat niet mag volgens de Nederlandse wet. Steeds moeten keuzes gemaakt worden die principieel samenhangen met rechtstatelijke waarden als vrijheid en gelijkheid die, zoals in paragraaf 5.4 werd betoogd, bovendien een grote dynamiek kennen. Veel gedrag dat als afkeurenswaardig wordt gezien, is niet vastgelegd in wetten en regels, maar staat desalniettemin op gespannen voet met normen die in Nederland breed gedragen worden. Het is moeilijk te duiden wat 'breed gedragen' Nederlandse normen zijn, maar op een elementair niveau is toch wel een aantal normen te benoemen. Een norm die in dit hoofdstuk centraal staat, is bijvoorbeeld die van de individuele autonomie en het recht van het individu om zijn eigen keuzes te maken. Hoewel er geen wet op de individualiteit bestaat, zijn de Nederlandse wetgeving en het beleid er vaak toch op gericht deze te bevorderen. Ook in het emancipatiestreven, dat traditioneel op de verheffing van groepen is gericht, staan juist het individu en zijn keuzemogelijkheden centraal. Zo zijn de kernpunten van het emancipatiebeleid van het ministerie van szw bijvoorbeeld: 'Keuzevrijheid, Participatie en Rechten \& Veiligheid' en streeft het integratiebeleid van het ministerie van Justitie naar een actief burgerschap van leden van minderheidsgroepen. Zo bezien kan wel gesproken worden van in de Nederlandse maatschappij en overheid verzonken en breed gedeelde normen.

In hoofdstuk 2 werd het onderscheid tussen sociale, morele en juridische normen geïntroduceerd. Juist de verschillen tussen deze 'soorten' normen in termen van verplichtingen en verwachtingen en het feit dat ze in sommige gevallen overlappen, maken de indeling een geschikt - maar nog niet eenvoudig of eenduidig - kader voor de hier besproken problemen. In veel van de in dit hoofdstuk besproken gevallen gaat het om het naleven van een groepsnorm die op gespannen voet staat met in de Nederlandse samenleving breed gedragen 
sociale of morele normen, aangaande zaken als de gelijkwaardigheid van man en vrouw en het belang dat wordt gehecht aan zelfontplooiing en een niet-autoritaire opvoeding van kinderen. Het kan voorkomen dat een beroep wordt gedaan op een eigen groepsnorm om gedrag te rechtvaardigen dat niet overeenkomt komt met breed gedragen sociale en morele normen. Dergelijk gedrag kan irritatie oproepen. In het normale sociale verkeer zal de gemiddelde Nederlander niet van mening zijn dat een vrouw drie meter achter haar man aan dient te lopen en wordt er dus een sociale norm overtreden. Op moreel niveau zullen velen bovendien het veronderstelde achterliggende principe (de vrouw is minderwaardig aan de man) achter dit gedrag afkeuren en wordt er dus ook een morele norm overschreden. Toch zal het moeilijk zijn een meerderheid te vinden die bereid is deze sociale en morele normen om te zetten in een juridische. Vermoedelijk zal slechts een enkeling bereid zijn de politie in te zetten om man en vrouw naast elkaar te laten lopen dan wel te bekeuren voor het achter elkaar lopen.

Er is echter sprake van een glijdende schaal in de verhouding en overlap tussen de drie soorten normen. Hetzelfde morele principe dat de vrouw ongelijkwaardig is aan de man, kan immers ook 'ingezet worden' om gedrag te rechtvaardigen dat veel sterker tegen het morele normbesef van grote groepen Nederlanders ingaat. Indien een man zijn vrouw slaat en dat rechtvaardigt met een verwijzing naar een groepsnorm die de man tot hoofd van het gezin verklaart en het gebruik van geweld sanctioneert, druist dat dusdanig in tegen sociale en morele normen dat het inzetten van een juridische norm die dat gedrag veroordeelt, door de meerderheid wordt gesteund. De moeilijkste vraagstukken van het omgaan met verschillende normen in een multiculturele samenleving zitten uiteraard op het midden van de glijdende schaal. Welk gedrag dat onder verwijzing naar een groepsnorm wordt gerechtvaardigd, is binnen de context van de Nederlandse samenleving acceptabel en wanneer overschrijdt het die grens? Wanneer is 'de' Nederlandse samenleving bereid om sociale en/of morele afkeuring om te zetten in juridische afkeuring? Wanneer is een beroep op een groepsnorm ondanks sociale en morele afkeuring wel gerechtvaardigd of in ieder geval geen aanleiding voor dwingende juridische normen? En wat te doen in het grote grijze tussengebied? Een extra complicatie bij dit soort vragen is bovendien dat ze zich in de praktijk in verschillende contexten afspelen. Een belangrijk verschil in context is bijvoorbeeld al de vraag of het gedrag in kwestie zich afspeelt in de publieke dan wel de private sfeer. De grens tussen het publieke en het private is niet scherp te trekken en daar komt bij dat er verschil van mening is of en onder welke omstandigheden de overheid de meer private sfeer mag binnentreden. Dit alles beïnvloedt de beoordeling van gedrag en de mogelijkheden voor de overheid om zich uit te spreken en eventueel in te grijpen.

We concentreren ons in het uitwerken van deze vragen op een aantal thema's die verbonden zijn met het beroep op groepsnormen en de spanning die kan ontstaan met Nederlandse normen als een gevolg daarvan. Dergelijke spanningen kunnen twee vormen aannemen. In de eerste plaats kan het gaan om spanningen tussen de groep en haar leden en in de tweede plaats tussen de groep en andere 
delen van de samenleving. Hierbij kan aangetekend worden dat er legio situaties te bedenken zijn waarin de eerste spanning naadloos overgaat in de tweede. In het naleven van een eigen groepsnorm ten opzichte van de leden kunnen de rechten van een lid van de groep immers zodanig geschaad worden dat dit zich niet verdraagt met de normen van de samenleving als geheel. Een 'intern' conflict wordt op die manier ook een conflict tussen de groep en de samenleving. In het onderstaande schema wordt dit kader samengevat.

\section{Figuur 6.1 Spanningsrelaties tussen individu, groep en maatschappij}

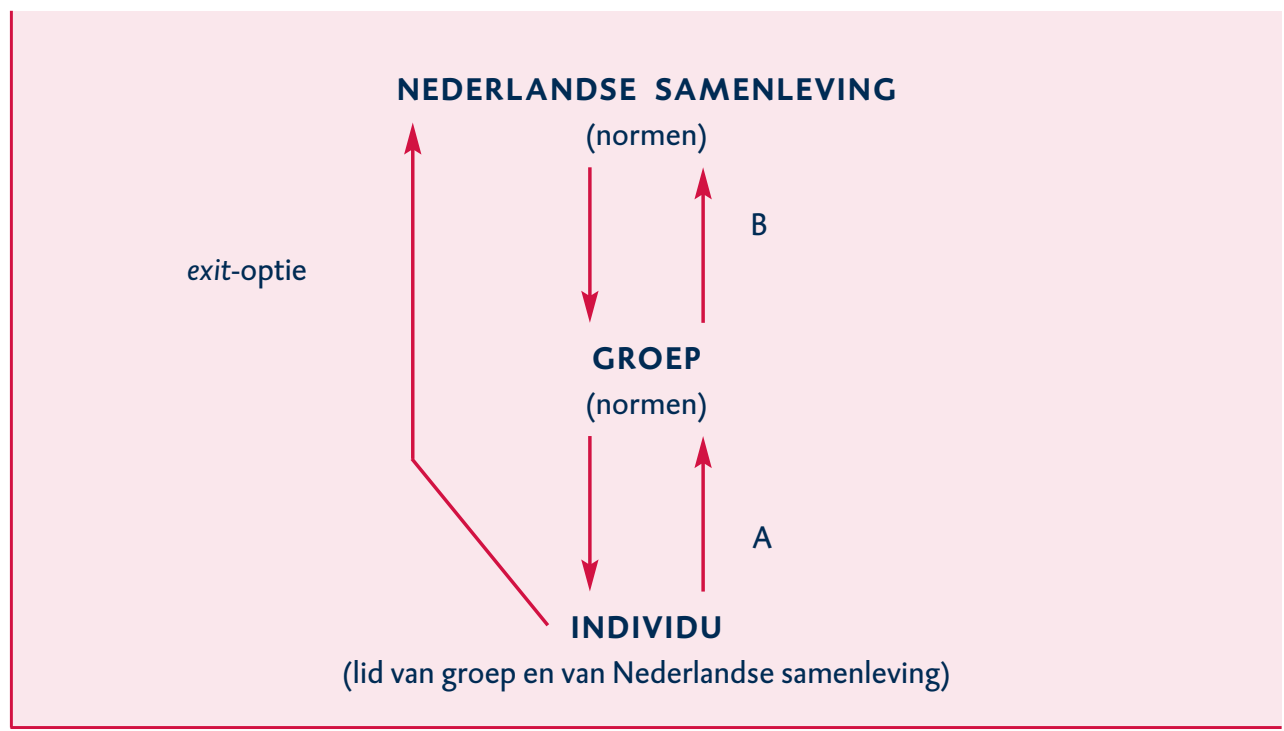

Met deze figuur zijn de belangrijkste conflictlijnen tussen groepen en de bredere samenleving in kaart gebracht. De relatie tussen de groep en het individu (relatie A) is conflictueus wanneer een groep haar normen dwingend oplegt of probeert op te leggen aan een individueel groepslid. Het centrale probleem is hier dat een groep een van haar leden een individuele keuze ontzegt, waarmee de in Nederland breed gedeelde norm dat een individu zijn eigen autonome keuzes maakt onder druk komt te staan. Bij etnische groepen geldt echter, net als bijvoorbeeld bij het gezin en de staat, dat het groepslidmaatschap in eerste instantie geen vrijwillige keuze is: men wordt in de groep geboren. Dit brengt bijzondere afwegingen van loyaliteit en verzet met zich mee, aangezien de prijs van verzet of uittreding hoog kan zijn. Ook hier spelen tal van ingewikkelde vragen, zeker in relatie tot de overheid. Een individueel groepslid dat zich wil onttrekken aan de druk van de groep (een groep die bereid is conformisme met geweld af te dwingen) en daarbij luidkeels een beroep op de overheid doet, is een relatief eenvoudig geval. Hier dient de overheid de exit-optie voor het individu te garanderen. Meer sluipende en in de geslotenheid van de groep verborgen processen van groepsdruk op het individuele lid zijn al lastiger te beoordelen, temeer daar in zo'n situatie de grens tussen het publieke en het private in het geding is. Betrokkenen doen overigens ook een beroep op deze grens om ongewenste externe bemoeienis te 
weren. De moeilijkste vorm in deze categorie is de onderdrukking van individuele leden van de groep op basis van een groepsnorm, terwijl die groepsnorm door het lid zelf onderschreven wordt. In dit geval speelt het dilemma of en wanneer een individu tegen zichzelf in bescherming genomen mag worden. Behalve het garanderen van de exit-optie staat er, in termen van Hirschmanns trits exit, voice en loyalty, nog een weg voor de overheid open: namelijk het bevorderen van voice binnen de groep. Dit is de vaak indirecte weg van het stimuleren van discussie en debat met leden van de groep en het bieden van ruimte en een platform aan de verschillende stemmen binnen groepen.

De tweede relatie, die tussen de groep en de bredere samenleving (B), is moeilijker in een kernwoord te vangen. Grofweg gezegd komen groep en samenleving met elkaar in conflict als de groep haar eigen normen boven die van de Nederlandse samenleving stelt. De relatie is te omschrijven als (het streven naar) 'het opleggen van de groepsnormen aan de samenleving als geheel'. Voorbeelden waarbij een groep ernaar streeft de eigen normen aan de samenleving als geheel op te leggen, zijn te vinden in de pleidooien van bepaalde minderheidsgroepen voor bijvoorbeeld een verbod op abortus (waarin verschillende geloven elkaar kunnen vinden) of bijvoorbeeld het beperken van de vrijheid van meningsuiting waar het gaat om geloof. Aan het uiterste eind van het spectrum staat het nastreven van politiek en/of religieus fundamentalisme en extremisme.

Hieronder worden vier subthema's uitgewerkt in voorbeelden uit de praktijk die onder de relatie groep-individu (A) of de relatie groep-samenleving (B) vallen, met de kanttekening dat de eerste relatie uiteraard vaak in de tweede overloopt. Het gaat om handhaving van normen binnen de eigen groep, positie van de vrouw en positie van het kind ten opzichte van de ouders (A) en het opleggen van de groepsnormen aan de samenleving als geheel (B). Gepoogd wordt om bij elk thema de glijdende schaal in het normatief handelen en de bijbehorende dilemma's in kaart te brengen. De gekozen voorbeelden worden dus steeds 'conflictueuzer' ten opzichte van breed gedeelde Nederlandse normen.

\subsubsection{NORMHANDHAVING BINNEN DE EIGEN GROEP EN AFVALLIGHEID}

Groepen genereren vaak zowel mogelijkheden als belemmeringen; een gegeven dat voor alle soorten groepen geldt en zeker niet voorbehouden is aan etnische groepen. In vele soorten groepen wordt er door de leden onderling op toegezien dat eenieder zich houdt aan de normen of regels van de groep. Dat kan heel expliciet, zoals bijvoorbeeld bij een beroepsgroep (professie) waarbij normen vaak vastgelegd zijn in reglementen en soms zelfs in een toezichthoudend orgaan is voorzien (zoals bijvoorbeeld een tuchtcommissie). Vaak zijn zowel de normen als het toezicht op de naleving daarvan implicieter. Maar ook de gevolgen van overtreding van impliciete (sociale) groepsnormen kunnen zeer groot zijn; peer pressure en de druk om zich te conformeren aan de norm zijn in zeer uiteenlopende milieus niet te onderschatten. Daarbij gaat het om religieuze en sociale groepen, maar bijvoorbeeld ook meer onverwachte groepen zoals de kraakbewe- 
ging en groepen hooligans. Afhankelijk van de hechtheid van de groep en de mate waarin bepaalde normen als zeer zwaarwegend worden ervaren, wordt afwijking meer of minder zwaar gestraft. De journalist of wetenschapper die (herhaaldelijk) op plagiaat wordt betrapt, kan uitkijken naar een nieuwe baan en zal die vaak in een nieuw vakgebied moeten bemachtigen. Uitstoting is de ultieme straf van de groep voor afwijking en afvalligheid. Een groep kan echter ook veel voordelen bieden aan zijn leden. Beroepsgroepen ontlenen bevoegdheden en een zekere autoriteit aan hun groepslidmaatschap. In de meeste sociale groepsverbanden biedt een groep een gevoel van saamhorigheid en onderlinge bijstand (solidariteit) en kan (het netwerk van) de groep kansen creëren.

De voor- en nadelen van een groepslidmaatschap spelen voor (de leden van) sommige etnische groepen een belangrijke rol. Naarmate groepen hechter zijn georganiseerd en ook geografisch zijn geconcentreerd geldt dat sterker. Vaak wordt bijvoorbeeld de sterke cohesie van de Turkse gemeenschap genoemd als een voorbeeld van groepssamenhang die kansen creëert. Het zelfstandig ondernemerschap in deze gemeenschap is groot, nieuwe ondernemingen worden vaak met geld uit de gemeenschap opgezet en baantjes worden aan leden van de groep toegespeeld. Ook kan een hechte gemeenschap voordelen bieden bij mobiliteit in het onderwijs; oudere broers en zussen, neven en nichten en soms ooms en tantes die een (hogere) opleiding hebben genoten, kunnen een begeleidende rol vervullen en helpen bij schoolwerk van kinderen als de ouders die rol niet kunnen vervullen. Dit blijkt een belangrijke factor voor de slaagkansen van Turkse en Marokkaanse kinderen in het onderwijs (Crul 2000).

Hechte groepen hebben echter ook soms hun schaduwkanten. Naarmate een groep meer gesloten is en de mogelijkheden heeft haar leden in de gaten te houden, kan de controle verstikkend werken. Zeker de geografische concentratie van groepen (in zwarte wijken in de steden, maar ook in blanke dorpen op de Veluwe) kan een groep sterk isoleren en het moeilijk maken voor een individueel lid om zich daaraan te onttrekken. In de eerste plaats kan het (zelfgekozen) isolement van groepen het zicht ontnemen op wat er zich achter de schermen allemaal afspeelt. Chinezen golden bijvoorbeeld lange tijd als een relatief succesvolle maar op zichzelf gerichte groep die weinig (overheids)aandacht behoefde. Achter de façade van het isolement ontwikkelde zich echter ook een realiteit waarbinnen een specifiek Chinese maffia criminele praktijken binnen de geslotenheid van de eigen groep ontwikkelde. De hechte Turkse gemeenschap is bijvoorbeeld ook een vehikel geweest voor de illegale Turkse immigratie. Nederlandse Turken stonden garant voor de toeristenvisa van landgenoten die uiteindelijk in de illegaliteit verdwenen en de Turkse gemeenschap verzorgde vaak opvang en werk (Staring 2001). Met de verscherpingen van het illegalenbeleid van de afgelopen jaren worden illegalen echter steeds dieper de illegaliteit in gedrongen, afhankelijker gemaakt van landgenoten en komt uitbuiting van Turkse illegalen door Nederlandse Turken ook steeds meer voor (Engbersen et al. 2002). De hechtheid van een groep waarin men zich kan verbergen, is niet per definitie een warme hechtheid en kent zijn perverse effecten. 
In de tweede plaats kan, zeker ook bij migrantengemeenschappen, het gewicht van de groep sterk drukken op individuele leden. Enkelingen die zich willen ontrekken aan de groep hebben vaak maar één echte keuze en dat is breken met de groep. Afwijking wordt soms niet toegestaan en gereduceerd tot een keuze voor aanpassing of uitstoting. Vaak zijn het vrouwen en kinderen die in de moeilijkste posities geplaatst worden, maar denk ook aan homoseksuelen binnen een groep die homoseksualiteit op bijvoorbeeld religieuze gronden verwerpt. Kinderen groeien in de Nederlandse samenleving op en verhouden zich op een andere manier tot de waarden en normen van het land van herkomst die door de ouders vaak hooggehouden worden. Zeker als respect voor en gehoorzaamheid aan de ouders als een belangrijke waarde binnen een groep wordt ervaren, kan dit kinderen in een moeilijke positie plaatsen en processen van integratie bovendien hinderen. ${ }^{3}$ De klassieke mogelijkheden van de exit, voice en loyalty zijn niet altijd een optie voor kinderen die gevangen zitten tussen hun eigen wensen en loyaliteiten en de normen en eisen van de ouders en de groep. De optie waar in die gevallen wel veel gebruik van wordt gemaakt, is de optie 'liegen' (Yerden 2001). Net als veel andere kinderen kiezen kinderen uit migrantengroepen ervoor hun feitelijke gedrag te verbergen achter leugens over uitgaan, omgang met de andere sekse enzovoort. Voor een deel betreft het hier de normale problematiek van opgroeiende kinderen ten opzichte van hun ouders. Voor een ander deel is de situatie echt anders, aangezien men zich niet alleen aan de ouders probeert te ontworstelen, maar aan een gehele groep die toeziet op naleving van normen. De uiteindelijke sanctie kan dan veel groter zijn en leiden tot verstoting uit de groep (vaak inclusief de naaste familie). In de meest extreme - en weinig voorkomende - gevallen gaat de sanctie nog veel verder; het uit de groep stappen of het overtreden van de normen van de groep wordt dan bestempeld als 'afvalligheid' en beschouwd als het (moedwillig) schade toebrengen aan de groep. Een gedrag dat in de ogen van sommige (leden van) groepen extreme en gewelddadige repercussies zoals ontvoering en eerwraak rechtvaardigt.

\subsubsection{POSITIE VAN DE VROUW}

In verschillende groepen in Nederland worden strikte normen gehanteerd voor wat meisjes in de publieke sfeer wel en vooral niet worden geacht te doen. Met name als een bepaalde groep of gemeenschap hecht is georganiseerd en geografisch sterk is geconcentreerd, kunnen de leden door middel van sociale controle toezien op het doen en laten van hun leden. Sociale controle kan soms dicht tegen sociale cohesie aanliggen en wordt in veel gevallen niet als bezwaarlijk gezien maar zelfs als wenselijk. Een deel van de normvervaging die in dit rapport centraal staat wordt, al dan niet terecht, toegewezen aan het verdwijnen van gemeenschappen waarin men een oogje op elkaar houdt en mensen elkaar aanspreken op afwijkend gedrag. Sociale controle kan echter ook verstikkend werken en leden van gemeenschappen ernstig beperken in hun doen en laten. In sommige gemeenschapen wordt aan vrouwen en meisjes weinig toegestaan en wordt er door jongens op toegezien dat meisjes zich niet 'te buiten gaan' aan door de groep verboden gedrag. De gemeenschap dwingt dan af dat meisjes zich 
binnen die paden bewegen die door de groep - vaak op basis van traditie - als norm zijn gesteld. Dit beperkt meisjes in hun bewegingsvrijheid en vaak ook in hun ontplooiingsmogelijkheden. De titel van het boek Ogen in je rug over dit mechanisme van sociale controle op meisjes in de Turkse gemeenschap, spreekt wat dat betreft boekdelen (De Vries 1987; Yerden 2001). De dubbele emancipatie van allochtone jongeren (ten opzichte van de ouders enerzijds en de Nederlandse maatschappij anderzijds) waaraan eerder werd gerefereerd, is voor meisjes vaak een driedubbele emancipatie. De derde laag is de ('klassieke') emancipatie ten opzichte van het vrouwbeeld van de eigen groep dat vaak door de mannen wordt uitgedragen en verdedigd. Dat de klassieke vrouwenemancipatie de laatste vijftig jaar ook in Nederland zwaar bevochten is, kan worden geillustreerd met het feit dat de gehuwde vrouw pas in 1956 bij wet handelingsbekwaam werd verklaard (Schoonenboom en In 't Veld-Langeveld 1976). Overigens is de emancipatie nog geenszins afgerond en nog steeds onderwerp van overheidsbeleid.

Een vaak terugkerend debat over de emancipatie en positie van moslimvrouwen, is dat over het dragen van hoofddoekjes en het verbieden of toestaan daarvan in verschillende situaties in het publieke domein. Dit is een debat dat zeker niet alleen in Nederland wordt gevoerd. In verschillende West-Europese landen speelt deze kwestie van tijd tot tijd op (Broeders 2001), maar ook in Turkije, dat een strikte scheiding van religie en staat hanteert, wordt hierover regelmatig gedebatteerd. Uit verschillende uitspraken van de rechter en de Commissie Gelijke Behandeling (CGB) aangaande conflicten over hoofddoekjes, blijkt echter dat het emancipatieargument - de vrije keuze of het gebrek aan vrije keuze - niet in de argumentatie wordt meegenomen (Verhaar 1999). Er worden steeds andere argumenten genoemd. Ter illustratie volgen hier verschillende voorbeelden.

Een griffier in Zwolle wenste tijdens de rechtszitting een hoofddoek te dragen. Zij stelde dat het dragen van een hoofddoek bij haar geloofsovertuiging hoort. Verbod op het dragen van de hoofddoek zou een vorm van discriminatie zijn, zo luidde haar stelling, en haar het uitoefenen van haar beroep op oneigenlijke gronden onmogelijk maken. De wens van deze griffier om tijdens de rechtszitting een hoofddoek te dragen werd niet gehonoreerd. Het dragen van een hoofddoek in de rechtszaal werd in strijd geacht met het leerstuk van de scheiding tussen kerk en staat. De meest gehanteerde betekenis is die van het verbod van inmenging van de kerk op het terrein van staatszaken. Religieuze symbolen zoals een hoofddoek horen niet thuis in staatsinstellingen als de rechterlijke macht en de politie, omdat dan de onafhankelijkheid van de staat in het geding is. Eind jaren negentig heeft de CGB verschillende zaken behandeld over het dragen van een hoofddoek in werksituaties. In al deze gevallen ging het om een werkgever die het dragen van een hoofddoek had verboden en waartegen de vrouw in kwestie in beroep ging. In al deze zaken heeft de commissie de vrouw in het gelijk gesteld. De commissie vat de hoofddoek in al deze gevallen op als een van de voorschriften die rechtstreeks voortvloeien uit de moslimovertuiging. Op basis van deze argumentatie wordt gesteld dat de werkgever zich schuldig maakt aan discriminatie op grond van godsdienst. Begin 2003 kwamen enkele moslim- 
leerlingen aan het ROC in Amsterdam gekleed in een nikaab (een gewaad dat lichaam en gezicht volledig bedekt). De directeur van de school weigerde de leerlingen toe te laten. $\mathrm{Na}$ een korte openbare discussie zijn de richtlijnen van het ministerie zodanig aangepast dat de leerlingen bepaalde kledingvoorschriften dienen te volgen. Ook deze zaak is voorgelegd aan de CGB; volgens de leerlingen zou het een vorm van discriminatie zijn op grond van levensovertuiging. De commissie oordeelde in dit geval echter dat het verbod gehandhaafd mocht blijven. Hoewel er formeel wel sprake was van indirecte discriminatie op basis van godsdienst, was de grond voor het verbod objectief en voldoende zwaarwegend. Het verbod had volgens het Roc een drieledig doel: het bevorderen van de onderlinge communicatie, het kunnen vaststellen van de identiteit van studenten en het naleven van de wettelijke taken die op de school rusten. Op basis van deze argumenten achtte de CGB het middel (het verbod) passend en noodzakelijk (CGB 2003a).

In alle gevallen stellen de betrokkenen dat er sprake is van discriminatie op grond van levensovertuiging en eisen zij het recht op gelijke behandeling op (Galenkamp 2002). Wat onder gelijke behandeling wordt verstaan is echter vaak niet duidelijk en op z'n minst voor meerdere interpretaties vatbaar. Om duidelijkheid te scheppen publiceerde de CGB (2003b) onlangs een advies waarin uiteen werd gezet wat volgens de Algemene wet gelijke behandeling wel en niet mag binnen de context van scholen. Hier stuit men ogenblikkelijk op de andere zijde van de medaille die scheiding van kerk en staat heet. De wet verbiedt zowel directe als indirecte discriminatie op basis van geloof. Directe discriminatie is echter wel toegestaan aan scholen in het bijzonder onderwijs die op basis van hun grondslag onderscheid mogen maken tussen (potentiële) leerlingen. Indirecte discriminatie is alleen toegestaan op basis van een 'objectieve rechtvaardigingsgrond', zoals naar oordeel van de CGB in de zaak van het ROC Amsterdam aan de orde was. Wat duidelijk wordt uit het advies van de CGB is dat de rechterlijke macht zich op grote afstand van religie moet houden. Letterlijk wordt gesteld: “Omdat de rechter en de CGB (zoals de Hoge Raad heeft bepaald) niet treden in verschillen van mening over theologische leerstellingen, wordt alleen getoetst of die uiting onder een godsdienstuiting kán vallen." Deze positie is historisch te verklaren en betreft een belangrijk beginsel van de godsdienstvrijheid, maar levert uiteraard ook wel de nodige problemen op, met name vanuit het perspectief van de positie van de vrouw.

De voorbeelden geven aan dat het niet makkelijk is een eenduidig beroep te doen op grondrechten. Er zal altijd sprake moeten zijn van een interpretatie in de specifieke context. Alle genoemde voorbeelden laten zien dat de kwestie van de positie van de vrouw wordt omzeild door argumenten uit een andere sfeer te halen. Aangezien in deze gevallen het recht om een hoofddoek te mogen dragen wordt opgeëist, is deze positie meestal niet als zodanig aan de orde. Het dragen van een hoofddoek is voor veel jonge moslimvrouwen een bewuste keuze en een uiting van trots en een eigen identiteit (Saharso 2000; Phalet et al. 200o). Een vraag die echter ook vaak in deze context wordt gesteld, is in hoeverre het dragen 
van een hoofddoek een individuele keuze is of niet. Wordt de hoofddoek gedragen onder druk van een patriarchale cultuur en dient dan de hoofddoek met een beroep op het principe van seksegelijkheid verboden te worden, in plaats van deze toe te laten uit naam van godsdienstvrijheid? Daar komt bij dat met de directe verbinding van het dragen van een hoofddoek met de islam, per definitie een bepaalde interpretatie van de islam wordt gehanteerd (Verhaar 1999). Zoals hierboven echter al werd aangegeven, heeft de rechter zich, bij monde van de Hoge Raad, onbevoegd verklaard waar het gaat om interpretatie van 'theologische leerstellingen', inclusief hoofddoekjes in welke vorm dan ook. Het gaat in deze gevallen in essentie om de vraag of er een spanning bestaat tussen 'multiculturalisme' en feminisme (Saharso 200o). Een debat dat enige jaren geleden op scherp werd gezet door de Amerikaanse filosofe Okin in een essay onder de veelzeggende titel Is multiculturalism bad for women?, een vraag die zij volmondig met 'ja' beantwoorde. Over haar stelling dat vrouwen de verliezers zijn wanneer er speciale rechten worden toegekend aan minderheidsculturen is binnen en buiten de kringen van de vrouwenstudies en etnische studies heftig gedebatteerd. Het gebrek aan een eenduidig antwoord heeft zowel te maken met theoretische posities die worden ingenomen (voor een overzicht zie Saharso 200o) als met de diversiteit van de groep waarover het debat wordt gevoerd. Voorbeelden waarbij het dragen van een hoofddoek samengaat met een eigen identiteit en emancipatie zijn net zo goed te vinden als voorbeelden waarbij de hoofddoek een uiting en element is van zeer traditionele man-vrouwverhoudingen.

Verwacht mag worden dat een verbetering van de positie van vrouwen meer gediend is bij pluralisme binnen de moslimgemeenschap en bij een expliciete afweging tussen het 'culturele recht' op het dragen van een hoofddoek en het recht van vrouwen op keuzevrijheid. Deze twee rechten zijn niet per definitie strijdig met elkaar; waar het om gaat is de context waarbinnen die culturele rechten worden uitgeoefend: ongelijke machtsverhoudingen kunnen ertoe leiden dat een recht in de praktijk verwordt tot een plicht (Verhaar 1999). Het lastige is natuurlijk dat die context (dwang, drang of eigen keuze) veelal niet duidelijk is en dat de beoordelaars in de rechterlijke macht zich goeddeels onbevoegd hebben verklaard voor de interpretatie hiervan.

De kwetsbare positie van vrouwen uit zich ook in het slachtofferschap van huiselijk geweld. Hoewel exacte gegevens hierover niet bekend zijn, nemen bijvoorbeeld aantallen allochtone vrouwen die zich bij de blijf-van-mijn-lijfhuizen melden sterk toe: inmiddels zou het om ruim 6o procent gaan (Ulger 2003). Uit een recent onderzoek in opdracht van het ministerie van Justitie (Van Dijk et al. 2002) naar huiselijk geweld onder de vier grote groepen allochtonen bleek huiselijk geweld minder voor te komen in vergelijking met autochtonen (24\% en $35 \%$ respectievelijk), maar ging het wel vaak om intenser geweld. De onderzoekers schatten echter in dat er sprake is van een behoorlijke onderrapportage van huiselijk geweld onder allochtonen. Hoe dan ook gaat het om een significant probleem onder zowel autochtonen als allochtonen. De vraag is natuurlijk in hoeverre huiselijk geweld onder allochtone groepen elementen bevat die het 'apart' zet van huiselijk geweld in algemene zin. Een mogelijke factor is dan (het 
misbruiken van) een groepsnorm die geweld rechtvaardigt. Het meest gecompliceerde geval is ook hier het geval waarin zowel dader als slachtoffer in een norm gelooft die het gewelddadige gedrag rechtvaardigt. Hierbij moet echter worden aangemerkt dat dergelijk gedrag in meer algemene termen vaak voorkomt bij huiselijk geweld; dader maar ook slachtoffer gaat vaak op zoek naar een 'verhaal' dat het geweld rechtvaardigt. Het is dus moeilijk te zien wat de factor cultuur hier significant maakt.

Een zeer specifiek geval van mishandeling betreft de besnijdenis van jonge meisjes die in Nederland met name voorkomt bij Somaliërs, Ghanezen en Egyptenaren. Specifieke gegevens over Nederland zijn nauwelijks bekend, mede vanwege het taboe op het onderwerp in de gemeenschappen waarin het voorkomt (Fokkema et al. 2000). De medische en psychologische gevolgen van besnijdenis zijn zeer groot: de meeste varianten van besnijding brengen grote risico's met zich mee voor de gezondheid die ook op de lange termijn blijven spelen (bijvoorbeeld bij zwangerschappen). De internationale consensus over de afwijzing van vrouwenbesnijdenis is zeer groot, ondanks de wijde verspreiding van het verschijnsel. De wereldgezondheidsorganisatie van de vN veroordeelt vrouwenbesnijdenis (de organisatie spreekt van genitale verminking) als "een van de meest ernstige vormen van geweld tegen vrouwen en kinderen, een schending van verscheidene universele mensenrechten (waaronder het recht op leven, vrijheid en onschendbaarheid, lichamelijke zelfbeschikking en integriteit) en een gevaar voor de gezondheid". Ook de vN namen zelf in 1999 unaniem een resolutie aan die landen oproept vrouwenbesnijdenis uit te bannen (Fokkema et al. 200o). In de ogen van de Nederlandse wetgever gaat het in ieder geval om een mishandelingsdelict waarvoor de ouders kunnen worden vervolgd (Minister van Justitie 2001). Tot op heden is er in Nederland echter nog nooit een veroordeling geweest voor vrouwenbesnijdenis. Bij deze praktijk wordt duidelijk een groepsnorm opgelegd aan individuele, minderjarige kinderen waarbij de meeste ouders zullen handelen vanuit de idee dat ze doen wat het beste voor hun kind is. Door de zware aspecten van gezondheid en psychisch trauma onderscheidt het gebruik zich van besnijdenis van jongens, zoals die voorkomt bij joden en moslims en waar ook de lichamelijke integriteit van het kind in het geding is. Ook hier speelt de vraag voor de overheid of en in hoeverre ze in het gezinsleven van haar ingezetenen in wil grijpen. Het beleid zoals het nu geformuleerd is, leunt hoofdzakelijk op informatievoorziening: "Het Nederlandse beleid beoogt door middel van bewustwording op termijn te komen tot uitbanning van vrouwenbesnijdenis in Nederland" (Minister van Justitie 2001: 8). Hoewel informatievoorziening in aanvulling op wetgeving zeker nodig is, zou gezien de ernst van de problematiek toch meer verwacht kunnen worden. Zo handelt de hierboven vermelde brief van de minister van Justitie alleen over Somalische vrouwen, terwijl bekend is dat de praktijk waarschijnlijk wijder verspreid is onder andere migrantengroepen in Nederland. Gezien het feit dat men een redelijk idee kan hebben van de risicogroepen in de Nederlandse samenleving (zie bijvoorbeeld de inschatting daarvan voor Somalische meisjes in de risicocategorie in de brief van de minister van Justitie), zou een meer gerichte aanpak mogelijk en wenselijk 
zijn. De huidige activiteiten wijzen er bepaald niet op dat de bestrijding van vrouwenbesnijdenis een speerpunt van het overheidsbeleid is.

\subsubsection{POSITIE VAN HET KIND TEN OPZICHTE VAN DE OUDERS}

\section{Opvoeding}

Bij het zoeken naar verklaringen voor culturele verschillen wordt vaak gewezen op verschillen in opvoedingspatronen. In de ene cultuur gelden andere waarden dan in de andere en die waarden worden bij uitstek via de opvoeding overgedragen. Ook is de verwachting dat er culturele verschillen zijn in de mate waarin waarden van ouders met die van kinderen overeenkomen. Via de opvoeding brengen ouders hun kinderen normbesef bij. Het zogenaamde normloos gedrag bij jongeren - in het bijzonder criminele jongeren - wordt voor een deel ook toegeschreven aan de onmacht en de onwil van ouders om normen over te dragen. Opmerkelijk is dat in deze redenering het (impliciete) uitgangspunt is dat ouders er wel de gewenste waarden op zouden nahouden, maar deze niet kunnen overdragen op hun kinderen (De Regt en Brinkgreve 200o). Uit onderzoek in westerse landen, waaronder Nederland, is echter gebleken dat er sprake is van een grote overeenkomst tussen ouderen en jongeren (Rispens 1996; Meeus en 't Hart 1994). Jongeren zijn gemiddeld gesproken economisch iets conservatiever (meer nadruk op economische vrijheid, op concurrentie en op bezit, en voelen zich iets minder aangetrokken tot een egalitaire inkomenspolitiek) en zijn cultureel iets progressiever dan ouderen. Jongeren zijn bijvoorbeeld meer geporteerd voor seksuele vrijheid en voor een egalitaire verhouding tussen mannen en vrouwen, waarbij op het laatste punt het sekseverschil groter is dan het leeftijdsverschil. Jongeren willen in wezen hetzelfde als hun ouders: een goede baan, trouwen, kinderen en een eigen huis.

De vraag is nu of er etnische verschillen zijn in opvoedingswaarden, of de opvoedingswaarden sterk afwijken van de Nederlandse (westerse) opvoedingswaarden en of er verschillen zijn tussen ouders en kinderen. Van der Hoek (200o) geeft een overzicht van vier studies naar opvoedingspatronen in Chinese, Turkse, Marokkaanse en Surinaams-creoolse gezinnen. Deze onderzoeken laten zien dat deze vier groepen tamelijk overeenkomen in de opvoedingsdoelen die zij nastreven en in wat zij belangrijk vinden voor hun kinderen. Prestatiedoelen worden het meest genoemd (een opleiding halen, werk vinden, persoonlijke inzet) gevolgd door conformistische doelen. Het gaat hier om meer dan gehoorzaamheid en respect tonen aan de ouders. Deze aspecten hebben zelfs aan belang ingeboet ten gunste van een meer open relatie tussen ouders en kinderen. Genoemd worden beleefdheid, goede manieren en bescheiden gedrag. Van der Hoek (2002) geeft verder aan dat ouders in alle vier de populaties de term 'op het rechte pad blijven' gebruiken. Het gaat hier in feite om de morele kant van conformisme: weten wat goed en slecht is. Bij jongens ligt de nadruk op zaken zoals stelen, drugs gebruiken, op straat rondhangen, bij meisjes staat kuisheid centraal. Na maatschappelijke prestatie en conformisme worden in volgorde van belangrijkheid achtereenvolgens genoemd: sociale autonomie, sociabiliteit en welbevin- 
den. Sociabiliteit en autonomie zijn waarden die voor de vier groepen migranten dicht bij elkaar liggen. Bij sociabiliteit gaat om de sociale eigenschappen die ouders graag in hun kinderen willen zien: behulpzaamheid, sociaal voelend zijn, begrip hebben, betrouwbaarheid, tolerantie en rekening houden met anderen. Bij autonomie gaat het meer om sociale autonomie, omdat ouders in de vier populaties - anders dan Nederlandse ouders - niet zozeer de nadruk leggen op puur individuele eigenschappen zoals zelfstandigheid en onafhankelijkheid, maar meer op sociale eigenschappen zoals eerlijkheid, zelfredzaamheid, zelfvertrouwen en verantwoordelijkheid. Uit onderzoek onder Marokkaanse moeders (Pels 1998) komt naar voren dat het vooral gaat om een vorm van praktische zelfstandigheid: taken in de huishouding op zich kunnen nemen, het helpen van de jongere kinderen, voor zichzelf kunnen zorgen. "Zelfstandigheid in de zin van onafhankelijkheid, zich losmaken van de ouders en de eigen gang gaan komt nauwelijks op het repertoire voor" (Pels 1998). Overigens leggen Surinaamscreoolse ouders wel meer nadruk op individualistische aspecten, zoals weten wat je wilt en voor jezelf opkomen. Zij geven echter aan dat deze eigenschappen vooral belangrijk zijn om je staande te kunnen houden in de Nederlandse samenleving; deze eigenschappen passen veel minder in de eigen creoolse omgeving (Nijsten 1999).

Als we deze uitkomsten vergelijken met Nederlandse opvoedingswaarden, dan blijkt dat dezelfde waarden belangrijk worden gevonden, maar dat de volgorde van belangrijkheid anders ligt: autonomie en welbevinden scoren het hoogst. Daarbij wordt autonomie in de Nederlandse context opgevat als een individuele eigenschap met een sterke nadruk op onafhankelijkheid. Maatschappelijke prestaties en conformisme scoren relatief het laagst. Bij deze vergelijking passen twee kanttekeningen. In de eerste plaats zijn de verschillen gradueel en in de tweede plaats worden de verschillen beïnvloed door sociaal-economische omstandigheden. Nederlandse ouders uit de lagere sociaal-economische klassen komen, als het gaat om de hiërarchie van opvoedingswaarden, dicht in de buurt van migrantenouders, die ook overwegend uit de lagere sociaal-economische klassen komen. Bij opvoeding gaat het niet alleen om de opvoedingswaarden maar ook om de opvoedingspraktijk. Met uitzondering van de creoolse populatie blijkt de communicatie tussen ouderen en jongeren veelal beperkt te zijn tot eenrichtingverkeer: de ouders geven hun mening, of houden een belerend verhaal, waarna de jongere zich schikt (Van der Hoek 2000) of tenminste de schijn ophoudt (Yerden 2001). Hier blijkt dat meisjes zich meer dan jongens conformeren aan de wensen van hun ouders. Hoewel de ouders van de onderzochte groepen van mening zijn dat zij een meer open en vrijere opvoeding geven aan hun kinderen dan de opvoeding die zij zelf hebben genoten, is in de praktijk nauwelijks ruimte voor een gesprek over heikele onderwerpen. Bij conflicten wordt verwacht dat jongeren zich aanpassen aan de ouders.

In de hier aangehaalde onderzoeken wordt, zoals gezegd, ook aandacht besteed aan de veranderingen in opvoedingsstijl: ouders voeden zelf minder streng op dan zij zelf zijn opgevoed. Opmerkelijk daarbij is dat de veranderingen - naar 
eigen zeggen - primair worden ingegeven door veranderingen in het land van herkomst. Slechts in beperkte mate worden aspecten overgenomen van de Nederlandse opvoeding. Voor deze opvoeding hebben zij over het algemeen weinig waardering: te weinig respect tussen ouders en kinderen, te vrije omgang tussen de seksen en een te vrije opvoeding van meisjes. Hierbij moet worden opgemerkt dat deze waardering vooral gebaseerd is op wat zij op school zien en meemaken. Net zoals dat voor de Nederlanders geldt, hebben zij weinig direct zicht op opvoedingsstijlen in de thuissituatie. De confrontatie tussen opvoedingsstijlen is het scherpst in de fase van de puberteit. Voor alle onderzochte ouders geldt dat zij juist in deze fase te maken krijgen met verschillen in normen en waarden die de opvoeding erg bemoeilijken: grote mond, onbeleefdheid en openlijke aantasting van het ouderlijk gezag vinden zij ongepast. Zij verwachten juist dat kinderen op die leeftijd in moreel en sociaal opzicht weten hoe het hoort en in staat zijn om zelfstandig gezinstaken te vervullen. Het is met name in de puberteit en de adolescentie dat ouders moeten laveren tussen eigen waarden en normen en die van de Nederlandse samenleving. Dit geldt overigens ook voor de kinderen. De invloeden van vriendjes en vriendinnetjes zijn in deze fase sterk en het is natuurlijk ook de fase waarin belangrijke keuzes worden gemaakt.

\section{Gearrangeerde huwelijken}

Het huwelijk of een andere relatievorm wordt in Nederland gezien als een individuele keuze die vrijwillig aangegaan wordt. Vanuit dit perspectief wordt er in Nederland veelal met een scheef oog gekeken naar het gearrangeerde huwelijk dat onder bepaalde groepen in Nederland, zoals Hindoestanen, Turken en Marokkanen (veel) voorkomt. Hoewel Hooghiemstra (200o) er terecht op wijst dat het gearrangeerde huwelijk wereldwijd gezien nog steeds de meest voorkomende manier is waarop een huwelijk totstandkomt, is het in Nederland in de afgelopen decennia verdrongen door de vrije partnerkeuze. Een gearrangeerd huwelijk, waarbij de wederzijdse families het voortouw nemen in het bijeenbrengen van de partners, moet echter wel onderscheiden worden van een gedwongen huwelijk waarbij (een van) de partners zelf geen enkele keuze meer wordt toegestaan, ook niet de keuze om eenvoudigweg nee te zeggen. ${ }^{4}$ Het gearrangeerde huwelijk wordt in Nederland vooral geassocieerd met Marokkanen en Turken die in relatief groten getale huwelijkspartners over laten komen uit het land van herkomst. Onder deze huwelijken bevinden zich ook gedwongen huwelijken, zoals blijkt uit verschillende studies (Hooghiemstra 2003). Algemeen gesteld is het moeilijk vast te stellen waar en wanneer advies en ouderlijke betrokkenheid overgaan in drang of zelfs dwang, zeker als de loyaliteitsgevoelens van kinderen ten opzichte van ouders groot zijn. Daarnaast speelt mee dat jongeren zelf het passend of zelfs aantrekkelijk kunnen vinden om - net zoals leeftijdgenoten - met een partner van het land van herkomst te trouwen. Vermeldenswaard is echter het gegeven dat, hoewel een overgrote meerderheid $(75 \%)$ van de migranten van Turkse en Marokkaanse afkomst met een partner trouwt uit het land van herkomst, er toch sprake is van een lichte kentering. Voor deze groepen geldt dat er sinds begin jaren tachtig een lichte doch constante daling is opgetreden in het percentage mannen en vrouwen dat met een partner uit het land van 
herkomst trouwt, ten gunste van gemengde huwelijken en ten gunste van huwelijken met herkomstgenoten in Nederland. Wanneer gekeken wordt naar de verschillen in huwelijksgedrag over de generaties, dan is sprake van een toenemende gerichtheid op Nederland (bij Marokkanen iets meer dan bij Turken) bij het zoeken van een partner (Hooghiemstra 2003). Bij deze gegevens moet de kanttekening worden geplaatst dat bij deze trends en cijfers de ontbindingen van huwelijken niet zijn meegenomen. Over deze ontbindingen is weinig bekend.

Aangezien veel Nederlandse Turken en Marokkanen hun partners uit het land van herkomst over laten komen in het kader van de regelingen voor gezinsvorming, heeft de overheid het probleem vooral als een immigratiekwestie beschouwd. De maatregelen die tot stand zijn gekomen, betreffen het vreemdelingenbeleid en zijn erop gericht deze migratie tegen te gaan door middel van het ophogen van de voorwaarden om naar Nederland te mogen migreren. Om zogenaamde importhuwelijken te ontmoedigen worden er financiële eisen gesteld aan de partner die in Nederland verblijft. Deze zijn gedurende de afgelopen jaren verzwaard. Bovendien wordt de vereiste huwelijksleeftijd verhoogd. De binnenkomende partner wordt, als de financiële horden eenmaal genomen zijn, echter nauwelijks door de overheid opgemerkt (Broeders en Meurs 2002). Hoewel het ondenkbaar is dat de overheid zich direct met de partnerkeuze van haar onderdanen gaat bemoeien, verhoudt de eenzijdige aandacht voor de immigratiekant van dit vraagstuk zich slecht met de emancipatiedoelstellingen van het overheidsbeleid. Zo is de afhankelijke verblijfstitel van partners in het kader van gezinsvorming voor sommige wetenschappers en politici al jaren een steen des aanstoots, omdat het (vooral) vrouwen in een kwetsbare en afhankelijke positie plaatst (zie bijvoorbeeld Spijkerboer 2002 en Staatssecretaris van Justitie 2000).

\subsubsection{HET OPLEGGEN VAN DE GROEPSNORMEN AAN DE SAMENLEVING ALS GEHEEL}

Met het verabsoluteren van de normen van de eigen groep wordt bedoeld dat een groep de eigen waarden niet alleen van toepassing zou willen zien op de eigen groep, maar op de samenleving als geheel. Aangezien dit bijna een definitie van de 'politieke partij' behelst, zal duidelijk zijn dat het hier gaat om groepen die daarbij de grenzen van de rechtsstaat en het politieke proces in twijfel trekken of zelfs verwerpen. Meestal spreekt men van politiek en/of religieus fundamentalisme. De laatste tijd is de aandacht voornamelijk gericht op islamitisch fundamentalisme, oftewel islamisme (zie voor een uitgebreide beschrijving van islamisme Buijs 2002a; Buijs en Harchaoui 2003). In het verleden zijn er echter ook andere groepen geweest die zich radicaal afzetten tegen de Nederlandse samenleving en rechtsstaat en met extreme middelen een eigen agenda aan de samenleving probeerden op te leggen. Te denken valt aan de Molukkers in de jaren zeventig die in feite een buitenlandse agenda nastreefden, maar ook aan de kraakbeweging die zich begin jaren tachtig organiseerde onder de veelzeggende slogan 'Uw rechtsstaat is de mijne niet'. Zeker in de nasleep van de aanslagen in Amerika van 11 september 2001 staat in Nederland echter de vraag centraal in hoeverre 
Nederlandse moslims betrokken zijn bij islamistische stromingen en hoe groot de aantrekkingskracht van deze stroming op moslims in Nederland is. De AIVD (2002) constateerde, in een rapport met de weinig geruststellende titel Rekrutering in Nederland voor de Jihad. Van incident naar trend, dat deze aantrekkingskracht ook in Nederland aanwezig is. Ook bij dit onderwerp staan met name jonge Marokkanen weer in de schijnwerpers. Het is bij het probleem van het islamisme moeilijk laveren tussen een effectieve en open aanpak van het probleem en het voorkomen van stigmatisering en het voeden van (onterechte) angsten. Buijs en Harchaoui (2003) wijzen erop dat jongeren die het in sociaal-economisch opzicht goed doen maar die gefrustreerd worden in hun ontwikkeling en weinig respect krijgen - die zich in criminologische terminologie 'gekrenkt' voelen - beïnvloedbaar zijn voor handige rekruteurs die "een causaal verband stellen tussen hun lage welbevinden, het feit dat ze zijn afgedwaald van het ware geloof en de immoraliteit van de Nederlandse samenleving” (Buijs en Harchaoui 2003: 107).

Hoewel (gewelddadig) politiek en religieus extremisme met alle kracht bestreden moet worden, is het wel van groot belang te zoeken naar wegen die niet een bepaalde bevolkingsgroep, zoals jonge Marokkaanse mannen, permanent in de hoek van de verdachten plaatst. Dat dit geen denkbeeldig scenario is, kan een beetje afgelezen worden aan de heftige reacties die het oprichten van een Nederlandse tak van de politieke beweging AEL opriep bij sommige politici en commentatoren. Deze organisatie, die een zekere aantrekkingskracht heeft op voornamelijk jonge Marokkanen, werd met een voor Nederland ongekende felheid bekritiseerd en ter discussie gesteld. Er werd zelfs, nog voor oprichting in Nederland, in de Tweede Kamer al gezinspeeld op een verbod (Sijses en Huinder 2003). Hoewel dit een partij is met een aantal scherpe kanten ${ }^{5}$, presenteert zij zich als een democratische partij die het debat zoekt met de rest van de samenleving. Bovendien is het positief dat de AEL een groep jonge moslims die voorheen niet vertegenwoordigd waren, binnen het democratische debat brengt. Dit ondanks het feit dat bepaalde doelstellingen van de partij (zoals de invoering van de sjaria) buiten het huidige kader van de democratie en rechtsstaat liggen. Zij willen die doelstellingen immers binnen het democratische stelsel binnenhalen. CDA-senator Woldring (2003) wijst er terecht op dat Nederland ruim honderd jaar ervaring heeft met wat hij 'tolerantie van antidemocratisch fundamentalisme' noemt, in de vorm van de SGP, een partij die het beginsel van de theocratie voorstaat. Die tolerantie is gebaseerd op het feit dat deze partij weliswaar antidemocratische idealen voorstaat, maar "geen rechtstreekse aanvallen doet op de grondslagen van de rechtsstaat, de vrijheid van anderen niet aantast, geen gebruikmaakt van geweld of bedreiging, niet aanzet tot haat en zich niet schuldig maakt aan discriminatie in strafrechtelijke zin" (Woldring 2003: 89). Dezelfde redenering zou zijns inziens dus ook voor eventuele fundamentalistische moslimpartijen moeten gelden.

Zoals ook op andere plaatsen in dit rapport is betoogd, is de meest centrale waarde van de Nederlandse rechtsstaat immers de waarde van pluriformiteit. 
Daartoe moeten de spelregels van de democratie en de rechtsstaat wel gewaarborgd zijn. Dat stelt eisen aan alle deelnemers aan het debat maar ook aan de overheid die de randvoorwaarden voor het debat moet scheppen. In dit licht is het opvallend dat de VVD-Kamerleden Wilders en Hirsi Ali recentelijk een pleidooi hielden voor een 'liberale jihad' waarin de spelregels niet meer gelijkelijk voor iedereen zouden moeten gelden. Letterlijk stelden zij dat "voor het behoud van een tolerant en liberaal Nederland moeten ook elementaire rechten en wetten opzij worden gezet van de mensen die ze misbruiken en vervolgens willen verwijderen als fundament van onze maatschappij”. Het is zeer de vraag of de Nederlandse rechtsstaat en democratie gebaat zijn met een methode van vuur met vuur bestrijden, waarin bijna noodzakelijkerwijs veel verworvenheden verloren zullen gaan. De onderzoeker Buijs ziet gevaren in een dergelijke bestrijding van extremisme: "Hier komen we bij de kern van de botsing tussen democratie en terreur, namelijk het gevaar dat de democratie precies die waarden en normen opgeeft die ze juist wilde verdedigen" (Buijs 2002b). Hij bepleit juist een opener debat, een 'radicaal democratische revival' waarin men zich afkeert van een hardere opstelling tegenover minderheden in het debat, men meer ruimte laat voor afwijkende meningen en een zelfgenoegzame houding in de trant van 'zij zijn achterlijk en wij met onze democratie zijn superieur' vermijdt. Er moet ook meer moeite gedaan worden om daadwerkelijk een dialoog aan te gaan met (potentiële) aanhangers en rekruten en zo ook de voedingbodem voor extremisme te adresseren. Hier is een integrale benadering op zijn plaats waarbij juist ook gematigde moslims betrokken worden. Een daadwerkelijk preventief beleid werkt waarschijnlijk het best wanneer extreme elementen binnen de groep door de groep zelf uitgestoten worden (de voice van niet-radicale elementen binnen de gemeenschap zou versterkt moeten worden). In de nasleep van het Molukse terrorisme in de jaren zeventig werden ook niet alleen de daders bestraft, maar werd er tevens een beleid ontwikkeld dat tot doel had Molukkers uit hun politieke isolement te halen (Van Dam, in Fennema 2002: 6).

\subsection{STRATEGIEËN}

In dit hoofdstuk is betoogd dat sprake is van een glijdende schaal die loopt van groepsnormen die niet of nauwelijks in strijd zijn met de normen van de samenleving als geheel, tot en met normen die daarmee fundamenteel in strijd zijn. Bij het zoeken naar antwoorden en oplossingen is het van belang rekening te houden met de verschillende posities op die glijdende schaal. Het gaat steeds om het vinden van een 'passende' oplossing. Aan de hand van het onderzoek dat in dit hoofdstuk is besproken, kunnen drie mechanismen worden onderscheiden om problemen aan te pakken die het gevolg zijn van uiteenlopende normen:

- dulden;

- confronteren en beslechten;

- normeren en verbieden.

Deze drie mechanismen worden kort toegelicht.

Bij dulden gaat het om het aanvaarden van gedragingen/opvattingen van anderen, ook al zijn deze niet geheel in overeenstemming met de eigen voorkeuren of 
opvattingen. 'Leven en laten leven' is immers een belangrijke voorwaarde om te kunnen samenleven. Dulden heeft te maken met tolerantie in de zin van "het bewust achterwege laten van een negatieve reactie tegen iets of iemand waar men reële en serieuze bezwaren tegen heeft" (Schuyt 2001: 117). Het gaat met andere woorden om 'een zone van gelatenheid': situaties die als onprettig worden ervaren, maar waarbij het niet past om actief tegen op te treden. De Marokkaanse buurvrouw die op straat drie meter achter haar man loopt, is een voorbeeld van een zone van gelatenheid: het getoonde gedrag wordt gezien als een aantasting van het principe van gelijkwaardige verhoudingen tussen man en vrouw, een reactie wordt echter achterwege gelaten. Ouders die de piercing van hun dertienjarige dochter dulden, vormen in een geheel andere context een voorbeeld van hetzelfde mechanisme: ouders keuren het af, want het is in strijd met de eigen opvattingen over zedelijkheid en schoonheid, maar laten het erbij. De voorbeelden die hier genoemd worden laten zien dat dulden als mechanisme kan worden ingezet ter voorkoming van een te grote en zelfs onoverbrugbare kloof tussen betrokkenen. Het verbieden van de piercing - zo zou de afweging van de ouders kunnen zijn - kan leiden tot een ongewenste verwijdering tussen ouders en kind en deze is veel moeilijker te aanvaarden dan de piercing zelf. Het Marokkaanse echtpaar aanspreken op hun gedrag zou kunnen leiden tot een ongewenste en wellicht moeilijk te beslechten burenruzie. Bij dulden gaat het om een min of meer bewuste afweging tussen (de effectiviteit van) het middel en de aard van de kwaal. Dulden wijst op een zekere terughoudendheid bij het beoordelen van het gedrag en actief ingrijpen in het gedrag van anderen.

Confronteren verwijst naar een meer actieve opstelling dan dulden. Het 'er niet bij laten zitten' en het bespreekbaar maken en bediscussiëren van verschillen. De achterliggende gedachte bij dit mechanisme is dat geconstateerde verschillen zo problematisch zijn dat ze niet onbesproken kunnen blijven. Het bespreken van verschillen kan behulpzaam zijn bij het accepteren van die verschillen (en dan wordt het dulden), het verkleinen van verschillen dan wel het zetten van een volgende stap: normeren of verbieden van het gedrag / de opvattingen die de verschillen hebben veroorzaakt. Door de confrontatie aan te gaan worden de posities duidelijk en worden partijen in hun standpunten ook serieus genomen. Daarnaast is confrontatie een mechanisme dat kan worden ingezet in situaties waar sprake is van diffuse grenzen tussen wat geoorloofd is en wat niet, waar niet zonder meer een eenduidig standpunt kan worden ingenomen. Confrontatie krijgt ook vorm en inhoud bij een open debat. Hierbij gaat het zeker niet uitsluitend om het debat tussen groepen, het gesprek en de confrontatie binnen de groep is zeker zo belangrijk en in veel gevallen onontbeerlijk om tot veranderingen te komen. Vaak gaat een debat tussen krantenkoppen over het hoofd van de groep in kwestie heen en wordt er weinig geïnvesteerd in de direct betrokkenen. Voor uitermate belangrijke problemen, bijvoorbeeld de voedingsbodem voor extremisme binnen bepaalde moslimkringen, is de interne confrontatie echter van het grootste belang en een noodzakelijke, maar niet voldoende voorwaarde voor oplossingen. Bij confronteren hoort beslechten. Het gaat immers om de uitwisseling en verscherping van posities als een middel om een stap verder te komen en niet als een 
middel om het conflict in stand te houden. Mechanismen van conflictbeslechting beginnen bijvoorbeeld al bij de spelregels die in een bepaald debat worden afgesproken: niet op de man spelen, niet vloeken enzovoort. Ook valt te denken aan allerlei vormen van mediation die in de formele en informele sfeer worden ingezet. Van de drie hier beschreven mechanismen zijn confronteren en beslechten de moeilijkste. Er moet bereidheid zijn om de confrontatie aan te gaan zonder dat er vooraf inzicht is in het resultaat. Het vergt een inspanningsverplichting om problemen aan te kaarten, maar ook om eruit te komen. Bovendien wordt met dit mechanisme uitgegaan van de principiële gelijkwaardigheid van de verschillende posities en standpunten, terwijl die gelijkwaardigheid van posities nu juist het strijdpunt is. Overigens, zo laat Ellian (2003) zien, valt op dit uitgangspunt van principiële gelijkwaardigheid van standpunten het nodige af te dingen. Op basis van een analyse van de jurisprudentie van zaken waarin sprake is van kwetsende meningen (zoals die van Janmaat en El Moumni) stelt hij dat religieuze en niet-religieuze meningen in het strafrecht de facto verschillend worden behandeld. Zijn conclusie is "dat wie een heilig boek onder zijn arm heeft meer mag zeggen dan iemand die zonder een heilig boek zijn gedachten openbaar maakt".

Normeren - het woord zegt het al - betreft het stellen van een norm. Het gaat om het bepalen van wat wel en niet geboden en verboden is in een bepaalde situatie. Bij het overtreden van juridische normen is het relatief overzichtelijk wat er moet gebeuren. De rechter moet dat wat verboden is handhaven. In andere of nieuwe situaties wordt een nieuwe norm gemaakt en opgelegd. De wijze waarop met de hoofddoekjes wordt omgegaan in Nederland is hiervan een voorbeeld. Het voorbeeld maakt overigens ook duidelijk dat het bij normeren niet altijd hoeft te gaan om algemeen geldende normen, het kan ook gaan om contextgebonden normen die in een bepaalde situatie gevolgd moeten worden. Bij dit mechanisme kan het bepalen van de norm lastig zijn. Nog moeilijker is - in sommige van de voorbeelden uit dit hoofdstuk - het handhaven van de norm. Zoals gezien in het voorgaande, gaat het in veel gevallen om gedrag om normoverschrijdend gedrag dat zich sterk in de privé-sfeer bevindt, hetgeen de mogelijkheden van de overheid in handelende zin sterk beperkt.

In de praktijk van vandaag wordt niet adequaat gebruikgemaakt van deze drie mechanismen. Een beoordeling van wat passend is in een bepaalde situatie wordt te gemakkelijk overgeslagen, met als gevolg dat oplossingen worden gekozen die de problemen kunnen verergeren in plaats van oplossen. Enkele jaren geleden stelde De Beus (1998) zich nog teweer tegen de Nederlandse cultus van vermijding waarin de Nederlandse samenleving en maatschappij waardegeladen conflicten bij voorkeur uit de weg ging. Nu lijkt het debat alle kanten uit te gaan en geen enkele 'waarde' meer te schuwen. Tegelijkertijd is gebleken dat een debat over culturele verschillen en culturele waarden allesbehalve onschuldig is. Woorden treffen hier wel degelijk doel en afhankelijk van de toon en de formuleringen kunnen wij-zij-tegenstellingen naarmate de tijd vordert behoorlijk verharden. Onder deze omstandigheden gaan groepen migranten zich minder welkom voelen dan voorheen en zich terugtrekken binnen de eigen groep. In de 
praktijk komt het ook voor dat eerst wordt ingezet op normeren en verbieden, terwijl confrontatie en beslechten gepast zouden zijn. Het organiseren van 'deugdelijke vormen van confrontatie' (gemeenschappelijke inzet, duidelijke spelregels en gericht op een werkbaar resultaat) is in eerste aanleg de verantwoordelijkheid van partijen zelf. Daarnaast kunnen en moeten de media een belangrijke bijdrage leveren.

Voor de overheid geldt dat zij - meer dan nu gebeurt - moet bepalen waar zij zelf het debat over wil entameren en waarover niet. Een standpuntbepaling van de overheid is nodig in die kwesties die het beginsel van pluriformiteit van waarden aantasten, dan wel schuren tegen de principes van de democratische rechtsstaat. Deze kwesties kunnen niet in dit rapport of elders limitatief worden opgesomd. Het gaat erom dat de overheid alert is en blijft en weet wanneer zij moet ingrijpen en op welke wijze en wanneer dulden en terughoudendheid aan de orde zijn. Wat de rol van de overheid betreft moet hier nog worden gewezen op het gegeven dat daar waar problemen en misstanden zich in de privé-sfeer voordoen, haar interventiemogelijkheden beperkt zijn. Hiermee is echter niet gezegd dat ingrijpen onmogelijk is. Juist daar waar sprake is van ernstige vermoedens van groepsdwang moet de overheid garant staan voor een exit-optie en dient de overheid de drempel van deze optie te verlagen. Dit kan de overheid doen door bijvoorbeeld blijf-van-mijn-lijfhuizen in woord en daad beleidsmatig en financieel te ondersteunen. Ook de versterkte inzet van de kinderbescherming en bijvoorbeeld vertrouwenspersonen op scholen kan drempelverlagend werken. De opdracht tot alertheid geldt niet alleen voor de overheid maar ook voor individuen en instituties, zoals de school, het werk, de vrije tijdsverenigingen. Niet alleen de overheid maar ook burgers en organisaties hebben een taak in het laveren tussen de drie genoemde mechanismen als ingewikkelde culturele verschillen in het geding zijn. Ook zij hebben een verantwoordelijkheid als het gaat om het opspelen, nuanceren dan wel downplayen van culturele verschillen. Het beginsel van behoud van waardepluriformiteit binnen de context van de democratische rechtsstaat dient leidend te zijn bij het zoeken naar oplossingen voor die culturele verschillen die het samenleven bedreigen.

\subsection{CONCLUSIES}

In dit hoofdstuk is de vraag behandeld in hoeverre sprake is van botsing van waardestelsels dan wel van uiteenlopende normen die het gevolg zijn van verschillen in culturele achtergronden. Meer in het bijzonder is aandacht besteed aan de betekenis van groepsnormen, omdat deze vaak door leden van de groep worden gebruikt om een bepaald gedrag te rechtvaardigen en door niet-leden om datzelfde gedrag af te keuren. Een nadere analyse aan de hand van voorbeelden van de werking van deze groepsnormen voor de groep zelf en voor de samenleving als geheel, heeft duidelijk gemaakt dat het weinig vruchtbaar is verschillen in gedrag, uiteenlopende opvattingen over wat hoort en wat niet hoort in algemene zin te beschouwen als een 'normen- en waardenkwestie'. Het gevaar - en dat is de laatste tijd gebleken - is levensgroot dat het steeds opnieuw labelen van 
verschillen in termen van andere (afwijkende) normen en waarden leidt tot een reactie gericht op eenvormigheid (monoculturaliteit) en onterechte uitvergroting van verschillen. Een dergelijke reactie is in strijd met het beginsel van waardepluriformiteit dat in de Nederlandse samenleving centraal staat. Daarenboven heeft labeling ongewenste neveneffecten zoals het isoleren en stigmatiseren van groepen, waardoor ook de capaciteiten en talenten van dergelijke groepen on(der)benut blijven. De maatschappij heeft hier met andere woorden ook gewoon een welbegrepen eigenbelang (vgl. Veenman 2003).

Hiermee is natuurlijk niet gezegd dat er helemaal geen problemen zijn in een samenleving die steeds meer te maken heeft met culturele diversiteit. Sommige praktijken van leden van bepaalde (etnische) groepen zijn in strijd met de Nederlandse wet, andere praktijken verhouden zich zeer moeizaam met wat in Nederland belangrijk wordt gevonden - bijvoorbeeld het principe van individuele autonomie - en er zijn situaties die als ongemakkelijk zijn te bestempelen. Er is - zo is betoogd - sprake van een glijdende schaal in de mate waarin (groeps)normen strijdig zijn met wat in Nederland aanvaarde normen zijn. Bij het inzetten van strategieën om met deze verschillen en strijdpunten om te gaan, is het van belang goed af te wegen wat passend is in welke situatie. Dit criterium van 'passendheid' kan niet zonder meer en op voorhand worden ingevuld. In veel gevallen zal de context waarbinnen verschillen en strijdpunten zich voordoen in ogenschouw moeten worden genomen. Evenmin kan op voorhand worden bepaald wie verantwoordelijk is om wat te doen. In dit hoofdstuk is aan de hand van de verschillende voorbeelden duidelijk gemaakt dat individuen, leden van de groep en instituties, zoals school en werk, hier een taak hebben.

De overheid heeft echter een bijzondere verantwoordelijkheid. Uiteindelijk is het aan de overheid om te garanderen dat er een maatschappelijk klimaat is waarin groepen goed met elkaar kunnen samenleven. Dat samenleven vindt plaats binnen de kaders van de democratische rechtsstaat en de gedeelde waarden zoals deze in hoofdstuk 5 zijn beschreven. Het spreekt vanzelf dat de overheid de eerstverantwoordelijke is bij het normeren, verbieden en handhaven van praktijken die in strijd zijn met de wet. De overheid zou in dit opzicht - meer dan nu gebeurt - zichtbaar moeten optreden en duidelijk maken wat in Nederland niet geaccepteerd wordt. Aan de andere kant van het spectrum kan de overheid bevorderen dat verschillen geaccepteerd worden en dat het dulden van verschillen een noodzakelijke voorwaarde is voor het goede leven. De overheid kan en moet zelf het voorbeeld geven en de bepleite zones van gelatenheid ook zelf in ere houden. In het tussengebied waar zich situaties kunnen voordoen die niet zonder meer onwettig zijn, maar wel zodanig conflictueus dat oplossingen nodig zijn, heeft de overheid een procedurele rol te vervullen. Deze rol kan afhankelijk van de situatie andere vormen aannemen. Waar het om gaat is dat verschillen van mening en conflicten op tafel komen en worden besproken en dat er voldoende conflictbeslechtende mechanismen voorhanden zijn om tot een oplossing te komen dan wel tot een aanvaardbaar compromis. Overigens is hiermee niet gezegd dat deze procedurele rol uitsluitend door de overheid dient te 
worden vervuld, integendeel. Instituties en burgers zelf hebben hierin ook een rol. In meer algemene zin kan gezegd worden dat de overheid ervoor moet zorgen dat burgers voldoende zijn toegerust om met die confrontaties en conflicten om te gaan. Dit is uiteraard een langetermijnkwestie, maar daarom niet minder belangrijk. De rol van de overheid is delicaat waar het gaat om groepsnormen die primair de privé-sfeer betreffen. Dit betekent niet dat de overheid niets kan doen. Ten eerste moet zij burgers toerusten om hun stem te laten horen en in sommige gevallen een podium organiseren. Groepsleden kunnen de geschilpunten in de openbaarheid brengen, de discussie in eigen geledingen aanzwengelen en bijdragen aan een verandering van knellende of voor hen onaanvaardbare normen. Ten tweede is de overheid verantwoordelijk voor de garantie van de zogenaamde exit-optie, mogelijkheden bieden voor betrokkenen om uit de groep te stappen. 


\section{NOTEN}

Zie voor een uitgebreide analyse van de berichtgeving in de media na de aanslagen van 11 september 2001: Fennema (2002).

Hierop zijn natuurlijk al de eerste uitzonderingen zoals het onderzoek van Van den Tillaart et al. (2000) onder vluchtelingen uit Afghanistan, Ethiopië en Eritrea, Iran, Somalië en Vietnam.

Een heel duidelijk voorbeeld hiervan is te vinden in de aanpak van de integratieproblemen van Somalische jongeren in Den Haag. Aangezien deze problematiek voor een deel veroorzaakt wordt door de integratieproblemen van de oudere generatie, wordt die nu meegenomen in de aanpak van het probleem (Van den Tillaart en Warmerdam 2003).

$4 \quad$ Zie voor dit onderscheid bijvoorbeeld: Working group on Forced Marriage (200o) A choice by right. Londen: Home Office communications directorate, p. 10.

$5 \quad$ Hierbij gaat de aandacht met name uit naar de buitenlandse politiek en het standpunt van de AEL over de staat Israël waarvan zij het bestaansrecht niet erkent. Overigens tolereert Nederland wel meer organisaties die er een specifieke mening op nahouden over de legitimiteit of het bestaansrecht van soevereine staten, zoals de RMS (de Molukken) en Koerdische organisaties. 


\section{DE BIJDRAGE VAN DE SAMENLEVING}

\subsection{INLEIDING: DEEL VAN HET PROBLEEM, DEEL VAN DE OPLOSSING}

Waarden en normen ontstaan en worden overgedragen in de interacties tussen personen, binnen maatschappelijke instituties en organisaties en in de samenleving als geheel. In dit hoofdstuk komt de vraag aan de orde wat de maatschappij zelf bijdraagt aan de handhaving van door haarzelf ontwikkelde waarden en zelf opgestelde normen. Als men zich beklaagt over een mogelijk verval van waarden en normen, dan moet de oorsprong daarvan toch in eerste instantie gezocht worden in de samenlevingsverbanden zelf. Het is opvallend dat in de discussies over waarden en normen vooral het gedrag van anderen wordt bekritiseerd: zij houden zich niet aan onze normen; jouw gedrag voldoet niet aan mijn maatstaven (vgl. de Belevingsmonitor van de regering). De oplossing wordt vervolgens van de overheid gevraagd, maar het is duidelijk dat dit een veel te eenzijdige benadering van het probleem is. De samenleving is deel van het probleem en moet daarom ook een onderdeel van de oplossing uitmaken. Maar wie is de samenleving? De bekende Sire-reclame, waarin iemand u met een vinger aanwijst en zegt: 'De samenleving, dat ben jij', geeft op deze prikkelende vraag een duidelijk antwoord, maar het is eerder een oproep dan een vaststelling. Juist de noodzaak van dergelijke reclameteksten duidt op het verdwijnen van een vanzelfsprekend wij-perspectief en op de kracht van een individualiseringstendens, die het onderlinge vertrouwen mogelijkerwijs aan het ondergraven is.

Want wie zijn die wij? Allereerst zijn dit individuen, in meer of minder losse verbanden. Het is een feit dat oude instituties zoals kerkelijke instellingen of vakbonden hun invloed hebben zien afnemen. Individuen kiezen meer zelf hoe ze hun leven inrichten en kiezen meer voor zichzelf. Ze verbinden zich in minder hechte sociale relaties en in vluchtigere netwerken. Hiermee zijn niet alleen meer open en informele verbanden ontstaan en is tevens de variëteit aan verbanden gegroeid, maar is ook de structurerende invloed van lange tijd dominante sociale instituties op het gedrag afgenomen. Ook de invloed van gezin en opvoeding, een van de oudste primaire sociale verbanden, is afgenomen. Tegelijkertijd is het patroon van opvoeding zeer gevarieerd geworden. Er zijn nog steeds strenge ouders die hun kinderen met strikte geboden en verboden opvoeden en er zijn ouders die een vrije opvoeding geven en die veel minder strenge gedragsregels aan hun kinderen opleggen. Veel kinderen groeien op in eenoudergezinnen of zelfs zonder ouders of opvoeders. Al deze verschillend getrainde kinderen, komen elkaar voor het eerst tegen op de basisschool, die met deze veelvoud aan aangeleerde nette en onnette, beleefde en onbeleefde, prettige en onprettige gedragingen moet zien om te gaan. Een groot deel van het probleem van waarden en normen is te vinden in veranderde opvoedingspatronen, maar dit is tegelijkertijd een maatschappelijke sfeer waar de overheid het minst in kan of wil inter- 
veniëren. Opvoeding en onderwijs vormen dus een deel van het probleem en vormen evenzeer een deel van de oplossing.

Hetzelfde kan gezegd worden van andere instituties en organisaties binnen die instituties. De moderne media oefenen een enorme invloed uit op het gedrag en op het normbesef van kinderen en volwassenen. Een tendens tot het uitvergroten van extreme, conflictrijke en aandachttrekkende gedragingen is niet vreemd aan media als internet, televisie, film en video. Maar tegelijkertijd hoeven de particuliere organisaties achter deze media nauwelijks verantwoording af te leggen voor de mogelijke negatieve gevolgen van hun eigen optreden. Moderne media zijn dus, net als andere sociale instituties, in meer of mindere mate onderdeel van het probleem van waarden en normen, terwijl ze wellicht ook kunnen bijdragen aan de oplossing ervan (bijvoorbeeld door gepopulariseerde programma's waarin deze problematiek kan worden gevisualiseerd of besproken). Veel van deze instituties zijn bovendien op allerhande manieren vervlochten met de overheid (dit geldt niet alleen voor scholen, opvoedingsinstellingen, ziekenhuizen en andere arbeidsorganisaties, maar eveneens voor (publieke) omroeporganisaties en andere particuliere instellingen). Een analyse van deze instellingen en organisaties behoort derhalve in dit rapport aan de orde te komen en zal consequenties dienen te hebben voor de aan de regering uit te brengen aanbevelingen: als de samenleving als geheel deel uitmaakt van het probleem, kan de oplossing van dat probleem niet uitsluitend bij de overheid gelegd worden of van de overheid alleen komen. Individuen, losse en vaste sociale verbanden zoals buurtgenootschappen, gezinnen en onderwijsinstellingen en andere organisaties en instituties, dragen bij aan de overdracht en het onderhoud van waarden en normen. Zij zijn de vanzelfsprekend aangewezen figuren voor de gewenste oplossing van tekorten in de samenleving, mede door de minder van zelfsprekende algemene acceptatie van een publieke moraal. In dit hoofdstuk gaat de speciale aandacht uit naar de rol van instituties bij de overdracht van waarden en normen.

\subsection{WAARDEN, NORMEN, REGELS EN GEDRAG IN EEN INSTITUTIONELE CONTEXT}

Waarden en normen komen niet uit de lucht vallen. Het zijn ook geen granieten blokken die als weerbarstige gehelen op elkaar stuiten. De idee dat de verschillende stelsels van waarden en normen in een samenleving scherp van elkaar zijn te onderscheiden en de maatschappelijke steun voor waarden gemakkelijk valt vast te stellen, gaat misschien op voor een premoderne samenleving, maar is voor een moderne samenleving, na de Franse Revolutie en de Verlichting, achterhaald. Verschillende waarden en waardestelsels en daarbijbehorende normen hebben zich historisch ontwikkeld binnen sociale instituties (zoals het gezin, de school, de kerk, het werk, de markt, de politiek, verenigingen en de media) en zijn derhalve ingebed in deze instituties. Deze instituties hebben bovendien allemaal een zekere eigen sfeer geschapen waarbinnen sommige waarden en normen benadrukt worden en andere juist buitengesloten worden. Goede voorbeelden van dergelijke relatief autonome instituties zijn het gezin, de 
kerk, de gezondheidszorg en het onderwijs. Binnen de sfeer van het gezin gelden andere waarden en normen dan op het werk of op het sportveld. Wat in de ene sfeer wel kan, hard schreeuwen bijvoorbeeld, kan elders niet en omgekeerd. Intimiteit is in het gezin normaal, maar op het werk verboden. Zakelijkheid is een algemene norm op de markt, maar in het gezin schadelijk voor de goede sfeer.

De Amerikaanse socioloog Tipton heeft in een artikel, 'Social Differentiation and Moral Pluralism' (2002: 15-41), gewezen op de belangrijke rol die instituties spelen bij de ontwikkeling en overdracht van morele waarden in de (Amerikaanse) samenleving. Zijn uitgangspunt is het bestaan van "contrasting styles of ethical evaluation, structurally arranged within different sectors of social life" (Tipton 2002: 15). Contrast is een gelukkige term voor de verschillende morele waarderingen die in institutionele sferen worden gepraktiseerd. Contrast is immers neutraler dan botsing van waarden, zoals we ook het contrast kennen tussen voorgrond en achtergrond, zonder te hoeven beslissen of de voorgrond belangrijker is dan de achtergrond. De verschillen zijn er en hebben een zinvolle functie. Wel heeft elke institutie een eigen mode of moral understanding en mode of moral argument ontwikkeld. Binnen de institutionele sfeer kennen de deelnemers deze morele standaarden en ze brengen die vaak als vanzelfsprekend in praktijk. Er is een vertrouwen in elkaar dat men de 'waarden en normen' van de institutie eerbiedigt en handhaaft.

Op basis van een grondige inhoudelijke studie van dergelijke ethische evaluatiesystemen kwam Tipton met de beschrijving van vier verschillende en goed van elkaar te onderscheiden stelsels van morele waardering. Waarden evalueren immers gedrag. Evaluatie is altijd het inroepen van waarden bij de beoordeling van de wereld om ons heen. Elke evaluatiestijl stelt de vraag: 'Wat moet ik doen?', 'Hoe moet ik handelen?' en het antwoord op die vraag - in termen van gedrag en niet alleen in termen van waarden en normen - is kenmerkend voor een bepaalde stijl van evalueren. Zo zijn er grosso modo vier stelsels van morele waardering te beschrijven, die elk op zich een historische oorsprong, wortels en ontwikkeling hebben.

1 Het religieuze waardestelsel met een beroep op bovennatuurlijk gezag bij de vraag 'Wat moet ik doen?'. Hier aan te duiden met de term: gezagsmoraal (naar het bovennatuurlijke gezag van heilige boeken en van de kerkelijke leiders).

2 Het seculier humanisme met een verwijzing naar een bepaalde deugd, een funderend beginsel of een relevante regel bij de vraag 'Wat moet ik doen?'. Hier aan te duiden met de term: regulatieve moraal (naar Kants regulatieve idee).

3 Het utilitair individualisme met een verwijzing naar de bevrediging van wensen en noden bij de vraag 'Wat moet ik doen?'. Hier aan te duiden met de term: nutsmoraal (naar de ideeën van Smith, Bentham en Mill).

4 Het expressief (of romantisch) individualisme met een verwijzing naar een goed gevoel op de vraag 'Wat moet ik doen?'. Hier aan te duiden met de term: 
expressiemoraal (naar de romantici, dadaïsten en postmoderne kunstenaars).

Als die typologie wordt toegepast, ziet men dat de vier stelsels van morele waardering min of meer zijn verspreid over de verschillende maatschappelijke instituties. De gezagsmoraal komt het meest voor in het gezin, in kerkelijke aangelegenheden, in hiërarchisch gestructureerde organisaties, en is bij uitstek aanwezig in theocratische staten. De typische sociale relaties (met bijbehorende symboliek) zijn die van vader en kind, vorst en onderdaan, officier en soldaat, heer en knecht.

De regulatieve moraal is typerend voor juridisch-politieke instituties (democratie en rechtsstaat als regulatief idee), voor wetenschappelijke gemeenschappen, voor onderwijsinstellingen en voor sommige, vooral vrijzinnige, religieuze broederschappen. De gemeenschap en gemeenschapszin worden bevorderd via deliberatie en argument aan de hand van de relevante regels en beginselen. De typische sociale relatie is hier die van volksvertegenwoordiger en burger, van leraar en leerling, van professionele beroepsgenoten onderling. De relatie is in principe horizontaal, niet verticaal: het gezag komt niet van boven, maar van elkaar. De nutsmoraal komt - niet verrassend - het meest voor in de markteconomie en in bedrijfsorganisaties. Maar ook bij belangengroepen, bij pressie- en actiegroepen en bij commerciële dienstverlenende beroepen. Contract- en ruilrelaties zijn typerend (koper-verkoper, klant-bedrijf, leverancier-geleverde, dienstverlenercliënt) en de onderlinge relaties worden beheerst door de eigen nutsoverwegingen van de partijen. Voorzover corporate actors zich hebben ontwikkeld tot grote bureaucratieën, vertonen deze bureaucratieën, inclusief grote overheidsdiensten, voornamelijk, maar natuurlijk nooit voor honderd procent, deze stijl van morele waardering. De expressiemoraal, ten slotte, is typerend voor de vrije tijd, voor de kunsten, voor het privé-leven, voor mystieke en occulte clubs. Esthetische en gevoelswaarden overheersen en zijn soms allesbepalend ('Hoe voelt het? Het voelt goed'). Levensstijl en smaakstijlen zijn een bindende factor tussen soortgenoten. De typische sociale relaties zijn hier de jonge liefdesparen, de minnaar met zijn minnares, de kunstenaar en de kunstliefhebber, de entertainer en de fan, de komediant en de bewonderaar. In de moderne massamedia wordt op vele manieren deze expressiemoraal uitgedragen.

Deze analyse in termen van morele stijlen en sociale differentiatie wordt door Tipton benut om een van de meest opvallende kenmerken van de huidige, moderne samenleving op het einde van de twintigste en aan het begin van de eenentwintigste eeuw te typeren, namelijk de mixed moral meanings of modern society (2002: 20). Het meest kenmerkende van een moderne westerse samenleving is niet dat keurig van elkaar afgebakende waarde- en normenstelsels van elkaar verschillen en met elkaar concurreren, zoals in een verzuilde samenleving, maar dat er allerlei mengvormen zijn ontstaan van morele codes die, afhankelijk van de situatie en de institutionele context, na en door elkaar heen worden gebruikt en gepraktiseerd. De verschillen tussen de codes manifesteren zich niet 
alleen tussen de instituties, maar ook binnen één persoon. Dat is de moderne burger die nu eens iets meer gezagsmoraal volgt, dan weer een professionele beroepscode naleeft met bijbehorende wetenschappelijke argumentatie, daarna zich als een nutsmaximerende consument gedraagt, die in zijn privé-ruimten vooral zijn gevoel laat spreken. Omdat we allemaal deel uitmaken van veel instituties (maar nooit allemaal tegelijkertijd), zijn we gewend om van ethische code te switchen zonder ons nadrukkelijk in allerlei bochten te hoeven wringen. Dit is in feite de beschrijving van een postmoderne ervaringswereld. De morele verwarring en de vaak uitgesproken zorgen over 'waarden en normen' zijn mede het gevolg van de niet-eenduidigheid van de verschillende gelijktijdig opererende morele codes en morele waarderingen van gedragingen en situaties. Een roep om 'herstel' van waarden en normen gaat vaak gepaard aan een verlangen naar een overal geldende gezagsmoraal. Kortom: men beoordeelt elkaar vanuit de telkens wisselende morele evaluaties. De ene institutie wordt beoordeeld naar de maatstaven van de andere, maar verkeert men in een andere institutionele sfeer, dan keert men de zaken weer om: men geeft aan God wat God toekomt en aan de mammon wat de mammon toekomt. Alleen religieuze en politieke fundamentalisten kunnen slecht tegen deze wisselingen, hoewel ook fundamentalisten zich bedienen van een nutsmoraal en van moderne wetenschap en techniek, waardoor hypocrisie ook bij deze fundamentalisten constant aan te treffen valt.

Naast de - verhelderende - stelling van de gemengde morele codes als typerend voor de moderne samenleving brengt Tipton nog een tweede en eveneens fundamentele bewering in stelling, namelijk: elk stelsel van morele waardering (of morele code) is imperialistisch. Dat wil zeggen, elk moreel stelsel heeft de neiging om het eigen morele domein uit te breiden en het te laten uitstrekken over alle andere sociale instituties. Zo had de kerk lange tijd het gezag over de staat, de juridische instellingen, de scholen, en tot de zestiende eeuw zelfs over de economie (dit is nog steeds het geval in fundamentalistische moslimstaten). Zo brengen de rechtsinstellingen langzamerhand alles onder het domein van de rationele regels en regulatieve beginselen (dit is in feite het voortgaande proces van juridisering). Zo relativeert het postmoderne levensgevoel alle andere morele waarderingen. Zo werkt de nutsmoraal, vooral de laatste tijd, door in die maatschappelijke instituties, die in principe niet van het nutsbeginsel uitgaan, maar van regulatieve beginselen en van zorg voor elkaar, zoals het onderwijs of de gezondheidszorg. De marktwerking heeft de neiging alles op haar weg mee te nemen wat ze tegenkomt, ook de publieke (overheids)diensten. Wat men ervaart als botsing van waarden, is derhalve vaak een interinstitutionele penetratie van niet-eigen waarden. In de gezondheidszorg en het onderwijs hebben grosso modo (er zijn natuurlijk uitzonderingen op de regel) de professionele waarden het onderspit gedolven ten gunste van de nutsmoraal van markt en bureaucratisch management. De positieve en negatieve gevolgen van deze langetermijnprocessen zijn nog nauwelijks te schatten, maar deze onzekerheid draagt ontegenzeggelijk bij aan de verzwakking van sociale binding en samenhang in sociale instituties afzonderlijk als in de samenleving als geheel. 
De overgang van een monistische moraal naar een pluralistische moraal, zoals die eerder in hoofdstuk 2 is beschreven, wordt goed geillustreerd door de in deze paragraaf beschreven sociale differentiatie van morele waarderingen in de diverse sectoren van de samenleving. Dit kan de verontrusting over de stand van zaken in de publieke moraal en de wijdverbreide belangstelling voor het debat over waarden en normen in onze samenleving mede verklaren.

\subsection{DE PRIMAIRE, SECUNDAIRE EN TERTIAIRE TAKEN VAN INSTITUTIES}

\subsubsection{ONBEHAGEN, VOORGESTELDE OPLOSSINGEN EN ANDERE SUGGESTIES}

In een sfeer van onzekerheid en onbehagen floreren eenvoudige oplossingen voor het vraagstuk van de tekorten in de publieke moraal die in de samenleving worden ervaren. Een veelvuldige gewoonte hierbij is met een beschuldigende vinger te wijzen naar het onderwijs, dat te kort zou schieten in zijn pedagogische taak van morele opvoeder en in het bijbrengen van waarden en normen. Haast tegelijkertijd wijst men dan op het onderwijs als mogelijke probleemoplosser: 'Als er nu maar meer aandacht zal worden besteed aan waarden en normen in het onderwijs, dan zal de situatie in de nabije toekomst verbeteren.' Kortom, velen stellen hun hoop op het onderwijs. Suggesties als 'lessen in moraal' of het apart invoeren van 'waarden en normen' als onderdelen van het curriculum komen dan ter sprake. Overdracht van waarden en normen wordt in deze gedachtegang gelijkgesteld aan morele vorming. Er is een hele traditie van value education op deze gedachtegang geschoeid, namelijk de theorie van Kohlberg over de verschillende stadia van morele ontwikkeling die kinderen achtereenvolgens doormaken (Emberley 1995). Deze benadering besteedt veel aandacht aan de cognitieve ontwikkeling van leerlingen, die beïnvloed kan worden door discussies over morele dilemma's en dergelijke. Maar volgens andere pedagogen is dit een te idealistische voorstelling van zaken (vgl. Levering 2004). Morele vorming ontstaat vooral in en door de instandhouding van gedragspraktijken. Het gaat uiteindelijk om het gedrag van volwassenen zelf. Door het zien en overnemen van voorbeelden verbreidt dit gedrag zich over anderen. Ouders geven in het gezin en daarbuiten het voorbeeld, zoals ook leraren en leraressen dat doen op school, conducteurs in de tram, of journalisten bij de omroep. Daarnaast gaat er een sterke voorbeeldwerking uit van het gedrag van medeleerlingen en medepassagiers. De overdracht van waarden en normen zit vooral in de imitatie van - goede en slechte - gedragsvoorbeelden: "Het gewichtigste probleem waar we met de huidige wens tot hernieuwde overdracht van waarden en normen tegen aanlopen, is dat ouders kinderen regels willen aanleren, waar ze zichzelf niet aan houden" (Levering 2003). Persoonlijke aandacht en persoonlijke betrokkenheid zijn onmisbaar in de overdracht van moraal. Om nogmaals Levering te citeren: "We moeten nu eens en vooral duidelijk maken dat, als het om morele opvoeding en ontwikkeling gaat, de lang alom aangehangen Kohlbergsiaanse benadering en de deugdenbenadering eigenlijk uiterst zwak zijn. De sterke, op affecties gerichte benadering, die nog altijd onderbelicht is gebleven, vraagt om een 
persoonlijke betrokkenheid. (...) Cruciaal is het uitgangspunt dat we niet over waarden - en normenoverdracht moeten zeuren, als we onze eigen praktijk van waarden en normen niet op orde hebben. (...) Een groot deel van de kinderen groeit in een sfeer van onmatigheid op. Dat is geen sfeer waarin je rekening leert houden met anderen. Daarin moet dan ook expliciet worden geïnvesteerd. Doordachte omgangsregels moeten als elegante gewoonten worden aangebracht opdat en zodat mensen (weer) naar elkaar omzien" (ibidem).

De school kan geen compensatie leveren voor de tekorten in de grotemensenmaatschappij, zo luidt deze krachtige waarschuwing tegen een overbelasting van het onderwijs bij de expliciete overdracht van waarden en normen. Impliciet speelt de school daarbij uiteraard wel een rol, maar die wordt vervuld in een ingewikkelde context van de sociale organisatie van het onderwijs als geheel, de steeds zwaardere druk van de maatschappelijke omgeving van het onderwijs en de overige zelfstandige eisen die de overheid stelt aan het onderwijs, met name eisen van efficiency en meetbare prestaties. Bij het zoeken naar oplossingen voor het morele tekort (vgl. hoofdstuk 4) behoort derhalve de gehele institutionele setting van het onderwijs mede in beschouwing te worden genomen. Simpele oplossingen blijken in de werkelijkheid van alledag meestal niet te bestaan, of de uiteindelijke nadelen van invoering van de eenvoudigste blijken groter te zijn dan de bestaande kwaal.

Wat hier wordt opgemerkt voor de taakverzwaring van de scholen geldt in enigszins andere zin ook voor andere suggesties voor eenvoudige oplossingen. Neem bijvoorbeeld het vraagstuk van de overlast op straat, veroorzaakt door een grote groep daklozen en andere zwervers. Wat voorheen Perron Nul heette in Rotterdam gold hiervoor lang als standaardvoorbeeld. 'Jaag ze weg!' is hier de meest eenvoudige oplossing, maar de complexiteit van de werkelijkheid dwingt eerst te vragen waar ze eigenlijk vandaan komen, vervolgens waar ze heen gedirigeerd kunnen worden en ten slotte of de oplossingen de overlast werkelijk verminderen of slechts verplaatsen naar andere plaatsen of sectoren van de samenleving. Overlast op straat kan onder andere worden veroorzaakt door op criminaliteit beluste jongeren en door psychische en psychiatrische patiënten die van een residentiële behandeling plotseling zijn overgebracht naar een zelfstandig bestaan buiten de muren van een inrichting. Ook hier is de institutionele context bepalend voor de veroorzaking van de als te groot ervaren overlast en tegelijk ook voor de oplossing. Met andere woorden, in een analyse van de bijdrage van de maatschappij aan de overdracht en het onderhoud van waarden en normen zullen de betekenis en werking van instituties en de interinstitutionele betrekkingen niet mogen ontbreken. Begonnen wordt allereerst met een uiteenzetting van de institutionele invalshoek. 


\subsubsection{DE INSTITUTIONELE FOCUS: INSTITUTIES ALS WERKPLAATSEN VAN WAARDEN EN NORMEN}

Het dagelijkse handelen speelt zich af in de context van instituties. Maar wat wil dat zeggen en wat zijn instituties? Het begrip institutie is een verzamelnaam voor verschillende verbanden van activiteiten die zich tegelijkertijd afspelen in een subsector van de samenleving en gericht zijn op het realiseren van bepaalde doelen of waarden. "By an institution I mean that subdivision of society which consists in social groups, established by means of a charter, together with their customs, laws, material artefacts and organized around a certain aim or purpose" (Feibleman 1987: 33). Huwelijk en gezin, onderwijs en opvoeding, gezondheidszorg en maatschappelijke hulpverlening, arbeid en onderneming, leger, politie en rechtspraak zijn de bekende voorbeelden van dergelijke instituties. Instituties worden gekenmerkt door vanzelfsprekende gewoonten (mores), maar vaak ook door gespecialiseerde organisaties die gezamenlijk de min of meer uitgesproken doeleinden van de instituties nastreven. Er zijn wetten, statuten van verenigingen en stichtingen, gebouwen, vroeger ook nog gesierd met vlaggen, emblemen, verenigingsbladen; er zijn overlegorganen, gespecialiseerde beroepsgroepen met hun eigen normen en waarden, gericht op de institutionele doeleinden; er zijn cliënten en cliëntvertegenwoordigers, zaakwaarnemers en gespecialiseerde belangengroepen. Gezinnen en familieleven worden meestal ook tot instituties gerekend, zij het dat ze minder in formele organisaties zijn terug te vinden (wel in de algemene maatschappelijke instellingen op dit terrein zoals de Gezinsraad en de Kinderbescherming).

De samenleving als geheel is opgebouwd uit een reeks van dergelijke instituties (en hun typerende maatschappelijke organisaties), die vooral van elkaar verschillen in de specifieke doeleinden en waarden die ze nastreven. Sportbonden vinden andere waarden belangrijk dan ziekenhuizen en artsenorganisaties. In het gezin gelden andere regels, normatieve articulaties en werkwijzen (maar vaak deels wel dezelfde waarden) dan op het werk (vgl. Walzer 1984). Ook de overheid en overheidsorganisaties vertegenwoordigen aldus een eigen institutie, namelijk die van de staat. De politie vertegenwoordigt bijvoorbeeld belangrijke waarden in de samenleving, heeft daarvoor specifieke normen en regels opgesteld en symboliseert op deze wijze legitiem 'de sterke arm' van de maatschappij. Dit sluit samenwerking met andere instituties natuurlijk geenszins uit, maar er zijn principiële verschillen tussen bijvoorbeeld de taken van de school en die van de politie, ook al komt een agent in de klas een les geven over criminaliteit en drugs en krijgt de schoolleiding te maken met crimineel gedrag op school. De specificatie (differentiatie) van taken sluit samenwerking niet uit, maar leidt weleens tot spanningen tussen instituties.

Men kan de taken van instituties (én van de daarbijbehorende organisaties) onderscheiden in:

- primaire taken: het realiseren van doelen en waarden, waar ze voor zijn opgericht; 
- secundaire taken: het instandhouden van de economische, sociale en morele voorwaarden die nodig zijn voor de uitoefening van de eerste taak;

- tertiaire taken: het leveren van een bijdrage aan sociaal gedrag en publieke moraal in andere instituties, door de manieren waarop men die in de eigen institutie onderhoudt en bevordert.

\section{Illustraties aan de hand van het onderwijs}

Deze drie soorten taken zijn goed te illustreren aan de taken van het onderwijs, de institutie als geheel, en van afzonderlijke scholen (als de maatschappelijke organisaties). Zo moet de school zorgen voor de overdracht van kennis en vaardigheden, van culturele waarden en normen en moet zij voorbereiden op het participeren in de samenleving als geheel (dit zijn haar primaire taken). Daarnaast moet de school zelf zorgen voor een zekere orde en regelmaat, zodanig dat leerkrachten en leerlingen in staat worden gesteld om aan de primaire taken toe te komen. Als er steevast ongeregeldheden plaatsvinden in en rondom de school, of als er een sfeer ontstaat waarin het lesgeven voortdurend wordt gestoord, dan kunnen afspraken en gedragsregels die voor de gehele school gelden, functioneren om 'de rust' weer terug te brengen. In een bijdrage aan het debat over waarden en normen schreef Prick in NRC Handelsblad (2003a) dat de beste bijdrage die de scholen aan 'waarden en normen' in Nederland zouden kunnen leveren was om orde op zaken te brengen in eigen huis en te doen wat ze moesten doen. In onze terminologie: de secundaire taakvervulling was nodig om de primaire taak goed te kunnen volbrengen. Zorgen dat leerlingen huiswerk maken vervult verschillende taken tegelijk: daarmee leren ze wat ze moeten leren (primair), ze leren enige zelfdiscipline, waardoor het primaire leren vergemakkelijkt wordt (secundair) en ze oefenen bij zichzelf een algemene gedragsregel, die geldt voor de samenleving als geheel en die hen later als burger ook van pas komt (tertiair).

\section{Illustraties aan de hand van de sport}

In principe zijn bij alle instituties dergelijke patronen van primaire, secundaire en tertiaire taken waar te nemen, al zal er altijd wel enige discussie blijven bestaan welk specifiek taakonderdeel nu tot de primaire of tot de secundaire taak moet worden gerekend. De primaire taken van sportbeoefening zijn het brengen van ontspanning en een goede tijdsvervulling, eventueel een bijdrage leveren aan de gezondheid van de beoefenaren. Secundaire taken zijn het beoefenen van fair play, het zich (leren) houden aan de regels van het spel, de onderlinge competitie niet vervalsen en dergelijke. Van de primaire en secundaire taken gaat een maatschappelijk effect uit op de omgeving en op de samenleving als geheel: zich houden aan de regels van het spel geldt ook voor andere maatschappelijke sectoren en voor de maatschappij als geheel. Waarden en normen in de sport (Steenbergen et al 1998) behelzen aldus sportintrinsieke waarden (primair en secundair) én sportextrinsieke waarden (tertiair). De wisselwerking tussen deze waarden is van belang bij de overdracht en het onderhoud van waarden en normen in het algemeen. Naarmate de instituties, in hun vele gedaanten, de eigen primaire en secundaire taken zo goed mogelijk vervullen en daarbij ook 
nog oog hebben voor of tijd en geld schenken aan de tertiaire taken, die met name de relatie met hun maatschappelijke omgeving raken, zijn er gunstige voorwaarden voor het onderhoud van waarden en normen in de samenleving als geheel. Naarmate ze de eigen taken verwaarlozen of minder in staat gesteld worden om die te vervullen, zullen ze ook de algemenere taken minder goed onderhouden. De vraag is hoeveel ruimte er in de verschillende instituties bestaat om de morele dimensie van de eigen werkzaamheden, inclusief de tertiaire taken, te blijven onderhouden.

\section{Illustraties aan de hand van de aandacht voor maatschappelijke neveneffecten}

Een terugkerende vraag bij elke institutie is hoeveel aandacht besteed wordt en kan worden aan de meer algemene, tertiaire taken. Hoeveel aandacht besteden particuliere bedrijven aan internalisering van de maatschappelijke neveneffecten van hun handelingen en aan normen van transparantie en verantwoording et cetera (vgl. WRR 1992; en ook enkele van de aanbevelingen voor corporate governance van de commissie-Tabaksblat). Hoeveel aandacht besteden kerken of particuliere verenigingen, naast hun primaire en secundaire taken, aan maatschappelijk verantwoord handelen? Hebben de scholen een taak, de tijd en de ruimte om het algemeen maatschappelijke probleem van de scheiding tussen witte en zwarte scholen mee te helpen oplossen? Dit zijn vragen die in een algemener verband kunnen worden geanalyseerd. Zij verwijzen ook terug naar de doorwerking van de waardestelsels van Tipton. Botsingen tussen waardestelsels binnen instituties zetten de instituties vaak ook klem. Zo lijken veel instituties in de laatste twee decennia steeds meer onder druk te staan. Enerzijds komt die druk van buiten, van veranderingen in de maatschappij als geheel zoals door individualisering en de veranderende samenstelling van de bevolking. Anderzijds komt de druk van boven, van de kant van de overheid, die zowel door intensievere regelgeving als door financiële bezuinigingen een grote invloed heeft uitgeoefend op de vervulling van de primaire, secundaire en tertiaire taken van instituties. Er zijn eenzijdige vormen van invloed ontstaan, die de nadruk zijn gaan leggen op vooral meetbare prestaties en financiële prioriteiten. Denk hierbij aan kwantitatieve indicatoren in het onderwijs, prestatiecontracten met de politie (vgl. Vollaard 2003), plafondbudgetten in de gezondheidszorg, en reïntegratiecontracten met bedrijven over aantallen WAO'ers. Door het eenzijdig benadrukken van bepaalde vormen van sturing is niet alleen veel accent komen te liggen op de primaire taken van de organisaties ten koste van de overige en met name de meer algemene tertiaire taken, maar werd de primaire taak bovendien nog versmald tot zichtbare productiecijfers. In dit klimaat van beïnvloeding en taakvervulling kwamen de meer morele en normatieve aspecten van dezelfde taakvervulling in de klem, terwijl ze soms ook al werden verwaarloosd. Het laat zien dat we belangrijk maken wat meetbaar is in plaats van meetbaar wat belangrijk is. Dit is van belang voor het debat over waarden en normen, want een overheid (als principaal) die haar burgers (als consumenten, cliënten) en de instituties bijna uitsluitend aanspreekt op berekenbare eenheden en gedragingen, bevordert daarmee een houding van die burgers, waarin de minder goed berekenbare, morele 
factor eveneens verwaarloosd wordt (vgl. ook Reinders 2003). Het is ook een illustratie van de doorwerking van het derde waardestelsel van Tipton dat typerend is voor het commerciële bedrijfsleven in andere instituties en sferen.

Illustraties aan de hand van veranderingen in de context van de instituties Normoverschrijdende verschijnselen binnen bepaalde instituties in de afgelopen decennia, zoals de нво-fraude, de bouwfraude en socialezekerheidsfraude, kunnen beter worden begrepen (uiteraard niet vergeven) door de institutionele context in ogenschouw te nemen dan door uitsluitend een moreel appèl op het geweten van burgers te doen. ${ }^{1}$ En die institutionele context is niet onberoerd gebleven door de reeds eerdergenoemde processen, waaronder vooral individualisering. In het kader van dit rapport over waarden, normen en gedrag zijn de belangrijkste aspecten van individualisering de grotere mondigheid, het hogere opleidingsniveau, de hogere verwachtingen, de toename van de gevoeligheid en de roldifferentiatie van burgers. Door individualisering, secularisatie en immigratiestromen is de verscheidenheid in soorten gebruikers groter geworden en is de pluriformiteit en dynamiek in de omgeving van veel instituties toegenomen. Zo blijken actoren in de maatschappelijke dienstverlening (woningbouwverenigingen, scholen enz.) telkens te worden verrast door de differentiatie binnen de groepen van nieuwkomers, door onverwachte tegenstellingen maar ook door onverwachte ad-hoccoalities tussen groepen nieuwkomers en autochtonen (bijvoorbeeld tussen bepaalde orthodox gereformeerden en islamieten) (vgl. WRR 2001). En ook al is de samenstelling van een groep bij aanvang homogeen, dan nog kan na verloop van tijd blijken dat die veelzijdiger is dan gedacht door verschillen in gekozen levensstijl en mobiliteit. Ten slotte kan blijken dat veronderstellingen over de aard van de omgeving van de institutie niet opgaan, omdat bijvoorbeeld de categorie-indelingen in soorten gebruikers en hun gedrag niet meer blijken te kloppen; de omgeving blijkt kortom ongekender dan gedacht (vgl. Van Gunsteren en Van Ruyven 1995). Het gaat om factoren die vanuit de ruimere maatschappelijke context, dus van opzij, druk uitoefenen op de instituties. Er is echter ook een druk van bovenaf, door de manier waarop de overheid een deel van de instituties aanstuurt nadat zij deze eerst heeft verzelfstandigd. In de volgende paragraaf wordt hier nader op ingegaan. Nu kan er reeds over worden gezegd dat veel instituties in zekere zin klem zijn komen te zitten tussen de veranderende eisen die van bovenaf door de overheid aan hen worden gesteld en de nieuwe eisen van de burgers waaraan zij, ten gevolge van de veranderingen in de bevolkingssamenstelling en in de wensen van de burgers, dienen te voldoen. Terwijl de overheid van de instituties verlangt dat zij efficiënter en meer kostenbewust worden, worden zij tegelijkertijd geconfronteerd met meer en onoverzichtelijkere maatschappelijke problemen (vanwege het samenleven van verschillende culturen) en hogere eisen van (een deel van de geïndividualiseerde) moderne burgers. Terwijl de overheid van instituties en hun organisaties verlangt dat ze zich laten richten door de vraag, zien zij zich geconfronteerd met de noodzaak meer nadruk te leggen op hun aanbodfuncties, zoals onderhoud en overdracht van waarden en normen, ordehandhaving, gedragsnormering en soms ook bevordering van normbesef en waardevorming. Als zij er niet vanuit 
zichzelf aan denken, is er altijd wel een sociale beweging of actiegroep die hen eraan helpt te herinneren.

De conclusie uit het bovenstaande is dat er ruimte moet zijn voor de ontwikkeling van de secundaire en vooral tertiaire taken van de instituties. Op deze niveaus geven instituties invulling en uitvoering aan hun werk, waarbij de differentiatie in maatschappelijke waardestelsels als modes of moral understanding and moral argument (Tipton) een belangrijke rol spelen. Zij verbinden de instituties langs verschillende lijnen met elkaar (bijvoorbeeld door hun stijl van opereren, de manier waarop zij hun externe betrekkingen onderhouden, met gebruikers en met personeel omgaan, conflicten beslechten enz.). Tegelijk bieden zij de instituties de mogelijkheid om zich actief van elkaar te onderscheiden door de manieren waarop zij bijvoorbeeld tot normatieve afwegingen komen. Aldus dragen ze ook bij aan de maatschappelijke pluriformiteit en keuzevrijheid (vgl. hoofdstuk 5).

\subsection{INSTITUTIES ONDER DRUK}

\subsubsection{INDIVIDUALISERING EN VERZAKELIJKING}

Veel maatschappelijke instituties hebben steeds meer moeite om hun in paragraaf 7.3 geschetste rol ten aanzien van waarden en normen naar behoren te vervullen. De oorzaak hiervan is mede gelegen in een aantal maatschappelijke en politieke ontwikkelingen die niet alleen het (interne) functioneren van de instituties niet onberoerd hebben gelaten, maar bovendien ertoe hebben geleid dat er vanuit de samenleving steeds zwaardere eisen aan hen worden gesteld. Er komt een druk van buiten door de individualisering en de toenemende verscheidenheid van de gebruikers én er komt een druk van boven van overheidseisen: de verzakelijking.

\section{Individualisering}

De term 'individualisering' kan worden gebruikt als verzamelnaam voor een breed scala aan sociaal-culturele veranderingen die zich de laatste decennia aftekenen. In het kader van dit rapport over waarden, normen en gedrag zijn de belangrijkste aspecten van de individualisering de afname van het belang van traditionele sociale kaders en verbanden, de hogere verwachtingen van burgers en de toename van de gevoeligheid en de roldifferentiatie van burgers. Enigszins gechargeerd gesteld werden de waarden en normen van burgers in het verleden, in de tijd van de verzuiling, in hoge mate bepaald door de niet zelfgekozen sociale verbanden waarvan men deel uitmaakte: de familie, de wijk, de kerk, enzovoort. Bovendien oefenden deze sociale verbanden een sterke sociale controle uit op de gedragingen van het individu: wie zich niet aan de regels van de groep hield werd daarop aangesproken en eventueel gestraft, met als uiterste consequentie de uitstoting uit de sociale groep. Tegenwoordig hebben individuen een grotere vrijheid om zelf te kiezen tot welke groep zij willen behoren en welke waarden en normen zij aanhangen. Het is daardoor ook niet meer vanzelfsprekend dat men door anderen op zijn of haar gedrag wordt aangesproken. Dit 
wordt nog versterkt door het sterk gestegen opleidingsniveau, de secularisatie en de toegenomen informatievoorziening via de massamedia, waardoor mensen beter zijn geïnformeerd en mondiger zijn geworden, minder ontzag hebben voor autoriteit en gezagsdragers en zich minder gemakkelijk door anderen de wet laten voorschrijven. Als gevolg hiervan neemt de voorspelbaarheid van het gedrag van burgers af en neemt de pluriformiteit toe. Overigens is de toename van de keuzevrijheid slechts relatief: het gedrag van mensen blijft in hoge mate bepaald door de omstandigheden waarin zij verkeren en de invloeden die zij 'van buiten' ondervinden (vgl. WRR 20O2).

Een enigszins paradoxaal gevolg van individualisering is dat de moderne mondige burger enerzijds een grotere keuzevrijheid wenst en minder betuttelend en bevoogdend door de overheid wil worden behandeld, maar anderzijds ook hogere eisen stelt aan de overheid en sneller ontevreden is indien deze daaraan niet kan voldoen (vgl. Van den Brink 2002). Overigens moet individualisering niet worden verward met atomisering. Mensen blijven sociale wezens die een sterke behoefte hebben om deel uit te maken van een groep en zich doorgaans in hoge mate schikken in de waarden en normen van die groep, al kunnen zij nu gemakkelijker dan in het verleden van groep wisselen indien die waarden en normen hen niet bevallen.

\section{Verzakelijking}

Aan het begin van de jaren tachtig markeerde het aantreden van het eerste kabinet-Lubbers een belangrijke omslag in het overheidsbeleid ten aanzien van de publieke sector. Na enkele decennia van haast ongelimiteerde uitbouw en expansie van de verzorgingsstaat en de publieke dienstverlening, brak een periode aan van uitgavenbeheersing en -beperking. Aanvankelijk werd deze beleidsomslag vooral ingegeven door financiële motieven: de publieke uitgaven dreigden onbeheersbaar te worden. Maar gaandeweg werden ook andere argumenten aangevoerd: verhoging van de doelmatigheid en doeltreffendheid, versterking van de klantgerichtheid, het bieden van meer keuzevrijheid. Concreet kwam de beleidsomslag onder meer tot uitdrukking in bezuinigingen op (of in ieder geval beperking van de groei van) het budget van tal van maatschappelijke instellingen, schaalvergroting, introductie van elementen van concurrentie, vraagsturing en marktwerking, verschuiving van inputsturing naar outputsturing ('afrekenen op resultaat'), lump sum-financiering, uitbesteding aan private partijen en vooral verzelfstandiging van overheidsdiensten, waardoor de afstand naar andere diensten en werken toenam. In algemene zin kunnen al deze verschillende vormen worden geschaard onder de noemer van verzakelijking: publieke instanties en maatschappelijke organisaties dienden zich meer te spiegelen aan de private sector, oftewel de zakenwereld. Het toenemende gebruik van termen als product, markt en klant, waar vroeger werd gesproken over dienstverlening, doelgroep en cliënt, geeft hier het meest pregnant uitdrukking aan. Maar ook intern in de instituties vonden onder dezelfde noemer veranderingen plaats, door verschuiving van verantwoordelijkheden naar lagere echelons in de hiërarchie en door introductie van bijvoorbeeld cliëntenrechten en klachtenregelingen. 


\section{Criteria voor goede instituties}

Het is hier niet de plaats om een waardeoordeel uit te spreken over de geschetste ontwikkelingen. Het staat buiten kijf dat zij zowel positieve als negatieve gevolgen hebben gehad. Wel moet duidelijk blijven wat de criteria zijn waaraan instituties moeten voldoen. Een goede institutie:

- heeft niet alleen oog voor goed meetbare en kwantificeerbare outputindicatoren, maar ook voor de kwaliteit van de output en van het proces waarlangs deze totstandkomt;

- richt zich niet alleen op kortetermijndoelstellingen en op haalbaarheid, maar heeft ook oog voor de gevolgen van haar activiteiten op langere termijn en voor legitimiteit;

- schuift geen problemen die zij zelf kan aanpakken af op andere instituties;

- biedt ruimte aan haar professionals om hun taak, binnen helder gedefinieerde grenzen, naar eigen inzicht en op basis van vakmanschap en eisen van integriteit uit te voeren;

- geeft openheid van zaken over haar doelstellingen ten aanzien van de overdracht en handhaving van waarden en normen en over de wijze waarop zij hieraan in de praktijk gestalte geeft; en

- legt verantwoording af aan haar stakeholders, dat wil zeggen zowel aan de overheid of een ander bevoegd bestuur als aan haar 'klanten' en aan derden die met de gevolgen van haar activiteiten (kunnen) worden geconfronteerd (bijvoorbeeld buurtbewoners).

Daaraan kan worden toegevoegd dat, waar het gaat om een grotendeels of geheel door de overheid gefinancierde institutie, de overheid er zorg voor dient te dragen dat de institutie over voldoende middelen beschikt om het bovenstaande waar te maken. Hieronder wordt ingegaan op de gevolgen van de hiervoor genoemde ontwikkelingen voor het functioneren van instituties, met name voor hun taak van overdracht en handhaving van waarden en normen.

\subsubsection{GEVOLGEN VOOR DE OVERDRACHT EN HANDHAVING VAN WAARDEN EN NORMEN}

Alle instituties vervullen een belangrijke rol in de productie, overdracht en handhaving van waarden en normen. Vaak is dit geen expliciet geformuleerde taak van de betreffende institutie, maar een impliciete functie die iedere institutie vervult om überhaupt te kunnen voortbestaan. In iedere institutie gelden bepaalde regels en codes waaraan de medewerkers van organisaties moeten voldoen en (dezelfde of andere) regels en codes voor de omgang met externe relaties. Deze regels en codes geven concreet uitdrukking aan de waarden en normen van de institutie. Het kan hierbij gaan om waarden en normen die eigen zijn aan de betreffende institutie (zoals de beroepsethiek van de arts), maar ook om algemeen geldende waarden en normen (zoals betrouwbaarheid). Elk van deze instituties dient op enigerlei wijze te zorgen dat deze waarden en normen worden overgedragen op nieuwe medewerkers en nieuwe klanten. Vervolgens dienen zij deze waarden en normen ook te handhaven. Medewerkers of klanten die zich niet conform de geldende waarden en normen gedragen, dienen tot de orde te 
worden geroepen en hun dient in het uiterste geval de toegang te worden ontzegd. Welke gevolgen hebben de hiervoor besproken trends in concrete organisaties en instellingen nu voor de productie, overdracht en handhaving van waarden en normen?

Ten aanzien van de productie en overdracht van waarden en normen duiden de hiervoor geschetste trends vooral op een meer 'zakelijke', formele benadering en waardering van zowel medewerkers als klanten op basis van objectiveerbare kenmerken en prestaties. Loyaliteit en vertrouwen worden minder gezien als vanzelfsprekende kenmerken van een relatie, maar moeten worden 'verdiend'. Relaties krijgen daardoor een meer instrumenteel karakter. Dit zou afbreuk kunnen doen aan hooggewaardeerde 'deugden' als naastenliefde, solidariteit, mededogen en altruïsme. Als je weet dat je organisatie je primair beoordeelt op kwantificeerbare en objectieve criteria, zul je je minder inspannen om aan andere criteria te voldoen die daarbij geen rol spelen. Je loopt immers het risico dat het je door je leidinggevende niet in dank wordt afgenomen als je een collega of klant een handje helpt, zonder dat dit een onderdeel is van je formele taak. Het gevaar bestaat dat dergelijk gedrag op den duur ook van invloed is op de normen die men heeft geïnternaliseerd, waardoor men aan 'zakelijke' waarden steeds meer gewicht gaat toekennen.

Hier staat tegenover dat deze zakelijke benadering ook meer ruimte schept voor individuele keuzevrijheid, initiatief en autonomie, samenwerking en overleg op voet van gelijkwaardigheid. Er is minder ruimte voor vriendjespolitiek (nepotisme) en discriminatie. Autoriteit en hiërarchie verliezen hun vanzelfsprekendheid en dienen eveneens te worden 'verdiend'. Vertrouwen blijft een essentiële waarde voor alle instituties, maar de aard van het vertrouwen zou kunnen veranderen. Waar men een ander in het verleden vaak vertrouwen schonk louter op grond van zijn of haar lidmaatschap van een bepaalde groep ('informele vertrouwensgrondslagen'), wordt vertrouwen nu steeds meer gebaseerd op een beoordeling van het (te verwachten) gedrag van de ander ('formele vertrouwensgrondslag') (vgl. Mosch en Verhoeven, te verschijnen). Maar het kan ook zijn dat waar de samenleving veranderlijker is, vertrouwen meer gebaseerd wordt op het reputatiemechanisme (je vertrouwt een instelling omdat die een goede reputatie heeft). Deze veranderingen gelden vooral voor de externe formele (of geformaliseerde) waarden en normen van instituties. Alle instellingen en organisaties kennen overigens ook een interne informele cultuur met eigen waarden en normen die aanzienlijk kunnen afwijken van de formele waarden en normen van de organisatie. Om door collega's te worden geaccepteerd en te worden opgenomen in de informele groep - hetgeen vaak een noodzakelijke voorwaarde is om goed te kunnen functioneren - is het net zo belangrijk om aan de informele waarden en normen te voldoen als aan de formele waarden en normen. Het is echter niet eenvoudig vast te stellen wat de gevolgen zijn van de geschetste veranderingen in formele waarden en normen voor deze informele waarden en normen. Of er moet ook hier sprake zijn van een grens waarboven afbraak van informele vanzelfsprekendheden, loyaliteiten en compliance, de institutie zo 
veel schade toebrengen dat de institutie zelf in de gevarenzone komt. Is het zo dat een informele cultuur van zorg en betrokkenheid lange tijd overeind blijft in weerwil van verzakelijkingstendenties, maar dat als die informele cultuur op een gegeven moment sneuvelt, ook de betreffende formele organisatie 'door het ijs zakt'? (Vergelijk voor de redenering de analogie met de grens die niet moet worden overschreden bij opheffing van socialecontrolemechanismen uit hoofdstuk 4 en de bijlage bij hoofdstuk 4.)

\section{Problemen in de aansluiting van formele en informele sociale controle}

De mechanismen die organisaties hanteren om de naleving van de geldende waarden en normen af te dwingen zijn deels een afspiegeling van deze waarden en normen zelf. Het benadrukken van waarden als prestatie en eigen initiatief gaat doorgaans gepaard met het gebruik van formele controle- en beheersingsinstrumenten. Medewerkers worden beoordeeld op grond van de vraag of zij bepaalde targets halen. Ook de beloning en sanctie voor het al dan niet voldoen aan deze normen hebben vaak een formeel karakter: een extra periodiek (of juist geen periodiek), een promotie of degradatie, of zelfs ontslag. Informele controlemechanismen lijken daardoor aan belang in te boeten, al blijven zij ongetwijfeld een belangrijke rol spelen. Informele controle kan er bijvoorbeeld uit bestaan dat collega's elkaar erop aanspreken als iemand zich niet aan bepaalde regels of codes houdt. Ook in de relatie met klanten winnen formele controle- en afrekenmechanismen aan belang ten opzichte van informele mechanismen. Iemand die niet betaalt voor wat jij levert (een zwartrijder in het openbaar vervoer), of die wel heeft betaald maar zich niet gedraagt zoals de organisatie van hem of haar verwacht, krijgt bijvoorbeeld een boete opgelegd of wordt eenvoudigweg de toegang ontzegd. Een boete voor normoverschrijdend gedrag kan er echter toe leiden dat men dit gaat zien als geoorloofd gedrag waarvoor men een prijs moet betalen. Dit kan worden geillustreerd met het voorbeeld van een (Israëlische) crèche die boetes ging opleggen aan ouders die hun kind te laat ophaalden (СРB 2001: 130). Het gevolg was dat nog méér ouders te laat kwamen: nu zij er een prijs voor betaalden, hadden zij immers een legitimatie en hoefden zich niet langer schuldig te voelen. Toen de boeteregeling werd afgeschaft, liep het aantal laatkomers echter niet meer terug: veel ouders hadden de norm van op tijd komen inmiddels niet meer geïnternaliseerd. Men ziet hetzelfde dilemma ook dichter bij huis bij het al dan niet betalen van vrijwilligers. Daarvoor valt veel te zeggen. Maar is er eenmaal een werknemers-werkgeversrelatie ontstaan, dan is een deel van het goede van het vrijwilligerschap weg.

\section{Functieversmalling}

De in paragraaf 7.4.1 geschetste maatschappelijke ontwikkelingen (individualisering en verzakelijking) zijn er - in combinatie met de hiervoor geschetste trends in organisaties - (mede) verantwoordelijk voor dat op een aantal terreinen de in hoofdstuk 4 beschreven negatieve spiraalbeweging van toenemende normoverschrijding en afnemend normbesef zich voordoet of heeft voorgedaan. Aan de ene kant is het minder vanzelfsprekend geworden dat burgers de geldende normen onderschrijven en door hun medeburgers worden gecorrigeerd indien 
zij deze normen overschrijden. Aan de andere kant hebben de toenemende prestatie- en resultaatgerichtheid en het sterkere kostenbesef van maatschappelijke instituties ertoe geleid dat organisaties zich minder sterk richten op hun secundaire taken ten aanzien van de overdracht en handhaving van normen. De afname van sociale controle als gevolg van autonome maatschappelijke ontwikkelingen (individualisering, toenemende grootschaligheid, mobiliteit en anonimiteit) werd dus niet gecompenseerd door een toename van de controle en handhaving door formele instituties, maar werd juist versterkt doordat de instituties hun controlefunctie verwaarloosden. Het openbaar vervoer vormt hiervan een sprekend voorbeeld. Juist in een periode waarin onder de reizigers de vanzelfsprekendheid om een kaartje te kopen afnam, werd de formele controle hierop verminderd - de conducteur verdween van bus en tram en werd vervangen door een stempelautomaat; in treinen werd minder gecontroleerd en het perronkaartje werd afgeschaft. Tegelijkertijd verminderde ook de informele sociale controle: het werd minder gebruikelijk dat reizigers elkaar op hun gedrag aanspraken. Niet langer ondersteunden norminternalisering, sociale controle en formele controle elkaar wederzijds, zoals voorheen het geval was, maar de afname van het ene mechanisme ondergroef de werkzaamheid van de andere mechanismen, waardoor een neerwaartse spiraalbeweging in gang werd gezet. In andere instituties hebben zich soortgelijke ontwikkelingen voorgedaan. Naarmate de wijkagent steeds minder op straat werd gezien, zag een groep jongeren met een gebrek aan geïnternaliseerd normbesef zijn kans schoon dit domein te veroveren, waar zij in een anoniemere omgeving ook niet meer door de bewoners tot de orde werden geroepen. De kruidenier, die persoonlijk toezicht hield op zijn waren die achter de toonbank waren uitgestald, maakte plaats voor de supermarkt waar alle goederen letterlijk voor het grijpen liggen en informele sociale controle door andere klanten heeft plaatsgemaakt voor cameratoezicht (en zo nu en dan een alerte filiaalchef, voor wie het vervolgens lastig is te bepalen waar de grenzen van zijn bevoegdheden liggen).

\subsubsection{INTERACTIES TUSSEN INSTITUTIES}

De hiervoor beschreven ontwikkelingen in instituties en de gevolgen daarvan voor de overdracht en handhaving van waarden en normen worden nog versterkt door de sterke verwevenheid van instituties. De wijze waarop de ene institutie zich van haar taak ten aanzien van waarden en normen kwijt, blijft vaak niet zonder gevolgen voor de wijze waarop haar klanten en medewerkers in andere instituties de geldende waarden en normen onderschrijven en naleven. Anders gezegd, de overdracht en handhaving van waarden en normen genereren vaak externe effecten voor andere instituties. Als gevolg hiervan komen de positieve gevolgen van een succesvolle overdracht en handhaving niet volledig ten goede aan de hiervoor eerstverantwoordelijke institutie, terwijl de gevolgen van het verwaarlozen van deze taak deels worden afgewenteld op andere instituties. Juist wanneer instituties steeds meer worden afgerekend op hun prestaties ten aanzien van hun eigen primaire taak, kunnen zij in de verleiding komen om de problemen waarmee zij worden geconfronteerd af te schuiven naar andere insti- 
tuties. Het gaat hierbij niet alleen om de wisselwerking tussen formele instituties onderling, maar evenzeer om de wederzijdse beïnvloeding tussen formele en informele instituties (zoals school en gezin).

Hiervan kunnen vele voorbeelden worden gegeven: scholen die hun leerlingen onvoldoende orde en discipline bijbrengen dragen bij aan het wangedrag van (sommige) jongeren in het openbaar vervoer, het uitgaansleven en het voetbalstadion. Openbaarvervoerbedrijven die tolereren dat reizigers hun medereizigers overlast bezorgen, doen afbreuk aan het besef van sommige groepen dat men zich in de openbare ruimte op een bepaalde manier heeft te gedragen en rekening dient te houden met anderen. Politieagenten die niet ingrijpen als fietsendieven hun slag slaan of te laat ter plekke zijn als winkeliers een winkeldief in de kraag grijpen, ontmoedigen informele sociale controle of nodigen burgers in zekere zin uit om het recht in eigen hand te nemen. Tv-zenders die 'extreme' gedragingen in de vorm van geweld, seks, drank- en drugsgebruik romantiseren, ondergraven de pogingen van ouders en scholen om kinderen zelfbeheersing en matigheid bij te brengen.

Hoe aannemelijk deze wederzijdse invloeden ook mogen zijn, er is weinig bekend over de omvang van deze effecten. Zo heeft jarenlang onderzoek naar de invloed van televisie op het gedrag van de kijkers nog zo goed als geen onbetwiste conclusie opgeleverd. Toch mag het gebrek aan degelijk empirisch onderzoek ter ondersteuning van deze effecten geen reden zijn om ze te negeren. Dat dergelijke effecten bestaan, wordt immers zelden betwist, alleen over het belang ervan lopen de meningen uiteen. Een institutie mag zich dan ook niet verschuilen achter het feit dat niet wetenschappelijk is aangetoond dat zij van invloed is op het gedrag van haar medewerkers of klanten in een andere omgeving.

Er doen zich met name twee mechanismen voor waardoor de vervlechting van instituties tot uit maatschappelijk oogpunt suboptimale uitkomsten kan leiden. Het eerste mechanisme is het al genoemde afwentelingsmechanisme: instituties schuiven hun verantwoordelijkheid geheel of ten dele af op andere instituties, met als excuus dat bepaalde activiteiten niet tot hun primaire taken behoren, of dat zij onvoldoende middelen hebben om deze taken uit te voeren. De Nederlandse Spoorwegen verdedigen zich bijvoorbeeld met de stelling dat zij noch de bevoegdheid, noch de middelen hebben om politietaken uit te voeren. Daarmee schuiven de NS de verantwoordelijkheid voor groepen die reizigers beroven of anderszins lastigvallen af op de (spoorweg)politie. Commerciële media beperken zich tot het amuseren van hun kijkers en luisteraars en beschouwen het niet als hun taak om ook een opvoedende en voorlichtende functie te vervullen. Publieke media volgen uit concurrentieoverwegingen dit voorbeeld. En anders dan bijvoorbeeld in het Verenigd Koninkrijk waar voor de commerciële omroepen publieke taakstellingen gelden, gecontroleerd door het nieuwe onafhankelijke Office of Communications (ОFСOM), ontbreken dergelijke regelingen in Nederland. Ten slotte zijn er middelbare scholen die menen dat hun taak zich 
slechts beperkt tot het overdragen van kennis en cognitieve vaardigheden en die de uitoefening van opvoedkundige taken louter zien als iets van de ouders.

Een tweede mechanisme dat tot suboptimale uitkomsten kan leiden, bestaat eruit dat van bepaalde instituties juist méér wordt gevraagd dan zij kunnen waarmaken; wat dan weer de hiervoor genoemde afwentelingsmechanismen extra kan stimuleren. Vooral bestaat vaak de neiging om het onderwijs te overvragen (bijvoorbeeld met de invoering van een cursus weerbaarheid). Doordat het onderwijs de enige formele institutie is waarin alle jongeren minimaal een jaar of tien van hun vormende levensfase doorbrengen, is het erg aantrekkelijk om van het onderwijs te vragen dat het een bijdrage levert aan de oplossing van zo'n beetje alle problemen die zich later (kunnen) manifesteren. Dit kan echter een steeds sterkere overbelasting van het onderwijs tot gevolg hebben, waardoor het niet alleen weinig bijdraagt aan deze afgeleide taken, maar ook tekortschiet in zijn primaire taken (overdracht van kennis en vaardigheden). Ook de verwachtingen ten aanzien van de politie lijken vaak te hooggespannen: naast haar primaire taak van orde handhaven en wetsovertreders opsporen en aanpakken, zijn haar in de loop van de tijd ook steeds meer taken op het gebied van leefbaarheid en welzijn toebedeeld, mede door de bezuinigingen op het gebied van welzijnsinstellingen. Politieagenten moesten tevens een soort maatschappelijk werkers zijn. Nog afgezien van het feit dat zij hiertoe niet zijn opgeleid, legde dit ook een extra taak op aan de politie, juist op het moment dat steeds duidelijker werd dat de politie kampte met grote capaciteitstekorten. Die capaciteitstekorten werden hierdoor extra vergroot, waardoor de politie nog minder toekwam aan haar primaire taken en haar gezag werd aangetast.

De wederzijdse beïnvloeding van instituties kan echter ook in positieve zin uitwerken. Zij biedt immers ook mogelijkheden voor ondersteuning en een efficiënte arbeidsverdeling tussen instituties. Het besef dat instituties niet geïsoleerd opereren maar gezamenlijk voor bepaalde taken staan, kan een stimulans zijn voor netwerkvorming, waarbij verschillende instituties elkaars inspanningen wederzijds ondersteunen. Men kan leren van elkaars ervaringen en andere instituties vroegtijdig attenderen indien zich problemen voordoen die zich ook buiten de eigen institutie kunnen manifesteren. Dit vereist wel dat verkokering wordt tegengegaan en dat instituties zich niet verschansen op hun eigen terrein, maar accepteren dat ook andere instituties zich daarmee bemoeien. De wederzijdse beïnvloeding van instituties biedt ook mogelijkheden voor een efficiënte taakverdeling, afstemming en profilering. Door heldere afspraken te maken over de taken van verschillende instituties kan worden voorkomen dat men elkaar tegenwerkt, dubbel werk doet of dat juist bepaalde taken door geen enkele institutie worden aangevat. 


\subsection{WAARDEN EN NORMEN IN HET ONDERWIJS}

\subsubsection{INLEIDING}

Er zijn verschillende redenen om speciale aandacht te besteden aan het onderwijs. De eerste is dat er in de adviesaanvraag om gevraagd wordt, evenals voor de onderwerpen inburgering en media, die respectievelijk in paragraaf 7.6 en 7.7. aan de orde komen. Ook wordt speciale aandacht besteed aan onderwijs, omdat, zoals reeds in paragraaf 7.3. werd opgemerkt, de verwachtingen ten aanzien van de bijdrage van het onderwijs aan de oplossing van tal van maatschappelijke problemen vaak hooggespannen zijn. Het is dan ook belangrijk om na te gaan op welke wijze en in welke mate het onderwijs aan deze verwachtingen zou kunnen voldoen. Verder is het onderwijs bij uitstek een institutie die van invloed is op en zelf beïnvloed wordt door tal van andere instituties, zowel formele als informele. Scholen hebben te maken met de invloed van de opvoeding door de ouders, de sociale relaties in vriendenkringen (peer groups), de rolmodellen van de televisie, internet, enzovoort. Het onderwijs is zelf weer van invloed op het gedrag van de leerlingen in tal van andere instituties: werk, verkeer, sportverenigingen, maatschappelijke organisaties, enzovoort. Het onderwijs is als formele institutie uniek, doordat het zowel taken heeft ten aanzien van de overdracht als ten aanzien van de handhaving van waarden en normen, die bovendien niet alleen gelden binnen de eigen institutie, maar ook een meer algemene maatschappelijke betekenis hebben. Dit geldt met name voor het functioneren van het primaire en secundaire onderwijs, waartoe deze paragraaf zich zal beperken. Het belang van onderwijs voor overdracht van waarden en normen blijkt ten slotte uit het paradoxale gegeven dat, hoewel het aantal uren dat kinderen op school doorbrengen in de loop van de tijd is afgenomen, de betekenis van de school voor overdracht van waarden en normen eerder is toegenomen. Dit komt wellicht omdat het zo ongeveer het enige formele en verplichte institutionele verband is waaraan alle toekomstige volwassen burgers moeten deelnemen ongeacht hun talent, etnische achtergrond of sociale klasse. Door de nadruk die aldus wordt gelegd op het schoolsysteem als bindend kader wordt de samenleving overigens ook geconfronteerd met het verschijnsel van kinderen die niet passen in een langdurig voortgezet onderwijssysteem en die wellicht meer gediend zijn met het direct leren van een vak (vgl. ook het pleidooi voor herwaardering van laaggeschoolde arbeid, WRR 1996).

\subsubsection{ONTWIKKELINGEN IN HET ONDERWIJS}

De in paragraaf 7.4.1 geschetste maatschappelijke ontwikkelingen van individualisering en verzakelijking, hebben de afgelopen decennia nadrukkelijk hun stempel gedrukt op het onderwijs. Hier worden enkele van de meest markante ontwikkelingen besproken: toenemende aandacht voor prestatiemeting, schaalvergroting, bureaucratisering en cyclische ontwikkelingen in de aandacht voor het 'pedagogische vraagstuk'. 


\section{Prestatiemeting}

Er is de laatste jaren steeds meer aandacht voor de prestaties van scholen. Het ging hierbij aanvankelijk alleen om de cognitieve prestaties van de leerlingen, zoals die worden gemeten aan de hand van Cito-scores, eindexamenresultaten, aantallen voortijdige schoolverlaters en dergelijke. Het risico van zulke kwantitatieve outputindicatoren is dat zij scholen stimuleren om zich louter hierop te richten, ten koste van moeilijk meetbare kwalitatieve resultaten en het proces waarlangs deze resultaten totstandkomen, zoals de waardevorming in het onderwijs en de bijdrage aan normbesef. Het kan ook leiden tot ongewenste selectieprocessen, zoals het weren van leerlingen met leerachterstanden of gedragsproblemen die afbreuk doen aan de prestaties van de school. ${ }^{2}$ Hoewel bij het vaststellen van de schoolprestaties getracht wordt voor allerlei factoren te corrigeren (door bijvoorbeeld rekening te houden met de sociale en etnische achtergrond van leerlingen en te corrigeren voor zittenblijvers en voortijdige schooluitval), blijft het gevaar bestaan dat scholen en schoolbesturen zich te zeer richten op de kwantitatieve prestatie-indicatoren in plaats van op hun primaire taak van het geven van zo goed mogelijk onderwijs. Dat gevaar blijft aanwezig, ondanks het feit dat scholen zich in toenemende mate in het openbaar moeten verantwoorden over hun eigen ambities en over wat ervan terechtkomt, en ondanks het feit dat de inspectie een toetsingskader hanteert waarin ook aspecten als het pedagogische klimaat en leerlingzorg belangrijk worden bevonden. Hierbij lijkt de eenzijdigheid ook niet zozeer te zitten bij de keuze van ouders van een basisschool - zij blijken vooral te letten op de 'zachtere' kwalititeitsaspecten en zouden dat soms wellicht wat minder moeten doen. Het probleem ligt veeleer bij de keuzes van scholen voor voortgezet onderwijs en bij de interne reguleringen binnen deze scholen die leerkrachten moeten prikkelen om vooral te letten op hun kwantitatieve meetbare resultaten. Rookmaker, rector van een school, wijst erop dat scholen de neiging zullen hebben om veeleisende docenten te ontmoedigen, door hen te wijzen op hun verantwoordelijkheden voor de totaalscores van de school: "Wat meer terughoudendheid met de vakinhoud, wat meer aanpassen aan de belevingswereld van de kinderen en bij toetsen niet meer vragen dan wat ook de minder begaafde of gemotiveerde leerling kan beantwoorden" (Rookmaker 2003). Zij zijn een voorbeeld van de doorwerking in de wereld van het onderwijs van het derde waardestelsel van Tipton uit paragraaf 7.2, dat hoort bij met elkaar concurrerende bedrijven op eenzelfde markt.

In toenemende mate wordt echter ook gebruikgemaakt van andere verantwoordingsmechanismen en vormen van kwaliteitsbewaking die niet louter op kwantificeerbare indicatoren zijn gebaseerd. Zo kunnen scholen met elkaar kwaliteitskringen vormen, waarbij zij zich van tevoren vastleggen op professionele waarden waarop zij als uitvoerders mogen worden beoordeeld. Als zij niet zelf dergelijke kringen vormen kan een beroep worden gedaan op de Onderwijsinspectie. Het huidige inspectiesysteem kent overigens al twee lagen van inspectie: een toetsing op punten uit de formele onderwijswetgeving en een toetsing op punten die uit beleidsregels volgen, zoals doelnormen. Deze laatste stelt de inspectie vast na overleg met het veld en zij worden gepubliceerd, opdat scholen 
vooraf weten waarop zij worden beoordeeld. Als deze doelnormen ook betrekking hebben op de sociale en morele vaardigheden van de docenten, gaat hiervan tevens druk uit op de lerarenopleidingen om hieraan meer aandacht te besteden. Ook het reeds genoemde verplichte openbare jaarverslag biedt de school een kader om verantwoording af te leggen over haar prestaties. Het biedt, anders dan de kwantitatieve outputcijfers, de mogelijkheid om ook te attenderen op de kwalitatieve aspecten van het onderwijs. In een jaarverslag kan bijvoorbeeld een samenvatting zijn opgenomen van een visitatierapport, die ouders en/of leerlingen de mogelijkheid biedt om de kwaliteit van de school te beoordelen en te vergelijken met die van andere scholen.

\section{Bureaucratisering en schaalvergroting}

Onder druk van de overheid heeft zich het afgelopen decennium een omvangrijk proces van schaalvergroting in het onderwijs voorgedaan. Zo werd het aantal scholen met name voor voortgezet onderwijs in de jaren negentig meer dan gehalveerd, van ruim 1.400 naar minder dan 600 (SCP 2002: 494). Aanvankelijk was die schaalvergroting bedoeld om de overstap van leerlingen van de ene schoolsoort naar de andere te vergemakkelijken, later werd die gestimuleerd door de verzelfstandiging en lump sum-financiering, die weliswaar veel bestedingsvrijheid geeft, maar die tegelijkertijd vraagt om een behoorlijke omvang - en eigen vermogensopbouw - om risico's te kunnen opvangen. Zij heeft ook geleid tot een groei van de overhead en een toename van bureaucratisering in het onderwijs. Zo is er een bureaucratisering opgetreden in de scholen zelf. Dat leerlingen in bijvoorbeeld de brugklas met soms wel tien verschillende en autonome leerkrachten worden geconfronteerd, leidt tot regels van coördinatie, tot methoden om meetbaar maken wat leerkrachten doen en tot meer verantwoording aan de schoolleiding. Daarom is er ook niet slechts sprake van een bureaucratisering door verantwoording aan Zoetermeer en Den Haag, maar ook door de vele kleine 'Zoetermeertjes' van de grote scholengemeenschappen, die ook weer de verschillende eenheden binnen de school moeten coördineren. Er is vaak gewezen op het gevaar dat scholen hierdoor de 'kwalitatieve', minder meetbare factoren, zoals hun eigen onderwijskundige en pedagogische niveau en profiel, gaan verwaarlozen. Zo wees Elchardus voor België - maar het geldt ook voor ons land - op het haasje-over van toenemende autonomie en toenemende bureaucratisering in het onderwijs en op de trivialisering van de waardeprofilering en van de autonomie van de scholen, die hiervan het gevolg is (Elchardus 1994: 190). Die bureaucratisering maakt het beroep van leraar er overigens ook niet aantrekkelijker op. Zo verlaat in Nederland circa 25 procent van de nieuw opgeleide leraren binnen vijf jaar het onderwijs en vertrekt over de gehele loopbaan gezien zo'n 30 procent. Maar behalve door sturing op afstand is de overheid ook als subsidiegever voor allerlei vernieuwingsprojecten veel directer actief in het onderwijsveld. Levering (2003) spreekt in dit verband van een 'projectencarrousel'. Als de overheid de scholen op die manier direct gaat steunen bestaat volgens Van der Zwan (2001) echter het risico dat deze te zeer afhankelijk worden van overheidsbeleid. De oplossing van dit probleem wordt in de regel gezocht in nog meer ruimte voor de instellingen en in slimmere manieren van sturen (vgl. WRR 2002). 
Cycli in aandacht voor waarden- en normenoverdracht in het onderwijs Soms is het thema meer latent aanwezig en soms meer manifest. De aandacht van de politiek voor de problematiek van waarden en normen in het onderwijs is allerminst van recente datum. Zo is het thema - of het nu vorming heet, de pedagogische opdracht of waarden en normen in het onderwijs - in abstracto telkens hetzelfde, maar is de concrete vorm telkens anders. De laatste keer was in 1992 (de zogeheten 'Pedagogische opdracht' van toenmalig minister Ritzen). De aandacht lijkt op en neer te gaan met de conjunctuur. Verder blijkt het volgende.

- Het Nederlandse bestel is van zichzelf sterk waardegeladen (vgl. de normatieve identiteit van scholen), waarbij de bepaling van die normatieve identiteit is voorbehouden aan de schoolbesturen (geen staatspedagogiek).

- De politieke ambivalentie als het gaat om de versterking van gemeenschapswaarden. Het gaat dan immers om de vraag welke waarden van welke gemeenschap (te onderscheiden naar schaalniveau: lokaal, nationaal, Europees, en naar soort cultuur) spelen.

- De keuzevrijheid van ouders blijkt in de loop der tijd steeds belangrijker te zijn geworden op de 'markt van het onderwijs', evenals de invloed van de gemeenten met hun instrumenten op het gebied van onderwijsinfrastructuur, -achterstanden en -integratie; vergelijk ook het recente advies over onderwijs en burgerschap van de Onderwijsraad (2003).

- De afkeer van staatspedagogiek blijkt niet te verhinderen dat menig kerndoel voor het primair onderwijs nu reeds normatieve doelen bevat, zoals antidiscriminatie en tolerantie.

- Het Nederlandse pluriforme onderwijssysteem fungeert als model in discussies over waarden en normen en burgerschap in andere landen (vgl. Ravitch en Vitteri 2001). ${ }^{3}$

\subsubsection{PRIMAIRE, SECUNDAIRE EN TERTIAIRE TAKEN VAN HET ONDERWIJS}

In de adviesaanvraag wordt aandacht gevraagd voor de implicaties van waarden en normen voor het onderwijs. Waar zitten hiertoe de aangrijpingspunten in het onderwijs, gezien de eerdere indeling in primaire (kennisoverdracht), secundaire (het instandhouden van de economische, sociale en morele voorwaarden) en tertiaire taken (externe effecten voor andere instituties)?

\section{Primaire taken}

Op welke wijze zou de aandacht voor de overdracht van waarden en normen in het curriculum kunnen worden versterkt? In een openbaar tweegesprek kwamen Hofstee en Hirsch Ballin (1993) tot de conclusie dat de enig haalbare vorm er één is van deugdenonderricht. Hoe dit moest worden gegeven bleef in dat gesprek deels open, maar voor de gemiddelde leerling lijken deugden als vak te hoog gegrepen. Hoewel de bijdrage van de school voor de overdracht vooral zit in de hieronder te bespreken secundaire en tertiaire taken van de scholen, zit die daarnaast ook in de gewone schoolvakken, waaronder met name ook in de gymnastiek en sport. SCP-onderzoek wijst op het belang van sport voor het leren van de eigen kracht en hoe die te bedwingen. Gedragsregels worden spelenderwijs 
aangeleerd en hebben een uitwerking op lange termijn. Bovendien wijst onderzoek op de positieve correlatie van sportbeoefening met schoolprestaties en dus ook met de kwalificerende functie van het onderwijs. Van Lidth de Jeude (2004) houdt in dit verband een prikkelend pleidooi voor kunstenonderwijs. De schrijver en oud-leraar Robert Anker (2003) doet dat voor het onderwijs in de Nederlandse literatuur. Hierbij constateert hij overigens wel dat de behoefte om in het literatuuronderwijs aan te sluiten bij de belevingswereld van de leerlingen grote gevolgen heeft gehad voor de culturele waarde van het literatuuronderwijs, zoals: "onvoldoende confrontatie met het onbekende, de verrijkende ervaring van groei en grensverlegging, begeleiding en sturing van zelfwording, kennisname van andere opvattingen en gedragingen leidend tot vergroting van empathie, vergroting ook van sensibiliteit voor ongrijpbare esthetische ervaringen" (Anker 2003: 79). Naast literatuuronderwijs zijn er meer schoolvakken die raakvlakken hebben met waarden, normen en gedrag, zoals ook de Onderwijsraad laat zien (Onderwijsraad 2002).

Het duidelijkste ligt die relatie traditioneel bij geschiedenis en bij maatschappijleer. Op de basisschool gaat het hierbij slechts om geschiedenis; naast uiteraard het goed leren beheersen van het Nederlands, al vanaf het eerste begin op school. Geschiedenis is belangrijk, omdat leerlingen erdoor vertrouwd worden gemaakt met historische oriëntaties en de 'bronnen van onze beschaving', waardoor zich bij hen ook een gevoel voor morele en culturele vraagstukken kan ontwikkelen. Een en ander draagt ook bij aan confrontaties en vergelijking met andere tijden en andere waarden, normen en instituties en stelt de veranderingen in de publieke moraal en van de positie van de burger (zijn rechten en plichten) tegenover de staat aan de orde. Het laat zien dat normen en instituties zijn voortgekomen uit maatschappelijke strijd tussen volken, standen en klassen, bijvoorbeeld als het gaat om de vrijheid van godsdienst, het eigendomsrecht en de vrijheid van meningsuiting. Geschiedenis biedt ook de mogelijkheid om de eigen publieke moraal in perspectief te zien en een gevoel te krijgen voor de plaats en identiteit van de Nederlandse en Europese geschiedenis.

Internationale discussies over de inhoud van het vak laten zien dat er veel in beweging is en dat in veel landen wordt gesproken over de vraag of en hoe moet worden ingespeeld op nieuwe maatschappelijke dynamiek en pluriformiteit. Zo speelt in de Verenigde Staten mede de vraag in hoeverre de etnische heterogeniteit van de klassen ertoe heeft geleid dat aan de behandeling van normatieve kwesties in bijvoorbeeld geschiedenisonderwijs minder tijd en aandacht wordt besteed dan de bedoeling was en het vak vlak en neutraal wordt overgedragen (Ravitch 2002); een risico dat Bronneman voor Nederland in enkele gevallen ook ziet voor heterogeen samengestelde scholen in de grote steden en meer in het algemeen door de neiging om het niveau van het onderwijs aan te passen aan de omgeving waarin het gegeven wordt (Bronneman 2004). In 2001 verscheen het advies Verleden, heden en toekomst van de commissie-De Rooy (2001). De commissie legt hierin veel nadruk op de historische vaardigheden en de historische oriëntatiekennis die burgers in de huidige pluriforme samenleving nodig 
hebben. De verantwoordelijkheid voor de bewaking van het niveau van het vak ligt bij de beroepsgroep en bij onderlinge visitatierondes. Naast Nederlandse taal en geschiedenis kent het basisonderwijs ook het onderdeel geestelijke stromingen dat verplicht is voor iedere leerling, ${ }^{4}$ en waarin in principe aandacht kan worden besteed aan de religieuze waardestelsels van het christendom, de islam, het jodendom, en het hindoeïsme en het seculiere waardestelsel van het humanisme (vgl. par. 7.2, de waardestelsels van Tipton). Bronneman waarschuwt in haar bijdrage echter voor al te hoge verwachtingen van waarden en normen in het basisonderwijs. Zij wijst erop dat normen pas voor de leerlingen gaan leven als ze hun vanzelfsprekendheid gaan verliezen en als kinderen zich bewust worden van verschillen in normen en gedrag, en dat is pas vanaf circa hun tiende jaar (Bronneman 2003). Maar ook dan nog zal het thema een ver-van-mijn-bedshow blijven, zo vreest zij, laat staan dat het model van de leerkracht als begeleider van groepsdiscussies, die hoort bij dit onderwerp, voor het basisonderwijs geschikt lijkt.

Voor de waarden- en normenthematiek is het meest voor de hand liggende aanknopingspunt het vak maatschappijleer. Het vak heeft nog steeds een lage status - vergelijk de Onderwijsraad (2002) en Veugelers (2003) - en is niet verplicht in het profiel maatschappij en economie in het voortgezet onderwijs, terwijl men dat juist daar zou verwachten. Gezien de noodzaak van meer aandacht voor burgerschap (vgl. hoofdstuk 8) meent de raad dat een herwaardering van het vak meer dan noodzakelijk is; door het verder te professionaliseren mede in lijn met het vak civic education in enkele andere landen. In dat kader is het van belang in herinnering te roepen wat Hofstee in 1992 in het kader van de burgerschapsstudie van de WRR heeft voorgesteld (Hofstee 1992). Hij stelde toen voor om in het onderwijs veel meer te doen aan bevordering van inzicht in de collectieve consequenties van individueel handelen ontleend aan de gedragswetenschappen: economie, sociologie en psychologie. Weliswaar onderkende hij een aantal problemen bij de introductie van een dergelijk vak, zoals de associatie met bepaalde politieke ideeënstelsels, de mogelijke strijd tussen wetenschappelijke scholen bij het maken van het curriculum en het gevaar van onvoldoende stabiliteit van het curriculum, doordat uit onderzoek telkens nieuwe gegevens en inzichten naar voren komen. Toch meende hij dat dit soort kennis moet worden overgedragen in verband met het zijns inziens grote gebrek aan inzicht in collectieve consequenties van handelen bij kinderen, wat men ook ziet bij normoverschrijding. ${ }^{5}$

Over een dergelijke invulling van het vak maatschappijleer kan wellicht sneller consensus worden bereikt dan over een curriculum waarden en normen, gezien artikel 23 Grondwet, de bezwaren tegen een door de staat opgelegde pedagogiek (vgl. debatten in het verleden over de 'staatspedagogiek', en 'De school van je leven' van de commissie-De Ruiter) en de ambivalenties rondom handhaving van groepsidentiteit, die erdoor zouden worden vergroot. De voorgestelde meer gedragswetenschappelijke invulling van het vak sluit ook goed aan op de secundaire taak van de school, als voorportaal voor de oefening in disciplinering en 
handhaving van normen van algemeen menselijk verkeer (zie ook peer groupmechanismen en conflictregulering die hieronder worden behandeld). Maar behalve dat dit vak meer nog dan andere vakken gevoed wordt door de invulling van de secundaire en tertiaire taken van de school, geeft het zelf ook weer steun aan deze taken. Door de meer gedragswetenschappelijke invulling kan het accent in het vak maatschappijleer ook meer komen te liggen op burgerschapsvorming (civic education), zodat hiervoor ook geen nieuw vak behoeft te worden ingevoerd. Vooral het curriculum civic education in het Verenigd Koninkrijk biedt wellicht aanknopingspunten, omdat de nadruk hier ligt op de gedragsregels van burgers in hun verschillende rollen, als consument, werknemer, lid van maatschappelijke organisaties en lid van de politieke gemeenschap en de openheid om met die verschillende rollen om te gaan. Bij dit laatste is het dan weer van belang om naast de gebruikelijke aandacht voor de nationale rechtsstaat en nationale gemeenschap, voor de toekomst meer dan gebruikelijk aandacht te besteden aan de Europese Unie en de Europese Grondwet (vgl. Eijsbouts 2003). De Onderwijsraad heeft onlangs voorgesteld om in de onderwijswetgeving een algemene doelbepaling op te nemen, waarin een verplichting tot burgerschapsvorming is opgenomen (Onderwijsraad 2003).

\section{Secundaire taken}

Zoals gezegd is de overdacht van waarden en normen in het onderwijs in die zin bijzonder dat die tevens deel uitmaakt van de primaire taak. Dat komt nu eenmaal door de aard van het onderwijs als institutie. Maar evenals bij alle andere instituties ontleent de overdracht toch vooral haar kracht aan de gedragsvoorbeelden die de leerlingen zien en in de omgang met normen op school, dus in de secundaire taken. De overdracht van waarden en normen zit in het feitelijke gedrag en de imitatie van gedragsvoorbeelden. "Onderwijsgevenden bieden door hun interacties met leerlingen per definitie een scala van modellen en identificatiemogelijkheden. In feite is de school een integrale leeromgeving, waarbinnen waarden en normen op allerlei manieren worden geleerd" (Van Haaften 1992). De ene keer gaat dat bijvoorbeeld via een verhaal, de andere keer via afspraken over regels, of door de manier van lesgeven (bijvoorbeeld klassikaal), of door stages (vgl. ook KPC-groep 2003). Soms staat de leerkracht centraal en soms het kind zelf. Het hangt ervan af waar het over gaat. Van Haaften maakt hierbij verder onderscheid tussen inprenting, onderrichting en aanvaarding. Inprenting impliceert in zijn termen alle soorten van gewoontevorming, van het aanleren van een gedragsrepertoire. Het initiatief ligt hier geheel bij de opvoeder. Hij of zij, en dus niet het kind, bepaalt de inhoud van het gedragsrepertoire. Het kind moet eenvoudigweg leren bepaalde dingen te doen en te laten. "Onderrichting omvat alle min of meer dwingende vormen van informatieoverdracht, met als doel dat het kind zich volgens de juiste normen gaat gedragen. Ook hier ligt het initiatief bij de opvoeder. Maar informatieoverdracht vergt altijd ook een beantwoording van dat initiatief; een bereidheid van de kant van de leerling zich ervoor open te stellen. Waarden en normen vragen ook om aanvaarding. Dat aanvaarden, of beter gezegd het op zich willen nemen, is echter iets dat de leerling uitsluitend zelf kan doen" (Van Haaften 1992). In die fase is de nadruk volle- 
dig verlegd in de richting van de zich ontwikkelende persoonlijkheid van de leerling zelf.

De pendant van overdracht van waarden en normen in het onderwijs is derhalve de handhaving van de (eigen) waarden en normen. Waarden- en normenoverdracht zal doorgaans niet beklijven indien het gedrag van leerlingen en/of leraren op school zelf hiermee in strijd is. Internalisering van waarden en normen wordt het beste bevorderd door deze zelf te praktiseren. Scholen dienen dan ook evenzeer aandacht te besteden aan de controle en correctie van het gedrag van hun leerlingen. Dit is een van de onderwerpen die al in 1992 aan de orde kwamen in de discussie over de versterking van de pedagogische functie van scholen (Ritzen 1992; commissie-De Ruiter 1995). Sedertdien is de belangstelling voor dit onderwerp alleen maar toegenomen, zoals onlangs bleek uit de aandacht in de media voor het schoolklimaat op enkele scholen en de vergelijking ervan met dat op enkele buitenlandse scholen (Jippes 2003). In dezelfde richting wijst een initiatief en oproep van leraren, ouders en opvoedkundigen (Derkse 2002). Het schoolklimaat lijkt te (kunnen) worden beïnvloed door verschillende condities. Hierbij valt te denken aan condities als schoolgrootte, klassengrootte en klassikaal stelsel, de kwaliteit van de gebouwen, de helderheid van de regels op school, het gebruik van peer group-mechanismen, de steun van de lokale gemeenschap voor de school en de relatie van de school met de gezinnen van de leerlingen. Deze condities worden hier kort toegelicht.

1 Schoolgrootte Vaak wordt gewezen op de nadelen van te grote scholen en scholengemeenschappen, zoals bijvoorbeeld door de RMO (2000, 2002). Deze constateert, zonder te kiezen voor schaalverkleining zonder meer, dat grote scholengemeenschappen onvoldoende maatwerk leveren en dat zij hun 'dienstverlening' te weinig afstemmen op verschillende groepen van gebruikers, hoewel zij daartoe gezien hun omvang wel in staat zouden zijn. Een te kleine schaal is echter weer om andere redenen nadelig, bijvoorbeeld omdat leerlingen dan niet binnen de school kunnen schakelen van de ene onderwijssoort naar de andere en de school te klein is voor goede vervangingsregelingen en voor bijscholingsvoorzieningen voor de docenten.

2 Klassengrootte en klassikaal stelsel Gedragsproblemen zijn lang niet altijd met repressie op te lossen. Preventieve strategieën gaan uit van tijd en aandacht voor de internalisering van gedragsnormen door het individuele kind. In dit verband kan worden verwezen naar onderzoek naar het effect van klassenverkleining. Hieruit blijkt dat alleen een aanzienlijke klassenverkleining effect sorteert (bijvoorbeeld terug naar 17 leerlingen per klas; Junger-Tas 2001). Er zijn echter ook onderzoekingen die tot andere resultaten komen. De verschillen in uitkomsten hebben te maken met de samenstelling van de groepen, met de diversiteit van de schoolbevolking en met de manier waarop de klassenverkleining is georganiseerd (bijvoorbeeld de aanwezigheid van remedial teachers, waardoor in sommige gevallen individuele begeleiding mogelijk is). Junger-Tas (2001) concludeert bijvoorbeeld dat bij allochtone leerlingen klassikaal onderwijs over het algemeen juist succesvol is. Deze 
vorm van lesgeven leent zich ook goed voor grotere klassen; een grote groep dwingt juist tot meer orde en structuur in de klas (bijvoorbeeld omdat anders niemand meer iets kan verstaan). Maar het kan ook afhangen van de manier waarop het lesgeven is georganiseerd. Men moet zich dan ook niet blind staren op de voordelen van klassenverkleining. Ook klassenvergroting met meer leerkrachten tegelijk kan voordelen hebben. Er is bovendien niet één enkel model. Klassikale methodes en intensieve face to face-relaties kunnen goed samengaan in grote klassen en groepen als hiervoor tenminste meer leerkrachten en begeleiders beschikbaar zijn.

3 Kwaliteit van de publieke ruimte Grote scholen in het voortgezet onderwijs hebben vaak ook (te) grote gebouwen, of zij hebben gebouwen van wisselende omvang en kwaliteit, verspreid over de stad. ${ }^{6}$ Voorts lijkt er onnadenkend en onzorgvuldig met de kwaliteit van de openbare ruimte te worden omgegaan en is er soms sprake van onveilige situaties op schoolpleinen.Vuile klassen en vuile en onveilige ruimtes zijn niet bevorderlijk voor het pedagogische klimaat op school. En waarom zouden schoonheid en architectuur alleen voor het bedrijfsleven moeten gelden en niet ook voor jeugd en jongeren van belang zijn? De pluriformiteit en de expressieve moraal (vgl. Tipton, par. 7.2) van de school kan er ook mee tot uitdrukking worden gebracht.

4 Consequente handhaving van gestelde normen Het is belangrijk dat er op school sprake is van heldere regels en dat normen die gesteld zijn ook daadwerkelijk consequent worden gehandhaafd. Orde begint immers bij een systematische handhaving van aanwezigheidsregels en gedragsregels. Prick (2004) wijst er terecht op dat gedragsregels alleen dan zin hebben als zij ook daadwerkelijk worden gehandhaafd en verwijst hierbij naar het Franse voorbeeld, waar elke school een aparte functionaris heeft die verantwoordelijk is voor de regelgeving op school en voor de handhaving hiervan. Daarnaast zijn er voorbeelden uit andere landen, zoals de Verenigde Staten. Daar wordt bijvoorbeeld ook meer wetenschappelijk onderzoek gedaan naar strategieën die wel en die niet werken bij geweldspreventie en conflictregulering op scholen. In Nederland is de invloed van onveiligheid op school en in de buurt op het functioneren van de leerlingen op school echter nog een relatief nieuw onderzoeksgebied.

5 Gebruikvan peer group-mechanismen Om ongewenst gedrag tegen te gaan zijn ook de meer informele sociale controlemechanismen van belang, zoals die van de peer group van de vrienden. In dat kader lijken strategieën die thans in de Verenigde Staten worden getest en die bekend staan onder de verzamelnaam social norms approach, interessante aanknopingspunten te bieden. Het gaat hier om mechanismen waardoor normconform gedrag wordt uitgelokt. Tot nu toe lijkt de social norms approach succesvol te zijn toegepast op jongeren met drank- en drugsproblemen, maar de methodes lijken ook voor andere vormen van problematisch gedrag hanteerbaar (Perkins 2003; recensie door Sunstein 2003). Eigenlijk zijn die mechanismen ook niet nieuw, vergelijk de discipline in het voetbalelftal ('Als je niet komt opdagen, schaadt je je medespelers'). Door dit soort mechanismen wordt ook de ruime marge tussen onprettig en onwettig gedrag benut (vgl. hoofdstuk 6). De confrontatie met de formele mechanismen van de overheid en de 
rechtsstaat, bijvoorbeeld door het optreden van politie en leerplichtambtenaren, kan immers nooit het enige middel zijn en vernietigt soms ook de ruimte om er op andere en meer informele manieren uit te komen, zoals door bevordering van normconform gedrag door gebruikmaking van vriendennetwerken.

6 Normhandhaving als onderdeel van de lerarenopleiding Ligt in de pabo-opleiding weleens te weinig nadruk op de kernvakken, bij de lerarenopleiding lijkt soms de sterke vakinhoudelijke oriëntatie van de opleiding weinig ruimte te laten voor aandacht aan handhaving van gedragsregels en omgang met de multiculturele samenstelling van klassen.

7 Steun van de gemeenschap voor de school Ook de steun vanuit de gemeenschap(pen) is een conditie voor bevordering van sociale controle op school. Bij haar taakuitoefening staat een school namelijk niet op zichzelf. Ze maakt deel uit van gemeenschappen en het succes van de scholen hangt deels af van de vitaliteit van die gemeenschappen. Empirisch onderzoek laat zien dat die participatie nog steeds op peil blijft en vergeleken met andere landen opmerkelijk hoog ligt, waarbij deze zich zelfs uitbreidt tot nieuwe gebieden, zoals participatie door de gebruikers (overblijfouders, leesouders en leerlingenparticipatie). ${ }^{7}$

8 Heldere relaties school-huismilieu De uitoefening van sociale controle door de ouders is een conditie voor een effectieve werking van sociale controle op school. Hoe beter in het gezin sociale controle op het kind wordt uitgeoefend, des te beter dit ook op school werkt. Soms wordt gesuggereerd dat de school een deel van de taken van de ouders moet overnemen als kinderen thuis onvoldoende worden gedisciplineerd en begeleid. Vergeten wordt dan al snel dat vooral de basisschool al veel tekorten in de opvoeding op school moet opvangen. Zonder tegenwicht tegen deze ontwikkeling vanuit het onderwijs zelf is het niet denkbeeldig dat de moeilijke kerntaken van het onderwijs nog meer in de knel komen, want ook door de verzakelijking staan ze al onder druk. De school is bovendien een instelling van onderwijs en geen instelling voor de opvulling van maatschappelijke tekorten. Dat wil echter ook weer niet zeggen dat als de ouders meer op hun plichten worden gewezen het hierbij behoeft te blijven. Willems (2003) bekijkt de zaak daarentegen van de andere kant. Hij bekritiseert de standaardreactie van 'het is niet onze taak om de ouders te steunen'. Elk probleem met kinderen wordt door instellingen en rechters steeds gedefinieerd als een individuele aansprakelijkheid van ouders. Konden die ouders bij hun werkzaamheden vroeger nog vaak een beroep doen op steun van familie en sociale netwerken en werden zij niet individueel 'aansprakelijk' gesteld voor het doen en laten van hun kinderen, nu lijkt dit wel het geval te zijn (alsof het bovendien slechts gaat om een kwestie van maakbaarheid). En als zij het niet alleen blijken aan te kunnen, behoort het tot hun eigen verantwoordelijkheid om politie, maatschappelijk werk en anderen in te schakelen. Aandacht op school voor waardeontwikkeling, normbesef en gedragsregels herstelt zo bezien in zekere zin de steun van de gemeenschap, zij het in meer georganiseerde vorm. Bovendien sluit het een het ander niet uit: én de ouders (mede als burgers) én de school kunnen wat 
doen aan het bijbrengen van gedragsvormen en normatieve vaardigheden en kunnen hierover onderling afspraken maken, waarbij zij aangeven wat zij van elkaar verwachten.

9 Systemen van conflictregulering Een interessante en veelbelovende manier om al doende bij te dragen aan de overdracht en naleving van gedragsnormen is conflictregulering op school. Conflicten op school worden steeds vaker aan de rechter voorgelegd, bijvoorbeeld over het dragen van hoofddoekjes, over schade aan leerlingen vanwege langdurige door de school getolereerde pesterijen door medeleerlingen, over onvoldoende kwaliteit van onderwijs (bijvoorbeeld door uitval van lessen, onvoldoende kwaliteit van docenten enz.). De vraag dringt zich op waarom de school niet zelf meer aandacht besteedt aan conflictregulering. De school is immers ook een eigen microcivil society, een geheel van sociale betrekkingen tussen leerkrachten en leerlingen, leerlingen onderling, school en ouders, directie en bevoegd gezag, enzovoort. In die betrekkingen doen zich vaak problemen voor, zoals ook buiten de school het geval is. Naast de reeds genoemde onderwerpen valt te denken aan intimidatie van leraren door leerlingen of hun ouders en eenzijdig machtsgebruik door scholen en leerkrachten, zonder dat hier een juridisch tegenwicht tegenover staat. In zijn rapport over de nationale rechtsstaat heeft de WRR ervoor gepleit dat de rechtsbescherming van burgers op peil blijft, nu steeds meer bevoegdheden worden overgedragen aan de autonomie van de instellingen. Daarnaast zijn ook andere systemen denkbaar waarbij de schoolgemeenschap in eerste instantie zelf zorgt voor de beslechting en 'berechting' van conflicten. In Amerikaanse scholen zijn leerlingen bijvoorbeeld zelf medespelers in het juridische proces, terwijl in Duitsland scholen een schoolgrondwet kennen. Het voordeel van dergelijke methoden is dat men niet onmiddellijk een beroep hoeft te doen op de formele systemen van conflictbeslechting door politie en justitie, al blijft die mogelijkheid altijd bestaan. Tegelijkertijd moet worden voorkomen dat zaken die eigenlijk bij justitie of politie thuishoren, daar niet terechtkomen. Het een hoeft het ander echter niet uit te sluiten, zoals ook de meer informele rechtsprocedure bij de Commissie Gelijke Behandeling niet in de plaats hoeft te komen van de formele rechtsgang. Een neveneffect van conflictregulering in de school is bovendien dat ze ertoe dwingt om afspraken te formaliseren en ook om een etiquette van omgangsvormen te formuleren. Een ander neveneffect is dat leerlingen door te oefenen burgerschapsvaardigheden verkrijgen; het instructiemateriaal is om zo te zeggen direct bij de hand. In hoeverre dit leereffect ook optreedt, hangt onder meer af van de mate waarin de leerlingen zelf betrokken worden bij de conflictregulering en de mate waarin zij de effecten ervan kunnen merken in de verbetering van het schoolklimaat. Overigens moet wel worden gewaakt tegen het effect van juridisering dat hiervan zou kunnen uitgaan, waardoor de informele sociale controle zou kunnen worden uitgehold.

\section{Tertiaire taken}

De proef van het ministerie van Onderwijs onder tien scholen met vrijwillige stages voor middelbare scholieren bij vrijwilligersorganisaties, ideële clubs en 
zorginstellingen is een recente vorm van invulling van de derde taak (Tweede Kamer 2002-2003, 27400). Er moet uiteraard worden afgewacht wat het effect is voor de leerlingen. Zal er gebruik van worden gemaakt? En draagt het bij tot hun besef van waarden en normen en zal het invloed hebben op hun latere gedrag? Of ruimer: in hoeverre draagt onderwijs ook bij aan de algemene maatschappelijke waarden en normen, in hoeverre is het dan alleen de school en in hoeverre is het vooral de gezinsinvloed? Naar het zich laat aanzien spelen soortgelijke onzekerheden ook bij de effecten van invoering van het brede schoolconcept op verschillende scholen (vgl. Emmelot en Van der Veen 2003). Voor de vraag naar de externe effecten op langere termijn zou men natuurlijk het liefste terugvallen op gedegen empirisch onderzoek. Wat erover bekend is, is dat voor de doorsneeouder de pedagogische taak van de school ligt bij de maatschappelijke aspecten en vaardigheden en dat de persoonsgerichte doelstellingen als de vorming van evenwichtige mensen en bijbrengen van goede manieren eerder door de ouders wordt gezien als een taak voor henzelf. In de onderzoeken waaraan dit wordt ontleend komen de allochtone ouders echter nauwelijks aan het woord. En wat ervan bekend is, wijst erop dat allochtone ouders het Nederlandse onderwijs te weinig prestatiegericht en de pedagogische aanpak te slap vinden en zeker niet aansluitend op hun eigen manieren van opvoeden (vgl. Veugelers en De Kat 1998). Voor de eigenlijke vraag wat de externe effecten zijn van de vorming op school voor het verdere leven, moet vaak een beroep worden gedaan op de plausibiliteit van een bepaalde redenering. Hoewel moeilijk empirisch valt vast te stellen welke externe effecten de overdracht van waarden en normen in het onderwijs buiten het onderwijsgebied heeft, is het namelijk wel zeer aannemelijk dát dergelijke effecten bestaan. En dan gaat het om neveneffecten als: op tijd komen; de gewenning aan leren in interactie met anderen; het kunnen organiseren van je werk en de doorwerking van de regel dat je 'eerst je huiswerk moet maken'. Andere neveneffecten lijken moeilijker te bewijzen, zoals de houding ten opzichte van conflicten door ervaringen die zijn opgedaan met de omgang met conflicten op school. Of de relatie tussen het democratische klimaat op school (kiezen van klassenvertegenwoordigers) en de democratische gezindheid in het latere leven. Sommige scholen lijken ervan overtuigd dat elementen van het schoolklimaat van invloed zijn op het latere leven en profileren zich op bijvoorbeeld disciplinering en conflictregulering, en anderen daarnaast ook op expressievakken, zoals schooltoneel. Zij laten nogmaals zien dat scholen zich in normatieve zin kunnen profileren en zich hiermee willen onderscheiden van andere scholen. Het is een uitdrukking van de pluriformiteit van het Nederlandse onderwijs, waarin alle waardestelsels van Tipton terugkeren (religieus, seculier humanistisch, individueel-utilitaristisch en individueel-expressief).

De eerdergenoemde conflictregulering bevat ook een oefening in meer democratische en rechtsstatelijke competenties. De relaties tussen onderwijs en democratie en rechtsstaat, die hierin tot uitdrukking komen, bevinden zich op microniveau. Op macroniveau zijn er echter ook relaties tussen democratie en onderwijs, bijvoorbeeld als wordt geconstateerd dat er een relatie ligt tussen het democratische en rechtsstatelijke project van de twintigste eeuw (invoering alge- 
meen kiesrecht, uitbreiding van de grondrechten, toename maatschappelijke participatie en mondigheid) en het onderwijsproject (grotere deelname aan en mobiliteit in het onderwijs). Het scharnierpunt in die relatie wordt gevormd door de invoering van een voor alle burgers gelijke en verplichte participatie aan het onderwijs; rijk en arm in één klas, als een vroege oefening in het hebben van gelijke rechten en plichten, hoe maatschappelijk verschillend men ook geboren is. ${ }^{8}$ De algemene leerplicht onderstreept het gelijkheidsbeginsel dat kenmerkend is voor de democratische rechtsstaat. In Nederland is daarnaast een beginsel van self-government gehanteerd mede als antwoord op het godsdienstig en levensbeschouwelijke pluralisme. Het is een uitdrukking van de vrijheid van onderwijs (art. 23 Grondwet) en de vrijheid van vereniging. In hoofdstuk 5 is gewezen op de noodzaak om op school meer aandacht te besteden aan de beginselen van de democratische rechtsstaat. Dat kan door de oefeningen in de eerdergenoemde systemen van conflictregulering en bevordering van omgangsvormen, zoals die hierboven zijn genoemd, in samenhang met een meer op burgerschapsvorming gericht vak maatschappijleer. Het zou al met al een nieuwe fase zijn in de ontwikkeling van de relatie tussen onderwijs en rechtsstaat, in de zin dat die relatie nu ook binnen de schoolpraktijk zelf tot leven moet worden gebracht om die relatie aldus ook op langere termijn te handhaven.

\subsubsection{CONCLUSIES OVER ONDERWIJS}

1 Binnen het kader van de primaire taak moet niet een nieuw vak waarden en normen op school worden ingevoerd. Het is beter dat een herwaardering van het bestaande vak maatschappijleer plaatsvindt en dat burgerschapsvorming erin wordt opgenomen; dit naast de reeds ook door anderen gedane voorstellen om in het geschiedenisonderwijs meer aandacht te besteden aan de historische ontwikkeling van burgerschap in zijn pluriforme verschijningsvormen en naast het voorstel van de Onderwijsraad (2003) voor een algemene doelbepaling over burgerschapsvorming in de onderwijswetgeving.

2 Internalisering van normen wordt het beste bevorderd door deze zelf te praktiseren. Waarden- en normenoverdracht zal doorgaans niet beklijven indien het gedrag van leerlingen en/of leraren op school zelf hiermee in strijd is. De belangrijkste aangrijpingspunten voor de overdracht van waarden en normen in het onderwijs zitten derhalve in het schoolklimaat en in de externe betrekkingen van de school met haar omgeving, dus in de secundaire en tertiaire taak van de school.

3 In de lerarenopleiding voor het voortgezet onderwijs moet de secundaire (en tertiaire) taak meer aandacht krijgen, opdat de leerkrachten beter zijn voorbereid op normoverschrijdend gedrag en handhaving van regels in de klas en voorts op de omgang met morele vragen, samenhangend met de multiculturele samenstelling van de klassen. De betrokken instellingen voor hoger onderwijs kunnen in de eerste plaats hierbij zelf het initiatief nemen om te komen tot kwaliteitsregels.

4 Er zouden voor schoolbesturen meer methoden moeten worden ontwikkeld om - met name voor het voortgezet onderwijs - leerlingen meer te betrekken 
bij de vaststelling van de regels en bij conflictregulering, bij wijze van vooroefening in de omgang met waarden en normen in een samenleving van volwassen burgers. Scholen kennen weliswaar al schoolgidsen, schoolplannen en (anti-pest)protocollen, maar het bereik en het effect hiervan moeten niet worden overschat.

5 Er zijn vele manieren waarop scholen hun maatschappelijke taak ten aanzien van waarden, normen en gedrag kunnen vervullen. Niet één daarvan is de beste of in alle situaties toepasbaar. De lokale omgeving waarin scholen functioneren, de problemen waarmee zij worden geconfronteerd, de samenstelling van de schoolpopulatie en de wensen van de ouders lopen te zeer uiteen voor een standaardoplossing. Er moet meer ruimte komen voor institutionele variëteit, overigens zonder dat minimumvereisten van gelijkwaardigheid en gelijke toegang worden losgelaten.

\subsection{WAARDEN EN NORMEN IN DE INBURGERING}

In de context van de waarden- en normendiscussie wordt vaak nogal wat verwacht van het systeem van inburgering. Hoe reëel is dat? Als voor het onderwijs in het algemeen geldt dat er te veel van wordt verwacht, dan geldt dit zeker voor de rol van onderwijsinstellingen bij inburgering. Op dit moment moeten de deelnemers verplicht 600 uren deelnemen aan de inburgeringscursussen. Ze worden in opdracht van de gemeenten georganiseerd door het ROC en zij worden formeel na 12 maanden afgesloten met een verplichte toets, waarin wordt aangegeven wat de cursus voor de betrokkenen aan rendement heeft gehad op het niveau van eindtermen. Is dit niveau te laag, dan kan eventueel nog een verlenging volgen van een halfjaar. In andere gevallen treedt een vervolgtraject in van begeleiding naar de arbeidsmarkt of naar een vervolgopleiding. De inburgeringscursussen zijn de afgelopen jaren meermalen onderwerp geweest van publieke en politieke discussies, onder andere vanwege lage scores bij de taaltests, absentie, motivatieproblemen, uitval van lessen, onduidelijkheid van de toets en dergelijke (zie de evaluatie door de Algemene Rekenkamer 20oo; Tweede Kamer 2002-2003). Over de noodzaak van meer duidelijkheid over de status van de toets en het belang van inburgering van nieuwkomers zijn de meeste deskundigen het wel eens. Dit geldt ook voor het vak maatschappijoriëntatie, dat zich richt op bevordering van zelfredzaamheid in plaats van ook op burgerschapsvorming (vgl. Eindtermen 1997), dat slechts op één niveau wordt getoetst en soms nauwelijks te onderscheiden is van taalonderwijs (vgl. Verhallen 2001).

De overdracht van waarden en normen kan slechts zeer gedeeltelijk zitten in de maatschappijoriëntatie. Wat eerder is gezegd over value education geldt ook hier. De beste manier van overdracht is door imitatie van gedragsvoorbeelden. Dit is in de voorgaande paragraaf over onderwijs behandeld als tertiaire taak van instituties. De participatie aan de inburgeringsinstituties zelf biedt zo bezien de basis voor de overdracht van waarden en normen. De vraag is of dit niet een te smalle basis is voor participatie en of aldus niet te veel wordt verwacht van de onderwijsparticipatie van volwassenen (want dat is immers de doelgroep van de inbur- 
gering). Een bijkomende factor is de heterogene samenstelling van de klassen die niet echt bevorderlijk is voor een snelle imitatie van Nederlandse rolmodellen.

Daarom wordt ook wel gepleit voor een ruimere kijk op participatie, waarbij een geslaagde overdracht van waarden en normen fungeert als sluitstuk van een gefaseerd systeem van inburgering via de arbeidsmarkt (de indeling in fases ervan vertoont overigens een analogie met het onderscheid in primaire, secundaire en tertiaire taken). De eerste fase bestaat eruit dat nieuwkomers, nadat zij een vergunning tot voorlopig verblijf hebben verkregen, gaan deelnemen aan het arbeidsproces (vgl. Tiggelen en Vermaas 2002). De tweede fase is dat de nieuwkomers zich hierbij zo snel mogelijk de vaardigheden en kennis eigen maken om te kunnen participeren en dat zij een examen Nederlandse taal en cultuur afleggen. In de laatste fase moet dan de deelname aan arbeid en de samenleving leiden tot een groter commitment aan de Nederlandse samenleving, haar normen en rechtsstatelijke basiswaarden. Het is een neveneffect dat bovendien soms meer, soms minder als apart doel wordt beoogd (vgl. Verhoogt 2001; Couwenberg, Cliteur et al. 2003). Het succes van deze laatste fase is uiteraard afhankelijk van de eerste fase en van de kwaliteit van de inburgeringsvoorzieningen.

De uitvoering van de eerste fase, dus de participatie aan de arbeidsmarkt, blijft in Nederland echter onder de maat. Zo is de arbeidsparticipatie van nieuwkomers vergeleken met bijvoorbeeld Duitsland opmerkelijk laag (Koopmans 2002). Die lage participatie belemmert ook de uitvoering van de tweede fase, omdat nieuwkomers juist in de concrete arbeidspraktijk de taal het beste blijken te leren (zie ook WRR 2001). Daar ziet men ook de rolmodellen. Bovendien biedt de arbeidssituatie naast bijvoorbeeld de buurt een min of meer gestructureerd kader dat gunstig is voor eventuele discussies tussen de betrokkenen (autochtonen en allochtonen, maar ook tussen allochtonen onderling) over gedrag en regels voor gedrag (zie ook hoofdstuk 6). De derde fase van de neveneffecten van de participatie en het beheersen van het Nederlands, kan evenmin totstandkomen als de toetreding tot de arbeidsmarkt niet lukt. Belangrijk hierbij is dat ook het omgekeerde kan gaan gelden. Als nieuwe immigranten niet deelnemen aan de arbeidsmarkt - vanwege de conjunctuur of de eisen voor deelname aan arbeid (bijvoorbeeld diploma's die niet worden erkend) of om welke andere reden dan ookbestaat zelfs het gevaar van een voortijdige afwijzing van hier geldende normen en gedragsregels door de nieuwe immigranten.

Er is daarom veel voor te zeggen om werk te maken van deelname aan de arbeidsmarkt door nieuwe immigranten, en om deze participatie als een zaak van de eerst orde te blijven zien. Deelname aan inburgeringscursussen is een kwestie van ondersteuning en daarmee van de tweede orde. In het huidige systeem lijkt die verhouding daarentegen soms omgekeerd en lijkt het middel - de door de overheid georganiseerde inburgeringscursus - te veel in de plaats te komen van het doel. De inburgeringscursus is in dit opzicht een treffend voorbeeld van functieversmalling. Het gaat echter het doel van dit rapport te buiten om een geheel nieuw stelsel voor inburgering voor te stellen. Bovendien wordt er al 
geëxperimenteerd met dualiseringstrajecten waarbij van het begin af aan arbeid en onderwijs gecombineerd zijn. Ten slotte heeft het kabinet onlangs voorgesteld om aan het niet behalen van de toets gevolgen te verbinden, zoals het niet verkrijgen door nieuwkomers van een verblijfsvergunning voor onbepaalde tijd als zij de examens niet gehaald hebben.

\subsection{WAARDEN EN NORMEN IN DE MEDIA}

\subsubsection{INLEIDING: PRIMAIRE, SECUNDAIRE, TERTIAIRE TAKEN}

De media (kranten, weekbladen, radio en televisie, omroeporganisaties) en nieuwe vormen van elektronische communicatie (internet) zijn een prachtig voorbeeld om de dubbele relatie van de maatschappij tot de waarden- en normendiscussie te illustreren. Beïnvloeden de media op een geheel zelfstandige wijze de maatschappij of geven ze slechts door wat er in de maatschappij leeft? Zijn de media, en in het bijzonder televisie, scheppers van nieuwe waarden en van het steeds verder opschuiven van normen van betamelijkheid of sluiten programma's aan op wat de mensen altijd al dachten en meenden? De moeilijkheid van een positiebepaling van de media in het waarden- en normendebat is dat bijna geen wetenschappelijk verantwoord antwoord te geven valt op bovenstaande vragen. Ondanks het veel geuite vermoeden dat media een grote invloed hebben op het normbesef en de waardebeleving van kijkers en luisteraars, is gedegen onderzoek naar de 'invloed van de media op waarden en normen in de samenleving' zeer schaars. Er is veel speculatie. In deze paragraaf wordt terughoudendheid betracht ten aanzien van uitspraken over de inhoudelijke waardenen normenoverdracht via de media. Wel kunnen uitspraken gedaan worden over de rechtsstatelijke positie van de media, de economische invloeden die van de toegenomen onderlinge concurrentie in de media uitgaan op bijvoorbeeld programmering, én over de primaire, secundaire en tertiaire taken van de media. Ook over de verschuivende verhouding tussen deze taken kan iets gezegd worden, want bij de media kan men waarnemen - net als bij zoveel andere instituties - dat de economische druk van buitenaf gevolgen heeft gehad voor de aandacht voor secundaire en tertiaire taken van de media.

Onder primaire taken van de media vallen bijvoorbeeld de vrije en onafhankelijke nieuwsgaring, de nieuwsvoorziening, de verantwoordelijkheid voor de waarheid en juistheid van de berichtgeving en de dienstverlening aan het grotere publiek via kranten, radio en televisie, waaronder de niet onbelangrijke taak van het brengen van verstrooiing. De secundaire taken van de media: het instandhouden van de pluriformiteit van publieke meningsvorming in een samenleving, de media als forum of ontmoetingsplaats voor het open en kritische debat, het leveren van openbare kritiek, onder andere op gezagsdragers en vertegenwoordigers van andere instituties. De tertiaire taken van de media bestaan - net als bij de andere instituties - uit de zelfstandige bijdrage aan de publieke zaak, de democratie en het democratische gehalte van de samenleving. Deze tertiaire taak krijgt voor de media zelfs een bijzonder accent, omdat zij immers inhoud geven aan 
een van de klassieke grondrechten: vrijheid van drukpers en van meningsuiting. Deze rechten steunen op de grondwet én ze kunnen door ruime beoefening ervan door de media in stand worden gehouden. Zonder vrije en onafhankelijke pers is er geen levendige democratie mogelijk.

Een tendens is echter waar te nemen dat onder invloed van een moordende concurrentieslag om de kijkersgunst (gemeten via dagelijkse en wekelijkse kijkcijfers en populariteitspolls) juist de aandacht voor de kritische meningsvorming en pluriformiteit (secundaire taak) én voor de democratische opdracht van de media (tertiair) verloren gaat, zoals Keane (1991) in zijn studie The Media and Democracy aantoonde. Dit ondanks de vele mogelijkheden die de media hebben én zouden kunnen benutten om de democratie te versterken (Keane 1991). Planken (2003) spreekt in dit verband van 'een pijnlijk tekort aan eigen onafhankelijke informatie of informatiebronnen bij de media'.

\subsubsection{DE INHOUDELIJKE INVLOED VAN DE MEDIA OP WAARDEN EN NORMEN IN DE SAMENLEVING}

Op welke wijze kunnen media nu de waarden en normen in de samenleving beïnvloeden? Men kan hierbij denken aan de vele op de televisie uitgestalde levenswijzen, die bijvoorbeeld in immens populaire soaps (GTST) of andere programma’s (Big Brother) worden vertoond. Deze levenswijzen krijgen vaak een normatieve meerwaarde. Men wil leven zoals de sterfiguren op de televisie. Jongeren richten hun eigen normen en waarden naar wat ze zien. Of is het toch omgekeerd? Vertoont de televisie de normen die jongeren zelf al geïnternaliseerd hebben? Bij deze vraag komt een oeroude tegenstelling naar voren die reeds tussen Plato en Aristoteles waar te nemen was, namelijk het beeld als aanstichter, katalysator, of het beeld als katharsis. Plato wilde de kunst en de kunstenaars uit de stadstaat weren, omdat die naar zijn mening een slechte invloed hadden via de verbeelding en de fantasieën - op de opvoeding van de jeugd en op het morele besef van de gehele stad. Aristoteles daarentegen zag in de kunsten een mogelijkheid tot ontlading van allerlei reeds bij de stadsbewoners bestaande spanningen, de katharsis. De kunsten leverden de acting out van de innerlijke, reëel bestaande wensen en verlangens.

In de hedendaagse discussie over de invloed van de media, in het bijzonder van televisie, op gewelddadig gedrag keert een soortgelijke discussie terug. Geweld, veelvuldig vertoond op televisie, is een voorbeeld van slecht gedrag en van conflictbeslechting én heeft een negatieve invloed op dit gedrag (Plato's echo). Ofwel de vertoonde beelden van geweld nemen de spanningen juist weg (Aristoteles' late invloed). Het vele onderzoek naar de invloed van televisie op geweld, in het bijzonder op het gedrag van kinderen, heeft twee 'scholen' opgeleverd: er wordt een negatieve invloed toegekend aan de rol van televisiegeweld; een invloed die door andere onderzoekers weer ernstig wordt bestreden of gerelativeerd (zie hiervoor Van der Voort 1997; Nikken 2000). De bestrijders van een zelfstandige invloed van media op gewelddadig gedrag beweren dat de media 
slechts een afspiegeling bieden van de waarden en normen die de samenleving als geheel instandhoudt. Er is een ruime markt in de samenleving voor deze vertoningen van geweld (mutatis mutandis ook voor pornografische films). De media beantwoorden aan deze vraag, ondanks het feit dat deze vraag naar vertoningen van geweld vergaande consequenties zou kunnen hebben voor de samenleving als geheel (Hamilton 1998). Deze externe effecten van geweld en andere vormen van extreem gedrag, bijvoorbeeld in bekentenissenprogramma's, worden verwaarloosd en de concurrentie(positie) domineert de programmering. Over de invloed van televisie op gewelddadig gedrag is op dit moment geen eenduidig wetenschappelijk antwoord te geven. Dat de onderlinge strijd tussen commerciële zenders de tendens tot het veelvuldig vertonen van geweld, conflicten, extravagant gedrag en dergelijke bevordert, staat wetenschappelijk wél vast (Scholten 2004). Maar dergelijke programmakeuzen vallen onder een grondwettelijke bescherming van vrije meningsuiting. Daarnaast vallen ze onder de verantwoordelijkheid van privaatrechtelijke organisaties, zoals de commerciële en publieke omroepen, zodat de grenzen van overheidsinterventie snel in zicht komen.

Maar dat wil nog niet zeggen dat er op dit punt geen verschillen zijn tussen de stelsels in de verschillende landen. Zo is er eerder op gewezen dat in het Verenigd Koninkrijk al geruime tijd voor de commerciële omroepen publieke taakstellingen zijn vastgesteld, ter controle waarvan het nieuwe onafhankelijke Office of Communications (OFCOM) is opgericht. ${ }^{9}$

\subsubsection{CONCURRENTIE EN PROGRAMMERING}

De concurrentie tussen mediaorganisaties is de afgelopen twee decennia toegenomen door de komst van veel nieuwe en wereldwijd opererende commerciële zenders en organisaties. Dat geldt ook in het bijzonder voor de concurrentie tussen commerciële en publieke omroeporganisaties. Uit angst leden of kijkers te verliezen richten de publieke omroeporganisaties zich op de programmering van de commerciële omroepen en hebben daar zelfs veel geld voor over (bijvoorbeeld NOVA als concurrent van Barend en Van Dorp). Waar vroeger de publieke omroeporganisaties werden beoordeeld om hun ledenaantallen, worden ze nu beoordeeld op voornamelijk kwantitatieve prestatienormen in de vorm van kijkcijfers. Net als bij andere instituties (zie 7.3 en onderwijs en inburgering) vindt een functieversmalling plaats, wat nadelig is voor de secundaire en tertiaire taken van de (publieke) omroep. Welke consequenties deze verschuiving in de programmeringsaandacht voor met name de publieke omroepen zullen hebben is een vraag die in dit rapport over waarden en normen niet aan de orde kan worden gesteld. Wel bereidt de raad een uitvoerige studie voor over het medialandschap, waarin ook aandacht wordt besteed aan het omroepbestel (zie Werkprogramma WRR 2003). Als kijkcijfers bepalend worden voor de inhoud van de programma's, zal de variatie van de programmering vermoedelijk verminderen, hetgeen consequenties kan hebben voor de kritische functie van de media; de media fungeren dan niet meer als horzel in de pels van de samenleving, maar vooral als dekmantel van de maatschappelijke (en politieke ${ }^{10}$ ) favorieten. 


\subsubsection{VERANTWOORDELIJKHEID EN VERANTWOORDING}

Dit roept de vraag op naar verantwoordelijkheid en verantwoording. Het ligt voor de hand om zorgen uit te spreken over de hierboven kort gesignaleerde functieversmalling van de media. In het voorjaar van 2003 heeft de RMO een advies uitgebracht over 'medialogica'. De klachten die daarin werden geuit over de media, betroffen het jagen van meutes journalisten op dezelfde nieuwsfeiten, te snelle berichtgeving, te weinig kennis van onderwerpen bij journalisten, de personalisering van de dagelijkse, vooral politieke actualiteit, de vele herhalingen van 'uitsneden' uit de programma's waardoor die een te groot accent krijgen en te veel versimpeling van ingewikkelde (politieke) zaken optreedt, met name bij de televisie (RMO 2003). Deze klachten zijn niet nieuw. Niettemin is het de vraag of op deze bekritiseerde 'medialogica' moet worden gereageerd met een jaarlijks te organiseren mediapolitiek verantwoordingsdebat, zoals bepleit door de RMO. Anderzijds moet ook niet alle heil worden verwacht van zelfregulering door de professionele beroepsgroep. Journalisten zijn geen professionals in de zin van vrije beroepen met een eigen wettelijke niet-hiërarchische tuchtrechtspraak. Het is verder de vraag of het in die sfeer van tuchtrechtspraak moet worden gezocht, nog afgezien van het feit dat ook die tuchtrechtspraak in de gebieden waar die tot voor kort goed functioneerde onder druk lijkt te staan (vgl. Kleiboer en Huls 2001). De WRR volgt hier een andere 'logica', namelijk een die geheel in de lijn ligt van wat in dit hoofdstuk over de rol van instituties in het algemeen gezegd is: instituties dienen in de eerste plaats hun primaire taken zo goed mogelijk te vervullen. $\mathrm{Zij}$ zijn zelf hiervoor verantwoordelijk en ze zouden onder andere door benadrukking van professionele verantwoordelijkheden deze primaire taak extra gewicht kunnen geven. In het geval van de media betekent dit dat enkele hoofdverantwoordelijkheden van de journalistiek door de mediaorganisaties en de journalisten zelf (weer) voorop moeten worden gesteld.

Norris (200o) heeft enkele van grondregels voor de journalistiek uiteengezet in haar studie A virtuous circle, political communication in postindustrial democracies. Daarnaast gaven twee journalisten (Kovack en Rosenstiel 2003) enkele grondregels van professionele ethiek, zoals de volgende.

1 De eerste verplichting van de journalistiek is het dienen van de waarheid.

2 Haar eerste loyaliteit ligt bij burgers, niet bij organisaties.

3 Het wezen van de journalistiek als discipline is verificatie van feiten en beweringen.

4 De beoefenaren moeten onafhankelijk zijn van degenen over wie ze berichten.

5 Journalistiek moet dienen als een onafhankelijke inspectie van macht.

$6 \mathrm{Zij}$ moet een forum voor openbare kritiek en debat verschaffen.

$7 \mathrm{Zij}$ moet ernaar streven zaken van belang te presenteren als interessant en relevant.

$8 \mathrm{Zij}$ moet het nieuws begrijpelijk maken en in de juiste verhouding plaatsen.

9 De journalisten moeten hun eigen geweten kunnen volgen (zie hiervoor Broertjes 2003). 
Deze regels vormen als het ware de waarden en normen van de journalisten en werken zo door in de media. Met name de vierde regel dat journalisten onafhankelijk moeten zijn van degenen over wie zij berichten, sluit een al te gretige jaarlijkse verantwoording aan publiek en politiek uit. Meer ruimte en aandacht voor deze primaire taken en primaire regels kan de verantwoordelijkheid van de media leggen waar die hoort: bij de media en de mediaorganisaties zelf. Op analoge wijze zouden de media meer ruimte moeten krijgen om hun secundaire en tertiaire taken te vervullen, waar nodig door meer helderheid over wat zij geleerd hebben uit media-incidenten, hoe zij bepaalde gebeurtenissen voor zichzelf geëvalueerd hebben, welke lessen zij eruit getrokken hebben en welke gevolgen de media willen verbinden aan de zelfevaluatie voor hun toekomstig gedrag. Het belang van een pluriforme samenleving, waar zeer vele waardestelsels een spreekbuis via de media moeten kunnen krijgen, weegt zwaar. De democratische rechtsstaat garandeert de vrijheid en onafhankelijkheid van de media (zie hoofdstuk 5). De media zijn derhalve bij uitstek de sociale institutie om zelfstandig deze pluriformiteit en levendige democratische verhoudingen uit te dragen. Ze vormen een onderdeel van de problematiek van waarden en normen, maar ze vormen evenzeer een onderdeel van de oplossing.

\subsection{CONCLUSIES}

1 Veel onbehagen in de samenleving zal worden weggenomen als de instituties hun primaire taken (het realiseren van hun doelen en waarden waarvoor zij zijn opgericht) zo goed mogelijk vervullen.

2 De instituties zijn zelf verantwoordelijk voor een goede vervulling van hun secundaire taken (de instandhouding van de randvoorwaarden voor hun functioneren), door de gedragsvoorbeelden in de instituties en de handhaving van interne regels. Gaat het goed in de instituties, dan gaat het ook goed in de samenleving als geheel en richt het persoonlijke gedrag zich op de positieve voorbeelden en effecten ervan. Versterking van de eigen inbreng van instituties in de samenleving is nodig en kan onder andere worden bevorderd door meer ruimte en aandacht te schenken aan de normatieve en morele aspecten van de werkzaamheden binnen instituties, te beginnen met een goede handhaving van de gedragsregels binnen instituties. Hierbij zou ook meer moeten worden gekeken naar voorbeelden en systemen uit andere landen, waar al langer ervaring bestaat met handhaving van gedragsregels binnen instituties.

3 Instituties zijn evenzeer verantwoordelijk voor hun tertiaire taken (externe effecten voor andere instituties). Dit betekent dat zij zich er rekenschap van moeten geven wat de effecten van hun handelen zijn op andere instituties en op de samenleving als geheel. Al met al gaat het bij de versterking van de primaire, secundaire en tertiaire taken van de instituties om: bringin' the institutional vitality back in.

4 Over de manier waarop de instituties meer kunnen worden aangesproken op hun verantwoordelijkheden voor een goede vervulling van hun primaire, secundaire en tertiaire taken moet meer worden nagedacht. Hierbij moet het 
gehele spectrum van maatschappelijke sturingsmethodes worden betrokken, variërend van lichte instrumenten, zoals codes of conduct, zelfregulering, kwaliteitskringen van instituties en maatschappelijke kenniscentra, tot aan zwaardere instrumenten, zoals directe aansturing en controle door een onafhankelijke inspectie. De zorg voor de kwaliteit van de instituties is een maatschappelijke verantwoordelijkheid. De raad pleit voor meer ruimte voor institutionele variëteit, onder handhaving van minimumvereisten van gelijkwaardigheid en gelijke toegang.

5 Een goede institutie let op de samenhang tussen de drie taken en verzaakt geen van de drie taken. De secundaire en tertiaire taken staan echter niet op zichzelf en dienen er in de eerste plaats toe om de primaire taak goed uit te voeren. Daarnaast hebben zij belangrijke neveneffecten voor de andere instituties en voor de samenleving als geheel.

6 De raad wijst invoering van een apart vak 'waarden en normen' op school af. In plaats hiervan beveelt de raad een herwaardering aan van het vak maatschappijleer, waarin ook de overdracht van rechtsstatelijke waarden en burgerschapsvorming is opgenomen.

7 De raad beveelt aan om in de lerarenopleidingen voor met name het voortgezet onderwijs meer tijd en aandacht te besteden aan gedragsregels en handhaving ervan en aan het thema van omgang met morele vraagstukken in de klas.

8 De raad bepleit een zodanige aanpak van inburgering dat deze ertoe bijdraagt dat de arbeidsparticipatie van nieuwkomers aanzienlijk wordt verhoogd en de bureaucratisering rond de inburgeringscursussen wordt teruggedrongen. Voorts is de raad van mening dat het vak maatschappijoriëntatie meer gericht moet zijn op burgerschapsvorming en kennis van de beginselen van de rechtsstaat.

9 Ten slotte pleit de raad bij de media voor transparante systemen van zelfevaluatie, waarbij ook duidelijk wordt welke gevolgen de media willen verbinden aan de zelfevaluatie voor hun toekomstig gedrag.

Tot slot: er moet ruimte zijn voor de ontwikkeling van de secundaire en vooral tertiaire taken van de instituties. De betekenis van instituties voor waarden en normen ligt vooral op het niveau van hun secundaire en tertiaire taken. Bij de invulling en uitvoering ervan spelen de gedifferentieerde maatschappelijke waardestelsels een belangrijke rol. De gedifferentieerde waardestelsels - modes of moral understanding and moral argument - verbinden de instituties op veel verschillende manieren met elkaar (bijvoorbeeld door hun overeenkomsten in stijl, werkwijze en manieren van conflictbeslechting en omgang met gebruikers). Tegelijk bieden zij de instituties de mogelijkheid om zich actief van elkaar te onderscheiden door de manieren waarop zij bijvoorbeeld tot normatieve afwegingen komen en hun externe betrekkingen onderhouden. Aldus dragen ze ook bij aan de maatschappelijke pluriformiteit, in hoofdstuk 5 reeds aangeduid als een groot rechtsstatelijk goed. 
Zie voor fraude in ruimer perspectief ook hoofdstuk 4.

Wel is er sinds enige jaren het beleid 'Weer Samen Naar School' (WSNs) om de groei van het speciaal onderwijs in te dammen en de moeilijke leerlingen meer te integreren in het reguliere onderwijs, waarvoor de reguliere scholen worden gecompenseerd (het 'rugzakje').

Overigens moet het systeemniveau worden onderscheiden van de dagelijkse uitvoeringspraktijk in de klas en op het schoolplein. Buitenlandse waarnemers en bewonderaars van ons pluriforme onderwijsstelsel wekken soms ten onrechte de indruk dat in het Nederlandse onderwijs vanwege de nadruk op identiteit ook veel aandacht wordt besteed aan waardevorming en burgerschapsvorming. Dat hoeft echter niet het geval te zijn.

Dit moet worden onderscheiden van godsdienstonderwijs, dat wordt gegeven op confessionele scholen uitgaande van één bepaalde overtuiging.

Een tegenargument kan zijn dat zo'n curriculum voor de universiteiten al moeilijk genoeg is, zodat het niet voor de hand ligt om zo'n vak al aan kinderen op de middelbare school te geven. Zie echter ook hoofdstuk 4 .

De gemeente is verantwoordelijk voor de huisvesting van de scholen, de schoolbesturen voor het onderhoud.

De organisatie van het onderwijs is in Nederland vooral een zaak van maatschappelijke actoren. Scholen maken immers deel uit van de civil society, waarin maatschappelijke actoren allerlei publieke functies vervullen (Onderwijsraad 2002). Particuliere aanspraken en overheidsbeleid zijn dus op allerlei wijzen met elkaar en met het onderwijs vervlochten. In onderzoeken naar de vitaliteit van de civil society in het algemeen slaat Nederland geen slecht figuur (Burger en Dekker 2001). Dit komt niet het minst door het aandeel van de onderwijsparticipatie in de Nederlandse civil society; het onderwijs is er welhaast het prototype van. Sarason wees erop dat dit ook de grootste vooruitgang is geweest in het onderwijs in de afgelopen eeuw. In het bekende rapport A nation at risk (Us Department of Education 1983) wordt die relatie tussen democratie en onderwijs expliciet gelegd (onder verwijzing naar de filosoof Dewey). Het onderwijs heeft behalve indirect (via de bijdrage aan de economie) volgens hem ook direct bijgedragen aan de ontwikkeling van de democratie.

Een punt van discussie in het Verenigd Koninkrijk is thans of ook een zich commerciëler gedragende $\mathrm{BBC}$ in de toekomst onder dit regime moet gaan vallen. In een recent boek over de Amerikaanse media wordt het beeld opgeroepen van een journalistiek die zich sterk laat leiden door de 'conservatieve' strevingen van de federale regering van dit moment; een beeld dat nogal afwijkt van dat van de bekende Amerikaanse liberale media in: Alterman, What liberal media? (zie de bespreking van Veldman in Het Financieele Dagblad van 6 September 2003). 


\section{DE ROL VAN DE OVERHEID; CONCLUSIES EN AANBEVELINGEN}

\subsection{INLEIDING}

De overheid is op velerlei wijzen betrokken bij de vorming, overdracht en handhaving van waarden en normen: als wetgever, als ordehandhaver, als financier en 'regelaar' van het onderwijs en van tal van andere instituties, als beheerder van de openbare ruimte en als bewaker van de integriteit van de openbare dienst. Toch zijn de mogelijkheden voor de overheid om direct invloed uit te oefenen op de vorming, overdracht en handhaving van waarden en normen beperkt. Waarden en normen zijn allereerst een product van menselijk samenleven, in welke vorm dan ook. Weliswaar ontwikkelen zij zich niet geheel spontaan buiten de invloed van de overheid om, maar het zou een overschatting van de invloed van de overheid zijn om te menen dat zij de richting van de waarden- en normenontwikkeling en de mate waarin deze worden onderschreven en nageleefd in belangrijke mate zou kunnen bepalen. De rol van burgers en van hun instituties is hierbij immers veel meer bepalend. Toch wordt de overheid er vaak als eerste op aangesproken als er naar de mening van de burgers iets schort aan (de naleving van) de waarden en normen in de samenleving. Het is in zoverre niet onterecht dat de overheid verantwoordelijk is om op te treden als wettelijk vastgelegde normen worden overschreden - handhaving van de rechtsorde is immers de klassieke overheidstaak bij uitstek. Hiernaast draagt zij een belangrijke verantwoordelijkheid om de condities te scheppen waaronder de maatschappelijke instituties de gewenste ontwikkeling, overdracht en handhaving van waarden en normen kunnen bevorderen. Ook al moeten burgers en instituties het uiteindelijk 'zelf doen', dan nog dient de overheid wel zorg te dragen dat zij hiertoe in staat zijn, door onnodige belemmeringen in regelgeving en subsidievoorwaarden weg te nemen en ook door hen de juiste prikkels te geven.

Een belangrijke vraag waarop dit hoofdstuk een antwoord zoekt, is dan ook hoe de overheid kan bevorderen dat de instituties zich tot 'goede' instituties ontwikkelen. Wat kan de rolverdeling zijn tussen de taken van de overheid en die van burgers en instituties in de samenleving? Alvorens het antwoord op deze vraag te geven, is het nodig eerst in meer algemene zin in te gaan op het belang van een publieke moraal, om vervolgens de onderzoeksvragen te beantwoorden die in hoofdstuk 1 van dit rapport zijn geformuleerd.

\subsection{HET BELANG VAN EEN PUBLIEKE MORAAL}

Uit de grote steun voor de essentiële waarden en normen van de democratische rechtsstaat kan geen doemscenario van 'verval' of een algeheel crisisgevoel worden afgeleid. Toch is het onbehagen over het gedrag in de publieke sfeer wijdverbreid en geenszins overdreven of uit de lucht gegrepen. Als Kamerleden met journalisten op de vuist gaan, als hard schreeuwen de enige manier is gewor- 
den om aandacht te krijgen en met elkaar te communiceren, als buurtbewoners elke onbekende vreemdeling wantrouwen, dan is er aanleiding voor de samenleving als geheel - en niet alleen voor de overheid - om zich af te vragen wat er aan de hand is en wat eraan te doen valt. Er lijkt een sfeer te zijn ontstaan waarin normoverschrijdend gedrag in verschillende, in dit rapport beschreven gradaties vaak niet meer volgens vertrouwde methoden wordt gecorrigeerd. In Rotterdam en Gouda zijn stadsetiquettes ontwikkeld en in praktijk gebracht, op veel scholen werkt men al met gedragsregels en met schooletiquettes om te voldoen aan de verwachtingen van velen die graag willen weten wat men van elkaar kan verwachten. Er is een behoefte aan enige zekerheid over de vele onzekere morele en sociale gedragsnormen. Men voelt zich vaak bedreigd en gaat daarom uit angst medeburgers op onvriendelijke wijze bejegenen. Er is een kennelijk verlangen naar meer beschaafd gedrag en naar beleefdheid.

Onbeschaafde tendenties zijn niet alleen te constateren in de directe uiterlijke gedragssfeer, maar betreffen evenzeer de onderlinge solidariteit. In de loop van de wordingsgeschiedenis van de verzorgingsstaat is de sociale solidariteit geëvolueerd van een op de noden van ouderen en sociaal zwakkeren gerichte steun, zoals bij de totstandkoming van de AOw in 1956, tot een systeem waarin het berekenbare eigen voordeel meer op de voorgrond getreden is. Dat ging gepaard met veranderingen in gevoelens en emoties. Er is meer sprake van een ik-gerichte motivatie en morele houding dan van altruïstische emoties. Er is een gebrek ontstaan aan inschikkelijkheid en hoffelijkheid jegens medeburgers (Schnabel 2004). De financiële terugtred van de overheid en de sterk outputgerichte sturing hebben de tendens van berekenend eigenbelang slechts versterkt. Ethische verplichtingen en wederkerigheid, die de basis vormden van collectieve solidariteitssystemen, worden vervangen door eigen verantwoordelijkheid, calculatie en eigenbelang. Voor de groepen die niet aan deze hogere eisen van eigen verantwoordelijkheid en eigen rekening kunnen voldoen, wordt het gevaar van sociale uitsluiting en marginalisering groter. De samenleving als geheel, inclusief vele maatschappelijke instellingen, reageert op de uitgeslotenen en de devianten steeds meer met bestraffing en sociale controle. Armen, mentaal en fysiek gehandicapten en werklozen raken meer en meer geïsoleerd van het heersende sociale systeem. Bauman spreekt hier van mental separation en Rodges van banishing the poor from the world of ethical duty (Rodges 2003: 418). Door een afname in solidariteit neemt ook het sociaal vertrouwen tussen burgers onderling en tussen burgers en vreemdelingen af (Uslaner 2002).

Fysieke onzekerheid, onveiligheid en afnemend sociaal vertrouwen worden onder de grote paraplu gebracht van waarden en normen. Om zinvol met het vraagstuk van waarden en normen om te gaan, dient men er wel de juiste interpretatie aan te geven. In de huidige samenleving zijn de bronnen van waardeoriëntaties zeer uitgebreid en gevarieerd geworden en daardoor ook de mogelijkheden om individuele keuzes te maken (zie ook hoofdstuk 7). Al deze particuliere voorkeuren krijgen iets ongeremds, juist omdat de anderen, de medeburgers ogenschijnlijk geen bijdrage meer leveren aan die keuzes. Bovendien kan het 
uitwerken en uitleven van deze particuliere keuzes ook niet zonder regels, al was het maar om voor de anderen nog enige voorspelbaarheid in het eigen gedrag aan te brengen. Hier raakt men aan de gemakkelijk te vergeten en snel verwaarloosde publieke functie van de vele private voorkeuren die in de hedendaagse samenleving mogelijk zijn geworden. De publieke dimensie van het geïndividualiseerde gedrag raakt zo verloren. De communitaristische denkers hebben terecht gewezen op deze schaduwkanten van de individualisering en van de nadruk op individuele rechten, maar hun diagnose hoeft niet uitsluitend te wijzen in de richting van het terugvinden van gemeenschappelijke waarden in gezinsverband en in andere kleinere, private gemeenschappen. Hun diagnose kan ook leiden tot een publieke remedie, namelijk: eigentijds burgerschap.

In de studie onder leiding van de politiek filosoof Van Gunsteren over burgerschap, die de WRR in 1992 publiceerde, staat de vraag centraal hoe gewone mensen tot burgers worden gemaakt, hoe ze competenties aanleren om in de openbare en publieke ruimte met elkaar om te gaan - precies waar het nu vaak aan lijkt te schorten. De onmiskenbare pluraliteit van mensen komt in het verband van een staat, de res publica of republiek van burgers, het beste tot uiting. Burgerschap is in de opvatting van Van Gunsteren (1992) een ambt van regeerders en van geregeerden gelijkelijk. De publieke zaak, de publieke dimensie van alle particuliere belangen en verlangens, wordt het beste gediend door het in praktijk brengen van dit ambt van burgerschap door zo veel mogelijk spelers. In zekere zin is dit wat nu gebeurt bij het opstellen van stadsetiquettes of schoolregels, die totstandkomen door de actieve participatie van zo veel mogelijk betrokkenen. Al doende worden burgerlijke vaardigheden geleerd. Is er nu naast een stadsetiquette ook behoefte aan een etiquette voor democratie, zoals door Carter (1998) is bepleit in zijn studie naar Civility, manners, morals and the etiquette of democracy? De overheid heeft in de ogen van Van Gunsteren en Carter inderdaad de taak om de competenties van burgers in het omgaan met elkaar en met de veelheid van meningen en meningsverschillen te bevorderen. Uit het oogpunt van de publieke zaak is het van groot belang dat vaardig burgerschap wordt mogelijk gemaakt. Samen regels maken, hetgeen - net als alle andere publieke aangelegenheden - vaak tot compromissen en tot het rekening houden met elkaar leidt. Het gaat er in deze publieke moraal niet om allemaal dezelfde waarden en normen aan te leren, maar juist om blijvend met de verschillen in moraal en morele waarderingen om te gaan. Er komt eerder nadruk te liggen op consensus over regels en gedrag op de werkvloer, in de buurtgenootschap, op school en op de universiteiten, dan dat men het eens wordt over alle achterliggende, abstracte waarden en normen. Doordat men gezamenlijk aan deze praktische 'overlappende' consensus werkt, neemt het onderlinge sociale vertrouwen toe. Gedragscodes, sociale afspraken en werkbare praktijken vormen de dagelijkse producten van dit eigentijdse, vaardige burgerschap. De beoefening van de kleine deugden, zoals die in hoofdstuk 5 zijn genoemd (waarachtigheid, empathie, respect voor andere meningen, verantwoordelijkheidszin), kan een praktijk van burgerschap ondersteunen, omdat immers de kenmerken van vaardig burgerschap soortgelijke eigenschappen behelzen (zich kunnen verplaatsen in 
andermans positie, zichzelf en anderen kunnen vertegenwoordigen, onderscheidingsvermogen, opkomen voor de eigen en respect voor andermans rechten). Uit de voorbeelden blijkt dat de burgerschapspraktijken niet beperkt blijven tot de overheidsdiensten of overheidszaken. Dit burgerschap strekt zich ook uit tot de maatschappelijke instellingen en andere publieke instituties (sportverenigingen, woningbouwcorporaties en dergelijke). Maar ze kunnen ook worden gezien als oefeningen in democratie en rechtsstaat, die immers het overkoepelend kader bieden waarbinnen burgerschap kan worden uitgeoefend.

De taak van de overheid bij het mogelijk maken en bevorderen van degelijke burgerschapspraktijken volgt uit het publieke belang ervan. Het gaat uiteindelijk om het uitdragen van 'civiliteit' en 'integriteit'. Carter heeft, niet toevallig, aan deze twee belangrijke waarden twee achtereenvolgende studies gewijd. Integriteit is een primaire deugd die de eigenwaarde van de ik-persoon betreft, namelijk instaan voor wat je meent en doet en oprecht menen wat je zegt, er geen show van maken of omwille van de indruk die je wilt maken afwijken van de vereiste eerlijkheid of van het opkomen voor een eigen mening. Integriteit is een deugd voor regeerders en geregeerden, voor burgers en bestuurders (Carter 1996). De integriteit van bestuurders is een van de belangrijkste voorwaarden voor het vertrouwen tussen burgers onderling en tussen burgers en openbaar bestuur. Het recente integriteitsbeleid van de overheid onderkent het publieke belang van deze waarden, die echter niet uitsluitend gelden voor bestuurders. Civiliteit, beschaafdheid, is de tweede deugd, die vooral te maken heeft met de relatie van het ik met de medeburgers, precies waaraan het nu zo vaak lijkt te ontbreken. De taak van de overheid ten aanzien van waarden en normen betreft vooral de onderliggende en uiterst gewichtige problematiek van het minder als vanzelfsprekend algemeen onderschreven worden van een publieke moraal, een moraal die opkomt voor de publieke zaak en die de res publica instandhoudt, en die door regeerders en geregeerden als eigentijds burgerschap dagelijks in praktijk wordt gebracht.

\subsection{DE BEANTWOORDING VAN DE ONDERZOEKSVRAGEN}

Zoals in hoofdstuk 1 beschreven was de aanleiding voor het huidige debat over waarden en normen en voor de adviesaanvraag gelegen in de ergernis over het veelvuldig plaatsvinden van normoverschrijdend gedrag, in de onzekerheid over de algemene aanvaarding van bepaalde waarden, in de mogelijkheid tot conflicterende waarden, samenhangend met culturele verschillen en ten slotte in de vraag wat de juiste rol zou kunnen zijn voor de overheid in al deze kwesties. Op basis van de analyse in voorgaande hoofdstukken komt de raad tot de volgende formulering van de antwoorden op de gestelde vragen.

Algemene probleemstelling: Is er in Nederland sprake van een afnemende steun voor essentiële waarden en normen in onze samenleving? Is er sprake van een afnemende naleving van deze waarden en normen? Op welke wijze kan de overheid de steun voor en naleving van deze waarden bevorderen?

In abstracto is de steun voor essentiële waarden groot, in het bijzonder de steun 
voor de democratische rechtsstaat. Indien men let op de resultaten van onderzoeken naar waardeopvattingen van de gehele bevolking, zoals onder andere blijkt uit enquêtes van het Sociaal en Cultureel Planbureau, dan is er geen reden tot ongerustheid over de steun voor essentiële waarden (zie hoofdstuk 3). Let men echter op het gedrag van specifieke groepen in de bevolking, dan is er wel reden tot zorg. Met name zijn bepaalde vormen van normoverschrijdend gedrag de afgelopen twee decennia fors toegenomen, zoals enkele vormen van geweldscriminaliteit: berovingen, bedreigingen, mishandelingen en moord- en doodslag (hoofdstuk 4). Ook een aantal andere vormen van wetsovertreding lijkt een sterke groei te vertonen zoals verkeersovertredingen. Daarnaast lijkt vrij algemeen de overtuiging te heersen dat de omgangsvormen in de openbare ruimten achteruitgaan: hoffelijkheid wordt zeldzamer, onbehoorlijk en onbeschaamd gedrag zijn in opmars (zie hoofdstuk 4). Het is echter niet goed mogelijk vast te stellen of de 'gemiddelde' burger zich tegenwoordig inderdaad minder fatsoenlijk gedraagt dan dertig jaar geleden: vergelijkbaar onderzoek naar deze lichtere vormen van onbehoorlijk gedrag in het verleden is niet voorhanden. Het is niet uit te sluiten dat de gevoeligheid van de bevolking voor afwijkend gedrag is toegenomen.

Bij het optreden van de overheid tegen normoverschrijdend gedrag is het van belang onderscheid te blijven maken tussen de overtredingen van sociale en morele normen en van rechtsnormen. Sommige vormen van sociaal onprettig en onbehoorlijk gedrag dienen geduld te worden; andere, ernstiger vormen van onbehoorlijk en onduldbaar sociaal gedrag dienen bij voorkeur in onderlinge confrontaties bespreekbaar gemaakt te worden (zie hoofdstuk 2 en 4).

De overheid heeft echter niet alleen een primaire taak op het gebied van rechtshandhaving. De waarden van de rechtsstaat ondervinden nu nog een grote steun onder de bevolking, maar bij een grotere pluriformiteit van waarden is de kans op conflicten en botsingen tussen groeperingen met uiteenlopende waarden eveneens groter geworden. De rechtsstaat biedt de garantie voor een nietgewelddadige afhandeling van dergelijke conflicten, ook al is het staatsmonopolie op geweldsuitoefening ondermijnd door technologische ontwikkelingen, onder andere door de beschikbaarheid van goedkope wapensystemen en kleine handwapens. Een cultuur van gewelddadige conflictoplossing heeft zich in toenemende mate ook in Nederland gemanifesteerd, zowel in de internationaal opererende georganiseerde criminaliteit alsook in enkele gevallen van uit andere culturen afkomstige eerwraak. Naast rechtshandhaving behoort het derhalve tot de taak van de overheid om de belangrijkste waarden van de rechtsstaat, met name de geweldloze conflictbeslechting, uitdrukkelijk te ondersteunen en uit te dragen. Praktijken van burgerschap en inburgering zijn de juiste plaatsen waar oude en nieuwe burgers kunnen leren om hun onderlinge en soms hoogoplopende conflicten op een democratische wijze bij te leggen.

Welke gemeenschappelijke waarden en normen zijn essentieel voor het goed functioneren van onze samenleving? 
Pluriformiteit aan waarden en normen is essentieel voor het goed functioneren van onze samenleving, die juist daardoor het karakter van een open samenleving houdt met voldoende dynamiek en vertrouwen in de toekomst. De waarden van een open samenleving, zoals persoonlijke autonomie, rede en redelijkheid, gelijkheid en universaliteit, rechtvaardigheid en geloof in de toekomst, vormen een onderlinge samenhang die niet licht verbroken kan worden (zie hoofdstuk 5). De pluriformiteit van waarden wordt bovendien gegarandeerd door de democratische rechtsstaat. Democratie en rechtsstaat belichamen in hun unieke combinatie zelf essentiële waarden en zorgen tegelijkertijd voor het wettelijke en institutionele kader dat het mogelijk maakt om andere waarden na te streven en dat onvermijdelijke conflicten over waarden op vreedzame wijze kan behandelen. Door het dynamisch karakter van de rechtsstaat kunnen wel aanzienlijke interpretatieverschillen ontstaan tussen bevolkingsgroepen, die niet geheel genegeerd kunnen worden (zie hoofdstuk 5, tweede deel). Het behoort tot de taak van de overheid de waarden van de rechtsstaat na te komen, uit te dragen en te bevorderen dat de verplichtende consensus over deze waarden behouden blijft (zie hoofdstuk 7).

In welke mate worden deze waarden en normen door de bewoners van ons land onderschreven en in welke mate is er sprake van conflicterende waarden, al dan niet samenhangend met cultuurverschillen?

De waarden van pluriformiteit en van de democratische rechtsstaat worden zowel in zeg-gedrag (zie hoofdstuk 3 ) als in daadwerkelijk gedrag (zie hoofdstuk 5) ruimschoots onderschreven. Er is wel sprake van conflicterende waarden die samenhangen met cultuurverschillen, in die zin dat er tegenover elkaar staande opvattingen zijn aan te treffen onder allochtone en autochtone groeperingen. Dit geldt met name op het gebied van de verhouding tussen ouders en kinderen en daarmee samenhangende opvattingen over opvoeding, over de verhoudingen tussen mannen en vrouwen en de gelijke positie van vrouwen en over de tolerantie ten opzichte van afwijkende gedragingen (hetzij van religieuze, hetzij van sociale aard) in eigen kring (zie hoofdstuk 6). In sommige gevallen conflicteren deze opvattingen en gedragingen met de waarden van de rechtsstaat, bijvoorbeeld bij de vrije partnerkeuze of bij het aanbrengen van verminkingen (zie hoofdstuk 5). De overheid zal hierbij op verstandige wijze moeten kiezen tussen de strategieën van confronteren, verbieden en handhaven. Overigens wordt geconstateerd dat ook de verschillen binnen en tussen allochtone groeperingen zeer groot zijn, zodat moet worden gewaakt tegen al te simpele generalisaties ten aanzien van de conflicterende waarden. Met name blijken jongeren onder deze groeperingen zich sneller aan te passen aan de in Nederland dominante gebruiken en gewoonten dan vorige generaties (zie hoofdstuk 6).

Wat is de gewenste en mogelijke rol van de overheid bij het bevorderen van de gemeenschappelijke waarden en normen?

Waarden en normen komen voort uit de samenleving, zodat de overheid nooit alleen de taak heeft om de gemeenschappelijke waarden en normen te bevorderen (hoofdstuk 7). De overheid heeft directe taken waar het gaat om de vervul- 
ling van de eigen primaire taken, zoals rechtshandhaving en andere essentiële overheidstaken. Het is weinig zinvol indien de overheid een algemeen beleid ten aanzien van waarden en normen zou ontwikkelen. Het is echter des te meer gewenst dat de overheid haar verantwoordelijkheid neemt ten aanzien van de reële problemen die in dit rapport worden gesignaleerd. De overheid dient zich te richten op duidelijk omschreven thema's die zich lenen voor beleid. Wel kan de overheid de aandacht en alertheid van maatschappelijke instituties voor het waarden- en normenaspect stimuleren en ze op indirecte wijze steunen bij de eigen bevordering van de erkenning van de morele dimensie van hun taken, onder andere door ze niet te eenzijdig te controleren en door meer ruimte te bieden aan deze instituties of aan professionele dienstverleners die daarin werkzaam zijn (zie hoofdstuk 7 en 8.4 en 8.5). Daarnaast heeft de overheid een uitdrukkelijke taak om de gemeenschappelijke waarden van de democratische rechtsstaat hoog te houden en in het gedrag van publieke gezagsdragers zichtbaar uit te dragen, zoals reeds bij de beantwoording van de algemene probleemstelling werd gesteld. De overheid dient deze zelfde waarden ook bij de burgers te bevorderen, onder andere door de door burgers zelf gecreëerde gunstige condities en contexten voor eigentijds burgerschap en een publieke moraal ruim te ondersteunen, en in ieder geval niet door beperkende eisen en maatregelen tegen te gaan.

Welke waarden zijn van belang voor de toekomstige Nederlandse samenleving? De waarden die van belang zijn voor de toekomstige Nederlandse samenleving zijn die van de open samenleving, zoals in hoofdstuk 5 beschreven en bij de eerste onderzoeksvraag behandeld. De nadruk zal blijven liggen op persoonlijke vrijheid, gelijkheid en gelijkwaardigheid, solidariteit, universaliteit, rede en rechtvaardigheid. Het geloof in de toekomst hangt nauw samen met deze waarden, zodat dit geloof zelf niet mag worden veronachtzaamd. Een open samenleving kan zichzelf op tijd corrigeren en kan ervoor zorgen dat eenzijdige ontwikkelingen worden afgeremd door ruimte te laten voor tegenovergestelde maatschappelijke krachten. Nieuwe inzichten worden door de waarde van de open samenleving opgeroepen en verwelkomd. De maatschappelijke dynamiek die voor de hedendaagse welvaart heeft gezorgd wordt door deze belangrijke gedeelde waarden voortgezet. Door internationalisering en een voortschrijdende individualisering is het zeer aannemelijk dat de Nederlandse samenleving in de komende tien à twintig jaar eenzelfde grote pluriformiteit zal kennen als tegenwoordig. Hoe in deze toekomstige samenleving de waardeoriëntaties zullen zijn van de niet onaanzienlijke aantallen burgers van tweede en derde generaties immigranten is niet volledig te voorspellen, maar veel hiervan hangt af van de wijze waarop deze jonge Nederlanders zich zullen ontwikkelen. Een grote inspanning op het gebied van onderwijs en opvoeding, waarin deze universeel gerichte waarden een vanzelfsprekende plaats innemen, is derhalve op dit moment de belangrijkste voorwaarde voor de toekomst. Taalvaardigheden, sociale vaardigheden en deelname in burgerschapspraktijken voor deze speciale groepen zijn geen luxe voor de open samenleving van de toekomst, maar eenvoudige noodzaak. Hieraan dient de overheid prioriteit te schenken. 
Welke relatie bestaat er tussen gedrag en de waarden en normen die de normovertreders al dan niet onderschrijven?

In het algemeen is de relatie tussen waarden en specifieke gedragingen niet sterk (zie hoofdstuk 2). Normoverschrijdend gedrag komt niet in de allereerste plaats voort uit het niet aanvaarden van bepaalde abstract geformuleerde waarden. Integendeel, vaak beroepen normovertreders zich op dezelfde waarden of op andere waarden, ter rechtvaardiging van hun eigen normovertredend gedrag. Ook wijzen ze vaak, ter rechtvaardiging, op het gedrag van andere burgers die de normen eveneens niet naleven. Dit mechanisme van rechtvaardiging van normoverschrijding heeft negatieve effecten op het normbesef van de gehele bevolking (zie hoofdstuk 4 en bijlage bij hoofdstuk 4). Door hun abstracte karakter dienen waarden meer ter rechtvaardiging van al of niet normconform gedrag dan dat ze gedrag op een directe wijze bepalen. Het probleem dat de adviesaanvraag aan de orde stelt en dat wordt besproken onder de algemene noemer van waarden en normen, schuilt minder in de uiteenlopende opvattingen over waarden en normen dan in het feit dat het gedrag daarmee niet in overeenstemming is (zie hoofdstuk 2). Daarnaast moet worden geconstateerd dat de meeste mensen zich in de meeste omstandigheden aan de geldende regels houden, zonder dat hiervoor permanente controle nodig is. Men zou zich ook kunnen verbazen over het feit dat er in een dichtbevolkt land als Nederland, waarin zoveel mensen elkaar dagelijks in anonieme situaties ontmoeten, relatief zo weinig botsingen (in letterlijke en figuurlijke zin) plaatsvinden. Daarenboven houdt een groot deel van de bevolking zich niet alleen aan de regels, maar doen velen meer ten bate van hun medeburgers dan van hen geëist kan worden. Het lidmaatschap van maatschappelijke organisaties - dat overigens weinig zegt over de geleverde inzet of over de spreiding naar leeftijdscategorieën en culturele achtergronden - groeit en de deelname aan vrijwilligerswerk en informele zorg is niet alleen hoog, maar ook opvallend stabiel (zie hoofdstuk 3). In aansluiting op wat op de vierde onderzoeksvraag werd geantwoord ten aanzien van jonge immigranten, is het ook hier van het grootste belang alle jongeren van de nieuwe generaties ervaring te laten opdoen in vrijwillige maatschappelijke verbanden, in sportorganisaties en met burgerschapspraktijken in verschillende instituties.

Welke rol spelen maatschappelijke instituties, zoals onderwijs, media en inburgering, bij de overdracht en de handhaving van waarden en normen en bij het omgaan met conflicten?

Maatschappelijke instituties zijn werkplaatsen voor het vormen en overdragen van waarden, normen en gedragsvormen. Datgene wat zij doen heeft een sterke externe component: het bepaalt mede de wijze waarop men buiten de institutie met waarden, normen en gedrag omgaat (denk aan scholen, sportverenigingen, het openbaar vervoer en vele andere). Instituties zijn zelf in eerste instantie verantwoordelijk voor de instandhouding van hun eigen waarden en normen en voor het vernieuwen en revitaliseren ervan. De overheid heeft echter de afgelopen tijd onvoldoende oog gehad voor deze betekenis van instituties. Bij regelstelling, bekostiging en toezicht ligt het accent sterk op de meetbaar gemaakte primaire taak van de instituties, zodat veel instellingen zich daarop (moeten) 
concentreren. Het is van belang na te gaan hoe deze eenzijdige nadruk van de overheid op meetbare prestaties kan worden aangevuld met een benadering waarin de tertiaire taak van instituties, die betrekking heeft op de morele dimensie en op de externe betekenis daarvan, voldoende wordt erkend.

\subsection{DE PRAKTISCHE TAKEN VAN DE OVERHEID TEN AANZIEN VAN WAARDEN, NORMEN EN GEDRAG}

Wat is de gewenste en mogelijke rol van de overheid bij het tegengaan van normoverschrijdend gedrag, het bevorderen van normconform gedrag en het ondersteunen van instituties bij de overdracht en handhaving van waarden en normen? Meningsverschillen over waarden zijn in het algemeen geen probleem, maar juist een positief te waarderen aspect van een democratische rechtsstaat. Over de normen die van belang zijn voor een soepele omgang tussen de burgers bestaan doorgaans geen al te grote meningsverschillen. Waar het echter aan schort is de bereidheid van mensen om zich daadwerkelijk aan deze normen houden. De aandacht van de overheid zou zich dan ook primair moeten richten op het voorkomen en bestrijden van normoverschrijdend gedrag in negatieve zin (in het bijzonder wetsovertreding) en het bevorderen en ondersteunen van positief te waarderen gedrag.

\subsubsection{GEDRAG: DE NOODZAAK VAN EEN CONSISTENTE RECHTSHANDHAVING}

Mensen kunnen zich aan velerlei soorten gedrag storen. Het kan gaan om onprettig gedrag dat botst met de eigen preferenties of goede smaak, maar geen inbreuk maakt op belangrijke sociale normen (denk aan onconventionele kleding). Dergelijk gedrag dient men te tolereren en het verdient de voorkeur er zo weinig mogelijk aanstoot aan te nemen. Dulden is hierbij veelal de meest passende houding. Onbehoorlijk gedrag heeft een hinderlijker karakter en staat op gespannen voet met breed gedeelde normen (bijvoorbeeld voordringen in het openbaar vervoer, of in een treincoupé luidkeels een telefoongesprek voeren). Desalniettemin is dit gedrag niet van dien aard dat het reden kan zijn om de ander er met dwang van te weerhouden of ervoor te bestraffen. Wel kan er reden zijn om de overtreder erop aan te spreken en te overtuigen van de ongewenstheid van zijn gedrag. Onduldbaar gedrag is een graad erger. Dit gedrag is weliswaar niet strijdig met wettelijke normen, maar doorgaans wel in strijd met de interne gedragsregels van maatschappelijke instituties (bijvoorbeeld bij lastigvallen en intimideren van medereizigers in het openbaar vervoer), die afhankelijk van de situatie corrigerend moeten optreden. Onwettig gedrag ten slotte is strijdig met wettelijke regels en dient dan ook bestraft te worden (bijvoorbeeld diefstal). Alleen bij het laatste soort normoverschrijdend gedrag is het boven twijfel verheven dat de overheid de taak heeft dit gedrag tegen te gaan. Bij de andere gedragsvormen spreekt dit veel minder voor zich, al is zeker niet uitgesloten dat de overheid hierbij een rol dient te spelen. 
Normoverschrijdend gedrag kan velerlei oorzaken hebben, maar duidt er in het algemeen op dat de combinatie van internalisering van normen, formele controle en informele sociale controle tekortschiet om het voordeel dat iemand aan normoverschrijdend gedrag kan ontlenen afdoende te compenseren. Het meest directe aangrijpingspunt voor de overheid (en voor tal van maatschappelijke instituties) om normoverschrijdend gedrag tegen te gaan, is het verscherpen van de formele controle en het verzwaren van de sancties die op normovertreding staan. De afname van controle en/of sancties in de afgelopen decennia was in veel gevallen een van de oorzaken van de toename van normoverschrijdend gedrag. In hoofdstuk 4 is betoogd dat een toename van normoverschrijdend gedrag op den duur ook de informele sociale controle en norminternalisering aantast, nog los van de autonome tendensen die deze mechanismen verminderen (zoals schaalvergroting, anonimisering en individualisering). De effectiviteit van verscherping van controle en sancties moet daarom niet worden overschat. Niettemin zijn meer formele controle en consequente toepassing van sancties vaak wel noodzakelijke voorwaarden om een neerwaartse spiraal van normoverschrijding en 'normverval' tot staan te kunnen brengen. Dit vereist een aanzienlijke extra inspanning bij het ondersteunen en faciliteren van formeel toezicht en controle. Hiervoor is in veel gevallen een uitbreiding van het aantal toezichthouders en controleurs nodig (politieagenten, conducteurs, bewakers, conciërges, enzovoort), maar ook een betere toerusting, in de vorm van adequate scholing, bevoegdheden en hulpmiddelen (wapentuig, communicatiemiddelen en dergelijke). Hiernaast is ook een duidelijke en consequente toepassing van sancties noodzakelijk. Heenzending zonder bestraffing van (wets)overtreders kan de effectiviteit van formele controle en toezicht ernstig aantasten. Ook een lange tijdsduur tussen het moment van overtreding en bestraffing schaadt de afschrikwekkende werking van sancties.

Intensievere formele controle en bestraffing zullen echter niet in alle gevallen afdoende zijn. Om de effectiviteit van formele controle en sancties te vergroten dienen zij daarom niet alleen gericht te worden op directe beheersing van het gedrag, maar moeten zij ook ondersteunend zijn voor informele sociale controle en internalisering van normen. Anders gezegd, indien men de formele controle vergroot om een bepaalde vorm van normoverschrijdend gedrag tegen te gaan, dient men zich er niet alleen van te vergewissen dat deze voldoende afschrikkend werkt voor potentiële wetsovertreders, maar dient men zich ook af te vragen of deze controle ertoe bijdraagt hen te overtuigen van het belang van de norm en of zij de sociale controle door andere burgers ondersteunt of juist ondergraaft. Ter illustratie: camera's die snelheidsovertredingen registreren kunnen weliswaar, indien de boete hoog genoeg is, voldoende afschrikwekkend zijn om het aantal overtredingen te beperken, maar dragen er waarschijnlijk niet toe bij dat automobilisten de maximumsnelheid als een zinvolle norm ervaren die zij ook naleven als er geen camera's zijn. Dat de bestraffing van de overtreding voor andere weggebruikers niet zichtbaar is, lijkt evenmin bevorderlijk voor de steun van deze norm. Hoewel het aantal verkeersboetes de afgelopen zeven jaar is verdrievoudigd (zie par. 4.10), is het dan ook de vraag of de doorsnee weggebruiker zich, 
ook wanneer hij of zij niet wordt gecontroleerd, hierdoor vaker aan de verkeersregels zal houden.

Hoewel formele normen in beginsel voortvloeien uit wettelijke regels, is de overheid (laat staan de rijksoverheid) lang niet altijd de aangewezen instantie om de naleving van deze normen te bevorderen of af te dwingen. In veel gevallen berust deze taak in de eerste plaats bij maatschappelijke instituties die dichter bij de burger staan: onderwijsinstellingen dienen spijbelen, geweld en criminaliteit op school tegen te gaan, openbaarvervoerbedrijven dienen zwartrijden, overlast en criminaliteit in treinen, bussen en trams en op stations en haltes te bestrijden, bedrijven dienen fraude, diefstal en geweld - zowel door het eigen personeel als door klanten - aan te pakken, sportverenigingen dienen agressie en verbaal en fysiek geweld van zowel spelers als toeschouwers te bestrijden, enzovoort. Vanzelfsprekend betekent dit niet dat deze instituties het recht in eigen hand kunnen nemen. Als het normoverschrijdende gedrag zich daadwerkelijk voordoet, is in veel gevallen de rechterlijke macht de aangewezen instantie om de overtreder te bestraffen. Dit neemt echter niet weg dat de verschillende instituties zelf het meest kunnen bijdragen aan preventie van normoverschrijdend gedrag. De taak van de overheid is vooral om deze instituties zowel aan te moedigen als in staat te stellen hun taken op dit gebied naar behoren te vervullen. In de volgende paragraaf wordt nader ingegaan op de wijze waarop de overheid dit kan bevorderen.

\section{De overschrijding van informele normen}

Heeft de overheid ook een taak als informele normen worden overtreden? Veel van de huidige onvrede lijkt immers te maken te hebben met onfatsoenlijk en onbehoorlijk gedrag, veelal als 'onbeschoft' aangeduid, dat op zichzelf niet strijdig is met formele regels, maar niettemin door velen als uiterst hinderlijk en onaangenaam wordt ervaren. Het is duidelijk dat, indien er geen sprake is van wetsovertreding, de overheid de persoon die een informele norm overschrijdt, niet kan bestraffen. Dit neemt niet weg dat de overheid - of de ambtsdragers die haar vertegenwoordigen - de normovertreder wel kan aanspreken en wijzen op diens ongewenste gedrag. Toch dient men hiermee in het algemeen terughoudend te zijn. Als men geen sanctie kan opleggen, is het risico aanwezig dat de terechtwijzing eenvoudig wordt genegeerd. Een overtreder van een informele norm aanspreken heeft alleen zin indien deze het gezag van de ambtsdrager erkent. Maar het probleem is nu juist dat ambtsdragers de afgelopen decennia sterk aan gezag hebben ingeboet. Ambtsdragers zullen dus eerst, langs de hierboven geschetste weg, hun gezag en autoriteit moeten zien te herstellen alvorens zij een effectieve rol kunnen spelen bij het corrigeren van informele normoverschrijding. Hiervoor is het allereerst nodig dat zij hun taak ten aanzien van het handhaven van formele regels adequaat uitoefenen.

Een ander probleem bij het handhaven van informele normen door formele ambtsdragers is dat het niet altijd duidelijk is welke informele normen in bepaalde omstandigheden gelden. Juist vanwege het informele karakter van de 
norm kan een normovertreder claimen dat de betreffende norm voor hem of haar eenvoudigweg niet geldt. Als de overheid dit excuus niet wenst te accepteren, dient zij de informele norm om te zetten in een formele regel, waarvan zij de naleving wel met de wet in de hand kan afdwingen.

Overdracht en handhaving van informele normen zijn in de eerste plaats taken van uiteenlopende maatschappelijke instituties. Voorzover het gaat om normen die alleen in de betreffende institutie gelden, spreekt dit voor zich. In de meeste gevallen doen zich hier ook geen grote problemen voor. Mensen gedragen zich overwegend zoals in de specifieke omgeving waarin zij zich bevinden van hen wordt verwacht. Doorgaans zijn zij voldoende doordrongen van de geldende normen - het is eerder opvallend hoe snel mensen zich aanpassen aan de cultuur van de organisatie of groep waarvan zij deel uitmaken. Indien mensen zich niet aan die normen houden, zijn de (vaak informele) sancties die (de leden van) de organisatie hen opleggen doorgaans afdoende om hen van verdere normovertreding af te houden. In het uiterste geval kan een onverbeterlijke normovertreder ook buiten de organisatie worden gesloten.

Toch lijken zich steeds vaker situaties voor te doen waarin deze mechanismen niet (meer) adequaat functioneren. Dit kan verschillende oorzaken hebben. Het kan te maken hebben met de toenemende anonimiteit in grootschalige organisaties, waardoor mensen elkaar niet meer aanspreken op hun (normoverschrijdende) gedrag: iemand die je niet persoonlijk kent, roep je minder snel tot de orde, terwijl de ander zich waarschijnlijk minder aan jouw terechtwijzing gelegen laat liggen. Het kan ook te maken hebben met een minder sterke binding (commitment) van mensen met de instituties en organisaties waarvan zij deel uitmaken, omdat men gemakkelijker naar een andere institutie kan uitwijken. Mensen zouden daardoor vaker een 'consumptieve' houding tegenover een institutie aannemen en minder rekening houden met (de opvatting van) andere leden van de organisatie. Denk aan patiënten met licht letsel die op de afdeling spoedeisende hulp eisen dat zij met voorrang worden geholpen. Een toename van informele normoverschrijding kan ook voortkomen uit het feit dat mensen in steeds meer verschillende domeinen functioneren waarin uiteenlopende normen gelden en niet iedereen in staat (of bereid) is zich steeds weer aan de geldende normen aan te passen.

Het is in de eerste plaats de verantwoordelijkheid van de instituties zelf om te zoeken naar oplossingen voor de geschetste problemen. Hierbij dient men er echter oog voor te hebben dat een toename van normoverschrijdend gedrag binnen de ene institutie ook negatieve gevolgen kan hebben voor andere instituties. Wanneer normovertreding in de ene institutie niet wordt gecorrigeerd, kan dit ertoe leiden dat men zich ook in een andere omgeving minder aan de geldende normen gelegen laat liggen. Als de ene institutie blijkbaar niet zo zwaar aan de normen tilt, waarom zou dit elders dan niet ook het geval kunnen zijn? Zo zou gebrek aan orde en discipline op school ook het wangedrag van scholieren in andere omgevingen (op straat, in winkels, in het openbaar vervoer) kunnen 
vergroten. De overheid dient maatschappelijke instituties daarom niet alleen aan te spreken op de mate waarin zij hun 'eigen' waarden en normen overdragen en handhaven, maar ook op de gevolgen hiervan voor het gedrag van de klanten in andere domeinen. De wijze waarop de overheid dit dient te doen is overigens niet zo eenvoudig aan te geven. In paragraaf 8.5 wordt hierop nader ingegaan.

\section{Conflictbemiddeling en vrijwilligerswerk}

Zowel bij formele als bij informele normen zijn controle en sancties niet altijd de aangewezen weg om met normoverschrijding om te gaan. Wanneer normoverschrijding leidt tot conflicten tussen personen - doordat degene die de norm naleeft last ondervindt van de normovertreder - kan het soms verstandiger zijn om deze informeel, via bemiddeling of mediation, te beslechten. In plaats van een van de partijen als schuldige aan te wijzen, is mediation erop gericht om de belangen van beide partijen tegen elkaar af te wegen en tot een oplossing te komen die voor beide aanvaardbaar is. De actieve participatie van beide partijen in een dergelijk proces kan niet alleen de acceptatie van de uitkomst vergroten, maar ook bijdragen aan de internalisering van bepaalde regels die conflicten in de toekomst kunnen helpen voorkomen. Instituties zouden, vaker dan nu het geval is, van dergelijke conflictbemiddeling gebruik kunnen maken als tussenweg tussen het tolereren of gedogen van normoverschrijdend gedrag aan de ene kant en het toepassen van formele sancties aan de andere kant. Voorzover het gaat om conflicten die zich afspelen in de publieke ruimte (bijvoorbeeld conflicten tussen buurtbewoners over het gedrag op straat) heeft de (lokale) overheid een taak om dergelijke bemiddeling te stimuleren.

In hoofdstuk 3 is geconstateerd dat er naast degenen die regelmatig of incidenteel de geldende normen in negatieve zin overschrijden gelukkig ook velen zijn die juist méér doen dan volgens die normen van hen kan worden verwacht. Waar de overheid negatieve normoverschrijding zo veel mogelijk dient tegen te gaan, zou zij deze positieve 'normoverschrijding' juist moeten bevorderen. Het gaat hierbij in het algemeen om activiteiten die mensen vrijwillig ondernemen en die aan meer dan alleen hun eigenbelang ten goede komen, zoals vrijwilligerswerk, buurtactiviteiten, informele zorg, giften aan charitatieve instellingen en milieuvriendelijk gedrag. Ook nu al worden sommige van deze activiteiten door de overheid ondersteund, zoals bij sommige milieuvriendelijke investeringen. Juist voor activiteiten die niet zozeer geld als wel tijd kosten is de ondersteuning door de overheid vaak echter minimaal. In het algemeen verdient het niet de voorkeur om deze activiteiten aantrekkelijker te maken door ze financieel te belonen. Het omzetten van vrijwilligerswerk in betaald werk, zoals weleens wordt bepleit, kan ook nadelige effecten hebben, bijvoorbeeld doordat het de intrinsieke motivatie om deze activiteiten te verrichten, vermindert (vgl. Frey en Jegen 2001). Vrijwilligersactiviteiten dienen veeleer te worden gestimuleerd door het de burgers gemakkelijker te maken de activiteiten te verrichten. Een andere mogelijkheid is dat vrijwilligers worden ondersteund door betaalde beroepskrachten. Zo is het voor het verrichten van mantelzorg vaak essentieel dat er ook voldoende professionele thuiszorg beschikbaar is. Buurtactiviteiten van bewoners 
blijken vaak alleen van de grond te komen of te worden gecontinueerd indien zij worden geholpen door officiële hulpverleners of instanties. Net zoals formele controle van normoverschrijdend gedrag ertoe zou moeten bijdragen om informele sociale controle te versterken, dient formele hulp en dienstverlening zo mogelijk informele, vrijwillige activiteiten te ondersteunen. Fiscale faciliteiten vormen een mogelijkheid hiertoe.

Men mag er echter niet voetstoots van uitgaan dat er altijd voldoende vrijwilligers beschikbaar en bereid zijn om de noodzakelijke hulp te bieden en andere activiteiten te verrichten. Te vaak missen hulpbehoevenden het sociale netwerk om informele hulpverleners te kunnen inschakelen of ontbreekt in een wijk de sociale samenhang om vrijwillige buurtactiviteiten van de grond te krijgen. In die gevallen zal de overheid (of een andere instantie) haar verantwoordelijkheid moeten nemen om de professionele hulp en ondersteuning te bieden die in de betreffende situatie noodzakelijk is.

\subsubsection{NORMEN: ONZEKERHEID BESPREEKBAAR MAKEN}

Een hoge mate van normoverschrijdend gedrag is niet alleen onwenselijk vanwege de (over)last die het vaak voor anderen oplevert, maar ook omdat dit op den duur het geloof in de norm kan ondermijnen. Zo vindt zo'n veertig procent van de bevolking een zekere mate van belastingontduiking weliswaar verkeerd, maar wel begrijpelijk en geeft zo'n zestig procent toe dat men bepaalde diensten 'zwart' zou laten verrichten (zie par. 3.4). Ook bepaalde verkeersregels, zoals de maximumsnelheid en het dragen van veiligheidsgordels, lijken lang niet op ieders steun te kunnen rekenen. Het effectief aanpakken van normoverschrijdend gedrag zou in deze gevallen ook de steun voor de norm zelf ten goede kunnen komen. Het is echter de vraag of strengere controle en hoger en sneller straffen altijd de aangewezen weg zijn. Soms verdient het de voorkeur om regels te vereenvoudigen, waardoor zij beter zijn te handhaven en er minder mogelijkheden voor overtreding zijn (bijvoorbeeld minder aftrekposten in de belasting). Voorzover normen primair een coördinatiefunctie vervullen, zoals bij veel verkeersregels het geval is, kunnen ze soms overbodig worden gemaakt door een beroep te doen op zelfregulering (bijvoorbeeld verkeerslichten vervangen door rotondes, ritsen op de rijbaan). Soms is tijdelijk gedogen van bepaalde, specifiek benoemde normoverschrijdingen de beste oplossing, ook al dient men hierin zeer terughoudend te zijn (vgl. WRR 2002: 261).

Er is echter ook een relatief beperkte groep criminelen (vooral jongeren) die chronisch moeite hebben zich aan rechtsregels te houden. Pogingen om hen te doordringen van het belang van deze normen maken alleen enige kans van slagen als deze onderdeel uitmaken van een voortgezet programma, inclusief strafoplegging, dat erop gericht is hun leven in een andere en betere richting te sturen. Halt-bureaus en de reclassering zijn hiervoor de aangewezen instanties. Op langere termijn dient dit probleem vooral te worden aangepakt met preventief beleid. De bron van deviant gedrag is vaak in de vroege jeugd gelegen, zodat 
de opvoeding en de basisschool hierbij een belangrijke rol (kunnen) spelen. Opvoedingsondersteuning voor ouders van wie een kind probleemgedrag vertoont en alert reageren van scholen bij aanwijzingen voor deviant gedrag, zouden ertoe moeten bijdragen dat deze kinderen toch voldoende normbesef wordt bijgebracht. Vroegtijdig optreden lijkt een belangrijke voorwaarde om latere 'ontsporing' van deze kinderen tegen te gaan. Ontwikkelingspsychologen wijzen er steevast op dat de morele vorming en de internalisering van belangrijke waarden reeds in de vroege kindertijd plaatsvindt. Love and limits zijn cruciaal voor de vorming van waarden (Lee 2002: 126; Coles 1997: 169). Als er te weinig liefdevolle opvoeding wordt gegeven, te weinig goede voorbeelden worden getoond en te weinig grenzen worden gesteld, verschraalt de waardevorming.

Groepen met een andere culturele of religieuze achtergrond dan de 'doorsnee'Nederlander claimen soms dat voor hen andere normen gelden dan de in ons land algemeen aanvaarde normen. Wanneer deze normen strijdig zijn met wettelijke regels is er echter geen aanleiding om deze te tolereren. De Nederlandse wet geldt in gelijke mate voor alle ingezetenen en er is geen enkele reden om hiervan bepaalde groepen uit te zonderen. Specifieke groepsrechten passen niet in een moderne democratische samenleving als Nederland. Dit hoeft overigens niet uit te sluiten dat bepaalde cultuur- of geloofsgebonden gebruiken die strijdig zijn met de Nederlandse wet, maar op zichzelf geen schade aan derden berokkenen, op een gegeven moment kunnen worden 'gelegaliseerd'. Voorbeelden hiervan zijn ritueel slachten en bepaalde begrafenisrituelen (vgl. hoofdstuk 6). Informele normen die uit een geloof of culturele traditie voortvloeien en niet strijdig zijn met wettelijke regels dienen te worden geaccepteerd, ook als ze op gespannen voet staan met de normen die een grote meerderheid van de Nederlandse bevolking onderschrijft. Confrontatie is in dit geval de gewenste reactie, mits deze zich beperkt tot een verbale uitwisseling van argumenten en men geen gebruik maakt van fysieke middelen (geweld) of bedreigingen daarmee.

Bij informele regels spreekt het minder vanzelf dan bij formele regels dat zij op brede steun kunnen rekenen. Dit is niet zo verwonderlijk omdat in verschillende groepen en omstandigheden verschillende normen gelden. Wat de ene groep een minimaal blijk van fatsoen vindt (zoals de ander een hand geven) kan door een andere groep als betekenisloos of zelfs onfatsoenlijk (een orthodox islamitische man ten opzichte van een vrouw) worden beschouwd. Op zichzelf is het niet problematisch dat in verschillende domeinen of instituties verschillende omgangs- en fatsoensnormen gelden. Meestal zijn mensen uitstekend in staat bij het wisselen van omgeving zich aan te passen aan de daar geldende normen (vgl. hoofdstuk 7). Er kunnen zich echter problemen voordoen wanneer mensen met verschillende normen elkaar ontmoeten in de publieke ruimte, waar het niet altijd duidelijk is welke informele normen er gelden. Voorzover de naleving van die verschillende normen niet met elkaar botst (denk aan verschillende kledingvoorschriften) is 'gelatenheid' de aangewezen reactie. Wanneer gedrag conform de normen van de een hinder of overlast bezorgt voor anderen, die 
andere normen aanhangen, kunnen er conflicten ontstaan (bijvoorbeeld kinderen die 's avonds laat op straat spelen en lawaai maken, of jongeren die samenscholen op een plein). In ruimten met een duidelijk aanwijsbare beheerder is deze de aangewezen persoon of instantie om dergelijke conflicten te beslechten, bijvoorbeeld door bepaalde informele normen te formaliseren. Zo heeft de NS huisregels opgesteld waaraan alle reizigers zich dienen te houden. Ontbreekt een dergelijke beheerder, dan ligt een oplossing vaak niet voor het grijpen. Een aantrekkelijke mogelijkheid is dat de personen met verschillende normen die elkaar in de openbare ruimte treffen, zelf afspraken maken over gedeelde normen die voor iedere partij acceptabel zijn (zie de Stadsetiquette in Rotterdam en de Gouden Regels in Gouda). Hiervoor dient echter wel aan de nodige voorwaarden te zijn voldaan. Allereerst dienen er in de betreffende buurt voldoende sociale samenhang en regelmatige interactie tussen de bewoners te zijn. Vervolgens veronderstelt het dat de verschillende partijen de eigen normen niet verabsoluteren en bereid zijn om water bij de wijn te doen. Bovendien werken dergelijke afspraken alleen indien in de betreffende omgeving weinig 'vreemden' komen die geen weet van de betreffende afspraken hebben en er zich ook niet aan gebonden achten. De directe rol van de overheid hierbij is in het algemeen beperkt. De lokale overheid kan wel initiatieven van burgers om tot dergelijke afspraken te komen aanmoedigen en ondersteunen (vgl. Diekstra 2003). Komen deze initiatieven niet van de grond en nemen de botsingen tussen de gedragingen van verschillende groepen onacceptabele vormen aan, dan zal de overheid zelf op een gegeven moment maatregelen moeten nemen om de orde te handhaven en een escalatie van de botsingen tussen de burgers te voorkomen.

\subsubsection{WAARDEN: PLURIFORMITEIT HANDHAVEN}

Pluriformiteit van waarden is een wezenskenmerk van onze democratische rechtsstaat. De enige uitzondering hierop vormen de fundamentele waarden van die rechtsstaat zelf. De overheid dient dus de pluriformiteit van waarden te waarborgen en tegelijkertijd de waarden van de rechtsstaat te beschermen. Het gaat hierbij om zulke waarden als vrijheid van (geloofs)overtuiging, vrijheid van meningsuiting, integriteit van het lichaam, gelijkheid voor de wet, enzovoort. Dit zijn echter geen tegenstrijdige taken: bescherming van de rechtsstaat garandeert immers waardepluriformiteit.

Er kan zich wel een probleem voordoen indien bepaalde waarden strijdig zijn met de rechtsstaat, bijvoorbeeld orthodox religieuze of fundamentalistische opvattingen over de ondergeschiktheid van de (rechts)staat aan het geloof of een kerk. De oplossing van dit probleem is niet gelegen in het verbieden van dergelijke waarden. Waarden schuilen in de hoofden en harten van mensen en laten zich eenvoudigweg niet verbieden. Ook een verbod op het uitdragen van die waarden is geen begaanbare weg, aangezien men daarmee een van de essentiële waarden van de rechtsstaat - vrijheid van meningsuiting - zou beperken om diezelfde rechtsstaat te beschermen. Er wordt echter een grens overschreden als het uitdragen van 'fundamentalistische' waarden gepaard gaat met een aanmoe- 
diging om de rechtsstaat te ondergraven, bijvoorbeeld door geweld uit te lokken. Het is daarom een taak van de overheid - die zij ten dele kan overlaten aan instituties als het onderwijs, inburgering en de media - om de burgers zo veel mogelijk te doordringen van het belang van de waarden die ten grondslag liggen aan de rechtsstaat. De overdracht van deze essentiële waarden dient zich met name te richten op nieuwe ingezetenen, dat wil zeggen op kinderen en immigranten. Hiernaast is het wenselijk het belang van deze waarden ook bij de gevestigde burgers onder de aandacht te blijven brengen.

Hoe dient de overheid om te gaan met botsingen tussen waarden of waardestelsels? In het algemeen is het vrije publieke debat - in het parlement, in kranten, op radio en tv, op internet, in debatcentra, maar ook op het werk, op school en in het gezin - het aangewezen middel voor een vreedzame botsing van waarden en waardestelsels. De overheid dient dit debat zo veel mogelijk te stimuleren, onder meer door de pluriformiteit van de media te waarborgen. Juist door met andersdenkenden in debat te gaan, naar de argumenten van de tegenstander te luisteren, maar deze desgewenst ook ten felste te bestrijden, kan begrip en tolerantie voor andere opvattingen worden gekweekt en worden voorkomen dat mensen naar andere middelen (juridische procedures, bedreiging of geweld) grijpen om 'hun gelijk te halen'.

Er kunnen zich ook botsingen voordoen tussen de fundamentele waarden die ten grondslag liggen aan de rechtsstaat, of beter gezegd tussen claims die partijen ontlenen aan verschillende waarden van de rechtsstaat: de vrijheid van meningsuiting of de vrijheid van godsdienst kan bijvoorbeeld op gespannen voet staan met het antidiscriminatiebeginsel (zie hoofdstuk 5). Hoewel ook in dergelijke gevallen het debat de te verkiezen weg is om het conflict te beslechten, dient in laatste instantie, als het conflict onoplosbaar blijkt, de rechter een uitspraak te doen. Hierbij doet zich het probleem voor dat bij de afweging van grondrechten ook de rechter zich uiteindelijk slechts kan beroepen op de 'redelijkheid' van een bepaalde keuze in dit bijzondere geval (casuspositie). De rechter kan niet oordelen over niet-aangebrachte zaken of over ideologische conflicten in het algemeen. De overheid (eigenlijk: het parlement) kan in haar rol als wetgever door een heldere formulering van wetten zo veel mogelijk proberen te voorkomen dat dergelijke conflictbeslechting afhankelijk is van de interpretatie van de rechter. Maar door de algemeenheid van de wetsteksten biedt ook dit geen definitieve oplossing. Evenmin is het aan te bevelen om een wettelijke hiërarchie in de grondrechten aan te brengen, aangezien een dergelijke rangorde onvoldoende recht zou doen aan de uiteenlopende contexten waarin een beroep op de grondrechten kan worden gedaan. In het ene geval zal men bijvoorbeeld aan het gelijkheidsbeginsel voorrang willen verlenen en in het andere geval aan de vrijheid van godsdienst, zonder dat dit in een algemene regel valt te vatten (zie hoofdstuk 5). Wel kan de grondwetgever of, waar de grondwet daarvoor ruimte laat, de gewone wetgever, desgewenst door precisering/beperking onderlinge verhoudingen verduidelijken tussen grondrechten waarvan de toepassing steeds meer vragen oproept. 
Behalve de waarden die tot uitdrukking komen in de instituties van de rechtsstaat, zijn er ook andere waarden die essentieel zijn voor het goed functioneren van de samenleving. Het gaat dan om waarden als respect en verdraagzaamheid, tolerantie, inschikkelijkheid, gelijkheid en vrijheid, integriteit en mededogen. Deze hebben niet zozeer betrekking op de rechten van individuen die door de staat dienen te worden gewaarborgd als wel op de gewenste omgang tussen individuele burgers onderling. Terwijl discriminatie en geweld bij wet zijn verboden en dus door de overheid dienen te worden bestreden, is het weliswaar wenselijk, maar kan het niet formeel worden voorgeschreven, dat burgers elkaar als gelijkwaardig behandelen, tolerant en verdraagzaam zijn tegenover personen die opvattingen huldigen die zij afwijzen, enzovoort. Als dergelijke waarden onvoldoende worden onderschreven, kan dit op den duur echter ook de steun voor (de waarden van) de rechtsstaat aantasten. Er zijn evenwel weinig mogelijkheden voor de overheid om de overdracht van deze waarden direct ter hand te nemen. Het gaat hier in de eerste plaats om een verantwoordelijkheid van ouders, opvoeders en leerkrachten en van alle andere gezagsdragers in de overige instituties.

Vooral het onderwijs heeft hierin een belangrijke taak. De overdracht van dergelijke waarden mag niet ondergeschikt worden gemaakt aan de overdracht van kennis en vaardigheden. Het onderwijs dient echter vrij te worden gelaten in de wijze waarop het deze taak vervult. Zo is het denkbaar dat men hiervoor ruimte vrijmaakt bij vakken als maatschappijleer, geschiedenis en filosofie. Vooral het vak maatschappijleer verdient het een meer volwaardige positie in het curriculum te krijgen. De waardeoverdracht in het onderwijs zal echter vooral deel moeten uitmaken van het pedagogische proces in de klas zelf, los van concrete vakken. Anders gezegd, waardeoverdracht dient integraal onderdeel te zijn van de overdracht van kennis en vaardigheden.

Dat waarden vrij zijn en waardepluriformiteit dient te worden toegejuicht, betekent nog niet dat aan alle waarden evenveel ruimte moet worden geboden om zich te manifesteren. In de publieke ruimte kan het gewenst zijn beperkingen op te leggen aan waarden die de grote meerderheid van de bevolking als verwerpelijk of onwenselijk beschouwt. Bij publieke ruimte valt in het bijzonder te denken aan de openbare weg en de publieke omroep.

De openbare weg is de afgelopen decennia steeds meer een uitstalling geworden van commerciële boodschappen in de vorm van aanplakbiljetten in abri's, op bussen en trams, op gevels en op speciale borden en zuilen. Los van de vraag hoe men dit verschijnsel in zijn algemeenheid waardeert dient zich de vraag aan of elke vorm van reclameboodschappen moet worden toegelaten. Niet iedereen is ervan gediend om op straat met afbeeldingen van naakte dames of seksueel getint gedrag te worden geconfronteerd. Wanneer zij pontificaal in de openbare ruimte worden tentoongesteld, kan men ze echter moeilijk ontlopen. Daar komt bij dat dergelijke reclame-uitingen vaak een bepaald gedrag of ideaal promoten dat men, vooral voor jongeren, als onwenselijk kan beschouwen. Het verdient 
daarom aanbeveling dat lokale overheden meer bewust omgaan met de vraag of zij alle reclame-uitingen in de publieke ruimte willen toelaten.

Een belangrijk verschil tussen de openbare ruimte enerzijds en televisie en radio anderzijds is dat men met de laatste niet ongewild geconfronteerd hoeft te worden: ieder kan immers zelf bepalen waar hij of zij naar kijkt of luistert. Er is dan ook geen reden om in het algemeen beperkingen op te leggen aan radioen tv-programma's. Dit zou al niet kunnen vanwege de gegarandeerde vrijheid van meningsuiting. Het spreekt minder voor zich dat de omroepen (zowel publieke als commerciële) hierin geen eigen verantwoordelijkheid dragen. De rechtvaardiging voor het feit dat publieke omroeporganisaties grotendeels uit publieke middelen worden gefinancierd, moet zijn gelegen in het feit dat zij een ander programma-aanbod bieden dan commerciële omroepen en zenders.

Terwijl het vanwege de vrijheid van meningsuiting ongewenst is om zenders te beperken in hun vrijheid om programma's uit te zenden met veel seks, geweld, drankgebruik en dergelijke, dienen de publieke omroepen vanuit hun primaire taak hoge eisen aan zichzelf te stellen. De meerwaarde van de publieke omroepen zou immers mede moeten zijn gelegen in het feit dat zij bepaalde waarden uitdragen die bij de commerciële zenders onvoldoende aan bod hoeven te komen. Dit betekent zeker niet dat het publieke programma-aanbod vooraf of achteraf moet worden onderworpen aan een toets op de inhoud. Maar bij het toelaten van een nieuwe omroepvereniging, of het verdelen van de zendtijd over de omroepen, zouden dergelijke aspecten in de afspraken die de overheid met de omroepen maakt wel degelijk een rol mogen spelen. Ook in visitaties van de omroepen en in vormen van zelfregulering zouden het onderhoud en de overdracht van waarden en normen via de media aan de orde gesteld kunnen worden. Zelfregulering en vormen van publieke verantwoording van hun keuze in de bijdrage aan waarden en normen kunnen ook voor commerciële omroeporganisaties worden ontwikkeld, zoals in het Verenigd Koninkrijk is gebeurd.

\subsection{ONDERSTEUNING VAN INSTITUTIES}

In de voorgaande paragraaf is betoogd dat de overdracht en handhaving van waarden en normen in veel gevallen geen taken van de overheid zelf zijn, maar van uiteenlopende maatschappelijke instituties. Het is wel aan de overheid om te waarborgen dat die instituties hun taak naar behoren vervullen, hetzij door hen bepaalde verplichtingen op te leggen en deze te controleren, hetzij door de instituties de ruimte te geven en te faciliteren bij het uitoefenen van hun taak. Hierbij doet zich in het algemeen het probleem voor dat de overheid enerzijds uitgesproken wensen heeft met betrekking tot het functioneren van die instituties, maar anderzijds slechts beperkte mogelijkheden heeft om dat functioneren direct te sturen en te beïnvloeden. Bij het vormgeven van haar beleid ten aanzien van die instituties staat de overheid hierdoor voor een aantal lastige afwegingen. Het gaat hierbij om instituties aan wie de overheid bepaalde taken heeft gedelegeerd en die geheel of grotendeels door de overheid worden gefinancierd, maar ook om instituties die op particuliere basis belangrijke openbare functies vervullen, zoals 
het openbaar vervoer, de gezondheidszorg en delen van het onderwijs. De overheid dient hierbij onder meer een afweging te maken tussen:

- uitvoeringsvrijheid bieden en prikkels geven;

- beleidsruimte bieden en de (rechts)gelijkheid waarborgen;

- meer middelen ter beschikking stellen en de kwaliteit en uitrusting van de professionals verbeteren;

- meer discretionaire bevoegdheden geven aan professionals en striktere regels formuleren voor professionals;

- een strikte scheiding van verantwoordelijkheden tussen de overheid en private actoren en een gedeelde verantwoordelijkheid.

\section{Uitvoeringsvrijheid of prikkels?}

Er bestaat nauwelijks verschil van mening dat het, om instituties in staat te stellen adequaat in te spelen op maatschappelijke ontwikkelingen en uiteenlopende omstandigheden, gewenst is ze meer vrijheid te bieden om zelf te bepalen hoe zij hun taak willen uitvoeren. Tegelijkertijd wil de overheid zich er natuurlijk wel van vergewissen dat de instituties hun taak naar behoren vervullen. Meer vrijheid mag niet worden geïnterpreteerd als vrijblijvendheid. Dit betekent dat de overheid er veelal naar streeft om instituties zodanige prikkels te geven dat zij zich inderdaad op de door de overheid gewenste doeleinden richten. Op zichzelf hoeven meer ruimte bieden en prikkels geven niet strijdig met elkaar te zijn: de prikkels hebben immers betrekking op de doelen ('afrekenen op resultaat') en de ruimte op de middelen om deze doelen te bereiken. Financiële prikkels worden echter bijna altijd gekoppeld aan meetbare en kwantificeerbare indicatoren, terwijl doelstellingen juist vaak (mede) een kwalitatief karakter hebben, dat zich lastig laat meten of registreren. Prikkels op basis van objectieve indicatoren kunnen er daardoor toe leiden dat instituties zich vooral op kwantitatieve doelen richten, met verwaarlozing van de kwalitatieve aspecten ervan. Om dit te voorkomen is het wenselijk om bij het 'afrekenen op resultaat' niet alleen gebruik te maken van kwantitatieve indicatoren, maar ook van kwalitatieve maatstaven. Deze kunnen bijvoorbeeld worden vastgesteld door een inspecterende instantie (zoals de onderwijsinspectie) of een visitatiecommissie. Ook de direct betrokkenen (klanten bijvoorbeeld) zouden hierbij een rol kunnen spelen. Zo zou men instanties kunnen verplichten om jaarlijks aan de direct betrokkenen publiekelijk verantwoording af te leggen over hun prestaties.

Hiernaast valt te overwegen om de criteria waaraan een institutie moet voldoen niet van bovenaf op te leggen, maar in samenspraak met de betreffende institutie zelf te formuleren. Dit zou zelfs kunnen gelden voor individuele instellingen of organisaties. Zo is het denkbaar dat een school - naast uiteraard haar wettelijke taken - in overleg met de ouders van leerlingen eigen prioriteiten stelt en daarop wordt afgerekend. Jaarlijks dient de school dan aan de ouders verantwoording af te leggen over de inspanningen die zij heeft verricht om deze prioriteiten te realiseren. De school wordt daardoor gedwongen om zelf aan te geven op welke wijze een externe partij kan vaststellen of zij aan haar doeleinden heeft voldaan. 


\section{Meer beleidsruimte of rechtsgelijkheid?}

Meer beleidsruimte bieden aan instituties betekent automatisch dat er grotere verschillen (kunnen) ontstaan tussen organisaties. Dit kan ertoe leiden dat personen in vergelijkbare omstandigheden door verschillende organisaties verschillend worden behandeld. Dit wordt al snel geïnterpreteerd als rechtsongelijkheid. Politici zijn vaak erg gevoelig voor dit bezwaar. Daardoor hebben besluiten tot decentralisatie en delegering vaak iets halfslachtigs: lokale overheden en instituties mogen zelf over hun beleid beslissen, mits zij maar doen wat 'Den Haag' wil. Het ware beter te erkennen dat twee situaties nooit volledig identiek zijn en dat rechtsgelijkheid in die zin een fictie is. Vaak is niet ondubbelzinnig vast te stellen wat in een bepaalde situatie de 'juiste' reactie is van een instelling en is er dan ook geen reden om verschillen in behandeling als een onaanvaardbare vorm van rechtsongelijkheid aan te merken. Belangrijker dan de aandacht te richten op gelijkheid in termen van uitkomsten, is het om te waarborgen dat de procedures waarlangs een bepaalde behandeling tot stand is gekomen door de desbetreffende klant of cliënt als rechtvaardig worden ervaren. Dat wil zeggen, het gaat meer om procedurele rechtvaardigheid dan om distributieve (verdelende) rechtvaardigheid (vgl. Malsch 2004). Dit houdt bijvoorbeeld in dat instellingen hun klanten inzicht bieden in de wijze waarop een besluit totstandkomt, dat zij de klant daarbij zo mogelijk inspraak bieden en dat zij heldere beroepsprocedures hebben voor het geval de klant meent onheus bejegend te zijn.

\section{Vrij te besteden middelen of beter personeel?}

Als instituties hun taken beter moeten vervullen, leidt dit gemakkelijk tot een roep om meer vrij te besteden middelen. Dit sluit bovendien aan bij het streven naar meer uitvoeringsvrijheid. Toch kan het soms beter zijn om extra middelen niet vrij ter beschikking te stellen, maar te investeren in de kwaliteit en uitrusting van professionals. Als er bijvoorbeeld een tekort is aan gekwalificeerde leerkrachten, wordt dit probleem niet opgelost door scholen meer geld te geven. Zij kunnen dan hooguit met elkaar concurreren om de beste leerkrachten aan te trekken, maar de schaarste wordt daardoor niet minder. Het is dan beter om de middelen te besteden aan de opleiding van goede nieuwe leerkrachten. Op korte termijn zullen er dan echter minder middelen beschikbaar zijn voor de instellingen zelf en bovendien wordt hun vrijheid ingeperkt om zelf te bepalen of zij in personeel dan wel in andere zaken (zoals huisvesting of leermiddelen) willen investeren.

\section{Discretionaire bevoegdheden of strikte regels?}

Organisaties staan voor een vergelijkbare afweging ten aanzien van hun personeel als de overheid ten aanzien van instituties: moeten professionals meer ruimte krijgen om naar eigen inzicht zo goed mogelijk hun taak uit te oefenen of moeten zij voldoen aan heldere regels, normen en protocollen die hun ruimte aanzienlijk inperken? Een sterke inperking van de discretionaire ruimte voor professionals doet hun status waarschijnlijk geen goed en kan hun motivatie en gevoel van eigen verantwoordelijkheid voor het werk ondergraven. Dit wordt nog versterkt indien die regels gepaard gaan met een aanzienlijke bureaucratische 
rompslomp om aan te tonen dat daadwerkelijk conform die regels wordt gehandeld. Te veel ruimte bieden aan professionals roept echter het gevaar op dat zij hun taak niet naar behoren uitoefenen. Bovendien kan het leiden tot ongelijkheid in behandeling tussen de klanten van dezelfde instantie, wat problematischer lijkt dan verschillen in behandeling tussen instanties van dezelfde soort (bijvoorbeeld leerlingen van dezelfde school dienen gelijk te worden behandeld, maar niet leerlingen van verschillende scholen). Een tussenoplossing kan worden gevonden in beroepsnormen van en controle door de beroepsgroep zelf in plaats van de organisatie waarbij men in dienst is. Dit vereist wel dat de beroepsgroep in kwestie zich voldoende bewust is van en gelegen laat liggen aan de maatschappelijke taak van de beroepsbeoefenaren en zich niet louter als een belangenvereniging opstelt. Bij veel beroepsgroepen is hiervan overigens al sprake (bijvoorbeeld medische beroepen), maar bij andere beroepsgroepen zou dit meer kunnen worden gestimuleerd. Net als andere instituties zouden ook de beroepsgroepen openlijk verantwoording moeten afleggen over het gevoerde beleid.

\section{Gescheiden verantwoordelijkheden of gedeelde verantwoordelijkheden?} Het gezamenlijk dragen van verantwoordelijkheden is kenmerkend voor het Nederlandse poldermodel. Dit model heeft in het verleden zijn grote waarde bewezen, maar is ook periodiek aan scherpe kritiek onderhevig geweest. Het grootste bezwaar tegen het delen van verantwoordelijkheden is dat op het moment dat er iets mis gaat, de verleiding groot is de verantwoordelijkheid af te schuiven naar een ander, waardoor het vaak niet duidelijk is wie daarop kan worden aangesproken (het probleem van de 'vele handen', zie bijvoorbeeld de conclusie van de commissie-Oosting over de vuurwerkramp in Enschede). Een strikte scheiding van verantwoordelijkheden heeft als bezwaar dat deze kan leiden tot verkokering en 'afschuifgedrag'. Een instantie die formeel geen verantwoordelijkheid draagt voor een bepaalde zaak, maar feitelijk wel van belang is voor het realiseren van een bepaalde doelstelling kan zich dan te gemakkelijk geheel aan die verantwoordelijkheid onttrekken. Een tussenweg zou kunnen zijn om in die gevallen waarin er sprake is van gezamenlijke verantwoordelijkheden altijd een persoon of instantie aan te wijzen die de eindverantwoordelijkheid draagt en dus kan worden aangesproken op de resultaten. Deze eindverantwoordelijke heeft dan mede tot taak om te waarborgen dat de andere partijen die medeverantwoordelijk zijn hun verantwoordelijkheid niet ontlopen. Er moeten dan natuurlijk wel voorwaarden worden gecreëerd om te verzekeren dat men deze eindverantwoordelijkheid ook kan waarmaken, bijvoorbeeld doordat men de medeverantwoordelijken verplicht om medewerking te verlenen indien de eindverantwoordelijke dit vraagt.

\section{Afleggen van verantwoording}

Het zou te ver voeren om op basis van bovenstaande afwegingen voor alle instituties die in hoofdstuk 7 zijn genoemd concrete aanbevelingen te doen voor het te voeren overheidsbeleid. In algemene zin kan hierover echter wel iets worden gezegd. Het uitgangspunt voor het aansturen van instituties door de 
overheid zou moeten zijn dat zij worden aangesproken op hun eigen verantwoordelijkheid ten aanzien van de overdracht en handhaving van waarden en normen. Afhankelijk van het soort institutie dient de overheid meer of minder gedetailleerd de taken van de institutie te formuleren. De overheid dient in het algemeen niet voor te schrijven hoe de instituties hun taak moeten uit-voeren. Het spreekt voor zich dat de overheid voor een institutie als de politie, die belast is met de uitvoering van bepaalde wettelijke taken, een veel scherpere en gedetailleerder taakomschrijving opstelt dan voor het bedrijfsleven, dat een private taak uitoefent. Niettemin vervult ook deze laatste institutie bepaalde maatschappelijke taken, waarop de overheid haar kan aanspreken, zoals bescherming van de gezondheid van werknemers en klanten en het ontzien van het milieu.

Vervolgens is het de vraag hoe de overheid die taken dient te formuleren. Sinds een aantal jaren is het streven er veelal op gericht om organisaties 'af te rekenen op resultaat' en daarvoor scherpe kwantitatieve doelstellingen op te stellen waaraan een organisatie dient te voldoen. Zonder hierover in algemene zin een positief of negatief oordeel te vellen, moet worden geconstateerd dat dergelijke kwantitatieve criteria zich vaak minder goed lenen om de prestaties van instituties ten aanzien van de overdracht en handhaving van waarden en normen vast te stellen. Het gaat hierbij immers veelal om kwalitatieve aspecten van het functioneren van organisaties die zich niet in enkele kengetallen laten vangen. Dit betekent niet dat in het geheel geen gebruik kan worden gemaakt van kwantitatieve indicatoren. Zo is het heel wel mogelijk de prestaties van scholen mede te beoordelen op basis van het percentage spijbelaars of voortijdige schoolverlaters en kan het openbaar vervoer mede worden 'afgerekend' op het percentage zwartrijders of het aantal incidenten dat zich voordoet. Voorkomen moet echter worden dat organisaties zich louter gaan richten op het behalen van dergelijke kwantitatieve resultaten en daardoor minder aandacht besteden aan de lastig meetbare kwalitatieve prestaties. Het alternatief is evenwel niet dat organisaties geen verantwoording hoeven af te leggen over hun prestaties. Wel kan het tot op zekere hoogte aan de instituties zelf worden overgelaten op welke wijze zij hierover verantwoording afleggen. Dit dient echter geen vrijblijvende mogelijkheid te zijn, maar een verplichting die onderdeel uitmaakt van hun taakstelling. Zij dienen, met andere woorden, zelf aan te geven op welke wijze zij aannemelijk willen maken dat zij hebben voldaan aan hun taken ten aanzien van de overdracht en/of handhaving van waarden en normen. In sommige gevallen geldt een dergelijke verplichting overigens al. Bij deze verantwoording kunnen zij zowel gebruikmaken van objectieve, kwantitatieve maatstaven als van meer intersubjectieve en kwalitatieve indicatoren. Hierbij valt te denken aan een beoordeling van de prestaties door onafhankelijke externe deskundigen (bijvoorbeeld een visitatiecommissie of een inspectiedienst), door collega-instellingen (intervisie) of door de klanten van de betreffende organisatie. 


\subsection{DE OPBRENGST VAN INVESTERINGEN IN WAARDEN, NORMEN EN GEDRAG}

Investeren in het onderhoud van instituties is geen goedkope oplossing om de gewenste overdracht en handhaving van waarden en normen te realiseren. Hoewel meer geld zeker niet dé oplossing is van de problemen die in dit rapport in kaart zijn gebracht, is het veelal wel een noodzakelijke voorwaarde om de gewenste verbeteringen tot stand te brengen. Dit roept, zeker in een tijd waarin de overheid zich grote inspanningen moet getroosten om de onvermijdelijk geachte bezuinigingen te realiseren, de vraag op of dit een verstandige manier is om de schaarse beschikbare middelen aan te wenden. Op deze vraag valt geen objectief, wetenschappelijk antwoord te geven. Uiteindelijk gaat het hier om een politieke afweging. Het is wel mogelijk in algemene zin iets te zeggen over de mogelijke opbrengsten van een beleid dat, langs de lijnen die in de voorgaande paragrafen zijn geschetst, erop is gericht om overdracht en handhaving van waarden en normen te ondersteunen.

Hoewel de term 'investeringen' nog weleens wordt misbruikt om een uitgave te rechtvaardigen die in wezen een consumptief karakter heeft, kunnen extra uitgaven die bijdragen aan de steun voor essentiële waarden en de naleving van belangrijke normen wel degelijk als een investering worden aangemerkt. Hiervoor zijn twee, onderling samenhangende redenen. In de eerste plaats gaat het vaak om uitgaven waarvan de opbrengsten pas op langere termijn zichtbaar worden. De kost gaat hier daadwerkelijk (ruim) voor de baat uit. Investeren in betere scholen en leerkrachten betaalt zich terug in minder spijbelen en uitval, minder geweld en een sterker normbesef. Het kost echter tijd om zichtbare resultaten te boeken. In de tweede plaats kunnen extra uitgaven een lange doorwerking hebben. In hoofdstuk 4 is geschetst hoe een vermindering van handhavingsinspanningen (bijvoorbeeld formele controle) in eerste instantie weinig effect heeft op de mate van normoverschrijdend gedrag. Op een gegeven moment kan echter een omslagpunt worden gepasseerd, waarna zich een sneeuwbaleffect voordoet waarvan de gevolgen niet eenvoudig ongedaan zijn te maken. Er is dan een grote en langdurig volgehouden inspanning nodig om op termijn het oude niveau van normhandhaving weer te bereiken. Als dit op den duur de internalisering van normen en de informele sociale controle weer versterkt, schept dit ruimte om de formele controle weer enigszins te beperken. Met andere woorden, een grote inspanning die men nu levert kan op langere termijn ruimte bieden om de inspanning (en dus ook de uitgaven) weer te verminderen.

De financiële baten van het in dit hoofdstuk bepleite beleid zijn van tweeërlei aard. Allereerst zijn er de baten van het terugdringen van normoverschrijdend gedrag. Vanwege de zeer diverse vormen van normoverschrijding waarom het hier gaat, kan hiervan geen betrouwbare schatting worden gegeven. Alleen kan een grove indicatie worden gegeven van de directe materiële baten die zouden kunnen worden gerealiseerd indien men erin zou slagen een specifieke vorm van normoverschrijding, namelijk criminaliteit, vergaand terug te dringen. Het 
WODC schatte in 2000 de materiële kosten van criminaliteit voor het bedrijfsleven, particulieren en de overheid gezamenlijk op 3,3 miljard euro, dat is circa één procent van het bruto binnenlands product. De kosten van opsporing, vervolging en berechting van verdachten en tenuitvoerlegging van straffen beliepen 4,3 miljard euro, ofwel zo'n 1,2 procent van het BBP (Schreuders et al. 2000: 174). Hierbovenop komen nog de immateriële kosten, zoals het letsel van slachtoffers van lichamelijk geweld, onveiligheidsgevoelens en dergelijke, die echter onmogelijk in geld zijn uit te drukken. De kosten van andere vormen van normoverschrijding zijn mogelijk nog groter. Te denken valt aan de kosten van verkeersongevallen ten gevolge van roekeloos rijden, het verlies aan human capital ten gevolge van voortijdige schooluitval, productieverlies door ziekteverzuim en arbeidsongeschiktheid ten gevolge van verstoorde relaties op de werkvloer, enzovoort. Het is een illusie dat deze maatschappelijke kosten van normoverschrijdend gedrag ooit tot nul kunnen worden gereduceerd. Niettemin staat het buiten kijf dat beleid dat een aanzienlijke reductie van normoverschrijding zou kunnen bewerkstelligen, op termijn omvangrijke kostenbesparingen zou opleveren.

Waarschijnlijk nog veel omvangrijker dan de baten van een vermindering van normoverschrijdend gedrag, zijn de mogelijke opbrengsten van een versterking van het waarden- en normenbesef in de samenleving. Steeds meer onderkennen sociologen en economen dat het vertrouwen tussen de burgers onderling en tussen de burgers en maatschappelijke instituties een essentiële voorwaarde is voor een florerende samenleving en economie (vgl. Hazeu 2003). Recent sociologisch en economisch onderzoek levert sterke aanwijzingen op dat vertrouwen en sociaal kapitaal belangrijke bronnen zijn van welvaart(sgroei) (Zak en Knack 2001). Essentieel hierbij is dat burgers de verwachting hebben dat hun medeburgers en maatschappelijke instituties zich voorspelbaar en coöperatief gedragen. Dit sociale vertrouwen is in belangrijke mate gebaseerd op wederkerigheid en draagt ertoe bij dat mensen wederzijds voordelige relaties met elkaar durven en willen aangaan, ook als men elkaar (nog) niet persoonlijk kent. Een gebrek aan vertrouwen tussen burgers kan verhinderen dat vele op zichzelf rendabele transacties totstandkomen, waardoor een enorm welvaartspotentieel onbenut blijft. Het functioneren van formele en informele instituties wordt gezien als een van de belangrijkste factoren die verklaren waarom sommige landen welvarend zijn en andere achterblijven (vgl. North 1990; WRR 2003). Gedeelde waarden en normen fungeren in zekere zin als de smeerolie van de samenleving. De winst die men op korte termijn wellicht kan behalen door hierop te bezuinigen zal men op langere termijn dubbel en dwars moeten terugbetalen, doordat de wrijvingen tussen burgers onderling toenemen en de motor van de economie begint te haperen. 


\subsection{SAMENVATTENDE CONCLUSIES EN AANBEVELINGEN AAN DE REGERING}

\subsubsection{ALGEMENE CONCLUSIES IN HOOFDLIJNEN}

Dit rapport begon in hoofdstuk 1 met de constatering dat van de vele en uiteenlopende maatschappelijke kwesties die onder de noemer van waarden en normen werden gebracht, twee kwesties de meeste aandacht vroegen, namelijk de vele vormen van normoverschrijdend gedrag en de vraag naar gemeenschappelijke waarden in onze samenleving. Beide zijn in dit rapport uitvoerig aan de orde gekomen. Voor beide kwesties geldt dat burgers onderling en instituties zelf veel kunnen doen aan het herstel van onderling vertrouwen en aan het instandhouden van voor de samenleving essentiële waarden. Maar ook de overheid heeft in beide kwesties een belangrijke rol te spelen. De conclusies van dit rapport over de rol van de overheid ten aanzien van waarden en normen kunnen in twee hoofdlijnen worden samengevat.

\section{Het bewaken van de gemeenschappelijke waarden en het ondersteunen van een} publieke moraal

Er is een duidelijke en ruime steun te constateren voor de essentiële waarden van de democratische rechtsstaat (zie hoofdstuk 3 en 5). Deze waarden zijn als het ware de gemeenschappelijke kern van een moderne open samenleving, die gekenmerkt wordt door een grote mate van geïndividualiseerde keuzevrijheid van burgers en door een groter geworden pluriformiteit in waardeoriëntaties. De rechtsstaat en de democratie bieden een garantie voor deze pluriformiteit en persoonlijke vrijheid. Ze zijn bovendien dynamisch, in de zin dat er nieuwe interpretaties van oude en gevestigde waarden mogelijk blijven. Tegelijkertijd leggen democratie en rechtsstaat verplichtingen op. Men kan hier beter spreken van een verplichtende consensus, namelijk om de waarden van democratie en rechtsstaat en het open karakter ervan in stand te houden. Het is een primaire taak van de overheid om deze verplichtende consensus te bewaken en ervoor te zorgen dat ook in de toekomst de samenleving dit open karakter zal blijven behouden. Concreet betekent dit dat de overheid de waarden van pluriformiteit en de doorwerking ervan in de democratische rechtsstaat zichtbaar zal dienen uit te dragen. Bescherming van mensenrechten als basiswaarde van elke samenleving krijgt zo een prominente plaats.

Door maatschappelijke ontwikkelingen die met de ruime persoonlijke vrijheden en de vele mogelijkheden tot eigen keuzen te maken hebben, is de praktische ondersteuning voor de publieke zaak verschraald (zie hoofdstuk 7 en het begin van hoofdstuk 8). Het onderlinge vertrouwen van burgers dat anderen zich aan de regels zullen houden is afgenomen, en daarmee de bereidheid om zelf de waarden en normen van het politieke systeem te respecteren. De overheid dient in verband hiermee het bevorderen en ondersteunen van een publieke moraal eveneens tot haar primaire taak te rekenen. Hoewel de overheid zich, naar de mening van de raad, bij de bevordering van religieuze en morele overtuigingen 
terughoudend dient op te stellen ten aanzien van de vele uiteenlopende inhoudelijke overtuigingen, ligt dat bij de publieke moraal anders. De publieke moraal gaat vooral over de manieren waarop burgers onderling, juist met hun uiteenlopende meningen, overtuigingen, standpunten en belangen, toch op vreedzame en fatsoenlijke wijze met elkaar willen en kunnen omgaan en hun onderlinge conflicten en geschillen leren beslechten. De publieke moraal krijgt vooral vorm in praktijken van burgerschap. De overheid dient allerhande vormen van deze burgerschapspraktijken te stimuleren (zie hoofdstuk 5).

\section{Het ondersteunen en versterken van de tertiaire taken van instituties}

De tweede hoofdlijn van het rapport betreft het gedrag in relatie tot waarden en normen. De relatie tussen waarden, normen en gedrag is ingewikkeld. Veel waarden en normen worden onderschreven, maar komen in het uiterlijke gedrag van een toenemend aantal burgers niet dienovereenkomstig tot uiting (zie hoofdstuk 3 en 4 ). Normoverschrijdende gedragingen en andere vormen van ergerniswekkend gedrag vinden hun oorsprong in de samenleving zelf en in de manier waarop instituties functioneren. Instituties dragen derhalve zelf verantwoordelijkheid voor het creëren, onderhouden en overdragen van hun eigen waarden en normen. Dit wordt zichtbaar in de primaire en secundaire taken van instituties (zie hoofdstuk 7). De tertiaire taken van instituties, die bestaan in het bijbrengen van gedragingen die ook voor andere instituties van groot belang blijken te zijn (bijvoorbeeld respect voor anderen, behoorlijk gedrag, eerlijkheid) zijn echter, net als de publieke moraal, verwaarloosd en verschraald, zoals de analyse van hoofdstuk 7 aangeeft. Ook de overheid heeft bijgedragen aan deze verschraling, onder andere door te weinig ruimte te bieden aan de morele dimensie van instituties (zie hoofdstuk 4 en 7 ). In dit kader dient de overheid meer ruimte te laten aan instituties om allereerst hun primaire en secundaire taken goed te verrichten en daarmee hun tertiaire taak te kunnen uitvoeren.

Op basis van deze twee algemene conclusies worden in de volgende paragraaf concrete aanbevelingen gedaan.

\subsubsection{CONCRETE AANBEVELINGEN}

De maatschappelijke problemen die onder de noemer van 'waarden en normen' onder de aandacht worden gebracht, zijn zeer divers van aard. Maatschappelijke problemen als het onfatsoenlijke gedrag van medeburgers, de uithuwelijking van Marokkaanse meisjes, incidentele botsingen tussen de vrijheid van meningsuiting en het verbod op discriminatie, toename van onbeschoft gedrag in het verkeer en uitkeringsfraude, hebben weinig met elkaar te maken. Het is daarom niet verstandig deze problemen steeds onder de algemene paraplu van de 'waardenen normenproblematiek' samen te brengen, als dat een uniforme aanpak van sterk uiteenlopende verschijnselen zou impliceren. Het is naar het oordeel van de raad disfunctioneel om een dergelijk uniform en generiek waarden- en normenbeleid te voeren. Er is wel, vooral in de sfeer van norm-overschrijdend gedrag, sprake van reële problemen die serieuze aandacht van de overheid en 
maatschappelijke instituties verdienen. Dit kan echter het beste geschieden door ieder probleem op zijn eigen merites te beoordelen en voor ieder probleem een gepaste aanpak te kiezen. De volgende aanbevelingen hebben betrekking op een aantal van deze concrete problemen en probleem-gebieden.

\section{De noodzaak van gedragsregulering en de variaties daarin}

Bij het tegengaan van normoverschrijdend gedrag dient te worden onderscheiden tussen de overtredingen van lichtere en zwaardere aard en tussen sociale, morele en juridische normen (zie hoofdstuk 2). Het gehele scala van normen loopt van onprettige gedragingen, via onbehoorlijke en overlast gevende gedragingen naar onduldbare en onwettige gedragingen. Reactiewijzen op normoverschrijdingen dienen overeenkomstig te variëren, zodanig dat er (1) een zone van dulden in stand wordt gehouden voor de onprettige en sommige onbehoorlijke gedragingen; (2) een zone van confrontatie en bespreekbaar maken ontstaat voor sommige vormen van onbehoorlijk gedrag en voor bepaalde onduldbare, maar wettelijk niet ongeoorloofde gedragingen; (3) een zone van wettelijk verbieden; en (4) een daarop aansluitende zone van consistente wet- en rechtshandhaving voor onwettig gedrag ontstaat (zie het schema in hoofdstuk 4).

Inadequate reacties kunnen bestaan uit het richten van de zwaardere reactievormen op de lichtere normoverschrijdingen, zoals het wettelijk (willen) verbieden van bepaalde onfatsoenlijke gedragingen, of het willen aanspreken van medeburgers op elke vorm van als ongewenst of onprettig ervaren gedragingen. Omgekeerd is het met gelatenheid reageren op serieuze en zware vormen van onwettig gedrag evenzeer inadequaat.

\section{Aanbevelingen}

De overheid dient een consistent en helder opsporings- en vervolgingsbeleid aan te houden, waarin in elk geval prioriteit wordt gegeven aan de wettelijke normoverschrijdingen die de persoonlijke integriteit van burgers aantasten en aan de wettelijke normoverschrijdingen in de openbare ruimte die het onderling vertrouwen tussen burgers ondermijnen (WRR 2002).

Omdat zware vormen van criminaliteit en geweldplegingen niet weggenomen worden door bordjes met gedragsregels, stadsregels of de tien geboden op te hangen, dient naast een consistent opsporings- en vervolgingsbeleid ook een preventief programma voorrang te krijgen. Preventieprogramma's kunnen zich richten op wetsovertreders en op niet-wetsovertreders. In Engeland is uit experimenten van het Home Office gebleken dat gerichte informatie over de strafrechtspleging, verstrekt aan niet-wetsovertreders, de ontevredenheid over de rechtspleging en de onveiligheidsgevoelens sterk kan verminderen. Daarnaast werkt een grotere participatie van niet-wetsovertreders bij de rechtspleging in dezelfde richting (Malsch 2004). Van een faire bejegening van wetsovertreders kan een preventieve werking uitgaan die ertoe kan bijdragen de recidive van veelvoorkomende criminaliteit te verminderen. 


\section{$2 \quad$ Antimarginaliseringsbeleid}

Veel zwaardere delicten worden gepleegd door groepen die een marginale positie in de samenleving innemen. Hoe wenselijk het ook is om de repressie van deze criminaliteit te vergroten door meer effectieve controle, opsporing en gepaste sancties, hiermee kan niet worden volstaan. Naast repressie past ook een intensief preventiebeleid. Een deel van de criminaliteit die voor veel maatschappelijke onrust en overlast zorgt, zoals berovingen op straat, bedreigingen en diefstal, wordt veroorzaakt door jeugdige criminelen en psychiatrische patiënten die over straat zwerven. Voor deze groepen dient een specifiek antimarginaliseringsbeleid te worden gevoerd. Dit dient zich te richten op het voorkomen dat 'onaangepaste' individuen al te snel maatschappelijk worden uitgesloten en gemarginaliseerd, waardoor zij in een vicieuze cirkel van steeds ernstiger criminaliteit en marginalisering terechtkomen en de terugweg naar een 'normaal' bestaan definitief wordt afgesloten. Een dergelijk beleid kan ook betekenen dat de instituties per saldo langer met de zorg voor de betrokkenen worden belast; zo'n afwenteling op andere instituties of op de samenleving moet zo veel mogelijk vermeden worden.

\section{Aanbevelingen}

Naast effectieve repressie dienen de overheid en maatschappelijke instellingen ook een intensief preventiebeleid te voeren. Dit dient mede gericht te zijn op het voorkomen van marginalisering en uitsluiting van groepen die onvoldoende kunnen voldoen aan de eisen die onze samenleving aan volwaardige participatie stelt. Maatregelen die de samenwerking bemoeilijken tussen de organisaties die met de opvang van deze groepen zijn belast, moeten worden aangepast, zodat een effectievere opvang en resocialisatie worden bewerkstelligd.

\section{Het belang van opvoeding en onderwijs}

Waarden worden primair gevormd en overgedragen in de opvoeding van (jonge) kinderen. Hoewel de overheid een groot belang heeft bij de kwaliteit en de resultaten van deze opvoeding, kan ze zelf niet eenvoudig en niet te snel interveniëren in dit proces van opvoeden. De belangrijkste vormende waarde van de opvoeding met betrekking tot de internalisering van waarden en normen komt van:

a het zelf voordoen van die waarden door ouders en ouderen, door leerkrachten en gezagsdragers waar kinderen mee te maken hebben;

b het met respect behandelen en tegemoet treden van kinderen en leerlingen, ze behandelen als personen in wording en niet als 'ding';

c het met behoud van liefde stellen van grenzen aan het gedrag van kinderen en leerlingen (love and limits). Het stellen van grenzen is moeilijk in een tijd van grote welvaart en bijna onbegrensde en onmiddellijke behoeftebevrediging. Het gedrag van jongeren volgt hierin het gedrag van ouderen. Het opvoedingsproces vergt derhalve ook een heroriëntatie van het gedrag van volwassenen (Levering 2004);

d het participeren van kinderen en leerlingen in het opstellen van de noodzakelijke gedragsregels thuis, op school en in de buurt. Het eenzijdig opleggen van dergelijke gedragsregels werkt minder effectief dan het gezamenlijk vinden van deze regels (Diekstra 2004). 


\section{Aanbevelingen}

Opvoedingsondersteuning moet algemener beschikbaar komen voor ouders die dit nodig hebben en moet op vrijwillige basis worden geëntameerd. De lokale overheid en plaatselijke instellingen die met de zorg voor jeugd en gezin belast zijn, zijn de aangewezen instanties om deze opvoedingsondersteuning mogelijk te maken, voorzover dit al niet op ruime schaal geschiedt. Signalering van opvoedingstekorten en diagnosestelling kunnen in de samenwerking van plaatselijke instellingen geschieden, waarbij speciale aandacht dient te komen liggen bij vroege signalering en vroege diagnostiek. Verbetering van de samenwerking tussen jeugdhulpverleningsinstellingen, met name voor gezinnen waarin sprake is van een problematische opvoedingssituatie, is hard nodig. Indien bestaande maatregelen deze samenwerking verhinderen, dienen de hindernissen daarvoor weggenomen te worden.

Omdat jongeren die thuis tekorten ondervinden in hun sociale of morele opvoeding ook de buurt vaak overlast bezorgen met hun gedrag, dienen analoog aan programma's voor opvoedingsondersteuning buurtprojecten ondersteund te worden die de onderlinge betrokkenheid van buurtbewoners en de sociale controle in de buurt kunnen verbeteren. De lokale overheid is hiervoor de aangewezen instantie om de initiatieven, die uit de verschillende buurten zelf komen, van bovenaf te ondersteunen (Diekstra 2003). Buurtregels en stadsetiquettes kunnen een goed middel zijn om de sociale samenhang te bevorderen, maar gezien de grote variatie in plaatselijke en gemeentelijke context zijn algemene voorschriften voor dergelijke gedragsregels niet aan te raden. Op gemeentelijk niveau zouden speciale wijkbudgetten hiervoor beschikbaar kunnen worden gesteld.

De raad beveelt de regering niet aan om scholen te verplichten om lessen in 'waarden en normen' of in omgangskunde in het curriculum op te nemen. Belangrijker is het dat scholen in hun eigen situatie en context voldoende ruimte krijgen om op hun eigen manier aandacht te besteden aan de morele dimensie van opvoeding en onderwijs, en aan burgerschapsvorming als 'algemene doelbepaling' (Onderwijsraad). Dat kan door het met de leerlingen formuleren van gedragsregels voor de school, voor leerlingen, leerkrachten en ouders. Aan de verscheidenheid van culturele normen en waarden en aan de historische verworvenheden van democratie en rechtsstaat kan in het huidige curriculum, bijvoorbeeld in de vakken geschiedenis, maatschappijleer of aardrijkskunde, voldoende aandacht besteed worden; de lerarenopleidingen moeten hier uiteraard op voorbereiden. In het algemeen moet de regering ervoor waken dat morele tekorten die in de maatschappij als geheel worden geconstateerd, vooral of bij voorkeur worden afgewenteld als een taakverzwaring in het onderwijs. Als het goede voorbeeld van moreel correct gedrag niet door volwassenen wordt gegeven, kunnen scholen deze morele taak niet alleen op hun schouders nemen. 


\section{Bewaren en bewaken van de pluriformiteit van waarden}

Pluriformiteit van waarden is al lang een gegeven van de moderne samenleving. Ze wordt door de democratische rechtsstaat weliswaar niet aangemoedigd, maar wel mogelijk gemaakt en gegarandeerd. Er hoeft niet gestreefd te worden naar een volledige inhoudelijke gemeenschappelijkheid van waarden. Een overlappende consensus is hiervoor voldoende: een moord wordt algemeen afgewezen, ook al verschillen de morele motieven waarom dit wordt afgewezen enorm (tegen Gods wil of tegen de menselijke natuur ingaand, vanwege de sociale consequenties die moord heeft voor het samenleven of omdat moord indruist tegen de afspraken van een sociaal contract en dergelijke). Wel veronderstelt een dergelijke pluriformiteit van waarden een bereidheid bij alle partijen om op een beschaafde wijze verschillen van opvatting en inzicht bespreekbaar te maken en te houden. Waardepluriformiteit vereist geciviliseerde omgangsvormen in publieke discussies en in publieke ontmoetingen. Het parlement is bij uitstek een plaats voor deze geciviliseerde publieke meningsvorming en meningsuiting.

\section{Aanbevelingen}

De overheid heeft een taak om, naast de eigen verantwoordelijkheid van andere instituties, de mogelijkheden voor publieke discussies over waarden en normen en de vele dimensies van morele pluriformiteit te ondersteunen en, waar nodig, te verruimen. Confrontaties tussen verschillende waardeopvattingen, vooral indien ze te maken hebben met cultuurverschillen, dienen gestimuleerd te worden. Dit betekent echter niet dat elk debat dat gevoerd kan worden ook daadwerkelijk gevoerd moet worden. Zeker waar het cultuurverschillen betreft, kan er ook te veel gedebatteerd worden, hetgeen tot labelling en stigmatisering kan leiden. Met name de overheid dient - meer dan nu het geval is - selectief te zijn in de kwesties waarover zij het debat wil entameren en waarover niet.

Bij de overheid berust ook een bijzondere taak in het uitdragen en het onderhouden van de waarden van democratie en rechtsstaat. De vormen waarin dit geschiedt en de instanties die dit uitvoeren, kunnen van geval tot geval en van tijdperk tot tijdperk verschillen. Moderne media kunnen hiervoor een geschikte vorm bieden.

\section{De noodzaak van conflictpreventie}

In het verlengde van de erkende pluriformiteit van waarden in de samenleving is het onvermijdelijk dat er voortdurend sprake is van conflicten over de inhoudelijke keuze tussen diverse waarden: conflicten binnen en tussen individuele personen, binnen en tussen groepen en organisaties, en binnen en tussen instituties. De Nederlandse samenleving heeft een goede traditie om dergelijke conflicten te dempen, maar geen traditie in het voluit bespreekbaar maken en 'uitdiscussiëren' van dergelijke groepsconflicten. De vele vormen van formeel en informeel normoverschrijdend gedrag kunnen daarbij aan de orde komen. Dienen normoverschrijdingen uitgevochten of uitgepraat te worden, dient men medeburgers op hun gedrag aan te spreken of dient dit gedrag in bredere kring bespreekbaar gemaakt te worden? De houding van bepaalde groepen ten aanzien 
van geweld en gewelddadige conflictbeslechting verdient aparte aandacht te krijgen in het kader van conflictpreventie.

\section{Aanbevelingen}

Uit het oogpunt van te voorziene en onvermijdelijke waardeconflicten tussen etnische groepen en tussen diverse culturen verdient het speciale aanbeveling te gaan werken aan praktische programma's voor conflictpreventie en conflictbeslechting (zie hoofdstuk 7). In deze programma's zal de nadruk dienen te liggen op de gedrags- en handelingscomponent. Ze kunnen op scholen, in buurten, in diverse organisaties en instellingen, inclusief overheidsorganisaties, worden geïntroduceerd. Omdat er in Nederland, in tegenstelling tot andere immigratiesamenlevingen, weinig wetenschappelijke kennis is ontwikkeld over dergelijke conflictpreventieprogramma's, dient deze kennis, in het kader van waarden en normen, verbeterd te worden.

\section{$6 \quad$ Ondersteuning door de overheid van instituties}

Zoals in hoofdstuk 7 is betoogd, berust de verantwoordelijkheid voor het onderhoud van waarden en normen bij sociale instituties zelf. Niettemin speelt de overheid een belangrijke rol bij de financiering en de (procedurele) controle van de vele werkzaamheden van deze instituties, met name als ze publieke taken vervullen die mede met publieke middelen worden bekostigd. De overheid dient deze instituties meer ruimte te laten en, indien nodig, ook te geven om aan de morele dimensie van hun maatschappelijke rol meer aandacht te besteden dan de laatste twee decennia het geval was. Met name zou er weer meer aandacht kunnen worden besteed aan de speciale verantwoordelijkheid van professionele dienstverleners (onder andere leerkrachten, verpleegkundigen en artsen, pedagogen en jongerenwerkers). Naast het vergroten van de discretionaire bevoegdheid van deze professionals dient tegelijkertijd aan de morele aspecten van de hulpverlening meer aandacht geschonken te worden. In controles en beoordelingen kan deze morele dimensie apart genoemd worden (bijvoorbeeld voor scholen en andere onderwijsinstellingen). Een verbeterde participatie van de kant van burgers en cliënten van deze instellingen, onder andere ook bij het opstellen van gedragsregels van deze organisaties, analoog aan buurtregels, kan normoverschrijdend gedrag tegengaan en op bepaalde waarden gericht gedrag bevorderen. Er moet lering worden getrokken uit eerdere experimenten met cliëntparticipatie (onder andere in de gezondheidszorg) om hiervoor een vorm te vinden die daadwerkelijk bijdraagt aan het versterken van het draagvlak voor de normen en waarden van een institutie en aan het voorkómen van normoverschrijdend gedrag.

\section{Aanbevelingen}

De overheid dient instituties, organisaties en instellingen die publieke taken vervullen, op ruime schaal gelegenheid te geven meer aandacht te besteden aan de morele dimensie van hun werkzaamheden. Waar nodig kan de overheid deze 'cultuuromslag' in organisaties ondersteunen met bepaalde middelen en programma's (bijvoorbeeld conflictpreventie, bespreekbaar maken van te lang 
gedoogde normoverschrijdingen, integriteitsdilemma's). De vorm van deze ondersteuning moet vooral stimulerend zijn en van tijdelijke aard, en slechts lichte administratieve verplichtingen met zich meebrengen. De uitvoering van dergelijke ondersteuning zal gedecentraliseerd, naar gemeente of rekening houdend met de institutionele context, moeten geschieden.

\section{Intensivering van onderzoek naar en discussie over waarden, normen en gedrag}

De problemen ten aanzien van waarden, normen en gedrag die in dit rapport zijn beschreven en geanalyseerd, verdienen een maatschappelijke vertaling te krijgen. Er is behoefte aan voorlichting en informatievoorziening, aan uitvoerige publieke discussies over waarden en normen, aan experimenten met de aanpak van concrete problemen en aan nader onderzoek. Deze activiteiten vinden nu reeds op tal van plekken in de samenleving plaats, in werkplaatsen voor informatie, overdracht, onderzoek en discussie over waarden, normen en gedrag. Het gaat hierbij vooral om bestaande instellingen (waaronder de WRR) en niet om nieuw op te richten instituten. In deze werkplaatsen voor waarden, normen en gedrag zal in elk geval aan de volgende aspecten aandacht moeten worden besteed:

a voorlichting en elektronische informatievoorziening, in interactieve vorm, over waarden, normen en gedag;

b het entameren van de publieke discussie over waarden, normen en gedrag in de vorm van fora, conferenties, publieke geschriften en openbare debatten; centraal hierbij staan problemen die worden opgeroepen door de pluriformiteit van waarden, religies en levensbeschouwingen in relatie tot de waarden van de democratische rechtsstaat;

c het uitdrukkelijk werken met rolmodellen van voorbeeldige personen in de verschillende instituties;

d het ontwikkelen, beschikbaar stellen en verspreiden van conflictpreventieprogramma's en het verzorgen van de praktische toepassing van deze programma's in diverse sociale situaties en instellingen;

e het entameren van wetenschappelijk onderzoek op het terrein van waarden (value inquiry), zoals dat al veel langer bestaat in enkele Noord-Amerikaanse landen. Centraal dient hierbij te staan het onderzoek naar de manier waarop waarden in opvoeding en onderwijs en in een pluriforme samenleving als geheel het beste kunnen worden geïnternaliseerd, overgedragen en onderhouden. Op dit terrein is er in Nederland te weinig kennis, terwijl die kennis nodig is om de overige gewenste activiteiten op het terrein van waarden en normen deskundig te begeleiden.

\section{Aanbevelingen}

De raad beveelt de regering aan om te bevorderen dat er in bestaande instituten onderzoek op het punt van waarden, normen en gedrag wordt geëntameerd of voortgezet dat kan bijdragen aan informatievoorziening, discussie, experimenten en onderzoek met betrekking tot de in dit rapport beschreven problemen. 


\subsubsection{TOT BESLUIT}

Nederland heeft een zeer lange traditie in het omgaan met verschillen in religie, levensovertuiging en daarmee verbonden waarden en normen. Deze traditie begon ruim vier eeuwen geleden bij Erasmus (1466-1536) met in zijn voetspoor een krachtige vertegenwoordiger in de persoon van Coornhert (1522-1590). Gedurende Coornherts leven waren godsdiensttwisten aan de orde van de dag. De discussies over de waarheid en de juistheid van de verschillende godsdienstige en morele stellingen en opvattingen tierden welig. Hij wijdde zijn hoofdwerk aan deze twisten: Zedekunst dat is Wellevenskunste (1585, laatste editie 1982). Coornhert schreef het niet in het Latijn, maar in de taal van het volk. Het begrip 'wellevendheid' was toen nog onlosmakelijk verbonden met ethiek en moraal. Wellevendheid in deze meeromvattende betekenis werd als een van de belangrijkste waarden van die tijd beschouwd. Ook lang daarna, in de zeventiende eeuw, riep Coornherts wellevenskunst vele discussies en reacties op, bijvoorbeeld door de stichtelijke gedichten van Jan Luyken, die door Coornhert waren geïnspireerd. De kern van Coornherts ethiek was de gulden regel: 'Behandel Uw naaste zoals U zelf door die naaste behandeld wilt worden', ofwel: 'Wat gij niet wilt dat U geschiedt, doe dat ook een ander niet.' Die gulden regel heeft ook voor de eenentwintigste eeuw nog niets van zijn geldigheid verloren. 


\section{LITERATUUR}

Adang, O. (1998) Hooligans, autonomen, agenten. Geweld en politie-optreden in relsituaties, z.p.: Samsom.

Adriaansens, H. (2004) 'Context en verantwoordelijkheid', in: P. de Beer en C.J.M. Schuyt (red.) Bijdragen aan waarden en normen, WRR Verkenning 2, Amsterdam: Amsterdam University Press.

AIVD (2002) Rekrutering in Nederland voor de jihad. Van incident naar trend, Den Haag: AIVD.

Akerlof, G.A. (1980) 'A theory of social custom, of which unemployment may be one consequence', Quarterly Journal of Economics 90: 749-775.

Algemene Rekenkamer (2000) Inburgering en taalonderwijs allochtonen, TK 1999-2000, 27 275, nr. 1-2.

Alkema, E.A. (1995) 'De reikwijdte van fundamentele rechten - de nationale en internationale dimensies', blz. 1-129, in: Handelingen Nederlandse Juristen-Vereniging, jrg. 125, dl. I, Zwolle: W.E.J. Tjeenk Willink.

Anderson, E. (1993) Value in Ethics and Economics, Cambridge, Mass.: Harvard University Press.

Anker, R. (2003) 'Over de nog altijd erbarmelijke wijze waarop op de meeste middelbare scholen de liefde tot de literatuur en het helder lezen wordt afgeleerd', Tirade, nr. 400: 65-79 (Uitgeverij G.A. van Oorschot).

Arendt, H. (1958) The Human Condition, Chicago: Chicago University Press.

Aristoteles, Ethica Nicomachea, vertaald en toegelicht door Ch. Hupperts en B. Poortman (1997), Amsterdam: Kallias.

Ayer, A.J. (1952) Language, Truth and Logic, New York: Dover (eerste uitgave 1937).

Bauman, Z. (1998) Work, Consumerism and the New Poor, Buckingham: Open University Press.

Becker, G.S. (1968) 'Crime and punishment: an economic approach', Journal of Political Economy 76: 169-217.

Beer, P. de (1994) Arbeidsmarkt in perspectief, $3^{\mathrm{e}}$ herziene druk, Houten/Diegen: Bohn Stafleu Van Loghum.

Beer, P.T. (2001) Over werken in de postindustriële samenleving, Den Haag: Sociaal en Cultureel Planbureau.

Beke, B.M.W.A., W.J.M. de Haan en G.J. Terlouw (2001) Geweld verteld. Verklaringen van daders, slachtoffers en getuigen van geweld op straat, Den Haag: Wetenschappelijk Onderzoek- en Documentatiecentrum (WODC) (Ministerie van Justititie).

Belastingdienst (2002) Jaarverslag 2001.

Bellekom, Th.L, D.J. Elzinga en J.E. Goldschmidt (1983) 'Botsing van grondrechten: de vrijheid van meningsuiting contra het gelijkheidsbeginsel', NJCM-bulletin 8: 270-280.

Berlin, I. (1969) Four Essays on Liberty, Oxford: Oxford University Press.

Beus, J. de (1998) De cultus van vermijding, Utrecht: Forum.

Bie, E. de en J. Korpel (2002) Onderweg naar een veiliger openbaar vervoer. Onderzoek naar sociale veiligheid in het openbaar vervoer in Nederland, Den Haag: ES\&E. 
Boer, Th. de en S. Griffioen (red.) (1995) Pluralisme, cultuurfilosofische beschouwingen, Amsterdam: Boom.

Bol, M.W. en C.J. van Netburg (1997) Voetbalvandalen/voetbalcriminelen, Den Haag:

Wetenschappelijk Onderzoek- en Documentatiecentrum (WODC) (Ministerie van Justititie).

Bowles, S. en H. Gintis (1998) 'How communities govern: the structural basis of prosocial norms', blz. 206-230, in: A. Ben-Ner en L. Putterman (red.) Economic, values, and organization, Cambridge: Cambridge University Press.

Brink, G. van den (2001) Geweld als uitdaging. De betekenis van agressief gedrag bij jongeren, Utrecht: NIZW.

Brink, G. van den (2002) Mondiger of moeilijker? Een studie naar de politieke habitus van hedendaagse burgers, WRR Voorstudies en achtergronden V 115, Den Haag: Sdu Uitgevers.

Brink, G. van den (2004) Schets van een beschavingsoffensief: over normen, normaliteit en normalisatie in Nederland, wRR Verkenning 3, Amsterdam: Amsterdam University Press.

Broeders, D (2001) Immigratie- en integratieregimes in vier Europese landen, WRR Werkdocumenten 125, Den Haag.

Broeders, D. en P. Meurs (2002) 'Het “importhuwelijk”: weren of inburgeren?', Beleid en Maatschappij 29, nr. 2: 110-112.

Broertjes, P. (2003) Jaarrede voor het Genootschap van Hoofdredacteuren, Amsterdam, 25 april 2003.

Bronneman, R. (2004) 'De pedagogische opdracht van het onderwijs: aangrijpingspunten en beperkingen', in: P. de Beer en C.J.M. Schuyt (red.) Bijdragen aan waarden en normen, WRR Verkenning 2, Amsterdam: Amsterdam University Press.

Bui Trong, L. (200o) Violences Urbaines, Paris: Bayard.

Buijs, F. (2002a) Democratie en terreur. De uitdaging van het Islamitisch extremisme, Amsterdam: uitgeverij swP.

Buijs, F. (2002b) Inleiding bij boekpresentatie 'Democratie en terreur. De uitdaging van het Islamitisch extremisme', Rode Hoed, 11 september 2002.

Buijs, F. en S. Harchaoui (2003) 'Islamitisch radicalisme en rekrutering in Nederland. Een verkenning', Proces, 2003/2, 98-108.

Bunkers, H. (1995) 'Agressie tegen reizigers', blz. 66-76, in: I.H.J. Starmans (red.) Niet alleen normvervaging: achtergronden van de belangrijkste vormen van criminaliteit en overlast in het openbaar vervoer, Den Haag: Eysink Smeets \& Etman.

Burg, W. van der (2001) De Verbeelding aan het werk, pleidooi voor een realistisch idealisme, Kampen: Agora.

Burkens, M.C. (1989) Algemene leerstukken van grondrechten naar Nederlands constitutioneel recht, Zwolle: W.E.J. Tjeenk Willink.

Carter, S.L. (1996) Integrity, New York: Basic Books.

Carter, S.L. (1998) Civility, Manners, Morals and the Etiquette of Democracy, New York: Basic Books.

CDA Verkenningen, interview met Roché, december 2002.

CGB (2003a) Verweerder maakt geen verboden onderscheid op grond van godsdienst door het hanteren van een verbod op het dragen van een gezichtsbedekkende sluier binnen zijn instellingen, Oordeel 2003-40, 20 maart 2003. 
CGB (2003b) Advies Commissie Gelijke Behandeling inzake 'gezichtssluiers en hoofddoeken op scholen’, CGB-advies/2003/o1, 16 april 2003.

Chouraqui, A. (200o) De Tien Geboden anno Nu, Amsterdam: Meulenhoff.

CIV (2002) Jaarverslag seizoen 2001-2002, Utrecht: Centraal Informatiepunt Voetbalvandalisme.

Coleman, J.S. (1990) Foundations of social theory, Cambridge (MA)/Londen: The Belknap Press of Harvard University Press.

Coles, R. (1997) The Moral Intelligence of Children, New York: Random House.

Commissie-De Rooy (2001) Verleden, Heden en Toekomst. Advies van de Commissie historische en maatschappelijke vorming, Enschede: SLO.

Commissie-De Ruiter (1995) De school van je leven, Eindrapport, opgesteld door het Platform pedagogische opdracht van het onderwijs onder voorzitterschap van J. de Ruiter.

Comte-Sponville, A. (1997) Kleine verhandeling over de grote deugden, Amsterdam: Atlas (oorspr. Frans 1995).

Connell, D. en M. Joint (1997) ‘Driver aggression’, in: Aggressive driving: three studies, Washington (DC): American Automobile Association Foundation for Traffic Safety.

Coornhert, D.V. (1982) Zedekunst dat is Wellevenskunste (oorspronkelijke editie 1586), Utrecht: HES Publishers.

Couwenberg S.W, P. Cliteur et al. (2003) 'Inburgering een permanente opgave', Civis Mundi, jrg. 42, themanummer inburgering.

СРВ (2001), Centraal Economisch Plan 2001, Den Haag: Centraal Planbureau.

Creel, R.E. (2001) Thinking Philosophically, an introduction to critical reflection and rational dialogue, Oxford: Blackwell.

Crul, M. (200o) De sleutel tot succes. Over hulp, keuzes en kansen in de schoolloopbanen van Turkse en Marokkaanse jongeren van de tweede generatie, Amsterdam: Het Spinhuis.

Dagevos, J. en R. Schellingerhout (2003) 'Sociaal-culturele integratie: contacten, cultuur en oriëntatie op de eigen groep', Rapportage Minderheden 2003, Den Haag: Sociaal en Cultureel Planbureau.

Daily Telegraph, The (2002) Scoop that could have changed the course of history, 30 september 2002.

Dan-Cohen, M. (2002) Harmful thoughts. Essays on law, self, and morality, Princeton/ Oxford: Princeton University Press.

Dekker, P. (2001) 'Morele feiten: opvattingen en ontwikkelingen in Nederland', blz. 15-36, in: C. Brinkgreve, R. Gude en S. Noorda (red.) De morele staat van Nederland, Amsterdam: Amsterdam University Press/Salomé.

Dekker, P., J. de Hart, C. Hubers en P. de Beer (2003) Normen en waarden in bevolkingsenquêtes, Den Haag: Sociaal en Cultureel Planbureau (te verschijnen).

Derkse, W. (red.) (2002) Pleidooi voor een onderwijs 'Wende' vitaal leren, Vught: Tempora.

Diekstra, R. (2004) 'Stadsetiquette: over waarden, normen en collectieve zelfredzaamheid van burgers', in: P. de Beer en C.J.M. Schuyt (red.) Bijdragen aan waarden en normen, WRR-Verkenning 2, Amsterdam: Amsterdam University Press.

Diekstra, R.F.W., M. van Toor, M. den Ouden en M. Schweitzer (2002) Vriendelijker, 
verantwoordelijker, veiliger. Stadsetiquette: van idee naar programma - verslag van een pilot, Rotterdam: Bestuursdienst gemeente Rotterdam (Directie Sociale en Culturele Zaken).

Dijk, T. van et al. (2002) Huiselijk geweld onder Surinamers, Antillianen en Arubanen, Marokkanen en Turken in Nederland. Aard, omvang en hulpverlening, Hilversum: Intomart Beleidsonderzoek.

Dunning, E. (2000) 'Towards a sociological understanding of football hooliganism as a world phenomenon', European Journal on Criminal Policy Research 8, 2: 141-162.

Eck, R. van en B. Kazemier (1989) Zwarte arbeid. Een empirische en methodologische studie, proefschrift, Amsterdam: Universiteit van Amsterdam.

Eijsbouts W.T. (2003) 'Opsteker: "grondwet gebaseerd op burger”; interview met Tom Eijsbouts', Staatscourant, 29-08-2003.

Eindtermen maatschappelijke oriëntatie voor nieuwkomers (1997) vastgesteld op basis van het Concept Eindtermen door M. van der Vegt, september sept. 1996.

Elchardus, M. (1994) 'Culturele moderniteit en waardevorming', in: Op de rü̈nes van de waarheid; lezingen over tijd, politiek, cultuur, Leuven, uitgeverij Kritak.

Ellian, A. (2003) 'Van Janmaat tot El Moumni; de discriminatie tussen gewone en heilige meningen', Justitiële Verkenningen, jrg. 29, nr. 3: 26-35.

Elster, J. (1993) The Cement of Society, Cambridge: Cambridge University Press.

Emberley, P.C. (1995) Values Education and Technology, Toronto: Toronto University Press.

Emmelot Y. en I. van der Veen (2003) Brede basisscholen uitgelicht, sco Kohnstamm Instituut, Amsterdam, sco rapport nr. 680.

Engbersen, G. (1990) Publieke bijstandsgeheimen; het ontstaan van een onderklasse in Nederland, Leiden/Antwerpen: Stenfert Kroese.

Engbersen, G. en R. Staring (2002) Armoede en informaliteit. De morele economie van lage inkomensgroepen, Rotterdam: RISBO/Erasmus Universiteit Rotterdam.

Engbersen, G. et al. (2002) Illegale vreemdelingen in Nederland. Omvang, overkomst, verblijf en uitzetting, Rotterdam: RISBO.

Esping-Andersen, G. (1990) The Three Worlds of Welfare Capitalism, Cambridge: Cambridge University Press.

Etzioni, A. (1988) The moral dimension. Toward a new economics, New York: The Free Press.

Etzioni, A. (1993) The Spirit of Community, New York: Simon and Schuster.

Etzioni, A. (1996) The new Golden Rule, New York: Basic Books.

Etzioni, A. (2001) The Monochrome Society, Princeton: Princeton University Press.

Feibleman, J.K. (1987) Education and Civilization, The Hague: Martinus Nijhoff Publishers.

Feldblum, M. (1999) Reconstructing citizenship. The politics of nationality reform and immigration in contemporary France, New York: State University of New York Press.

Fennema, M. (2002) 'Het publieke debat na 11 september', De Gids, Vol 165, 3 (maart): 229-244.

Fershtman, Ch. en Y. Weiss (1998) 'Why do we care what others think about us?’, blz. 133-150 in: A. Ben-Ner en L. Putterman (red.) Economic, values, and organization, Cambridge: Cambridge University Press. 
Ferwerda, H., M. Bottenberg, A. Hakkert en A. Eijken (2002) Straatroof: omvang, achtergronden en praktijkervaringen, Cluster Beleidsanalyse en Informatievoorziening, Directie jeugd en criminaliteitspreventie, Den Haag: Ministerie van Justitie.

Fokkema, T., C. Huisman en N. Smidtman (200o) 'Vrouwenbenijdenis', Demos, jrg. 16, juni/juli 2000.

Frey, B.S. en R. Jegen (2001) 'Motivation crowding theory', Journal of Economic Surveys 15, 5: 589-611.

Gageldonk, P. van (1999) Geen woorden maar daden. Het drama van Beverwijk en hoe het verder ging met de hooligans van Feyenoord, Amsterdam: Nijgh \& Van Ditmar.

Galenkamp, M. (2002), 'De multiculturele samenleving in het geding; op zoek naar Fundamenten', Justitiële Verkenningen, jrg. 28, nr. 5: p.75-84.

Geach, P.T. (1977) The Virtues, Cambridge: Cambridge University Press.

Geiger, Th. (1947) Vorstudien zu einer Soziologie des Rechts, Neuwied am Rhein: Luchterhand, tweede druk 1964.

Gerards, J.H. (2002) Rechterlijke toetsing aan het gelijkheidsbeginsel, Den Haag: Sdu uitgevers.

Gerbranda, Tj. (2002) 'Botsing van grondrechten: is een botsing onvermijdelijk?', blz. 115-131 in: M. Kroes, J.P. Loof en H.M.Th.D. ten Napel (red.) Gelijkheid en rechtvaardigheid. Staatsrechtelijke vraagstukken rondom 'minderheden', Publikaties van de Staatsrechtkring 6, Deventer: Kluwer.

Gladwell, M. (200o) The tipping point. How little things can make a big difference, Little Brown \& Company.

Goldschmidt, J.E. (1984) 'Een model voor de afweging van botsende grondrechten: een moedige, doch mislukte poging', NJCM-bulletin 9: 348-351.

Goudzwaard, B. en H.M. de Lange (1986) Genoeg van te veel/Genoeg van te weinig, Baarn: Ten Have.

Griffin, J. (1997) Value Judgment, improving our ethical beliefs, Oxford: Claridon Press.

Guardian, The (1993) Major goes back to the old values, 9 oktober 1993.

Guardian, The (1999) Blair revives back to basics angst, 6 september 1999.

Guillebaud, J.C. (2001) Re-founding the World, New York: Algora Publishing (oorspr. Frans 1999).

Gunsteren, H.R. (red.) (1992) Eigentijds burgerschap, Wetenschappelijke Raad voor het Regeringsbeleid, Den Haag: Sdu Uitgevers.

Gunsteren H. van en E. van Ruyven (red.) (1995) Bestuur in De Ongekende Samenleving, Den Haag: Sdu Uitgevers.

Gutmann, A. en D. Thompson (1996) Democracy and Disagreement, Cambridge, Mass.: Harvard University Press.

Haaften, A.W. van (1992) 'Pedagogiek tussen norm en grondslag', in: Pedagogisch Tijdschrift, p. 123-138.

Hagelund, A. (2002) 'De kwestie van cultuur. Noorse debatten over integratie', Migrantenstudies, jrg. 18, nr. 2: 274-287.

Halman, L. (2001) The European Values Study: a third wave, Tilburg: Evs/worC/Tilburg University.

Hamilton, J.J. (1998) Channeling Violence, The economic market for violent television programming, Princeton: Princeton University Press.

Handelingen Tweede Kamer (2002-2003), Behandeling van de briefvan de minister-presi- 
dent over waarden en normen (28600, nr. 42), vergaderjaar 2002-2003, nr. 35, blz. 2609-2646.

Hansen, R. en P. Weil (red.) (2001) Towards a European nationality. Citizenship, immigration and nationality law in the EU, Houndmills, Basingstoke, Hampshire: Palgrave.

Harchaoui, S. en C. Huinder (2003) Stigma: Marokkaan!, Utrecht: FORUM.

Hart, H.L.A. (1969) The Concept of Law, Oxford: Oxford University Press.

Hartkamp, A.S. (2000) 'De Nederlandse rechter en het EVRM', blz. 25-35, in: R.A. Lawson en E. Myjer (red.) 50 jaar EVRM, Leiden: Stichting NJCM-Boekerij.

Hauber, A.R. (1995) 'Onveiligheidsgevoelens bij openbaar vervoerpersoneel', blz. 112125, in: I.H.J. Starmans (red.) Niet alleen normvervaging: achtergronden van de belangrijkste vormen van criminaliteit en overlast in het openbaar vervoer, Den Haag: Eysink Smeets \& Etman.

Hazeu, C.A. (2003) 'Wat heeft een econoom aan sociaal kapitaal ?’, in: A.P. Ros en H.R.J. Vollebergh (red.) Liber amicorum prof. dr. P.A. Cornelisse, Rotterdam: Erasmus Universiteit Rotterdam.

Heertje, A. en H. Cohen (1980) Het officieuze circuit. Een witboek over zwart en grijs geld, Utrecht/Antwerpen: Het Spectrum.

Hessing-Couvret, E. en A. Reuling (2002) Het WIN-model ${ }^{T M}$ : waardensegmenten in Nederland, Amsterdam: NIPO.

Hirsch Ballin, E.M.H (1993) Burgerschap en zijn betekenis voor het publiek domein, in: Beleid en Maatschappij, nr.1, themanummer 'Burgerschap; De moralisering voorbij?, p. 10-14.

Hoek, J. van der (200o) 'Niet met zoveel woorden; de opvoeding van migrantengezinnen', in: I. van der Zande (red.) Deugt de jeugd? Normen en waarden in gezin, school en politiek, Maarssen: Elsevier/De Tijdstroom, blz. 83-107.

Hoeven, J. van der (1983) Botsing van grondrechten, Amsterdam e.a : B.V. NoordHollandsche Uitgevers Maatschappij.

Hoff, S. en G. Jehoel-Gijsbers (1998) Een bestaan zonder baan. Een vergelijkende studie onder werklozen, arbeidsongeschikten en werkenden (1974-1995), Rijswijk/Den Haag: Sociaal en Cultureel Planbureau/Elsevier bedrijfsinformatie.

Hofstee W.K. B. (1993) 'Oproepen en opvoeden', in: Beleid en Maatschappij, nr. 1, themanummer 'Burgerschap; De moralisering voorbij?’ p. 15-19.

Hofstee W.K.B. (1992) ‘Een curriculum voor burgerschap', in: P. den Hoed en H.R. van Gunsteren Burgerschap in Praktijken, deel I, WRR Voorstudies en achtergronden V77, Den Haag, Sdu Uitgevers, p. 257-281.

Holtmaat, R. (2003) 'Stop de inflatie van het discriminatiebegrip! Een pleidooi voor het maken van onderscheid tussen discriminatie en ongelijke behandeling', Nederlands Juristenblad 78, 25: 1266-1276.

Hooghiemstra, E. (200o) 'Voor de keuze: een specifieke of algemene blik op partnerkeuze van migranten', Migrantenstudies, 16, nr. 4: 209-228.

Hooghiemstra, E. (2003) Trouwen over de grens. Achtergronden van partnerkeuze van Turken en Marokkanen in Nederland, Den Haag: SCP.

HP/De Tijd, 24 januari 2003.

Hull, R.T. (red.) (1994) A Quarter Century of value Inquiry, Atlanta: Rodopi.

InterView (1991) Verzorgingsstaat op drift, Amsterdam: InterView Nederland B.V. 
Interview-NSS (2003) Fraude anno 2003, Amsterdam: Interview-NSS.

Jansen, I., J. Korpel, V. Wijkhuijs en E. de Bie (2002) Sociale veiligheid van het personeel in het openbaar vervoer 2002, Den Haag: ES\&E.

Jippes, H. (2003) 'Het braafste jongetje van de Europese klas', NRC Handelsblad Magazine, mei 2003, p. 13-29.

Joppke, C. (2003) The retreat of multiculturalism in the liberal state, Russell Sage Foundation working paper 203, January 2003.

Junger-Tas, J. (2001) 'Normhandhaving op school', in: Herman Vuijsje (red.) Mores Leren, Assen, Van Gorcum, p.47-54.

Junger-Tas, J. (2002) Diploma's en goed gedrag II, preventie van antisociaal gedrag in het onderwijs, Den Haag: Ministerie van Justitie.

Keane, J. (1998) The Media and democracy, Oxford: Polity Press.

Kekes, J. (1989) Moral Tradition and Individuality, Princeton: Princeton University Press.

Kekes, J. (1993) The Morality of Pluralism, Princeton: Princeton University Press.

Kinneging, A. (2003) 'Kleine fenomenologie van waarden en normen', in: CDA Verkenningen Zomer 2003, p. 18-25, Den Haag: Wetenschappelijk Instituut van het CDA.

Klapwijk, J. (1994) 'Pluralism of Norms and Values: on the Claim and Reception of the Universal', in: Philosophia Reformata, 59: 158-192.

Klapwijk, J. (1995) 'Ethisch pluralisme en de opdringerigheid van het universele', blz. 180-203, in: Th. de Boer en S. Griffioen (red.) Pluralisme, cultuurfilosofische beschouwingen, Amsterdam: Boom.

Kleiboer M.A. en N.J.H. Huls (2001) Toezicht op de terugtocht? Wettelijke niet hiërarchisch tuchtrect. Een vergelijkende analyse, Utrecht: Lemma.

Klink, B. van, P. van Seters en W. Witteveen (red.) (1993) Gedeelde normen? gemeenschappelijk recht, Zwolle: Tjeenk Willink.

Koopmans R. (2002) 'Zachte heelmeesters... Een vergelijking van het Nederlandse en Duitse integratiebeleid en wat de WRR daaruit niet concludeert', Migrantenstudies, jrg. 18, nr. 2, p. 87-92.

Koopmans, C.C. (1989) Informele arbeid. Vraag, aanbod, participatie en prijzen, proefschrift, Amsterdam: Universiteit van Amsterdam.

Kovach B. en T. Rosenstiel (2003) A statement op purpose, project for excellence in journalism, www.journalism.org/resources/guidelines.

KPC Groep (2003) Scholen voor actief burgerschap, Uitgangspunten, Den Bosch: KPC.

Kreps, D.M. (1997) 'Intrinsic motivation and extrinsic incentives', American Economic Review, Papers \& Proceedings 87, 2: 359-364.

Kroft, H., G. Engbersen, K. Schuyt en F. van Waarden (1989) Een tijd zonder werk. Een onderzoek naar de levenswereld van langdurig werklozen, Leiden/Antwerpen: Stenfert Kroese.

Kruissink, M. en A.A.M. Essers (2003) Ontwikkeling van de jeugdcriminaliteit: periode 1980-1999, Onderzoeksnotitie 2001/3. Den Haag: WODC.

Lee, D.E. (2002) Navigating Right and Wrong, Ethical Decision Making in a Pluralistic Age, Lanham: Rowman and Littlefield.

Lensvelt-Mulders, G.J.L.M., G.H.C. van Gils en P.G.M. van der Heijden (1999) Een overzicht van schattingsmethoden voor de omvang van fraude, Utrecht: Universiteit van Utrecht (IOPS). 
Levelt, P.B.M. (2001) 'Boze agressie in het verkeer: een emotietheoretische benadering', Justitiële verkenningen 27, 1: 95-109.

Levering, B. (2004) 'Opvoeding en de overdracht van waarden en normen', in: P. de Beer en C.J.M. Schuyt (red.) Bijdragen aan waarden en normen, WRR-Verkenning 2, Amsterdam: Amsterdam University Press.

Lidth de Jeude, J. van (2004) 'De dynamische gemeente. Over normen en waarden op lokaal niveau’, in: P. de Beer en C.J.M. Schuyt (red.) Bijdragen aan waarden en normen, WRR Verkenning 2, Amsterdam: Amsterdam University Press.

LISV (2001) Kerncijfers fraude werknemersverzekeringen 2000, Amsterdam: LISV.

Loenen, M.L.P. (2003) 'Het gelijkheidsbeginsel en andere grondrechten in de multiculturele samenleving - ontwikkelingen sinds 1983'; NJCM-bulletin 28, 3a: 259-275.

Macedo, S. (200o) Diversity and Distrust, Civic Education in a multicultural Democracy, Cambridge, Mass.: Harvard University Press.

Mackie, J.L. (1977) Ethics: Inventing Right and Wrong, Harmondsworth: Penguin Books.

Malsch, M. (2004) 'De aanvaarding en naleving van rechtsnormen door burgers: participatie, informatieverschaffing en bejegening', in: P. de Beer en C.J.M. Schuyt (red.) Bijdragen aan waarden en normen, WRR-Verkenning 2, Amsterdam: Amsterdam University Press.

Maris van Sandelingenambacht, C.W. (2002) 'Ik heb mijn namus gezuiverd.' Over eerwraak en cultureel verweer', Justitiële Verkenningen, jrg. 28, nr. 5: 61-74.

Matza, D. (1969) Delinquency and Drift, New York: Wiley and Sons.

Meeus, W. en H. 't Hart (1993) Jongeren in Nederland. Een nationaal survey naar ontwikkelingen in de adolescentie en naar intergenerationele overdracht, Amersfoort: Academische Uitgeverij.

Mendelts, P. (2002) Interpretatie van grondrechten. Grondrechtenclaims en verschuivingen in de reikwijdte van grondrechten, Deventer: W.E.J. Tjeenk Willink.

Middelhoven, L.K. en F.M.H.M. Driessen (2001) Geweld tegen werknemers in de (semi-) openbare ruimte, Utrecht: Bureau Driessen Sociaal Wetenschappelijk Onderzoek.

Ministerie van BZK (2002) Integrale veiligheidsrapportage 2002, Den Haag: Ministerie van Binnenlandse Zaken en Koninkrijksrelaties.

Ministerie van Justitie (2001) Vaststelling van de begroting van de uitgaven en de ontvangsten van het Ministerie van Justitie (VI) voor het jaar 2001, TK 2000-2001, 27400 VI, nr. 83 .

Ministerie van Justitie (2002) Vasthoudend en effectief. Versterking van de aanpak van jeugdcriminaliteit, Den Haag: Ministerie van Justitie.

Mizell, L. (1997) 'Aggressive driving', blz. 1-13, in: Aggressive driving: three studies, Washington (DC): American Automobile Association Foundation for Traffic Safety.

Mosch, R.H.J. en I. Verhoeven (2003) Blauwe ogen of zwart op wit? Een integraal perspectief op vertrouwensmechanismen, WRR Discussion paper 1, Den Haag (nog te verschijnen).

Motivaction (1999) De maatschappelijke betrokkenheid van jongeren, een Socioconsult onderzoek voor de Vereniging voor Bestuurskunde, projectnummer B375, Amsterdam: Motivaction.

Murphy, P. (2001) Civic Justice, From Greek Antiquity to the Modern World, New York: Humanity Press. 
Nauta, L. (2000) Onbehagen in de Filosofie, Amsterdam: Van Gennep.

Netburg, C.J. van, m.m.v. M.H. ter Horst-van Breukelen (2000) Supportersgeweld, Momentopname 2, Den Haag: Wetenschappelijk Onderzoek- en Documentatiecentrum (WODC) (Ministerie van Justititie).

Neuvel, J. (2002) Sociale veiligheid in de BVE-sector, Monitor 2001-2002, 's-Hertogenbosch: CINOP.

Nijsten, C. (1999) Opvoeding van Turkse gezinnen in Nederland, Assen: Van Gorcum.

Nikken, P. (2000) 'Media en geweld', in: Justitiële Verkenningen jrg. 26: 61-72.

Norris, P. (200o) A Virtuous Circle, Political Communications in Post-Industrial Societies, New York: Cambridge University Press.

North, D.C. (1990) Institutions, institutional change and economic performance, Cambridge: Cambridge University Press.

NRC Handelsblad (2002) Normendebat in Noorwegen sloeg op hol, 3 september 2002.

Onderwijsraad (2002) Samen leren leven, verkenning, Den Haag: Onderwijsraad.

Onderwijsraad(2003) Onderwijs en burgerschap, Een voorname rol voor onderwijsinstellingen en overheid, Den Haag: Onderwijsraad.

Parker, D., T. Lajunen en H. Summala (2002) 'Anger and aggression among drivers in three European countries', Accident Analysis \& Prevention 34: 229-235.

Pels, T. (1998) Opvoeding van Marokkaanse gezinnen in Nederland. De creatie van een nieuw bestaan, Assen: Van Gorcum.

Pepper, S. (1957) The Sources of Value, Berkeley: University of California Press.

Perkins, H.W. (2003) The social norms approach to preventing school and college age substance abuse; A handbookfor educators, counselers and clinicians, San Francisco: Jossey Bass.

Peters, J.A. (1981) Het primaat van de vrijheid van meningsuiting, vergelijkende aspecten Nederland-Amerika, Nijmegen: Ars Aequi Libri.

Pettit, Ph. (2002) Rules, Reasons and Norms, Oxford: Clarendon Press.

Phalet, K., C. van Lotringen en H. Entzinger (2000) Islam in de multiculturele samenleving, Opvattingen van jongeren in Rotterdam. Utrecht: ERCOMER.

Planken, T. (2003) 'Nuttig hoor, het debat over Moberg', in: NRC Handelsblad, 20-09-2003, Politiemonitor Bevolking 2001 (2001), Den Haag/Hilversum.

Popper, K. R. (1946) The Open Society and its Enemies, Vol. I and II, Londen: Routledge and Kegan Paul.

Prakke, L., J.L. de Reede en G.J.M. van Wissen (bew.) (2001) Handboek van het Nederlands Staatsrecht door C.W. van de Pot, bewerkt door A.M. Donner, $14^{\mathrm{e}}$ druk, Zwolle: W.E.J. Tjeenk Willink.

Prick, L.(2003) 'Doe er iets aan', NRC-Handelsblad Wetenschapsbijlage, 8-3-2003.

Prick, L. (2004) 'Gedragsregels op school en de noodzaak die ook daadwerkelijk te handhaven’, in: P. de Beer en C.J.M. Schuyt (red.) Bijdragen aan waarden en normen, WRR Verkenning 2, Amsterdam: Amsterdam University Press.

Putnam, H. (2002) The Collapse of the Fact/Value Dichotomy, Cambridge, Mass.: Harvard University Press.

Ravitch, D. (2002) 'Education after the culture wars', in: D. Ravitch et al., 'On education', uitgave Deadalus, summer 2002, p.5-21.

Ravitch, D. en J.P. Vitteri (red.) (2001), Making good citizens. Education and civil society, New Haven /Londen: Yale University. 
Rawls, J. (1971) A Theory of Justice, New York: Columbia University Press.

Rawls, J. (1993) Political Liberalism, Cambridge, Mass.: Harvard University Press.

Reformatorisch Dagblad (2001) Noors ethisch project afgerond. Rapport Waardencommissie grossiert in aanbevelingen, 29 maart 2001.

Regt, A. de en C. Brinkgreve (200o) 'De verborgen agenda voor sociale plaatsing', in: I. van der Zande (red.) Deugt de jeugd; normen en waarden in gezin school en politiek, Maarssen: Elsevier/De Tijdstroom.

Reinders, H. (2003) 'Verdere reflecties op het communitarisme van A. Etzioni', in: CDAVerkenningen, zomer 2003: 132-140.

Reinders, J.S. (2003) 'Het evenwicht tussen individu en gemeenschap: een nieuwe gulden regel?’ Christen Democratische Verkenningen zomer 2003: 97-111.

Rescher, N. (1969) Introduction to Value Theory, Englewood Cliffs: Prentice-Hall.

Rescher, N. (1993) The Validity of Values, Princeton: Princeton University Press.

Rescher, N. (1997) Objectivity, Notre Dame: University of Notre Dame Press.

Rispens J., J.M.A. Hermanns en W.H.J. Meeuws (1996) Opvoeden in Nederland, Assen: Van Gorcum.

Ritzen, J.M.M. (1992) De pedagogische Opdracht van het Onderwijs, een uitnodiging tot gezamenlijke actie, Zoetermeer: Ministerie van oc\&w.

RMO (2000) Aansprekend burgerschap; de relatie tussen de organisatie van het publieke domein en de verantwoordelijkheid van burgers, Adviesnr. 10, Den Haag: RMO.

RMO (2002) Geen woorden maar daden, bijdrage aan het waarden en normendebat, Adviesnr. 23, Den Haag: RMO.

RMO (2003) Medialogica, over het krachtenveld tussen burgers, media en politiek, Adviesnr. 26, Den Haag, Sdu Uitgevers.

Roberts, J.V. en C.J. Benjamin (200o) 'Spectator violence in sports: a North American perspective', European Journal on Criminal Policy Research 8, 2: 163-181.

Rodges, J.J. (2003) 'Social solidarity, welfare and post-emotionalism', Journal of Social Policy 32, 3: 403-421.

Rookmaker, H.R. (2003) 'Echte schoolkwaliteit is niet meetbaar', Trouw, 25-09-2003.

Saharso, S. (2000) Feminisme versus multiculturalisme?, Utrecht: FORUM.

Saharso, S. en O. Verhaar (2002) 'Hoofddoeken in Holland. Een verkenning van een contextuele benadering van een multicultureel conflict', Rechtsfilosofie $\mathbb{8}$ Rechtstheorie 31, 3: 282-294.

Sarason, S.B. (1998) 'Some features of a flawed educational system', in: Education yesterday, education tomorrow, speciale uitgave Deadalus (Fall, 1998).

Schnabel, P. (2004) 'Sociaal-culturele ontwikkelingen en veranderingen in waarden, normen en gedrag, in: P. de Beer en C.J.M. Schuyt (red.) Bijdragen aan waarden en normen, WRR-Verkenning 2, Amsterdam: Amsterdam University Press.

Schnapper, D., P. Krieff en E. Peignard (2000) French immigration and integration policy, EFFNATIS working paper, nr. 24, January 2000.

Schneider, F. en D. Enste (200o) Shadow economies around the world: size, causes, and consequences, IMF Working Paper oo/26, Washington: International Monetary Fund.

Scholten, O. (2004) 'Als de leugen regeert wie brengt hem dan in omloop? Media, overheid en het debat over waarden en normen', in: P. de Beer en C.J.M. Schuyt (red.) Bijdragen aan waarden en normen. WRR Verkenning 2, Amsterdam: Amsterdam University Press. 
Schoonenboom, J. en H. in 't Veld-Langeveld (1976) De emancipatie van de vrouw, Voorstudies en achtergronden voorlopige WRR, Den Haag: Staatsuitgeverij.

Schreuders, M.M., F.W.M. Huls, W.M. Garnier en K.E. Swierstra (200o) Criminaliteit en rechtshandhaving 1999. Ontwikkelingen en samenhangen, Onderzoek en beleid nr. 18o. Den Haag: wodc.

Schuyt, C.J.M. (1997) 'Bronnen van juridisering en hun confluentie', in: Nederlands Juristenblad 72, 21: 925-930.

Schuyt, C.J.M. (1995a) 'Het goede leven: moraal en sociaal-economische ontwikkelingen in de verzorgingsstaat', in: C.J.M. Schuyt, Tegendraadse werkingen, Amsterdam: Amsterdam University Press, p. 13-23.

Schuyt, C.J.M. (1995b) Kwetsbare jongeren en hun toekomst, Rijswijk: Ministerie van VWS.

Schuyt, K. (2001) 'Tolerantie en democratie', in: D. Fokkema en F. Grijzenhout (red.) Rekenschap 1650-2000, deel V Nederlandse Cultuur in Europese Context, p. 115 143.

Schuyt, K. en E. Taverne (2000) 1950: Welvaart in Zwart-Wit, deel 4 Nederlandse Cultuur in Europese Context, Den Haag: Sdu Uitgevers.

SCP (1998) Sociaal en cultureel rapport 1998: 25 jaar sociale verandering, Rijswijk/Den Haag: Sociaal en Cultureel Planbureau/Elsevier bedrijfsinformatie.

SCP (2002) Sociaal en cultureel rapport 2002: de kwaliteit van de quartaire sector, Den Haag: Sociaal en Cultureel Planbureau.

SCP (2003a) Het theorema van Thomas, Den Haag: Sociaal en Cultureel Planbureau.

SCP (2003b) De sociale staat van Nederland 2003, SCP-publicatie 2003/12, Den Haag: Sociaal en Cultureel Planbureau.

Selznick, Ph. (1992) The moral commonwealth, social theory and the promise of community, Berkeley: University of California Press.

Selznick, Ph. (2002) The Communitarian Persuasion, Baltimore: The John Hopkins University Press.

Sennet, R. (1997) 'The danger of seeking catharsis in shared values', in: Times Literary Supplement, 7-2-1997, blz. 3-4.

Shapiro, I. (2003) The Moral Foundations of Politics, New Haven: Yale University Press.

Sijses, B. en C. Huinder (2003) 'De Arabisch Europese Liga in Nederland: achtergrond, programmapunten en reacties', FORUM, 9 mei 2002, http://www.forum.nl/ pdf/ael.pdf.

Soethout, J. en M. Sloep (2000) Evaluatie Arbowet over seksuele intimidatie, agressie en geweld en pesten op het werk, eindrapport, Den Haag: Ministerie van Sociale Zaken en Werkgelegenheid.

Spaaij, R. en E. van der Torre (2003) 'Rotterdamse' hooligans. Aanwas, gelegenheidsstructuren, preventie, Alphen aan den Rijn: Kluwer/сот Instituut voor Veiligheidsen Crisismanagement.

Der Spiegel (2003) 'Ordnung, Höflichkeit, Disziplin, Familie', nr. 28: 124-137, 7 juli 2003 Spijkerboer, T. (2002) Het VN-vrouwenverdrag en het Nederlandse vreemdelingenrecht, Discussiestuk voor de Adviescommissie voor Vreemdelingenzaken, september 2002.

Staatssecretaris van Justitie (200o) Vreemdelingrechtelijke rechtspositie van vrouwen in het vreemdelingenrecht, TK 1999-2000, 27 111, nr. 1. 
Staring, R. (2001) Reizen onder regie. Het migratieproces van illegale Turken in Nederland, Amsterdam: Het Spinhuis.

Steenbergen, J. en A.J. Buisman (red.) (1998) Wen N in de sport, Houten: Bohn Stafleu Van Loghum.

Strategisch Akkoord (2002) Werken aan vertrouwen, een kwestie van aanpakken, strategisch akkoord voor kabinet CDA, LPF, VVD, Den Haag: Ministerie van Algemene Zaken.

Sunstein, C.R. (2003) 'Sober lemmings; the social norms approach van Perkins et al.', The new republic, 14 april 2003.

SVB (2002) Overzicht producten SVB, Amsterdam: Sociale Verzekeringsbank (http:// www.svb.nl).

swov (2003) Verkeersovertredingen (http://www.swov.nl/nl/kennisbank/index.html/ $\mathrm{nl} /$ kennisbank/9o_gegevensbronnen/inhoud/verkeersovertredingen.htm).

Tasca, L. (2000) A review of the literature on aggressive driving research, Paper for the first Global Web Conference on aggressive driving issues (http://www.aggressive. drivers.com/papers/tasca/tasca.pdf).

Taylor, Ch. (1985) 'The diversity of goods, philosophy and the human sciences', in:

Ch. Taylor, Philosophical Papers, Vol. 2, Cambridge: Cambridge University Press, p. $230-248$.

Taylor, Ch. (1989) Sources of the Self, the Making of Modern Identity, Cambridge, Mass.: Cambridge University Press.

Teldersstichting (1995) Tussen Vrijblijvendheid en Paternalisme, Den Haag: VvD.

Terlouw, G.J., W.J.M. de Haan en B.M.W.A. Beke (1999) Geweld: gemeld en geteld. Een analyse van aard en omvang van geweld op straat tussen onbekenden, Den Haag: Wetenschappelijk Onderzoek- en Documentatiecentrum (WODC) (Ministerie van Justititie).

Tigchelaar, H. (2002) 'De politieke partij, de trouwambtenaar en de imam', Nemesis 18, 4:71-74.

Tiggelen G. en A. Vermaas (2002) 'Inburgeren is leren door participeren', Sociaal Bestek, 7-8-2002: 7-11.

Tillaart, H. et al. (200o) Nieuwe etnische groepen in Nederland. Een onderzoek onder vluchtelingen en statushouders uit Afghanistan, Ethiopië en Eritrea, Iran, Somalië en Vietnam, Ubbergen: Tandem Felix.

Tillaart, H. van den en J. Warmerdam (2003) Somalische vluchtelingen in de gemeente Den Haag, Nijmegen: ITS.

Tipton, S.M. (2002) 'Social differentiation and moral pluralism', in: R. Madsen, W.M. Sullivan, A. Swidler en S.M. Tipton (red.) Meaning and modernity, religion, Polity and Self, Berkeley: University of California Press.

TNO Arbeid (2003) Intimidatie door collega's en leidinggevenden zorgwekkender dan intimidatie door klanten - Horeca en zorg grootste risicosectoren, TNO Arbeid - Perskamer (http://www.arbeid.tno.nl/perskamer/20030714).

Tocqueville, A. de (1969) Democracy in America, New York: Double Day Anchor Books (oorspr. 1848).

Tongeren, P. van (2003) Deugdelijk leven, Nijmegen: Sun.

Tweede Kamer (2002-2003) Briefvan de minister-president over de aanpak van waarden en normen, vergaderjaar 2002-2003, 28600, nr. 42. 
Tweede Kamer (2002-2003) Rapportage traject motie Atsma, vergaderjaar 2002-2003, 27400, nr. 33 .

Tweede Kamer (2002-2003) Vragen van het lid Sterk (CDA) aan de minister voor vreemdelingenzaken en integratie en aan de staatssecretaris van OC\&W, Nijs, over inburgeringscursussen, Kamervragen met antwoord 2002-2003, nr. 195.

Ulger, M. (2003) 'Huiselijk geweld. Alleen als mijn man voor de deur staat mag ik de politie bellen', Wordt Vervolgd, jrg. 36, nr. 3: 4-7.

United States Department of Education/by the National Commission on Excellence of Education (1983) A nation at risk: the imperative for educational reform, a report to the nation and the Secretary of Education.

Uslaner, E.M. (2002) The Moral Foundation of Trust, Cambridge: Cambridge University Press.

Valk, H. de et al. (2001) Oude en nieuwe allochtonen in Nederland, WRR Werkdocumenten 123 , Den Haag.

Veenman, J. (2003) 'Stigmatisering en onbegrepen eigenbelang' in: S. Harchaoui, en C. Huinder (red.) Stigma: Marokkaan!, Utrecht: FORUM.

Verhaar (1999) 'Maagdenvlieshersteloperaties tussen gedogen en verbieden', Migrantenstudies, 12, 2: 128-140

Verhallen, S. (2001) Nieuwe kansen voor taalonderwijs aan anderstaligen, WRR Werkdocumenten 124, Den Haag.

Verhoogt, J. (2001) 'Nederland verwaarloost rechtsstaat', in: Trouw, De verdieping, 13 oktober 2001.

Vermeulen, B.P. (2000) 'Godsdienst en gelijkheidsbeginsel', blz. 77-86, in: R. Holtmaat (red.) De toekomst van gelijkheid, Deventer: Kluwer.

Veugelers W. en E. de Kat (1998) Opvoeden in het voortgezet onderwijs, leerlingen, ouders en docenten over de pedagogische opdracht en de afstemming tussen gezin en school, Assen: Van Gorcum (hoofdstuk 3).

Veugelers, W. (2003) Waarden en normen in het onderwijs, zingeving en humanisering: autonomie en sociale betrokkenheid, Utrecht, Universiteit voor Humanistiek (oratie).

Voegelin, E. (1952) The New Science of Politics, Chicago: Chicago University Press.

Vollaard, B. (2003) Performance contracts for police officers, СРВ Documents, nr. 31, Den Haag: Centraal Planbureau.

Voort, T. H.A. van der (1997) De invloed van televisiegeweld, Lisse: Swets \& Zeitlinger.

Vries, G.H. de (2004) 'Politiek van preken en praktijken: het "normen- en waardendebat" als reactie op de "verplaatsing van de politiek", in: P. de Beer en C.J.M. Schuyt (red.) Bijdragen aan waarden en normen, WRR-Verkenning 2, Amsterdam: Amsterdam University Press.

Vries, M. de (1987) Ogen in je rug. Turkse meisjes en jonge vrouwen in Nederland, Alphen aan den Rijn: Samsom.

Vries, S. de et al. (2002) Gewenst beleid tegen ongewenst gedrag: voorbeelden van goed beleid tegen ongewenste omgangsvormen op het werk, Hoofddorp: TNO.

VVD (2003) Respect en Burgerzin, Waarden en normen in liberaal perspectief, Den Haag: VVD.

Waaldijk, C. en R.A.P. Tielman (1984) 'Een model voor de afweging van botsende grondrechten’, NJCM-bulletin 9: 208-228. 
Waardenburg, J. (2001) Institutionele vormgevingen van de Islam gezien in Europees perspectief, wRR Werkdocumenten 118, Den Haag .

Walzer, M. (1984) Spheres of Justice, New York: Basic Books.

Weber, M. (1970) Wetenschap als beroep en roeping, Alphen aan den Rijn: Samsom (oorspr. Duitse uitgave in 1919).

Wetenschappelijke Raad voor het Regeringsbeleid (1990) Een werkend perspectief. Arbeidsparticipatie in de jaren '9o, Rapporten aan de regering nr. 38, Den Haag: Sdu Uitgevers.

Wetenschappelijke Raad voor het Regeringsbeleid (1992) Milieubeleid; strategie, instrumenten en handhaafbaarheid, Rapporten aan de regering nr. 41, Den Haag, Sdu Uitgevers.

Wetenschappelijke Raad voor het Regeringsbeleid (1996) Tweedeling in Perspectief, Rapporten aan de regering nr. 50, Den Haag: Sdu Uitgevers, p. 133 e.v.

Wetenschappelijke Raad voor het Regeringsbeleid (2001) Nederland als immigratiesamenleving, Rapporten aan de regering nr. 6o, Den Haag: Sdu Uitgevers.

Wetenschappelijke Raad voor het Regeringsbeleid (2002) De toekomst van de nationale rechtsstaat, Rapporten aan de regering nr. 63, Den Haag: Sdu Uitgevers.

Wetenschappelijke Raad voor het Regeringsbeleid (2003) Nederland handelsland. Het perspectiefvan de transactiekosten, Rapporten aan de regering nr. 66, Den Haag: Sdu Uitgevers.

Wetenschappelijke Raad voor het Regeringsbeleid (2003) Kennis van het heden, wegen naar de toekomst, Werkprogramma van de $7^{e}$ Wetenschappelijke Raad voor het Regeringsbeleid, Den Haag: WRR.

Willems, J.C.M. (2003) 'Als opvoeders gefaald hebben, waar ligt dan de verantwoordelijkheid?’, NJB, afl. 16 mei, 20: 1019-1022.

Williams, C.C. en J. Windebank (1998) Informal employment in the advanced economies. Implications for work and welfare, Londen/New York: Routledge.

Winkel, F.W. (1995) 'Agressie tegen personeel in het openbaar vervoer', blz. 52-64, in: I.H.J. Starmans (red.) Niet alleen normvervaging: achtergronden van de belangrijkste vormen van criminaliteit en overlast in het openbaar vervoer, Den Haag: Eysink Smeets \& Etman.

Wittebrood, K. (2000) 'Trends in jeugdgeweld', in: Justitiële Verkenningen 26: 21-34.

Wittebrood, K. (2003) 'Preventieve en strafrechtelijke interventies ter voorkoming van jeugdcriminaliteit', blz. 197-216, in: Rapportage jeugd 2002, SCP-publicatie 2002/16, Den Haag: Sociaal en Cultureel Planbureau.

Wittebrood, K. en M. Junger (1999) 'Trends in geweldscriminaliteit: een vergelijking tussen politiestatistieken en slachtofferenquêtes', Tijdschrift voor Criminologie 3: 250-267.

Wittebrood, K. en S. Keuzekamp (2000) Rapportage jeugd 20oo, Den Haag: Sociaal en Cultureel Planbureau.

WODC (2001) Criminaliteit en rechtshandhaving 1999. Ontwikkelingen en samenhangen, Onderzoek en beleid, nr. 180, Den Haag: Ministerie van Justititie (Wetenschappelijk Onderzoek- en Documentatiecentrum).

Woldring, H. (2003) 'Tolerantie van antidemocratisch fundamentalisme', Christen Democratische Verkenningen, Lente 2003: 84-89.

Woldring, H.E.S. (2004) 'Bevrijdende waarden en bindende normen in de publieke 
moraal', in: P. de Beer en C.J.M. Schuyt (red.) Bijdragen aan waarden en normen, WRR-Verkenning 2, Amsterdam: Amsterdam University Press.

Wolfe, Th. (1976) 'The Me-decade and the third great awakening', New York Magazine, 23 augustus 1976 .

Working group on Forced Marriage (200o) A choice by right, Londen: Home Office communications directorate.

Yerden, I. (2001) Ik bepaal mijn eigen lot. Turkse meisjes in conflictsituaties, Amsterdam: Het Spinhuis.

Zeijl, E. (2003) 'Indicatoren voor een ontwikkelingsstaat', blz. 17-35 in: Rapportage jeugd 2002, SCP-publicatie 2002/16, Den Haag: Sociaal en Cultureel Planbureau.

Zwan, A. van der (2001) 'Het klassieke drama van een nieuwe maatschappelijke onderklasse', Socialisme en democratie, vol. 58, 4: 131-146.

Zak, P.J. en S. Knack (2001) 'Trust and growth', The Economic Journal 111, 47: 295-321. 
Minister-President

Ministerie van Algemene Zaken

\author{
Aan de voorzitter van de \\ Wetenschappelijke Raad voor het Regeringsbeleid \\ Prof.mr. M. Scheltema \\ Postbus 20004 \\ 2500 EA Den H

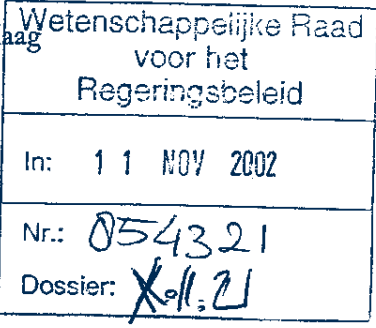 \\ Datum \\ Kenmerk \\ Onderwerp \\ 8 november 2002 \\ 02M442980 \\ Adviesaanvraag inzake \\ waarden en normen
}

Bij brief van 4 oktober 2002 (bijgevoegd) heb ik de Tweede Kamer ingelicht over de aanpak die het kabinet voorstaat inzake het debat over waarden en normen. Drie sporen zullen worden gevolgd.

In de eerste plaats zal, op zichtbare wijze, via verschillende methoden het debat verder worden bevorderd en zal bij de burgers worden nagegaan wat hun grootste ergemissen zijn in de omgang met elkaar en hoe zij denken dat die ergernissen zouden kunnen worden weggenomen. In de tweede plaats zullen afzonderlijke bewindspersonen bezien welke concrete initiatieven op het terrein van waarden en normen zij op hun beleidsterrein kunnen nemen of welke lopende initiatieven zij kunnen uitlichten, verbreden en versterken. Deze eerste twee sporen tichten zich vooral in praktische zin op uitingen en gedragingen in de onderlinge omgang tussen burgers ('fatsoen moet je doen').

Als complement daarvan heeft het kabinet er in de derde plaats behoefte aan meer zicht te krijgen op de achterliggende vraag naar de fundamentele waarden in onze samenleving. In dat verband verzoek ik $u$, gehoord de ministerraad, het

werkprogramma van uw raad zodanig aan te passen dat de raad vóór 1 januari 2004 aan de regering rapport uitbrengt over de navolgende vragen. Om te beginnen gaat het om de vraag naat het belang van gemeenschappelijke waarden voor onze samenleving respectievelijk om de vraag aan welke waarden daarbij in het bijzonder moet worden gedacht. Ook vraagt het kabinet de raad in te gaan op eventuele niet algemeen gedeelde respectievelijk conflicterende waarden in onze samenleving, al dan niet samenhangend met cultuurverschillen, in relatie tot de vraag of en in hoeverre het uiteenlopen van bepaalde waarden maatschappelijk problematisch moet worden geacht. Tot slot gaat het om de vraag welke implicaties een en ander zou dienen te hebben voor het toekomstige beleid van de overheid, zoals op het terrein van het onderwijs, op het terrein van de media, op het terrein van inburgering en integratie 


\section{Minister-President}

Ministerie van Algemene Zaken

etcetera. De raad wordt verzocht deze vragen te beantwoorden mede in het licht van de individualisering van onze samenleving, demografische ontwikkelingen, ontwikkelingen in de sfeer van de tijdsbesteding en andere relevante trends.

Met name de brede expertise van uw raad op de terreinen van onder meer integratie en de democratische rechtsstaat hebben het kabinet ertoe doen besluiten deze adviesaanvraag primair aan uw raad te tichten. Tegelijkertijd verzoekt het kabinet $u$ bij de opstelling van het advies optimaal gebruik te maken van elders aanwezige bijzondere expertise en ervaring en daarbij met name de samenwerking te zoeken met de Raad voor Maatschappelijke Ontwikkeling (RMO) en het Sociaal en Cultureel Planbureau (SCP). Bijgaand treft u kopieën aan van de brieven die ik hierover schreef aan de RMO en het SCP. Bij de totstandkoming van uw advies kan ook het briefadvies over waarden en normen worden betrokken dat de RMO voornemens is nog dit jaar uit te brengen aan de staatssecretaris van VWS. Tevens wordt de raad verzocht zijn voordeel te doen met voor de adviesaanvraag relevante inzichten van de Onderwijsraad. Ik wijs u er verder op dat het kabinet voomemens is een nota op te stellen over grondrechten in een pluriforme samenleving (Tweede Kamer, vergaderjaar 2002-2003, 28600 hoofdstuk VII, nr. 2, pagina 11). In de aanloop naar deze nota zal het ministerie van BZK zich met uw raad verstaan over de raakvlakken en samenloop met uw advisering.

Tot slot zou het kabinet het op prijs stellen indien uw raad bij de advisering nadrukkelijk zijn voordeel zou doen met inzichten die voortvloeien uit overeenkomstige discussies en onderzoeken in het buitenland.

De MINISTER-PRESIDENT, Minister van Algemene Zaken,

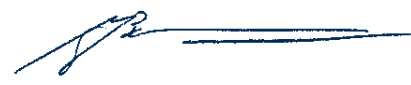

Mr.dr. J.P. Balkenende 


\section{RAPPORTEN AAN DE REGERING}

\section{Eerste raadsperiode (1972-1977)}

Europese Unie*

2 Structuur van de Nederlandse economie*

3 Energiebeleid

Gebundeld in één publicatie (1974)*

4 Milieubeleid (1974)*

5 Bevolkingsgroei (1974)*

6 De organisatie van het openbaar bestuur (1975)*

7 Buitenlandse invloeden op Nederland: Internationale migratie (1976)*

8 Buitenlandse invloeden op Nederland: Beschikbaarheid van wetenschappelijke en technische kennis (1976)*

9 Commentaar op de Discussienota Sectorraden $(1976)^{*}$

10 Commentaar op de nota Contouren van een toekomstig onderwijsbestel (1976)*

11 Overzicht externe adviesorganen van de centrale overheid (1976)*

12 Externe adviesorganen van de centrale overheid (1976)*

13 Maken wij er werk van? Verkenningen omtrent de verhouding tussen actieven en niet-actieven (1977)*

14 Interne adviesorganen van de centrale overheid (1977)*

15 De komende vijfentwintig jaar - Een toekomstverkenning voor Nederland (1977)*

16 Over sociale ongelijkheid - Een beleidsgerichte probleemverkenning (1977)*

Tweede raadsperiode (1978-1982)

17 Etnische minderheden (1979)*

A. Rapport aan de Regering

B. Naar een algemeen etnisch minderhedenbeleid?

Plaats en toekomst van de Nederlandse industrie (1980)*

Beleidsgerichte toekomstverkenning

Deel 1: Een poging tot uitlokking $(1980)^{*}$

Democratie en geweld. Probleemanalyse naar aanleiding van de gebeurtenissen in Amsterdam op 30 april 1980 * Vernieuwingen in het arbeidsbestel (1981)* Herwaardering van welzijnsbeleid (1982)*

Onder invloed van Duitsland. Een onderzoek naar gevoeligheid en kwetsbaarheid in de betrekkingen tussen Nederland en de Bondsrepubliek (1982)*

Samenhangend mediabeleid (1982)* 


\section{Derde raadsperiode (1983-1987)}

Beleidsgerichte toekomstverkenning

Deel 2: Een verruiming van perspectief (1983)*

Waarborgen voor zekerheid. Een nieuw stelsel van sociale zekerheid in hoofdlijnen (1985)

27 Basisvorming in het onderwijs (1986)

28 De onvoltooide Europese integratie (1986)

Ruimte voor groei. Kansen en bedreigingen voor de Nederlandse economie in de komende tien jaar (1987)

Op maat van het midden- en kleinbedrijf (1987)

Deel 1: Rapport aan de Regering;

Deel 2: Pre-adviezen

Cultuur zonder grenzen $(1987)^{*}$

32 De financiering van de Europese Gemeenschap. Een interimrapport (1987)

33 Activerend arbeidsmarktbeleid (1987)

34 Overheid en toekomstonderzoek. Een inventarisatie (1988)

\section{Vierde raadsperiode (1988-1992)}

Rechtshandhaving (1988)

36 Allochtonenbeleid (1989)

37 Van de stad en de rand (1990)

38 Een werkend perspectief. Arbeidsparticipatie in de jaren '90 (1990)

39 Technologie en overheid (1990)

40 De onderwijsverzorging in de toekomst (1991)

41 Milieubeleid. Strategie, instrumenten en handhaafbaarheid (1992)

42 Grond voor keuzen. Vier perspectieven voor de landelijke gebieden in de Europese Gemeenschap (1992)

43 Ouderen voor ouderen. Demografische ontwikkelingen en beleid (1993)

\section{Vijfde raadsperiode (1993-1997)}

44 Duurzame risico's. Een blijvend gegeven (1994)

45 Belang en beleid. Naar een verantwoorde uitvoering van de werknemersverzekeringen (1994)

46 Besluiten over grote projecten (1994)

47 Hoger onderwijs in fasen (1995)

48 Stabiliteit en veiligheid in Europa. Het veranderende krachtenveld voor het buitenlands beleid (1995)

49 Orde in het binnenlands bestuur (1995)

50 Tweedeling in perspectief (1996)

51 Van verdelen naar verdienen. Afwegingen voor de sociale zekerheid in de 21e eeuw (1997)

52 Volksgezondheidszorg (1997)

53 Ruimtelijke-ontwikkelingspolitiek (1998)

54 Staat zonder land. Een verkenning van bestuurlijke gevolgen van informatie- en communicatietechnologie (1998) 


\section{Zesde raadsperiode (1998-2002)}

55 Generatiebewust beleid (1999)

56 Het borgen van publiek belang (2000)

57 Doorgroei van arbeidsparticipatie (2000)

58 Ontwikkelingsbeleid en goed bestuur (2001)

59 Naar een Europabrede Unie (2001)

60 Nederland als immigratiesamenleving (2001)

61 Van oude en nieuwe kennis. De gevolgen van ICT voor het kennisbeleid (2002)

62 Duurzame ontwikkeling: bestuurlijke voorwaarden voor een mobiliserend beleid (2002)

63 De toekomst van de nationale rechtsstaat (2002)

64 Beslissen over biotechnologie (2003)

65 Slagvaardigheid in de Europabrede Unie (2003)

66 Nederland handelsland. Het perspectief van de transactiekosten (2003)

67 Naar nieuwe wegen in het milieubeleid (2003)

Rapporten aan de Regering en publicaties in de reeks Voorstudies en achtergronden zijn verkrijgbaar in de boekhandel of via Sdu Servicecentrum Uitgeverijen, Plantijnstraat, Postbus 20014, 2500 EA 's-Gravenhage, tel. 070-3789880, fax 070-3789783. 


\section{VERKENNINGEN}

\section{Zevende raadsperiode (2003-2007)}

1 Jacques Pelkmans, Monika Sie Dhian Ho en Bas Limonard (red.) (2003) Nederland en de Europese grondwet* 


\title{
VOORSTUDIES EN ACHTERGRONDEN
}

\author{
Hieronder worden de publicaties uit de WRR-serie Voorstudies en achtergronden opgesomd vanaf de \\ vijfde raadsperiode. Een volledig overzicht van de voorstudies is beschikbaar op de WRR-website \\ (http://www.wrr.nl) of aan te vragen bij het bureau van de WRR (070 - 3564625 ).
}

\section{Vijfde raadsperiode (1993-1997)}

W.J. Dercksen e.a. (1993) Beroepswijs onderwijs. Ontwikkelingen en dilemma's in de aansluiting van onderwijs en arbeid W.G.M. Salet (1994) Om recht en staat. Een sociologische verkenning van sociale, politieke en rechtsbetrekkingen J.M. Bekkering (1994) Private verzekering van sociale risico's

C. Lambers, D.A. Lubach, M. Scheltema (1994) Versnelling juridische procedures grote projecten Сऽнов (1995) Aspecten van hoger onderwijs. Een internationale inventarisatie T. van der Meij e.a. (1995) Ontwikkelingen in de natuur. Visies op de levende natuur in de wereld en scenario's voor het behoud daarvan

L. Hagendoorn e.a. (1995) Etnische verhoudingen in Midden- en Oost-Europa H.C. Posthumus Meyjes, A. Szász, Christoph Bertram, W.F. van Eekelen (1995) Een gedifferentieerd Europa J. Rupnik e.a. (1995) Challenges in the East J.P.H. Donner (rapporteur) (1995) Europa, wat nu? R.M.A. Jansweijer (1996) Gouden bergen, diepe dalen: de inkomensgevolgen van een betaalbare oudedagsvoorziening W. Derksen, W.A.M. Salet (red.) (1996) Bouwen aan het binnenlands bestuur SEO/Intomart (1996) Start-, slaag- en faalkansen van hoger opgeleide startende ondernemers L.J. Gunning-Schepers, G.J. Kronjee and R.A. Spasoff (eds.) (1996) Fundamental Questions about the Future of Health Care H.B.G. Ganzeboom en W.C. Ultee (red.) (1996) De sociale segmentatie van Nederland in 2015 J.C.I. de Pree (1997) Grenzen aan verandering. De verhouding tussen reorganisatie en structuurprincipes van het binnenlands bestuur M.F. Gelok en W.M. de Jong (1997) Volatilisering in de economie A.H. Kleinknecht, R.H. Oostendorp, M.P. Pradhan (1997) Patronen en economische effecten van flexibiliteit in de Nederlandse arbeidsverhoudingen J.P.H. Donner (1998) Staat in beweging W.J. Vermeulen, J.F.M. van der Waal, H. Ernste, P. Glasbergen (1997) Duurzaamheid als uitdaging. De afweging van ecologische en maatschappelijke risico's in confrontatie en dialoog W. Zonneveld en A. Faludi (1998) Europese integratie en de Nederlandse ruimtelijke ordening Verslag en evaluatie van de vijfde raadsperiode (1998)

\section{Zesde raadsperiode (1998-2002)}

Krijn van Beek (1998) De ondernemende samenleving. Een verkenning van maatschappelijke verandering en implicaties voor beleid W. Derksen et al. (1999) Over publieke en private verantwoordelijkheden Henk C. van Latesteijn (1999) Land use in Europe. A methodology for policy-oriented future studies Aart C. Liefbroer en Pearl A. Dykstra (2000) Levenslopen in verandering. Een studie naar ontwikkelingen in de levenslopen van Nederlanders geboren tussen 1900 en 1970 
Bart Wissink (2000) Ontworpen en ontstaan. Een praktijktheoretische analyse van het debat over het provinciale omgevingsbeleid

V109 H. Mommaas, m.m.v. W. Knulst en M. van den Heuvel (2000) De vrijetijdsindustrie in stad en land. Een studie naar de markt van belevenissen

V110 H. Dijstelbloem en C.J.M. Schuyt, red. (2002) De publieke dimensie van kennis

V111 M.C.E. van Dam-Mieras en W.M. de Jong, red. (2002) Onderwijs voor een kennissamenleving. De rol van ICT nader bekeken

V112 Wendy Asbeek Brusse, Harry van Dalen en Bart Wissink (2002) Stad en Land in een nieuwe geografie. Maatschappelijke veranderingen en ruimtelijke dynamiek

V113 G.A. van der Knaap (2002) Stedelijke bewegingsruimte. Over veranderingen in stad en land.

V114 F.J.P.M. Hoefnagel (2002) Internet en cultuurbeleid. Over de gevolgen van ICT voor het cultuurbeleid van de Nederlandse overheid

V115 Gabriël van den Brink (2002) Mondiger of moeilijker? Een studie naar de politieke habitus van hedendaagse burgers

V116 Willem Witteveen, Bart van Klink, met bijdragen van Wouter de Been en Peter Blok (2002) De sociale rechtsstaat voorbij. Twee ontwerpen voor het huis van de rechtsstaat

V117 Rein de Wilde, Nikki Vermeulen en Mirko Reithler (2003) Bezeten van genen. Een essay over de innovatieoorlog rondom genetisch gemodificeerd voedsel

\section{Overige publicaties}

Voor de eenheid van beleid. Beschouwingen ter gelegenheid van vijftig jaar Ministerie van Algemene Zaken (1987) Eigentijds burgerschap. WRR-publicatie onder leiding van H.R. van Gunsteren (1992)

Mosterd bij de maaltijd. 20/25 jaar WRR (1997)

De vitaliteit van de nationale staat in een internationaliserende wereld (2002) 